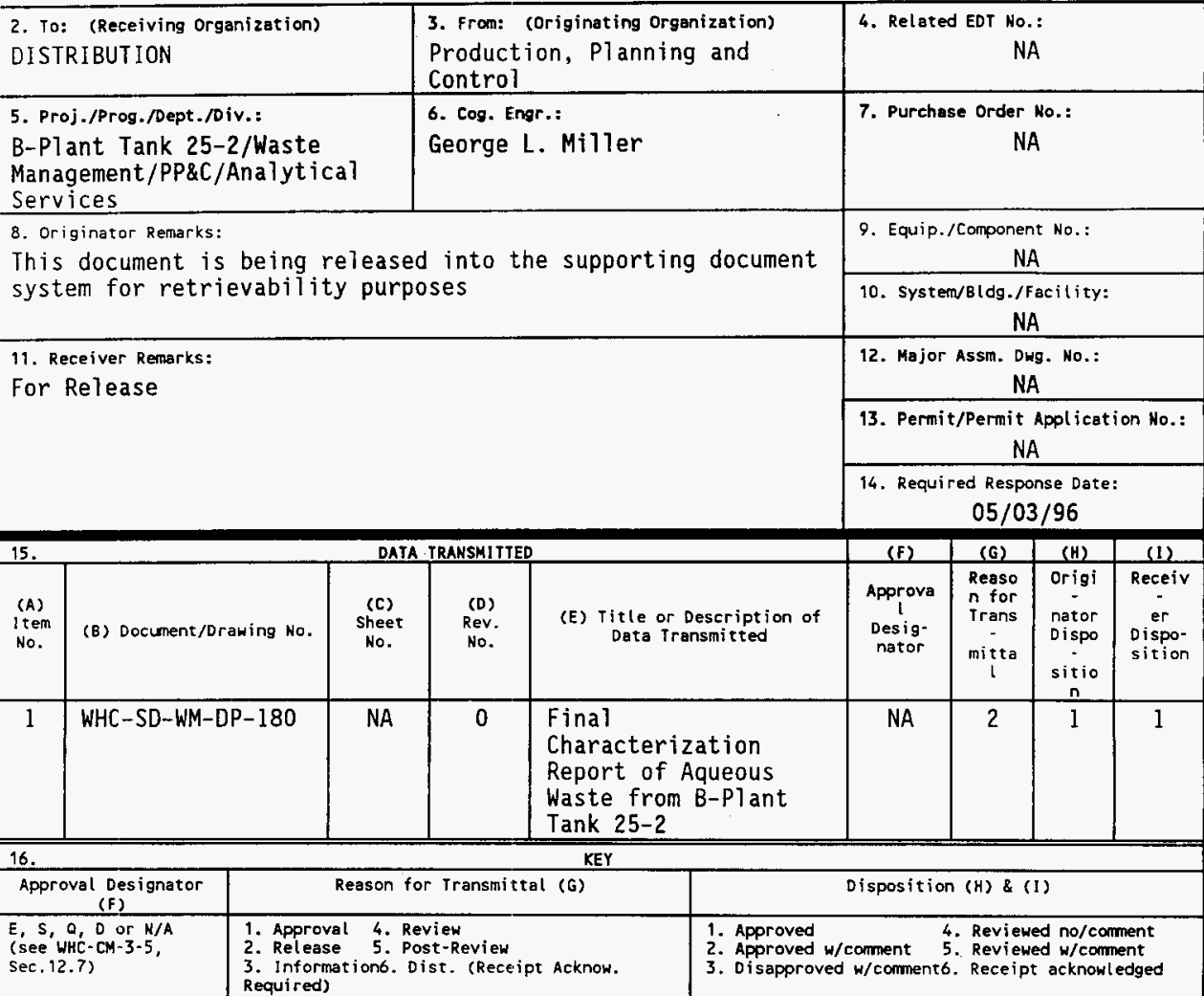

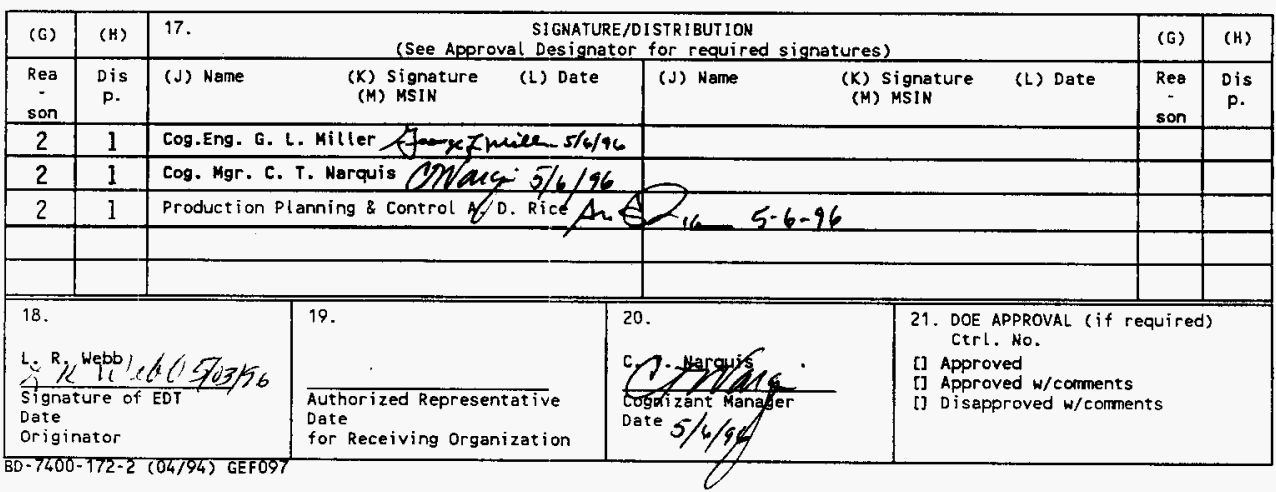




\section{"FINAL CHARACTERIZATION OF AQUEOUS WASTER FROM B-PLANT TANK 25-2"}

G. L. Miller

West inghouse Hanford Company, Richland, WA 99352

U.S. Department of Energy Contract DE-AC06-87RL10930
EDT/ECN: EDT-614790
Org Code: 75725
UC: 2070
B\&R Code: EW 3120074
Charge Code: MD378
Total Pages: 342

Key Words: B-Plant Tank 25-2, Final Characterization of Aqueous Waste Abstract: $N / A$

TRADEMARK DISCLAIMER. Reference herein to any specific commercial product, process, or service by trade name, trademark, manufacturer, or otherwise, does not necessarily constitute or imply its endorsement, recommendation, or favoring by the United States Government or any agency thereof or its contractors or subcontractors.

Printed in the United States of America. To obtain copies of this document, contact: WHC/BCS Document Control Services, P.0. Box 1970, Mailstop H6-08, R i chland HA_09352, Phone_5092 372-2430: Fax (509) 376-4989.
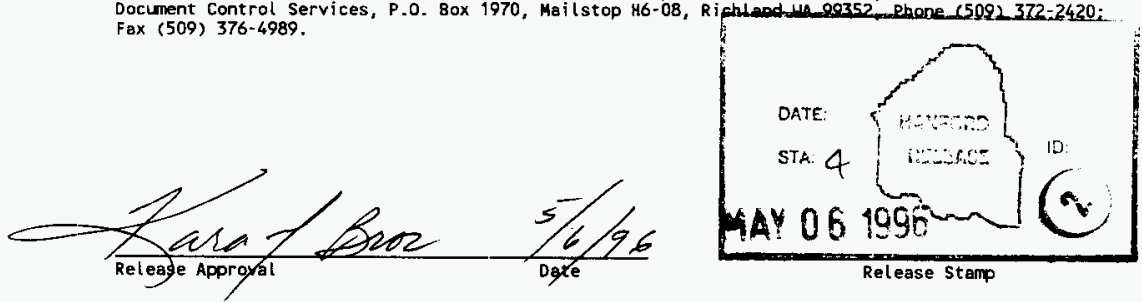

\section{Approved for Public Release}


P.O. Box 1970 Richland, WA 99352

$$
\text { WHC-SD-MM-DP-180, REV. } 0
$$

ANALYTICAL SERVICES

\section{FINAL CHARACTERIZATION REPORT OF AQUEOUS WASTE FROM B-PLANT \\ TANK 25-2}

Project Coordinator: GEORGE L. MILLER

Prepared for the U.S. Department of Energy

Office of Environmental Restoration

and Waste Management

by

Westinghouse Hanford Company

Box 1970

Richland, Washington 


\section{WHC-SD-WM-DP-180, REV. 0}

\section{TABLE OF CONTENTS}

Narrative . . . . . . . . . . . . . . . . . . . . . . 1

Sample Data Summary . . . . . . . . . . . . . . . . . . 18

Requests for Special Analysis ................ 31

Photograph .................... . . 34

ICP Interelement Correction Factors . . . . . . . . . . . . . . . . 37

Sample Preparations . . . . . . . . . . . . . . 53

Acid Digestion Work1ist \# $4823(115,116) \quad \ldots . . . . . . . . .55$

Inorganic Analyses . . . . . . . . . . . . . . 56

Differential Scanning Calorimetry (DSC)

DSC Worklist \# $4956(41,42) \ldots \ldots . \ldots . . \ldots 58$

Thermogravimetric Analysis (TGA)

TGA Worklist \# $4957(41,42) \ldots . . . . . . . . . . .665$

Specific Gravity Analysis (SpG)

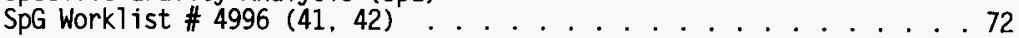

pH Analysis Worklist \# $5007(41,42)$. . . . . . . . . . . . 80

$\mathrm{OH}$ Analysis Workl ist \# $5002(41,42) \ldots . . . . . . . . .81$

OH Analysis Workl ist \# $6390(72) \ldots \ldots 33$

Cyanide Analysis ( $\mathrm{C}$ )

Cn Worklist \#5299 $(41,42) \ldots \ldots . \ldots . \ldots$

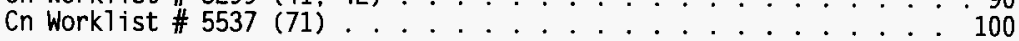

Ion Chromatographic Analysis (IC)

IC Work1 ist \# 5479 (71. 72) . . . . . . . . . . . . . . . . . . . 122

Inductively Coupled Plasma Spectroscopy Analysis (ICP)

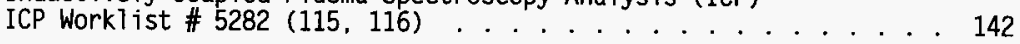

Total Inorganic Carbon Analysis (TIC)

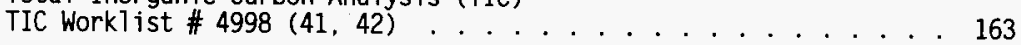

Total Organic Carbon Analysis (TOC)

TOC Work1 ist \# $5000(41,42)$ 
WHC-SD-WM-DP-180, REV. 0

TABLE OF CONTENTS (Continued)

Radiochemical Analyses . . . . . . . . . . . . . . 203

Total Alpha Analysis (AT)

AT Work list \# $5064(115,116) \ldots . . . . . . . . . .205$

Gamma Energy Analysis (GEA)

GEA Work1 ist $4973(41,42) \ldots \ldots 223$

Strontium Analysis ( $\mathrm{Sr}-90)$

Sr-90 Worklist \# $5089(115,116) \ldots . . . . . . . . . .249$

Americium Analysis (Am-241)

Am-241 Worlist \# $5065(115,116) \ldots . . . . . . . . .259$

P7utonium-239 (Pu-239)

Pu-239 Worklist \# $5091(115,116) \ldots . . . . . . . . .293$

Uranium-02 Analysis (U-02)

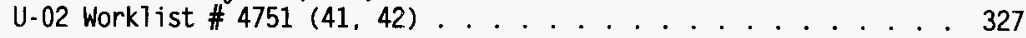

This Document consists of pages 1 through 338 plus pages $2,19,32,35,38$, 54,57 and 204 were intentionally left blank.

TRADEMARKS:

Perkin-Elmer is a Registered Trademark of Research and Manufacturing Company, Inc. Mettler is a Registered Trademark of Mettler Electronics 
WHC-SD-WM-DP-180, REV. 0

NARRATIVE 
WHC-SD-WM-DP-180, REV. 0

THIS PAGE WAS INTENTIONALLY LEFT BLANK 
WHC-SD-WM-DP-180, REV. 0

\author{
FINAL CHARACTERIZATION REPORT OF AQUEOUS WASTE FROM B-PLANT, TANK 25-2 \\ CASE NARRATIVE
}

\title{
SOURCE DOCUMENTATION
}

Liquid waste from B-Plant's aqueous phase tank 25-2 was characterized for physical, inorganic, organic and radiochemical parameters by the Westinghouse Hanford Company, 222-S Laboratory, and by the Battelle Pacific Northwest National Laboratory (PNNL), Analytical Chemistry Laboratory (ACL) as directed by the Sampling Analysis Plan (SAP), Reference 1. The SAP required the analysis of viscosity, however in subsequent communication with the program cognizant engineer, it was determined that this analysis should not be performed. Hydroxide demand was performed at the direction of the program cognizant engineer, although it was not specified in the SAP.

This data package is the final report for the aqueous phase samples collected from tank 25-2 for this project. A prel iminary report, Reference 2, was issued on March 29, 1996 in the form of summary analytical tables, which included all of the analytical results generated at the 222-S Laboratory. The preliminary report was provided to the project to enable timely generation of the Waste Analysis Profile Sheet, a waste compatibility requirement for transfer of the project waste to a Hanford, Tank Waste Remediation System, double shell tank.

Volatile organic analyses (VOA) were performed at the ACL Laboratory, and were reported to the program directly (not in this report).

Quality control analyses at the 222-S Laboratory were performed as defined and specified in the SAP and the Laboratory's Quality Assurance Plan, References 3 and 4. Any deviations from the instructions documented in the SAP are discussed in this narrative and are supported with documentation.

\section{SAMPLING}

The SAP, section 3, provided sampling information for waste samples collected from tank 25-2. Duplicate samples were collected in clear plastic bottles on December 6, 1995 from tank 25-2, and were labeled as B0065 and B0066. The sample bottles were filled using an air lift sampling system, which may have had an impact on the integrity of the sample with regard to VOA, $\mathrm{PH}$, and total organic carbon.

No field blank samples were delivered to the laboratory for analyses. 
None of the samples were preserved by acidification. The sample bottles destined for VOA analyses were placed in a refrigerator between the time that they were received at $222-\$$ until they were shipped to the 325 building (ACL). No attempt was made during sampling to assure the complete filling of the bottles so as to exclude all headspace. These actions were consistent with safety procedures, which attempt to limit personnel exposure to hazardous ionizing radiation.

Chain-of-Custody forms were not provided to the 222-5 Laboratory for these samples. Samples requiring volatile organic analyses (VOA) were transported in Hedgehog shipping casks, with accompanying Chain-of-Custody sheets, to the $A C L$ (PNNL) for analyses.

\section{SAMPLE RECEIVING}

Tank. 25-2 samples were received into the 222-S Laboratory by the laboratory's sample custodian on December 6,1995 at 1515 hours. The transport pigs containing the samples were moved to a hood where the sample bottles were removed, and visually inspected. A radioactive dose rate was measured by a Health Physics Technician. Samples were placed in shielded containers, relabeled to include the laboratory identification number, and transferred to metal storage cabinets in a secured area. Initially, it was determined that the sample dose rate was not sufficiently high to require processing in a hot cell. Hot cell processing of samples is required when the sample dose rate measured at the laboratory exceeds 7 rem per hour or 25 rad per hour. After 4 days of settling, the samples were brought out to begin analytical work, at which time it was discovered that the dose rate had increased significantiy and would require hot cell handling. It was conjectured that the reason for the change in dose rate was that solids had settled to the bottom. This seemed to be consistent with the visual observations taken at the time of sample receipt showing the presence of turbidity. The presence of solids and turbidity are discussed further beginning on page 13 in the section on sample appearance.

\section{SAMPLE IDENTIFICATION}

Customer generated sample identification numbers for each sample were provided on the Request for Special Analysis (RSA) form which was submitted to the laboratory at the time the samples were delivered. New sample identification numbers were assigned by LABCORE (the laboratory's information management system) to each sample when. logged into the 222-S Laboratory. Table l relates the customer sample identification numbers to the laboratory identification numbers. Figure 1 shows the breakdown of the samples and their relationships to the original samples. 
WHC-SD-WM-DP-180, Rev. 0

\begin{tabular}{|c|c|c|}
\hline $\begin{array}{l}\text { CUSTOMER SAMPLE } \\
\text { NUMBER }\end{array}$ & LABORATORY ID NUMBER & ANALYSES TO BE PERFORMED ON WASTE \\
\hline 80065 & S95R000113 (originăl sample) & Appearance, volume \% solids \\
\hline 80066 & 595R000114 (original sample) & Appearance, volume \% solids \\
\hline B0065 & S95R000115, acid cligestion & Alpha, Beta, ${ }^{241}$ Am, ICP, $239 / 240$ Pu, $89 / 90$ Sr \\
\hline 80066 & S95R000116, acid digestion & Alpha, Beta, ${ }^{241}$ Am, ICP, $239 / 240 \mathrm{Pu},{ }^{89 / 90} \mathrm{Sr}$ \\
\hline $\mathrm{B} 0065$ & S96R000041, direct & ${ }^{137} \mathrm{Cs}, \mathrm{U}, \mathrm{CH}, \mathrm{OH}, \mathrm{PH}, \mathrm{Sp}, \mathrm{G}, \mathrm{TIC}, \mathrm{TOC}, \mathrm{DSC}, \mathrm{TGA}$ \\
\hline 80066 & S96R000042, di rect & ${ }^{137} \mathrm{Cs}, \mathrm{U}, \mathrm{CN}, \mathrm{OH}, \mathrm{PH}, \mathrm{Sp}, \mathrm{G}, \mathrm{IIC}, \mathrm{TOC}, \mathrm{DSC}, \mathrm{TGA}$ \\
\hline B0065 & S96R000067 & Sent to PNL, ACL for VOA \\
\hline B0066 & \$96R000068 & Sent to PNL, ACL for VOA \\
\hline B0065 & S96R000071, direct & IC, $\mathrm{CN}$ \\
\hline B0066 & S96R000072, direct & IC, Caustic Demand \\
\hline B0065 & S96R000069 Aqueous Phase & Archive \\
\hline B0066 & S962000070 Aqueous Phase & Archive \\
\hline
\end{tabular}

\section{ANALYTICAL PROCEDURES}

Table 2 summarizes the analytical procedures which were used for sample analyses. The procedures used were the same as those cited in SAP, Table 1, except for $\mathrm{pH}$, and DSC analyses. Caustic demand was not included in the SAP.

Only the aqueous fraction of these samples was analyzed at the 222-S Laboratory and reported in this data package. 
WHC-SD-WM-DP- 180, Rev. 0

Figure 1. Subsample Relationships for Samples B0065 and B0066
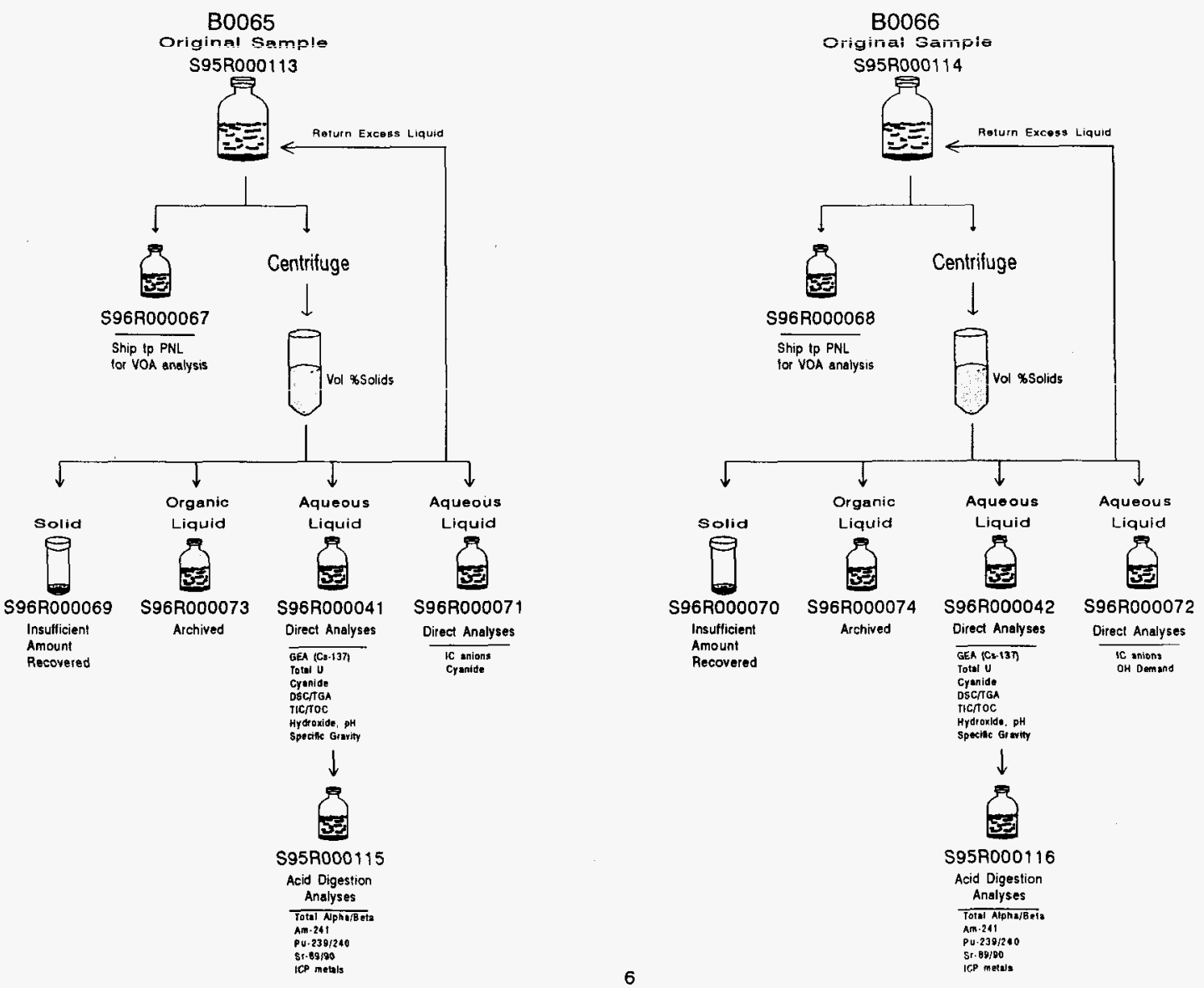
WHC-SD-WM-DP-180, Rev. 0

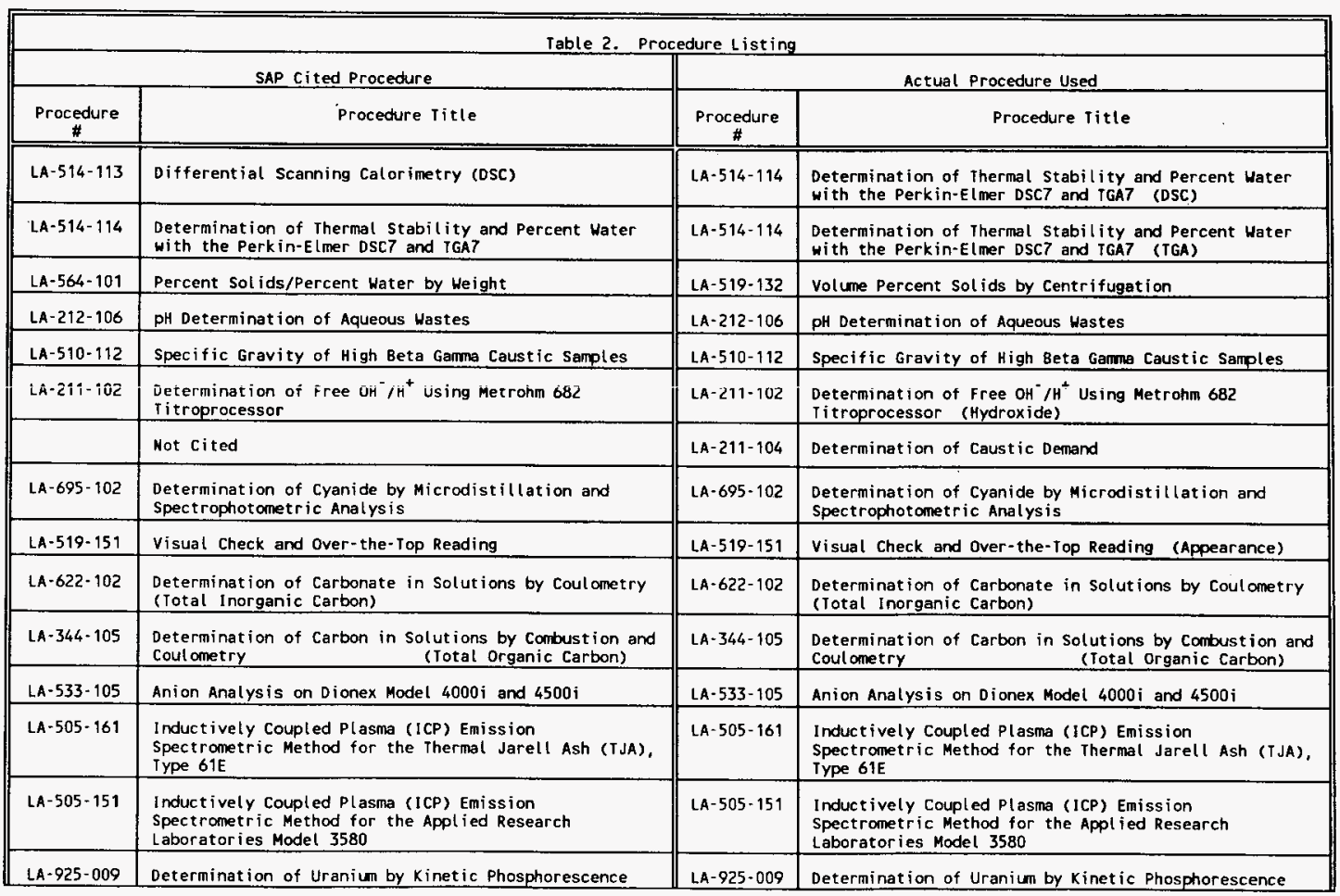


WHC-SD-WM-DP-180, Rev. 0

\begin{tabular}{|c|c|c|c|}
\hline \multicolumn{2}{|r|}{ SAP cited Procedure } & \multicolumn{2}{|r|}{ Actual Procedure Used } \\
\hline $\begin{array}{c}\text { Procedure } \\
\#\end{array}$ & Procedure Title & $\begin{array}{c}\text { Procedure } \\
\#\end{array}$ & Procedure Title \\
\hline \multirow[t]{2}{*}{$L A-548-121$} & $\begin{array}{l}\text { Preparation of Sample Mounts for GE(Li) GEA - Low } \\
\text { Level }\end{array}$ & $L A-548-121$ & $\begin{array}{l}\text { Preparation of Sample Mounts for GE(Li) GEA - Low } \\
\text { Level (preparation for LA-508-162) }\end{array}$ \\
\hline & Not cited & LA-508-162 & $\begin{array}{l}\text { Gamma Energy Analysis - The Genie System (subsequent } \\
\text { to LA-548-121) }\end{array}$ \\
\hline \multirow[t]{2}{*}{ LA-508-101 } & Low Level Alpha and Beta in Water Samples (prep) & LA-508-101 & $\begin{array}{l}\text { Low Level Alpha and Beta in Hater Samples } \\
\text { (preparation for LA-508-114) }\end{array}$ \\
\hline & Not cited & $2 A-508-114$ & $\begin{array}{l}\text { Operation of Gamma Products Alpha Beta Counting } \\
\text { Systems Using PC Control } \\
\text { (Subsequent to LA-508-101) }\end{array}$ \\
\hline$L A-953-103$ & $\begin{array}{l}\text { Determination of Americiun by Extraction with TRU.Spec } \\
\text { Resin }\end{array}$ & $L A-953-103$ & $\begin{array}{l}\text { Determination of Americium by Extraction with TRU.Spec } \\
\text { Resin }\end{array}$ \\
\hline \multirow[t]{2}{*}{$L A-220-101$} & High Level Stront ium-89,90 in Aqueous Samples & LA-220-101 & High Level Strontium- 89,90 in Aqueous Samples \\
\hline & Not Cited & LA- $505-158$ & $\begin{array}{l}\text { Acid Digestion of Aqueous Samples and Extracts for } \\
\text { Total Metals for Analysis by FLAA and ICP Spectroscopy }\end{array}$ \\
\hline
\end{tabular}


WHC-SD-WM-DP-180, Rev. 0

\section{DETECTION LIMITS}

Detection limits were defined for each procedure without reference to a uniform laboratory protocol to determine such limits. Some of the procedures used the reagent blank value as the detection limit. Some procedures used the concentration of the lowest standard in the calibration curve as the detection limit, and others used the EPA replicate procedure. The sample matrix was not considered in generating the detection limit, therefore it is an "instrument detection limit", not a "method detection limit". Wherever possible, the detection limit was modified by the typical dilution factor of the samples to provide a more representative value relative to the samples. All of the practices described above for estimation of the detection limit are allowed as estimated quantitation limits by $\mathrm{SW}-846$ protocol.

\section{SIGNIFICANT FIGURES}

A review was made of each controlled procedure to assure compliance with any stated significant figure requirements. Generally three significant figures were reported because data were formatted into scientific notation. Specific gravity was the only procedure for which significant figures were specified for reporting. For this analysis, the reported value must have three digits to the right of the decimal in standard numerical notation (not scientific notation) format. Specific gravity results were reported with the specified number of significant digits.

\section{STANDARDS}

Labcratory control standards (LCS) are required by Reference 3 to be analyzed with each batch of analyses. 222-S Laboratory analyzes such standards, whenever available, with each analytical batch. These standards were used as an independent confirmation of proper calibration of the analytical system. LCS standards were prepared from materials traceable to National Institute of Standards and Technology (NIST) standards and were not used for instrument calibration. The LCS standards, which were analyzed, were normally generated by a special group within 222-S Laboratory using controlled procedures. Analyte concentrations of these standards were known in advance to the analysts.

LCS control limits were typically defined as the statistical mean plus or minus three standard deviations of the existing values in the data base. For those procedures which didn't have a data base large enough to provide statistically significant data, an administratively set control limit was used.

If a standard failed to meet the control criteria, all data associated with that batch were invalidated. A new batch, including the appropriate standard and quality control analyses, was rerun. The standard associated with the new batch must pass the standard acceptance criteria before data from that batch 
WHC-SD-WM-DP-180, Rev. 0

are able to be reported. None of the data for this project failed the LCS criteria.

\section{BLANKS}

A reagent blank was analyzed with each batch. A blank was not run for analyses where blanks are not appropriate, such as for visual appearance, $\mathrm{pH}$, specific gravity, volume percent solids, TGA and DSC. A preparation blank was analyzed with each batch of acid digested samples.

\section{DUPLICATE ANALYSIS}

Precision quality control criteria were specified in the SAP only for those analytes capable of being spiked. This occurred because the evaluation of precision was based on the relative percent difference (RPD) between the percent recoveries of the sample spike and its corresponding spike duplicate. For analytes which were not able to be spiked (i.e. DSC, TGA, pH, Hydroxide, specific gravity and ${ }^{137} \mathrm{Cs}$ ), the $222-5$ Laboratory voluntarily evaluated precision based on the RPD between the sample and its corresponding duplicate. Rerun requirements were not specified by the SAP when its precision criteria were not met. No duplicate analytical data were provided for visual appearance, volume percent solids or caustic demand.

\section{SPIK.E/SPIKE DUPLICATE ANALYSIS}

To evaluate accuracy of data, Table 1 of the SAP required that samples be spiked when possible for each analyte. Those analytes capable of being spiked are $\mathrm{NO}_{2}, \mathrm{NO}_{3}, \mathrm{~F}, \mathrm{Cl}, \mathrm{PO}_{4}, \mathrm{SO}_{4}, \mathrm{Ag}, \mathrm{Al}, \mathrm{Cd}, \mathrm{Cr}, \mathrm{Fe}, \mathrm{Na}, \mathrm{Ni}, \mathrm{Pb}$, Total Inorganic Carbon (TIC), Total Organic Carbon (TOC), U-gross, total alpha, total beta, ${ }^{239 / 240} \mathrm{Pu},{ }^{241} \mathrm{Am},{ }^{90} \mathrm{Sr}$ and cyanide. The SAP criteria for acceptable spike accuracy was 75 to 125 percent recovery. Accuracy criteria as determined by percent recovery were valid only when the analyte concentration in the spiked sample was increased by at least 25 percent more than the original sample concentration.

The SAP criterion for acceptable precision between spikes and their duplicates was \pm 20 relative percent difference (RPD). A minimum of one spike and one spike duplicate was performed for each of the speakable analytes, except for the ICP metals. When precision criteria were based on the difference between the spike and spike duplicate, they were valid only when the analyte concentrations of the spike and spike duplicate were greater than ten times the detection limit. This allowed the precision evaluation to be made on analyte concentrations that were within the quantifiable range. 
WHC-SD-WM-DP-180, Rev. 0

\section{REVIEW OF DATA}

Descriptive information are provided on the Worklist Data Entry sheets and included in the case narrative if unusual conditions occur during analysis of a batch (unless the data were rejected and not reported). No anomalies or difficulties were noted for any of the analytes associated with this project.

Each analytical batch was reviewed for correctness of data at several levels. Chemists reviewed not only analytical calculations, and assured that the analytical system was performing appropriately. All analysis results, which had been entered into LABCORE, were reviewed by the cognizant chemist, verifying data accuracy and completeness. Once this process was completed, which was a step termed "validation" by LABCORE, then access to the data was locked to prevent further entries or corrections.

Data were reviewed by the project coordinator to also verify that correct values had been entered to LABCORE from any hand written Worklist Data Entry sheets. Correctness of case narrative text and tables was reviewed by the project coordinator.

\section{RESULTS OF ANALYSES (DATA SUMMARY AND EVALUATION)}

Analytical results were presented in tabular summary form with associated quality control data, beginning on page 18. Table 3 summarized the quality control (QC) information for reference convenience. When sample numbers are displayed in this table, a quality control failure occurred for that sample. $A n$ "OK" in the table indicates that the QC criteria were met for both samples. An " $n / a$ " indicates that this parameter was not applicable. Additional discussion on each QC failure and its significance was provided in the narrative below.

Raw analytical data were attached beginning on page 53 . These data are organized by analyte according to the general class of analyte.

Narrative comments are provided below for analytes, where the QC limits were exceeded or additional information relating to the analyses was relevant. 
WHC-SD-WM-DP-180, Rev. 0

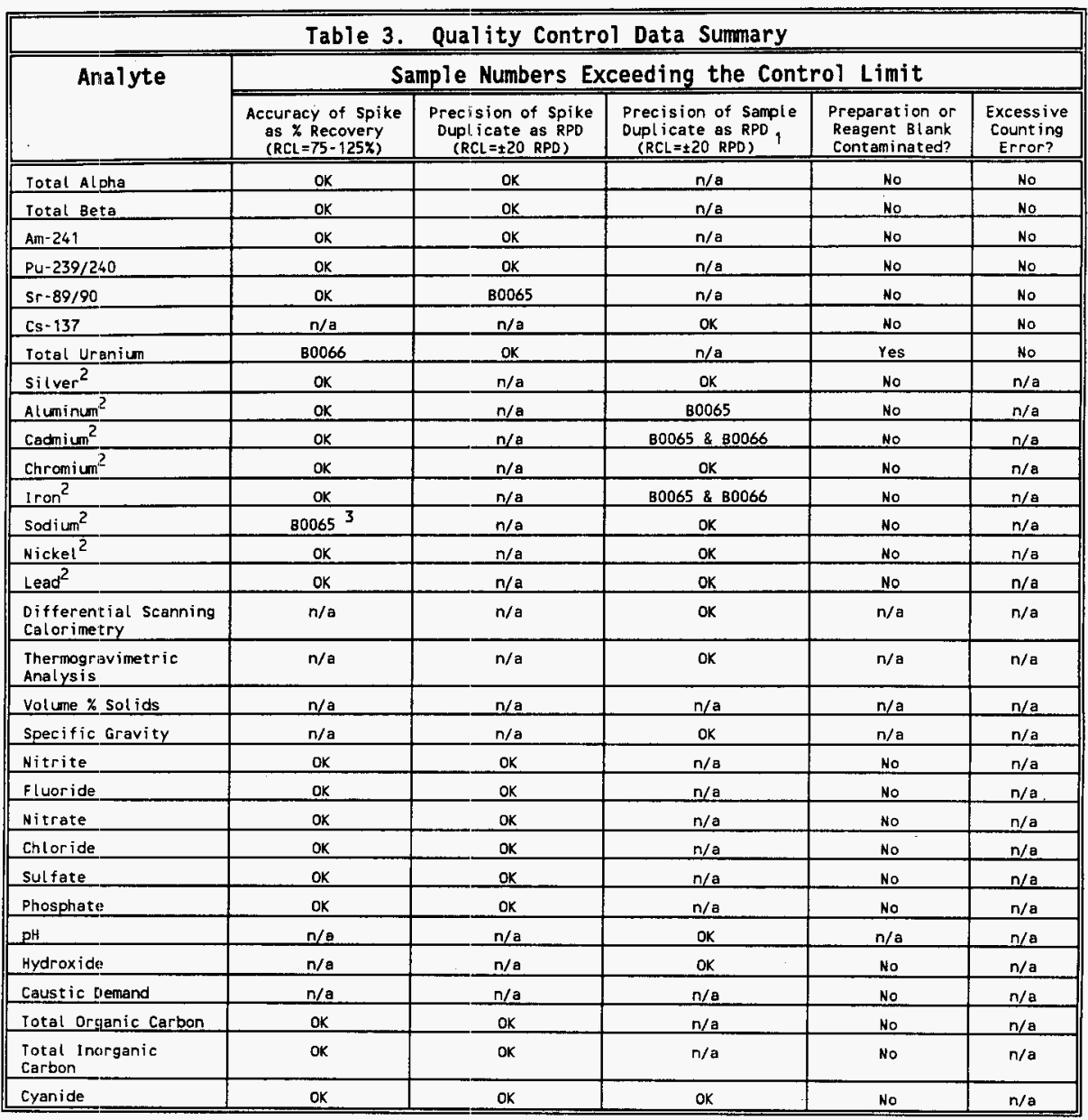

Footnotes:

1. The SAP did not specify quality control limits between samples and their corresponding duplicates, but a limit of \pm 20 RPD was assumed.

2. Spike duplicates were not performed on the ICP analytes as required in the SAP, however sample

duplicates were used to assess analytical precision.

3. Serial Dilution Results were acceptable (<10 RPD) for B0066, but were exceeded for 80065 . 


\section{WHC-SD-WM-DP-180, Rev. 0}

\section{SAMPLE APPEARANCE}

Observations were performed on the direct (unmodified) sample. No quality control criteria were specified in the SAP.

Upon arrival at the laboratory the visual appearance of both of these samples was essentially the same. Both were a non-viscous, dark brown colored liquid with a significant amount of turbidity. At that time no organic phase was observed. After having settled undisturbed for four days, it was discovered that the dose rate had increased significantly, requiring that the samples be handled further in a hot cell.

These samples were transferred to a hot cell and allowed to settle again for approximately 10 days. The photograph (attached on page 36 ) shows the visual appearance of sample B0065 (left) and B0056 (right). Visual inspection of the settled samples revealed that there was less than two percent solids by volume for both of the samples. There was a significant amount of dark brown organic liquid above the amber colored aqueous phase of the samples. The organic layer in sample B0065 was 9.2 percent by volume, and was 7.8 percent by volume for sample B0066. It was this organic material that caused the sample to appear very turbid when mixed into the aqueous phase, and was responsible for the original belief that the sample had a significant amount of solid material.

The sample dose rate for sample B0065 after settling was 36 Rad/hour and 1.3 rem/hour. The sample dose rate for sample B0066 after settling was 28.4 $\mathrm{Rad} /$ hour and $1 \mathrm{rem} / \mathrm{hour}$.

\section{DIFFERENTIAL SCANNING CALORIMETRY (DSC)}

Endotherms were observed as expected in the standards, as well as in all samples, although no exotherms were observed. The sample endotherms were due at least in part to the presence of water. The occurrence of exotherms is expected when the total organic carbon concentration (TOC) is high. For these samples, an exotherms were not observed, perhaps because the exotherm(s) that may have been exhibited due to the TOC content were masked by the very large endotherms.

\section{SPECIFIC GRAVITY}

These analyses appear to be consistent with TGA data.

\section{HYDROGEN ION ACTIVITY ( $\mathrm{pH})$}

Analyses of $\mathrm{pH}$ revealed sample results in the neutral $\mathrm{pH}$ range, which were not consistent with expectations. Because the source of the samples was from a highly caustic wash of organic material, a $\mathrm{pH}$ result exceeding 10 was 
WHC-SD-WM-DP-180, Rev. 0

expected. There did not appear to be any unusual instances or problems which occurred during $\mathrm{pH}$ analysis. These sample data appear to be consistent with the hydroxide analytical results, which were less than the detection limit.

It was postulated that these samples had a significant caustic demand. The analysis of sample $B 0066$ revealed this to be the case with a demand of 0.0103 moles of hydroxide per liter of sample. Table 4 compares the concentrations of hydroxide, nitrate and nitrite with the waste compatibility corrosion rules. These samples do not meet the corrosion rules because the ratios of these three compounds are not correct. To comply with the corrosion rule, the hydroxide concentration would need to be at least five times greater.

\section{TOTAL INORGANIC CARBON, (CARBONATE)}

The total inorganic carbon (TIC) result for sample $B 0065(<5 \mu \mathrm{g} \mathrm{C} / \mathrm{ml})$ was inconsistent with the results for sample $B 0066(23.0 \mu \mathrm{g} \mathrm{C} / \mathrm{ml})$. A rerun was not performed at the direction of the program's cognizant engineer.

\section{TOTAL ORGANIC CARBON (TOC)}

The TOC content of the samples is approximately 0.7 percent ( $w / v)$, which is rather high (as noted in the DSC comments). However, when considering that the source of the aqueous material was from a caustic wash of organic material [Tri-butyl phosphate (TBP) and normal paraffin hydrocarbons (NPH)], the high TOC content may not be unexpected. No attempt was made to compare the analytically derived results with the amount of organic carbon expected to be present due to the solubility of TBP and NPH in the aqueous phase.

\section{INDUCTIVELY COUPLED PLASMA/EMISSION SPECTROSCOPY (by ICP)}

Interelement correction data for the Inductively Coupled Plasma (ICP) analyses were provided as directed in the SAP, beginning on page 37 . Interelement data corrections were automatically performed for spectral interferences from calcium on iron; from chromium on iron; from iron on chromium; from sodium on nickel; from antimony on nickel; and from uranium on aluminum, chromium, iron, and nickel.

Analysis of a spike duplicate was requested, however the chemist performed a sample duplicate instead. Consequently, the precision standard in the SAP, based on a spike duplicate, should also apply to the sample duplicate.

For five of the elements, there were either inconsistencies in the data or QC failures. A rerun was not performed at the direction of the program.

For aluminum, precision between the sample B0065 and its duplicate was not acceptable with a 31.5 relative percent difference. Results were also inconsistent between the two samples. Sample aluminum concentrations are 
Table 5. Waste Compatibility Corrosion Rules

\begin{tabular}{|c|c|c|c|c|c|c|c|}
\hline \multirow[t]{2}{*}{ Sarmple ID } & \multirow[t]{2}{*}{ Analyte } & \multirow{2}{*}{$\begin{array}{l}\text { Result } \\
\text { (ug/mL) }\end{array}$} & \multirow{2}{*}{$\begin{array}{l}\text { Result } \\
\text { (M) }\end{array}$} & IS [NO3] & $18[\mathrm{OH}] \%$ & (15[HO2]:- & $18[\mathrm{OH}]+[\mathrm{NO} 2]$ \\
\hline & & & & $c=1.0 \mathrm{M} ?$ & $0.010 \mathrm{M}<=[\mathrm{OH}]<=5.0 \mathrm{M} ?$ & $0.011 \mathrm{M} c=[\mathrm{NO2}]<=5.5 \mathrm{M}$ & \\
\hline \multirow{4}{*}{$\begin{array}{c}\text { 8-Plant } \\
\text { Tank 25-2 } \\
\text { Sample B0065 } \\
\text { S96R000071 } \\
\text { S96R000041 }\end{array}$} & NO3 & $4.41 E+04$ & 0.711 & YES & NO & YES & \\
\hline & $\mathrm{OH}$ & $4.20 \mathrm{E}+01$ & 0.002 & & & & \\
\hline & & & & & & & \\
\hline & & & & $3.0 \mathrm{M}<[\mathrm{NO} 3]<=5.5 \mathrm{M} ?$ & $0.3<=[\mathrm{OH}]<10 \mathrm{M} ?$ & & $>=1.2 \mathrm{M} ?$ \\
\hline
\end{tabular}

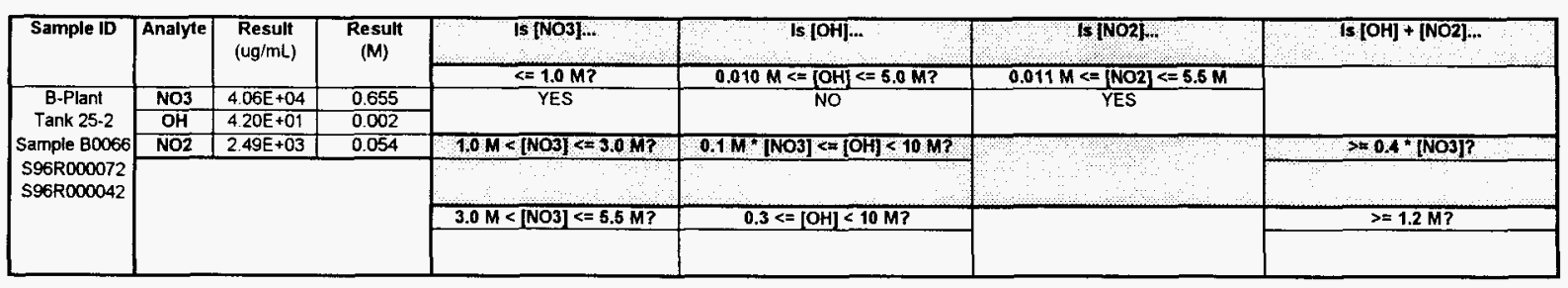


WHC-SD-WM-DP-180, Rev, 0

quite low (approaching the detection limit) where greater imprecision is expected. However, it was not certain why there was a difference of approximately three orders of magnitude between the samples. It is possible that sample B0065 could have been contaminated, however no rerun was performed to confirm or negate that possibility.

Precision for cadmium and iron was poor between the samples and their duplicates, indicating the possibility of sample inhomogeneity.

The sodium spike failed to meet the QC limit of 75 to 125 percent recovery. However, when sample sodium concentrations exceed $1000 \mu \mathrm{g} / \mathrm{ml}$, the normal control limits for accuracy determination are not applicable. This occurs because the instrument's detector is overwhelmed with the intensity of the signal at extremely high analyte concentrations (which happens when a spike is added to an already high sample concentration), causing detector insensitivity to even large concentration differences. The sodium concentration of samples B0065 and $B 0066(16,800$ and $16,600 \mu \mathrm{g} / \mathrm{ml}$, respectively) exceeded $1000 \mu \mathrm{g} / \mathrm{ml}$, consequently an alternative evaluation of accuracy was applied using serial dilution. Upon serial dilution, an expected dilution RPD value was calculated. The formula for this calculation follows:

$$
\text { Dilution RPD }=\frac{[\text { initial conc. }]-([\text { serial di]'n conc.] } \times \text { dilution factor })}{\text { [initia] concentration] }} \times 100
$$

Using a dilution rather than a spike has advantages and disadvantages as a data quality evaluation tool. Although an evaluation of the deviation between the actually derived concentration and the expected concentration following dilution does not definitively indicate the degree of matrix interference within a sample, it does establish whether or not the analys is was performed within the linear portion of the calibration curve. It should be understood, however, that matrix interference (the cause of a bias in accuracy) is generally insignificant when the analyte is present in such high concentrations in the sample. Conversely, a spike is not particularly useful when the initial sample concentration is very high. To be distinguishable above the initial sample concentration, spiking must generate a final concentration at least 25 percent greater than the initial concentration, yet this frequently places the analyte concentration within the region of calibration non-linearity. The result is that percent recovery is incorrectly estimated. For example, accuracy for sample B0065 was not acceptable as indicated by the spike recovery of 189.6 percent. As an alternative, the dilution method was applied to sodium (the only ICP analyte in which the sample concentrations exceeded $1000 \mu \mathrm{g} / \mathrm{ml}$ ). Dilution RPD values less than ten percent indicate that measurements are within the linear portion of the calibration curve. Sample B0066 had a dilution RPD value of 8.8 percent, which was within the $10 \%$ limit. The dilution RPD for B0055 of 12.6 exceeded the 10 percent limit, indicating that the analytical value for this sample may have been determine in the non-linear calibration range and may also be in 
error. The sample sodium concentrations, however, are the same, suggesting that the quality of data for both samples is similar, and because the serial dilution for B0066 met the QC 1 imit, it would appear that the analytical results are of usable quality.

\section{TOTAL URANIUM (by Kinetic Phosphorescence)}

Spike accuracy was acceptable for B0065, but slightly exceeded the QC limit for sample B0066. Even if it is assumed that the sample concentrations are biased high, they are very near the detection limit, making such bias relatively insignificant.

The reagent blank appeared to be slightly contaminated, indicating the possibility that the samples may have been slightly contaminated too. Because the sample concentrations were, however, near the detection limit, the significance of this potential contamination is questionable.

\section{STRONTIUN-89/90 (by Separation/Proportional Counting)}

Although the spike duplicate's precision for B0065 slightly exceeded the QC acceptance limit of $\pm 20 \mathrm{RPD}$, the spike duplicate precision for sample B0066 was well within acceptable limits. No rerun was performed to verify the precision quality of the data, however, the RPD between the ${ }^{89 / 90} \mathrm{Sr}$ activities of the samples was only 8.3, tending to indicate that imprecision may not be very significant.

\section{References}

1. WHC-SD-WM-EV-108, REV. 0, "Organic Phase and Aqueous Phase Sampling Analys is Plan, dated December 4, 1995, Westinghouse Hanford Company, Richland, WA 99352.

2. Internal Memo, Number 75725-96-019, to E. R. Hafla from G. L. Miller, "Interim Analytical Chemistry Report for B-Plant Samples from the Aqueous Phase Tank 25-2", dated March 29, 1996, Westinghouse Hanford Company, Richland, WA 99352.

3. WHC-SD-CP-QAPP-016, Rev. 1, "222-S Laboratory Quality Assurance Plan", dated July 31, 1995, Westinghouse Hanford Company, Richland, WA 99352.

4. WHC-SD-CP-QAPP-016, Rev. IA, "222-S Laboratory Quality Assurance P1 an", dated August 31, 1995, Westinghouse Hanford Company, Richland, WA 99352. 
WHC-SD-WM-DP-180, REV. 0

SAMPLE DATA SUMMARY

19 
WHC-SD-WM-DP-180, REV. O

THIS PAGE WAS INTENTIONALLY LEFT BLANK

19 
B Plant, Tank 25-2

Alpha in Liquid Samples

Acid Digestion

\begin{tabular}{|c|c|c|c|c|c|c|c|c|c|c|c|}
\hline \multicolumn{2}{|c|}{ SAMPLE INFORMATION } & \multicolumn{4}{|c|}{ SAMPLE RESULTS } & \multicolumn{6}{|c|}{ QUALITY CONTROL RESULTS } \\
\hline $\begin{array}{l}\text { Customer } \\
\text { Identification }\end{array}$ & $\begin{array}{c}\text { Laboratory } \\
\text { Identification }\end{array}$ & $\begin{array}{c}\text { Sample } \\
\text { Result } \\
\mu \mathrm{Ci} / \mathrm{mL}\end{array}$ & $\begin{array}{c}\text { Duplicate } \\
\text { Result } \\
\mu \mathrm{Ci} / \mathrm{mL}\end{array}$ & $\begin{array}{l}\text { Average } \\
\text { Result } \\
\mu \mathrm{Ci} / \mathrm{mL}\end{array}$ & $\begin{array}{c}\text { Sample } \\
\text { Precision } \\
\text { RPD }\end{array}$ & $\begin{array}{c}\text { Standard } \\
\text { Recovery } \\
\%\end{array}$ & $\begin{array}{c}\text { Preparation } \\
\text { Blank } \\
\mu \mathrm{Ci} / \mathrm{mL}\end{array}$ & $\begin{array}{c}\text { Spike } \\
\text { Recovery } \\
\%\end{array}$ & $\begin{array}{c}\text { Spike } \\
\text { Duplicate } \\
\text { RPD }\end{array}$ & $\begin{array}{c}\text { Detection } \\
\text { Limit } \\
\mu \mathrm{Ci} / \mathrm{mL}\end{array}$ & $\begin{array}{c}\text { Counting } \\
\text { Error } \\
\%\end{array}$ \\
\hline 80066 & S95R000116 & $<1.00 \mathrm{E}-02$ & $n / a$ & $n / a$ & $n / a$ & 94.6 & $<7.72 \mathrm{E}-03$ & 97.5 & 1.8 & $1.26 \mathrm{E}-02$ & 259.0 \\
\hline
\end{tabular}

\section{Beta in Liquid Samples}

Acid Digestion

\begin{tabular}{|c|c|c|c|c|c|c|c|c|c|c|c|}
\hline \multicolumn{2}{|c|}{ SAMPLE INFORMATION } & \multicolumn{4}{|c|}{ SAMPLE RESULTS } & \multicolumn{6}{|c|}{ QUALITY CONTROL RESULTS } \\
\hline $\begin{array}{c}\text { Customer } \\
\text { Identification }\end{array}$ & $\begin{array}{l}\text { Laboratory } \\
\text { Identification }\end{array}$ & $\begin{array}{l}\text { Sample } \\
\text { Result } \\
\mu \mathrm{Ci} / \mathrm{mL}\end{array}$ & $\begin{array}{c}\text { Duplicate } \\
\text { Result } \\
\mu \mathrm{Ci} / \mathrm{mL}\end{array}$ & $\begin{array}{l}\text { Average } \\
\text { Result } \\
\mu \mathrm{Ci} / \mathrm{mL}\end{array}$ & $\begin{array}{c}\text { Sample } \\
\text { Precision } \\
\text { RPD } \\
\end{array}$ & $\begin{array}{c}\text { Standard } \\
\text { Recovery } \\
\%\end{array}$ & $\begin{array}{c}\text { Preparation } \\
\text { Blank } \\
\mu \mathrm{Ci} / \mathrm{mL}\end{array}$ & \begin{tabular}{|c|} 
Spike \\
Recovery \\
$\%$
\end{tabular} & $\begin{array}{c}\text { Spike } \\
\text { Duplicate } \\
\text { RPD }\end{array}$ & $\begin{array}{c}\text { Detection } \\
\text { Limit } \\
\mu \mathrm{Ci} / \mathrm{mL}\end{array}$ & $\begin{array}{c}\text { Counting } \\
\text { Error } \\
\%\end{array}$ \\
\hline B0066 & S95R000116 & $2.34 \mathrm{E}+02$ & $n / a$ & $n / a$ & $n / a$ & 100.0 & $<4.12 \mathrm{e}-02$ & 102.4 & 2.3 & $2.84 \mathrm{E}-02$ & 0.2 \\
\hline
\end{tabular}

\section{Am-241 by Extraction}

Acid Digestion

is

\begin{tabular}{|c|c|c|c|c|c|c|c|c|c|c|c|}
\hline \multicolumn{2}{|c|}{ SAMPLE INFORMATION } & \multicolumn{4}{|c|}{ SAMPLE RESULTS } & \multicolumn{6}{|c|}{ QUALITY CONTROL RESULTS } \\
\hline $\begin{array}{c}\text { Customer } \\
\text { Identification }\end{array}$ & $\begin{array}{l}\text { Laboratory } \\
\text { Identification }\end{array}$ & $\begin{array}{l}\text { Sample } \\
\text { Result } \\
\mu \mathrm{Ci} / \mathrm{mL}\end{array}$ & $\begin{array}{c}\text { Duplicate } \\
\text { Result } \\
\mu \mathrm{Ci} / \mathrm{mL}\end{array}$ & $\begin{array}{l}\text { Average } \\
\text { Result } \\
\mu \mathrm{Ci} / \mathrm{mL}\end{array}$ & \begin{tabular}{|c|} 
Sample \\
Precision \\
RPD
\end{tabular} & $\begin{array}{c}\text { Standard } \\
\text { Recovery } \\
\%\end{array}$ & $\begin{array}{c}\text { Preparation } \\
\text { Blank } \\
\mu \mathrm{Ci} / \mathrm{mL}\end{array}$ & \begin{tabular}{|c|} 
Spike \\
Recovery \\
$\%$
\end{tabular} & $\begin{array}{c}\text { Spike } \\
\text { Duplicate } \\
\text { RPD }\end{array}$ & $\begin{array}{c}\text { Detection } \\
\text { Limit } \\
\mu \mathrm{Ci} / \mathrm{mL}\end{array}$ & $\begin{array}{c}\text { Counting } \\
\text { Error } \\
\%\end{array}$ \\
\hline B0066 & $595 R 000116$ & $<2.28 \mathrm{E}-03$ & $\mathrm{n} / \mathrm{a}$ & $n / a$ & $\mathrm{n} / \mathrm{a}$ & 91.2 & $<2.22 \mathrm{E}-03$ & 91.5 & 0.7 & $2.28 \mathrm{E}-03$ & 100.0 \\
\hline
\end{tabular}

\section{Pu-239/240 by TRU-SPEC Resin}

Acid Digestion

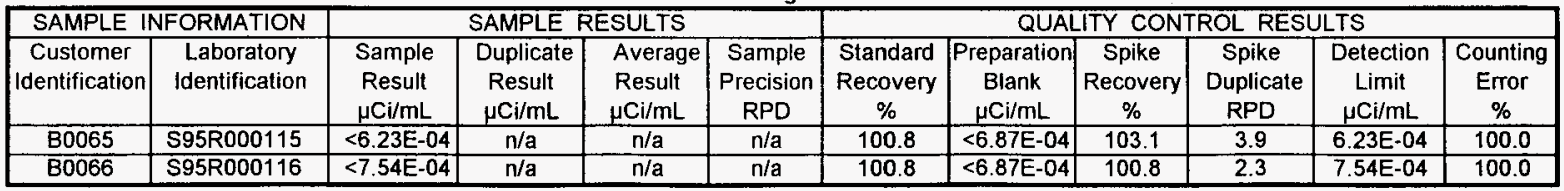


Strontium-89/90 High Level Acid Digestion

\begin{tabular}{|c|c|c|c|c|c|c|c|c|c|c|c|}
\hline \multicolumn{2}{|c|}{ SAMPLE INFORMATION } & \multicolumn{4}{|c|}{ SAMPLE RESULTS } & \multicolumn{6}{|c|}{ QUALITY CONTROL RESULTS } \\
\hline $\begin{array}{c}\text { Customer } \\
\text { Identification }\end{array}$ & $\begin{array}{l}\text { Laboratory } \\
\text { Identification }\end{array}$ & $\begin{array}{l}\text { Sample } \\
\text { Result } \\
\mu \mathrm{Ci} / \mathrm{mL}\end{array}$ & $\begin{array}{c}\text { Duplicate } \\
\text { Result } \\
\mu \mathrm{Ci} / \mathrm{mL}\end{array}$ & $\begin{array}{l}\text { Average } \\
\text { Result } \\
\mu \mathrm{Ci} / \mathrm{mL}\end{array}$ & $\begin{array}{c}\text { Sample } \\
\text { Precision } \\
\text { RPD }\end{array}$ & $\begin{array}{c}\text { Standard } \\
\text { Recovery } \\
\%\end{array}$ & $\begin{array}{c}\text { Preparation } \\
\text { Blank } \\
\mu \mathrm{Ci} / \mathrm{mL}\end{array}$ & $\begin{array}{c}\text { Spike } \\
\text { Recovery } \\
\%\end{array}$ & $\begin{array}{c}\text { Spike } \\
\text { Duplicate } \\
\text { RPD }\end{array}$ & $\begin{array}{c}\text { Detection } \\
\text { Limit } \\
\mu \mathrm{Ci} / \mathrm{mL}\end{array}$ & $\begin{array}{c}\text { Counting } \\
\text { Error } \\
\%\end{array}$ \\
\hline B0065 & S95R000115 & $2.67 \mathrm{E}+01$ & $\mathrm{n} / \mathrm{a}$ & $n / a$ & $\mathrm{n} / \mathrm{a}$ & 92.7 & $<1.20 \mathrm{E}-02$ & 118.5 & 20.2 & $1.34 \mathrm{E}-02$ & 0.9 \\
\hline $\mathrm{B} 0066$ & S95R000116 & $2.90 \mathrm{E}+01$ & $\mathrm{n} / \mathrm{a}$ & $\mathrm{n} / \mathrm{a}$ & $\mathrm{n} / \mathrm{a}$ & 92.7 & $<1.20 E-02$ & 87.9 & 13.7 & $1.34 E-02$ & 0.8 \\
\hline
\end{tabular}

\section{Cesium- 137 by GEA}

Direct Analysis

\begin{tabular}{|c|c|c|c|c|c|c|c|c|c|c|}
\hline \multicolumn{2}{|c|}{ SAMPLE INFORMATION } & \multicolumn{4}{|c|}{ SAMPLE RESULTS } & \multicolumn{5}{|c|}{ QUALITY CONTROL RESULTS } \\
\hline $\begin{array}{c}\text { Customer } \\
\text { Identification }\end{array}$ & $\begin{array}{l}\text { Laboratory } \\
\text { Identification }\end{array}$ & $\begin{array}{c}\text { Sample } \\
\text { Resuit } \\
\mu \mathrm{Ci} / \mathrm{mL}\end{array}$ & $\begin{array}{c}\text { Duplicate } \\
\text { Result } \\
\mu \mathrm{Ci} / \mathrm{mL}\end{array}$ & $\begin{array}{l}\text { Average } \\
\text { Result } \\
\mu \mathrm{Ci} / \mathrm{mL}\end{array}$ & $\begin{array}{c}\text { Sample } \\
\text { Precision } \\
\text { RPD } \\
\end{array}$ & $\begin{array}{c}\text { Standard } \\
\text { Recovery } \\
\% \\
\end{array}$ & $\begin{array}{c}\text { Reagent } \\
\text { Blank } \\
\mu \mathrm{Ci} / \mathrm{mL}\end{array}$ & $\begin{array}{c}\text { Spike } \\
\text { Recovery } \\
\% \\
\end{array}$ & $\begin{array}{c}\text { Detection } \\
\text { Limit } \\
\mu \mathrm{Ci} / \mathrm{mL} \\
\end{array}$ & $\begin{array}{c}\text { Counting } \\
\text { Error } \\
\%\end{array}$ \\
\hline $\mathrm{B} 0065$ & S96R000041 & $1.52 E+02$ & $1.69 \mathrm{E}+02$ & $1.61 \mathrm{E}+02$ & 10.6 & 96.2 & $<7.22 \mathrm{E}-03$ & $n / a$ & $7.00 \mathrm{E}-03$ & 0.2 \\
\hline B0066 & S96R000042 & $1.55 E+02$ & $1.55 \mathrm{E}+02$ & $1.55 \mathrm{E}+02$ & 0.0 & 96.2 & $<7.22 \mathrm{E}-03$ & $\mathrm{n} / \mathrm{a}$ & $7.00 \mathrm{E}-03$ & 0.2 \\
\hline
\end{tabular}

\section{Uranium by Phosphorescence}

Direct Analysis

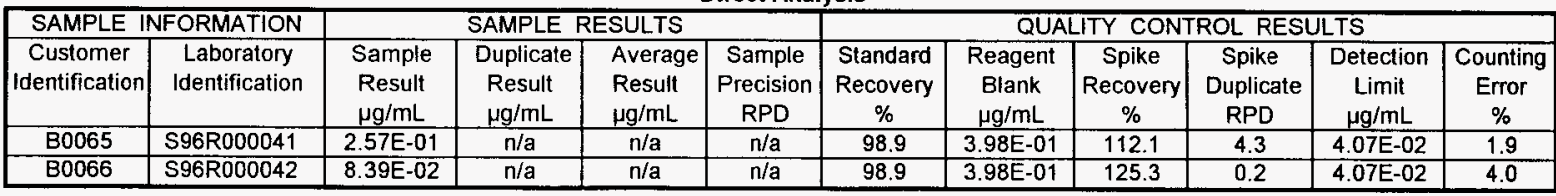


Silver -JCP-Acid Digest-Liquid Acid Digestion

\begin{tabular}{|c|c|c|c|c|c|c|c|c|c|c|}
\hline \multicolumn{2}{|c|}{ SAMPLE INFORMATION } & \multicolumn{4}{|c|}{ SAMPLE RESULTS } & \multicolumn{5}{|c|}{ QUALITY CONTROL RESULTS } \\
\hline $\begin{array}{c}\text { Customer } \\
\text { Identification }\end{array}$ & $\begin{array}{c}\text { Laboratory } \\
\text { Identification }\end{array}$ & $\begin{array}{l}\text { Sample } \\
\text { Result } \\
\text { yg/mL }\end{array}$ & $\begin{array}{c}\text { Duplicate } \\
\text { Result } \\
\mu \mathrm{g} / \mathrm{mL}\end{array}$ & $\begin{array}{l}\text { Average } \\
\text { Result } \\
\mu \mathrm{g} / \mathrm{mL}\end{array}$ & $\begin{array}{c}\text { Sample } \\
\text { Precision } \\
\text { RPD }\end{array}$ & $\begin{array}{c}\text { Standard } \\
\text { Recovery } \\
\%\end{array}$ & $\begin{array}{c}\text { Preparation } \\
\text { Blank } \\
\mu \mathrm{g} / \mathrm{mL}\end{array}$ & \begin{tabular}{|c|} 
Spike \\
Recovery \\
$\%$
\end{tabular} & $\begin{array}{c}\text { Detection } \\
\text { Limit } \\
\mu \mathrm{g} / \mathrm{mL}\end{array}$ & $\begin{array}{c}\text { Counting } \\
\text { Error } \\
\%\end{array}$ \\
\hline B0065 & S95R000115 & $2.04 \mathrm{E}+01$ & $2.08 \mathrm{E}+01$ & $2.06 E+01$ & 1.9 & 98.3 & $<1.00 \mathrm{E}-02$ & 94.6 & $1.00 \mathrm{E}-04$ & $n / a$ \\
\hline B0066 & S95R000116 & $1.94 E+01$ & $1.99 \mathrm{E}+01$ & $1.97 \mathrm{E}+01$ & 2.5 & 98.3 & $<1.00 \mathrm{E}-02$ & $n / a$ & $1.00 \mathrm{E}-04$ & $n / a$ \\
\hline
\end{tabular}

Aluminium -ICP-Acid Digest-Liq Acid Digestion

\begin{tabular}{|c|c|c|c|c|c|c|c|c|c|c|}
\hline \multicolumn{2}{|c|}{ SAMPLE INFORMATION } & \multicolumn{4}{|c|}{ SAMPLE RESULTS } & \multicolumn{5}{|c|}{ QUALITY CONTROL RESULTS } \\
\hline $\begin{array}{c}\text { Customer } \\
\text { Identification }\end{array}$ & $\begin{array}{l}\text { Laboratory } \\
\text { Identification }\end{array}$ & $\begin{array}{l}\text { Sample } \\
\text { Result } \\
\mu \mathrm{g} / \mathrm{mL}\end{array}$ & $\begin{array}{c}\text { Duplicate } \\
\text { Result } \\
\mu \mathrm{g} / \mathrm{mL}\end{array}$ & $\begin{array}{l}\text { Average } \\
\text { Result } \\
\mu g / \mathrm{mL}\end{array}$ & $\begin{array}{c}\text { Sample } \\
\text { Precision } \\
\text { RPD } \\
\end{array}$ & $\begin{array}{c}\text { Standard } \\
\text { Recovery } \\
\%\end{array}$ & $\begin{array}{c}\text { Preparation } \\
\text { Blank } \\
\mu \mathrm{g} / \mathrm{mL} \\
\end{array}$ & \begin{tabular}{|c|} 
Spike \\
Recovery \\
$\%$
\end{tabular} & $\begin{array}{c}\text { Detection } \\
\text { Limit } \\
\mu \mathrm{g} / \mathrm{mL}\end{array}$ & $\begin{array}{c}\text { Counting } \\
\text { Error } \\
\%\end{array}$ \\
\hline $\mathrm{B} 0065$ & S95R000115 & $3.20 \mathrm{E}-01$ & $2.33 E-01$ & 2.77E-01 & 31.5 & 104.0 & $<5.00 \mathrm{E}-02$ & 98.5 & $5.00 \mathrm{E}-04$ & $\mathrm{n} / \mathrm{a}$ \\
\hline B0066 & S95R000116 & $<5.00 \mathrm{E}-04$ & $8.03 E-01$ & $n / a$ & $n / a$ & 104.0 & $<5.00 \mathrm{E}-02$ & $\mathrm{n} / \mathrm{a}$ & $5.00 \mathrm{E}-04$ & $n / a$ \\
\hline
\end{tabular}

Cadmium -ICP-Acid Digest-Liq Acid Digestion

\begin{tabular}{|c|c|c|c|c|c|c|c|c|c|c|}
\hline \multicolumn{2}{|c|}{ SAMPLE INFORMATION } & \multicolumn{4}{|c|}{ SAMPLE RESULTS } & \multicolumn{5}{|c|}{ QUALITY CONTROL RESULTS } \\
\hline $\begin{array}{c}\text { Customer } \\
\text { Identification }\end{array}$ & $\begin{array}{l}\text { Laboratory } \\
\text { Identification }\end{array}$ & $\begin{array}{c}\text { Sample } \\
\text { Result } \\
\mu g / m L\end{array}$ & $\begin{array}{c}\text { Duplicate } \\
\text { Result } \\
\mu \mathrm{g} / \mathrm{mL}\end{array}$ & $\begin{array}{l}\text { Average } \\
\text { Result } \\
\mu \mathrm{g} / \mathrm{mL}\end{array}$ & $\begin{array}{c}\text { Sample } \\
\text { Precision } \\
\text { RPD }\end{array}$ & $\begin{array}{c}\text { Standard } \\
\text { Recovery } \\
\%\end{array}$ & $\begin{array}{c}\text { Preparation } \\
\text { Blank } \\
\mu \mathrm{g} / \mathrm{mL}\end{array}$ & $\begin{array}{c}\text { Spike } \\
\text { Recovery } \\
\%\end{array}$ & $\begin{array}{c}\text { Detection } \\
\text { Limit } \\
\mu \mathrm{g} / \mathrm{mL}\end{array}$ & $\begin{array}{c}\text { Counting } \\
\text { Error } \\
\%\end{array}$ \\
\hline$\overline{B 0065}$ & S95R000115 & $1.47 \mathrm{E}-01$ & $4.00 \mathrm{E}-02$ & $9.35 E-02$ & 114.0 & 100.6 & $<5.00 \mathrm{E}-03$ & 96.0 & $5.00 \mathrm{E}-05$ & $\mathrm{n} / \mathrm{a}$ \\
\hline B0066 & S95R000116 & $2.07 E-01$ & $1.17 \mathrm{E}-01$ & $1.62 \mathrm{E}-01$ & 55.6 & 100.6 & $<5.00 \mathrm{E}-03$ & $n / a$ & $5.00 \mathrm{E}-05$ & $n / a$ \\
\hline
\end{tabular}


B Plant, Tank 25-2

Chromium -iCF-Acid Digest-Liq Acid Digestion

\begin{tabular}{|c|c|c|c|c|c|c|c|c|c|c|}
\hline \multicolumn{2}{|c|}{ SAMPLE INFORMATION } & \multicolumn{4}{|c|}{ SAMPLE RESULTS } & \multicolumn{5}{|c|}{ QUALITY CONTROL RESULTS } \\
\hline $\begin{array}{c}\text { Customer } \\
\text { Identification }\end{array}$ & $\begin{array}{c}\text { Laboratory } \\
\text { Identification }\end{array}$ & $\begin{array}{c}\text { Sample } \\
\text { Result } \\
\mu \mathrm{g} / \mathrm{mL}\end{array}$ & $\begin{array}{c}\text { Duplicate } \\
\text { Result } \\
\mu \mathrm{g} / \mathrm{mL}\end{array}$ & $\begin{array}{l}\text { Average } \\
\text { Result } \\
\mu \mathrm{g} / \mathrm{mL}\end{array}$ & $\begin{array}{c}\text { Sample } \\
\text { Precision } \\
\text { RPD }\end{array}$ & $\begin{array}{c}\text { Standard } \\
\text { Recovery } \\
\%\end{array}$ & \begin{tabular}{|c|} 
Preparation \\
Blank \\
$\mu \mathrm{g} / \mathrm{mL}$
\end{tabular} & \begin{tabular}{|c|} 
Spike \\
Recovery \\
$\%$ \\
\end{tabular} & $\begin{array}{c}\text { Detection } \\
\text { Limit } \\
\mu \mathrm{g} / \mathrm{mL}\end{array}$ & $\begin{array}{c}\text { Counting } \\
\text { Error } \\
\%\end{array}$ \\
\hline B0065 & S95R000115 & $1.94 \mathrm{E}+00$ & $1.74 \mathrm{E}+00$ & $1.84 \mathrm{E}+00$ & 10.9 & 102.4 & $<1.00 \mathrm{E}-02$ & 97.6 & 1.00 E-04 & $n / a$ \\
\hline 80066 & S95R000116 & $1.87 \mathrm{E}+00$ & $1.81 \mathrm{E}+00$ & $1.84 \mathrm{E}+00$ & 3.3 & 102.4 & $<1.00 \mathrm{E}-02$ & $\mathrm{n} / \mathrm{a}$ & $1.00 \mathrm{E}-04$ & $n / a$ \\
\hline
\end{tabular}

Iron -ICP-Acid Digest-Liquid

Acid Digestion

\begin{tabular}{|c|c|c|c|c|c|c|c|c|c|c|}
\hline \multicolumn{2}{|c|}{ SAMPLE INFORMATION } & \multicolumn{4}{|c|}{ SAMPLE RESULTS } & \multicolumn{5}{|c|}{ QUALITY CONTROL RESULTS } \\
\hline $\begin{array}{l}\text { Customer } \\
\text { Identification }\end{array}$ & $\begin{array}{c}\text { Laboratory } \\
\text { Identification }\end{array}$ & $\begin{array}{c}\text { Sample } \\
\text { Result } \\
\mu \mathrm{g} / \mathrm{mL}\end{array}$ & $\begin{array}{c}\text { Duplicate } \\
\text { Result } \\
\mu \mathrm{g} / \mathrm{mL}\end{array}$ & $\begin{array}{l}\text { Average } \\
\text { Result } \\
\mu \mathrm{g} / \mathrm{mL}\end{array}$ & $\begin{array}{c}\text { Sample } \\
\text { Precision } \\
\text { RPD }\end{array}$ & $\begin{array}{c}\text { Standard } \\
\text { Recovery } \\
\%\end{array}$ & \begin{tabular}{|c|} 
Preparation \\
Blank \\
$\mu \mathrm{g} / \mathrm{mL}$
\end{tabular} & $\begin{array}{c}\text { Spike } \\
\text { Recovery } \\
\%\end{array}$ & $\begin{array}{c}\text { Detection } \\
\text { Limit } \\
\mu \mathrm{g} / \mathrm{mL}\end{array}$ & $\begin{array}{c}\text { Counting } \\
\text { Error } \\
\%\end{array}$ \\
\hline B0065 & S95R000115 & $2.47 \mathrm{E}+00$ & $3.20 \mathrm{E}+00$ & $2.84 E+00$ & 25.7 & 103.0 & $<5.00 \mathrm{E}-02$ & 98.3 & $5.00 E-04$ & $n / a$ \\
\hline B0066 & S95R000116 & $2.74 \mathrm{E}+00$ & $3.61 E+00$ & $3.18 \mathrm{E}+00$ & 27.4 & 103.0 & $<5.00 \mathrm{E}-02$ & $n / a$ & $5.00 \mathrm{E}-04$ & $n / a$ \\
\hline
\end{tabular}

Sodium -ICP-Acid Digest-Liquid

Acid Digestion

\begin{tabular}{|c|c|c|c|c|c|c|c|c|c|c|}
\hline \multicolumn{2}{|c|}{ SAMPLE INFORMATION } & \multicolumn{4}{|c|}{ SAMPLE RESULTS } & \multicolumn{5}{|c|}{ QUALITY CONTROL RESULTS } \\
\hline $\begin{array}{c}\text { Customer } \\
\text { Identification }\end{array}$ & $\begin{array}{l}\text { Laboratory } \\
\text { Identification }\end{array}$ & $\begin{array}{l}\text { Sample } \\
\text { Result } \\
\mu \mathrm{g} / \mathrm{mL}\end{array}$ & $\begin{array}{c}\text { Duplicate } \\
\text { Result } \\
\mu \mathrm{g} / \mathrm{mL}\end{array}$ & $\begin{array}{l}\text { Average } \\
\text { Result } \\
\mu \mathrm{g} / \mathrm{mL}\end{array}$ & $\begin{array}{c}\text { Sample } \\
\text { Precision } \\
\text { RPD }\end{array}$ & $\begin{array}{c}\text { Standard } \\
\text { Recovery } \\
\%\end{array}$ & $\begin{array}{c}\text { Preparation } \\
\text { Blank } \\
\mu \mathrm{g} / \mathrm{mL}\end{array}$ & $\begin{array}{c}\text { Spike } \\
\text { Recovery } \\
\%\end{array}$ & $\begin{array}{c}\text { Detection } \\
\text { Limit } \\
\mu \mathrm{g} / \mathrm{mL}\end{array}$ & $\begin{array}{c}\quad \text { Serial } \\
\text { Dilution } \\
\% \text { Difference }\end{array}$ \\
\hline B0065 & S95R000115 & $1.66 \mathrm{E}+04$ & $1.70 E+04$ & $1.68 \mathrm{E}+04$ & 2.4 & 108.9 & 1.47E-01 & 189.6 & $1.00 \mathrm{E}-03$ & $12 . \overline{6}$ \\
\hline B0066 & S95R000116 & $1.66 \mathrm{E}+04$ & $1.66 \mathrm{E}+04$ & $1.66 \mathrm{E}+04$ & 0.0 & 408.9 & 1.47E-01 & $\overline{n / a}$ & $1.00 \mathrm{E}-03$ & 8.8 \\
\hline
\end{tabular}


Nickel -ICP-Acid Digest-Liquid Acid Digestion

\begin{tabular}{|c|c|c|c|c|c|c|c|c|c|c|}
\hline \multicolumn{2}{|c|}{ SAMPLE INFORMATION } & \multicolumn{4}{|c|}{ SAMPLE RESULTS } & \multicolumn{5}{|c|}{ QUALITY CONTROL RESULTS } \\
\hline $\begin{array}{l}\text { Customer } \\
\text { Identification }\end{array}$ & $\begin{array}{c}\text { Laboratory } \\
\text { Identification }\end{array}$ & $\begin{array}{l}\text { Sample } \\
\text { Result } \\
\mu \mathrm{g} / \mathrm{mL}\end{array}$ & $\begin{array}{c}\text { Duplicate } \\
\text { Result } \\
\mu \mathrm{g} / \mathrm{mL}\end{array}$ & $\begin{array}{l}\text { Áverage } \\
\text { Result } \\
\mu \mathrm{g} / \mathrm{mL}\end{array}$ & \begin{tabular}{|c|} 
Sample \\
Precision \\
RPD
\end{tabular} & $\begin{array}{c}\text { Standard } \\
\text { Recovery } \\
\%\end{array}$ & $\begin{array}{c}\text { Preparation } \\
\text { Blank } \\
\mu \mathrm{g} / \mathrm{mL}\end{array}$ & \begin{tabular}{|c|} 
Spike \\
Recovery \\
$\%$
\end{tabular} & $\begin{array}{c}\text { Detection } \\
\text { Limit } \\
\mu \mathrm{g} / \mathrm{mL}\end{array}$ & $\begin{array}{c}\text { Counting } \\
\text { Error } \\
\%\end{array}$ \\
\hline 80065 & S95R000115 & $8.39 E+00$ & $8.69 E+00$ & $8.54 \mathrm{E}+00$ & 3.5 & 103.0 & $<2.00 \mathrm{E}-02$ & 98.1 & $2.00 \mathrm{E}-04$ & $\mathrm{n} / \mathrm{a}$ \\
\hline B0066 & S95R 000116 & $7.66 \mathrm{E}+00$ & $8.48 \mathrm{E}+00$ & $8.07 E+00$ & 10.2 & 103.0 & $<2.00 \mathrm{E}-02$ & $n / a$ & $2.00 \mathrm{E}-04$ & $\mathrm{n} / \mathrm{a}$ \\
\hline
\end{tabular}

(3)

4

Lead -ICP-Acid Digest-Liquid Acid Digestion

\begin{tabular}{|c|c|c|c|c|c|c|c|c|c|c|}
\hline \multicolumn{2}{|c|}{ SAMPLE INFORMATION } & \multicolumn{4}{|c|}{ SAMPLE RESULTS } & \multicolumn{5}{|c|}{ QUALITY CONTROL RESULTS } \\
\hline $\begin{array}{c}\text { Customer } \\
\text { Identification }\end{array}$ & $\begin{array}{l}\text { Laboratory } \\
\text { Identification }\end{array}$ & $\begin{array}{l}\text { Sample } \\
\text { Result } \\
\mu \mathrm{g} / \mathrm{mL}\end{array}$ & $\begin{array}{c}\text { Duplicate } \\
\text { Result } \\
\mu \mathrm{g} / \mathrm{mL}\end{array}$ & $\begin{array}{l}\text { Average } \\
\text { Result } \\
\mu \mathrm{g} / \mathrm{mL}\end{array}$ & $\begin{array}{c}\text { Sample } \\
\text { Precision } \\
\text { RPD }\end{array}$ & $\begin{array}{c}\text { Standard } \\
\text { Recovery } \\
\%\end{array}$ & \begin{tabular}{|c|} 
Preparation \\
Blank \\
$\mu \mathrm{g} / \mathrm{mL}$
\end{tabular} & \begin{tabular}{|c|} 
Spike \\
Recovery \\
$\%$
\end{tabular} & $\begin{array}{c}\text { Detection } \\
\text { Limit } \\
\mu \mathrm{g} / \mathrm{mL}\end{array}$ & $\begin{array}{c}\text { Counting } \\
\text { Error } \\
\%\end{array}$ \\
\hline B0065 & S95R000115 & $1.05 \mathrm{E}+00$ & $9.30 \mathrm{E}-01$ & $9.90 \mathrm{E}-01$ & 12.1 & 101.4 & \begin{tabular}{|l|}
$<1.00 \mathrm{E}-01$ \\
\end{tabular} & 96.8 & $1.00 \mathrm{E}-03$ & $n / a$ \\
\hline B0066 & S95R000116 & $<1.00 \mathrm{E}-03$ & $2.28 E+00$ & $\mathrm{n} / \mathrm{a}$ & $\mathrm{n} / \mathrm{a}$ & 101.4 & $<1.00 \mathrm{E}-01$ & $\mathrm{n} / \mathrm{a}$ & $1.00 \mathrm{E}-03$ & $n / a$ \\
\hline
\end{tabular}




\section{B Plant, Tank 25-2}

DSC Exotherm on Perkin Elmer Direct Analysis

\begin{tabular}{|c|c|c|c|c|c|c|c|c|c|c|}
\hline \multicolumn{2}{|c|}{ SAMPLE INFORMATION } & \multicolumn{4}{|c|}{ SAMPLE RESULTS } & \multicolumn{4}{c|}{ QUALITY CONTROL RESULTS } \\
\hline $\begin{array}{c}\text { Customer } \\
\text { Identification }\end{array}$ & $\begin{array}{c}\text { Laboratory } \\
\text { Identification }\end{array}$ & $\begin{array}{c}\text { Sample } \\
\text { Result } \\
\text { Joules/g }\end{array}$ & $\begin{array}{c}\text { Duplicate } \\
\text { Result } \\
\text { Joules/g } / g\end{array}$ & $\begin{array}{c}\text { Average } \\
\text { Result } \\
\text { Joules/g }\end{array}$ & $\begin{array}{c}\text { Sample } \\
\text { Precision } \\
\text { RPD }\end{array}$ & $\begin{array}{c}\text { Standard } \\
\text { Recovery } \\
\%\end{array}$ & $\begin{array}{c}\text { Reagent } \\
\text { Blank } \\
\text { Joules/g }\end{array}$ & $\begin{array}{c}\text { Spike } \\
\text { Recovery } \\
\%\end{array}$ & $\begin{array}{c}\text { Detection } \\
\text { Limit } \\
\text { Joules/g } / g\end{array}$ & $\begin{array}{c}\text { Counting } \\
\text { Error } \\
\%\end{array}$ \\
\hline B0065 & S96R000041 & $0.00 \mathrm{E}+00$ & $0.00 E+00$ & $0.00 \mathrm{E}+00$ & 0.00 & 92.8 & $\mathrm{n} / \mathrm{a}$ & $\mathrm{n} / \mathrm{a}$ & $\mathrm{n} / \mathrm{a}$ & $\mathrm{n} / \mathrm{a}$ \\
\hline B0066 & S96R000042 & $0.00 \mathrm{E}+00$ & $0.00 \mathrm{E}+00$ & $0.00 \mathrm{E}+00$ & 0.00 & 92.8 & $\mathrm{n} / \mathrm{a}$ & $\mathrm{n} / \mathrm{a}$ & $\mathrm{n} / \mathrm{a}$ & $\mathrm{n} / \mathrm{a}$ \\
\hline
\end{tabular}

$\%$ Water by TGA on Perkin Elmer Direct Anaiysis

\begin{tabular}{c|c|c|c|c|c|c|c|c|c|c|c|}
\hline \multicolumn{2}{|c|}{ SAMPLE INFORMATION } & \multicolumn{4}{c|}{ SAMPLE RESULTS } & \multicolumn{4}{c|}{ QUALITY CONTROL RESULTS } \\
\hline $\begin{array}{c}\text { Customer } \\
\text { Identification }\end{array}$ & Laboratory \\
Identification & $\begin{array}{c}\text { Sample } \\
\text { Result } \\
\%\end{array}$ & $\begin{array}{c}\text { Duplicate } \\
\text { Result } \\
\%\end{array}$ & $\begin{array}{c}\text { Average } \\
\text { Result } \\
\%\end{array}$ & $\begin{array}{c}\text { Sample } \\
\text { Precision } \\
\text { RPD }\end{array}$ & $\begin{array}{c}\text { Standard } \\
\text { Recovery } \\
\%\end{array}$ & $\begin{array}{c}\text { Reagent } \\
\text { Blank } \\
\%\end{array}$ & $\begin{array}{c}\text { Spike } \\
\text { Recovery } \\
\%\end{array}$ & $\begin{array}{c}\text { Detection } \\
\text { Limit } \\
\%\end{array}$ & $\begin{array}{c}\text { Counting } \\
\text { Error } \\
\%\end{array}$ \\
\hline B0065 & S96R000041 & 93.4 & 93.2 & 93.3 & 0.2 & 101.5 & $\mathrm{n} / \mathrm{a}$ & $\mathrm{n} / \mathrm{a}$ & $\mathrm{n} / \mathrm{a}$ & $\mathrm{n} / \mathrm{a}$ \\
\hline B0066 & S96R000042 & 93.3 & 91.8 & 92.6 & 1.6 & 101.5 & $\mathrm{n} / \mathrm{a}$ & $\mathrm{n} / \mathrm{a}$ & $\mathrm{n} / \mathrm{a}$ & $\mathrm{n} / \mathrm{a}$ \\
\hline
\end{tabular}

\begin{tabular}{|c|c|c|c|c|c|c|c|c|c|c|}
\hline \multicolumn{11}{|c|}{$\begin{array}{l}\text { Volume \% Solids } \\
\text { Direct Analysis }\end{array}$} \\
\hline SAMPLE IN & IFORMATION & \multicolumn{4}{|c|}{ SAMPLE RESULTS } & \multicolumn{5}{|c|}{ QUALITY CONTROL RESULTS } \\
\hline \begin{tabular}{c|} 
Customer \\
Identification
\end{tabular} & $\begin{array}{c}\text { Laboratory } \\
\text { Identification }\end{array}$ & $\begin{array}{c}\text { Sample } \\
\text { Result } \\
\%\end{array}$ & $\begin{array}{c}\text { Duplicate } \\
\text { Result } \\
\%\end{array}$ & $\begin{array}{c}\text { Average } \\
\text { Result } \\
\%\end{array}$ & $\begin{array}{c}\text { Sample } \\
\text { Precision } \\
\text { RPD } \\
\end{array}$ & $\begin{array}{c}\text { Standard } \\
\text { Recovery } \\
\%\end{array}$ & $\begin{array}{c}\text { Reagent } \\
\text { Blank } \\
\% \\
\end{array}$ & $\begin{array}{c}\text { Spike } \\
\text { Recovery } \\
\%\end{array}$ & $\begin{array}{c}\text { Detection } \\
\text { Limit } \\
\% \\
\end{array}$ & $\begin{array}{c}\text { Counting } \\
\text { Error } \\
\%\end{array}$ \\
\hline B0065 & S95R000113 & $<2$ & $\mathrm{n} / \mathrm{a}$ & n/a & $n / a$ & $n / a$ & $n / a$ & $\mathrm{n} / \mathrm{a}$ & $n / a$ & $n / a$ \\
\hline B0066 & S95R000114 & $<2$ & $n / a$ & $\mathrm{n} / \mathrm{a}$ & $n / a$ & $\mathrm{n} / \mathrm{a}$ & $\mathrm{n} / \mathrm{a}$ & $\mathrm{n} / \mathrm{a}$ & $\mathrm{n} / \mathrm{a}$ & $\mathrm{n} / \mathrm{a}$ \\
\hline
\end{tabular}


B Plant, Tank 25-2

Specific Gravity

Direct Analysis

39

\begin{tabular}{|c|c|c|c|c|c|c|c|c|c|c|}
\hline \multicolumn{2}{|c|}{ SAMPLE INFORMATION } & \multicolumn{4}{|c|}{ SAMPLE RESULTS } & \multicolumn{5}{|c|}{ QUALITY CONTROL RESULTS } \\
\hline \begin{tabular}{|c|} 
Customer \\
Identification
\end{tabular} & $\begin{array}{c}\text { Laboratory } \\
\text { Identification }\end{array}$ & $\begin{array}{l}\text { Sample } \\
\text { Result } \\
\text { Sp.G. }\end{array}$ & $\begin{array}{l}\text { Duplicate } \\
\text { Result } \\
\text { Sp.G. }\end{array}$ & $\begin{array}{l}\text { Average } \\
\text { Result } \\
\text { Sp.G. }\end{array}$ & \begin{tabular}{|c|} 
Sample \\
Precision \\
RPD
\end{tabular} & $\begin{array}{c}\text { Standard } \\
\text { Recovery } \\
\%\end{array}$ & $\begin{array}{l}\text { Reagent } \\
\text { Blank } \\
\text { Sp.G. }\end{array}$ & $\begin{array}{c}\text { Spike } \\
\text { Recovery } \\
\%\end{array}$ & $\begin{array}{c}\text { Detection } \\
\text { Limit } \\
\text { Sp.G. }\end{array}$ & $\begin{array}{c}\text { Counting } \\
\text { Error } \\
\%\end{array}$ \\
\hline B0065 & S96R000041 & 1.021 & 1.027 & 1.024 & 0.59 & 97.7 & $n / a$ & $\mathrm{n} / \mathrm{a}$ & $1.00 \mathrm{E}-03$ & $n / a$ \\
\hline B0066 & S96R000042 & 1.016 & 1.019 & 1.018 & 0.29 & 97.7 & $n / a$ & $\mathrm{n} / \mathrm{a}$ & $1.00 \mathrm{E}-03$ & $n / a$ \\
\hline
\end{tabular}


Sulfate by IC-Dionex4000i/4500 Direct Analysis

\begin{tabular}{|c|c|c|c|c|c|c|c|c|c|c|}
\hline \multicolumn{2}{|c|}{ SAMPLE INFORMATION } & \multicolumn{4}{|c|}{ SAMPLE RESULTS } & \multicolumn{5}{|c|}{ QUALITY CONTROL RESULTS } \\
\hline $\begin{array}{c}\text { Customer } \\
\text { Identification }\end{array}$ & $\begin{array}{c}\text { Laboratory } \\
\text { Identification }\end{array}$ & $\begin{array}{l}\text { Sample } \\
\text { Result } \\
\mu \mathrm{g} / \mathrm{mL}\end{array}$ & $\begin{array}{c}\text { Duplicate } \\
\text { Result } \\
\mu \mathrm{g} / \mathrm{mL}\end{array}$ & $\begin{array}{l}\text { Average } \\
\text { Result } \\
\mu \mathrm{g} / \mathrm{mL}\end{array}$ & $\begin{array}{c}\text { Sample } \\
\text { Precision } \\
\text { RPD }\end{array}$ & $\begin{array}{c}\text { Standard } \\
\text { Recovery } \\
\%\end{array}$ & $\begin{array}{c}\text { Reagent } \\
\text { Blank } \\
\mu \mathrm{g} / \mathrm{mL}\end{array}$ & $\begin{array}{c}\text { Spike } \\
\text { Recovery } \\
\%\end{array}$ & $\begin{array}{l}\text { Spike } \\
\text { Duplicate } \\
\text { RPD }\end{array}$ & $\begin{array}{c}\text { Detection } \\
\text { Limit } \\
\mu \mathrm{g} / \mathrm{mL}\end{array}$ \\
\hline $\mathrm{B} 0065$ & S96R000071 & $3.85 E+02$ & $\mathrm{n} / \mathrm{a}$ & $n / a$ & $n / a$ & 93.5 & $1.43 \mathrm{E}-01$ & 91.1 & 3.6 & $2.89 E+02$ \\
\hline $\mathrm{B} 0066$ & S96R000072 & $4.12 \mathrm{E}+02$ & $\mathrm{n} / \mathrm{a}$ & $n / a$ & $n / a$ & 93.5 & $1.43 \mathrm{E}-01$ & 90.9 & 0.1 & $2.89 E+02$ \\
\hline
\end{tabular}

Phosphate-IC-Dionex 4000i/4500

Direct Analysis

\begin{tabular}{c|c|c|c|c|c|c|c|c|c|c|}
\hline \multicolumn{2}{|c|}{ SAMPLE INFORMATION } & \multicolumn{3}{c|}{ SAMPLE RESULTS } & \multicolumn{4}{c|}{ QUALITY CONTROL RESULTS } \\
\hline $\begin{array}{c}\text { Customer } \\
\text { Identification }\end{array}$ & $\begin{array}{c}\text { Laboratory } \\
\text { Identification }\end{array}$ & $\begin{array}{c}\text { Sample } \\
\text { Result } \\
\mu \mathrm{g} / \mathrm{mL}\end{array}$ & $\begin{array}{c}\text { Duplicate } \\
\text { Result } \\
\mu \mathrm{g} / \mathrm{mL}\end{array}$ & $\begin{array}{c}\text { Average } \\
\text { Result } \\
\mu \mathrm{g} / \mathrm{mL}\end{array}$ & $\begin{array}{c}\text { Sample } \\
\text { Precision } \\
\mathrm{RPD}\end{array}$ & $\begin{array}{c}\text { Standard } \\
\text { Recovery } \\
\%\end{array}$ & $\begin{array}{c}\text { Reagent } \\
\text { Blank } \\
\mu \mathrm{g} / \mathrm{mL}\end{array}$ & $\begin{array}{c}\text { Spike } \\
\text { Recovery } \\
\%\end{array}$ & $\begin{array}{c}\text { Spike } \\
\text { Duplicate } \\
\mathrm{RPD}\end{array}$ & $\begin{array}{c}\text { Detection } \\
\text { Limit } \\
\mu \mathrm{m} / \mathrm{mL}\end{array}$ \\
\hline $\mathrm{B} 0065$ & $\mathrm{~S} 96 \mathrm{R} 000071$ & $1.31 \mathrm{E}+03$ & $\mathrm{n} / \mathrm{a}$ & $\mathrm{n} / \mathrm{a}$ & $\mathrm{n} / \mathrm{a}$ & 96.2 & $2.11 \mathrm{E}-01$ & 91.4 & 4.1 & $2.55 \mathrm{E}+02$ \\
\hline $\mathrm{B} 0066$ & $\mathrm{~S} 96 \mathrm{R} 000072$ & $1.10 \mathrm{E}+03$ & $\mathrm{n} / \mathrm{a}$ & $\mathrm{n} / \mathrm{a}$ & $\mathrm{n} / \mathrm{a}$ & 96.2 & $2.11 \mathrm{E}-01$ & 93.4 & 0.0 & $2.55 \mathrm{E}+02$ \\
\hline
\end{tabular}

Nitrate-IC - Dionex 4000i/4500

Direct Analysis

\begin{tabular}{|c|c|c|c|c|c|c|c|c|c|c|}
\hline \multicolumn{2}{|c|}{ SAMPLE INFORMATION } & \multicolumn{4}{|c|}{ SAMPLE RESULTS } & \multicolumn{5}{|c|}{ QUALITY CONTROL RESULTS } \\
\hline $\begin{array}{c}\text { Customer } \\
\text { identification }\end{array}$ & $\begin{array}{c}\text { Laboratory } \\
\text { Identification }\end{array}$ & $\begin{array}{l}\text { Sample } \\
\text { Result } \\
\mu \mathrm{g} / \mathrm{mL}\end{array}$ & $\begin{array}{c}\text { Duplicate } \\
\text { Result } \\
\mu \mathrm{g} / \mathrm{mL}\end{array}$ & $\begin{array}{l}\text { Average } \\
\text { Resułt } \\
\mu \mathrm{g} / \mathrm{mL}\end{array}$ & $\begin{array}{c}\text { Sample } \\
\text { Precision } \\
\text { RPD }\end{array}$ & $\begin{array}{c}\text { Standard } \\
\text { Recovery } \\
\% \\
\end{array}$ & $\begin{array}{c}\text { Reagent } \\
\text { Blank } \\
\mu \mathrm{g} / \mathrm{mL}\end{array}$ & $\begin{array}{c}\text { Spike } \\
\text { Recovery } \\
\%\end{array}$ & $\begin{array}{c}\text { Spike } \\
\text { Duplicate } \\
\text { RPD }\end{array}$ & $\begin{array}{c}\text { Detection } \\
\text { Limit } \\
\mu \mathrm{g} / \mathrm{mL}\end{array}$ \\
\hline B0065 & S96R000071 & $4.41 \mathrm{E}+04$ & $n / a$ & $n / a$ & $\mathrm{n} / \mathrm{a}$ & 94.5 & 2.91E-01 & 91.1 & 8.5 & $2.97 E+02$ \\
\hline B0066 & S96R000072 & $4.06 \mathrm{E}+04$ & $n / a$ & $\bar{n} / \mathbf{a}$ & $n / a$ & 94.5 & $2.91 E-01$ & 113.5 & 0.3 & $2.97 \mathrm{E}+02$ \\
\hline
\end{tabular}


Nitrite-IC - Dionex 4000i/4500 Direct Analysis

\begin{tabular}{|c|c|c|c|c|c|c|c|c|c|c|}
\hline \multicolumn{2}{|c|}{ SAMPLE INFORMATION } & \multicolumn{4}{|c|}{ SAMPLE RESULTS } & \multicolumn{5}{|c|}{ QUALITY CONTROL RESULTS } \\
\hline $\begin{array}{c}\text { Customer } \\
\text { Identification }\end{array}$ & $\begin{array}{c}\text { Laboratory } \\
\text { Identification }\end{array}$ & $\begin{array}{l}\text { Sample } \\
\text { Result } \\
\mu \mathrm{g} / \mathrm{mL}\end{array}$ & $\begin{array}{c}\text { Duplicate } \\
\text { Result } \\
\mu \mathrm{g} / \mathrm{mL}\end{array}$ & $\begin{array}{l}\text { Average } \\
\text { Result } \\
\mu \mathrm{g} / \mathrm{mL}\end{array}$ & $\begin{array}{c}\text { Sample } \\
\text { Precision } \\
\text { RPD }\end{array}$ & $\begin{array}{c}\text { Standard } \\
\text { Recovery } \\
\%\end{array}$ & $\begin{array}{c}\text { Reagent } \\
\text { Blank } \\
\mu \mathrm{g} / \mathrm{mL}\end{array}$ & $\begin{array}{c}\text { Spike } \\
\text { Recovery } \\
\%\end{array}$ & $\begin{array}{c}\text { Spike } \\
\text { Duplicate } \\
\text { RPD }\end{array}$ & $\begin{array}{c}\text { Detection } \\
\text { Limit } \\
\mu \mathrm{g} / \mathrm{mL}\end{array}$ \\
\hline 80065 & S96R000071 & $2.67 E+03$ & $n / a$ & n/a & $n / a$ & 92.7 & $2.01 \mathrm{E}-01$ & 90.2 & 6.1 & $2.27 \mathrm{E}+02$ \\
\hline 80066 & S96R000072 & $2.49 E+03$ & $n / a$ & $n / a$ & $n / a$ & 92.7 & $2.01 \mathrm{E}-01$ & 94.6 & 0.2 & $2.27 E+02$ \\
\hline
\end{tabular}

Fluoride-IC-Dionex $4000 \mathrm{i} / 4500$

\section{Direct Analysis}

\begin{tabular}{|c|c|c|c|c|c|c|c|c|c|c|}
\hline \multicolumn{2}{|c|}{ SAMPLE INFORMATION } & \multicolumn{4}{c|}{ SAMPLE RESULTS } & \multicolumn{4}{c|}{ QUALITY CONTROL RESULTS } \\
$\begin{array}{c}\text { Customer } \\
\text { Identification }\end{array}$ & $\begin{array}{c}\text { Laboratory } \\
\text { Identification }\end{array}$ & $\begin{array}{c}\text { Sample } \\
\text { Result } \\
\mu \mathrm{g} / \mathrm{mL}\end{array}$ & $\begin{array}{c}\text { Duplicate } \\
\text { Result } \\
\mu \mathrm{g} / \mathrm{mL}\end{array}$ & $\begin{array}{c}\text { Average } \\
\text { Result } \\
\mu \mathrm{g} / \mathrm{mL}\end{array}$ & $\begin{array}{c}\text { Sample } \\
\text { Precision } \\
\text { RPD }\end{array}$ & $\begin{array}{c}\text { Standard } \\
\text { Recovery } \\
\%\end{array}$ & $\begin{array}{c}\text { Reagent } \\
\text { Blank } \\
\mu \mathrm{g} / \mathrm{mL}\end{array}$ & $\begin{array}{c}\text { Spike } \\
\text { Recovery } \\
\%\end{array}$ & $\begin{array}{c}\text { Spike } \\
\text { Duplicate } \\
\text { RPD }\end{array}$ & $\begin{array}{c}\text { Detection } \\
\text { Limit } \\
\mu \mathrm{g} / \mathrm{mL}\end{array}$ \\
\hline $\mathrm{B} 0065$ & $\mathrm{~S} 96 \mathrm{R} 000071$ & $8.77 \mathrm{E}+01$ & $\mathrm{n} / \mathrm{a}$ & $\mathrm{n} / \mathrm{a}$ & $\mathrm{n} / \mathrm{a}$ & 95.1 & $<1.30 \mathrm{E}-02$ & 91.6 & 4.1 & $2.76 \mathrm{E}+01$ \\
\hline $\mathrm{B} 0066$ & $\mathrm{~S} 96 \mathrm{R} 000072$ & $8.90 \mathrm{E}+01$ & $\mathrm{n} / \mathrm{a}$ & $\mathrm{n} / \mathrm{a}$ & $\mathrm{n} / \mathrm{a}$ & 95.1 & $<1.30 \mathrm{E}-02$ & 91.5 & 0.3 & $2.76 \mathrm{E}+01$ \\
\hline
\end{tabular}

\section{Chloride-IC-Dionex 4000i/4500}

Direct Analysis

\begin{tabular}{|c|c|c|c|c|c|c|c|c|c|c|}
\hline SAMPLE INFORMATION & \multicolumn{3}{|c|}{ SAMPLE RESULTS } & \multicolumn{3}{c|}{ QUALITY CONTROL RESULTS } \\
\hline $\begin{array}{c}\text { Customer } \\
\text { Identification }\end{array}$ & $\begin{array}{c}\text { Laboratory } \\
\text { Identification }\end{array}$ & $\begin{array}{c}\text { Sample } \\
\text { Result } \\
\mu \mathrm{g} / \mathrm{mL}\end{array}$ & $\begin{array}{c}\text { Duplicate } \\
\text { Result } \\
\mu \mathrm{g} / \mathrm{mL}\end{array}$ & $\begin{array}{c}\text { Average } \\
\text { Result } \\
\mu \mathrm{g} / \mathrm{mL}\end{array}$ & $\begin{array}{c}\text { Sample } \\
\text { Precision } \\
\text { RPD }\end{array}$ & $\begin{array}{c}\text { Standard } \\
\text { Recovery } \\
\%\end{array}$ & $\begin{array}{c}\text { Reagent } \\
\text { Blank } \\
\mu \mathrm{g} / \mathrm{mL}\end{array}$ & $\begin{array}{c}\text { Spike } \\
\text { Recovery } \\
\%\end{array}$ & $\begin{array}{c}\text { Spike } \\
\text { Duplicate } \\
\text { RPD }\end{array}$ & $\begin{array}{c}\text { Detection } \\
\text { Limit } \\
\mu \mathrm{g} / \mathrm{mL}\end{array}$ \\
\hline $\mathrm{B} 0065$ & $\mathrm{~S} 96 \mathrm{R} 000071$ & $3.42 \mathrm{E}+02$ & $\mathrm{n} / \mathrm{a}$ & $\mathrm{n} / \mathrm{a}$ & $\mathrm{n} / \mathrm{a}$ & 92.3 & $4.00 \mathrm{E}-02$ & 93.9 & 5.4 & $3.61 \mathrm{E}+01$ \\
\hline $\mathrm{B} 0066$ & $\mathrm{~S} 96 \mathrm{R} 000072$ & $3.23 \mathrm{E}+02$ & $\mathrm{n} / \mathrm{a}$ & $\mathrm{n} / \mathrm{a}$ & $\mathrm{n} / \mathrm{a}$ & 92.3 & $4.00 \mathrm{E}-02$ & 96.3 & 0.3 & $3.61 \mathrm{E}+01$ \\
\hline
\end{tabular}


pH Direct

Direct Analysis

\begin{tabular}{|c|c|c|c|c|c|c|c|c|c|c|}
\hline \multicolumn{2}{|c|}{ SAMPLE INFORMATION } & \multicolumn{4}{|c|}{ SAMPLE RESULTS } & \multicolumn{3}{c|}{ QUALITY CONTROL RESULTS } \\
\hline $\begin{array}{c}\text { Customer } \\
\text { Identification }\end{array}$ & $\begin{array}{c}\text { Laboratory } \\
\text { Identification }\end{array}$ & $\begin{array}{c}\text { Sample } \\
\text { Result } \\
\mathrm{pH} \text { Units }\end{array}$ & $\begin{array}{c}\text { Duplicate } \\
\text { Result } \\
\mathrm{pH} \text { Units }\end{array}$ & $\begin{array}{c}\text { Average } \\
\text { Result } \\
\mathrm{pH} \text { Units }\end{array}$ & $\begin{array}{c}\text { Sample } \\
\text { Precision } \\
\text { RPD }\end{array}$ & $\begin{array}{c}\text { Standard } \\
\text { Recovery } \\
\%\end{array}$ & $\begin{array}{c}\text { Reagent } \\
\text { Blank } \\
\mathrm{pH} \text { Units }\end{array}$ & $\begin{array}{c}\text { Spike } \\
\text { Recovery } \\
\%\end{array}$ & $\begin{array}{c}\text { Detection } \\
\text { Limit } \\
\text { pH Units }\end{array}$ & $\begin{array}{c}\text { Counting } \\
\text { Error } \\
\%\end{array}$ \\
\hline B0065 & S96R000041 & 7.22 & 7.21 & 7.22 & 0.14 & 100.0 & $\mathrm{n} / \mathrm{a}$ & $\mathrm{n} / \mathrm{a}$ & $1.00 \mathrm{E}-02$ & $\mathrm{n} / \mathrm{a}$ \\
\hline B0066 & S96R000042 & 7.19 & $\mathrm{n} / \mathrm{a}$ & $\mathrm{n} / \mathrm{a}$ & $\mathrm{n} / \mathrm{a}$ & 100.0 & $\mathrm{n} / \mathrm{a}$ & $\mathrm{n} / \mathrm{a}$ & $1.00 \mathrm{E}-02$ & $\mathrm{n} / \mathrm{a}$ \\
\hline
\end{tabular}

Oi- by Pot. Titration

Direct Analysis

\begin{tabular}{c|c|c|c|c|c|c|c|c|c|c|c|}
\hline \multicolumn{2}{|c|}{ SAMPLE INFORMATION } & \multicolumn{4}{c|}{ SAMPLE RESULTS } & \multicolumn{4}{c|}{ QUALITY CONTROL RESULTS } \\
\cline { 2 - 11 } \\
$\begin{array}{c}\text { Customer } \\
\text { Identification }\end{array}$ & $\begin{array}{c}\text { Laboratory } \\
\text { Identification }\end{array}$ & $\begin{array}{c}\text { Sample } \\
\text { Result } \\
\mu \mathrm{g} / \mathrm{mL}\end{array}$ & $\begin{array}{c}\text { Duplicate } \\
\text { Result } \\
\mu \mathrm{g} / \mathrm{mL}\end{array}$ & $\begin{array}{c}\text { Average } \\
\text { Result } \\
\mu \mathrm{g} / \mathrm{mL}\end{array}$ & $\begin{array}{c}\text { Sample } \\
\text { Precision } \\
\mathrm{RPD}\end{array}$ & $\begin{array}{c}\text { Standard } \\
\text { Recovery } \\
\%\end{array}$ & $\begin{array}{c}\text { Reagent } \\
\text { Blank } \\
\mu \mathrm{g} / \mathrm{mL}\end{array}$ & $\begin{array}{c}\text { Spike } \\
\text { Recovery } \\
\%\end{array}$ & $\begin{array}{c}\text { Detection } \\
\text { Limit } \\
\mu \mathrm{g} / \mathrm{mL}\end{array}$ & $\begin{array}{c}\text { Counting } \\
\text { Error } \\
\%\end{array}$ \\
\hline $\mathrm{B} 0065$ & $\mathrm{~S} 96 \mathrm{R} 000041$ & $<4.20 \mathrm{E}+01$ & $<4.20 \mathrm{E}+01$ & $\mathrm{n} / \mathrm{a}$ & $\mathrm{n} / \mathrm{a}$ & 96.4 & $<4.20 \mathrm{E}+01$ & $\mathrm{n} / \mathrm{a}$ & $4.20 \mathrm{E}+01$ & $\mathrm{n} / \mathrm{a}$ \\
\hline $\mathrm{B} 0066$ & $\mathrm{~S} 96 \mathrm{R} 000042$ & $<4.20 \mathrm{E}+01$ & $<4.20 \mathrm{E}+01$ & $\mathrm{n} / \mathrm{a}$ & $\mathrm{n} / \mathrm{a}$ & 96.4 & $<4.20 \mathrm{E}+01$ & $\mathrm{n} / \mathrm{a}$ & $4.20 \mathrm{E}+01$ & $\mathrm{n} / \mathrm{a}$ \\
\hline
\end{tabular}

Caustic Demand

Direct Analysis

\begin{tabular}{|c|c|c|c|c|c|c|c|c|c|c|}
\hline \multicolumn{2}{|c|}{ SAMPLE INFORMATION } & \multicolumn{4}{|c|}{ SAMPLE RESULTS } & \multicolumn{5}{|c|}{ QUALITY CONTROL RESULTS } \\
\hline $\begin{array}{c}\text { Customer } \\
\text { Identification }\end{array}$ & $\begin{array}{c}\text { Laboratory } \\
\text { Identification }\end{array}$ & $\begin{array}{c}\text { Sample } \\
\text { Result } \\
\text { moles } \mathrm{OH} / \mathrm{L}\end{array}$ & \begin{tabular}{|c|} 
Duplicate \\
Result \\
moles $\mathrm{OH} / \mathrm{L}$ \\
\end{tabular} & $\begin{array}{l}\text { Average } \\
\text { Result } \\
\text { oles } \mathrm{OH} /\end{array}$ & $\begin{array}{c}\text { Sample } \\
\text { Precision } \\
\text { RPD }\end{array}$ & $\begin{array}{c}\text { Standard } \\
\text { Recovery } \\
\%\end{array}$ & \begin{tabular}{|c|} 
Reagent \\
Blank \\
moles $\mathrm{OH} / 1 /$ \\
\end{tabular} & $\begin{array}{c}\text { Spike } \\
\text { Recovery } \\
\%\end{array}$ & \begin{tabular}{|c|} 
Detection \\
Limit \\
moles $\mathrm{OH}^{-1 / \mathrm{L}}$
\end{tabular} & $\begin{array}{c}\text { Counting } \\
\text { Error } \\
\%\end{array}$ \\
\hline$B 0066$ & S96R000072 & $1.03 \bar{E}-02$ & $\pi / \mathbf{a}$ & $n / a$ & $n / a$ & 90.3 & 0.0 & $n / a$ & $2.50 \mathrm{E}-03$ & $\mathrm{n} / \mathbf{a}$ \\
\hline
\end{tabular}


Tot. Organic Carbon by Coul. Direct Analysis

\begin{tabular}{|c|c|c|c|c|c|c|c|c|c|c|}
\hline \multicolumn{2}{|c|}{ SAMPLE INFORMATION } & \multicolumn{4}{|c|}{ SAMPLE RESULTS } & \multicolumn{5}{|c|}{ QUALITY CONTROL RESULTS } \\
\hline $\begin{array}{c}\text { Customer } \\
\text { Identification }\end{array}$ & $\begin{array}{c}\text { Laboratory } \\
\text { Identification }\end{array}$ & $\begin{array}{c}\text { Sample } \\
\text { Result } \\
\mu \mathrm{g} / \mathrm{mL}\end{array}$ & $\begin{array}{c}\text { Duplicate } \\
\text { Result } \\
\mu \mathrm{g} / \mathrm{mL}\end{array}$ & $\begin{array}{l}\text { Average } \\
\text { Result } \\
\mu \mathrm{g} / \mathrm{mL}\end{array}$ & $\begin{array}{c}\text { Sample } \\
\text { Precision } \\
\text { RPD } \\
\end{array}$ & $\begin{array}{c}\text { Standard } \\
\text { Recovery } \\
\%\end{array}$ & $\begin{array}{c}\text { Reagent } \\
\text { Blank } \\
\mu g / \mathrm{mL}\end{array}$ & $\begin{array}{c}\text { Spike } \\
\text { Recovery } \\
\%\end{array}$ & $\begin{array}{c}\text { Spike } \\
\text { Duplicate } \\
\text { RPD }\end{array}$ & $\begin{array}{c}\text { Detection } \\
\text { Limit } \\
\mu \mathrm{g} / \mathrm{mL}\end{array}$ \\
\hline B0065 & S96R000041 & $7.55 E+03$ & n/a & $\mathrm{n} / \mathrm{a}$ & n/a & 96.0 & $2.70 \mathrm{E}+00$ & $n / a$ & $\mathrm{n} / \mathrm{a}$ & $5.50 \mathrm{E}+01$ \\
\hline B0066 & S96R000042 & $6.77 \mathrm{E}+03$ & $\mathrm{n} / \mathbf{a}$ & $n / a$ & $n / a$ & 96.0 & $2.70 \mathrm{E}+00$ & 108.8 & 1.11 & $5.50 \mathrm{E}+01$ \\
\hline
\end{tabular}

Tot. Inorg. Carbon by Coul. Direct Analysis

\begin{tabular}{|c|c|c|c|c|c|c|c|c|c|c|}
\hline \multicolumn{2}{|c|}{ SAMPLE INFORMATION } & \multicolumn{4}{|c|}{ SAMPLE RESULTS } & \multicolumn{5}{|c|}{ QUALITY CONTROL RESULTS } \\
\hline 80066 & S96R000042 & $2.30 \mathrm{E}+01$ & $\mathrm{n} / \mathrm{a}$ & $n / a$ & $n / a$ & 99.2 & $1.60 \mathrm{E}+00$ & $n / a$ & $n / a$ & $5.00 \mathrm{E}+00$ \\
\hline
\end{tabular}

Cyanide by Microdist. \& Spec.

Direct Analysis

\begin{tabular}{|c|c|c|c|c|c|c|c|c|c|c|}
\hline \multicolumn{2}{|c|}{ SAMPLE INFORMATION } & \multicolumn{4}{|c|}{ SAMPLE RESULTS } & \multicolumn{5}{|c|}{ QUALITY CONTROL RESULTS } \\
\hline $\begin{array}{c}\text { Customer } \\
\text { Identification }\end{array}$ & $\begin{array}{l}\text { Laboratory } \\
\text { Identification }\end{array}$ & $\begin{array}{c}\text { Sample } \\
\text { Result } \\
\mu \mathrm{g} / \mathrm{mL}\end{array}$ & $\begin{array}{c}\text { Duplicate } \\
\text { Result } \\
\mu \mathrm{g} / \mathrm{mL}\end{array}$ & $\begin{array}{l}\text { Average } \\
\text { Result } \\
\mu \mathrm{g} / \mathrm{mL}\end{array}$ & $\begin{array}{c}\text { Sample } \\
\text { Precision } \\
\text { RPD } \\
\end{array}$ & $\begin{array}{c}\text { Standard } \\
\text { Recovery } \\
\% \\
\end{array}$ & $\begin{array}{c}\text { Reagent } \\
\text { Blank } \\
\mu \mathrm{g} / \mathrm{mL}\end{array}$ & $\begin{array}{c}\text { Spike } \\
\text { Recovery } \\
\%\end{array}$ & $\begin{array}{c}\text { Spike } \\
\text { Duplicate } \\
\text { RPD }\end{array}$ & $\begin{array}{c}\text { Detection } \\
\text { Limit } \\
\mu \mathrm{g} / \mathrm{mL}\end{array}$ \\
\hline $\mathrm{B} 0065$ & S96R000041 & \multicolumn{9}{|c|}{ Insufficient Sample } \\
\hline$B 0066$ & S96R000042 & $1.28 E+01$ & $1.35 \mathrm{E}+01$ & $1.32 \mathrm{E}+01$ & 5.3 & 92.3 & $1.80 \mathrm{E}-02$ & 86.3 & $n / a$ & $1.10 \mathrm{E}+00$ \\
\hline B0065 & S96R000071 & $2.89 E+01$ & $\mathrm{n} / \mathrm{a}$ & $n / a$ & $n / a$ & 93.3 & $<1.10$ E-02 & 103.7 & 2.9 & $1.10 \mathrm{E}+00$ \\
\hline
\end{tabular}


WHC-SD-WH-DP-180, REV. 0

REQUEST FOR SPECIAL ANALYSIS

31 
WHC-SD-WM-DP-180, REV. 0

THIS PAGE WAS INTENTIONALLY LEFT BLANK

32 


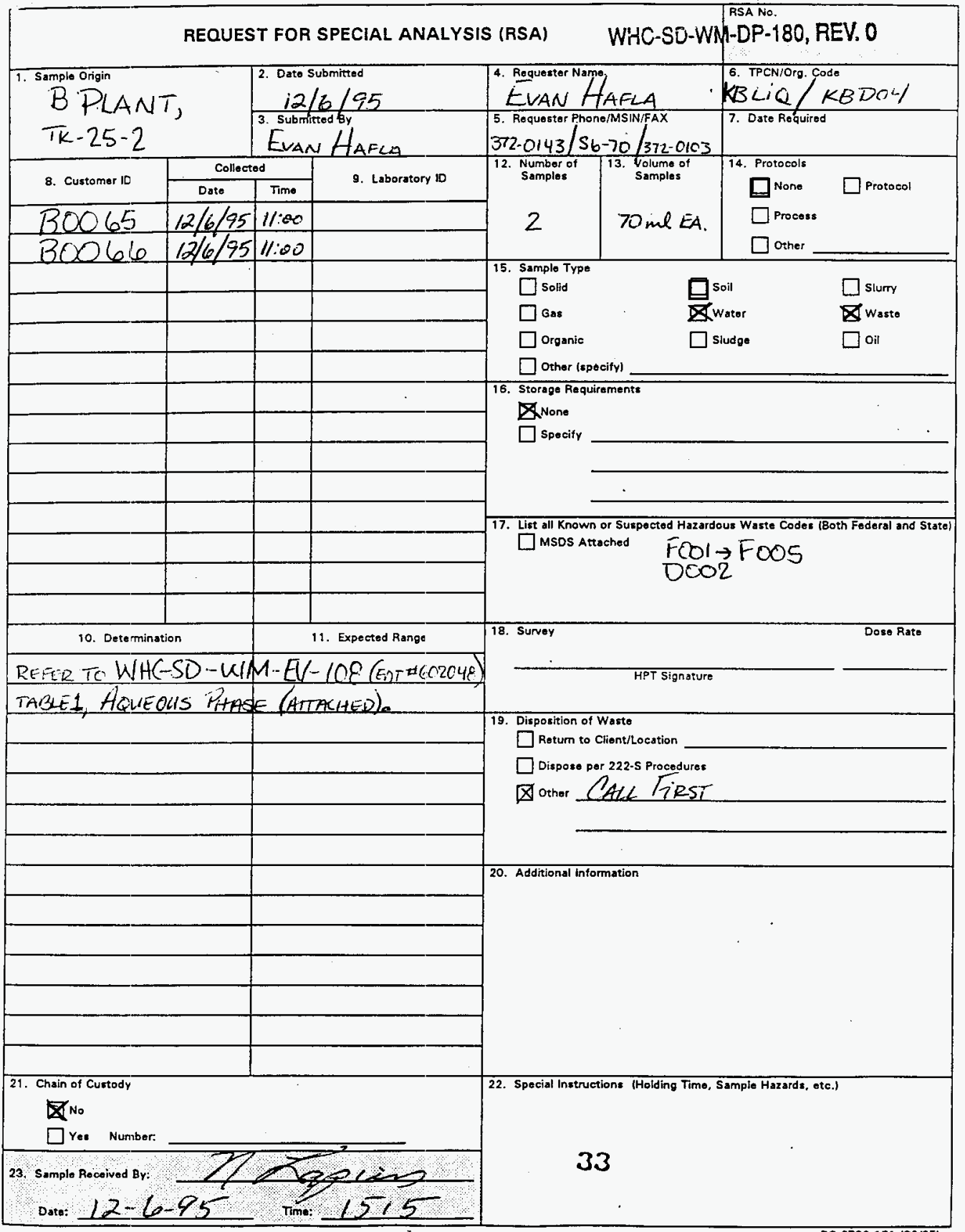


WHC-SD-WM-DP-180, REV. 0

PHOTOGRAPH

31 
WHC-SD-WM-DP-180, REV. 0

THIS PAGE WAS INTENTIONALLY LEFT BLANK

35 


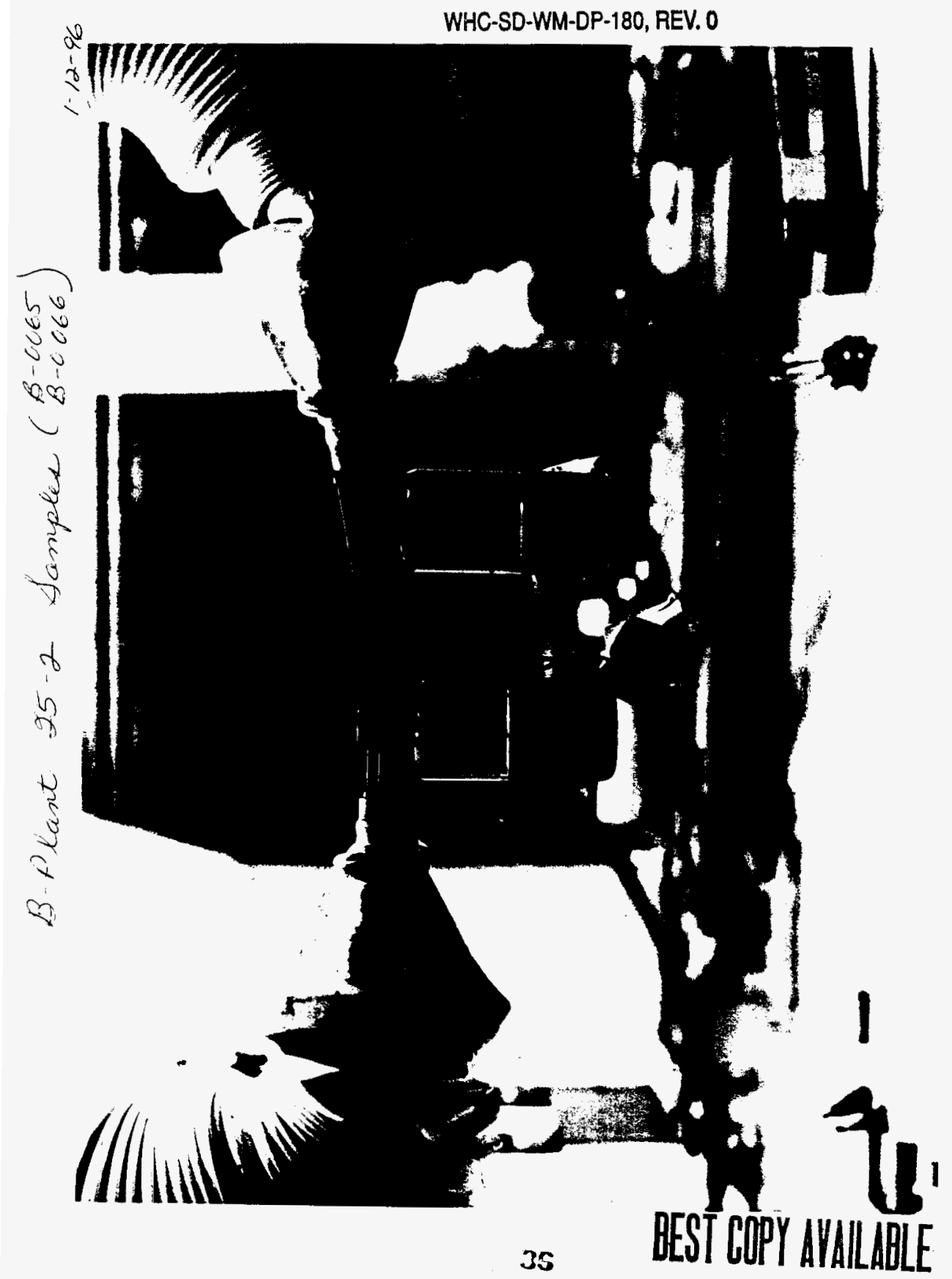


WHC-SD-WH-DP-180, REV. 0

INTERELEMENT CORRECTION FACTORS 
WHC-SD-WM-DP-180, REV. 0

THIS PAGE WAS INTENTIONALLY LEFT BLANK

38 
Jask : OPIIMA

3:23 PM 13/2/96

Interference Curve Details

Ca on $B i$ Interference Curve

Coefficient 1
Coefficient 2
Coefficient 3

Task : OPTIMA

3:23 PM 13/2/96

Interference Curve Details

Ca on Fe Interference Curve

Coefficient 1

$7.85462 \mathrm{E}-05$

Coefficient?

coefficient 3

Coeffic

Task : OPTIMA

$3: 23$ PM 13/2/96

Interference Curve Details

Ca on La Interference Curve

Coefficient 1

$7.50884 E-05$

Coefficient 2

Coefficient 3

Task : OPTIMA

3:23 PM 13/2/96

Interference Curve Details

Ca on Mn Interference Curve

Coefficient

Coefficient 2

coefficient 3

8.30000 E-04

Task : OPTIMA

3:23 PM 13/ 2/96

Interference Curve Details

Ca on Nd Interference curve

Coefficient 1

Coefficient 2

4.50000E-03
WHC-SD-WM-DP-180, REV. 0

\section{Coefficient 3}


Interference Curve Details

Ca on $\$$ Interference curve

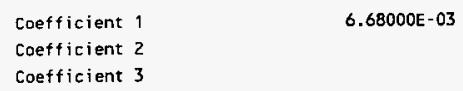

$6.68000 \mathrm{E}-03$

Interference Curve Details

Ca on Si Interference Curve

Coefficient 1

$1.51444 E-03$

Coefficient 2

Coefficient 3

Task : OPTIMA

$3: 23$ PM 13/ 2/96

Interference Curve Details

$\mathrm{Cr}$ on As Interference Curve

coefficient 1

Coefficient 2

coefficient 3

$9.05901 E-04$

Task : OPTIMA

$3: 23$ PM 13/ 2/96

Interference Curve Details

$\mathrm{C} r$ on $\mathrm{B}$ Interference Curve

Coefficient 1

Coefficient 2

Coefficient 3

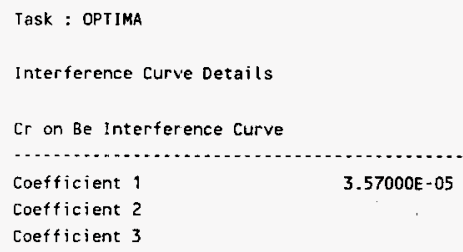

Interference Curve Details

$\mathrm{Cr}$ on Be Interference curve 


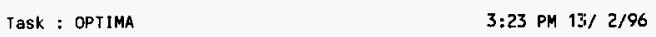

Task : OPT IMA

Interference Curve Details

$\mathrm{Cr}$ on Fe Interference Curve

Coefficient 1
Coefficient 2
Coefficient 3
Task : OPIIMA

Interference Curve Details

Cr on $K$ Interference Curve

Coefficient 1

coefficient 2

$-8.69696 \mathrm{E}-04$

Coefficient 3

Task : OPTIMA $3: 23$ PM 13; 2/96

Interference Curve Details

$\mathrm{Cr}$ on Mo Interference Curve

Coefficient 1

Coefficient 2

$-3.97048 E-05$

Coefficient 3 


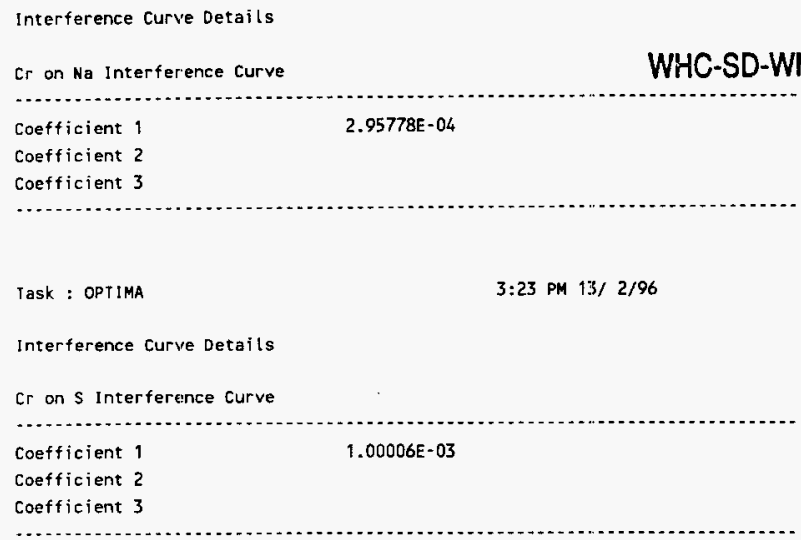

Task : OPTIMA
Interference Curve Details
Cr on Sb Interference Curve
Coefficient 1
Coefficient 2
Coefficient 3

Task : OPTIMA
Interference Curve Details
Cr on se Interference Curve
Coefficient 1
Coefficient 2
Coefficient 3

Task : OPTIMA $3: 23$ PM $13 / 2 / 96$

Interference Curve Details

$\mathrm{Cr}$ on Si Interference Curve

Coefficient 1

coefficient 2

Coefficient 3

Coefficient 3 .... 


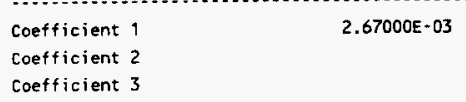

Interference Curvie Details

Fe on cd Interference curve

Interference Curve Details

$F e$ on La Interference Curve

Coefficient 1
Coefficient 2
Coefficient 3




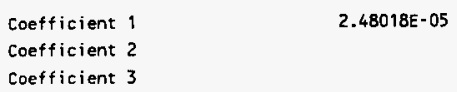

Interference Curve Details

Fe on In Interference Curve

Coefficient $1 \quad 1.36129 \mathrm{E}-04$

Coefficient 2

Coefficient 3

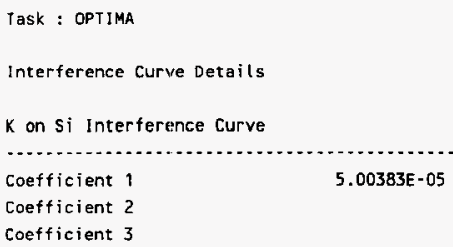

Interference Curve Details

$K$ on Si Interference Curve

coefficient 1

5.00383E-0.

Coefficient 2

Coefficient 3

C..........

Task : OPTIMA

Interference Curve Details

Mg on As Interference Curve

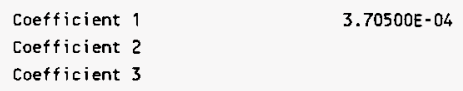

Interference Curve Details

Mg on Co Interference Curve

$\begin{array}{ll}\text { Coefficient } 1 & 9.27988 E-06 \\ \text { Coefficient } 2 & 9.27988 E-08 \\ \text { Coefficient } 3 & \end{array}$




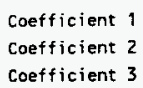

Interference Curve Details

Mn on Se Interference Curve

Coefficient $1 \quad 4.25000$ E-03

Coefficient 2

Coefficient 3

Task : OPTIMA

Interference Curve Details

Na on $N i$ Interference Curve

Coefficient 1

$-2.44269 \mathrm{E}-05$

Coefficient 2

coefficient 3

Task : OPTIMA

Interference Curve Details

Na on Si interference Curve

$\begin{array}{lr}\text { Coefficient } 1 & 3.26884 \mathrm{E}-05 \\ \text { Coefficient } 2 & -7.54347 \mathrm{E}-08\end{array}$

Coefficient 3

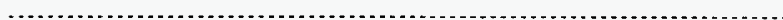

Task : OPTIMA $3: 23$ PM 13/2/96

Interference Curve Details

Sb on $\mathrm{Ni}$ Interference Curve

Coefficient 1

Coefficient 2

Coefficient 3

Task : OPT IMA

$3: 23$ PM 13/2/96

Interference Curve Details

$\mathrm{Sb}$ on $\mathrm{Pb}$ Interference Curve 

Coefficient 1
$-5.75780 E-04$
Coefficient 2
Coefficient 3
WHC-SD-WM-DP-180, REV. 0

Task : OPTIMA

$3: 23$ PM 13/ 2/96

Interference Curve Details

Sb on Se Interference Curve

coefficient 1

Coefficient 2

Coefficient 3

Iask : OPI IMA

3:23 PM 13/2/96

Interference Curve Details

Sm on Nd Interference Curve

Coefficient 1

2.23220E- 02

Coefficient 2

Coefficient 3

Task : OPT IMA

3:23 PM 13/2/96

Interference Curve Details

$\mathrm{U}$ on Ag Interference Curve

Coefficient 1

$-9.24728 E-04$

Coefficient 2

Coefficient 3

Coeffic

Task : OPTIMA

3:23 PM 13/ 2/96

Interference Curve Details

$U$ on Al Interference Curve

Coefficient 1

$-3.79000 \mathrm{E}-03$

Coefficient 2

Coefficient 3
Task : OPT IMA
3:23 PM 13/2/96
Interference Curve Details
$U$ on $B$ Interference Curve 


\section{Coefficient 3}

Task : OPT IMA

$3: 23$ PH 13/2/96

Interference Curve Details

$U$ on Be Interference Curve

Coefficient

$-1.29412 E-04$

Coefficient 2

Coefficient 3

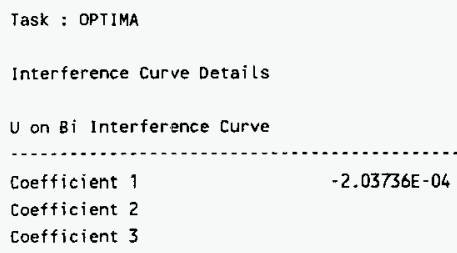

Interference Curve Details

$U$ on Cd Interference Curve

Coefficient 1

$-2.79678 \mathrm{E}-05$

Coefficient 2

Coefficient 3

Coefficient 3

Iask : OPIIMA

Interference Curve Details

$U$ on Ce Interference Curve

Coefficient 1

Coefficient 2

$-1.62545 E-03$

Coefficient 3
Task : OPTIMA
$3: 23$ PM 13/ 2/96
Interference Curve Details
$U$ on co Interference curve 


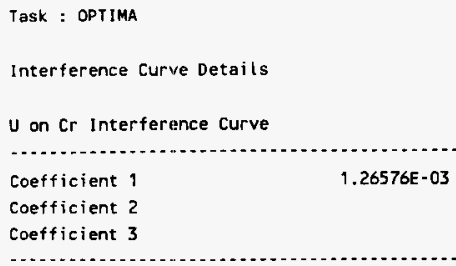

Interference Curve Details

$\mathrm{U}$ on $\mathrm{Cr}$ Interference Curve

Coefficient

$1.26576 \mathrm{E}-03$

Coefficient 2

Coefticient 3

-............

Task : OPTIMA

$3: 23$ PM 1:3/ 2/96

Interference Curve Details

$U$ on $\mathrm{Cu}$ Interference Curve

Coefficient 1
Coefficient 2
Coefficient 3

Task : OPTIMA

$3: 23$ PM 13/ 2/96

Interference Curve Details

$u$ on Fe Interference curve

Coefficient 1

Coefficient 2

Coefficient 3

$1.84497 \mathrm{E}-04$

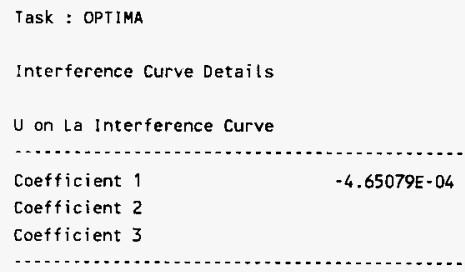

Task : OPTIMA

Interference Curve Details

$U$ on La Interference Curve

...................................

Coefficient 1

$-4.65079 E-04$

Coefficient 2

coefficient 3

Coefficient 3

Task : OPTIMA

3:23 PM 13/2/96

Interference Curve Details

$\mathrm{U}$ on Mn Interference Curve 
Task : OPTIMA

3:23 PM 13/2/96

Interference Curve Details

$U$ on Nd Interference Curve

Coefficient 1

$1.07890 \mathrm{E}-03$

Coefficient 2

Coefficient 3

-..-..-.-.

Task : OPIIMA

Interference Curve Details

$\mathrm{U}$ on $\mathrm{Ni}$ Interference Curve

Coefficient 1

5.72998E-05

Coefficient 2

coefficient 3

Task : OPT IMA

$3: 23$ PM $13 / 2 / 96$

Interference Curve Details

$U$ on $P$ Interference curve

Coefficient 1

Coefficient 2

$7.35516 E-04$

Coefficient 3

-

Task : OPTIMA $3: 23 \mathrm{PH} 13 / 2 / 96$

Interference Curve Details

$\mathrm{U}$ on $\mathrm{Pb}$ Interference Curve

- - 2 - n.

Coefficient 1

$1.25757 \mathrm{E}-03$

Coefficient 2

coefficient 3

C.

Task : OPTIMA

3:23 PM 13/2/96

Interference Curve Details

$\mathrm{U}$ on $\mathrm{S}$ Interference Curve

Coefficient

Coefficient 2

$-4.17806 E-04$

Coefficient 3 


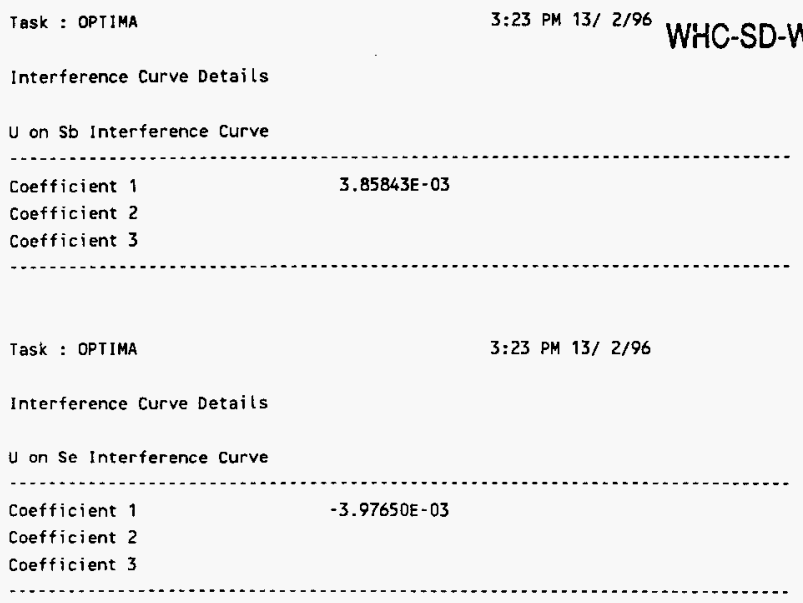
Task : OPTIMA
$3: 23$ PM 1.3/2/96

Interference Curve Details

$U$ on Si Interference Curve

Coefficient 1

Coefficient 2

1.37821E-03

Coefficient 3

Task : OPTIMA $\quad 3: 23$ PM $13 / 2 / 96$

Interference Curve Details

$U$ on Sm Interference Curve

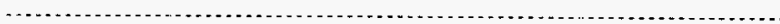

Coefficient 1

1. 16760E-02

Coefficient 2

Coefficient 3

Con

Task : OPTIMA $3: 23$ PM 13/ 2/96

Interference Curve Details

$U$ on $T i$ Interference Curve

Uan




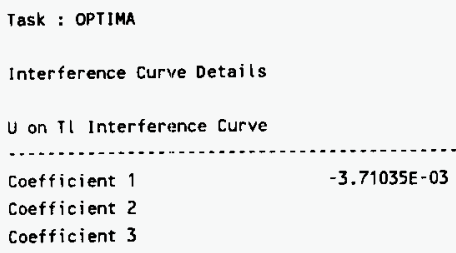

Interference Curve Detaits

$U$ on $V$ interference Curve

Coefficient 1

4. 24815E-03

Coefficient 2

Coefficient 3

Co.

Task : OPIIMA

$3: 23$ PH 13/2/96

Interference Curve Details

$U$ on $2 r$ Interference Curve

Coefficient 1

2. $29527 E-04$

Coefficient 2

Coefficient 3 
WHC-SD-WM-DP-180, REV. 0

SAMPLE PREPARATIONS

53 
WHC-SD-WM-DP-180, REV. 0

THIS PAGE WAS INTENTIONALLY LEFT BLANK

51 
Analyst: Instrument: ACD01 Book \# WHC A GAJ WHCWAL

Method: LA-505-158 Rev/Mod B-C

Worklist Comment: George Miller Tank 25-2 (B0065,B0066) Acid Dilution rkf

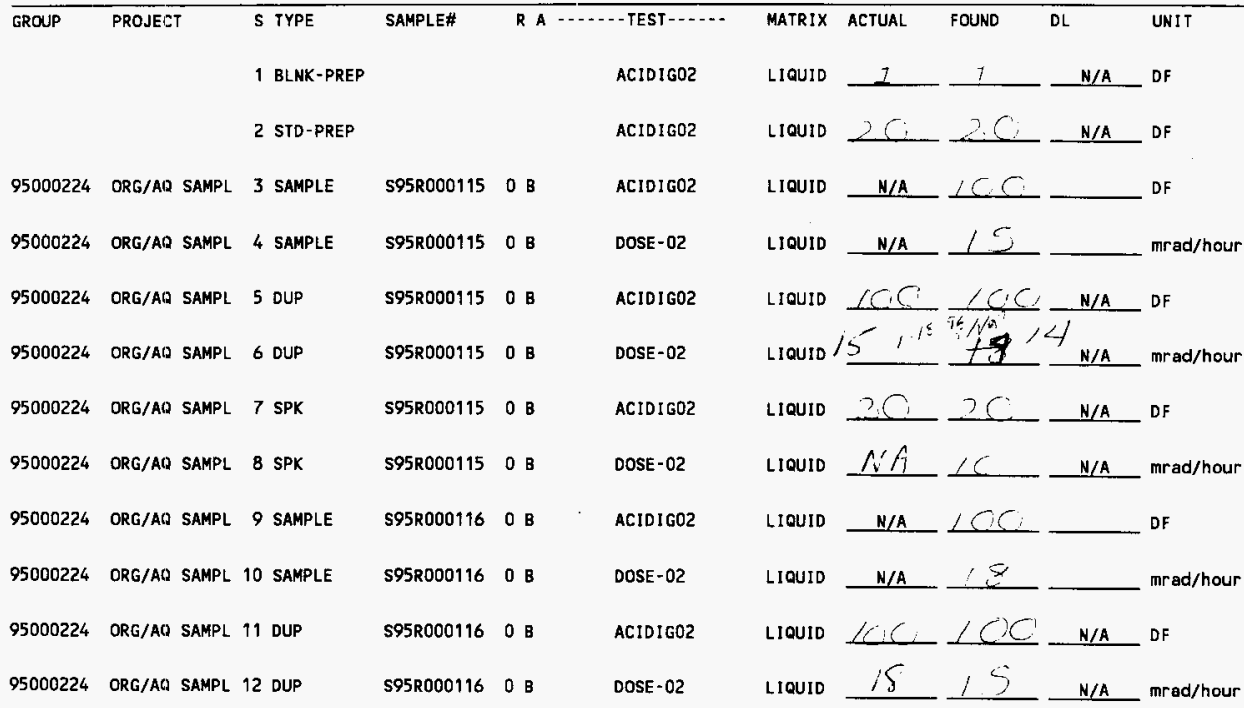

\section{Final page for worklist \# 4823}

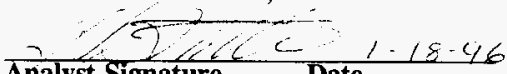

Analyst Signature Date

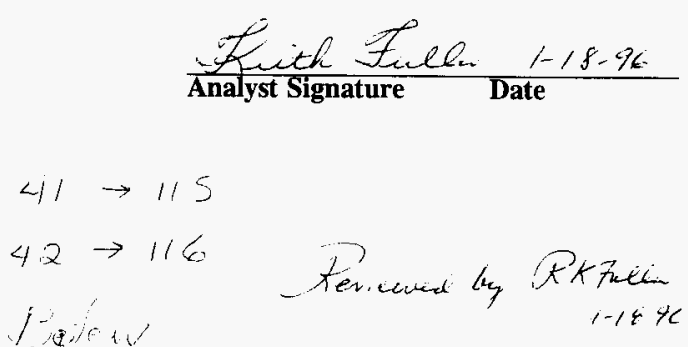

Data Entry Comments:

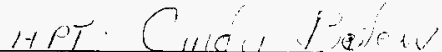
$1-1 \& \forall C$

Units shown for $Q C$ (SPK \& STD) may not reflect the actual units. $D L=$ Detection Limit, $S=$ Worklist Slot Number, $R=$ Replicate Number, $A=$ Aliquot Code. 
WHC-SD-WM-DP-180, REV. 0

INORGANIC ANALYSES

53 
WHC-SD-WM-DP-180, REV. 0

THIS PAGE WAS INTENTIONALLY LEFT BLANK

57 


\section{LABCORE Data Entry Template for Worklist\#}

Analyst: $\quad$ ROM Instrument: $\operatorname{DSCO}^{3} \quad$ Book \# 12 N $14 \mathrm{~B}$

Method: LA-514-114 Rev/Mod

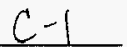

Worklist Comment: TK 25-2 DSC RUN UNDER N2. RCJ

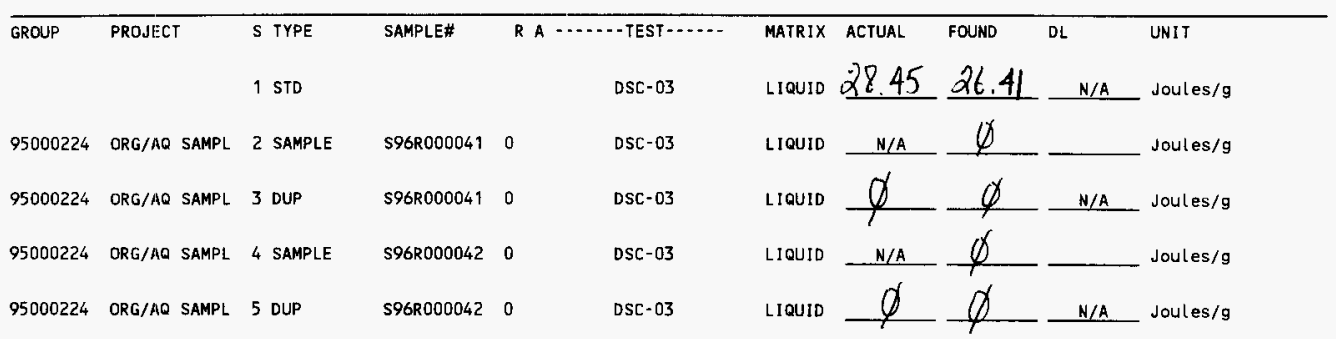

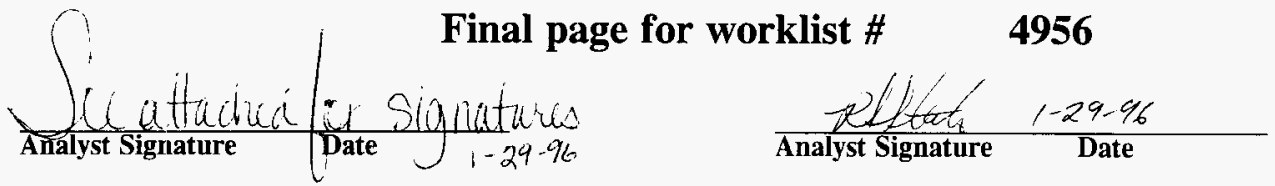

Data Entry Comments:

Units shown for QC (SPK \& STD) may not reflect the actual units. $D L=$ Detection Limit, $S=$ Worklist Slot Number, $R=$ Replicate Number, $A=$ Aliquot Code. 


\section{LABCORE Data Entry Template for Worklist\#}

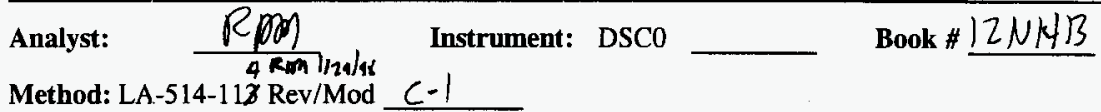

Worklist Comment: TK 25-2 DSC RUN UNDER N2. RCJ

\begin{tabular}{|c|c|c|c|c|c|c|c|c|c|c|}
\hline \multirow[t]{2}{*}{ GROUP } & PROJIECT & S TYPE & SAMPLE\# & R A & $\cdots$ & MATRIX & ACIUAL & FOUND & DL & UNIT \\
\hline & & 1 STD & & & DSc -01 & LIQUID & & & $N / A$ & Joules/g \\
\hline 95000224 & ORG/AQ SAMPL & 2 SAMPLE & S96R000041 & 0 & DSC-01 & LIQUID & $N / A$ & & & Joules/g \\
\hline 95000224 & ORG/AQ SAMPL & 3 DUP & S96R000041 & 0 & DSC-01 & LIQUID & & & $N / A$ & Joules/g \\
\hline 95000224 & ORG/AQ SAMPL & 4 SAMPLE & S96R000042 & 0 & DSC-01 & LIQUIO & $N / A$ & & & Joules/g \\
\hline 95000224 & ORG/AO SAMPL & 5 DUP & S96R000042 & 0 & DSC-01 & LIQUID & & & $N / A$ & Joules/g \\
\hline
\end{tabular}

\section{Final page for worklist \#}

4956

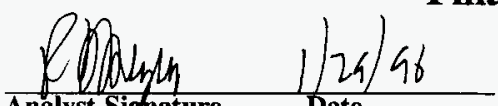

Analyst Signature Date

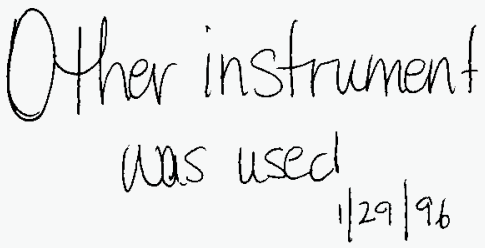

Data Entry Comments:

Units shown for $Q C$ (SPK \& STD) may not reflect the actual units. $D L=$ Detection Limit, $S=$ Worklist Slot Number, $R=$ Replicate Number, $A=$ Aliquot Code. 
Curve 1: DSC

File info: qsave Sun Jan 28 18:59: 411996

Sample Weight: 10.220 mg

$12 N 14 B$ Indiun at $10 \mathrm{C}$ imin

SIGNATURE BELON REPRESENTS CHEMICAL TBCHNOLOGIST/CHEMIST THAT

COMPLETED/VERIFIED THE CALIPRATION/ANALYSIS ON PAGES 7$)$ TO $6-4$.

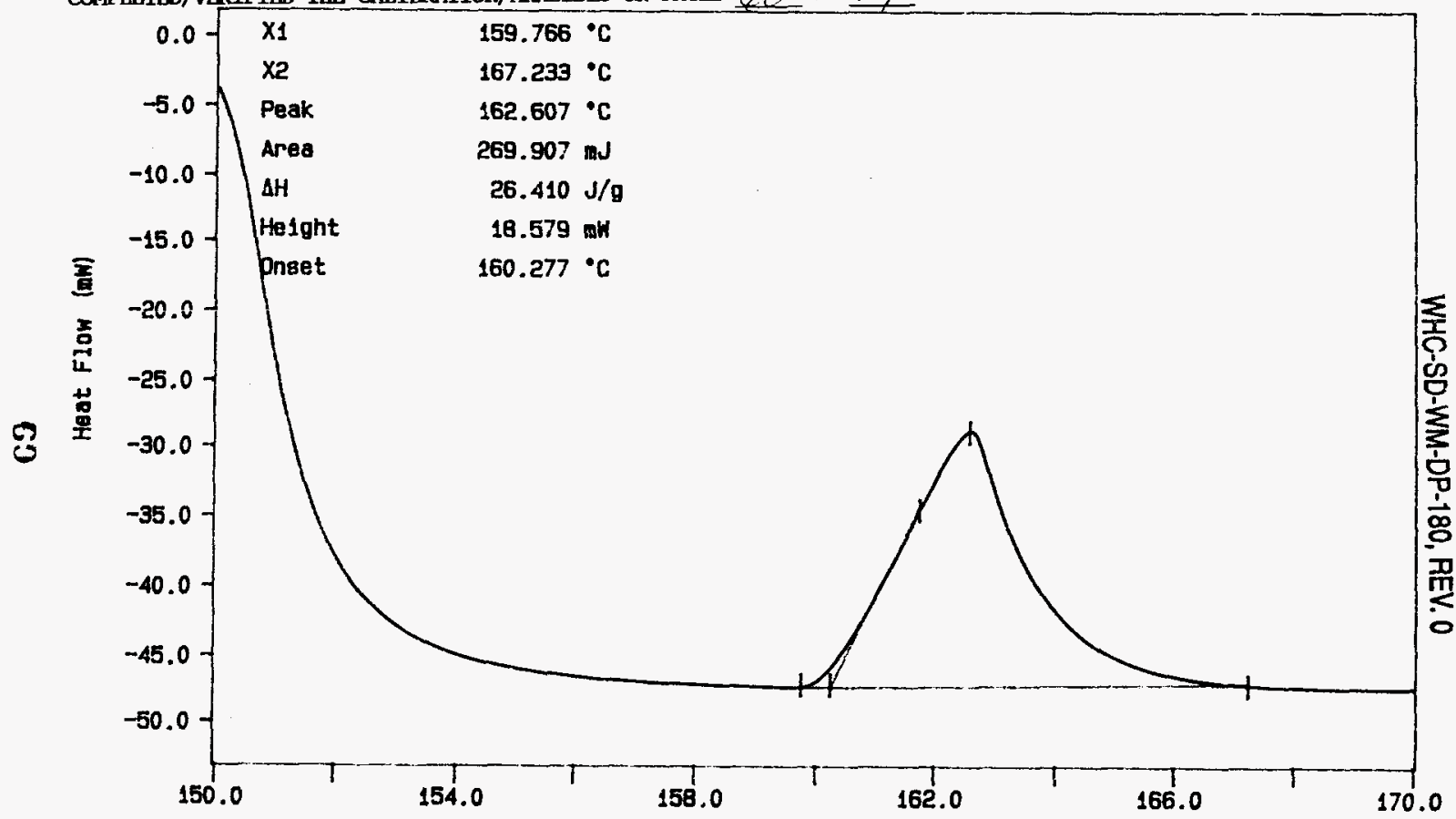

N2, EXOTHERM DONN

repi: $190.8 \mathrm{C}$ TIMEs:

0.0 men pates: 10.0 c/man

Temperature ("C)

RD NEYERS

PERKIN-ELMER

7 Serles Thermal Analysis System

Sun Jan 28 20:07: 181996

Hobuen :129196 
Curve 1: DSC

F1le info: sam012902 Mon Jan 29 01: 49:57 1996

Sample Neight: 10.640 mg

5957000044mup 52 at Ber

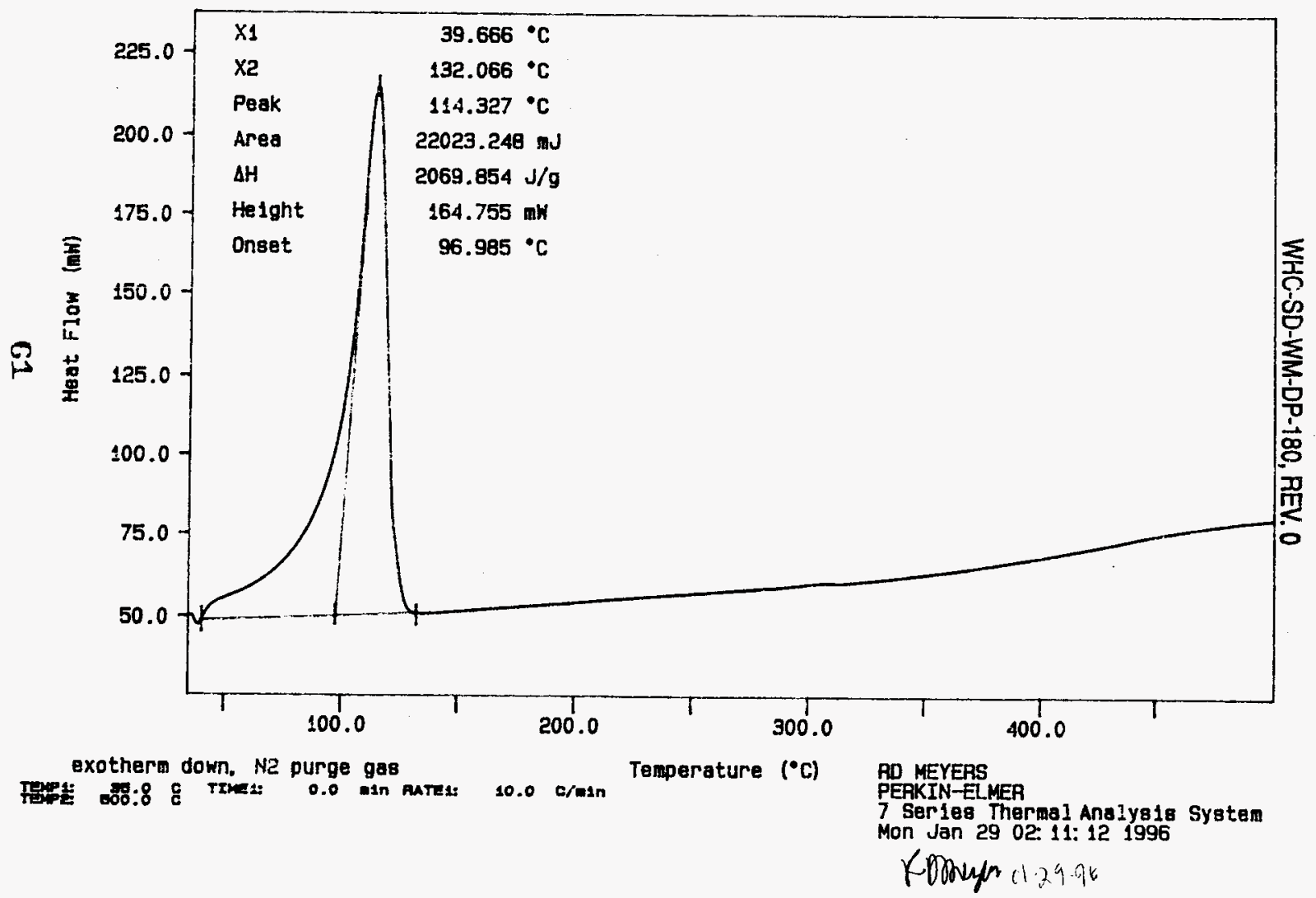


Curve 1: DSC

File info: qsav2 Mon Jan 29 03:03:50 1996

Sample Welght: $10.530 \quad \mathrm{Rg}$

S96R000041DUP

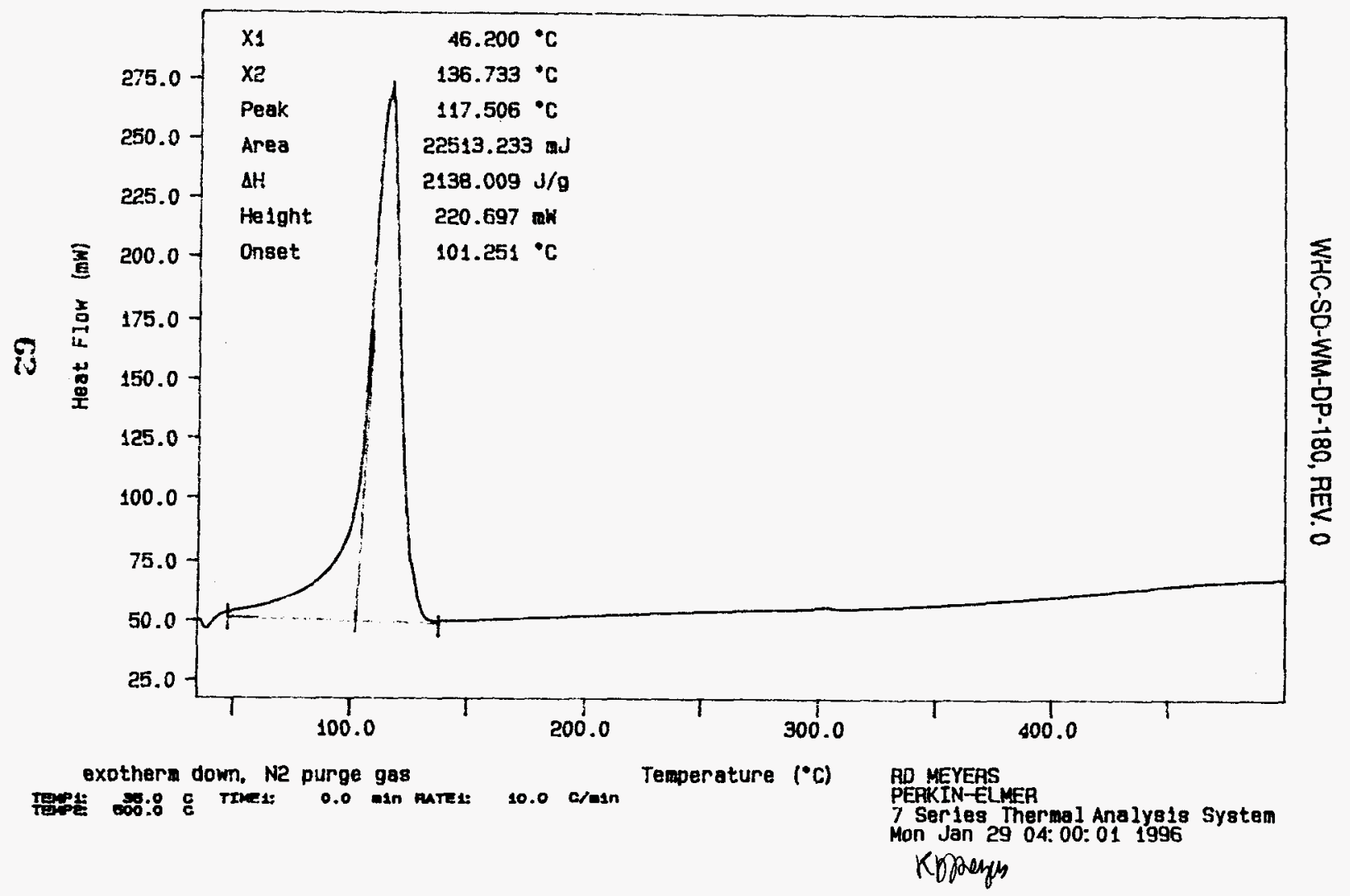


Curve 1: DSC

F1le info: sam012803 Mon Jan 29 04:52:24 1996

Samp le Vieight: 11.540

S96R000042

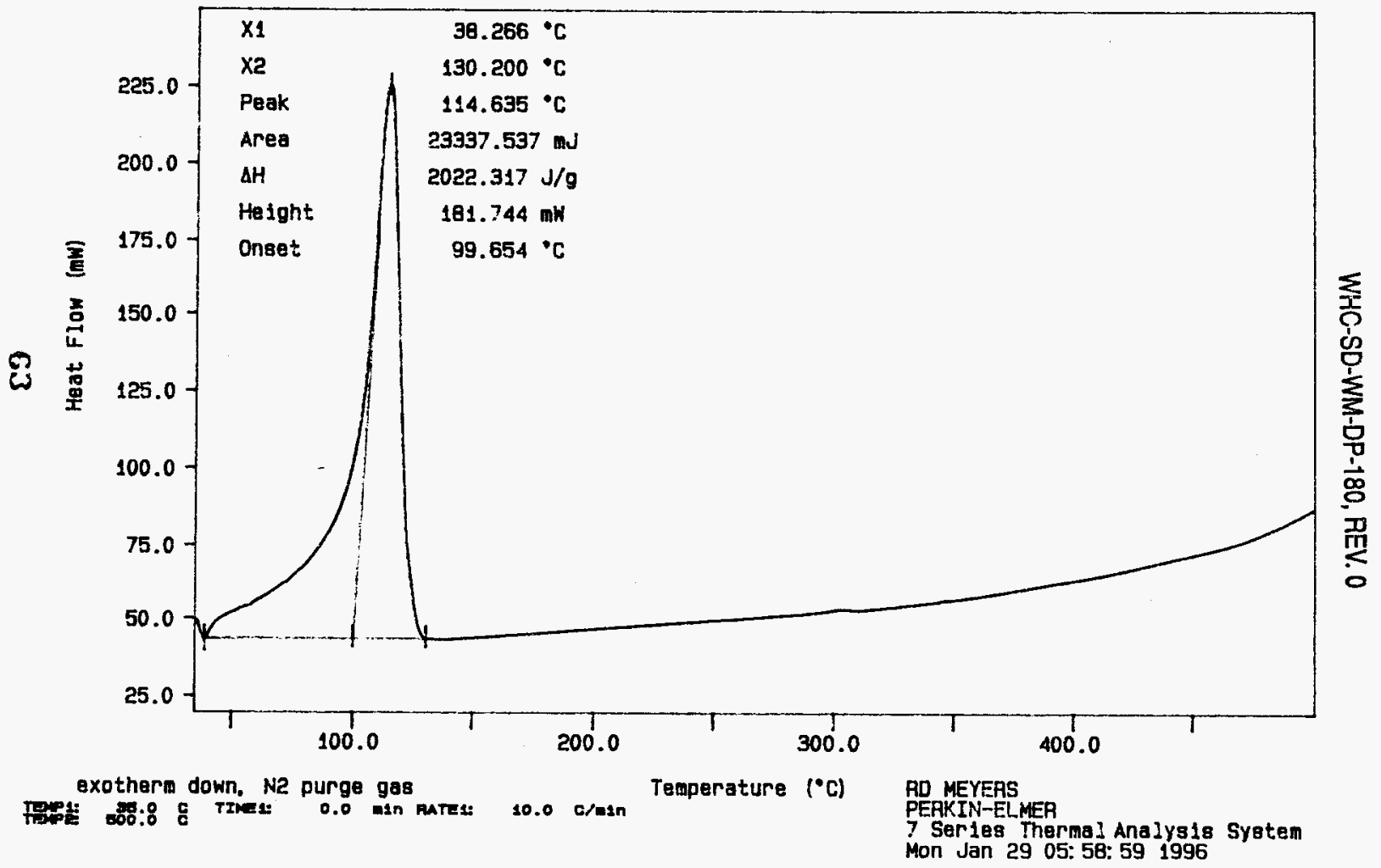


Curve 1: DSC

F1le info: SAM012904 Mon Jan 29 06: 53: 151996

Sample Neight: 18.760

mg

S96R000042 DUP

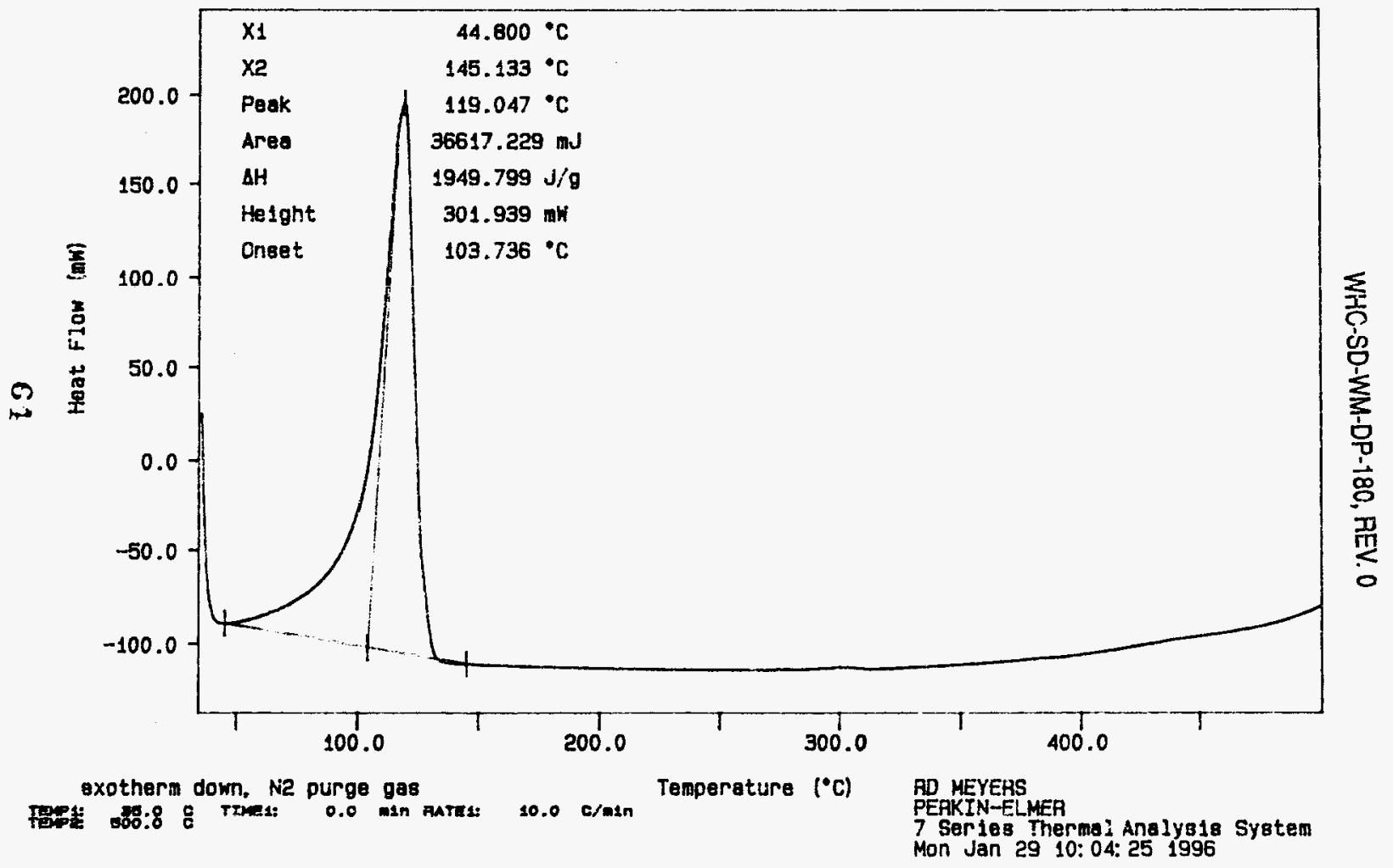




\section{LABCORE Data Entry Template for Worklist\#}

Analyst: RDM Instrument: TGA0 3 Book \# $75 N 8 A$

Method: LA-514-114 Rev/Mod C-1

Worklist Comment: TK 25-2 TGA RUN UNDER N2. RCJ

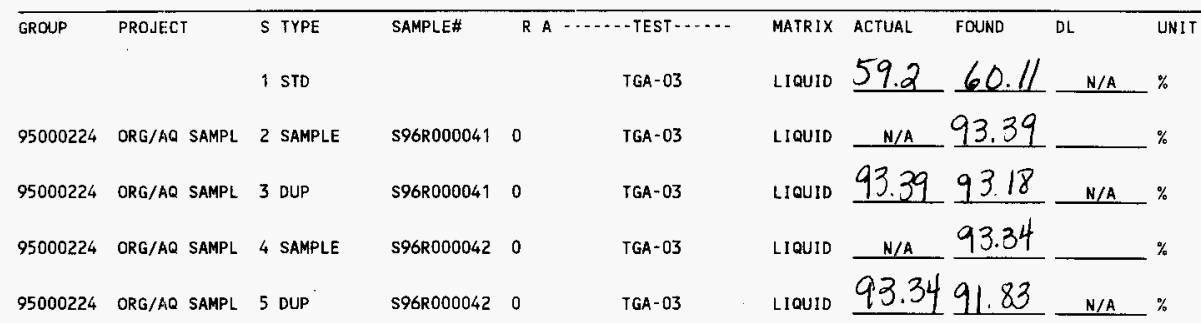

\section{Final page for worklist \# 4957}

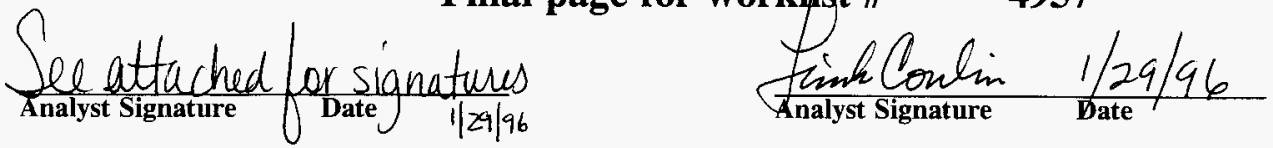

Data Entry Comments:

Units shown for QC (SPK \& STD) may not reflect the actual units. $D L=$ Detection Limit, $S=$ Worklist Slot Number, $R=$ Replicate Number, $A=$ Aliquot Code. 


\section{LABCORE Data Entry Template for Worklist\#}

Analyst: $\quad \mathrm{COM}$

$51 \overline{4-114 \text { Rom } 1 / h / 16}$

Instrument: TGA0

Book \# 75 N8A

Method: LA-560-1+2 Rev/Mod C-1

Worklist Comment: TK 25-2 TGA RUN UNDER N2. RCJ

\begin{tabular}{|c|c|c|c|c|c|c|c|c|c|c|}
\hline \multirow[t]{2}{*}{ GROUP } & PROJECT & & S TYPE & SAMPLE\# & RA & A.... TEST $\ldots$ & MATRIX & ACTUAL & FOUND & $\mathrm{DL}$ \\
\hline & & & 1 STD & & & TGA-01 & LIQUIO & & & N/A \\
\hline 95000224 & $\mathrm{ORG} / \mathrm{AQQ}$ & SAMPL & 2 SAMPLE & S96R000041 & 0 & TGA-01 & LIQUID & $\mathrm{N} / \mathrm{A}$ & & \\
\hline 95000224 & $O R G / A Q$ & SAMPL & 3 DUP & S96R000041 & 0 & TGA-01 & LIQUID & & & H/A \\
\hline 95000224 & $O R G / A Q$ & SAMPL & 4 SAMPLE & S96R000042 & 0 & TGA-01 & LIQUID & $N / A$ & & \\
\hline 95000224 & $O R G / A Q$ & SAMPL & 5 DUP & S96Re00042 & 0 & TGA-01 & LIOUID & & & N/A \\
\hline
\end{tabular}

Final page for worklist \#

4957

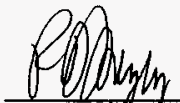

Analyst Signature

\section{$1 / 29 / 66$}

Date
Analyst Signature Date

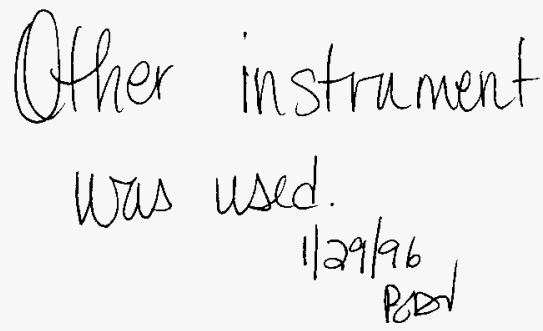

Data Entry Comments:

Units shown for $Q C$ (SPK \& STD) may not reflect the actual units. $D L=$ Detection Limit, $S=$ Worklist Slot Number, $R=$ Replicate Number, $A=$ Aliquot Code. 


\section{Curve 1: TGA}

File Info: q8ay1 Sun Jan 28 19: 31: 101996

Sample Weight: $11.993 \mathrm{mg}$

Terl19 75NO-A

SIGNATURE BELON REPRESANTS CHEMICAL TECHNOLOGIST/CHEMIST THAT

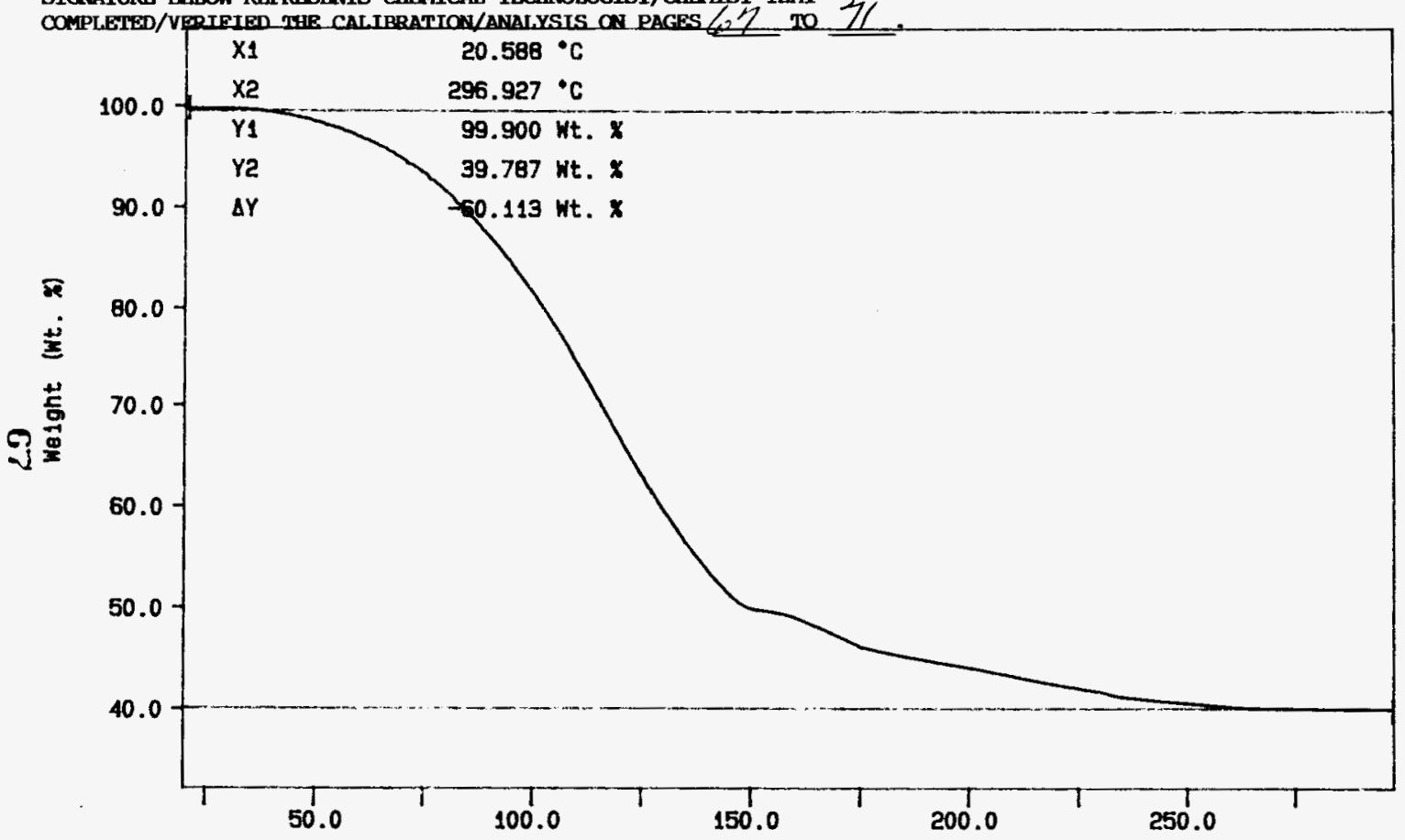

N2 $10 \mathrm{C} / \mathrm{MIN}$

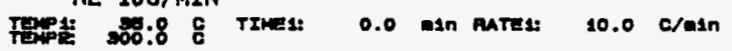

Temperature ("C) RD MEYEAS

PERKINI-ELMER

7 Serfes Thermal Analyg18 Systen Sun Jan 28 20: 20: 441996

foponeyra $1 / 28196$ 


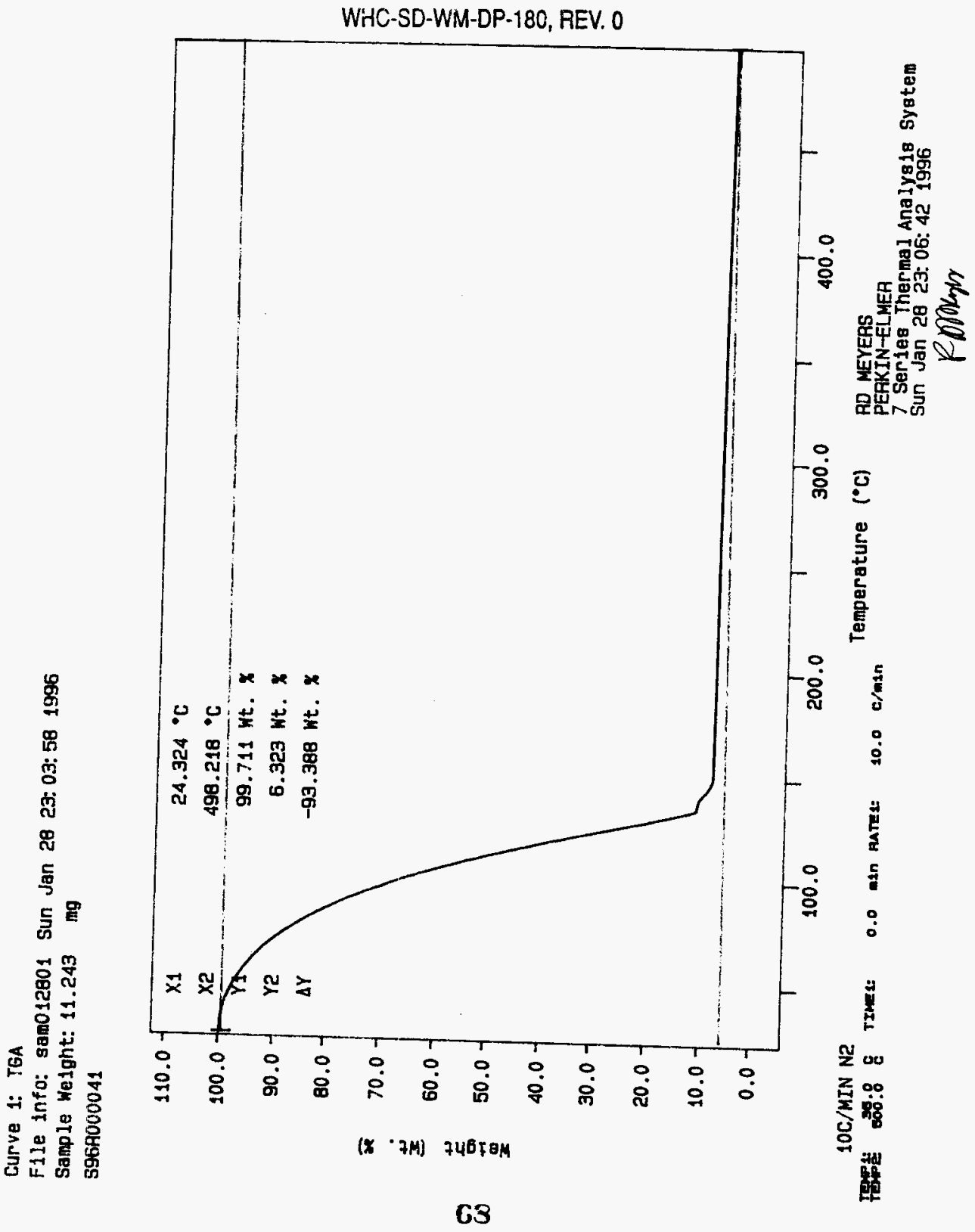




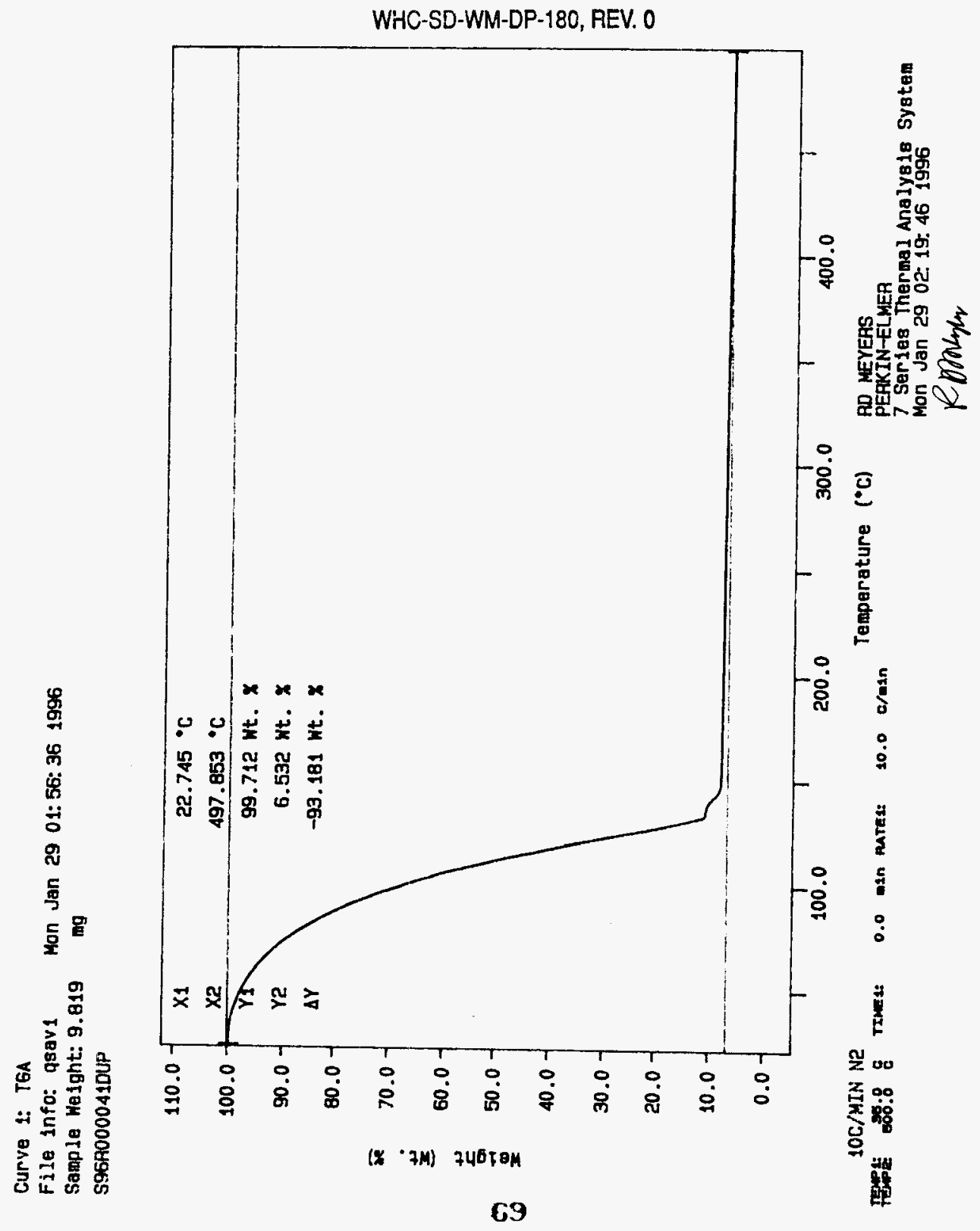


Curve 1: TGA

File info: qsav1 Mon Jan 29 03: 14: 421996

Sample Weight: $10.493 \mathrm{mg}$

S96R000042

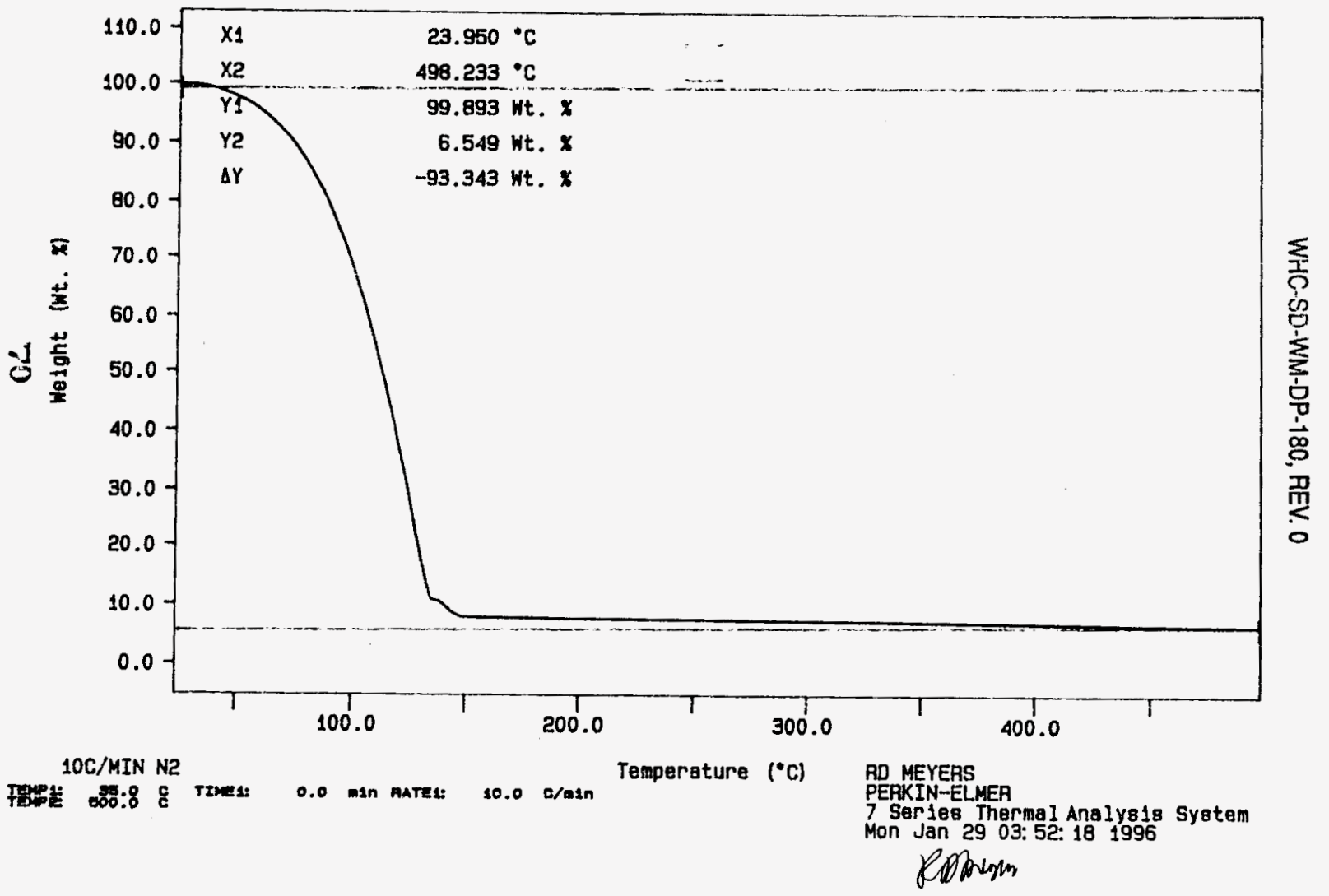


WHC-SO-WM-DP-180, REV. 0

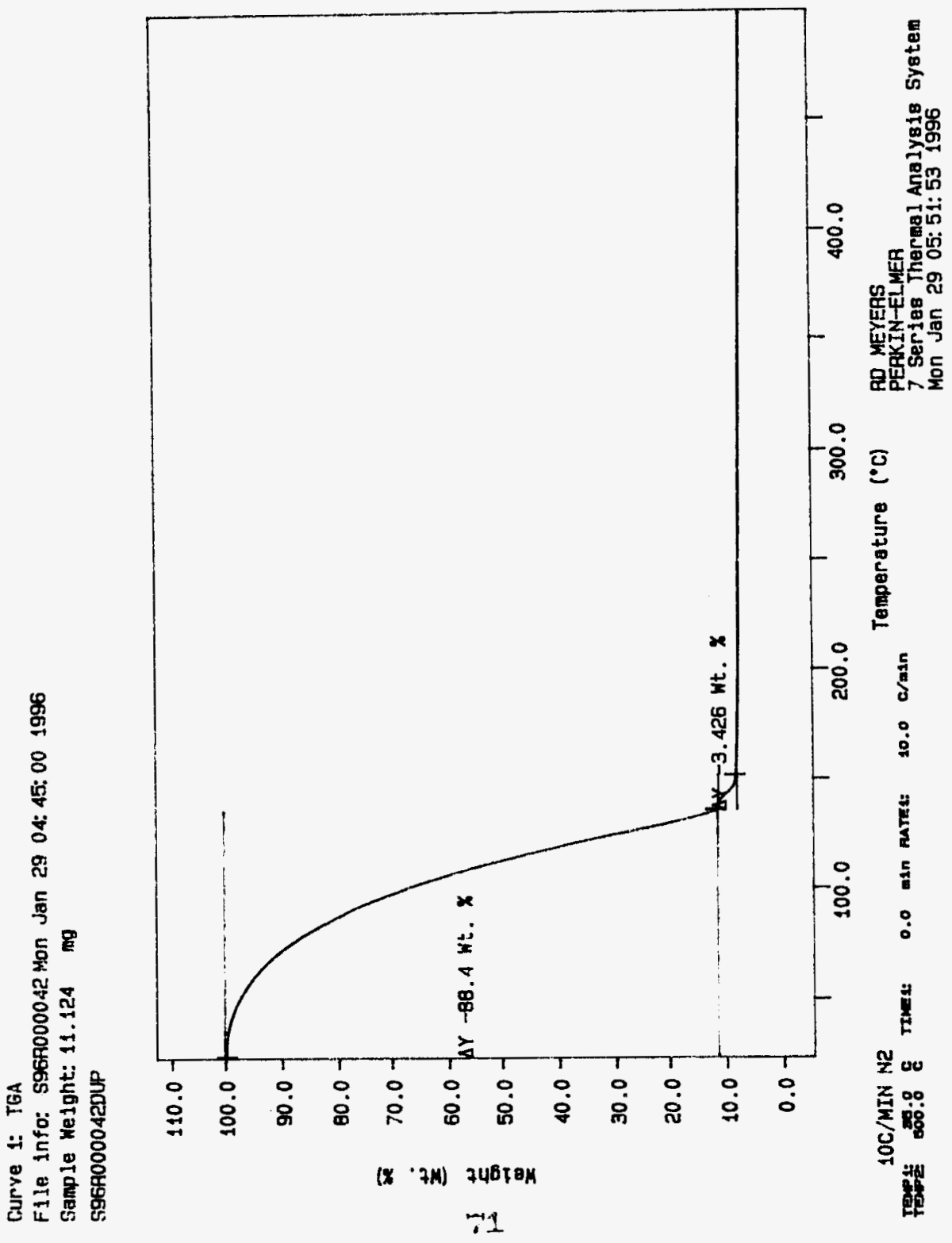




\section{Analyst: $\quad$ QQL Instrument: BA001 AL100 2 Book\# 133 N16-A}

Method: LA-510-112 Rev/Mod C -3

Worklist Comment: SpG B-203 \& 25-2 (Do not run replicates)

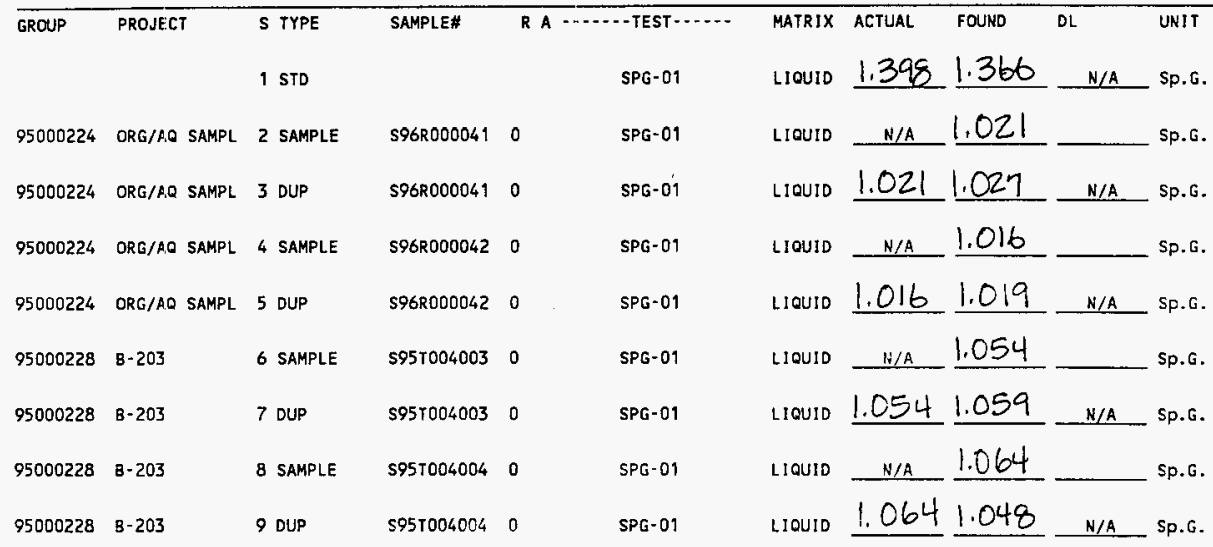

Final page for worklist \# 4996

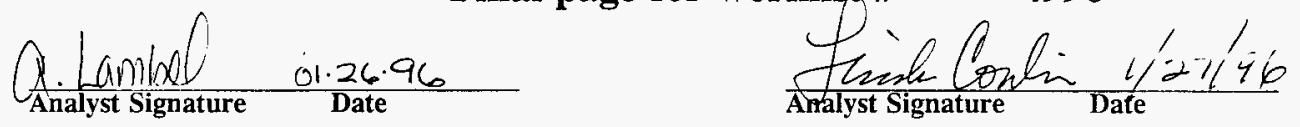

Data Entry Comments:

Rerived ly It Ancustor $1-29-96$

Units shown for $Q C$ (SPK \& STD) may not reflect the actual units. $D L=$ Detection Limit, $S=$ Worklist Slot Number, $R=$ Replicate Number, $A=$ Aliquot Code. 


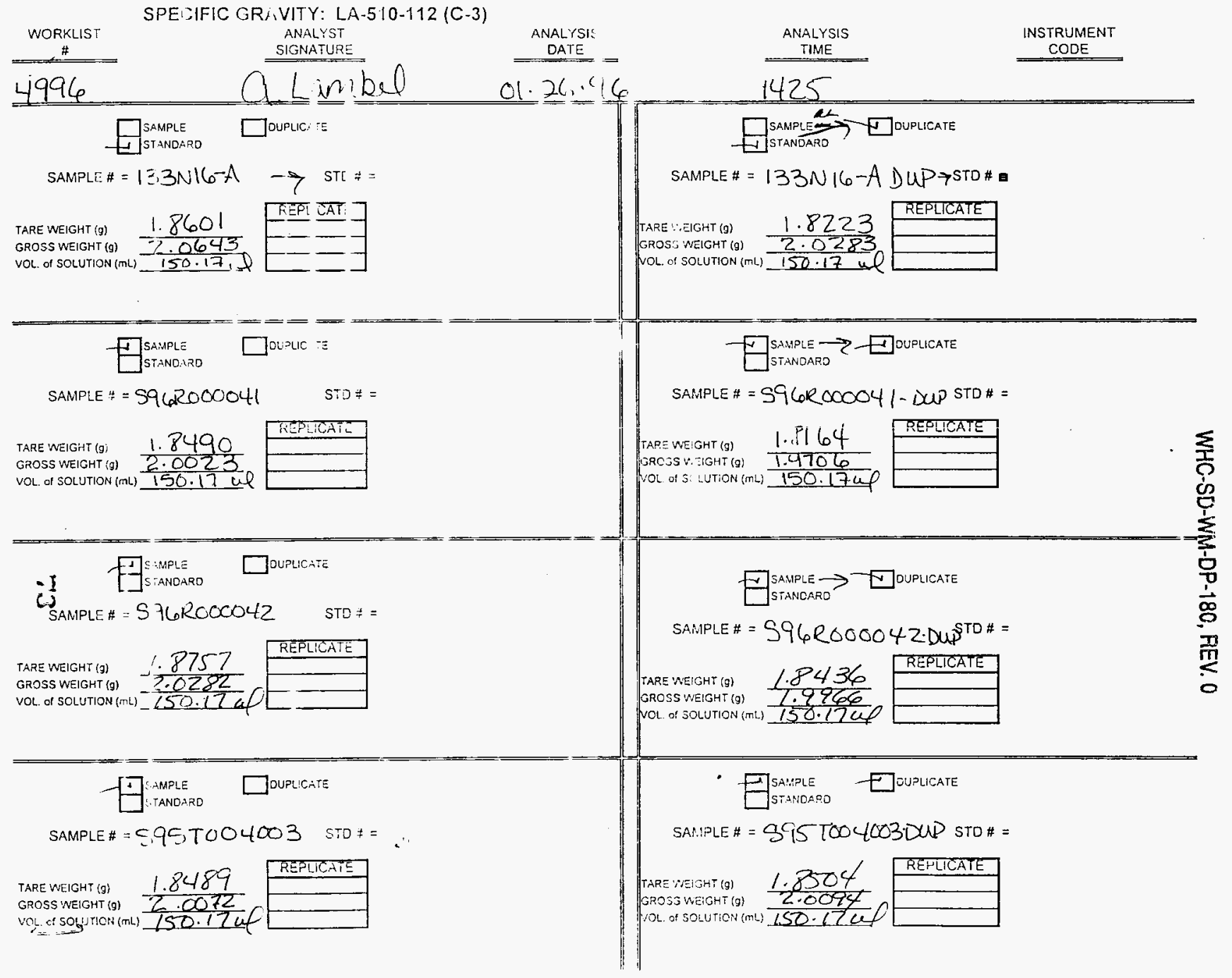


SPECIFIC GRAVITY: LA-510-112 (C-3)
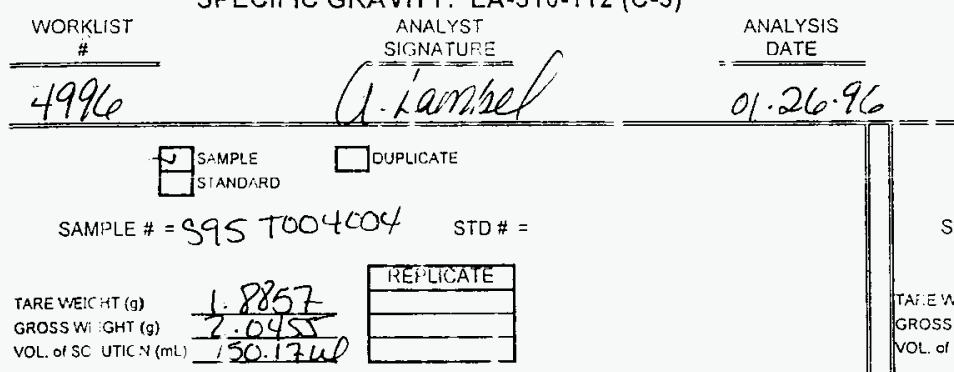

SAMPLE\# = $395500400404^{\text {STO\# }}=$

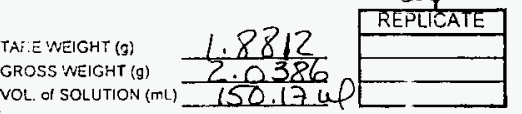

VOL al SOLUTION (mL) 150.17 Le

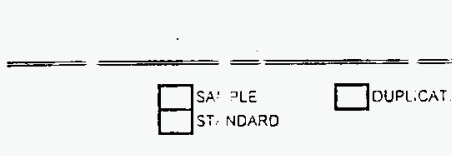

SAMPLE\# =

ST) $\#=$

\section{$\square_{\text {standaro }}^{\text {sample }}$}

SAMPLE \# =

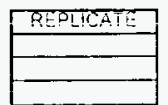

TARE WEIGHT (g)

SROSS WEIGHT (g)

/OL. of SOLUTION (mL)

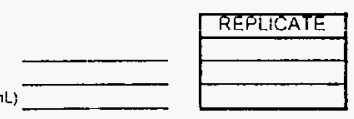

$-i_{\text {SAMPLE }}=$

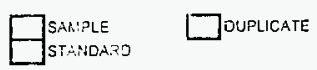

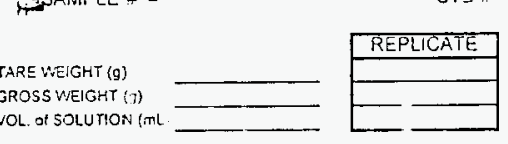

STD \# =
LICATE

SAMPLE \# =

STO\# REPUCATE

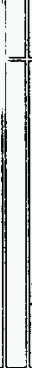

SAMPLE \# =

TA ?E $\because$ :EIGHT (g)

GFOS WEIGHT (g)

VISL. E' SOLUTION (m:L)

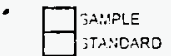

SAMPLE \# =

TARE WEIGHT (g)

GROSS WEIGHT (g)

VOL of SOLUTION (mL)
$S T D \#=$

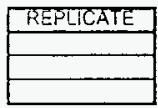

Duvlicate

STO\# =

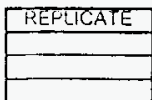


WHC-SD-WM-DP-180, REV. 0

SPECIFIC GRAVITY : LA-510-112 (C-3)

\begin{tabular}{|c|c|c|c|}
\hline 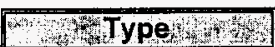 & & STANDARD & STANDARD \\
\hline STANDARD & Gross Weight (W2) & 2.0643 & 2.0283 \\
\hline 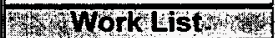 & Tare Weight (W1) & 1.8601 & 1.8223 \\
\hline 4996 & Weight of Solution (W2-W1) & 0.2042 & 0.206 \\
\hline W Test Code & Volume of Solution $\mu L$ & 150.1700 & 150.1700 \\
\hline SPG-01 & Specific Gravity & 1.3598 & 1.3718 \\
\hline 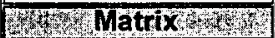 & Specific Gravity (Average) & 1.3658 & \\
\hline LIQUID & \multirow{9}{*}{\multicolumn{3}{|c|}{$\begin{array}{l}\text { Gross Weight }(W 2)=W t \text {. of vial }+ \text { cap }+ \text { cotton }+ \text { solution } \\
\text { Tare Weight }(W 1)=W t \text {. of vial }+ \text { cap }+ \text { cotton } \\
\text { Specific Gravity }=[(W 2-W 1) * 1000 \mu L / m L] /[\text { Vol. of Solution } \mu L * 1.000 \mathrm{~g} / \mathrm{mL}]\end{array}$}} \\
\hline Sample H $^{2}$ & & & \\
\hline 133N16A & & & \\
\hline Instrument Code & & & \\
\hline$A L 1002$ & & & \\
\hline 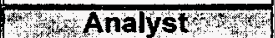 & & & \\
\hline A LAMBEL & & & \\
\hline Pris: & & & \\
\hline $01 / 26 / 96$ & & & \\
\hline Try & Specific Gravity Average = & 1.366 & \\
\hline
\end{tabular}

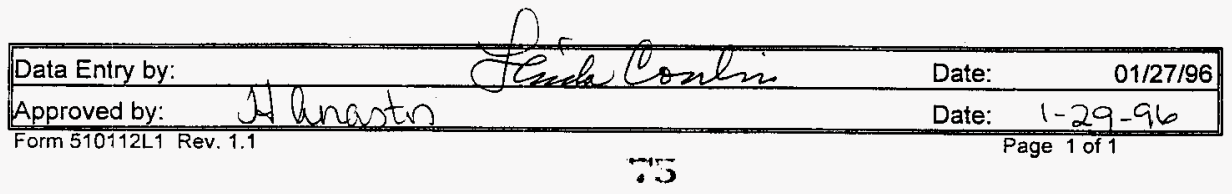


WHC-SD-WM-DP-180, REV. 0

\section{SPECIFIC GRAVITY : LA-510-112 (C-3)}

\begin{tabular}{|c|c|c|c|}
\hline 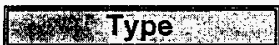 & & SAMPLE & REPLICATE \\
\hline SAMPLE & Gross Weight (W2) & 2.0023 & \\
\hline Wrat & Tare Weight (W1) & 1.8490 & \\
\hline 4996 & Weight of Solution (W2-W1) & 0.1533 & 0 \\
\hline 18 Test Code & Volume of Solution $\mu \mathrm{L}$ & 150.1700 & \\
\hline SPG-01 & Specific Gravity & 1.0208 & NA \\
\hline 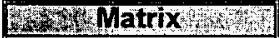 & & & \\
\hline LIQUID & \multirow{6}{*}{\multicolumn{3}{|c|}{$\begin{array}{l}\text { Gross Weight }(\mathrm{W} 2)=\text { Wt. of vial }+ \text { cap }+ \text { cotton }+ \text { solution } \\
\text { Tare Weight }(W 1)=W t \text {. of vial }+ \text { cap }+ \text { cotton } \\
\text { Specific Gravity }=[(W 2-W 1) * 1000 \mu L / m L] /[\text { Vol. of Solution } \mu L * 1.000 \mathrm{~g} / \mathrm{mL}]\end{array}$}} \\
\hline \begin{tabular}{|l} 
SET Sample \# \\
S96R000041
\end{tabular} & & & \\
\hline $\begin{array}{l}\text { Instrument Code } \\
\text { AL1002 }\end{array}$ & & & \\
\hline $\begin{array}{l}\text { 310 } \\
\text { A LAMBEL }\end{array}$ & & & \\
\hline 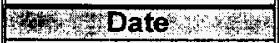 & & & \\
\hline $01 / 26 / 96$ & & & \\
\hline Sy, & Specific Gravity = & 1.021 & \\
\hline
\end{tabular}

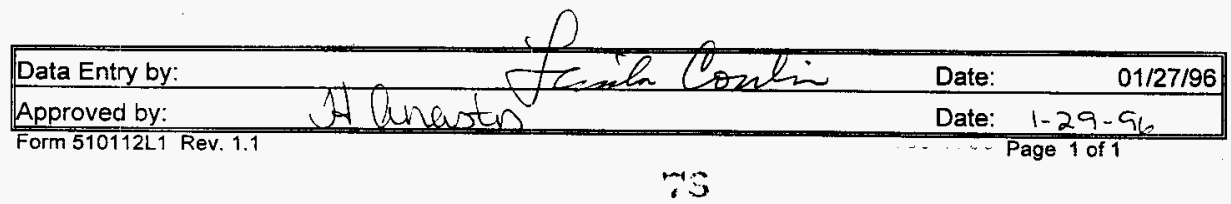


WHC-SD-WM-DP-180, REV. 0

\section{SPECIFIC GRAVITY : LA-510-112 (C-3)}

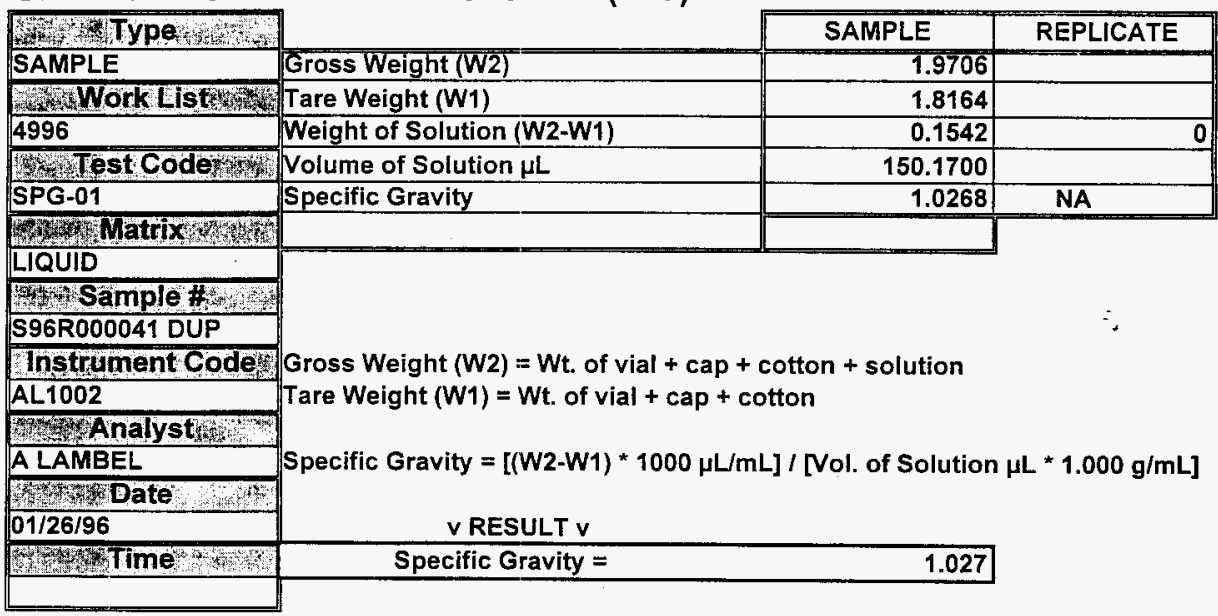

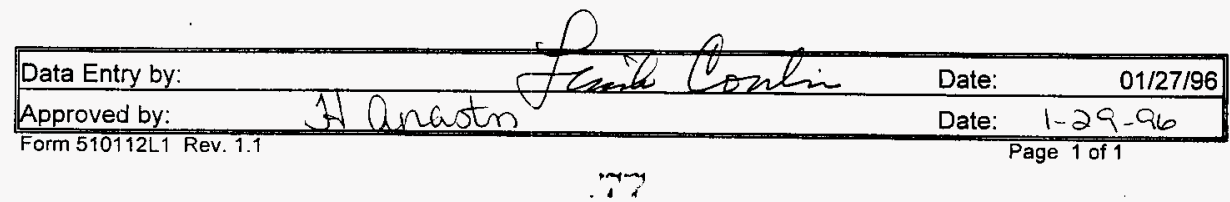


WHC-SD-WM-DP-180, REV. 0

\section{SPECIFIC GRAVITY : LA-510-112 (C-3)}

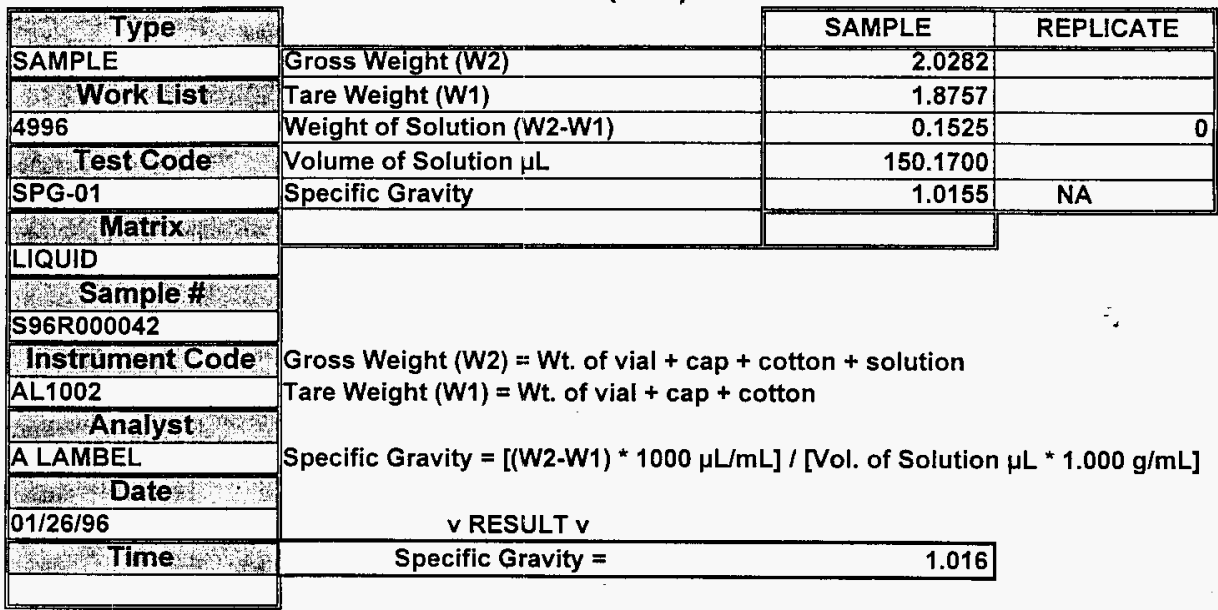

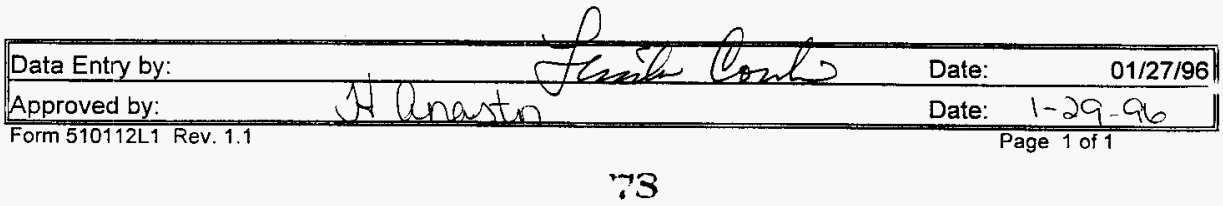




\section{WHC-SU-Wh-DP-180, REV. 0}

\section{SPECIFIC GRAVITY : LA-510-112 (C-3)}

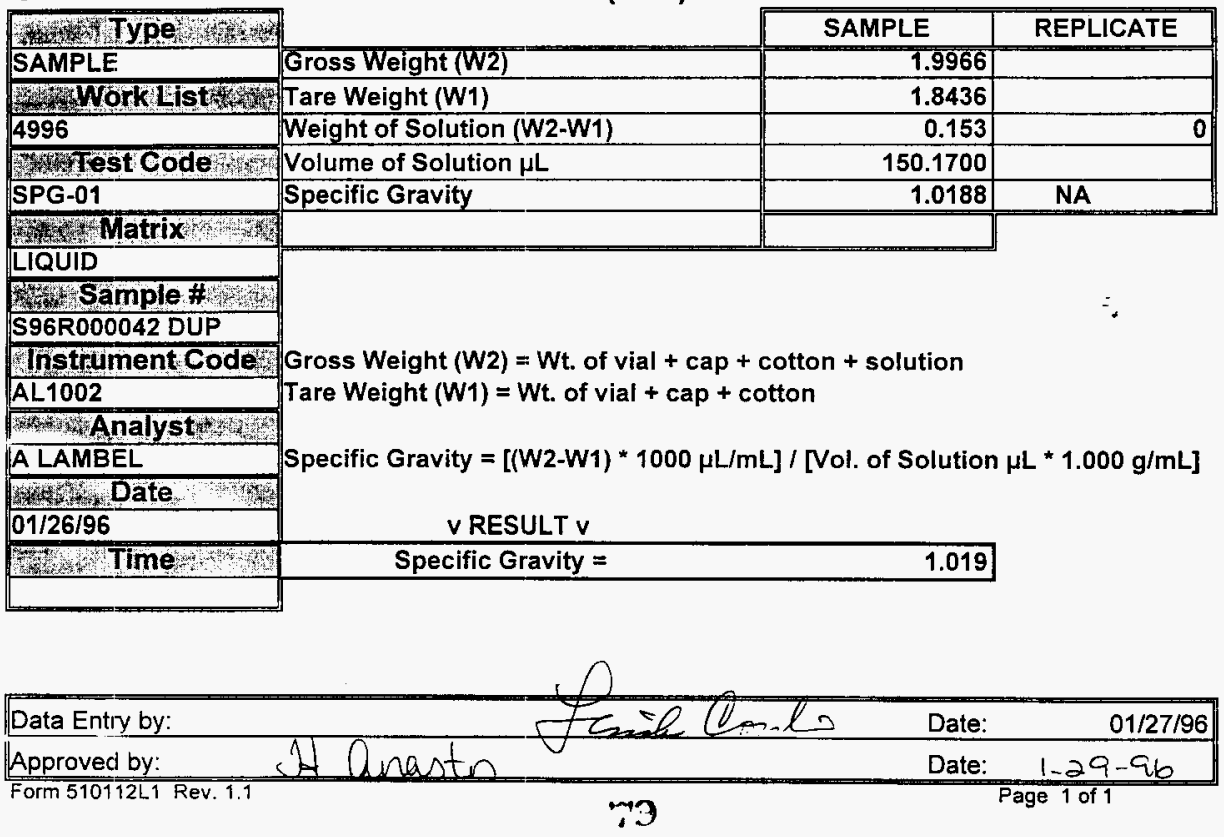




Analyst: $\quad$ 1) 8 S Instrument: $\mathrm{PHO1}$ Book 144 N/6-B

Method: LA-212-106 Rev/Mod A

Worklist Comment: PH FOR TK25-2 AND AP-108. RCJ

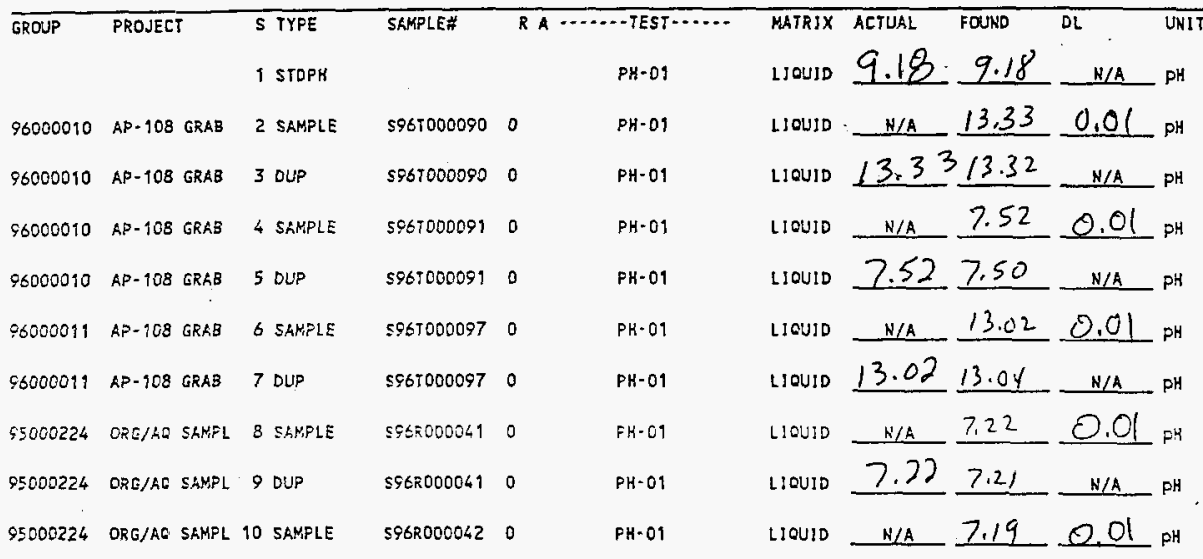

Final page for worklist \# 5007
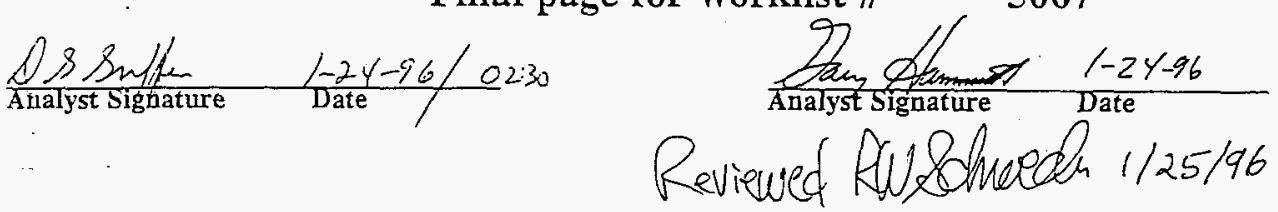

Data Entry Comments: Units shown for $Q C$ (SPK \& STD) moy not reflect the actual wits. $D L=$ Detection Limit, $S=$ Wrorklist Slot Number,
$R=$ Replicate Number, $A=$ Aliquot Code. 
worklistrpt Version 2.1 05/15/95

WHC-SD-WM-DP-180, REV. 0

Page: $\quad 1$

01/18/96 09:29

LABCORE Data Entry Template for Worklist\#

5002

Analyst: RAw Instrument: PH01 wC ob lat, Book \#57N8

Method: LA-211-102 Rev/Mod C-O

Worklist Comment: OH- 25-2

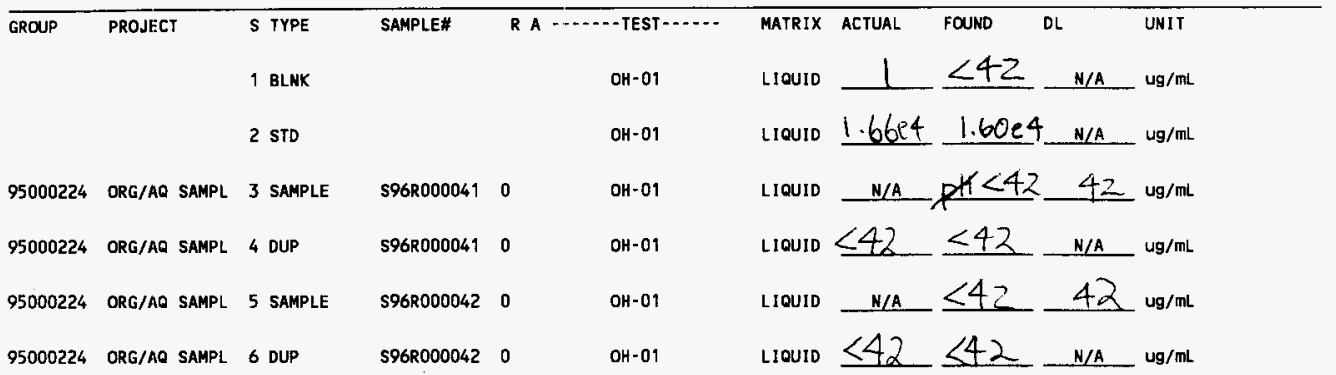

Final page for worklist \#

5002
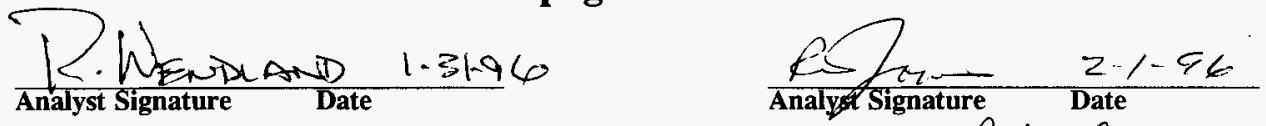

Reviewed Ru Ldwoedr 2/2/96

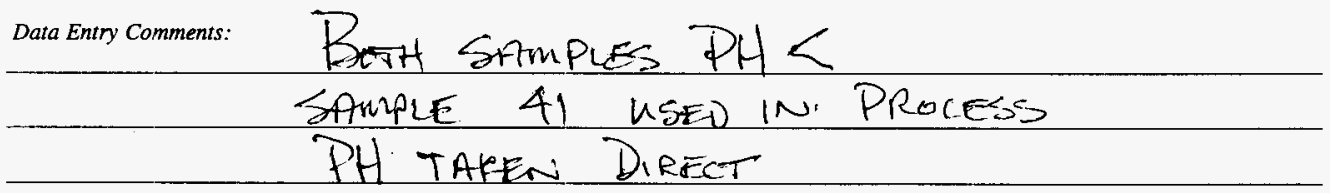

Units shown for $Q C$ (SPK \& STD) may not reflect the actual units. $D L=$ Detection Limit, $S=$ Worklist Slot Number, $R=$ Replicate Number, $A=$ Aliquot Code.

81 

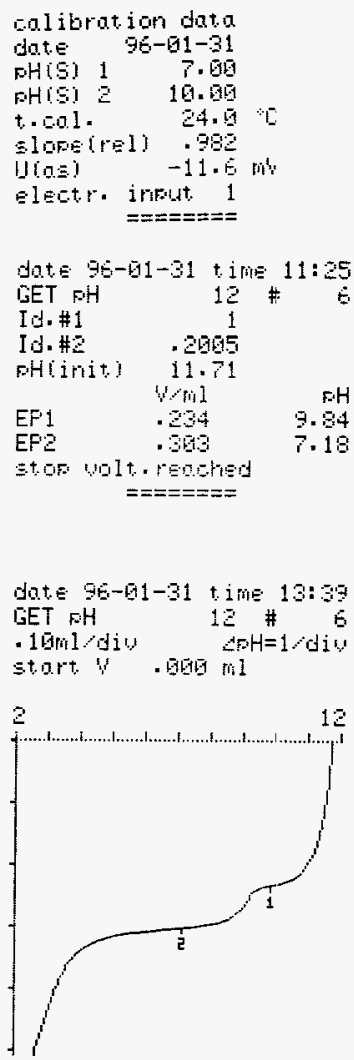

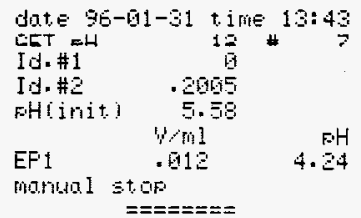

I的井 1

F.H

$7.11 \mathrm{w} / 0$

F.H

E.5E $\omega /$ / BACL

I的. \#1

$\mathrm{FH}$

$T=16 \quad w / 0$

FH

E. $38 \mathrm{~W} / \mathrm{BACL}$ 
worklistrpt Version $2.105 / 15 / 95$

WHC-SD-WM-DP-180, REV. 0

Page: $\quad 1$

$03 / 12 / 9608: 10$

LABCORE Data Entry Template for Worklist\#

6390

$\begin{array}{ll}\text { Analyst: } \quad \text { Instrument: PH01 } & \text { Book } \# \frac{73 N 8-A}{139 N 16-A} \text { SD K } \\ \text { Method: LA-211-104 Rev/Mod } A-1 & \text { STD }\end{array}$

Worklist Comment: Tank 25-2 OH demand rerun \#1 (run in replicate)

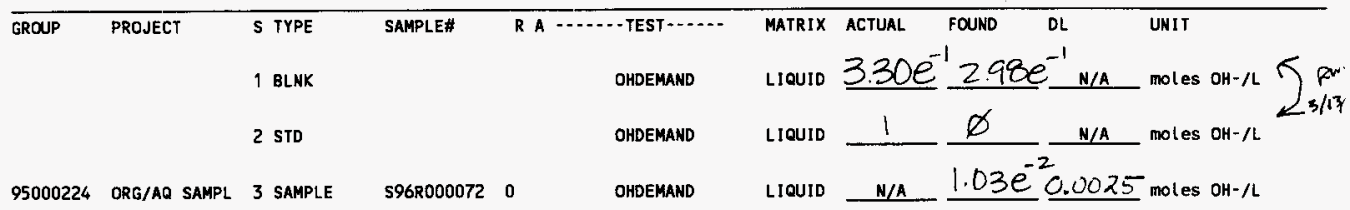

Final page for worklist \# 6390
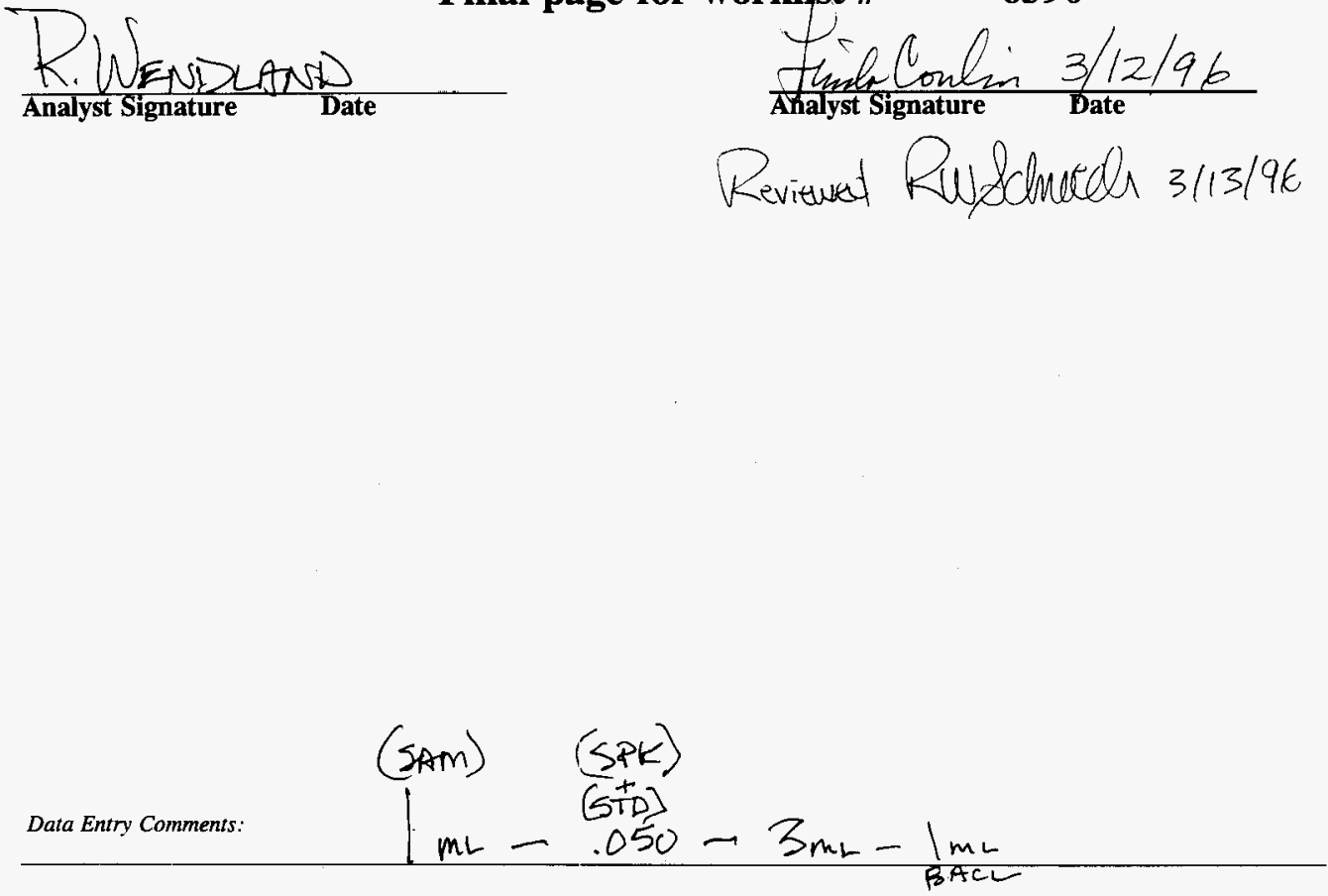

$$
\text { STD }-.050-.050-3 m L-\frac{1 m L}{H_{20}}-\frac{1}{B A C L}
$$

Units shown for QC (SPK \& STD) may not reflect the actual units. $D L=$ Detection Limit, $S=$ Worklist Slot Number, $R=$ Replicate Number, $A=$ Aliquot Code.

83 
$139 N 16-A$

WHC-SD-WM-DP-180, REV. 0

STD

$$
\begin{aligned}
& \mathrm{OH}_{\text {SP }}=0.9764 \mathrm{~m} \times 0.050 \mathrm{ml}=0.04882 \\
& \text { OHd }=0.2005 \mathrm{M} \times 0.169 \mathrm{ml}=0.0339 \\
& \mathrm{OH}_{\text {cond }}=0.04882-0.0339=0.0149
\end{aligned}
$$

Buffering Copacity $=0.0149 / 0.050 \mathrm{ml}=.2980$

3lank

$$
O H_{S p}=\varnothing
$$

Sample S96R000072

$$
\begin{aligned}
\text { OHSP } & =0.9764 \times 050 \mathrm{ml}=0.04882 \\
\text { OHd } & =0.2005 \mathrm{M} \times 0.192 \mathrm{ml}=0.0385 \\
\text { OHcons } & =0.04882-0.0385=0.0103 \\
\text { Buffering Capacity } & =0.0103 / 1 \mathrm{ml}=0.0103 \mathrm{~m}
\end{aligned}
$$

S1 


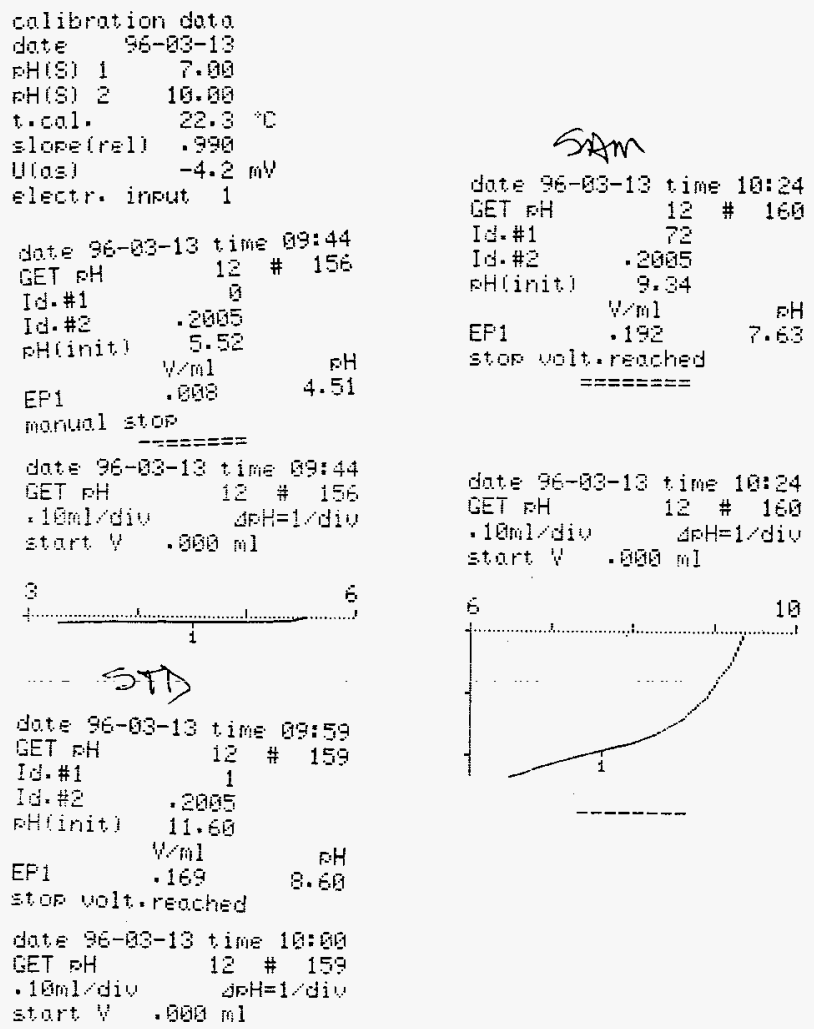

SAtm

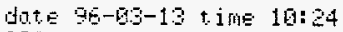

L.ET FEH

$I:-j=1$

I 19.

oflinit.

$12 \quad \# \quad 168$

it. 9.34

EFi 1 Inl

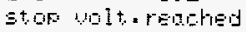

$-10 \times=$
$== \pm=$

7. 5

\section{$H$}


WHC-SD-WM-DP-180, REV. 0

THE FOLLOWING ANALYSES WERE RERUN. THEY ARE INCLUDED IN THE DATA PACKAGE BUT THE RESULTS HAVE NOT BEEN REPORTED IN THE FINAL SUMMARY REPORTS. 
worklistrpt Version $2.105 / 15 / 95$

WHC-SD-WM-DP-180, REV. 0

Page: $\quad 1$ 03/01/96 09:13

LABCORE Data Entry Template for Worklist\#

6005

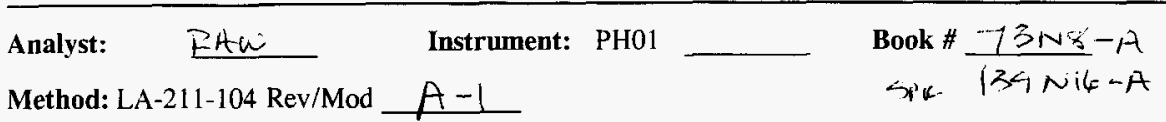

Worklist Comment: TK 25-2 OHDEMAND RUN IN REPLICATE. RCJ

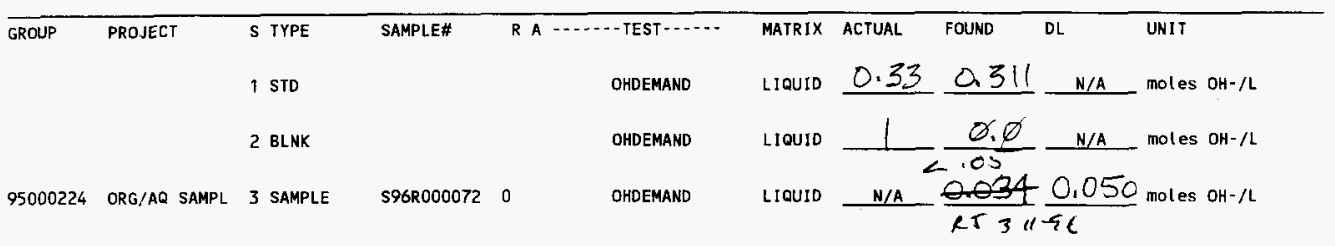

Final page for worklist \#

6005
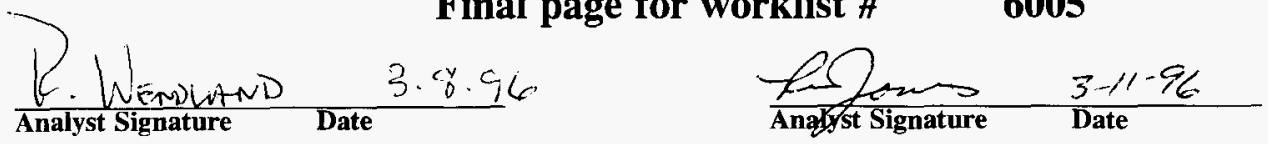

Reviewed 3/12/96

Results Rejected due to poor sensitivity.

Sample to be reanalyzed w/ greater sample

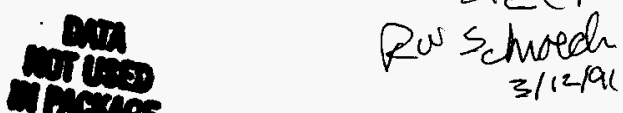

Comment: Result is "buffering Capacity." Refer to the LA 211-104 A-1 procedure to prepare solution for $[\mathrm{OH}]$ adjustment. Robert $W$ Schroeeh 3/11/96

Data Entry Comments:

$$
\begin{gathered}
(73)(139) \\
S T D-.050+.050+3 \mathrm{ml}_{2}\left(\mathrm{H}_{2} \mathrm{O}\right) \\
5 \mathrm{Am}-.05 \mathrm{~L}-.050(5 \mathrm{NO})-3 \mathrm{mi}\left(\mathrm{H}_{2} \mathrm{O}\right)
\end{gathered}
$$

Titrant . zoOn HNO,

Units shown for $Q C$ (SPK \& STD) may not reflect the actual units. $D L=$ Detection Limit, $S=$ Worklist Slot Number, $R=$ Replicate Number, $A=$ Aliquot Code.

87 
Calculations for wo 6005 Caustic Demand WHC-SD-WM-DP-180, REV. 0

STD

$$
\begin{aligned}
O_{S P} & =0.9764 \mathrm{~m} \times 0.050 \mathrm{ml}=0.04882 \\
O_{d} & =0.2005 \mathrm{~m} \times 0.166 \mathrm{ml}=0.03328 \\
O_{\text {COns }} & =0.04882-0.03328=0.01554 \\
& =0.01554 / 0.050 \mathrm{~mL}=0.3108
\end{aligned}
$$

Blank<smiles></smiles>

Sample S96R000072

$$
\begin{aligned}
\mathrm{OH}_{s_{p}} & =0.9764 \times 0.050 \mathrm{ml}=0.04882 \\
O H_{d} & =0.2005 \mathrm{~m} \times 0.239=0.04792 \\
O H_{\text {cons }} & =0.04882-0.048792=0.0009 \\
\text { Buffering Capacity } & =0.0009 / 0.050=0.018 \mathrm{M}
\end{aligned}
$$

Sample dup.

$$
\begin{aligned}
& \text { OHtp }_{\text {sp }}=0.9764 \times 0.050 \mathrm{ml}=0.04882 \\
& \text { std }=0.2005 \mathrm{~m} \times 0.231=0.04632 \\
& O_{\text {cons }}=0.04882-0.046 .32=0.0025 \\
& \text { Buffering Capacity }=0.0025 / 0.050=0.050 \mathrm{M} \\
& 39 \text { Ave. of replicates }=\frac{0.050+0.018}{2}=0.034 \mathrm{M}
\end{aligned}
$$


WHC-SD-WM-DP-180, REV. 0

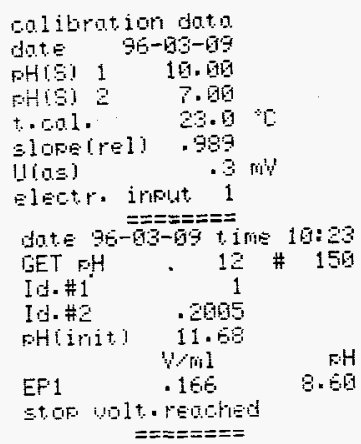

Jote $96-63-$ by time $19: 23$ GET $\mathrm{FH}$

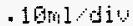
ఏtort $\because$. Ge16 ml

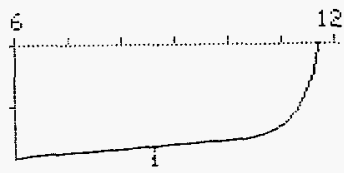

dote $96-63-69$ t. ins $19: 27$ IET FH, 12 \# $15 \mathrm{O}$ I‥ 1 $12 \quad \# 15 \mathrm{~s}$ $\mathrm{dP} H=1 \mathrm{di}$ 12

It. - 1165

Fot litit 5.6 $y$ [iा 1

EF 1 . E1EE

1.

[iteriugl 3 .top

ニニニニニニニ=

9ut $=95-03-09$ t 10 - 1927 GET FH 12 \# 152

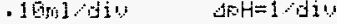
start . Bag ml

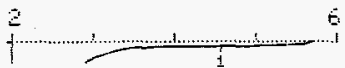

Jate 9s-as-69 time 10:48

GET FH 12 \# 159

Id. \#1 72

Id. 2.2019

Fitinit 11.71

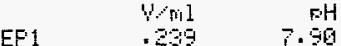

moruts stop

=ニニニ=ニニ=

date 95-93-99 time 19:48 EET FH IE \# 15 - Ibmldiv detiladiu Etot

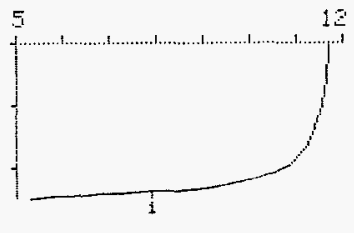

rute $95-83-89$ tine $18: 53$ $\mathrm{DET}$
$\mathrm{I} \mathrm{J}=\mathrm{H}+\mathrm{H}$

$I,-\frac{2}{2}=\frac{2}{t}=$

FHilint 11.7

-Fil FH

EF1 21

$7 \cdot 8 \mathrm{~s}$

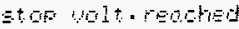

ニニニニニニニ

Jote $5 E-63-69$ tifie 1045 EET $\mathrm{PH} \quad 12$ \# 154

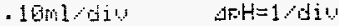
Etart. $\because$ a mas

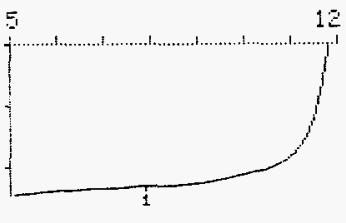




\section{LABCORE Data Entry Template for Worklist\#}

Analyst: PJM Instrument: $\mathrm{CN} 01$

Book \# 7IN $8 E$

Method: LA-695-102 Rev/Mod $D-O$

Worklist Comment: B-Plant CN Reruns RUSH Use 0.050mL Sample size.

\begin{tabular}{|c|c|c|c|c|c|c|c|c|c|c|c|}
\hline \multirow[t]{3}{*}{ GROUP } & \multirow{3}{*}{\multicolumn{2}{|c|}{ PROJECT }} & $S$ TYPE & SAMPLE\# & \multicolumn{2}{|c|}{ R A $\cdots$ - TEST - } & MATRIX & ACTUAL & FOUND & $\overline{D L}$ & UNIT \\
\hline & & & 1 BLNK & & & $\mathrm{CH}-01$ & LIQUID & 1 & $8 e^{-}$ & N/A & $\mathrm{ug} / \mathrm{mL}$ \\
\hline & & & 2 STO & & & $\mathrm{CN}-\mathbf{0} 1$ & LIQUID & 925 & & N/A & $\mathrm{ug} / \mathrm{mL}$ \\
\hline 95000224 & ORG/AQ & SAMPL & 3 SAMPLE & S96R000041 & 0 & $\mathrm{CH}-01$ & LIOUID & N/A & 1.5. & 1.5 & $u g / m L$ \\
\hline 95000224 & ORG/AQ & SAMPL & 4 DUP & S96R000041 & 0 & CN-01 & LIQUID & 1.5 & 1.5 & N/A & $\mathrm{ug} / \mathrm{mL}$ \\
\hline 95000224 & ORG/AQ & SAMPL & 5 SPK & S96R000041 & 0 & $\mathrm{CN}-01$ & LIQUID & 1.S. &. $\mathrm{S}$ & N/A & $u g / m L$ \\
\hline 95000224 & ORG/AQ & SAMPL & 6 SAMPLE & S96R000042 & 0 & $\mathrm{CN}-01$ & LIOUID & N/A & 12.8 & 1.10 & ug/mL \\
\hline 95000224 & ORG/AO & SAMPL & 7 DUP & S96R000042 & 0 & $\mathrm{CN}-01$ & LIQUID & 12.8 & 13.5 & N/A & $u g / m L$ \\
\hline 95000224 & $O R G / A Q$ & SAMPL & $8 \mathrm{SPK}$ & S96R000042 & 0 & $C N-01$ & LIQUID & 100 & 86.3 & N/A & $\mathrm{ug} / \mathrm{mL}$ \\
\hline & & & $9 \mathrm{ccV}$ & & & $\mathrm{CN}-01$ & LIQUIO & 925 & 868 & N/A & $\mathrm{ug} / \mathrm{mL}$ \\
\hline & & & 10 CCB & & & $\mathrm{CN}-01$ & LIQUID & 1 & $1.81 e^{-}$ & N/A & $\mathrm{ug} / \mathrm{mL}$ \\
\hline
\end{tabular}

Final page for worklist \#

5299

for PMCCown

Neathes anastor 2-1-96

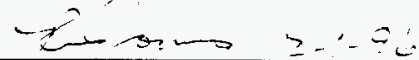
Analyst'Signature Date

Revieved Rü Schnoelen 2/2/96

Data Entry Comments:

Units shown for $Q C$ (SPK \& STD) may not reflect the actual units. $D L=$ Detection Limit, $S=$ Worklist Slot Number,

$R=$ Replicate Number, $A=$ Aliquot Code. 
Analyst: Bucloum

Instrument: $\mathrm{CN} 01$

Book \# Z/N8E

Method: LA-695-102 Rev/Mod D-O

Worklist Comment: B-Plant CN Reruns RUSH Use 0.050mL Sample size.

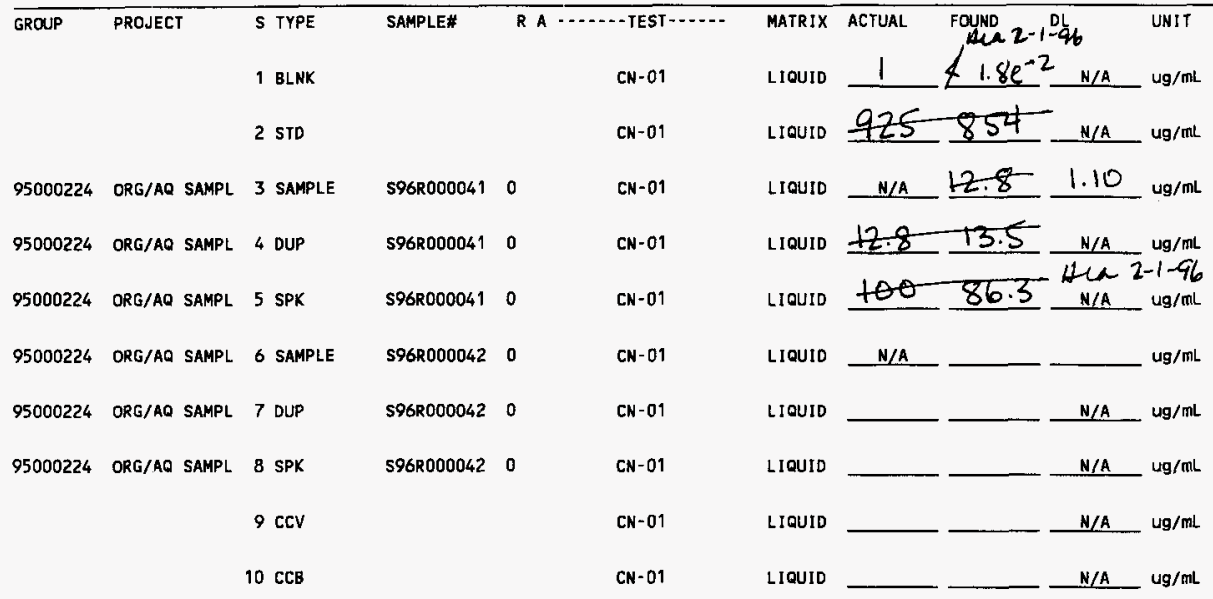

Final page for worklist \#

5299

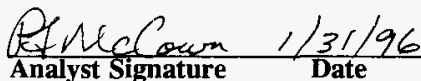

Analyst Signature

Date

Analyst Signature Date

Data Entry Comments:

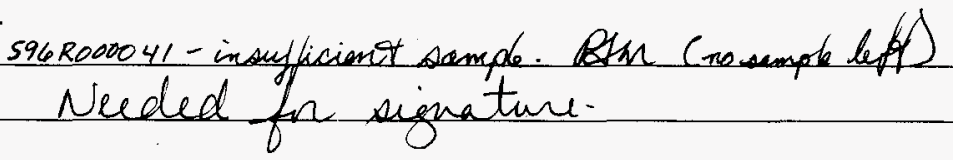

Units shown for $Q C$ (SPK \& STD) may not reflect the actual units. $D L=$ Detection Limit, $S=$ Worklist Slot Number, $R=$ Replicate Number, $A=$ Aliquot Code. 


\begin{tabular}{|c|c|c|c|c|}
\hline Worklist \# & Analyst & $\begin{array}{c}\text { Analysis Date } \\
\text { \& Time }\end{array}$ & Instrument Code & Standard Id \\
\hline 5299 & Binclown & $\begin{array}{l}1 / 31 / 96 \\
2230\end{array}$ & & $71 N 8 E$ \\
\hline
\end{tabular}

\begin{tabular}{|c|c|c|c|c|c|}
\hline Sample\# & & Dissolution & Dilution & Sample Size $(\mathrm{mL})$ & Abs. \\
\hline 1. LCS Standard & & $\mathrm{N} / \mathrm{A}$ & $0.250 \mathrm{~mL}$ to $25 \mathrm{~mL}$ & 0.500 & .715 \\
\hline 2. Reagent Blank & & $\mathrm{N} / \mathrm{A}$ & N/A & 5 & .005 \\
\hline $3.596 R 000041$ & $N / A$ & $\mathrm{~g}$ to $5 \mathrm{~mL}$ Water & & inaufficient somple & $N A$ \\
\hline 4. Duplicate & $N / A$ & $\mathrm{~g}$ to $5 \mathrm{~mL}$ Water & & & $W A$ \\
\hline 5. Spike & $N / A$ & Same as \#3 & $\begin{array}{l}\text { Same as \#3 } \\
0.250 \mathrm{~mL} \mathrm{Std}\end{array}$ & $\downarrow$ & $N A$ \\
\hline $6.596 R 000042$ & $N / A$ & $\mathrm{~g}$ to $5 \mathrm{~mL}$ Water & & $.050 \mathrm{mc}$ & .108 \\
\hline 7. Duplicate & $N / A$ & $\mathrm{~g}$ to $5 \mathrm{~mL}$ Water & & $.050 \mathrm{mc}$ & .114 \\
\hline 8. Spike & $N / A$ & Same as \#6 & $\begin{array}{l}\text { Same as \#6 } \\
0.250 \mathrm{~mL} \mathrm{Std} \\
\end{array}$ & $.050 \mathrm{mc}$ & .442 \\
\hline 9. CCV & & $\mathrm{N} / \mathrm{A}$ & $0.250 \mathrm{~mL}$ to $25 \mathrm{~mL}$ & 0.500 & .727 \\
\hline 10. CCB & & $\mathrm{N} / \mathrm{A}$ & N/A & 5 & .011 \\
\hline
\end{tabular}

Comments: 


\section{WHC-SD-WM-DP-180, REV. 0}

CN-DETERMINATION : LA-695-102 (D-0) BLANK, LIQUID, SOLID

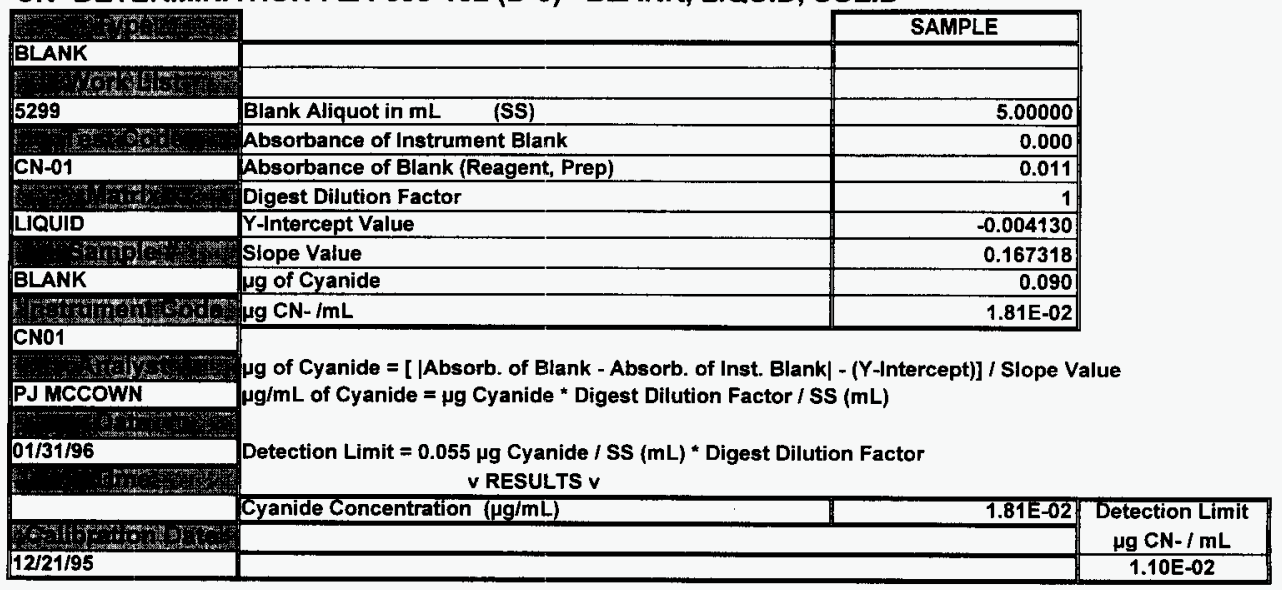

Data Entry by: by henator
Approved by:
Form 695102C1 Rev. 1.7




\section{WHC-SD-WM-DP-180, REV. 0}

\section{CN- DETERMINATION : LA-695-102 (D-0) SPIKE, STANDARD}

\begin{tabular}{|c|c|c|c|}
\hline 3 . & & NA & STANDARD \\
\hline STANDARD & Standard Aliquot in mL & & 0.250 \\
\hline & Diluent + Standard Volume & & 25.00 \\
\hline 5299 & Diluted Standard in $\mathrm{mL}$ to be Analyzed & & 0.500 \\
\hline 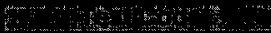 & True Value CN-Concentration ( $\mathrm{g} / \mathrm{mL}$ ) & & 925 \\
\hline CN-01 & Absorbance of Blank & & 0.005 \\
\hline & Absorbance of Standard & & 0.715 \\
\hline LIQUID & Y-Intercept Value & & -0.004130 \\
\hline 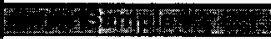 & Slope Value & & 0.167318 \\
\hline $71 \mathrm{NBE}$ & $\mu g$ of CN in Standard & & 4.268 \\
\hline In: & & & \\
\hline CNO1 & & & \\
\hline PJMccomn & & & \\
\hline PJ ACCOWN & & & \\
\hline $01 / 31 / 96$ & $\mu g$ of $\mathrm{CN}-\mathrm{mL}$ in Standard & & 854 \\
\hline 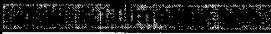 & Standard \% Recovery & & $92.3 \%$ \\
\hline 12/21/95 & imple Calculation from Forn & & \\
\hline
\end{tabular}

$\mu \mathrm{g}$ of $\mathrm{CN}$ - in Sample+Spike $=$ [(Absorbance of Sample+Spike - Absorbance of Blank $)-(Y-$ Intercept $)] /$ Slope Value $\mu \mathrm{g} / \mathrm{mL}$ of $\mathrm{CN}-=\mu \mathrm{g}$ of $\mathrm{CN}$ - in Standard / Diluted Standard * Dilution Factor

Dilution Factor $=$ Flask Volume $/$ Standard Aliquot

Standard \% Recovery $=(\mu \mathrm{g}$ of $\mathrm{CN}-/ \mathrm{mL}$ in Standard $/$ True Value $\mathrm{CN}$ - Concentration $(\mu \mathrm{gg} / \mathrm{mL})) * 100$

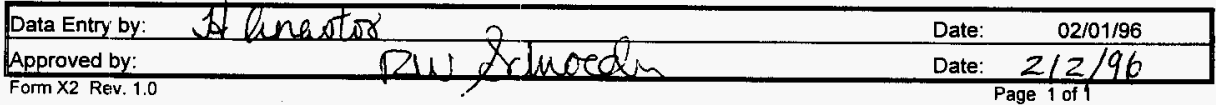


WHC-SD-WM-DP-180, REV. 0

CN- DETERMINATION : LA-695-102 (D-0) BLANK, LIQUID, SOLID

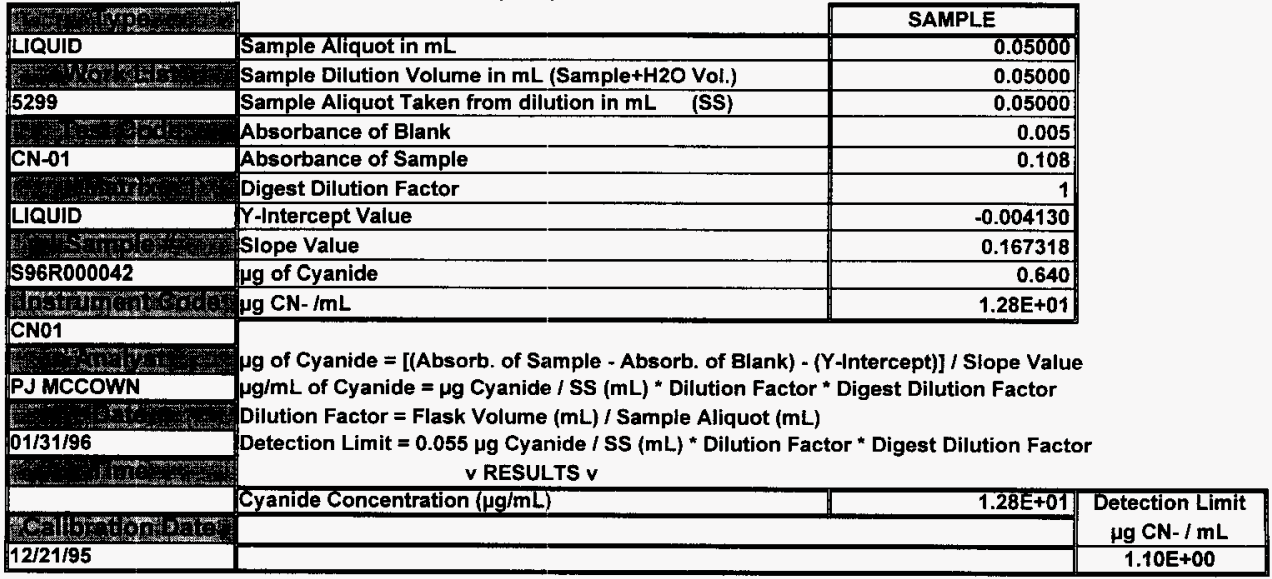

\begin{tabular}{|c|c|c|}
\hline Data Entry by: & Date: & $02 / 01 / 96$ \\
\hline Approved by: & Date: & \\
\hline
\end{tabular}




\section{WHC-SD-WM-DP-180, REV. 0}

CN- DETERMINATION : LA-695-102 (D-0) BLANK, LIQUID, SOLID

\begin{tabular}{|c|c|c|c|}
\hline 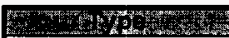 & & SAMPLE & \\
\hline LIQUtD & Sample Aliquot in mL & 0.05000 & \\
\hline 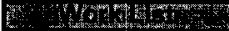 & Sample Dilution Volume in $\mathrm{mL}$ (Sample+H2O Vol.) & 0.05000 & \\
\hline 5299 & Sample Aliquot Taken from dilution in $\mathrm{mL} \quad$ (SS) & 0.05000 & \\
\hline & Absorbance of Blank & 0.005 & \\
\hline CN-01 & Absorbance of Sample & 0.114 & \\
\hline$\left(\begin{array}{l}3 \\
4\end{array}\right.$ & Digest Dilution Factor & 1 & \\
\hline LIQUID & Y-Intercept Value & -0.004130 & \\
\hline 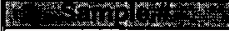 & Slope Value & 0.167318 & \\
\hline S96R000042 - DUP & pg of Cyanide & 0.676 & \\
\hline 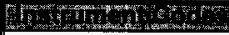 & $\mu \mathrm{g} \mathrm{CN}-/ \mathrm{mL}$ & $1.35 \mathrm{E}+01$ & \\
\hline \multicolumn{4}{|l|}{ CNO1 } \\
\hline PJ MCCOWN & \multirow{3}{*}{\multicolumn{3}{|c|}{ 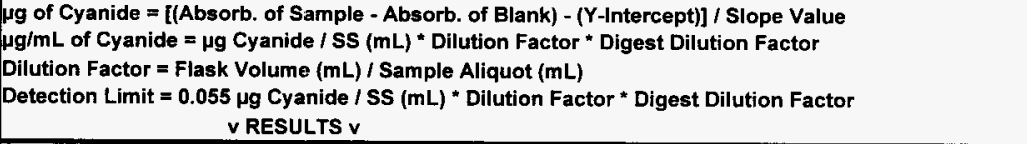 }} \\
\hline \multirow{3}{*}{ 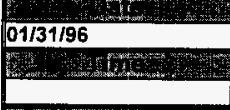 } & & & \\
\hline & & & \\
\hline & Cyanide Concentration $(\mu \mathrm{g} / \mathrm{mL})$ & 1.35E+01 & \multirow{2}{*}{$\begin{array}{l}\text { Detection Limit } \\
\mu \mathrm{g} \text { CN- / mL }\end{array}$} \\
\hline \multirow{2}{*}{ 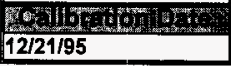 } & & & \\
\hline & & & $1.10 \mathrm{E}+00$ \\
\hline Data Entry by: & nastor & Date: & $02 / 01 / 96$ \\
\hline Approved by: & & Date: & 213196 \\
\hline
\end{tabular}




\section{WHC-SD-WM-DP-180, REV. 0}

CN- DETERMINATION : LA-695-102 (D-0) SPIKE, STANDARD

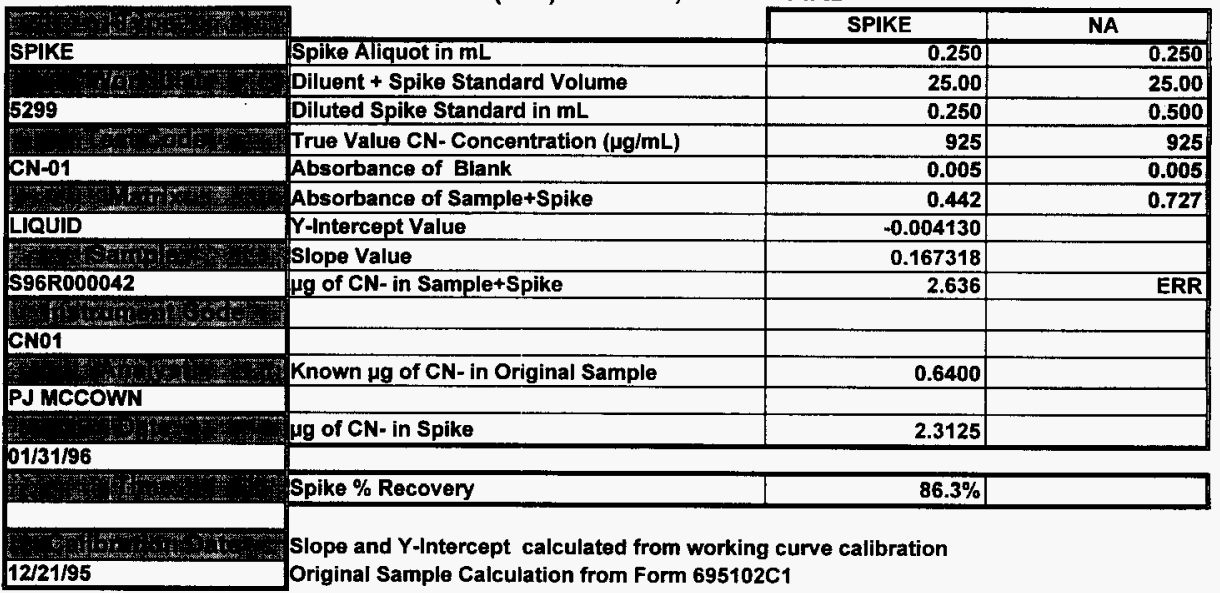

$\mu \mathrm{g}$ of $\mathrm{CN}$ - in Sample (Correced) = Known $\mu \mathrm{g}$ of $\mathrm{CN}$ - in Original Sample * $\mathrm{g}$ of Sample in Spike /g Used in Original Sample $\mu \mathrm{g}$ of CN- in Sample+Spike = [(Absorbance of Sample+Spike - Absorbance of Blank) $-(Y$-Intercept) $/$ Slope Value $\mu \mathrm{g}$ of $\mathrm{CN}$ - in Spike = LMCS Value $(\mathrm{ppm}) /$ Dilution Factor * Diluted Spike Standard

Dilution Factor $=$ Spike Dilution Volume $/$ Spike Aliquot

Spike \% Recovery $=(\mu \mathrm{g}$ of $\mathrm{CN}$ - in Sample+Spike $)-(\mu \mathrm{g}$ of CN- in Sample $) /(\mu \mathrm{g}$ of CN-in Spike) $* 100 \%$

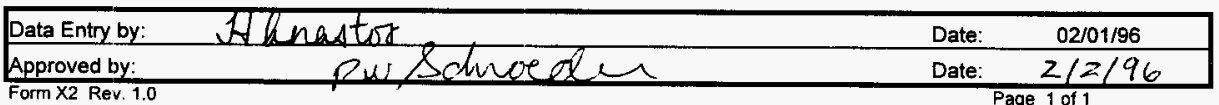


WHC-SD-WM-DP-180, REV. 0

CN- DETERMINATION : LA-695-102 (D-0) SPIKE, STANDARD

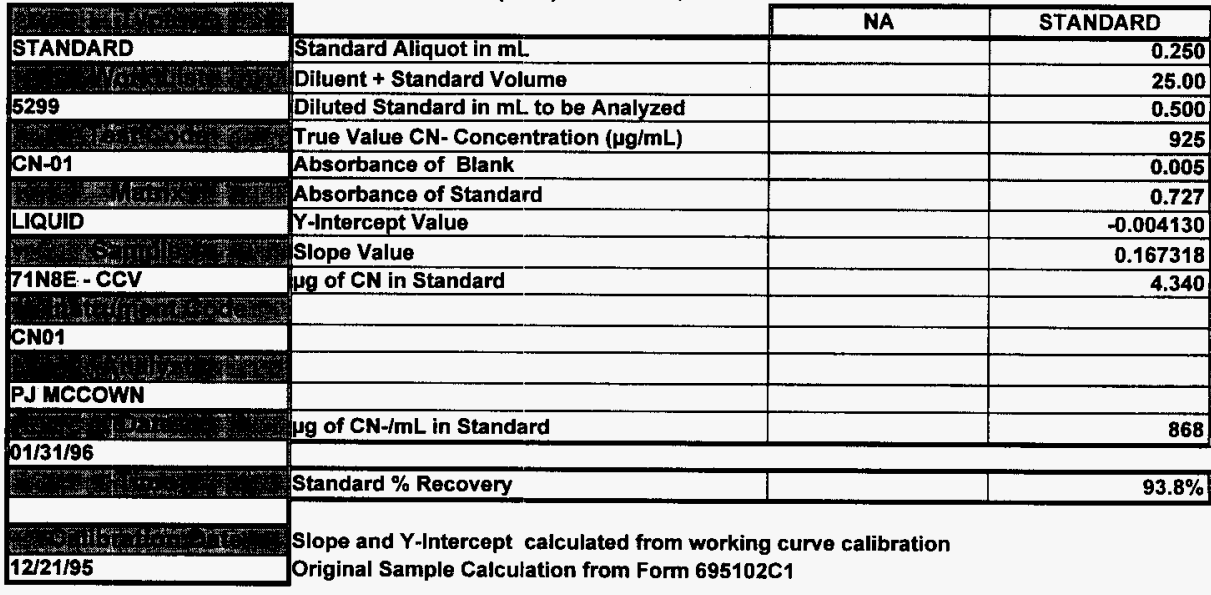

$\mu \mathrm{g}$ of $\mathrm{CN}$ - in Sample+Spike = [(Absorbance of Sample+Spike - Absorbance of Blank) - (Y-intercept) $/$ Stope Value $\mu \mathrm{g} / \mathrm{mL}$ of $\mathrm{CN}-=\mu \mathrm{g}$ of $\mathrm{CN}$ - in Standard / Diluted Standard * Dilution Factor

Dilution Factor $=$ Flask Volume $/$ Standard Aliquot

Standard \% Recovery $=(\mu \mathrm{g}$ of $\mathrm{CN}-/ \mathrm{mL}$ in Standard / True Value CN- Concentration $(\mu \mathrm{g} / \mathrm{mL})) * 100$

\begin{tabular}{|c|c|c|}
\hline Data Entry by: & Date: & $02 / 01 / 96$ \\
\hline Approved by: & Date: & $1 z / 96$ \\
\hline Form X2 Rev. 1.0 & \multicolumn{2}{|c|}{ Page 1 of 1} \\
\hline
\end{tabular}


WHC-SD-WM-DP-180, REV. 0

CN- DETERMINATION : LA-695-102 (D-0) BLANK, LIQUID, SOLID

\begin{tabular}{|c|c|c|}
\hline \multirow{2}{*}{$\begin{array}{l}\text { BLANK } \\
\text { BLA }\end{array}$} & & SAMPLE \\
\hline & & \\
\hline Tow & & \\
\hline 5299 & Blank Aliquot in $\mathrm{mL}$ & 5.00000 \\
\hline 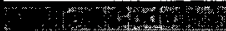 & Absorbance of Instrument Blank & 0.000 \\
\hline CN-01 & Absorbance of Blank (Reagent, Prep) & 0.011 \\
\hline . & Digest Dilution Factor & 1 \\
\hline LIQUUSD & Y-Intercept Value & -0.004130 \\
\hline 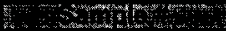 & Slope Value & 0.167318 \\
\hline $\mathrm{CCB}$ & pg of Cyanide & 0.090 \\
\hline 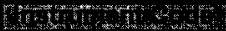 & $\mu g \mathrm{CN}-\mathrm{mL}$ & $1.81 E-02$ \\
\hline
\end{tabular}

\section{CN01}

$\mu g$ of Cyanide = [ |Absorb. of Blank - Absorb. of Inst. Blank| - (Y-Int
$\mu g / \mathrm{mL}$ of Cyanide = $\mu \mathrm{g}$ Cyanide * Digest Dilution Factor $/ \mathrm{SS}(\mathrm{mL})$

(1)

$01 / 31 / 96$

Detection Limit $=0.055 \mu \mathrm{g}$ Cyanide / SS $(\mathrm{mL})$ * Digest Dilution Factor

v RESULTS v

Cyanide Concentration ( $\mu \mathrm{g} / \mathrm{mL}$ )

I.

(2)

Detection Limit

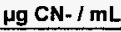
1.10E-02

\begin{tabular}{l}
\hline Data Entry by: N A naator \\
Approved by: \\
Form 695102C1 Rev. 1.7
\end{tabular}


Analyst: $\quad J T K \quad$ Instrument: $\mathrm{CNO1} \longrightarrow$ Book\# $71 N 8 F$

Method: LA-695-102 Rev/Mod D-O

Worklist Comment: TK 25-2 CN RCJ

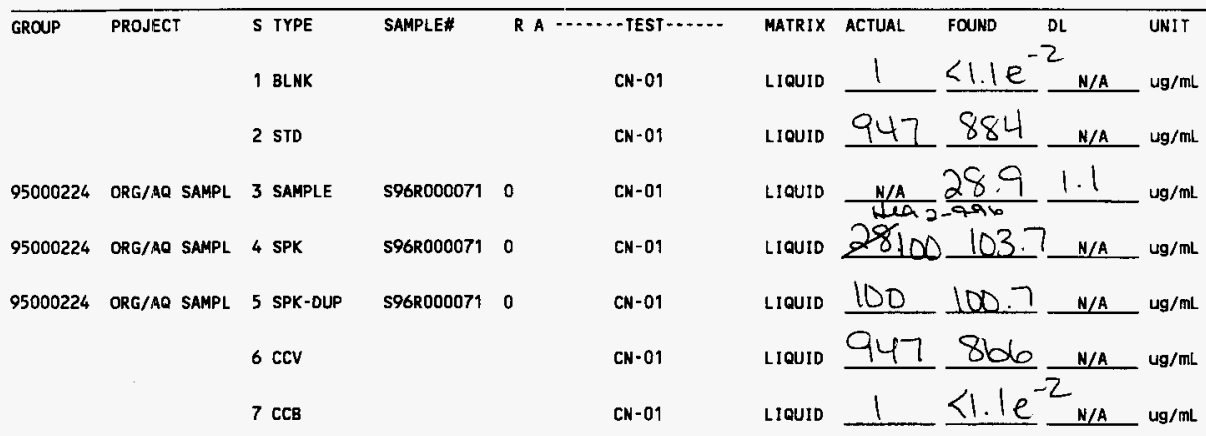

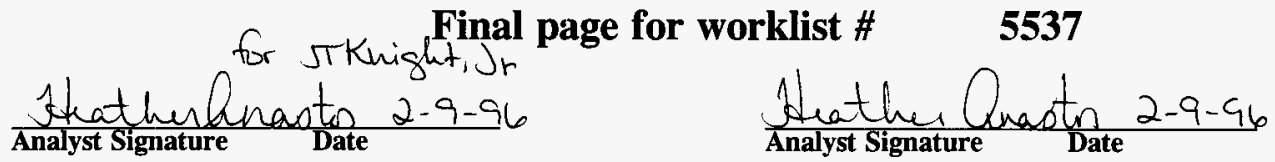

Data Entry Comments:

Units shown for $Q C$ (SPK \& STD) may not reflect the actual units. $D L=$ Detection Limit, $S=$ Worklist Slot Number, $R=$ Replicate Number, $A=$ Aliquot Code. 
CN: LA-695-102 (C-0)

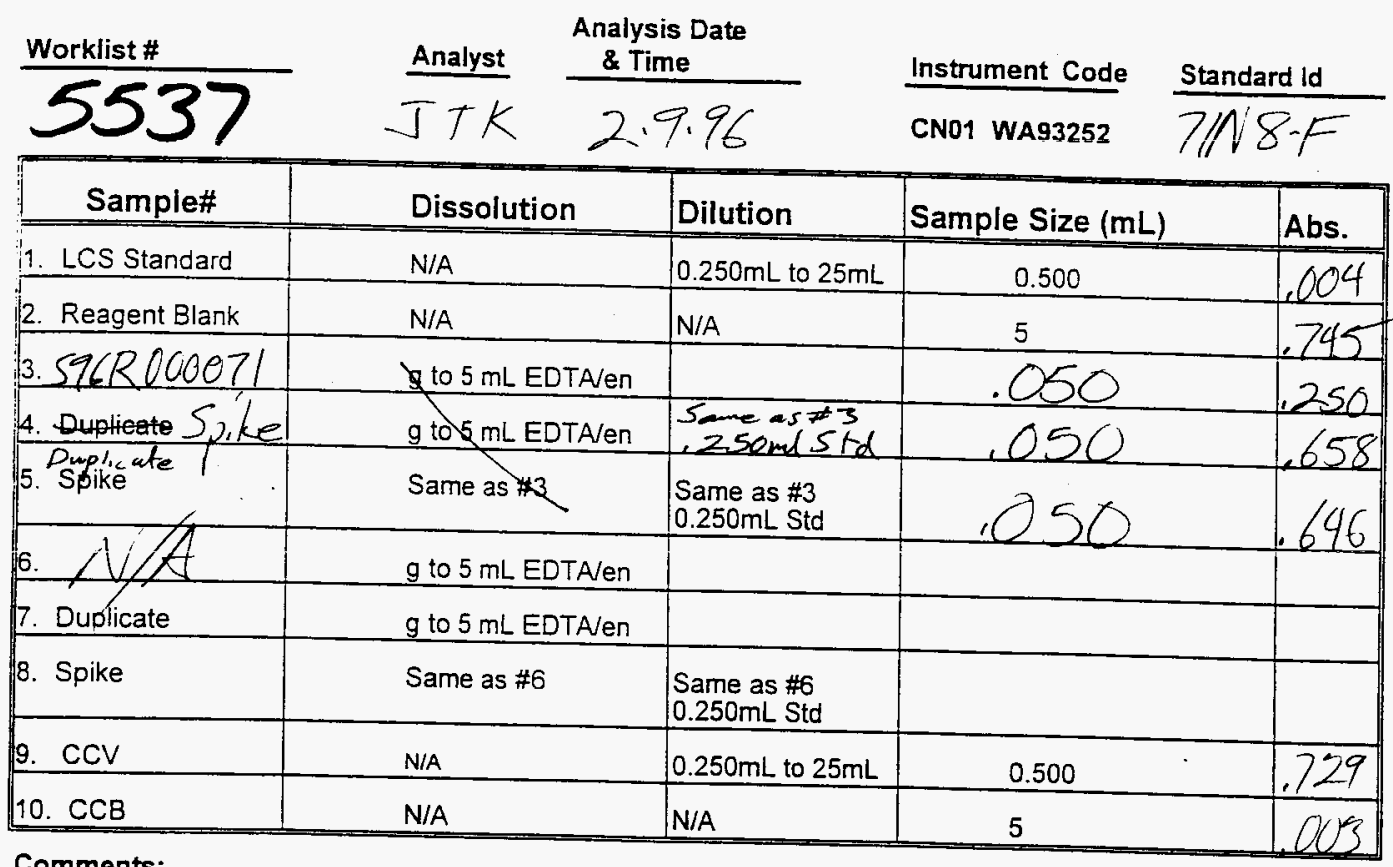

Comments:

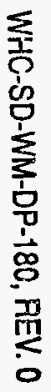




\section{WHC-SD-WM-DP-180, REV. 0}

\section{CN- DETERMINATION : LA-695-102 (D-0) BLANK, LIQUID, SOLID}

\begin{tabular}{|c|c|c|}
\hline \multicolumn{3}{|r|}{ SAMPLE } \\
\hline BLANK & & \\
\hline 8 & & \\
\hline 5537 & Blank Aliquot in $\mathrm{mL}$ & 5.00000 \\
\hline & Absorbance of Instrument Blank & 0.000 \\
\hline CN-01 & Absorbance of Blank (Reagent, Prep) & 0.004 \\
\hline $\log$ & Digest Dilution Factor & 1 \\
\hline LIQUID & Y-Intercept Value & 0.006138 \\
\hline 3 & Slope Value & 0.166182 \\
\hline BLANK & pg of Cyanide & -0.013 \\
\hline (1) & $\mu \mathrm{g} \mathrm{CN}-\mathrm{mL}$ & $-2.57 \mathrm{E}-03$ \\
\hline
\end{tabular}

CN01

JT KNIGHT, JR

$02 / 09 / 96$

ug of Cyanide = [ |Absorb. of Blank - Absorb. of Inst. Blank| - (Y-Intercept)] / Slope Value $\mu \mathrm{g} / \mathrm{mL}$ of Cyanide = $\mu \mathrm{g}$ Cyanide * Digest Dilution Factor / SS (mL)

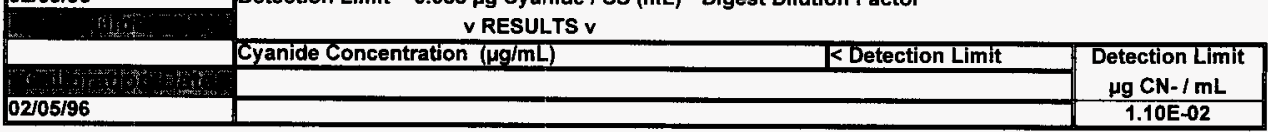

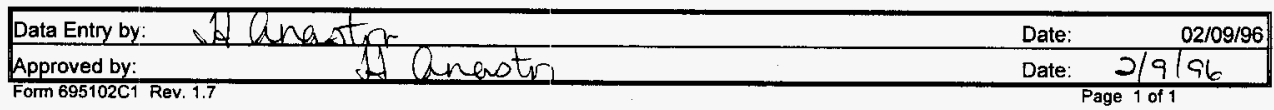


WHC-SD-WM-DP-180, REV. 0

CN- DETERMINATION : LA-695-102 (D-0) SPIKE, STANDARD

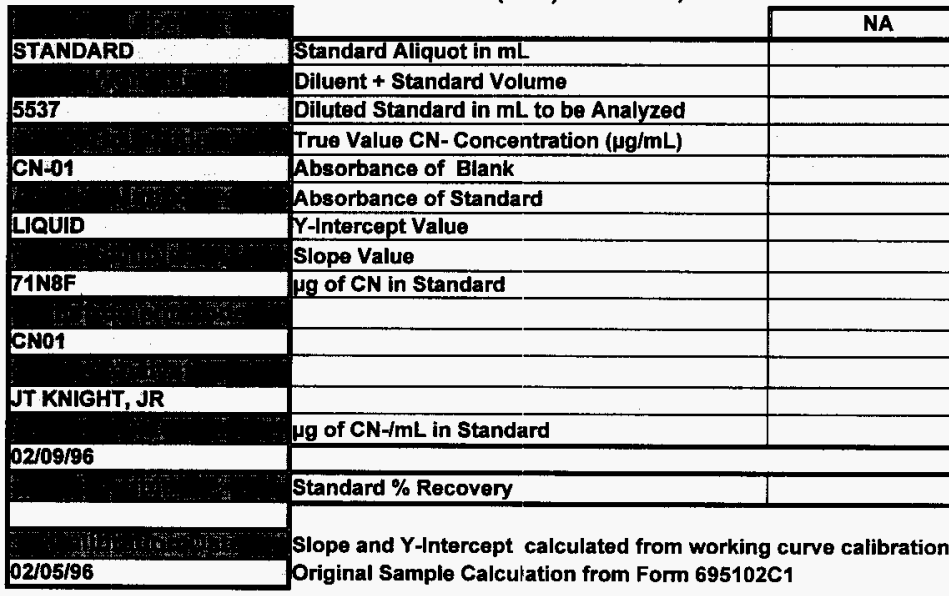

$\mu \mathrm{g}$ of $\mathrm{CN}$ - in Sample+Spike = [(Absorbance of Sample+Spike - Absorbance of Blank) - (Y-Intercept)] / Slope Value $\mu \mathrm{g} / \mathrm{mL}$ of $\mathrm{CN}-=\mu \mathrm{g}$ of $\mathrm{CN}$ - in Standard / Diluted Standard * Dilution Factor

Dilution Factor $=$ Flask Volume $/$ Standard Aliquot

Standard \% Recovery $=(\mu \mathrm{g}$ of $\mathrm{CN}-/ \mathrm{mL}$ in Standard / True Value CN-Concentration $(\mu \mathrm{g} / \mathrm{mL})) * 100$

\begin{tabular}{|c|c|c|}
\hline Data Entry by: & Date: & $02 / 09 / 96$ \\
\hline Approved by: & Date: & 01 \\
\hline
\end{tabular}


WHC-SD-WM-DP-180, REV. 0

\section{CN-DETERMINATION : LA-695-102 (D-0) BLANK, LIQUID, SOLID}

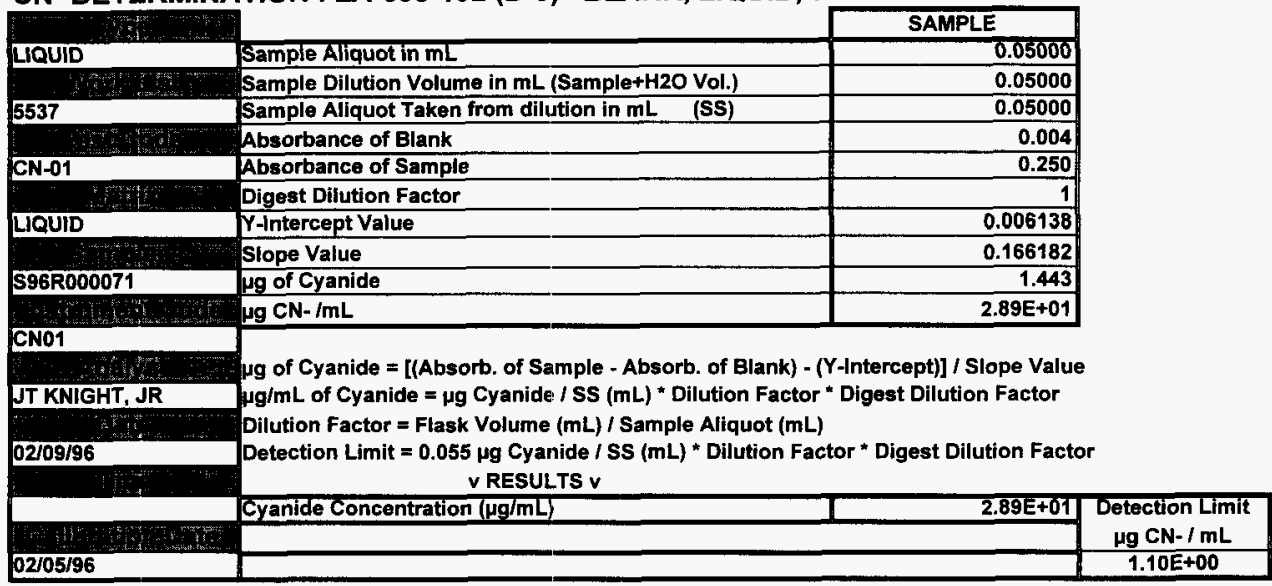

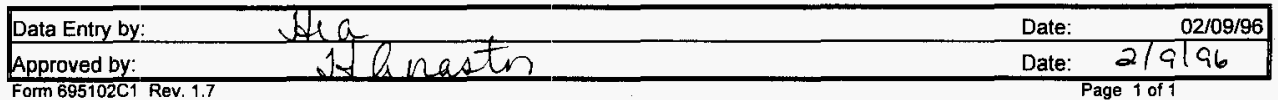




\section{WHC-SD-WM-DP-180, PEV. 0}

\section{CN- DETERMINATION : LA-695-102 (D-0) SPIKE, STANDARD}

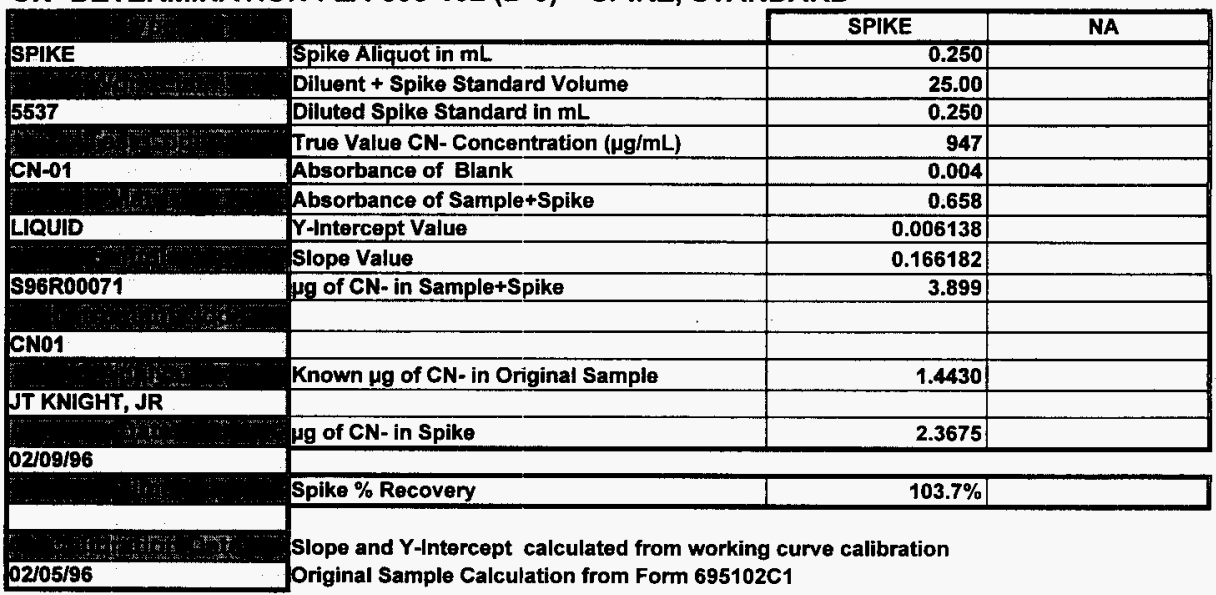

$\mu \mathrm{g}$ of $\mathrm{CN}$ - in Sample (Correced) = Known $\mu \mathrm{g}$ of $\mathrm{CN}$ - in Original Sample * $\mathrm{g}$ of Sample in Spike / $\mathrm{g}$ Used in Original Sample $\mu \mathrm{g}$ of $\mathrm{CN}$ - in Sample+Spike = [(Absorbance of Sample+Spike - Absorbance of Blank) - (Y-intercept)] / Slope Value $\mu \mathrm{g}$ of CN- in Spike = LMCS Value $(\mathrm{ppm}) /$ Dilution Factor * Diluted Spike Standard

Dilution Factor $=$ Spike Dilution Volume $/$ Spike Aliquot

Spike \% Recovery $=(\mu \mathrm{g}$ of $\mathrm{CN}$ - in Sample+Spike $)-(\mu \mathrm{g}$ of CN- in Sample $) /(\mu \mathrm{g}$ of CN- in Spike) $* 100 \%$

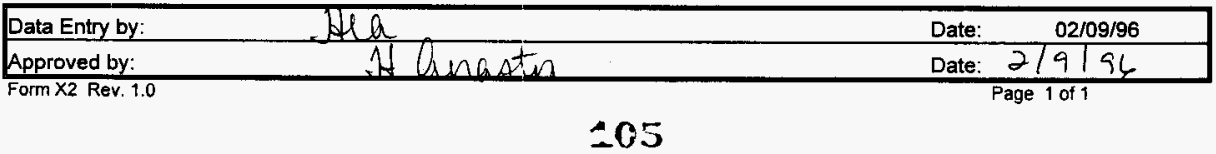


WHC-SD-WM-DP-180, FEV. 0

CN- DETERMINATION : LA-695-102 (D-0) SPIKE, STANDARD

\begin{tabular}{|c|c|c|c|}
\hline 35 & & SPIKE & NA \\
\hline SPIKE & Spike Aliquot in mL & 0.250 & \\
\hline W: & Diluent + Spike Standard Volume & 25.00 & \\
\hline 5537 & Diluted Spike Standard in $\mathrm{mL}$ & 0.250 & \\
\hline $1+t_{2}$ & True Value CN-Concentration ( $\mu \mathrm{g} / \mathrm{mL}$ ) & 947 & \\
\hline CN-01 & Absorbance of Blank & 0.004 & \\
\hline 20 & Absorbance of Sample+Spike & 0.646 & \\
\hline LIQUID & Y-Intercept Value & 0.006138 & \\
\hline atd & Slope Value & 0.166182 & \\
\hline S96R00071 SPK-DUP & $\mu g$ of CN-in Sample+Spike & 3.826 & \\
\hline 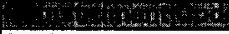 & & & \\
\hline \multicolumn{4}{|l|}{ CNO1 } \\
\hline $2 \pi$ & Known $\mu \mathrm{g}$ of $\mathrm{CN}$ - in Original Sample & 1.4430 & \\
\hline \multicolumn{4}{|l|}{ JT KNIGHT, JR } \\
\hline in: & $\mu \mathrm{g}$ of CN- in Spike & 2.3675 & \\
\hline \multicolumn{4}{|l|}{$02 / 09 / 96$} \\
\hline 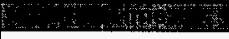 & Spike \% Recovery & $100.7 \%$ & \\
\hline
\end{tabular}

$\mu \mathrm{g}$ of $\mathrm{CN}$ - in Sample (Correced) = Known $\mu \mathrm{g}$ of CN- in, Original Sample * $\mathrm{g}$ of Sample in Spike / g Used in Original Sample $\mu \mathrm{g}$ of CN-in Sample+Spike = [(Absorbance of Sample+Spike - Absorbance of Blank) - (Y-intercept)] / Slope Value $\mu g$ of CN- in Spike = LMCS Vaiue $(\mathrm{ppm}) /$ Dilution Factor * Diluted Spike Standard

Dilution Factor $=$ Spike Dilution Volume $/$ Spike Aliquot

Spike \% Recovery = ( $\mu \mathrm{g}$ of CN- in Sample+Spike) - ( $\mu \mathrm{g}$ of CN- in Sample $) /(\mu \mathrm{g}$ of CN- in Spike) * 100\%

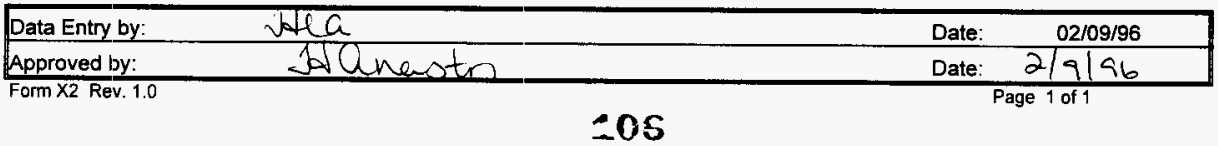




\section{WHC-SD-WM-DP-180, PEV. 0}

CN- DETERMINATION : LA-695-102 (D-0) SPIKE, STANDARD

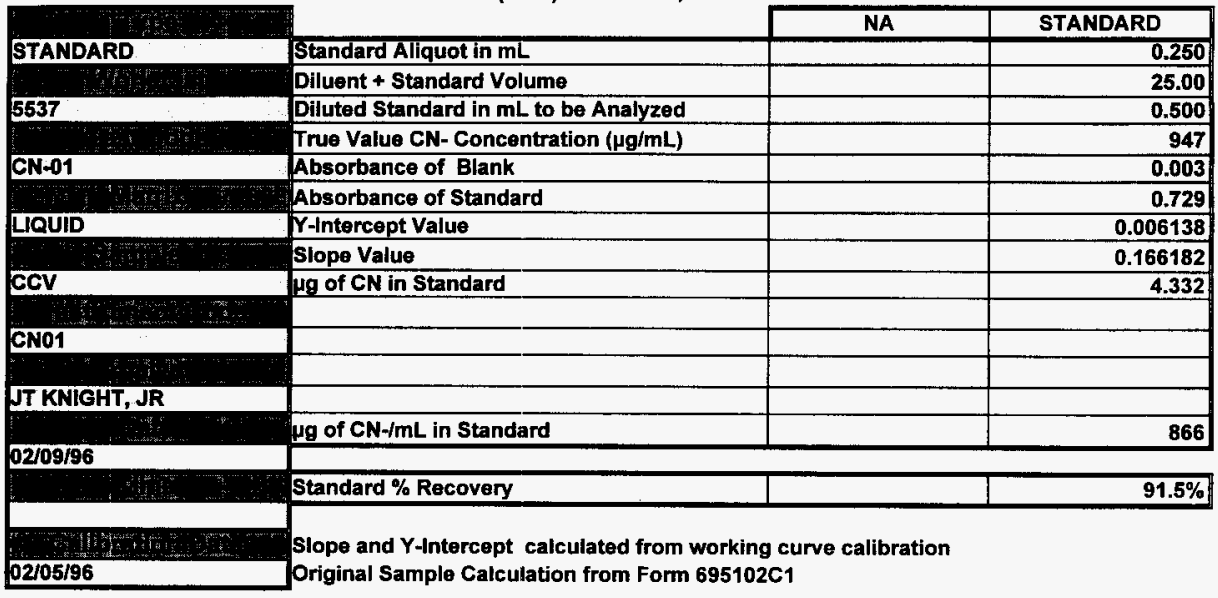

$\mu \mathrm{g}$ of $\mathrm{CN}$ - in Sample+Spike = [(Absorbance of Sample+Spike - Absorbance of Blank) - (Y-Intercept) $/$ Slope Value $\mu \mathrm{g} / \mathrm{mL}$ of $\mathrm{CN}-=\mu \mathrm{g}$ of $\mathrm{CN}$ - in Standard / Diluted Standard * Dilution Factor

Dilution Factor $=$ Flask Volume $/$ Standard Aliquot

Standard \% Recovery $=(\mu \mathrm{g}$ of $\mathrm{CN}-/ \mathrm{mL}$ in Standard / True Value CN-Concentration $(\mu \mathrm{g} / \mathrm{mL})) * 100$

\begin{tabular}{|c|c|c|}
\hline Data Entry by: & Date: & $02 / 09 / 96$ \\
\hline Approved by: & Date: & $2 / 9 / 91$ \\
\hline Form X2 Rev. 1.0 & & ge 1 of 1 \\
\hline
\end{tabular}




\section{WHC-SD-WM-DP-180, REV. 0}

\section{CN- DETERMINATION : LA-695-102 (D-0) BLANK, LIQUID, SOLID}

\begin{tabular}{|c|c|c|}
\hline has & & SAMPLE \\
\hline BLANK & & \\
\hline 5537 & Blank Aliquot in $\mathrm{mL}$ & 5.00000 \\
\hline 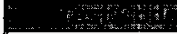 & Absorbance of Instrument Blank & 0.000 \\
\hline CN-01 & Absorbance of Blank (Reagent, Prep) & 0.003 \\
\hline & Digest Dilution Factor & \\
\hline LIQUID & Y-Intercept Value & 0.006138 \\
\hline 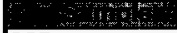 & Slope Value & 0.166182 \\
\hline CCB & ug of Cyanide & -0.019 \\
\hline ast 1 ? & $\mu \mathrm{g} \mathrm{CN}-/ \mathrm{mL}$ & $-3.78 \mathrm{E}-03$ \\
\hline
\end{tabular}

\section{CN01}

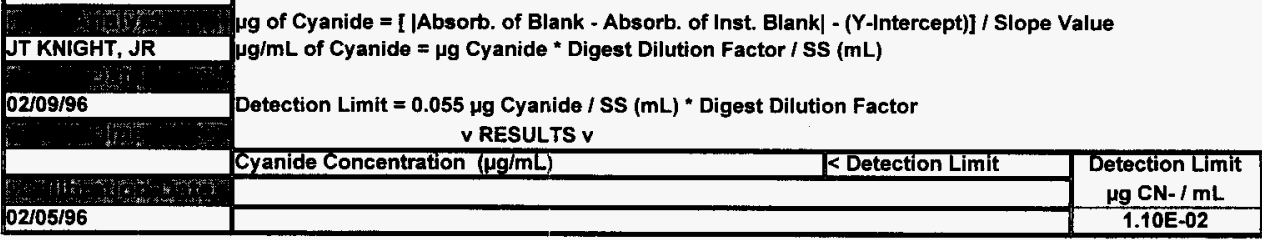

Data Entry by

Approved by:

Form 695102C1 Rev. 1.7

Date:

$02 / 09 / 96$

ton Qunton

Date: 
WriC-SD-WM-DP-180, REV. 0

\section{THE FOLLOWING ANALYSES WERE RERUN AND INCLUDED IN THE DATA PACKAGE, BUT THE RESULTS HAVE NOT BEEN REPORTED IN THE FINAL SUMMARY REPORTS.}




Analyst: Intrument: $\mathrm{CN01}$ Book \# I/A

Method: LA-695-102 Rev/Mod $\gg-0$

Worklist Comment: CN by Water Method B-Plant RUSH Samples

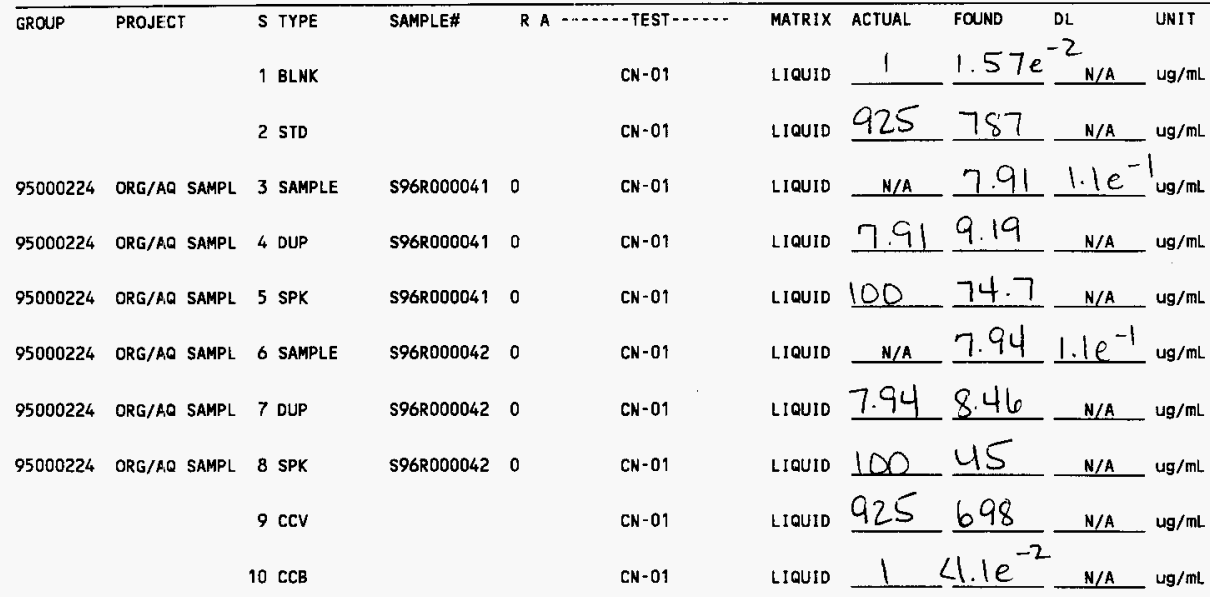

\section{Final page for worklist \# $\mathbf{5 2 1 3}$}

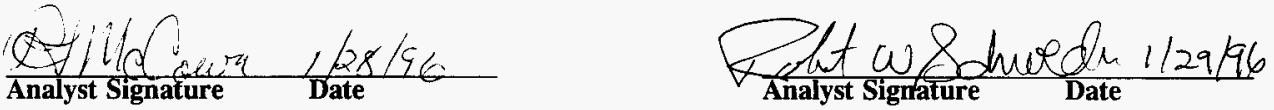

\section{Analyst Signature}


CN: LA-695-102 (C-D)

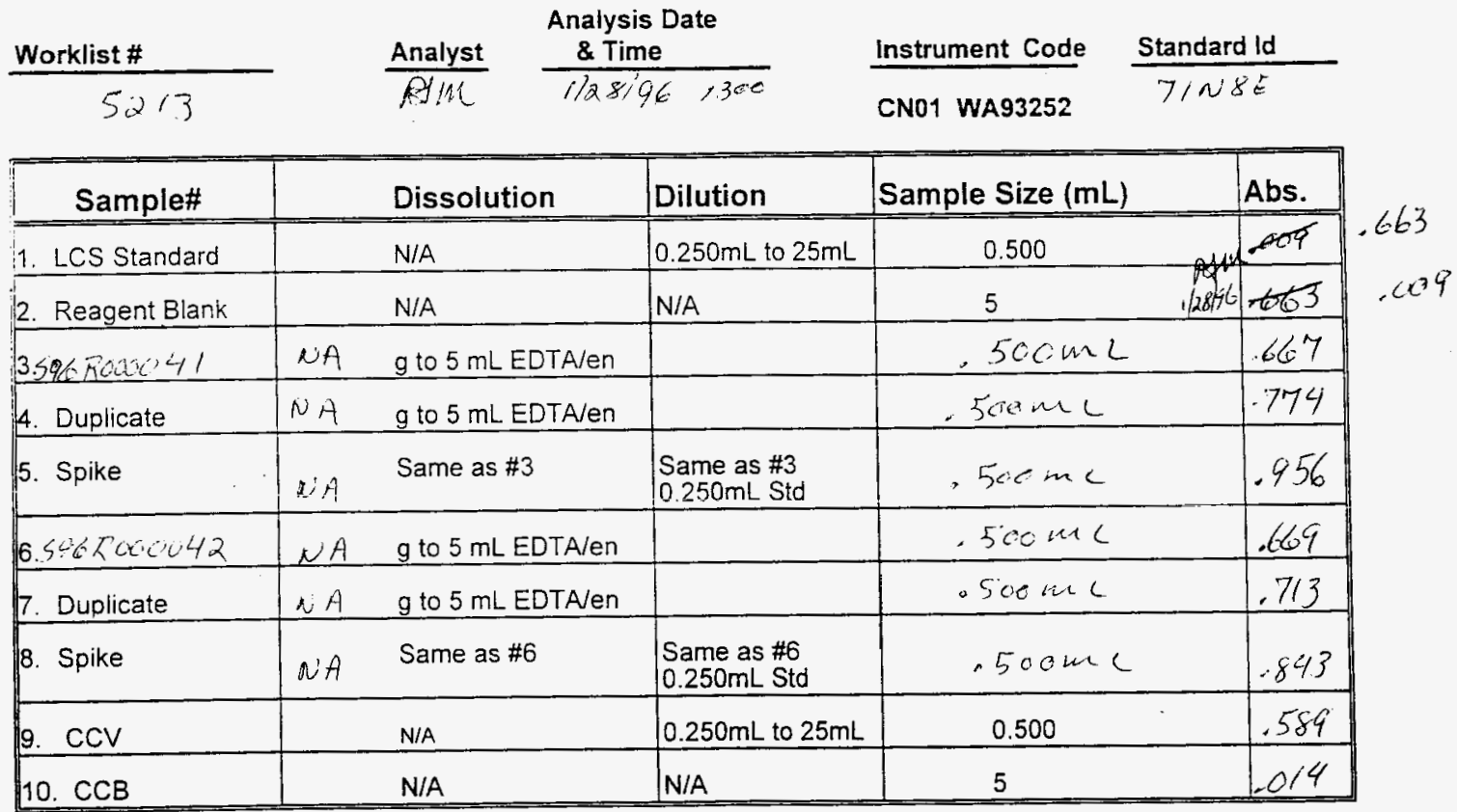

\section{Comments:}

$\rightarrow$
Matrix: Liquid/Solid

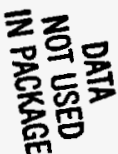


WHC-SD-WM-DP-180, REV. 0

CN- DETERMINATION : LA-695-102 (D-0) BLANK, LIQUID, SOLID

\begin{tabular}{|c|c|c|}
\hline 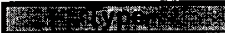 & & SAMPLE \\
\hline \multicolumn{3}{|l|}{ BLANK } \\
\hline 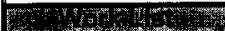 & & \\
\hline 5213 & Blank Aliquot in $\mathrm{mL} \quad$ (SS) & 5.00000 \\
\hline 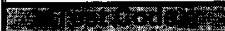 & Absorbance of Instrument Blank & 0.000 \\
\hline $\mathrm{CN}-01$ & Absorbance of Blank (Reagent, Prep) & 0.009 \\
\hline 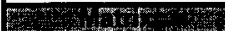 & Digest Dilution Factor & 1 \\
\hline LIQUID & Y-Intercept Value & -0.004130 \\
\hline 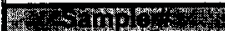 & Slope Value & 0.167318 \\
\hline BLANK & ug of Cyanide & 0.078 \\
\hline 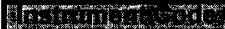 & $\mu g$ CN- /mL & 1.57E-02 \\
\hline
\end{tabular}

\section{CNO1}

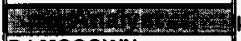

PJ MCCOWN

$\mu \mathrm{g}$ of Cyanide = [ |Absorb. of Blank - Absorb. of Inst. Blank| - (Y-Intercept) $/$ Slope Value $\mu \mathrm{g} / \mathrm{mL}$ of Cyanide $=\mu \mathrm{g}$ Cyanide ${ }^{*}$ Digest Dilution Factor $/ \mathrm{SS}(\mathrm{mL})$

$01 / 28 / 96$

Pryt.

Detection Limit $=0.055 \mu \mathrm{g}$ Cyanide $/ \mathrm{SS}(\mathrm{mL})$ * Digest Dilution Factor

$\checkmark$ RESULTS $v$
1.57E-02 Detection Limit $\mu \mathrm{g} \mathrm{CN}-/ \mathrm{mL}$ 1.10E-02

\section{6.}

$12 / 21 / 95$

Date:

Date:
Data Entry by

Approved by:

Form 695102C1 Rev. 1.7
Atchasta

II $\operatorname{sen} 1$ th

$01 / 29 / 96$

DATA

NOT USED 


\section{WHC-SD-WM-DP-180, REV. 0}

CN- DETERMINATION : LA-695-102 (D-0) SPIKE, STANDARD

\begin{tabular}{|c|c|c|c|}
\hline 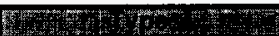 & & NA & STANDARD \\
\hline STANDARD & Standard Aliquot in $\mathrm{mL}$ & & 0.250 \\
\hline Why & Diluent + Standard Volume & & 25.00 \\
\hline 5213 & Diluted Standard in mL to be Analyzed & & 0.500 \\
\hline Her. & True Value CN- Concentration ( $\mu \mathrm{g} / \mathrm{mL}$ ) & & 925 \\
\hline CN-01 & Absorbance of Blank & & 0.009 \\
\hline 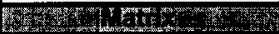 & Absorbance of Standard & & 0.663 \\
\hline LIQUID & Y-Intercept Value & & -0.004130 \\
\hline 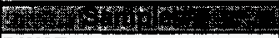 & Slope Value & & 0.167318 \\
\hline 71N8E & eg of CN in Standard & & 3.933 \\
\hline sing & & & \\
\hline \multicolumn{4}{|l|}{ CNO1 } \\
\hline Discomer & & & - \\
\hline \multicolumn{4}{|l|}{ PJ MCCOWN } \\
\hline 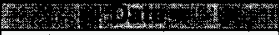 & $\mu \mathrm{g}$ of $\mathrm{CN}-1 \mathrm{~mL}$ in Standard & & 787 \\
\hline \multicolumn{4}{|l|}{$01 / 28 / 96$} \\
\hline 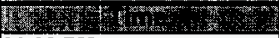 & Standard \% Recovery & & $85.0 \%$ \\
\hline $\begin{array}{l}01: 00 \mathrm{PM} \\
12 / 21 / 95 \\
\end{array}$ & $\begin{array}{l}\text { Slope and Y-Intercept calculated from } \\
\text { Original Sample Calculation from Form }\end{array}$ & alibration & $\begin{array}{l}\text { DATA } \\
\text { NOT USED } \\
\text { N PACKAGE }\end{array}$ \\
\hline
\end{tabular}

$\mu \mathrm{g}$ of $\mathrm{CN}$ - in Sample+Spike = [(Absorbance of Sample+Spike - Absorbance of Blank $)$ - (Y-Intercept)] $/$ Slope Value $\mu \mathrm{g} / \mathrm{mL}$ of $\mathrm{CN}$ - $=\mu \mathrm{g}$ of $\mathrm{CN}$ - in Standard / Diluted Standard * Dilution Factor

Dilution Factor $=$ Flask Volume $/$ Standard Aliquot

Standard \% Recovery $=(\mu \mathrm{g}$ of $\mathrm{CN}-/ \mathrm{mL}$ in Standard $/$ True Value CN- Concentration $(\mu \mathrm{g} / \mathrm{mL})) * 100$

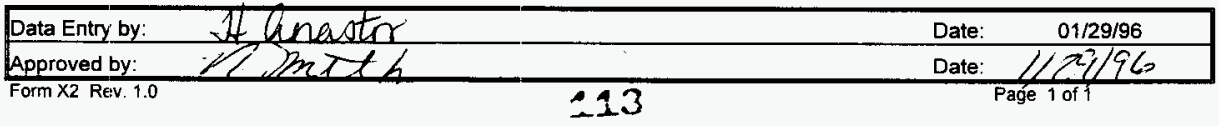




\section{WHC-SD-WM-DP-180, PEV. 0}

\begin{tabular}{|c|c|c|}
\hline CN-DETERMINA & $5-102(D-0)$ & \\
\hline 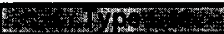 & & SAMPLE \\
\hline LIQUID & Sample Aliquot in mL & 0.50000 \\
\hline 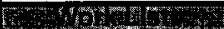 & Sample Dilution Volume in $\mathrm{mL}$ (Sample+H2O Vol.) & 0.50000 \\
\hline 5213 & Sample Aliquot Taken from dilution in $\mathrm{mL}$ (SS) & 0.50000 \\
\hline & Absorbance of Blank & 0.009 \\
\hline CN-01 & Ábsorbance of Sample & 0.667 \\
\hline 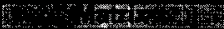 & Digest Dilution Factor & 1 \\
\hline LIQUID & Y-Intercept Value & -0.004130 \\
\hline 3.4. & Slope Value & 0.167318 \\
\hline S96R000041 & $\mu g$ of Cyanide & 3.957 \\
\hline 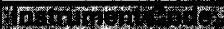 & $\mu g \mathrm{CN}-/ \mathrm{mL}$ & $7.91 E+00$ \\
\hline
\end{tabular}

\section{CNO1}

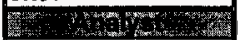

PJ MCCOWN

ug of Cyanide $=$ [(Absorb. of Sample - Absorb. of Blank $)$ - (Y-Intercept) $/$ Slope Value $\mu \mathrm{g} / \mathrm{mL}$ of Cyanide $=\mu \mathrm{g}$ Cyanide $/ \mathrm{SS}(\mathrm{mL})$ * Dilution Factor * Digest Dilution Factor Dilution Factor = Flask Volume $(\mathrm{mL}) /$ Sample Aliquot $(\mathrm{mL})$

$01 / 28 / 96$ Detection Limit $=0.055 \mu \mathrm{g}$ Cyanide / SS $(\mathrm{mL})$ * Dilution Factor * Digest Dilution Factor

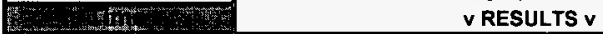
01:00 PM, Cyanide Concentration $(\mu \mathrm{g} / \mathrm{mL})$

Ran

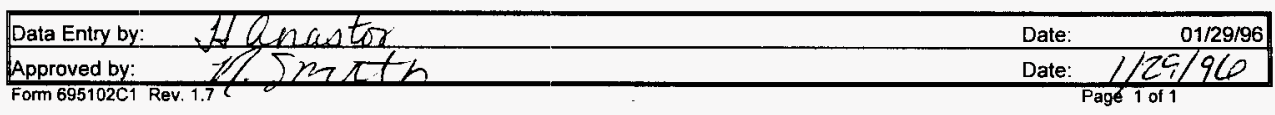

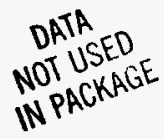




\section{WHC-SD-WM-DP-180, PEV. 0}

CN- DETERMINATION : LA-695-102 (D-0) BLANK, LIQUID, SOLID

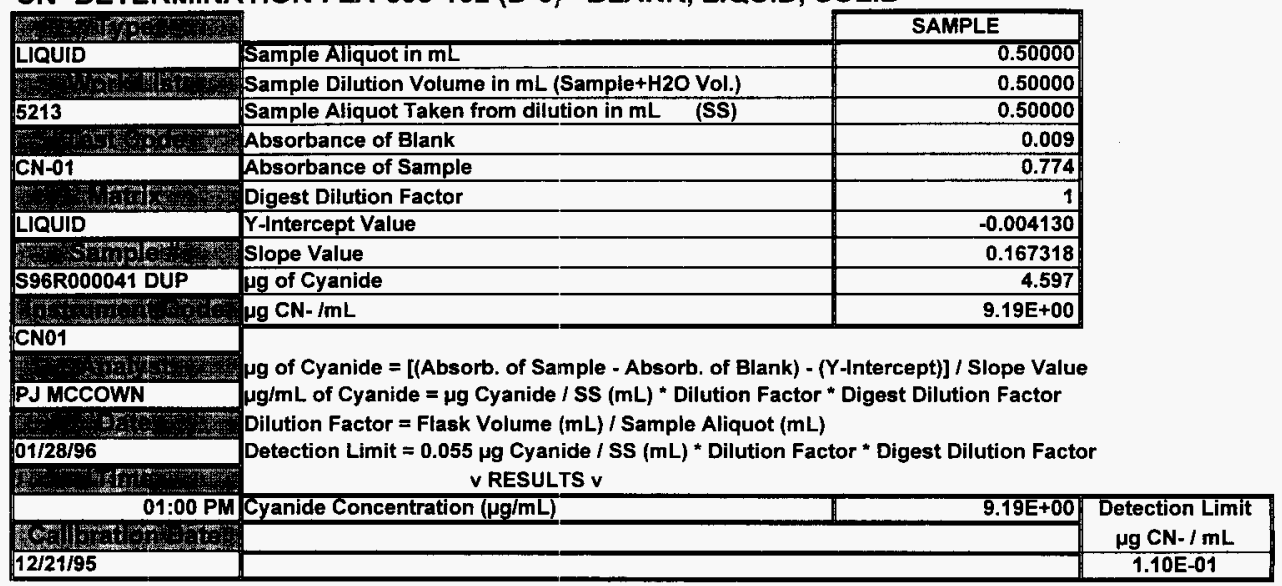

\begin{tabular}{|c|c|}
\hline Data Entry by: & Date: $\quad 01 / 29 / 96$ \\
\hline Approved by: & Date: $\quad|/ 7 G|$ \\
\hline Form $695102 \mathrm{C} 1$ Rev. 1.7 & Pagé 1 of 1 \\
\hline
\end{tabular}


WHC-SU-WM-DP-180, REV. 0

CN- DETERMINATION : LA-695-102 (D-0) SPIKE, STANDARD

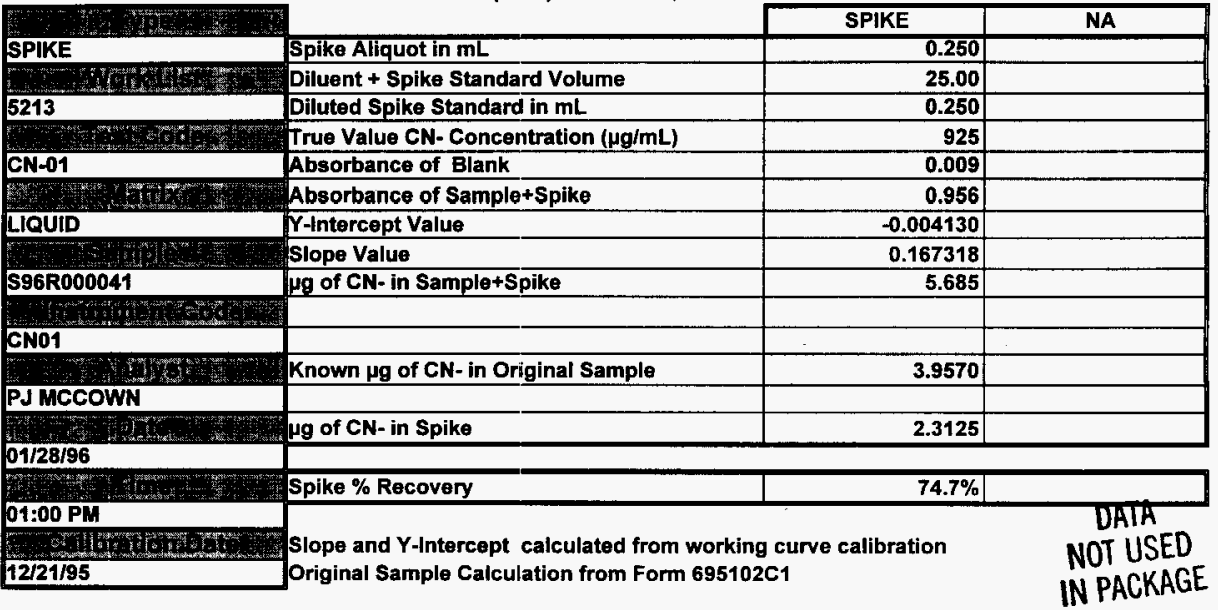

$\mu \mathrm{g}$ of $\mathrm{CN}$ - in Sample (Correced) $=$ Known $\mu \mathrm{g}$ of $\mathrm{CN}$ - in Original Sample * $\mathrm{g}$ of Sample in Spike / $\mathrm{g}$ Used in Original Sample $\mu \mathrm{g}$ of $\mathrm{CN}$ - in Sample+Spike = [(Absorbance of Sample+Spike - Absorbance of Blank) - (Y-Intercept)]/Slope Value $\mu \mathrm{g}$ of $\mathrm{CN}$ - in Spike = LMCS Value $(\mathrm{ppm}) /$ Dilution Factor * Diluted Spike Standard

Dilution Factor $=$ Spike Dilution Volume $/$ Spike Aliquot

Spike \% Recovery = ( $\mu \mathrm{g}$ of CN- in Sample+Spike $)-(\mu \mathrm{g}$ of CN- in Sample $) /\left(\mu \mathrm{g}\right.$ of CN- in Spike) ${ }^{*} 100 \%$

\begin{tabular}{|c|c|c|}
\hline Data Entry by: & Date: & $01 / 29 / 96$ \\
\hline
\end{tabular}


WHC-SD-WM-DP-180, REV. 0

CN- DETERMINATION : LA-695-102 (D-0) BLANK, LIQUID, SOLID

\begin{tabular}{|c|c|c|}
\hline and & & SAMPLE \\
\hline LIQUID & Sample Aliquot in $\mathrm{mL}$ & 0.50000 \\
\hline 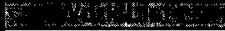 & Sample Dilution Volume in $\mathrm{mL}$ (Sample+H2O Vol.) & 0.50000 \\
\hline 5213 & Sample Aliquot Taken from dilution in $\mathrm{mL}$ (SS) & 0.50000 \\
\hline 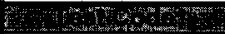 & Absorbance of Blank & 0.009 \\
\hline $\mathrm{CN}-01$ & Absorbance of Sample & 0.669 \\
\hline 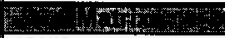 & Digest Dilution Factor & 1 \\
\hline LIQUID & Y-Intercept Value & -0.004130 \\
\hline H. & Slope Value & 0.167318 \\
\hline $596 R 000042$ & yg of Cyanide & 3.969 \\
\hline 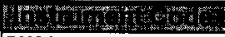 & $\mu \mathrm{g} C N-/ \mathrm{mL}$ & $7.94 E+00$ \\
\hline
\end{tabular}

\section{CNO1}

S of Cyanide = [(Absorb. of Sample - Absorb. of Blank) - (Y-Intercept)] / Slope Value

PJ MCCOWN $\mu \mathrm{g} / \mathrm{mL}$ of Cyanide $=\mu \mathrm{g}$ Cyanide / SS ( $\mathrm{mL})$ * Dilution Factor * Digest Dilution Factor (a) $01 / 28 / 96$ Dilution Factor = Flask Volume $(\mathrm{mL}) /$ Sample Aliquot $(\mathrm{mL})$

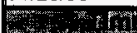
Detection Limit $=\mathbf{0 . 0 5 5} \mu \mathrm{g}$ Cyanide $/ \mathrm{SS}(\mathrm{mL})$ * Dilution Factor * Digest Dilution Factor v RESULTS $\mathbf{v}$ 01:00 PM Cyanide Concentration ( $\mu \mathrm{g} / \mathrm{mL}$ )

\section{Fis.}

Data Entry by: Hunastor

Approved by: in Jmoth

I

\begin{tabular}{|r|c|}
\hline $7.94 E+00$ & $\begin{array}{c}\text { Detection Limit } \\
\mu \mathrm{CN}-1 \mathrm{~mL}\end{array}$ \\
\hline $1.10 \mathrm{E}-01$
\end{tabular}

H Unastor Date:
$1.10 \mathrm{E}-01$ 
WHC-SD-WIM-DP-180, FEV. 0

CN- DETERMINATION : LA-695-102 (D-0) BLANK, LIQUID, SOLID

\begin{tabular}{|c|c|c|}
\hline ars & & SAMPLE \\
\hline LIQUID & Sample Aliquot in $\mathrm{mL}$ & 0.50000 \\
\hline 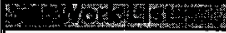 & Sample Dilution Volume in $\mathrm{mL}$ (Sample+H2O Vol.) & 0.50000 \\
\hline 5213 & Sample Aliquot Taken from dilution in $\mathrm{mL} \quad$ (SS) & 0.50000 \\
\hline 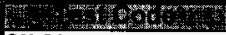 & Absorbance of Blank & 0.009 \\
\hline CN-01 & Absorbance of Sample & 0.713 \\
\hline 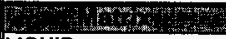 & Digest Dilution Factor & 1 \\
\hline LIQUID & Y-Intercept Value & -0.004130 \\
\hline 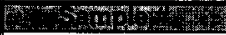 & Slope Value & 0.167318 \\
\hline S96R000042 DUP & pg of Cyanide & 4.232 \\
\hline 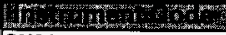 & $\mu g$ CN- $/ m L$ & $8.46 \mathrm{E}+00$ \\
\hline
\end{tabular}

CNOI

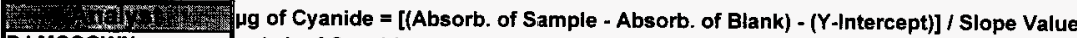

PJ MCCOWN

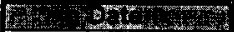

$01 / 28 / 96$

$\mu \mathrm{g} / \mathrm{mL}$ of Cyanide $=\mu \mathrm{g}$ Cyanide $/ \mathrm{SS}(\mathrm{mL})$ * Dilution Factor * Digest Dilution Factor

Thas

actor = Flask Volume $(\mathrm{mL}) /$ Sample Aliquot $(\mathrm{mL})$

Detection Limit $=0.055$ pg Cyanide $/ \mathrm{SS}(\mathrm{mL})$ * Dilution Factor * Digest Dilution Factor

01:00 PM Cyanide Concentration $(\mu \mathrm{g} / \mathrm{mL})$

W.

$\checkmark$ RESULTS $\checkmark$

8.46E+00 Detection Limit

$\mu \mathrm{g}$ CN- $/ \mathrm{mL}$

1.10E-01

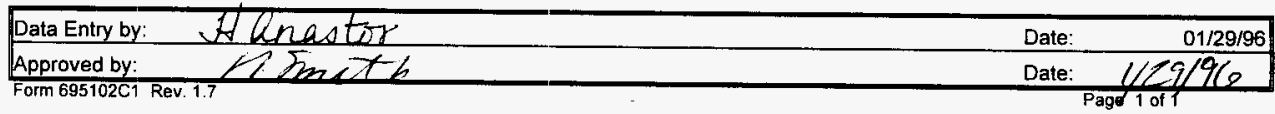

DATA

NOT USED

IN PACKAGE 
WHC-SD-WM-DP-180, FEV. 0

CN- DETERMINATION : LA-695-102 (D-0) SPIKE, STANDARD

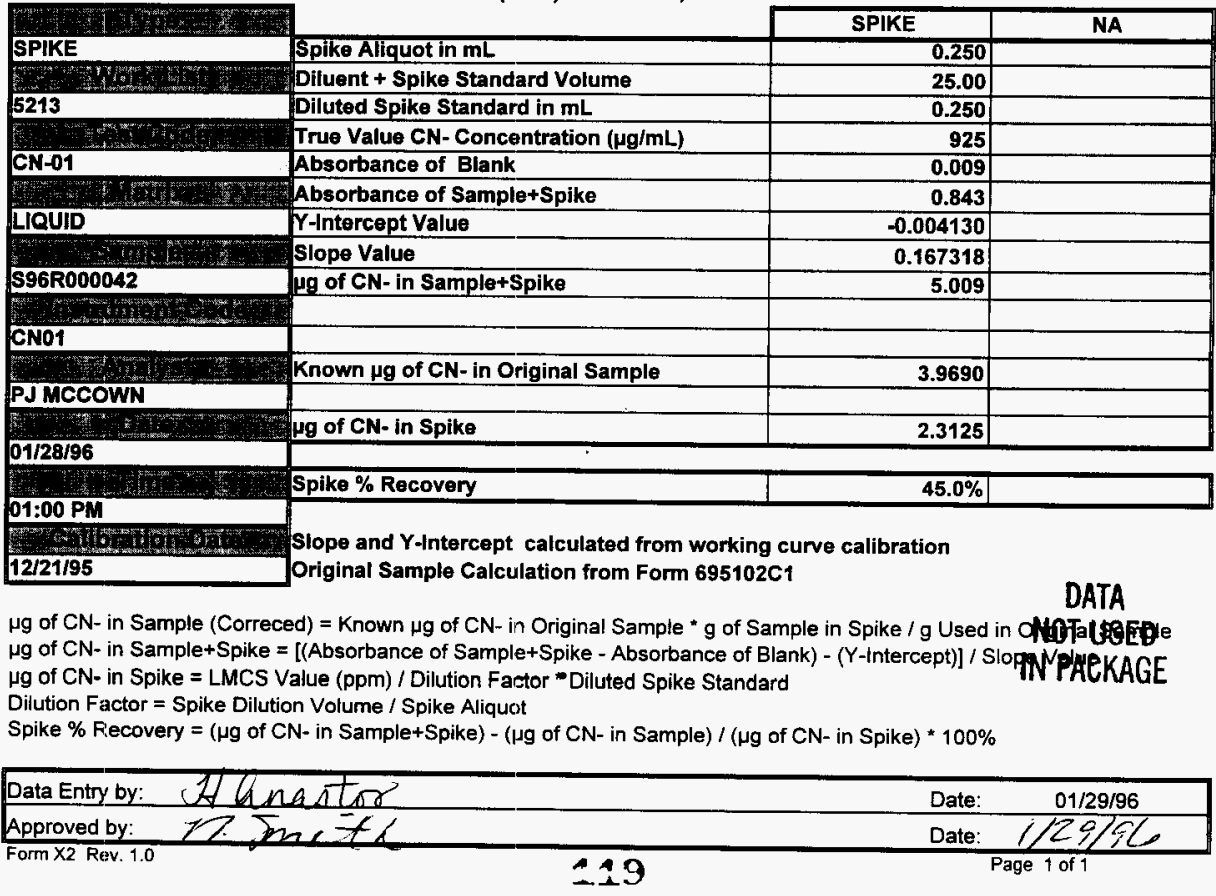


WHC-SD-WM-DP-180, PEV. 0

CN- DETERMINATION : LA-695-102 (D-0) SPIKE, STANDARD

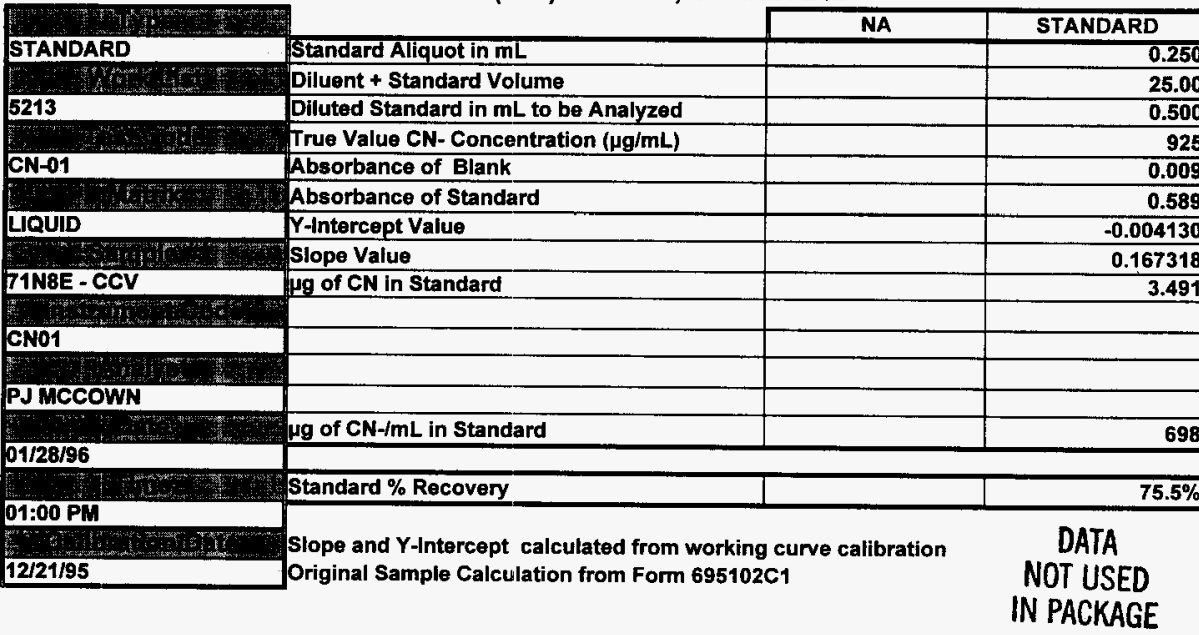

$\mu \mathrm{g}$ of $\mathrm{CN}$ - in Sample+Spike = [(Absorbance of Sample+Spike - Absorbance of Blank $)-(Y$-Intercept)] $/$ Slope Value $\mu \mathrm{g} / \mathrm{mL}$ of $\mathrm{CN}-=\mu \mathrm{g}$ of $\mathrm{CN}$ - in Standard / Diluted Standard * Dilution Factor

Dilution Factor $=$ Flask Volume $/$ Standard Aliquot

Standard $1 \%$ Recovery $=(\mu \mathrm{g}$ of $\mathrm{CN}-/ \mathrm{mL}$ in Standard $/$ True Value CN- Concentration $(\mu \mathrm{g} / \mathrm{mL})) * 100$

\begin{tabular}{|c|c|c|}
\hline Data Entry by: & Date: & $01 / 29 / 96$ \\
\hline Approved by: & Date: & $89 / 96$ \\
\hline
\end{tabular}




\section{WHC-SD-WM-DP-180, REV. 0}

\section{CN- DETERMINATION : LA-695-102 (D-0) BLANK, LIQUID, SOLID}

\begin{tabular}{|c|c|c|}
\hline Hown & & SAMPLE \\
\hline BLANK & & \\
\hline 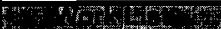 & & \\
\hline 5213 & Blank Aliquot in $\mathrm{mL}$ & 5.00000 \\
\hline a. & Absorbance of Instrument Blank & 0.009 \\
\hline CN-01 & Absorbance of Blank (Reagent, Prep) & 0.014 \\
\hline 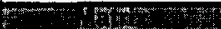 & Digest Dilution Factor & 1 \\
\hline LIQUID & Y-Intercept Value & -0.004130 \\
\hline 2. $+2,110$ & Slope Value & 0.167318 \\
\hline CCB & ug of Cyanide & 0.055 \\
\hline 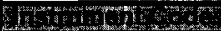 & $\mu \mathrm{g} \mathrm{CN}-/ \mathrm{mL}$ & $1.09 E-02$ \\
\hline
\end{tabular}

CNO1

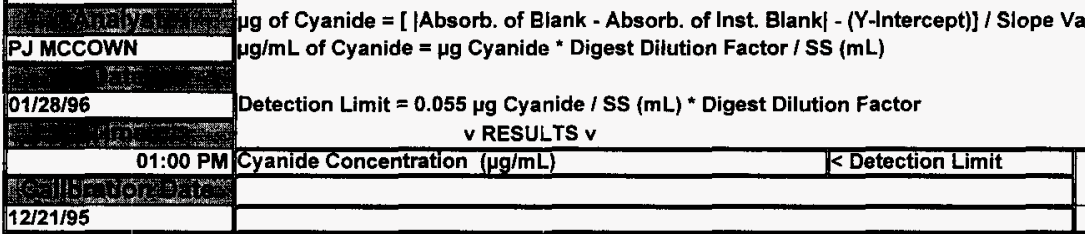

ug of Cyanide = [|Absorb. of Blank - Absorb. of Inst. Blank| - (Y-Intercept) ] / Slope Value

Data Entry by: Hlanestor

Date: $\quad 01 / 29 / 96$




\section{LABCORE Completed Worklist Report for Worklist\# 5479}

Analyst: vlm

Instrument: $\mathrm{ICO} 2$

Book\# $102 \Omega^{\prime \prime} E$

Method: $\angle 4-5.33-\cos R e v / \operatorname{Mod} D-1$

Worklist Comment: Tank 25-2, b plant IC. Treat for organics, see JMF first.

\begin{tabular}{|c|c|c|c|c|c|c|c|c|}
\hline \multirow{2}{*}{$\begin{array}{c}\text { Seq Type } \\
1 \mathrm{ccB}\end{array}$} & \multicolumn{2}{|c|}{ Sample\# R A } & \multicolumn{2}{|c|}{ Test } & \multirow{2}{*}{$\begin{array}{l}\text { Matrix } \\
\text { oc }\end{array}$} & \multirow{2}{*}{$\begin{array}{r}\text { Actual } \\
\\
\\
1\end{array}$} & \multirow{2}{*}{$\begin{array}{l}\text { Found } \\
<1.30-2\end{array}$} & DL or Yield Unit \\
\hline & & 0 & arc-oc & z & & & & ug/m \\
\hline $1 \mathrm{CCB}$ & & 0 & DIC-QC & CL & ec & 1 & $<1.70<-2$ & $\mathrm{ug} / \mathrm{mLt}$ \\
\hline $1 \mathrm{ccs}$ & & 0 & $\operatorname{arc}-\mathrm{ec}$ & no2 & oc & 1 & $<1: 07 \bullet-1$ & ug/mL \\
\hline $1 \mathrm{CCB}$ & & 0 & -IC-QC & BR & $\mathbf{Q c}$ & 1 & $<1.260-1$ & $\mathrm{ug} / \mathrm{mr}$ \\
\hline $2 \mathrm{ccB}$ & & 0 & arc-oc & no3 & Qc & 1 & $<1: 40,-1$ & $\mathrm{ug} / \mathrm{mit}$ \\
\hline $3 \operatorname{cen}$ & & 0 & $\operatorname{arc-oc}$ & PO4 & $o c$ & 1 & $<1,190-1$ & $\mathrm{ug} / \mathrm{mg}$ \\
\hline $1 \mathrm{CCB}$ & & o & - IC-oc & so4. & $\infty c$ & 1 & $1.47=-01$ & $0.150 \mathrm{ug} / \mathrm{mL}$ \\
\hline $1 \mathrm{CCB}$ & & 0 & arc-oc & OXALATE2 & $2 \mathrm{oc}$ & 1 & $1.23 \cdot-01$ & $0.120 \mathrm{ug} / \mathrm{mr}$ \\
\hline $2 \operatorname{cov}$ & & 0 & ac-oc & $\mathbf{z}$ & oc & 59 & $5.610+01$ & 95.080 \& Recovery \\
\hline $2 \mathrm{ccv}$ & & 0 & aIC-Qc & cl & oc & 79 & $7.290+01$ & $92.280 \%$ Recovery \\
\hline $2 \mathrm{ccs}$ & & 0 & aIc-ac & wo2 & Qc & 334 & $4.95-+02$ & 92.700 \& Recovery \\
\hline $2 \mathrm{ccv}$ & & o & arc-oc & $\mathbf{B R}$ & $Q C$ & 575 & $5.38 \bullet+02$ & $93.570 \&$ Recovery \\
\hline $2 \operatorname{ccv}$ & & 0 & IC- $\mathrm{ec}$ & nos & oc & 614 & $5,800+02$ & $94: 460$ : : Recovery \\
\hline $2 \mathrm{ccv}$ & & 0 & arc-oc & PO4 & $Q C$ & 546 & $5.25 \bullet+02$ & 96.150 \% Recovery \\
\hline $2 \mathrm{ccr}$ & & 0 & -IC-DC & sot & oc & 637 & $5.900+02$ & 93.500 \& Recovery \\
\hline $2 \mathrm{ccv}$ & & 0 & are-ge & OXALATE2 & QC & 526 & $4.77 \bullet+02$ & 90.680 \& Recovery \\
\hline 3 ELNR-PREP & & o. & eic-01 & $7-02$ & LIOEID & 2 & $<1.300-2$ & $\mathrm{ug} / \mathbf{m L}$ \\
\hline 3 BLAN-PRHP & & 0 & -IC-01 & CL-02 & LIQDID & 1 & $4.000-02$ & $4.0000-002 \mathrm{ug} / \mathrm{mL}$ \\
\hline 3 BLAX-EREP & & 0 & arc-02 & No2-02 & LIQUID & 1 & $2.01-01$ & $0.200 \mathrm{ug} / \mathrm{mL}$ \\
\hline 3 ELRK - PREP & & 0 & DIC-01 & BR-02 & LIQOID & 1 & $2.160-01$ & $0.220 \mathrm{ug} / \mathrm{mL}$ \\
\hline 3 GLMK-PREP & & 0 & are-01 & No3 -02 & LIOUID & 1 & 2.910 .01 & $0.290 \mathrm{ug} / \mathrm{mI}$ \\
\hline 3 BLNK-PRHP & & 0 & IC-01 & PO4-02 & LIRUID & 1 & $2.120-01$ & $0.210 \mathrm{ug} / \mathrm{mI}$ \\
\hline 3 BLNK-PREP & & 0 & $\operatorname{ma-02}$ & $504-02$ & LIQ0ID & 1 & $1.43=-01$ & $0.140 \mathrm{ug} / \mathrm{mI}$ \\
\hline 3 BLNK - PRRP & & 0 & - $1 \mathrm{C}-01$ & OXALATE2 & LIQUID & 1 & $1.100-01$ & $0.110 \mathrm{ug} / \mathrm{mI}$ \\
\hline 4 SALELI & 13962000071 & 0 & arc-0.1 & $\mathbf{F}+02:$ & I.I00ID & $\mathbf{n} / \mathrm{A}$ & $8.7720+01$ & $27.570 \mathrm{ug} / \mathrm{mI}$ \\
\hline 4 SAMPLI & 2968000071 & 0 & eIc-01 & CL-02 & LIOUID & $\mathbf{n} / \mathbf{A}$ & $3.4220+02$ & $36.060 \mathrm{ug} / \mathrm{mL}$ \\
\hline 4 SAKRLE & $\$ 958000071$ & 0 & erc-0I & NO2-02 & LIQUID & $\mathbf{s} / \mathbf{A}$ & $2.6680+0.3$ & $226,900 \mathrm{ug} / \mathrm{mL}$ \\
\hline 4 SAMPLE & $\$ 968000071$ & 0 & IC-01 & N03-02 & LIQUID & $\mathbf{n} / \mathbf{A}$ & $4.4100+04$ & $296.900 \mathrm{ug} / \mathrm{mL}$ \\
\hline 4 SMMPDIE & 43968000071 & 0 & are-01 & $P 04-02$ & LIQUID & H/A & $1.311 \bullet+03$ & $254.500 \mathrm{ug} / \mathrm{mL}$ \\
\hline 4 SAMPLB & $395 \mathrm{R} 000071$ & 0 & are-01 & s04-02 & LIQUID & $\mathbf{E} / \mathbf{A}$ & $3.8480+02$ & $280.500 \mathrm{ug} / \mathrm{mL}$ \\
\hline 5 SPK & $\$ 3968000071$ & 0 & eIc-01 & $\mathbf{F - 0 2}$ & LIQUTD & 59 & 54.068 & $91.640 *$ Recovexy \\
\hline $5 \mathrm{sPK}$ & 3968000071 & 0 & are-01 & $\mathrm{CL}-02$ & LIQUID & 79 & 74.142 & 93.850 \& Recovery \\
\hline $5 \operatorname{SPX}$ & $\$ 9668000071$ & 0 & IC-01 & $x 02-02$ & LIOUID & 534 & 481.712 & 90.210 \% Recovefy \\
\hline $5 \mathrm{SPK}$ & 39680000071 & 0 & -IC-01 & $\mathrm{BR}-02$ & LIQUID & 575 & $n / 2$ & \& Recovery \\
\hline 5 sPX & $\$ 968000071$ & 0 & $\operatorname{arc-02}$ & $203+02$ & LIRUID & 614 & 559.399 & 91.110 \& Recovexy \\
\hline 5 SPK & $\$ 96 R 000071$ & 0 & $\operatorname{arc}-01$ & PO4-02 & LIQUID & 546 & 498.982 & 91.390 \% Recovery \\
\hline 5 SpK & 4968000072 & 0 & exc-03 & $504-02$ & LIQUID & 631 & 57.4 .954 & 91.1.20 Recovery \\
\hline 5 SPK & $496 R 000071$ & 0 & exc-01 & OTASATE2 & LIQUID & 526 & $\mathrm{n} / \mathbf{a}$ & \& Recovery \\
\hline 6 SPK-DUP & $\$ 96 R 000071$ & 0 & eIc-02 & CL-02 & LIRUID & 100 & 99.1 & 99.200 ppos ofote \\
\hline 6 SPK-DUP & $\$ 968000071$ & $\circ$ & erc-01 & $F=02$ & LIQUID & 100 & 95.4 & $95.400 \mathrm{SPD}$ To 1 (1) \\
\hline 6 SPK-DOP & $\$ 9962000071$ & 0 & ax-01. & $\mathrm{NO2}-02$ & EIQUID & 100 & 95.9 & 95.900 afo 70 ibere \\
\hline
\end{tabular}




\section{LABCORE Completed Worklist Report for Worklist\# 5479}

\begin{tabular}{|c|c|c|c|c|c|c|c|c|c|c|}
\hline Seq & Type & Sample\# & & & & Matrix & Actual & Found & DL or Yield Unit & \\
\hline 6 & SPX-DOP & $596 R 000071$ & 0 & erc-01 & $8 R-02$ & LIQUXD & 100 & $n / a$ & RPE & \\
\hline 6 & SPX -DUP & 8962000071 & 0 & -IC-01 & xo3-02 & IIQTID & 100 & 99.2 & $99.200 \mathrm{nos} \%$ \% kex & 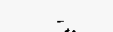 \\
\hline 6 & SER-DUP & 19682000071 & 0 & $\operatorname{erc}-01$ & PO4-02 & EIQTID & 100 & 95.2 & $95.200 \mathrm{mosec}$ & \\
\hline 6 & SFK-DUP & 3968000071 & 0 & eIc-01 & $504-02$ & LIQTID & 100 & 94.4 & 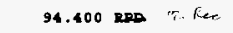 & \\
\hline 6 & SPK-DUP & $\$ 3968000071$ & 0 & arc-01 & OTAEATE2 & 2 IIOUID & 100 & $n / a$ & RPD & \\
\hline 7 & SAMPLE & 3968000072 & 0 & eIc-0I & F-02 & LIQTID & N/A & $8.903 e+01$ & $27.570 \mathrm{ug} / \mathrm{mL}$ & \\
\hline 7 & SAMPLB & 8968000072 & ○ & erc-0I & CE-02 & IIQUID & $\mathbf{N} / \mathrm{\lambda}$ & $3.227 *+02$ & $36.060 \mathrm{ug} / \mathrm{mr}$ & \\
\hline 7 & SAMPLE & 3968000072 & 0 & eIc-01 & x02-02 & LIOUID & N/A & $2.490 \bullet+03$ & $226.900 \mathrm{ug} / \mathrm{mL}$ & \\
\hline 7 & SAXPLE & 3968000072 & 0 & arc- 01 & NO3-02 & LIQUID & $N / A$ & $4.062=+04$ & $296.900 \mathrm{ug} / \mathrm{mr}$ & \\
\hline 7 & SAMPLE & $\$ 3968000072$ & 0 & IC-01 & PO4-02 & LIOOID & $\mathbf{N} / \mathbf{A}$ & $1.099 \bullet+03$ & $254.500 \mathrm{ug} / \mathrm{mL}$ & \\
\hline 7 & SAMPLI & 3968000072 & 0 & erc-01 & 504.02 & LTQUID & N/A & $4.115 \bullet+0.2$ & $288.500 \mathrm{ug} / \mathrm{mL}$ & \\
\hline$\theta$ & SPX & 39658000072 & 0 & ๑IC-0I & F-02 & LIQTID & 59 & 54.003 & $91.530 \%$ Recovery & \\
\hline 8 & spK & 5968000072 & 0 & $\operatorname{arc-01}$ & $\mathrm{cz}-02$ & EIOTID & 79 & 76.099 & 96.330 \& Recotery & \\
\hline 8 & SFK & :566R000072 & 0 & -1c-01 & No2-02 & IIOTID & 534 & 505.395 & 94.640 \& Recovery & \\
\hline 8 & sex & 3968000072 & 0 & arc-02 & $B R-02$ & LIOEID & .575 & $n / m$ & \& Recovery & \\
\hline 8 & SPK & :29680000072 & 0 & eIc-01 & xo3-02 & IIQUID & 614 & 697.074 & 113.530 \& Recovery & \\
\hline 8 & sPK & $\$ 9680000072$ & 0 & erc-01 & $804-02$ & LIOEID & 546 & 509.899 & 93.390 \% Recovery & \\
\hline 8 & SPK & 3968000072 & 0 & -1C-01 & $504-02$ & L.IQUID & 631 & 573.628 & 90.910 \& Recovery & \\
\hline 8 & SPK & 8962000072 & 0 & -re-01 & OXALATE2 & 2. EIOOID & 526 & $\pi /=$ & \& Recovery & \\
\hline 9 & SEK-DUP & $: 5962000072$ & 0 & erc-01 & CL-02 & LIOUID & 100 & 96.6 & 96.600 3. $R_{C z}$ & \\
\hline 9 & SPK-DEP & 6968R000072 & 0 & - Ic-01 & $7-02$ & IIgUID & 100 & 91.8 & $91,000+7, k$ kee & \\
\hline 9 & SFX-DUP & $\$ 996000072$ & 0 & -IC-01 & No2 -02 & Lrourd & 100 & 94.4 & 94.400 A20 $\%_{0} \gamma_{4}=$ & \\
\hline 9 & SPK-DUP & $\$ 96 \mathrm{R} 000072$ & 0 & arc-01. & $B R-02$ & LIQUID & 100 & $n / \mathbf{m}$ & met 9. ke & \\
\hline 9 & $S P K-D D P$ & $\$ 396 R 000072$ & 0 & erc-01 & No3-02 & IIQUID & 100 & 113.8 & $213.800 \mathrm{APO} T \cdot R=$ & \\
\hline 9 & SPK-DOP & $396 R 000072$ & 0 & $\operatorname{erc-01}$ & $204-02$ & IIQ⿴囗十 & 100 & 93.4 & 93.400 RPO $\%$ Rec & \\
\hline 9 & SPK-DUP & $\$ 3968000072$ & 0 & eIC-OI & $504-02$ & IIQUID & 100 & 91.0 & $91.000 \% \geqslant R_{c}$ & \\
\hline 9 & SPK-DUP & $\$ 96 \mathrm{R} 000072$ & 0 & erc-01 & Orazatr2 & 2 IIQUID & 100 & $n / a$ & TaRer & \\
\hline
\end{tabular}

\section{Comments Section:}

Comments for sample\# S96R000071 and test @IC-01 .

Blnk-prep was filtered through on-guard RP cartridges.JMF

\section{Final page for worklist\# 5479}

Analyst Signature $\quad$ Date

Analyst Signature Date

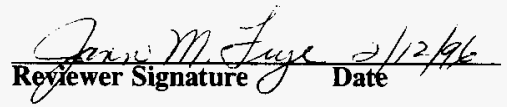




\section{LABCORE Data Entry Template for Worklist\# 5479}

Analyst:

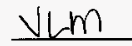

Instrument: ICO1 ICO2

Book\# $122 N q-E$

Method: LA-533-105 Rev/Mod Q4-D-1

Worklist Comment: Tank 25-2, b plant IC. Treat for organics, see JMF first.

\begin{tabular}{|c|c|c|c|c|c|c|c|c|}
\hline $\bar{s}$ & Type & Sample\# & $\mathbf{R A}$ & Test & Matrix & Group\# & Project & \\
\hline 1 & $\mathrm{CCB}$ & & & @IC-QC & QC & & & \\
\hline 2 & $\mathrm{CCV}$ & & & $@ I C-Q C$ & $Q C$ & & & \\
\hline \multirow[t]{2}{*}{3} & SAMPLE & S96R000071 & 0 & $@ I C-01$ & LIQUID & 95000224 & $\mathrm{ORG} / \mathrm{AQ}$ & SAMPL \\
\hline & & Analytes Reque & ested: & $\begin{array}{l}= \\
=\mathrm{CL}-02 \\
\mathrm{SO} 4-02\end{array}$ & $E-02$ & , $\mathrm{NO} 2-02$ & $\mathrm{NO} 3-02$ & , $\mathrm{PO} 4-02$ \\
\hline 4 & SPK & S96R000071 & 0 & $@ I C-01$ & LIQUID & & & \\
\hline 5 & SPK-DUP & $S 96 R 000071$ & 0 & @IC-01 & LIQUID & & & \\
\hline \multirow[t]{2}{*}{6} & SAMPLE & S96R000072 & 0 & @IC-01 & LIQUID & 95000224 & $\mathrm{ORG} / \mathrm{AQ}$ & SAMPL \\
\hline & & Analytes Reque & ested: & $\begin{array}{l}\text { CL- } 02 \\
\mathrm{SO} 4-02\end{array}$ & F-02 & , $\mathrm{NO} 2-02$ & $\mathrm{NO} 3-02$ & , PO4-02 \\
\hline 7 & SPK & $S 96 R 000072$ & 0 & $@ I C-01$ & LIQUID & & & \\
\hline 8 & SPK-DUP & S96R000072 & 0 & (aIC-01 & LIQUID & & & \\
\hline
\end{tabular}

\section{Final page for worklist \# 5479}

Ualeniz Masaie 02-06-96

Analyst Signature Date

Analyst Signature Date $0_{2}-06-9 \mathrm{C}$ samplea filtered thru pretreated organic cantridges. Vmase

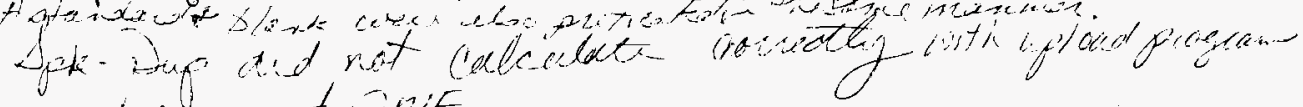
weict to ver uet. finit

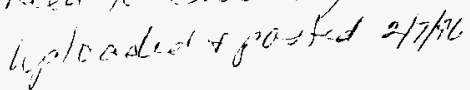

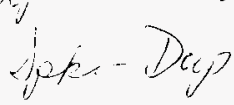

arrictid $3 / 2 / 969$

Data Entry Comments:

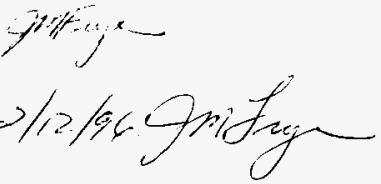

$S=$ Worklist Slot Number, $R=$ Replicate Number, $A=$ Aliquot Code. 
WHC-SU-vilt-DP-180, REV. 0

WESTINGHOUSE HANFORD COMPANY

222-S LABORATORY

INORGANIC ANALYTICAL BATCH AND SUMMARY SHEET

ANION ANALYSIS ON DIONEX

\begin{tabular}{|c|c|c|c|c|c|c|c|c|}
\hline $\begin{array}{l}\text { SAMPLE \#: } \\
\text { TEST CODE: } \\
\text { INSTRUMENT: } \\
\text { ICO2 } \\
\text { WORK LIST \#: } \quad 5479 \\
\text { BATCH ID: }\end{array}$ & & & & $\begin{array}{l}\text { ANALYST: } \\
\text { ANALYSIS } \\
\text { SAMPLE P } \\
\text { SAMPLE P }\end{array}$ & $\begin{array}{l}\text { DATE: } \\
\text { OINT: } \\
\text { REP: }\end{array}$ & $\begin{array}{l}\text { VALERIE } \\
\text { O2/06/96 } \\
25-2 \\
\text { DIRECT }\end{array}$ & ASSIE & \\
\hline Resuht Units & Fluoride & Chloride & Nitrite & Nitrate & Phosphate & Sulfate & Bromide & Oxalate \\
\hline \multicolumn{9}{|l|}{ 122N9E } \\
\hline & $<0.00$ & $<0.00$ & $<0.00$ & $<0.00$ & $<0.00$ & $<0.00$ & $<0.00$ & $<0.00$ \\
\hline S96R00007 IREP & $8.77 \mathrm{E}+01$ & $3.42 E+02$ & 2.67E+03 & $4.41 \mathrm{E}+04$ & $1.32 \mathrm{E}+03$ & 3.85E+02 & $<0.00$ & $<0.00$ \\
\hline \multirow[t]{2}{*}{ Duplicate 1 RPD } & $\mathbf{N} / \mathbf{A}$ & N/A & N/A & N/A & N/A & N/A & N/A & N/A \\
\hline & $<0.00$ & $<0.00$ & $<0.00$ & $<0.00$ & $<0.00$ & $<0.00$ & $<0.00$ & $<0.00$ \\
\hline S96R000072REP & $8.90 E+01$ & $3.23 E+02$ & $2.49 E+03$ & $4.06 E+04$ & $1.10 E+03$ & $4.12 E+02$ & $<0.00$ & $<0.00$ \\
\hline Duplicate 2 RPD & N/A & N/A & N/A & N/A & N/A & N/A & ERR & ERR \\
\hline & & & & & & & & \\
\hline & & & & & & & & \\
\hline & & & & & & & & \\
\hline & & & & & & & & \\
\hline & & & & & & & & \\
\hline & & & & & & & & \\
\hline & & & & & & & & \\
\hline S96R000072 & $91.8 \%$ & $96.6 \%$ & $94.4 \%$ & $113.8 \%$ & $93.4 \%$ & $91.0 \%$ & & \\
\hline
\end{tabular}

NARRATIVE:

Analyst Comments:

Chemist Comments:

Spk-dup calurlation you salecocolz

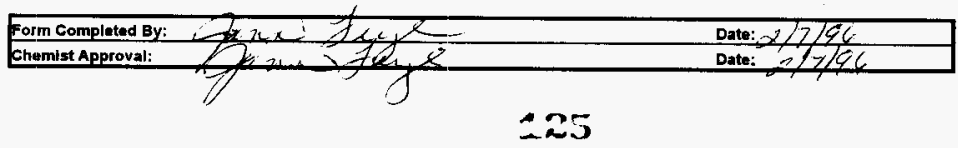




\section{WHC-SD-Wing-DP-180, REV. 0}

\begin{tabular}{|c|c|}
\hline \multicolumn{2}{|c|}{ LAB LEADER INFO } \\
\hline Method: & LA- $533-106$ \\
\hline Matrix: & LIOUNO \\
\hline \multicolumn{2}{|l|}{ Toot Code: } \\
\hline Work 니여: & 349 \\
\hline \multicolumn{2}{|l|}{ Bateh : } \\
\hline \multicolumn{2}{|l|}{ Result Units } \\
\hline$(\mu \mathrm{g} g$ or $\mu \mathrm{g} / \mathrm{mL} \mathrm{L}):$ & yog/mL \\
\hline spike Book Number: & 122nge \\
\hline \multicolumn{2}{|l|}{ Spike Samples: } \\
\hline Propared By: & JANM FRYE \\
\hline Propared Date: & 02107196 \\
\hline Chemist: & JM FRYE \\
\hline Analyst: & VALERIE MASSIE \\
\hline Anglysuls Date: & $02 / 06 / 96$ \\
\hline \multicolumn{2}{|l|}{ IIms Complete: } \\
\hline instrument Code: & 1002 \\
\hline \multicolumn{2}{|l|}{ Rerun: } \\
\hline Sample Prep: & DIREGT \\
\hline Sample Polnt: & $25-2$ \\
\hline \multicolumn{2}{|l|}{ Sample Type } \\
\hline STANDARD & 122N9E \\
\hline \multicolumn{2}{|l|}{ SAMPLE 1} \\
\hline DUPLICATE 1 & S96R000071REF: \\
\hline \multicolumn{2}{|l|}{ SAMPLE I } \\
\hline QUPLICATE 2 & S96R000072RER \\
\hline SAMPLE. 3 & $\ldots$ \\
\hline \multicolumn{2}{|l|}{ DUPLICATE 3} \\
\hline \multicolumn{2}{|l|}{ SAMPLE 4} \\
\hline \multicolumn{2}{|l|}{ DUPLICATE 4} \\
\hline \multicolumn{2}{|l|}{ SPIKE } \\
\hline SPIKE DUPLICATE & S96R000072 \\
\hline
\end{tabular}

\begin{tabular}{|c|c|c|c|c|c|c|c|c|}
\hline \multicolumn{9}{|c|}{ TECH INFO } \\
\hline & Fluorlde & Ghloride & Mitritte & Nitrate & Phosphnite & Sulfate & Gromide & Oxatate \\
\hline Blunk Data $(\mu \mathrm{g} / \mathrm{mL})$ & & & & & & & & \\
\hline
\end{tabular}

\begin{tabular}{|l|l|l|l|l|l|l|l|}
\hline standard Data $(\mu \mathrm{g} / \mathrm{mL})$ & $\mathrm{L}$ & & & & & & \\
\hline
\end{tabular}
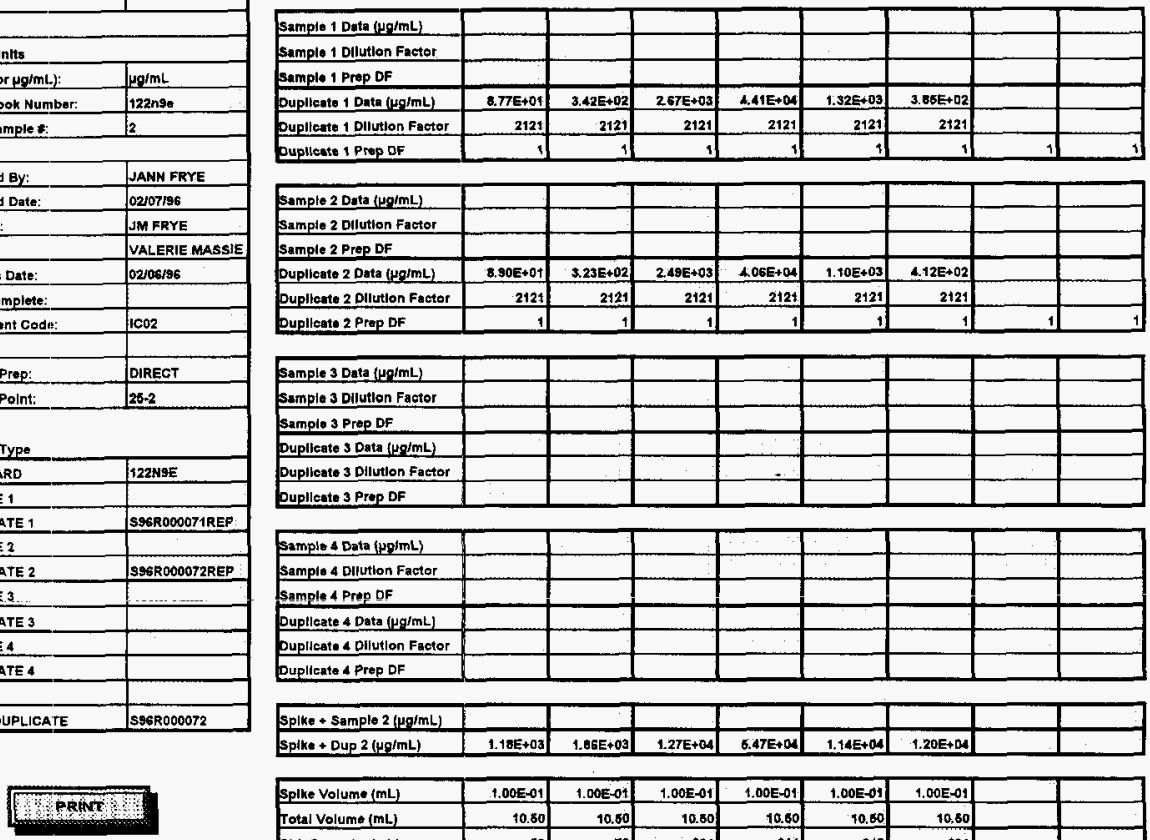

\begin{tabular}{|c|c|c|c|c|c|c|c|c|}
\hline Splke volume (mL) & 1.00E-01 & $1.00 E-01$ & 1.00E-01 & 1.000 -01 & $1.00 E-01$ & $1.00 E-01$ & & \\
\hline Lotal Volume (mL) & 10.80 & 10.60 & 10.80 & 10.80 & 70,60 & 10.50 & & \\
\hline ste. Conc. $(y \mathrm{~g} / \mathrm{mL})$ & 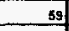 & 79 & \$34 & 614 & 646 & 631 & & \\
\hline Detection LImitt & 0.013 & $0.01 \gamma$ & 0.107 & 0.140 & 0.119 & 0.136 & & \\
\hline Matrix Dentection Limit 1 & $0.00 E \bullet 00$ & $0.005+00$ & $0.00 E+00$ & $0.00 E+00$ & $0.00 \mathrm{E}+00$ & $0.00 E+\infty 0$ & $0.00 \mathrm{E}+00$ & $0.00 \varepsilon+00$ \\
\hline Matrix Detection LIm|1 2 & $0.00 E \cdot 00$ & $0.00 E+00$ & $0.00 E+00$ & $0.00 E+00$ & $0.00 \xi+00$ & $0.00 E+00$ & $0.00 E+00$ & $0.00 E+00$ \\
\hline Matrix Detecllon Limit 3 & $0.00 \mathrm{E}+00$ & $0.00 E+\infty 0$ & $0.00 E+00$ & $0.00 E+00$ & $0.00 E+00$ & $0.00 E+\infty 0$ & $0.00 E+00$ & $0.00 E+00$ \\
\hline Matrlx Detection LImH 4 & $0.00 E+00$ & $0.00 E+00$ & $0.00 E+00$ & $0.00 E+00$ & $0.00 E+00$ & $0.00 E+60$ & $0.00 E+00$ & $0.00 E+00$ \\
\hline
\end{tabular}

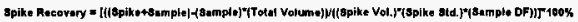

Mote: (For spike recovery when tha semple conc. is iess than defection linit you do Not subtract sample conc.)

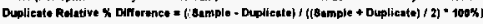

Less then Values are Calculated frem the Detsetion Limlt TDilution Fastor
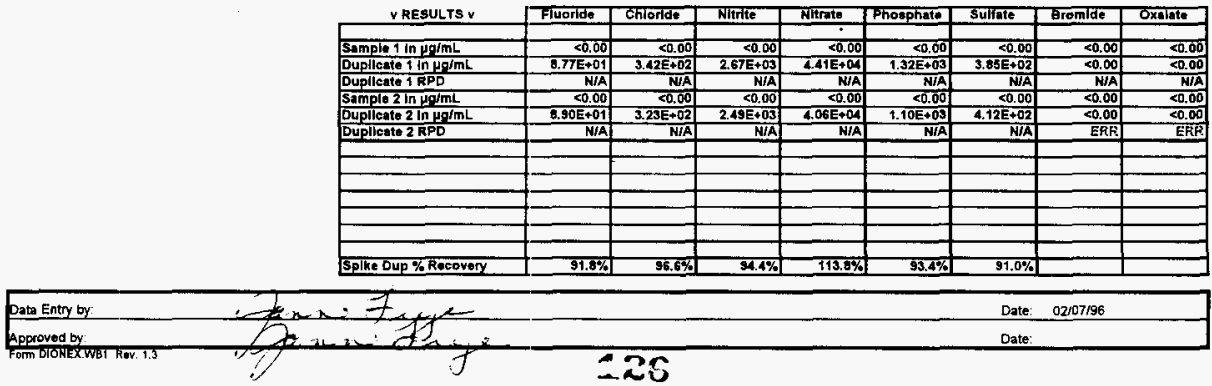

Date: $\quad 02707 / 96$ 
WHC-SU-V'M-DP-180, REV. 0

\section{WESTINGHOUSE HANFORD COMPANY 222-S LABORATORY \\ INORGANIC ANALYTICAL BATCH AND SUMMARY SHEET \\ ANION ANALYSIS ON DIONEX}

\begin{tabular}{llll|}
\hline SAMPLE\#: & A & & \\
TEST CODE: & & ANALYST: & VALERIE MASSIE \\
INSTRUMENT: & IC02 & ANALYSIS DATE: & 02/06/96 \\
WORK LIST \#: 5479 & SAMPLE POINT: & 25-2 \\
BATCH ID: & SAMPLE PREP: & DIRECT \\
\hline
\end{tabular}

\begin{tabular}{|c|c|c|c|c|c|c|c|c|}
\hline Rosult Unit: & Fluoride & Chloride & Nitrite & Nitrate & Phosphate & Sulfate & Bromide & Oxalate \\
\hline \multicolumn{9}{|l|}{ 122N9E } \\
\hline & $<0,00$ & $<0.00$ & $<0.00$ & $<0.00$ & $<0.00$ & $<0.00$ & $<0.00$ & $<0.00$ \\
\hline S96R000071REP & 8.77E+01 & $3.42 \mathrm{E}+02$ & $2.67 E+03$ & $4.41 E+04$ & $1.32 E+03$ & $3.85 \mathrm{E}+02$ & $<0.00$ & $<0.00$ \\
\hline \multirow[t]{2}{*}{ Duplicate 1 RPD } & N/A & N/A & N/A & N/A & N/A & N/A & N/A & N/A \\
\hline & $<0.00$ & $<0.00$ & $<0.00$ & $<0.00$ & $<0.00$ & $<0.00$ & $<0.00$ & $<0,00$ \\
\hline S96R000072REP & $8.90 \mathrm{E}+01$ & $3.23 E+02$ & $2.49 E+03$ & $4.06 E+04$ & $1.10 E+03$ & $4.12 E+02$ & $<0.00$ & $<0.00$ \\
\hline Duplicate 2 RPD & N/A & N/A & N/A & N/A & N/A & N/A & ERR & ERR \\
\hline & & & & & & & & \\
\hline & & & & & & & & \\
\hline & & & & & & & & \\
\hline & & & & & & & & \\
\hline & & & & & & & & \\
\hline & & & & & & & & \\
\hline & & & & & & & & \\
\hline S96R000071 & $95.4 \%$ & $99.1 \%$ & $95.9 \%$ & $99.2 \%$ & $95.2 \%$ & $94.4 \%$ & & \\
\hline
\end{tabular}

NARRATIVE: Analyst Comments:

Chemist Comments:

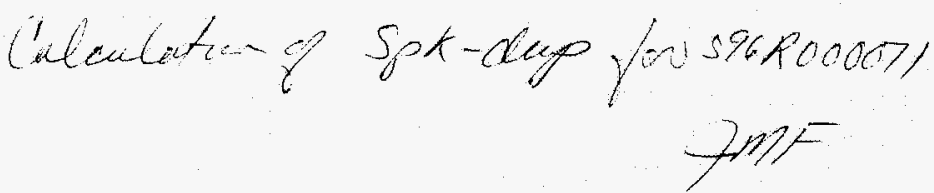


WHC-SD-WM-DP-180, REV. 0

\begin{tabular}{|c|c|}
\hline \multicolumn{2}{|c|}{ LAQ LEADER INFO } \\
\hline Method: & La-633-105 \\
\hline $\operatorname{matrix}$ & LIOUID \\
\hline \multicolumn{2}{|l|}{ Tost Code: } \\
\hline Work Lust : : & Sat9 \\
\hline \multicolumn{2}{|l|}{ Satens: } \\
\hline \multicolumn{2}{|l|}{ Result Units } \\
\hline (pgig or $\mu \mathrm{g} / \mathrm{mL}$ ): & $\mu \mathrm{g} / \mathrm{mL}$ \\
\hline Splke Book Nuniber: & $122 n s e$ \\
\hline Splkn Sample : & 1 \\
\hline Prepared By: & JANN FRYE \\
\hline Prepared Date: & 02107196 \\
\hline Chamist: & JM FRYE \\
\hline Anwlyst: & VALERIE MASSIE \\
\hline Anslysis Date: & $02105 / 96$ \\
\hline \multicolumn{2}{|l|}{ Time Complete: } \\
\hline Instrument Codn: & $1 \mathrm{CO2}$ \\
\hline \multicolumn{2}{|l|}{ Rerun: } \\
\hline Sample Prep: & DIREGT \\
\hline Sample Point: & $25-2$ \\
\hline \multicolumn{2}{|l|}{ Sample Type } \\
\hline STANDARD & 122N9E \\
\hline \multicolumn{2}{|l|}{ SAMPLE 1} \\
\hline DUPLICATE 1 & S96R000071REP. \\
\hline \multicolumn{2}{|l|}{ SAMPLE 2} \\
\hline DUPLICATE 2 & SE6R000072REP \\
\hline \multicolumn{2}{|l|}{ SAMPLE 3} \\
\hline \multicolumn{2}{|l|}{ DUPLICATE 3} \\
\hline \multicolumn{2}{|l|}{ SAMPLE 4 } \\
\hline \multicolumn{2}{|l|}{ DUPLICATE 4} \\
\hline \multicolumn{2}{|l|}{ SPIKE } \\
\hline SPIKE DUPLICATE & S96R000071 \\
\hline
\end{tabular}

\begin{tabular}{|c|c|c|c|c|c|c|c|c|}
\hline \multicolumn{9}{|c|}{ TECH WMFO } \\
\hline & Fiuorldo & Chloride & Nitrite & Nitrate & Phosphate & sulfate & Bromide & Oxalate \\
\hline alank Data ( $\mu \mathrm{g} / \mathrm{mL}$ ) & & & & & & & & \\
\hline
\end{tabular}

\begin{tabular}{|l|l|l|l|l|l|l|}
\hline Standard Data $(\mu \mathrm{g} / \mathrm{mL})$ & & & & & & \\
\hline
\end{tabular}

\begin{tabular}{|c|c|c|c|c|c|c|c|c|}
\hline Samplo 1 Data $(\mu \mathrm{g} / \mathrm{mL})$ & & & & & & & & \\
\hline Sample t Dllution Factor & & & & & & & & \\
\hline Sample 1 Prap DF & & & & & & & & \\
\hline Duplleste 1 Data $(\mu \mathrm{g} / \mathrm{mL})$ & $B .77 E+01$ & $3.425+02$ & $2.67 E+03$ & $4.41 E+04$ & $1.32 E+03$ & $3.06 E+02$ & & \\
\hline Duplleate 1 Dilution Fuctor & 2121 & 2124: & 2121 & 2121 & 2121 & 2121 & & \\
\hline Duplleate 1 Prep DF & 1 & & & & & 1 & t & 1 \\
\hline
\end{tabular}

\begin{tabular}{|c|c|c|c|c|c|c|c|c|}
\hline Sample 2 Data ( $\mathrm{g} \mathrm{g} / \mathrm{mL}$ ) & & & & & & & & \\
\hline Sample 2 Oilution Factor & & & & & & & & \\
\hline Sample 2 Prep DF & & & & & & & & \\
\hline Duplleate 2 Date $\{\mu \mathrm{g} / \mathrm{mL}\rangle$ & $8.90 E+0 t$ & $3.23 E+02$ & $2.49 E+03$ & $4.06 E+0 \mathrm{a}$ & $1.90 E+03$ & 4.12E+02 & & \\
\hline Duplleate 2 Diluulion Factor & 2121 & $2+21$ & 2121 & 2121 & 2121 & 2124 & & \\
\hline Dupllcate 2 Prep DF & † & & & & & & & \\
\hline
\end{tabular}

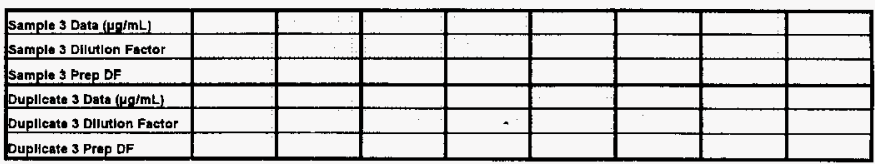

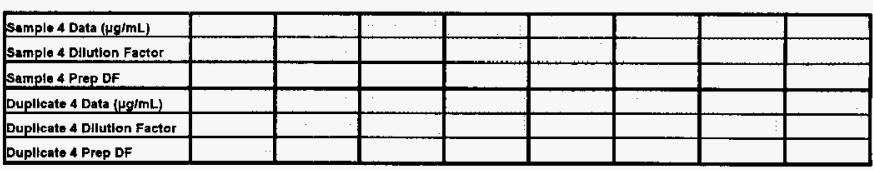

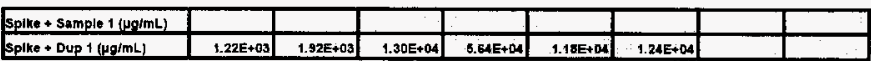

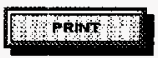

\begin{tabular}{|c|c|c|c|c|c|c|c|c|}
\hline Splke Volume (mL) & $1.00 \mathrm{E}-01$ & $1.00 E-01$ & 1:00E-01 & $1,00 \pm=01$ & $1.00 E-09$ & $1.00 E-01$ & & \\
\hline Total Volume (mL) & 10.50 & 10.50 & 10.60 & 10.50 & 10.60 & 10.60 & & \\
\hline Std. Conc. (ug/mL) & sg & 79 & 33ia & 614 & 646 & 631 & & \\
\hline Datuction Lirmit & 0,013 & 0.017 & 0.107 & 0.740 & 0.119 & 0.136 & & \\
\hline Matrix Dotection LImitt 1 & $0.00 E+00$ & $0.00 E+00$ & $0.00 E+00$ & $0.00 E+00$ & $0.00 E+00$ & $0,00 E+00$ & $0.00 E+00$ & $0.00 E+00$ \\
\hline Matrix Detectlon Limit 2 & $0.00 E+0.0$ & $0.00 E+00$ & $0.00 E+00$ & $0.00 E+0.0$ & $0.00 E+00$ & $0.00 E+0.0$ & $0.00 E+00$ & $0.00 E+00$ \\
\hline Matrix Detectilon Limit 3 & $0.00 E+00$ & $0.00 E+00$ & $0.00 \mathrm{E}+00$ & $0.00 E+00$ & $0.00 E+00$ & $0.00 E+00$ & $0.00 E+00$ & $0.00 E+00$ \\
\hline Matrix Detectlon Limit 4 & $0.00 E+00$ & $0.00 E+00$ & $0.00 E \cdot 00$ & $0.00 E+00$ & $0,00 E+00$ & $0.00 E+00$ & $0.00 E+0.0$ & $0.00 E+00$ \\
\hline
\end{tabular}

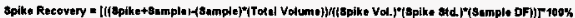

Note: (For spilke recovery when the sample conc. it lest than detection limit you do NOT subtract eampie cone,

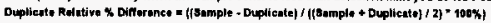

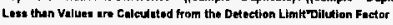

\begin{tabular}{|c|c|c|c|c|c|c|c|c|}
\hline V RESULTS V & Fluoride & Chlorde & Nltrte & Nitrate & Phosphtte & sulfite & Eromide & oxalato \\
\hline Sample I In uojmL & $<0.00$ & $<0.00$ & $<0.00$ & $<0.00$ & 20.00 & $<0.00$ & $<0,00$ & $<0,00$ \\
\hline Dupleate 1 In ugimL & $8.77 E+01$ & $3.42=+02$ & $2,67 E+03$ &.$\overline{44 E+04}$ & $9.32 E+03$ & $3.855+02$ & 80.00 & 80,00 \\
\hline Duplletto 1 RPD & $N / A$ & NIA. & N/A & NIA & N/A & N/A & N/A & NiA \\
\hline Sample 2/n $40 / \mathrm{mL}$ & $<0,00$ & $<0.00$ & $<0.00$ & 80.00 & $<0.00$ & $<0.00$ & $<0.00$ & $<0.00$ \\
\hline Duplicate 2 in $\mathrm{Jg} / \mathrm{mL}$ & $8.90 \overline{5}+01$ & $3.235+02$ & $2.49 E+03$ & $4.06 E+04$ & $1.10 \mathrm{E}+0 \mathrm{~s}$ & $412 E+02$ & 80.00 & $<0.00$ \\
\hline Dupllarte 2 RPD & N/A & N/A & NIA & N/A & NIA & N/A & 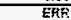 & EAH \\
\hline & & & & & & & & \\
\hline & & & & & & & & \\
\hline & & & & & & & & \\
\hline & & & & & & & & \\
\hline & & & & & & & & \\
\hline & & & & & & & & \\
\hline Splke Dup \% Recovery & $96.4 \%$ & $99.1 \%$ & $96.9 \%$ & $99.2 \%$ & 96.26 & $34.4 \%$ & & \\
\hline
\end{tabular}

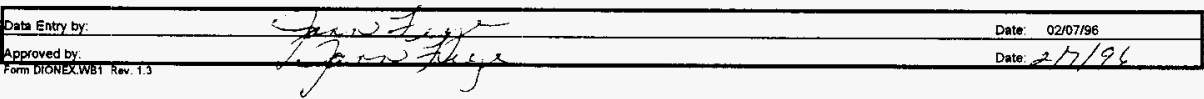




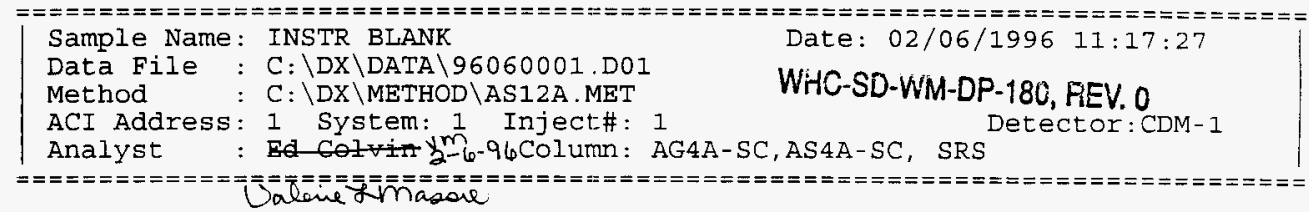

Calibration Volume Dilution Points Rate start Stop Area Reject

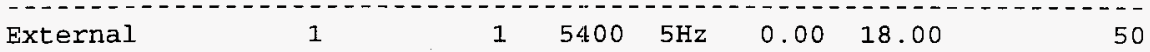

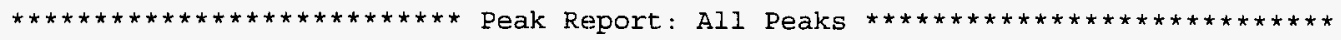

$\begin{array}{lrrr}\text { Pk. Ret Component } & \text { Concentration } & \text { Height } & \text { Area Bl. } \\ \text { Num Delta } & \text { Code }\end{array}$

$$
\text { Num Time Name }
$$

2.53 FORMATE

$-2.107$

12.40 SULFATE

0.147

58

0.000

17

13.40

16.30 OXALATE

0.123

7

$\begin{array}{rrr}581 & 1 & -5.00 \\ 257 & 1 & 2.90 \\ 52 & 1 & \\ 223 & 1 & 1.56\end{array}$

Totals

$-1.836$

97

1113

\section{File: 96060001.D01 Sample: INSTR BLANK}

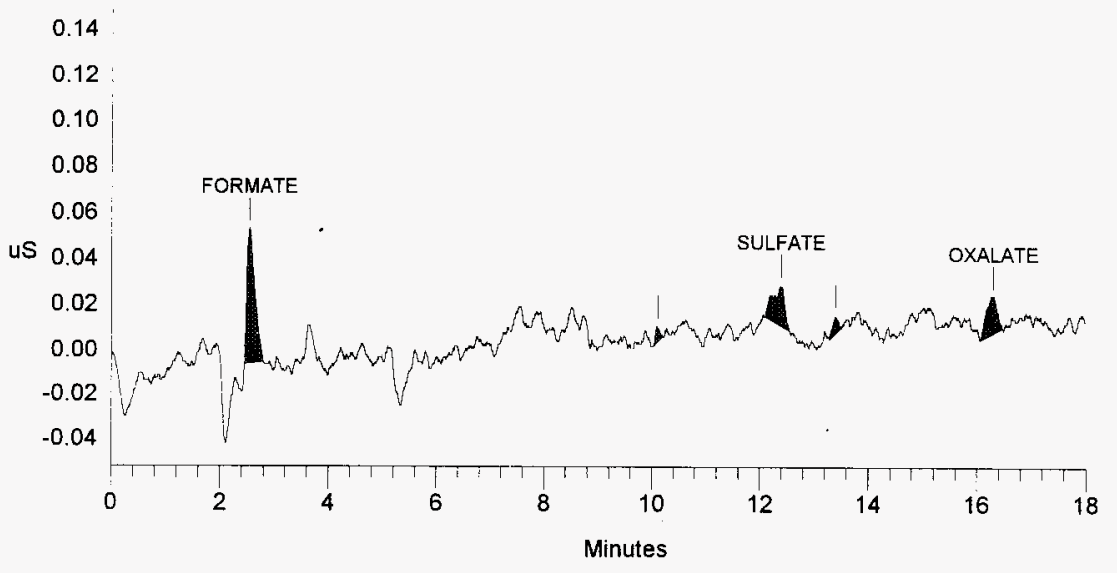

SIGNATURE ABOVE REPRESENIS CHENICAL TECHYLLOGST/CHEMIST THAT

COMPLETED/VERIFIED THE CALIBRATION/ANALYSIS ON PAGES $\angle 29$ TO $\angle 34$. 


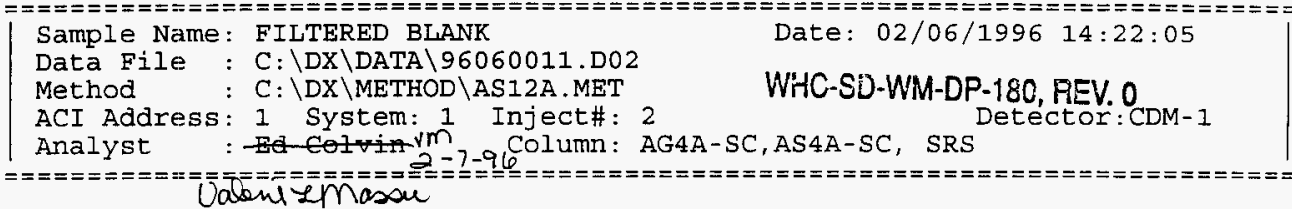

Calibration Volume Dilution Points Rate start stop Area Reject

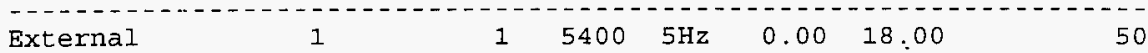

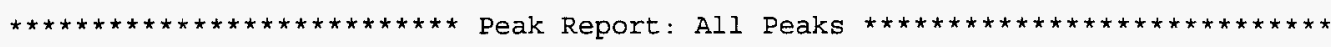

\begin{tabular}{|c|c|c|c|c|c|c|c|}
\hline $\begin{array}{l}\text { Pk. } \\
\text { Num }\end{array}$ & $\begin{array}{l}\text { Ret: } \\
\text { Time }\end{array}$ & $\begin{array}{l}\text { Component } \\
\text { Name }\end{array}$ & $\begin{array}{r}\text { Concentration } \\
u \mathrm{~g} / \mathrm{ml}\end{array}$ & Height & Area & $\begin{array}{l}\text { Bl } \\
\text { Code }\end{array}$ & $\div$ Delta \\
\hline & & & & & & & \\
\hline 1 & 2.53 & FORMATE & -2.216 & 103 & 1126 & 1 & -5.00 \\
\hline 2 & 3.65 & CHLOR IDE & 0.040 & 92 & 825 & 1 & -2.23 \\
\hline 3 & 4.55 & NITRITE & 0.201 & 70 & 688 & 1 & -1.80 \\
\hline 4 & 7.18 & BROMIDE & 0.216 & 31 & 504 & 1 & -1.1 \\
\hline 5 & 8.45 & NITRATE & 0.291 & 65 & 1154 & 1 & 0.6 \\
\hline 6 & 10.12 & PHOSPHATE & 0.211 & 18 & 429 & 1 & 1.1 \\
\hline 8 & 12.15 & SULFATE & 0.143 & 14 & 202 & 1 & 0.8 \\
\hline 10 & 15.40 & OXALATE & 0.110 & 8 & 78 & 1 & -4.0 \\
\hline
\end{tabular}

Totals $\quad-1.003 \quad 402 \quad 5006$

File: 96060011.D02 Sample: FILTERED BLANK

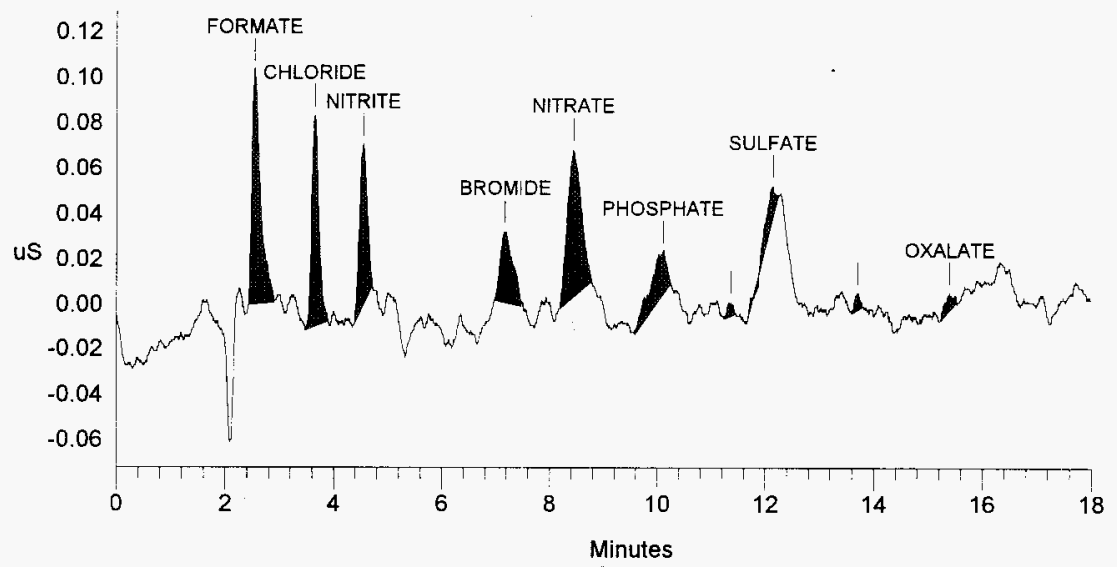




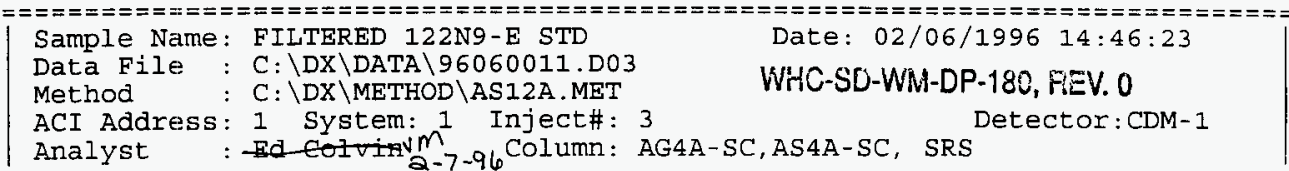

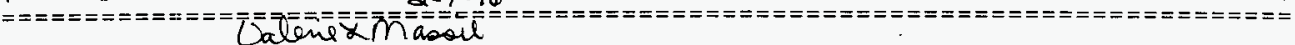
Calibration Volume Dilution Points Rate start Stop Area Reject

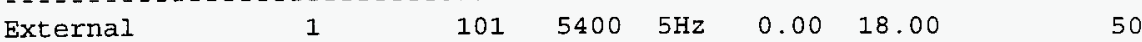

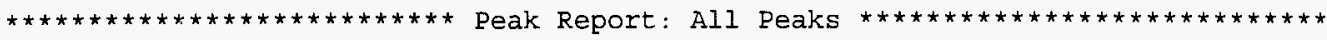
$\begin{array}{lrrr}\text { Pk. Ret Component } & \text { Concentration } & \text { Height } & \text { Ag/ml } \\ \text { Num Time Name } & & \text { Code }\end{array}$

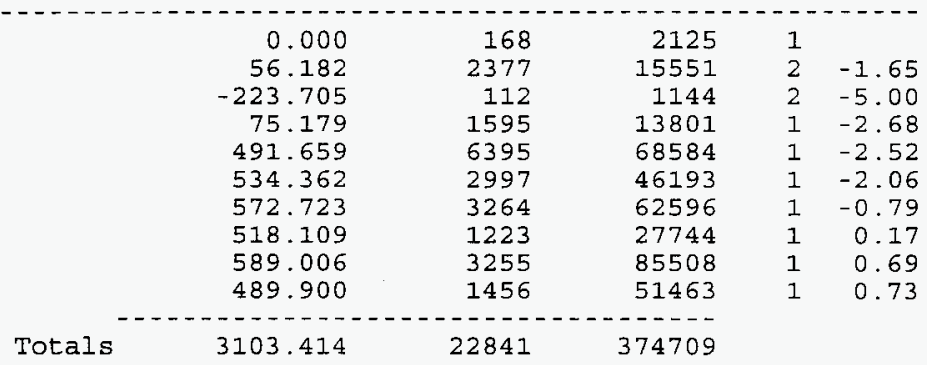

File: 96060011.D03 Sample: FILTERED 122N9-E STD

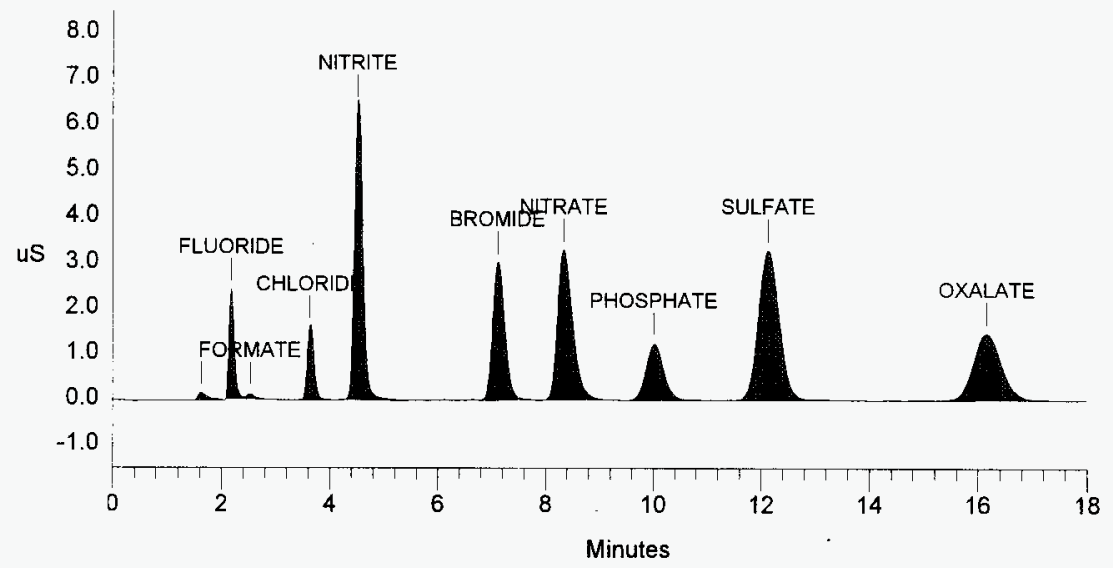


Sample Name: $122 \mathrm{~N} 9-\mathrm{E}$ STD

Data File : C: DXXDATA $\backslash 96060011$. D01

Method

C: $\backslash D X \backslash M E T H O D \backslash A S 12 A . M E T$

ACI Address: 1 System: 1 Inject\#: 1

Analyst : Col $V_{2-7}-96$ Column: AG4A-SC, AS4A-SC, SRS

Date: 02/06/1996 13:53:49

WHC-SD-WM-DP-180, FEV 0

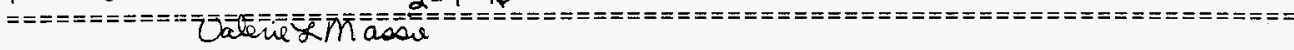
Calibration Volume Dilution Points Rate start Stop Area Reject

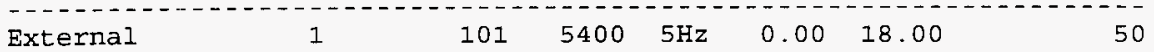

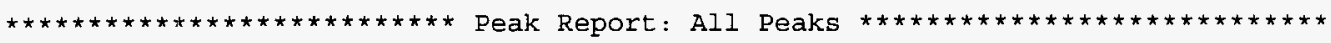

Pk. Ret Component Concentration Height Area Bl. $\%$ Delta Num Time Name ug/m

\begin{tabular}{|c|c|c|c|c|c|c|c|}
\hline 1 & 1.63 & & 0.000 & 143 & 1647 & 1 & \\
\hline 2 & 2.18 & FLUORIDE & 56.090 & 2366 & 15525 & 3 & -1.65 \\
\hline 3 & 2.53 & FORMATE & -218.928 & 72 & 748 & 4 & -5.0 \\
\hline 4 & 3.65 & CHLORIDE & 72.910 & 1601 & 13382 & 1 & -2.2 \\
\hline 5 & 4.53 & NITRITE & 495.407 & 6549 & 69126 & 1 & -2.1 \\
\hline 6 & 7.13 & BROMIDE & 538.217 & 3046 & 46542 & 1 & -1.8 \\
\hline 7 & 8.35 & NITRATE & 580.169 & 3290 & 63449 & 2 & -0.6 \\
\hline 8 & 9.42 & & 0.000 & 9 & 58 & 2 & \\
\hline 9 & 10.03 & PHOSPHATE & 524.542 & 1238 & 28104 & 1 & 0.3 \\
\hline 10 & 12.13 & SULFATE & 590.019 & 3257 & 85661 & 1 & $0 . \epsilon$ \\
\hline 12 & 16.17 & OXALATE & 477.466 & 1443 & 50116 & 1 & 0.7 \\
\hline
\end{tabular}

Totals

3115.893

23013

374356

File: 96060011.D01 Sample: 122N9-E STD

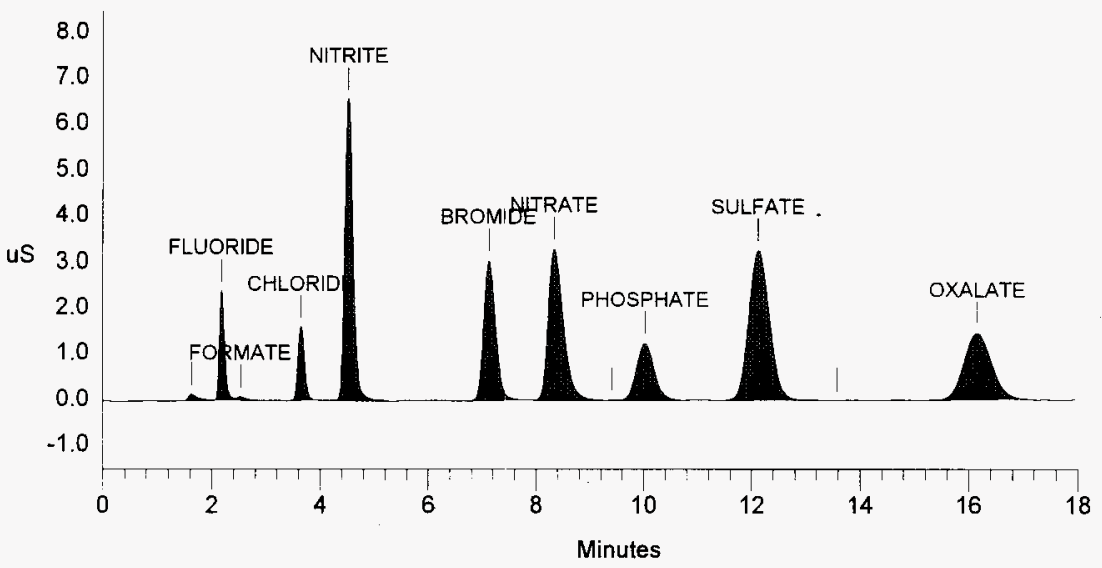




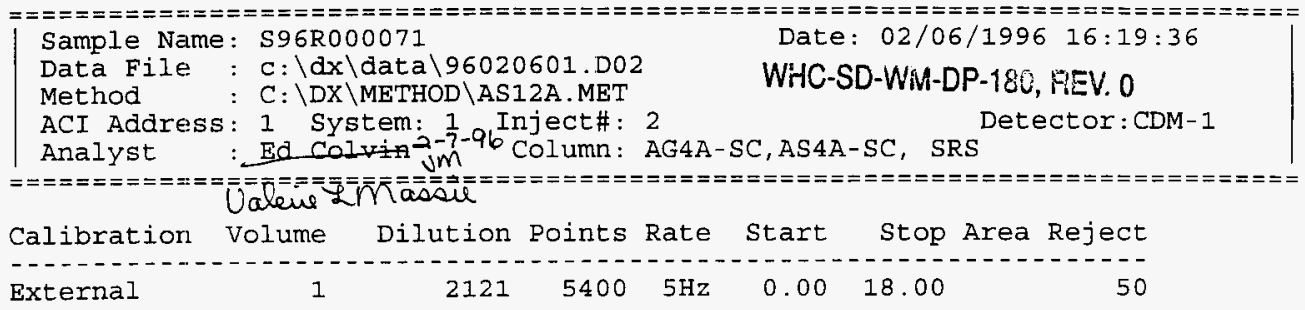

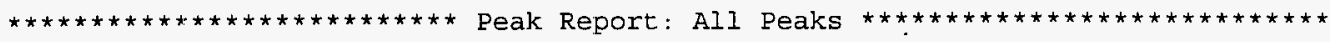

$\begin{array}{lrrr}\text { Bk. Ret Component } & \text { Concentration } & \text { Height } & \text { Area Bl. } \\ \text { Num Delta } & \text { Code }\end{array}$

Num Time Name ug/m

\begin{tabular}{|c|c|c|c|c|c|c|c|}
\hline 1 & 1.62 & & 0.000 & 115 & 1432 & 1 & \\
\hline 2 & 2.28 & FLUORIDE & 87.719 & 168 & 966 & 2 & 2.85 \\
\hline 3 & 2.52 & FORMATE & 5238.926 & 599 & 4353 & 2 & -5.63 \\
\hline 4 & 3.63 & CHLORIDE & 342.178 & 352 & 3032 & 1 & -2.68 \\
\hline 5 & 4.53 & NITRITE & 2668.441 & 1541 & 16012 & 1 & -2.16 \\
\hline 6 & 8.17 & NITRATE & 44099.048 & 12035 & 244150 & 2 & -2.78 \\
\hline 7 & 10.05 & PHOSPHATE & 1319.560 & 109 & 2679 & 2 & 0.50 \\
\hline 8 & 12.18 & SULFATE & 384.756 & 39 & 767 & 1 & 1.11 \\
\hline 9 & 14.40 & & 0.000 & 21 & 504 & 1 & \\
\hline 11 & 16.22 & OXALATE & 247.698 & 10 & 151 & 1 & 1.04 \\
\hline 12 & 17.17 & & 0.000 & 7 & 86 & 1 & \\
\hline & & & -7 & 5 & 2 & & \\
\hline
\end{tabular}

File: 96020601.D02 Sample: S96R000071

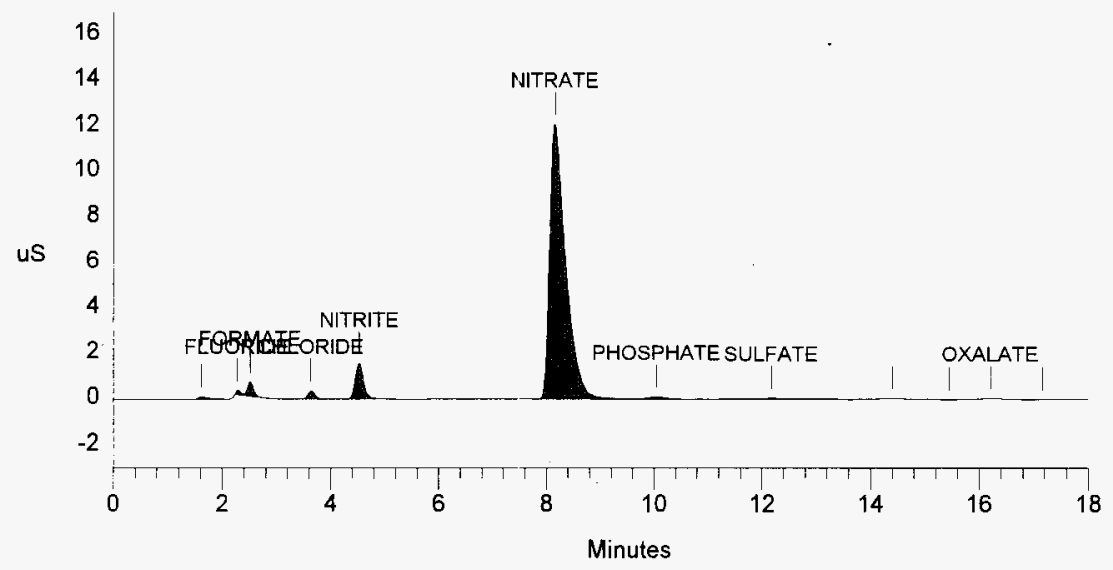




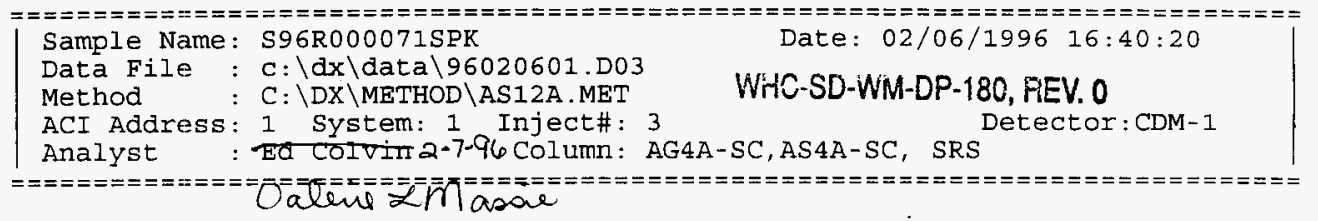

Calibration volume Dilution Points Rate start stop Area Reject

\begin{tabular}{|c|}
\hline External \\
\hline
\end{tabular}

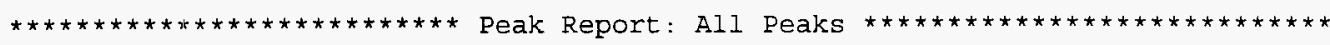

\begin{tabular}{|c|c|c|c|c|c|c|c|}
\hline $\begin{array}{l}\mathrm{Pk} \text {. } \\
\text { Num }\end{array}$ & $\begin{array}{l}\text { Ret } \\
\text { Time }\end{array}$ & $\begin{array}{l}\text { Component } \\
\text { Name }\end{array}$ & $\begin{array}{r}\text { Concentration } \\
\mathrm{ug} / \mathrm{ml}\end{array}$ & Height & Area & $\begin{array}{l}\text { Bl. } \\
\text { Code }\end{array}$ & oDelta \\
\hline$=-$ & -- & & & & & & \\
\hline 1 & 1.62 & & 0.000 & 239 & 2642 & 1 & \\
\hline 2 & 2.17 & FLUORIDE & 1182.164 & 2066 & 15583 & 2 & -2.40 \\
\hline 3 & 2.52 & FORMATE & 10843.007 & 624 & 5173 & 2 & -5.63 \\
\hline 4 & 3.63 & CHLORIDE & 1836.506 & 1924 & 16076 & 1 & -2.68 \\
\hline 5 & 4.52 & NITRITE & 12414.779 & 8065 & 82996 & 1 & -2.52 \\
\hline 6 & 7.10 & BROMIDE & 10949.141 & 3060 & 45020 & 1 & -2.2 \\
\hline 7 & 8.10 & NITRATE & 55417.911 & 14921 & 311778 & 1 & -3.57 \\
\hline 8 & 10.02 & PHOSPHATE & 11363.121 & 1291 & 29030 & 1 & 0.17 \\
\hline 9 & 12.12 & SULFATE & 12012.170 & 3166 & 82946 & 1 & 0.5 \\
\hline 10 & 14.37 & & 0.000 & 26 & 542 & 1 & \\
\hline 11 & 16.13 & OXALATE & 9999.560 & 1429 & 49975 & 1 & 0.52 \\
\hline
\end{tabular}

Totals $\quad 126018.359 \quad 36810 \quad 641760$

File: 96020601.D03 Sample: S96R000071SPK

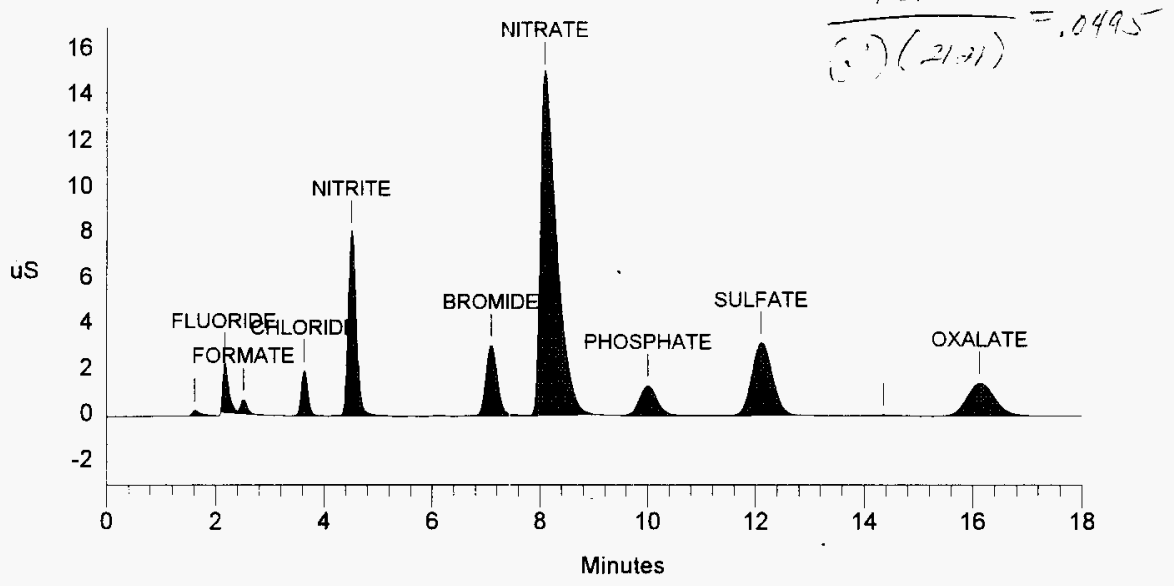




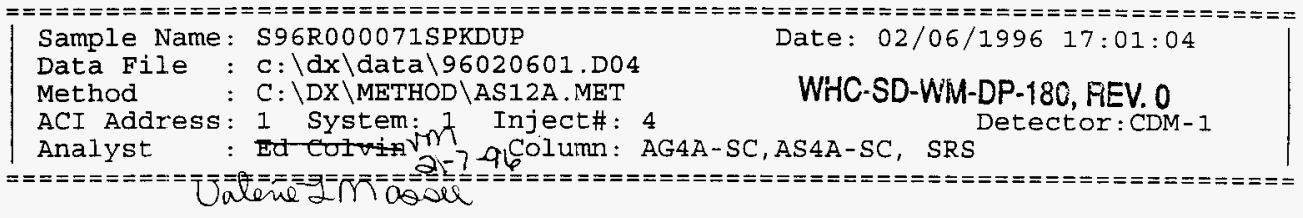

Calibration Volume Dilution Points Rate start stop Area Reject

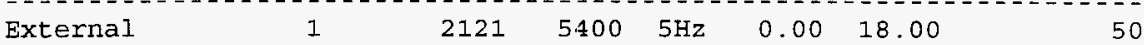

Peak Report: All Peaks

\begin{tabular}{|c|c|c|c|c|c|c|c|}
\hline $\begin{array}{l}\text { Pk. } \\
\text { Num }\end{array}$ & $\begin{array}{l}\text { Ret } \\
\text { Time }\end{array}$ & $\begin{array}{l}\text { Component } \\
\text { Name }\end{array}$ & $\begin{array}{r}\text { Concentration } \\
\mathrm{ug} / \mathrm{ml}\end{array}$ & Height & Area & \multicolumn{2}{|l|}{ Code } \\
\hline & $16 ?$ & & & & & & \\
\hline 1 & 1.62 & & 0.000 & 254 & 2874 & 1 & \\
\hline 2 & 2.17 & FLUORIDE & 1224.448 & 2162 & 16157 & 2 & -2.40 \\
\hline 3 & 2.52 & FORMATE & 9889.760 & 615 & 5045 & 2 & -5.63 \\
\hline 4 & 3.63 & CHLORIDE & 1923.440 & 2018 & 16845 & 1 & -2.68 \\
\hline 5 & 4.52 & NITRITE & .13007 .988 & 8370 & 87092 & 1 & -2.52 \\
\hline 6 & 7.10 & BROMIDE & 11497.480 & 3191 & 47382 & 2 & -2.29 \\
\hline 7 & 8.10 & NITRATE & 56398.607 & 15107 & 317735 & 2 & -3.57 \\
\hline 8 & 10.00 & PHOSPHATE & 11817.824 & 1341 & 30242 & 1 & 0.00 \\
\hline 9 & 12.12 & SULFATE & .12416 .467 & 3291 & 85848 & 1 & 0.55 \\
\hline 10 & 14.45 & & 0.000 & 18 & 486 & 1 & \\
\hline 11 & 16.13 & OXALATE & .10485 .310 & 1486 & 52481 & 2 & 0.52 \\
\hline 12 & 17.53 & & 0.000 & 12 & 200 & 2 & \\
\hline & & Totals & 128661.323 & 37864 & 662386 & & \\
\hline
\end{tabular}

File: 96020601.D04 Sample: S96R000071SPKDUP

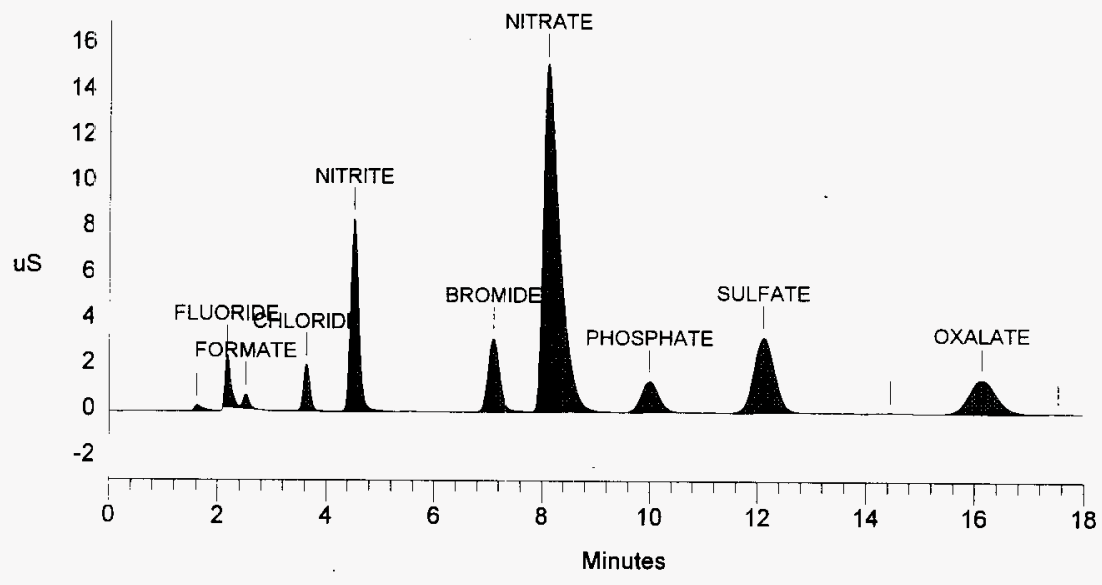




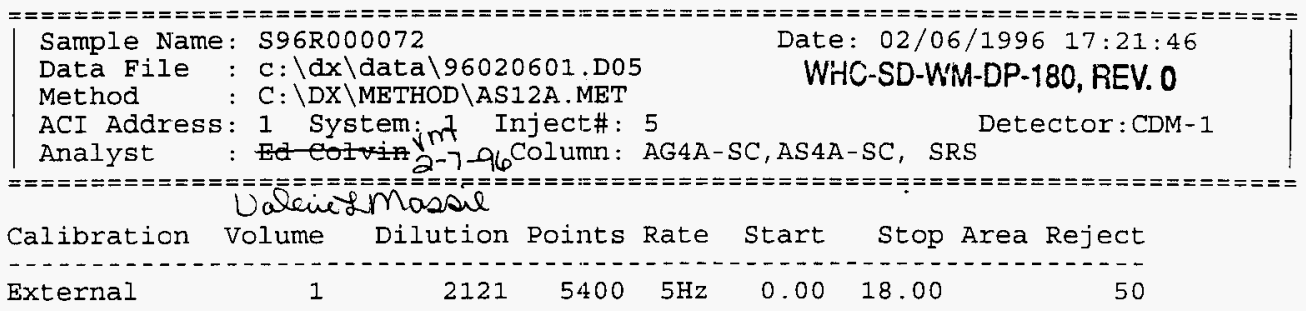

Peak Report: All Peaks

\begin{tabular}{|c|c|c|c|c|c|c|c|}
\hline $\begin{array}{l}\text { Pk. } \\
\text { Num }\end{array}$ & $\begin{array}{l}\text { Ret } \\
\text { Time }\end{array}$ & $\begin{array}{l}\text { Component } \\
\text { Name }\end{array}$ & $\begin{array}{r}\text { Concentration } \\
\mathrm{ug} / \mathrm{ml}\end{array}$ & Height & Area & \multicolumn{2}{|l|}{$\begin{array}{l}\text { Bl. } \\
\text { Code }\end{array}$} \\
\hline- & 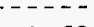 & & & & - & & \\
\hline 1 & 1.62 & & 0.000 & 96 & 1158 & 1 & \\
\hline 2 & 2.28 & FLUORIDE & 89.033 & 168 & 984 & 2 & 2.85 \\
\hline 3 & 2.52 & FORMATE & 5043.578 & 563 & 4321 & 2 & -5.6 \\
\hline 4 & 3.63 & CHLORIDE & 322.656 & 339 & 2863 & 1 & -2.6 \\
\hline 5 & 4.52 & NITRITE & 2490.003 & 1398 & 14791 & 1 & -2.5 \\
\hline 6 & 8.18 & NITRATE & 40617.740 & 11151 & 223750 & 1 & -2.5 \\
\hline 7 & 10.07 & PHOSPHATE & 1099.012 & 92 & 2109 & 1 & 0.6 \\
\hline 8 & 12.13 & SULFATE & 411.547 & 41 & 954 & 1 & 0.6 \\
\hline 9 & 14.33 & & 0.000 & 22 & 444 & 1 & \\
\hline 10 & 15.50 & & 0.000 & 6 & 51 & 1 & \\
\hline 11 & 16.13 & OXALATE & 245.525 & 12 & 140 & 1 & 0.5 \\
\hline & & & 50319.094 & 13888 & 251564 & & \\
\hline
\end{tabular}

File: 96020601.D05 Sample: S96R000072

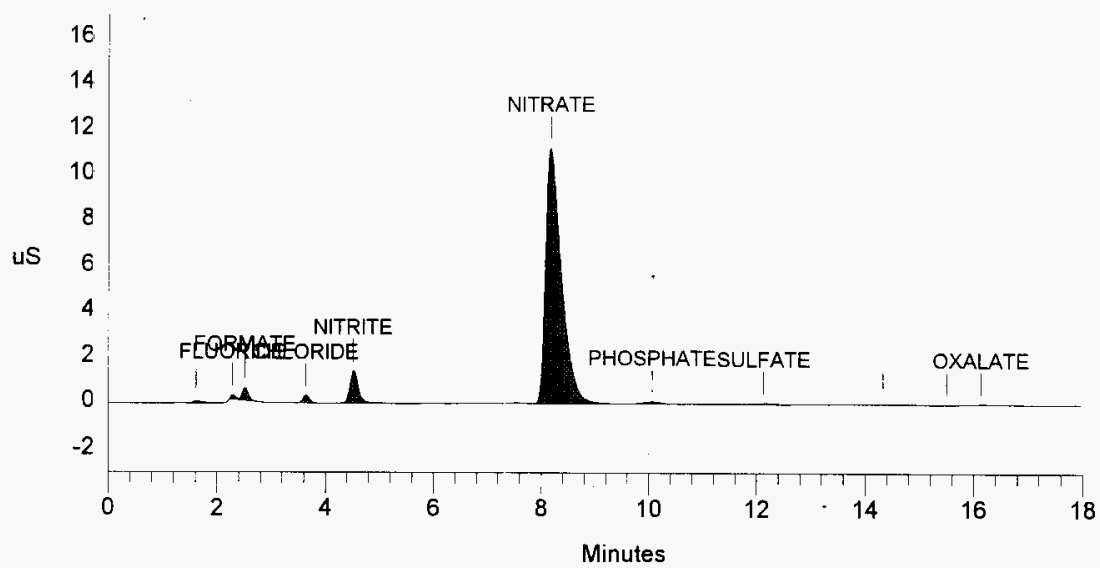




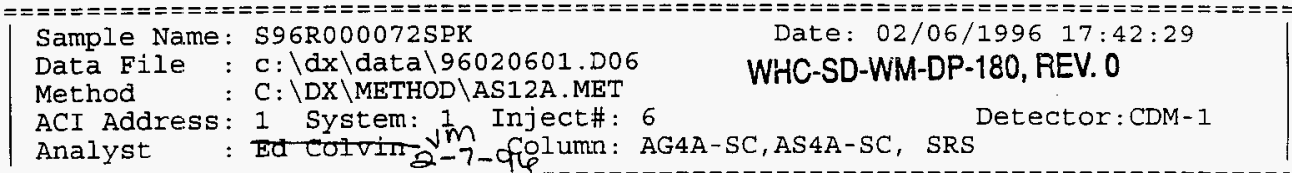

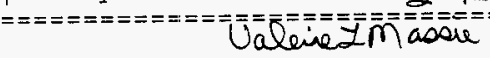

Calibration Volume Dilution Points Rate Start Stop Area Reject

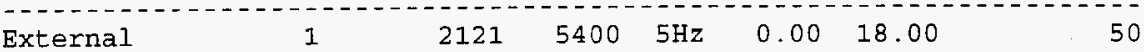

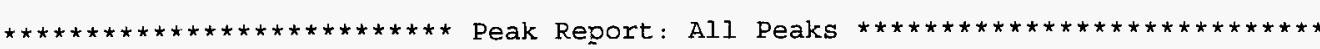

Pk. Ret. Component Concentration Height Area Bl. $\%$ Delta Num Time Name ug/m

\begin{tabular}{|c|c|c|c|c|c|c|c|}
\hline 1 & 1.62 & & 0.000 & 240 & 2778 & 1 & \\
\hline 2 & 2.17 & FLUORIDE & 1183.692 & 2042 & 15604 & 2 & -2.40 \\
\hline 3 & 2.52 & FORMATE & 10272.322 & 613 & 5097 & 2 & -5.63 \\
\hline 4 & 3.63 & CHLOR IDE & 1864.553 & 1935 & 16324 & 1 & -2.68 \\
\hline 5 & 4.52 & NITRITE & 12677.531 & 8021 & 84810 & 1 & -2.52 \\
\hline 6 & 7.10 & BROMIDE & 10987.363 & 3063 & 45185 & 2 & -2.29 \\
\hline 7 & 8.12 & NITRATE & 54735.060 & 14724 & 307639 & 2 & -3.37 \\
\hline 8 & 10.00 & PHOSPHATE & 11398.659 & 1304 & 29124 & 2 & 0.00 \\
\hline 9 & 12.10 & SULFATE & 12010.037 & 3188 & 82931 & 1 & 0.41 \\
\hline 11 & 14.33 & & 0.000 & 9 & 156 & 1 & \\
\hline 12 & 16.12 & OXALATE & 10042.683 & 1440 & 50198 & 1 & 0.42 \\
\hline & & & 125171.900 & 36578 & 639845 & & \\
\hline
\end{tabular}

File: 96020601.D06 Samp/e: S96R000072SPK

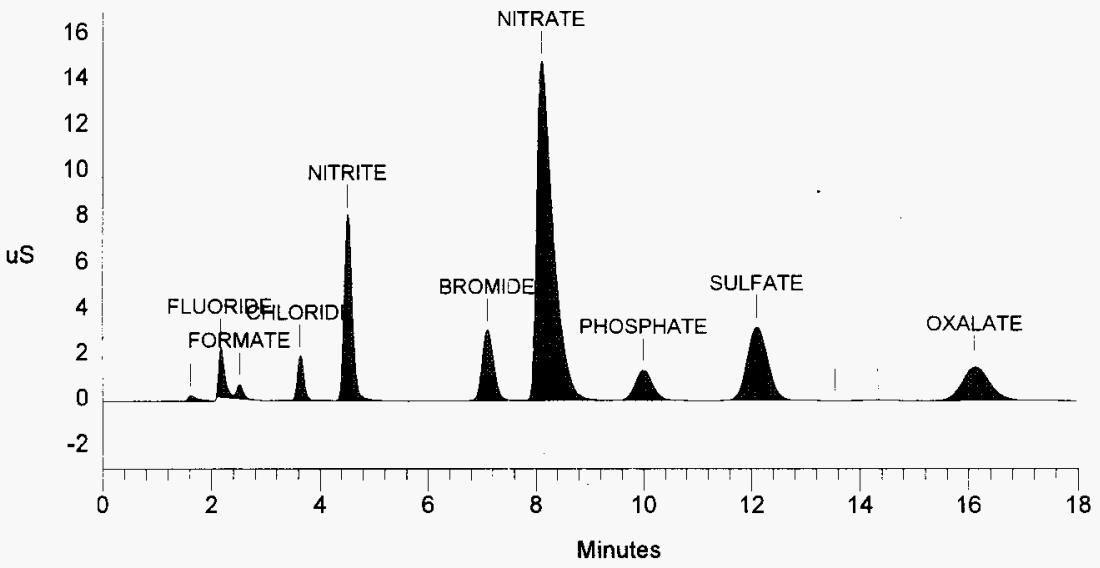




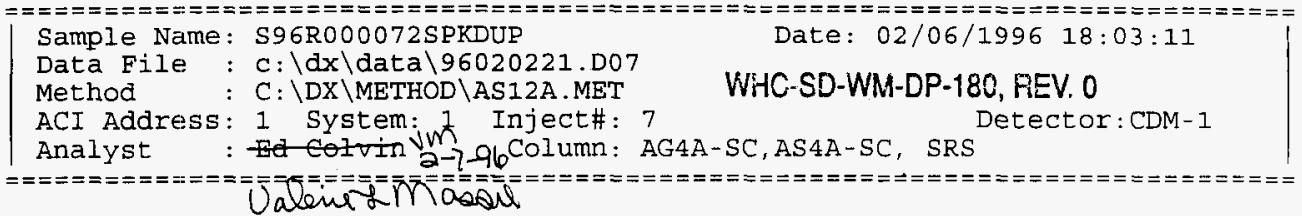

Calibration Volume Dilution Points Rate start stop Area Reject

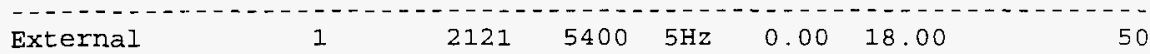

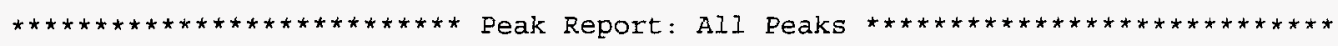

Pk. Ret Component Concentration Height Area Bl. $\div$ Delta

Num Time Name ug/ml

\begin{tabular}{|c|c|c|c|c|c|c|c|}
\hline 1 & 1.62 & & 0.000 & 238 & 2637 & 1 & \\
\hline 2 & 2.17 & FLUORIDE & 1074.626 & 1952 & 14127 & 2 & -2.40 \\
\hline 3 & 2.52 & FORMATE & 6649.983 & 573 & 4578 & 2 & -5.63 \\
\hline 4 & 3.63 & CHLORIDE & 1776.928 & 1839 & 15549 & 1 & -2.68 \\
\hline 5 & 4.52 & NITRITE & 12241.527 & 7803 & 81801 & 1 & -2.52 \\
\hline 6 & 7.12 & BROMIDE & 10864.476 & 3010 & 44656 & 2 & -2.06 \\
\hline 7 & 8.13 & NITRATE & 53251.795 & 14361 & 298677 & 2 & -3.17 \\
\hline 8 & 10.00 & PHOSPHATE & 11186.220 & 1260 & 28558 & 2 & 0.00 \\
\hline 9 & 12.10 & SULFATE & 11896.032 & 3119 & 82113 & 1 & 0.41 \\
\hline \multirow[t]{2}{*}{10} & 16.13 & OXALATE & 9762.475 & 1401 & 48753 & 1 & 0.52 \\
\hline & & & 118704.064 & 35556 & 621447 & & \\
\hline
\end{tabular}

File: 96020221.D07 Samp/e: S96R000072SPKDUP

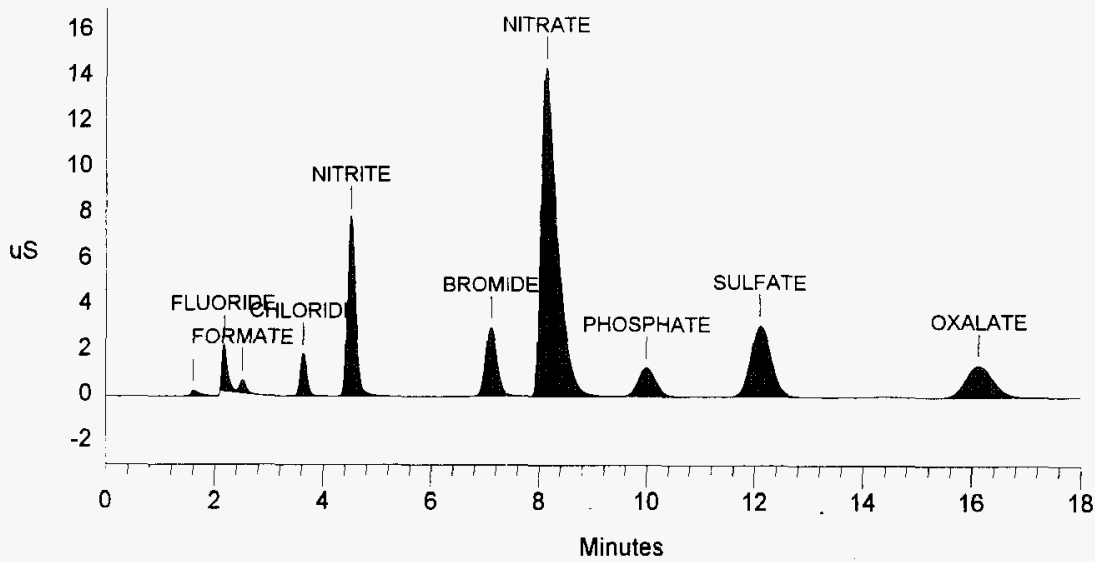




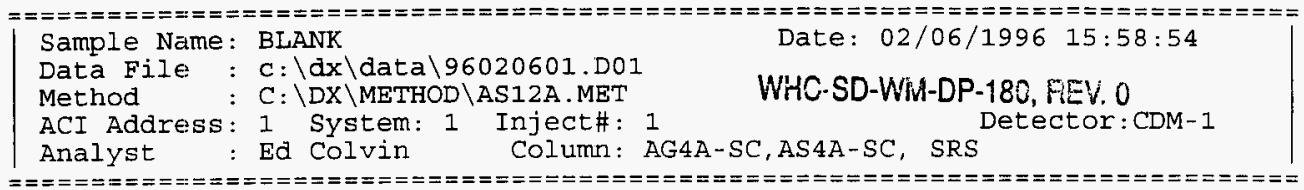

Calibration Volume Dilution Points Rate Start Stop Area Reject

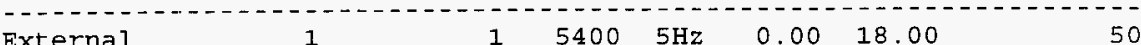

External

1

$1 \quad 5400 \quad 5 \mathrm{~Hz} \quad 0.00 \quad 18.00$

50

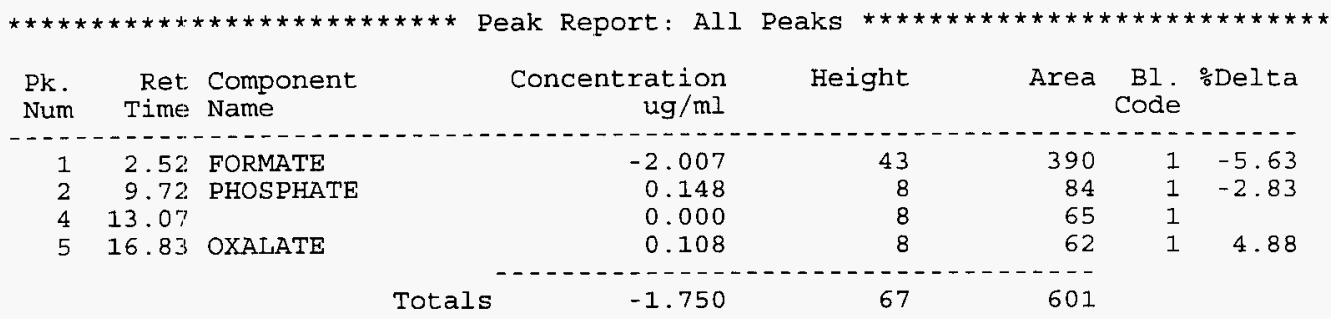

File: 96020601.D01 Sample: BLANK

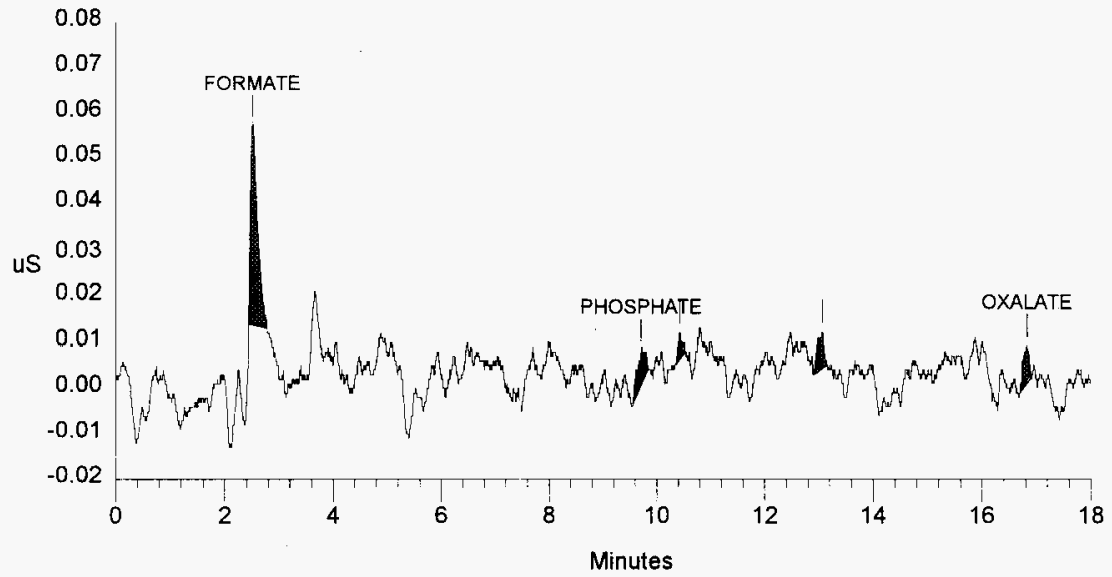


WHC-SD-Vít-DP-180, BEV.

THE FOLLOWING ANALYSES WERE RERUN AND INCLUDED IN THE DATA PACKAGE, BUT THE RESULTS HAVE NOT BEEN REPORTED IN THE FINAL SUMMARY REPORTS. 
Analyst:

Instrument: IC01

Book\#

Method: LA-533-105 Rev/Mod

Worklist Comment: TANK 25-2 FOR IC RTS!

s Type

Sample\#

R A Tegt

Matrix

$1 \mathrm{CCB}$

$2 \mathrm{CCV}$

3 SAMPLE

4 SPK

5 SPK-DUP

6 SAMPLE

7 SPK

8 SPK-DUP

बIC-QC QC

@IC-QC QC

S96R000041 0

@IC-01 LIQUID

Analytes Requested: $\mathrm{CL}-\mathrm{O} 2, \mathrm{~F}-02$

SO4-02

$$
\text { S96R00004I } 0 \text { @IC-0I LIQUID }
$$

S96R0000410 OIC-01 IIQUID

S96R00004200 @IC-0I LIQUID

Analytes Requested: CL-02 , F-02

SO4-02

S96R000042 O

@IC-01 LIQUID

S96R000042 0

@IC-0 01

LIQUID

\section{Final page for worklist \# 5066}

\section{S9SR000041)}
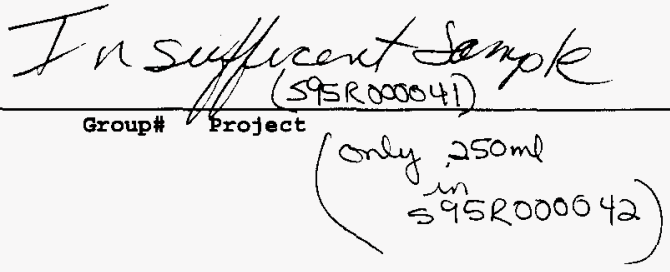

95000224 ORG/AQ SAMPL , $\mathrm{NO} 2-02, \mathrm{NO} 3-02, \mathrm{PO} 4-02$,

95000224 ORG/AQ SAMPL NO2-02, $\mathrm{NO} 3-02, \mathrm{PO} 4-02$,

\section{Analyst Signature}

Date

Analyst Signature

Date

Data Entry Comments:

$\bar{S}=$ Worklist Slot Number, $R=$ Replicate Nimber, $A=$ Aliquot Code. 


\section{LABCORE Data Entry Template for Worklist\# 5282}

Analyst: $\quad$ Book\# 5054850 Instrument: ICP01

Method: LA-505-151/161 Rev/Mod D 3

Worklist Comment: ICP B-PLANT (ACID DIGEST)

WHC-SD-WM-DP-180, REV. 0

\begin{tabular}{|c|c|c|c|c|c|c|c|c|}
\hline$s$ & Type & Sample\# & R A & Test & Matrix & Group\# & Project & \\
\hline 1 & ICV & & & $\otimes I C P-Q C$ & $Q C$ & & & \\
\hline 2 & $I C B$ & & & @ICP-QC & $Q C$ & & & \\
\hline 3 & ICSA & & & @ICP-QC & $Q C$ & & & \\
\hline 4 & ICSAB & & & @ICP-QC & $\mathrm{QC}$ & & & \\
\hline 5 & PREPSTDTTA & & & $@ I C P-B 01$ & LIQUID & & & \\
\hline 6 & PREPBLKTJA & & & $\triangle \mathrm{ICP}-\mathrm{B} 01$ & LIQUID & & & \\
\hline 7 & SAMPLE Ana & $\begin{array}{l}\text { S95R000115 } \\
\text { alytes Reque }\end{array}$ & $\begin{array}{l}0 \mathrm{~B} \\
\text { estec }\end{array}$ & $\begin{array}{r}\text { ICP-B01 } \\
\text { AG-B-01 } \\
\text { NA-B-01 }\end{array}$ & $\begin{array}{l}\text { LIQUID } \\
\text {, AL-B-O1 } \\
\text {, NI-B-OI }\end{array}$ & $\begin{aligned} & 95000224 \\
, & \mathrm{CD}-\mathrm{B}-01 \\
, & \mathrm{~PB}-\mathrm{B}-01\end{aligned}$ & $\begin{array}{r}4 \text { ORG/AQ } \\
\text { CR-B-OI }\end{array}$ & $\begin{array}{l}\text { SAMPL } \\
\text { FE-B-01 }\end{array}$ \\
\hline 8 & DUP & $595 R 000115$ & $O B$ & $@ I C P-B 01$ & LIQUID & & & \\
\hline 9 & SPK-PREDIG & $595 R 000115$ & $O B$ & @ICP-B01 & LIQUID & & & \\
\hline 10 & $\mathrm{CCV}$ & & & $\Theta I C P-Q C$ & $\mathrm{QC}$ & & & \\
\hline 11 & $\mathrm{CCB}$ & & & @ICP-QC & $Q C$ & & & \\
\hline 12 & SAMPLE Ana & $\begin{array}{l}\text { S95R000116 } \\
\text { aalytes Reque }\end{array}$ & $\begin{array}{c}0 \mathrm{~B} \\
\text { estec }\end{array}$ & $\begin{array}{r}@ I C P-B 01 \\
\text { AG-B-0I } \\
\text { NA-B-0I }\end{array}$ & $\begin{array}{l}\text { LIQUID } \\
, \quad \mathrm{AL}-\mathrm{B}-01 \\
, \mathrm{NI}-\mathrm{B}-01\end{array}$ & $\begin{aligned} & 95000224 \\
, & C D-B-01 \\
, & P B-B-01\end{aligned}$ & $\begin{array}{r}4 \text { ORG/AQ } \\
\text { CR-B-OI }\end{array}$ & $\begin{array}{l}\text { SAMPL } \\
, \quad \text { FE-B-01 }\end{array}$ \\
\hline 13 & DUP & S95R000116 & $0 \mathrm{~B}$ & QICP-B0I & LIQUID & & & \\
\hline 44 & ICSA & & & QICP-QC & $\mathrm{QC}$ & & & \\
\hline 5 & $I C S A B$ & & & $@ \mathrm{ICP}-\mathrm{QC}$ & $\mathrm{QC}$ & & & \\
\hline 16 & $\mathrm{CCV}$ & & & $@ \mathrm{ICP}-\mathrm{QC}$ & $\mathrm{QC}$ & & & \\
\hline 17 & $\mathrm{CCB}$ & & & @ICP-QC & $\mathrm{QC}$ & & & \\
\hline
\end{tabular}

Data Entry Comments:

$S=$ Worklist Siot Number, $R=$ Replicate Number, $A=$ Aliquot Code. 


\section{LABCORE Data Entry Template for Worklist\# 5282}

s Type

Sample\#

R A TeBt

Matrix

Group\# Project

Final page for worklist \# $\mathbf{5 2 8 2}$

$\frac{\mathcal{K} \text { Analyst Signature }}{0 / .31-46}$

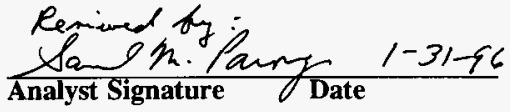

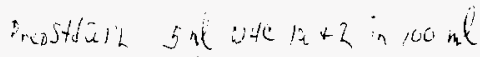

Frepulkuil direet

$545 \dot{k} \operatorname{coc} 115,<, 2.8$, , IJ 5

$535 x$ ioc 1155 dirat

$5 \times 500015, d$ diret 1

s45k00is sdiset

$5958000116-4,4.8, D 15$

$54580001 / 6$ dives,

$5458000114-0$ dreet !

Data Entry Comments:

$S=$ Worklist Slot Number, $R=$ Replicate Number, $A=$ Aliquot Code. 
WHC-SD-WM-DP-180, REV. O

Identity 1: ICV Identity 2: Quality Control 9:31 AM January 31, 1996

Iosk name : OPTIMA

Sample weight : 1.0000 solution volume : $\quad 1.00$

On-Peak Integrations : 3 off-Peak Integrations : 1

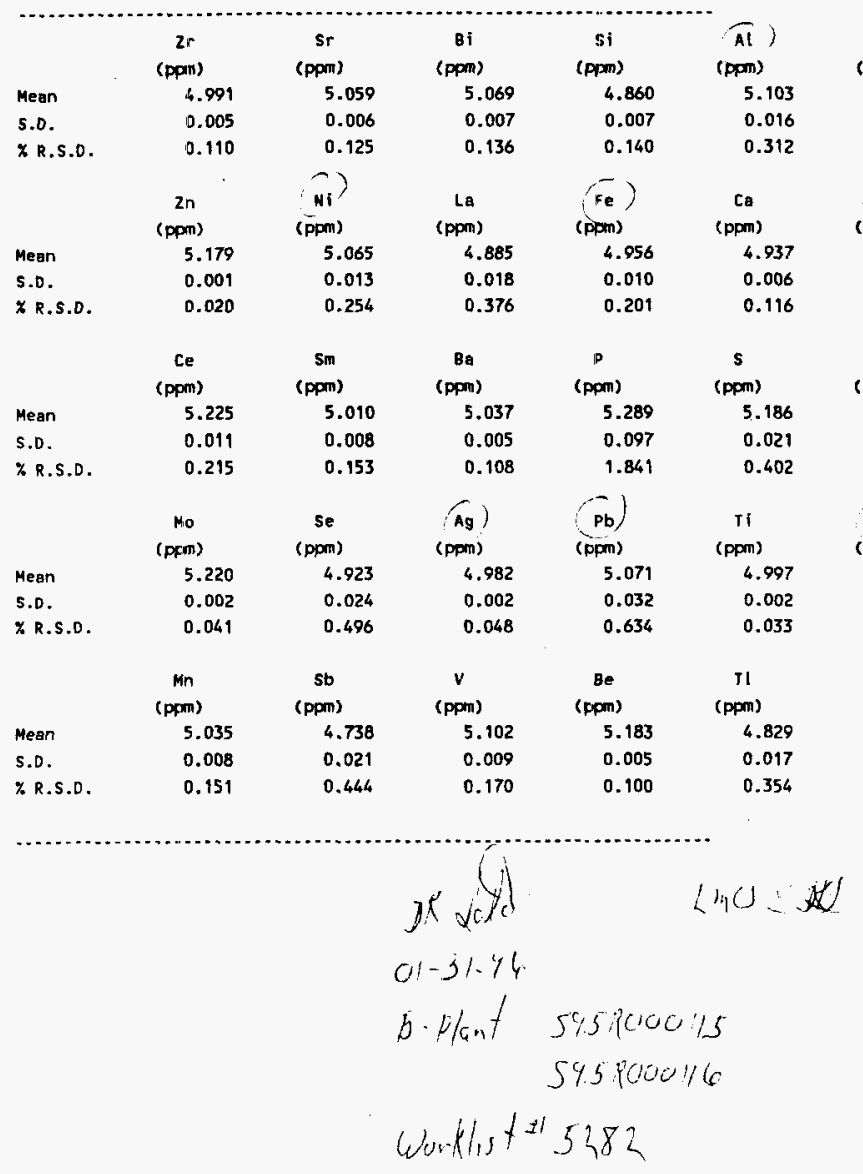

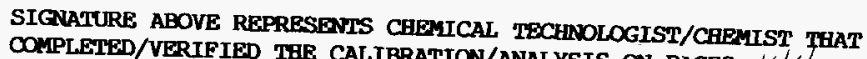

COMPLETED/VERIFIED THE CALIBRATION/ANALYSIS ON PAGES 144 TO T0 162. 
Identity 1: ICB

Tosk name : OPTIMA

Stmple Weight :

Identity 2: Quality Control

9:37 AM Jenuary 31, 1996

\begin{tabular}{|c|c|c|c|c|c|}
\hline & $\begin{array}{c}2 r \\
(p p m)\end{array}$ & $\begin{array}{c}\mathrm{sr} \\
(\mathrm{pptn})\end{array}$ & $\begin{array}{c}B i \\
(p p m)\end{array}$ & $\begin{array}{c}\text { si } \\
\text { (fpm) }\end{array}$ & $\begin{array}{c}\text { Al } \\
\text { (ppm) }\end{array}$ \\
\hline Mean & -0.002 & -0.000 & 0.014 & -0.001 & 0.01 \\
\hline S.D. & 0.001 & 0.000 & 0.008 & 0.002 & 0.00 \\
\hline \multirow[t]{2}{*}{ Z R.S.D. } & 56.900 & 183.303 & 54.036 & 189.381 & 41.2 \\
\hline & $\frac{2 n}{(p p m)}$ & $\begin{array}{c}\mathrm{Ni} \\
\text { (ppm) }\end{array}$ & $\begin{array}{c}\text { La } \\
\text { (ppm) }\end{array}$ & $\begin{array}{c}\text { Fe } \\
\text { (ppm) }\end{array}$ & $\begin{array}{c}\text { Ca } \\
\text { (ppm) }\end{array}$ \\
\hline Meen & 0.001 & 0.001 & 0.000 & -0.003 & 0.000 \\
\hline S.D. & 0.001 & 0.002 & 0.002 & 0.003 & 0.00 \\
\hline \multirow[t]{2}{*}{ XR.S.D. } & 72.061 & 197.579 & 515.201 & 104.139 & 19.24 \\
\hline & $\begin{array}{c}\text { Ce } \\
\text { (pFm) }\end{array}$ & $\begin{array}{c}\mathrm{Sm} \\
(\mathrm{ppm})\end{array}$ & $\begin{array}{c}B a \\
(p p n)\end{array}$ & $\underset{(p p m)}{P}$ & $\begin{array}{c}S \\
\text { (ppon) }\end{array}$ \\
\hline Mean & -0.012 & -0.019 & -0.000 & -0.007 & -0.004 \\
\hline S.o. & 0.014 & 0.012 & 0.000 & 0.004 & 0.004 \\
\hline \multirow[t]{2}{*}{ \% R.S.D. } & 114.298 & 60.101 & 121.565 & 63.045 & 115.17 \\
\hline & $\begin{array}{c}\text { Mo } \\
\text { (ppm) }\end{array}$ & $\begin{array}{c}\text { Se } \\
\text { (ppm) }\end{array}$ & $\begin{array}{c}\text { Ag } \\
\text { (ppm) }\end{array}$ & $\begin{array}{c}\mathrm{Pb} \\
\text { (PMm) }\end{array}$ & $\underset{(\mathrm{pPm})}{T i}$ \\
\hline Mean & 0.001 & -0.027 & 0.000 & 0.016 & -0.00 \\
\hline S.D. & 0.001 & 0.005 & 0.001 & 0.009 & 0.000 \\
\hline \multirow[t]{2}{*}{ X R.S.D. } & 100.820 & 19.118 & 146.460 & 55.767 & 88.716 \\
\hline & $\begin{array}{c}M n \\
\text { (pprn) }\end{array}$ & $\begin{array}{c}\mathrm{Sb} \\
(\mathrm{ppm})\end{array}$ & $\begin{array}{c}V \\
(p p m)\end{array}$ & $\begin{array}{c}\mathrm{Be} \\
\text { (ppm) }\end{array}$ & $\begin{array}{c}\mathrm{Tl} \\
\text { (ppm) }\end{array}$ \\
\hline Mean & -0.000 & 0.044 & 0.001 & -0.000 & -0.024 \\
\hline S.D. & 0.000 & 0.018 & 0.001 & 0.000 & 0.019 \\
\hline$X R, S . D$ & 198.607 & 41.312 & 86.695 & 154.999 & 79.770 \\
\hline
\end{tabular}

WHC-SD-WM-DP-180, REV. 0

\begin{tabular}{ccc} 
Co & \multicolumn{1}{c}{$c u$} & \multicolumn{1}{c}{$L i$} \\
(ppm) & (ppm) & \multicolumn{1}{c}{ (ppm) } \\
0.005 & -0.000 & -0.000 \\
0.001 & 0.000 & 0.000 \\
28.678 & 130.188 & 133.317
\end{tabular}

\begin{tabular}{ccc} 
Cr & Nd & \multicolumn{1}{c}{$U$} \\
(ppm) & (ppm) & \multicolumn{1}{c}{ (ppm) } \\
-0.001 & -0.009 & -0.088 \\
0.001 & 0.000 & 0.056 \\
106.982 & 5.560 & 62.913
\end{tabular}

\begin{tabular}{crr} 
Mg & \multicolumn{1}{c}{ As } & \multicolumn{1}{c}{ No } \\
(ppm) & \multicolumn{1}{c}{ (ppm) } & \multicolumn{1}{c}{ (ppm) } \\
0.000 & -0.001 & -0.007 \\
0.000 & 0.001 & 0.005 \\
28.868 & 114.568 & 62.988
\end{tabular}

\begin{tabular}{ccr} 
Cd & \multicolumn{1}{c}{ B } & \multicolumn{1}{c}{$K$} \\
(ppm) & (ppm) & \multicolumn{1}{c}{ (ppm) } \\
0.001 & -0.001 & -0.044 \\
0.000 & 0.000 & 0.019 \\
41.785 & 72.605 & 42.854
\end{tabular}


Identity 1: ICSA Identity 2: Ouality Control

9:41 AM January 31, 1996

Task name : OPTIMA

Somple weight : $\quad 1.0000$ solution Volume : $\quad \mathbf{1 . 0 0}$

on-peak Integrations : 3 off-Peak Integrations : 1

WHC-SD-WIM-DP-180, REV. 0

\begin{tabular}{|c|c|c|c|c|c|c|c|c|}
\hline & $\underset{(\mathrm{Ppm})}{\mathrm{Zr}}$ & $\begin{array}{c}\text { Sr } \\
(\mathrm{ppm})\end{array}$ & $\begin{array}{c}B i \\
(\mathrm{ppm})\end{array}$ & $\begin{array}{c}s i \\
\text { (ppm) }\end{array}$ & $\stackrel{\text { Al }}{\text { (pom) }}$ & $\begin{array}{c}\text { Co } \\
\text { (ppm) }\end{array}$ & $\begin{array}{c}c u \\
(p p m)\end{array}$ & $\underset{\text { (ppm) }}{L i}$ \\
\hline Mesn & 0.003 & 0.002 & -0.019 & 0.001 & 201.275 & 0.011 & 0.003 & 0.000 \\
\hline S.D. & 0.002 & 0.000 & 0.002 & 0.003 & 0.204 & 0.002 & 0.000 & 0.000 \\
\hline \multirow[t]{2}{*}{ X R.S.D. } & 65.073 & 5.338 & 8.121 & 291.386 & 0.101 & 21.819 & 15.708 & 365.078 \\
\hline & $\frac{\mathrm{Zn}}{(\mathrm{PPm})}$ & $\underset{(p p m)}{N 1}$ & $\begin{array}{c}\text { La } \\
\text { (pPm) }\end{array}$ & $\begin{array}{c}\text { Fe } \\
\text { (ppm) }\end{array}$ & $\begin{array}{c}\mathrm{Ca} \\
(\mathrm{ppm})\end{array}$ & $\begin{array}{c}\mathrm{Cr} \\
\text { (ppm) }\end{array}$ & $\begin{array}{c}\text { Nd } \\
\text { (ppm) }\end{array}$ & $\begin{array}{c}U \\
\text { (ppm) }\end{array}$ \\
\hline Mean & .0 .008 & 0.011 & -0.006 & 99.953 & 103.450 & 0.001 & 0.056 & -0.182 \\
\hline S.D. & 0.000 & 0.000 & 0.001 & 0.077 & 0.049 & 0.002 & 0.010 & 0.061 \\
\hline \multirow[t]{2}{*}{ X R.S.D. } & 2.846 & 0.223 & 23.528 & 0.077 & 0.048 & 366.815 & 17.607 & 33.718 \\
\hline & $\begin{array}{c}\text { ce } \\
\text { (ppm) }\end{array}$ & $\begin{array}{c}\mathrm{Sm} \\
(\mathrm{ppm})\end{array}$ & $\begin{array}{c}\mathrm{Ba} \\
\text { (ppm) }\end{array}$ & $\begin{array}{c}P \\
(\mathrm{ppm})\end{array}$ & $\begin{array}{c}\mathrm{s} \\
\text { (ppm) }\end{array}$ & $\begin{array}{c}\mathrm{Mg} \\
(\mathrm{ppm})\end{array}$ & $\begin{array}{c}\text { As } \\
(p p m)\end{array}$ & $\begin{array}{c}\mathrm{Ne} \\
(\mathrm{ppm})\end{array}$ \\
\hline Mean & 0.021 & -0.030 & 0.004 & 0.034 & -0.003 & 99.091 & 0.009 & 191.679 \\
\hline S.D. & 0.012 & 0.012 & 0.000 & 0.003 & 0.004 & 0.551 & 0.005 & 1.215 \\
\hline \multirow[t]{2}{*}{ * R.S.D. } & 56.810 & 38.141 & 7.087 & 7.804 & 160.846 & 0.556 & 53.187 & 0.634 \\
\hline & $\begin{array}{c}\text { Ho } \\
\text { (ppm) }\end{array}$ & $\begin{array}{c}\text { Se } \\
\text { (ppm) }\end{array}$ & $\begin{array}{c}\mathrm{Ag} \\
(\mathrm{PPm})\end{array}$ & $\begin{array}{c}\mathrm{Pb} \\
\text { (Fpm) }\end{array}$ & $\begin{array}{c}\mathrm{Ti} \\
\text { (ppm) }\end{array}$ & $\begin{array}{c}\mathrm{cd} \\
(\mathrm{ppm})\end{array}$ & $\begin{array}{c}\text { B } \\
\text { (ppm) }\end{array}$ & $\underset{\text { (ppm) }}{K}$ \\
\hline Mean & 0.002 & -0.055 & 0.002 & 0.031 & -0.001 & 0.002 & 0.014 & 0.044 \\
\hline s.o. & 0.001 & 0.019 & 0.001 & 0.004 & 0.000 & 0.001 & 0.001 & 0.020 \\
\hline$X$ R.S.D. & 28.366 & 35.091 & 32.040 & 13.038 & 61.255 & 40.085 & 7.756 & 46.605 \\
\hline
\end{tabular}

\begin{tabular}{lrrrrr} 
& \multicolumn{1}{c}{ Mn } & \multicolumn{1}{c}{ Sb } & \multicolumn{1}{c}{$\begin{array}{c}\text { Be } \\
\text { (ppm) }\end{array}$} & \multicolumn{1}{c}{$\begin{array}{c}\text { (ppm) } \\
\text { (ppm) }\end{array}$} & \multicolumn{1}{c}{$\begin{array}{c}\text { (ppm) } \\
\text { (ppm) }\end{array}$} \\
Mean & $\mathbf{0 . 0 0 2}$ & 0.023 & 0.003 & 0.003 & 0.048 \\
S.D. & 0.000 & 0.027 & 0.001 & 0.000 & 0.032 \\
\% R.S.D. & $\mathbf{8 . 6 9 8}$ & 117.962 & 36.147 & 7.434 & 66.857
\end{tabular}


Task name : OPI IMA

Semple Weight : $\quad 1.0000$ Solution Volume : $\quad 1.00$

On-Pegk Jntegrations : 3 off-peak Integrations : 1

\begin{tabular}{|c|c|c|c|c|c|c|c|c|}
\hline & $\begin{array}{c}2 r \\
(p p m)\end{array}$ & $\begin{array}{c}\mathrm{Sr} \\
(\mathrm{ppm})\end{array}$ & $\begin{array}{c}\text { Bi } \\
\text { (ppm) }\end{array}$ & $\begin{array}{c}\text { si } \\
(p p m)\end{array}$ & $\begin{array}{c}\text { Al } \\
(p p m)\end{array}$ & $\begin{array}{c}\text { Co } \\
\text { (ppm) }\end{array}$ & $\begin{array}{c}\mathrm{Cu} \\
(\mathrm{ppm})\end{array}$ & $\begin{array}{c}\mathrm{Li} \\
\text { (ppm) }\end{array}$ \\
\hline Mean & -0.001 & 0.002 & -0.023 & -0.004 & 203.784 & 0.499 & 0.511 & 0.958 \\
\hline S.D. & 0.002 & 0.000 & 0.001 & 0.002 & 0.600 & 0.001 & 0.002 & 0.008 \\
\hline \multirow[t]{2}{*}{ X R.S.D. } & 137.958 & 6.063 & 6.252 & 55.355 & 0.294 & 0.284 & 0.416 & 0.862 \\
\hline & $\underset{(\mathrm{ppm})}{\mathrm{Zn}}$ & $\begin{array}{c}N i \\
(\mathrm{ppm})\end{array}$ & $\begin{array}{c}\text { Lo } \\
\text { (ppm) }\end{array}$ & $\begin{array}{c}\text { Fe } \\
(p p m)\end{array}$ & $\begin{array}{c}\mathrm{Ca} \\
(\mathrm{ppm})\end{array}$ & $\begin{array}{c}\mathrm{Cr} \\
(\mathrm{ppm})\end{array}$ & $\begin{array}{c}\text { Nd } \\
(p p m)\end{array}$ & $\begin{array}{c}U \\
(\mathrm{ppm})\end{array}$ \\
\hline Mean & 1.011 & 0.993 & -0.004 & 101.089 & 104.438 & 0.506 & 0.035 & -0.186 \\
\hline S.D. & 0.003 & 0.005 & 0.001 & 0.152 & 0.161 & 0.004 & 0.001 & 0.071 \\
\hline \multirow[t]{2}{*}{ X R.S.D. } & 0.267 & 0.454 & 39.231 & 0.150 & 0.155 & 0.814 & 2.970 & 38.238 \\
\hline & $\begin{array}{c}\text { Ce } \\
\text { (ppm) }\end{array}$ & $\begin{array}{c}\text { Sm } \\
\text { (pom) }\end{array}$ & $\begin{array}{c}\text { Ba } \\
\text { (ppin) }\end{array}$ & $\begin{array}{c}p \\
\text { (pom) }\end{array}$ & $\begin{array}{c}s \\
\text { (ppm) }\end{array}$ & $\begin{array}{c}\mathrm{Mg} \\
(\mathrm{ppm})\end{array}$ & $\begin{array}{c}\text { As } \\
(p p m)\end{array}$ & $\begin{array}{c}\mathrm{Ne} \\
\text { (ppm) }\end{array}$ \\
\hline Mean & -0.018 & -0.003 & 0.513 & 0.031 & -0.016 & 100.096 & -0.001 & 194.730 \\
\hline S.D. & 0.013 & 0.013 & 0.001 & 0.006 & 0.004 & 0.156 & 0.002 & 1.624 \\
\hline \multirow[t]{2}{*}{$\dot{*}$ R.S.O. } & 74.773 & 420.634 & 0.292 & 18.164 & 26.808 & 0.156 & 403.080 & 0.834 \\
\hline & $\begin{array}{c}\text { Mo } \\
\text { (ppm) }\end{array}$ & $\begin{array}{c}\text { se } \\
\text { (ppm) }\end{array}$ & $\begin{array}{c}A g \\
\text { (ppm) }\end{array}$ & $\begin{array}{c}\mathrm{Pb} \\
\text { (Ppm) }\end{array}$ & $\begin{array}{c}\mathbf{T i} \\
\text { (ppm) }\end{array}$ & $\begin{array}{c}\text { cd } \\
\text { (ppm) }\end{array}$ & $\begin{array}{c}\text { B } \\
\text { (ppm) }\end{array}$ & $\begin{array}{c}K \\
(p p m)\end{array}$ \\
\hline Mean & 0.001 & -0.024 & 1.033 & 1.023 & .0 .001 & 1.010 & 0.018 & 0.072 \\
\hline S.D. & 0.001 & 0.018 & 0.000 & 0.010 & 0.000 & 0.004 & 0.001 & 0.017 \\
\hline \multirow[t]{2}{*}{ X R.S.D } & 123.710 & 74.849 & 0.025 & 0.966 & 10.992 & 0.372 & 4.729 & 23.625 \\
\hline & $\begin{array}{c}\text { Mn } \\
(p p m)\end{array}$ & $\begin{array}{c}\text { Sb } \\
\text { (ppm) }\end{array}$ & $\begin{array}{c}v \\
\text { (ppm) }\end{array}$ & $\begin{array}{c}\text { Be } \\
\text { (ppm) }\end{array}$ & $\begin{array}{c}t 1 \\
(p p m)\end{array}$ & & & \\
\hline Mean & 0.509 & 0.021 & 0.506 & 0.508 & -0.014 & & & \\
\hline S.D. & 0.001 & 0.031 & 0.002 & 0.000 & 0.023 & & & \\
\hline \% R.S.D. & 0.266 & 142.828 & 0.304 & 0.075 & 163.362 & & & \\
\hline
\end{tabular}


Identity 1: PREPSTDARL Identity 2: 5 whcles2 in 100

9:50 AM January 31, 1996

Task name : OPTIMA

Sample Weight :

1.0000 Solution volume :

1.00

WHC-SD-WM-DP-180, REV. 0

on-Peak Integrations : 3 off-Peak Integrations : 1

\begin{tabular}{|c|c|c|c|c|c|}
\hline & $\begin{array}{c}2 r \\
\text { (ppprin) }\end{array}$ & $\begin{array}{c}\mathbf{S r} \\
\text { (ppm) }\end{array}$ & $\begin{array}{c}\text { Bi } \\
\text { (ppm) }\end{array}$ & $\begin{array}{c}\text { si } \\
\text { (ppm) }\end{array}$ & $\begin{array}{c}\text { Al } \\
\text { (ppm) }\end{array}$ \\
\hline Mean & 5.030 & 5.042 & 4.945 & 7.813 & 5.198 \\
\hline S.D. & 0.006 & 0.005 & 0.018 & 0.010 & 0.008 \\
\hline \% R.S.D. & 0.123 & 0.097 & 0.366 & 0.129 & 0.145 \\
\hline
\end{tabular}

\section{rann}

s...

X R.S.D.

$2 n$
(pFom)
5.005
0.010
0.201

Mean

S.D.

\% R.S.D.

Ce
(ppm)
5.077
0.008
0.163

Mean

S.D.

\% R.S.O.

Mo
(ppm)
5.106
0.025
0.495

(Ppm)
5.150
0.008
0.154

La
(ppm)
5.159
0.001
0.014

fe
(ppm)
5.148
0.019
0.371

Ca
(ppm)
5.213
0.004
0.082

\begin{tabular}{cr}
$\begin{array}{c}5 m \\
(\mathrm{ppm})\end{array}$ & \multicolumn{1}{c}{ Ba } \\
(ppm) \\
5.085 & 5.030 \\
0.006 & 0.005 \\
0.119 & 0.102
\end{tabular}

$p$
(ppm)
5.071
0.063
1.239

s
(ppm)
4.980
0.062
1.249

se
(ppm)
4.923
0.031
0.628

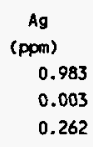

\begin{tabular}{cr} 
Pb & \multicolumn{1}{c}{ Ti } \\
(ppm) & (ppm) \\
5.072 & 4.993 \\
0.027 & 0.004 \\
0.532 & 0.077
\end{tabular}

\begin{tabular}{lc} 
& \multicolumn{1}{c}{ Mn } \\
& (ppm) \\
Mean & 5.114 \\
S.D. & 0.009 \\
\% R.S.D. & 0.174
\end{tabular}

$v$
(ppm)
5.096
0.008
0.160
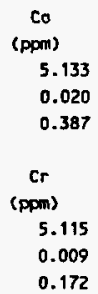

$\mathrm{Mg}$
(ppm)
5.032
0.012
0.229

cd
(ppm)
5.034
0.005
0.092

TI

\begin{tabular}{cr} 
Be & \multicolumn{1}{c}{ Tl } \\
(Ppm) & (ppm) \\
5.487 & 4.880 \\
0.007 & 0.023 \\
0.123 & 0.477
\end{tabular}


Identity 1: PREPBLK Identity 2: Duality Control

Task name : OPTIMA

Sample Weight : $\quad 1.0000$ Solution Volume : $\quad 1.00$

on-Peak Integrations : 3 off-Peak Integrations : 1

WHC-SD-WM-DP-180, FEV. 0

\begin{tabular}{|c|c|c|c|c|c|c|c|c|}
\hline & $2 r$ & Sr & Bi & si & Al & Co & $\mathrm{Cu}$ & Li \\
\hline & (ppm) & (ppm) & (ppm) & (ppm) & (ppm) & (ppm) & (ppm) & (ppm) \\
\hline Mesn & -0.004 & 0.000 & 0.006 & 0.008 & -0.005 & 0.006 & 0.005 & 0.000 \\
\hline S.D. & 0.001 & 0.000 & 0.002 & 0.002 & 0.005 & 0.000 & 0.000 & 0.000 \\
\hline \multirow[t]{2}{*}{ X R.S.0. } & 25.245 & 41925734279.000 & 37.317 & 23.544 & 108.190 & 0.082 & 5.813 & 131.68 \\
\hline & $\begin{array}{c}\text { zn } \\
(p p m)\end{array}$ & $\begin{array}{c}\mathrm{Ni} \\
\text { (ppm) }\end{array}$ & $\begin{array}{c}\text { La } \\
\text { (ppm) }\end{array}$ & $\begin{array}{c}\mathrm{Fe} \\
\text { (pPm) }\end{array}$ & $\begin{array}{c}\mathrm{Ca} \\
\text { (pPm) }\end{array}$ & $\begin{array}{c}\mathrm{Cr} \\
(\mathrm{ppm})\end{array}$ & $\begin{array}{c}\text { Nd } \\
\text { (ppm) }\end{array}$ & $\begin{array}{c}\mathbf{U} \\
(\mathrm{ppm})\end{array}$ \\
\hline Mean & 0.003 & 0.001 & -0.005 & 0.031 & 0.051 & 0.008 & -0.007 & -0.146 \\
\hline S.D. & 0.000 & 0.001 & 0.001 & 0.002 & 0.000 & 0.000 & 0.005 & 0.037 \\
\hline \multirow[t]{2}{*}{ * R.S.D. } & 6.518 & 129.412 & 15.693 & 6.253 & 0.443 & 4.268 & 69.009 & 25.213 \\
\hline & $\begin{array}{c}\text { Ce } \\
\text { (pCm) }\end{array}$ & $\begin{array}{c}\mathrm{Sm} \\
\text { (ppm) }\end{array}$ & $\begin{array}{c}\mathrm{Ba} \\
\text { (ppm) }\end{array}$ & $\begin{array}{c}P \\
\text { (ppm) }\end{array}$ & $\stackrel{\mathrm{S}}{(\mathrm{ppm})}$ & $\begin{array}{c}\mathrm{Mg} \\
(\mathrm{ppm})\end{array}$ & $\begin{array}{c}\text { As } \\
\text { (pprn) }\end{array}$ & $\begin{array}{c}\text { Na } \\
\text { (ppm) }\end{array}$ \\
\hline Mean & -0.021 & -0.013 & -0.000 & 0.003 & 0.075 & 0.008 & 0.003 & 0.147 \\
\hline S.D. & 0.008 & 0.006 & 0.000 & 0.002 & 0.002 & 0.000 & 0.003 & 0.001 \\
\hline \multirow[t]{2}{*}{ \% R.S.D. } & 40.419 & 49.478 & 56.855 & 62.712 & 2.116 & 0.000 & 98.908 & 0.798 \\
\hline & $\begin{array}{c}\text { Mo } \\
\text { (ppm) }\end{array}$ & $\begin{array}{c}\text { Se } \\
\text { (ppm) }\end{array}$ & $\begin{array}{c}\text { Ag } \\
\text { (ppm) }\end{array}$ & $\begin{array}{c}\mathrm{Pb} \\
\text { (PPm) }\end{array}$ & $\begin{array}{c}\mathrm{Ti} \\
(\mathrm{ppm})\end{array}$ & $\begin{array}{c}\text { Cd } \\
\text { (ppm) }\end{array}$ & $\begin{array}{c}\text { B } \\
\text { (ppm) }\end{array}$ & $\begin{array}{c}K \\
\text { (ppm) }\end{array}$ \\
\hline Mean & 0.002 & -0.010 & 0.001 & 0.011 & -0.001 & 0.001 & 0.051 & 0.032 \\
\hline S.D. & 0.001 & 0.005 & 0.000 & 0.013 & 0.001 & 0.001 & 0.001 & 0.008 \\
\hline * R.S.D. & 40.673 & 49.282 & 35.270 & 119.019 & 41.971 & 51.230 & 2.026 & 25.691 \\
\hline
\end{tabular}

\begin{tabular}{lrrrrr} 
& \multicolumn{1}{c}{$\begin{array}{c}\text { Mn } \\
\end{array}$} & \multicolumn{1}{c}{ sb } & \multicolumn{1}{c}{$v$} & \multicolumn{1}{c}{ Be } & \multicolumn{1}{c}{ Tl } \\
& $(\mathrm{ppm})$ & \multicolumn{1}{c}{$(\mathrm{ppm})$} & \multicolumn{1}{c}{$(\mathrm{ppm})$} & \multicolumn{1}{c}{$(\mathrm{ppm})$} & \multicolumn{1}{c}{ (ppm) } \\
Mean & 0.000 & 0.050 & -0.002 & -0.000 & 0.085 \\
S.D. & 0.000 & 0.026 & 0.001 & 0.000 & 0.017 \\
X.R.S.0. & 61.359 & 51.804 & 64.284 & 107.867 & 19.433
\end{tabular}


Identity 1: \$95R000115_L Identity 2: 2-8 mL

9:58 AM January 31, 1996

Task name : OPTIMA

Semple Weight : $\quad \mathbf{1 . 0 0 0 0}$ Solution Volume :

5.00

WHC-SD-WM-DP-180, FEV. 0

On-Peak Integrations : 3 off-Peak Integrations : 1

On Peak lntegrations :

\begin{tabular}{lrrrrr} 
& \multicolumn{1}{c}{ Zr } & \multicolumn{1}{c}{ Sr } & \multicolumn{1}{c}{ Bi } & \multicolumn{1}{c}{$5 i$} & \multicolumn{1}{c}{ Al } \\
& $(\mathrm{ppm})$ & \multicolumn{1}{c}{ (ppm) } & \multicolumn{1}{c}{$(\mathrm{ppm})$} & \multicolumn{1}{c}{ (ppm) } & \multicolumn{1}{c}{ (ppm) } \\
Meen & -0.031 & 0.009 & -0.000 & 0.118 & 0.015 \\
S.0. & 0.016 & 0.001 & 0.017 & 0.017 & 0.017 \\
XR.S.D. & 51.819 & 16.944 & 5437.306 & 14.613 & 113.308
\end{tabular}

Mean

$$
\text { In }
$$

(ppm)

S.D.

.0 .000

Ni

(ppm)

0.081

La

(pom)

$-0.032$

0.007

0.013

Fe

(ppm)

0.041

ca

(ppm)

0.212

0.008

0.002

41.738

19.368

1.153

Co
(ppm)
0.066
0.012
18.693

Cu

(ppm)

0.020

Li

Y R.S.D.

443.536

8.731

Ba

ce
(ppm)

$5 \mathrm{~m}$

(ppm)

0.003

$P$

(ppm)

12.511

0.365

s

$-0.283$

0.003

(ppm)

0.921

0.022

2.391

Cr
(ppm)
0.026
0.007
25.569

D. 005

(PPm)

0.003

0.003

24.337

104.403

* R.S.D.

136.187

45.009

85.541

2.914

Mg

(ppm)

0.133

0.000

Nd

(ppm)

0.103

0.062

59.977

u

(ppm)

$-1.309$

0.637

48.717

\begin{tabular}{|c|c|c|c|c|c|}
\hline & $\begin{array}{c}M_{0} \\
\text { (ppm) }\end{array}$ & $\begin{array}{c}\text { Se } \\
\text { (ppom) }\end{array}$ & $\begin{array}{c}\text { Ag } \\
\text { (ppm) }\end{array}$ & $\begin{array}{c}\mathrm{Pb} \\
(\mathrm{ppm})\end{array}$ & $\begin{array}{c}T i \\
\text { (ppm) }\end{array}$ \\
\hline Mean & 0.023 & -0.218 & 0.221 & 0.183 & -0.009 \\
\hline S.D. & 0.002 & 0.022 & 0.009 & 0.042 & 0.004 \\
\hline \multirow[t]{2}{*}{ XR.S.D. } & 10.719 & 9.907 & 4.084 & 22.681 & 43.649 \\
\hline & $\begin{array}{c}M_{n} \\
(p p m)\end{array}$ & $\begin{array}{c}\mathrm{Sb} \\
\text { (ppm) }\end{array}$ & $\begin{array}{c}v \\
\text { (ppm) }\end{array}$ & $\begin{array}{c}\text { Be } \\
\text { (ppm) }\end{array}$ & $\begin{array}{c}\text { Tl } \\
\text { (ppm) }\end{array}$ \\
\hline Mean & 0.026 & 0.226 & 0.014 & 0.002 & 0.383 \\
\hline S.D. & 0.001 & 0.071 & 0.008 & 0.001 & 0.276 \\
\hline XR.S.D. & 2.469 & 31.286 & 58.614 & 58.928 & 71.984 \\
\hline
\end{tabular}


Identity 1: \$95R000115 Identity 2: Direct Task name : OPIIMA

Sample Weight : $\quad 1.0000$ Solution Volume

on-Peak Integrations : 3 off-Peak Integrations : 1

\begin{tabular}{|c|c|c|c|c|c|}
\hline & $\begin{array}{c}2 r \\
(p p m)\end{array}$ & $\begin{array}{c}\text { Sr } \\
\text { (ppm) }\end{array}$ & $\begin{array}{c}B i \\
\text { (ppm) }\end{array}$ & $\begin{array}{c}\mathrm{si} \\
(\mathrm{pmm})\end{array}$ & $\begin{array}{c}\text { Al } \\
\text { (ppm) }\end{array}$ \\
\hline Mean & -0.004 & 0.007 & 0.018 & 0.189 & 0.003 \\
\hline S.D. & 0.001 & 0.000 & 0.010 & 0.009 & 0.005 \\
\hline \multirow[t]{2}{*}{ XR.S.D. } & 31.761 & 1.200 & 59.371 & 5.022 & 153.600 \\
\hline & $\begin{array}{c}2 n \\
(p p m)\end{array}$ & $\begin{array}{c}\boldsymbol{H i} \\
\text { (ppm) }\end{array}$ & $\begin{array}{c}\text { La } \\
\text { (pam) }\end{array}$ & $\begin{array}{c}\text { Fe } \\
\text { (ppm) }\end{array}$ & $\begin{array}{c}\mathrm{Ca} \\
\text { (ppm) }\end{array}$ \\
\hline Mean & 0.009 & 0.084 & -0.003 & 0.025 & 0.256 \\
\hline S.D. & 0.001 & 0.001 & 0.001 & 0.002 & 0.005 \\
\hline \multirow[t]{2}{*}{ * R.S.D. } & 7.537 & 1.442 & 20.898 & 9.924 & 1.915 \\
\hline & $\begin{array}{c}\text { Ce } \\
\text { (ppm) }\end{array}$ & $\stackrel{\mathrm{Sm}}{(\mathrm{pPm})}$ & $\begin{array}{c}\mathrm{Ba} \\
(\mathrm{ppm})\end{array}$ & $\begin{array}{c}P \\
(p p m)\end{array}$ & $\begin{array}{c}s \\
\text { (ppm) }\end{array}$ \\
\hline Mean & -0.018 & -0.028 & 0.001 & 12.767 & 0.940 \\
\hline S.D. & 0.010 & 0.009 & 0.000 & 0.053 & 0.002 \\
\hline \multirow[t]{2}{*}{ \# R.S.D. } & 58.257 & 30.319 & 14.950 & 0.414 & 0.217 \\
\hline & $\begin{array}{c}\text { Mo } \\
\text { (ppm) }\end{array}$ & $\begin{array}{c}\text { se } \\
\text { (ppm) }\end{array}$ & $\begin{array}{c}\mathrm{Ag} \\
(\mathrm{ppm})\end{array}$ & $\begin{array}{c}\mathrm{Pb} \\
(\mathrm{ppm})\end{array}$ & $\begin{array}{c}13 \\
\text { (ppm) }\end{array}$ \\
\hline Mean & 0.009 & -0.040 & 0.204 & 0.010 & -0.001 \\
\hline s.D. & 0.001 & 0.012 & 0.000 & 0.011 & 0.001 \\
\hline \multirow[t]{2}{*}{ \% R,S.D. } & 7.812 & 30.963 & 0.109 & 100.637 & 108.074 \\
\hline & $\begin{array}{c}\text { Mn } \\
\text { (ppm) }\end{array}$ & $\begin{array}{c}\mathrm{sb} \\
(\mathrm{ppm})\end{array}$ & $\begin{array}{c}V \\
\text { (ppm) }\end{array}$ & $\begin{array}{c}\mathrm{Be} \\
\text { (ppm) }\end{array}$ & $\begin{array}{c}\text { Tl } \\
\text { (Ppm) }\end{array}$ \\
\hline Mean & 0.024 & 0.001 & 0.002 & -0.000 & 0.003 \\
\hline s.o. & 0.000 & 0.015 & 0.001 & 0.000 & 0.027 \\
\hline \% R.S.D. & 0.581 & 1397.861 & 46.708 & 33.045 & 1081.982 \\
\hline
\end{tabular}

WHC-SD-WM-DP-180, FEV. 0

\begin{tabular}{ccc}
$c o$ & $c u$ & \multicolumn{1}{c}{$L i$} \\
(ppm) & (ppm) & \multicolumn{1}{c}{ (ppm) } \\
0.010 & 0.013 & 0.000 \\
0.009 & 0.000 & 0.000 \\
14.359 & 3.557 & 433.058
\end{tabular}

\begin{tabular}{ccr} 
Cr & \multicolumn{1}{c}{ Nd } & \multicolumn{1}{c}{$U$} \\
(ppm) & (ppon) & \multicolumn{1}{c}{ (ppm) } \\
0.019 & -0.008 & -0.190 \\
0.001 & 0.004 & 0.033 \\
3.015 & 45.083 & 17.459
\end{tabular}

Mg
(ppon)
0.123
0.000
0.178

As

0.009

0.003

34.772

$\mathrm{Ha}$
(ppm)
165.518
1.731
1.046

Cd
(ppm)
0.001
0.000
14.418

B
(pom)
0.041
0.001
2.189

K

(ppm)

0.269

0.019

6.891 
Identity 1: \$95R000115_0 Identity 2: Direct

10:05 AM January 31, 1996

Task name : OPT IMA

Sample Weight : $\quad 1.0000$ Solution Volume : $\quad \mathbf{1 . 0 0}$

on-Peak Integrations : 3 off-Peak Integrations : 1

WHC-SD-WM-DP-180, FEV. 0

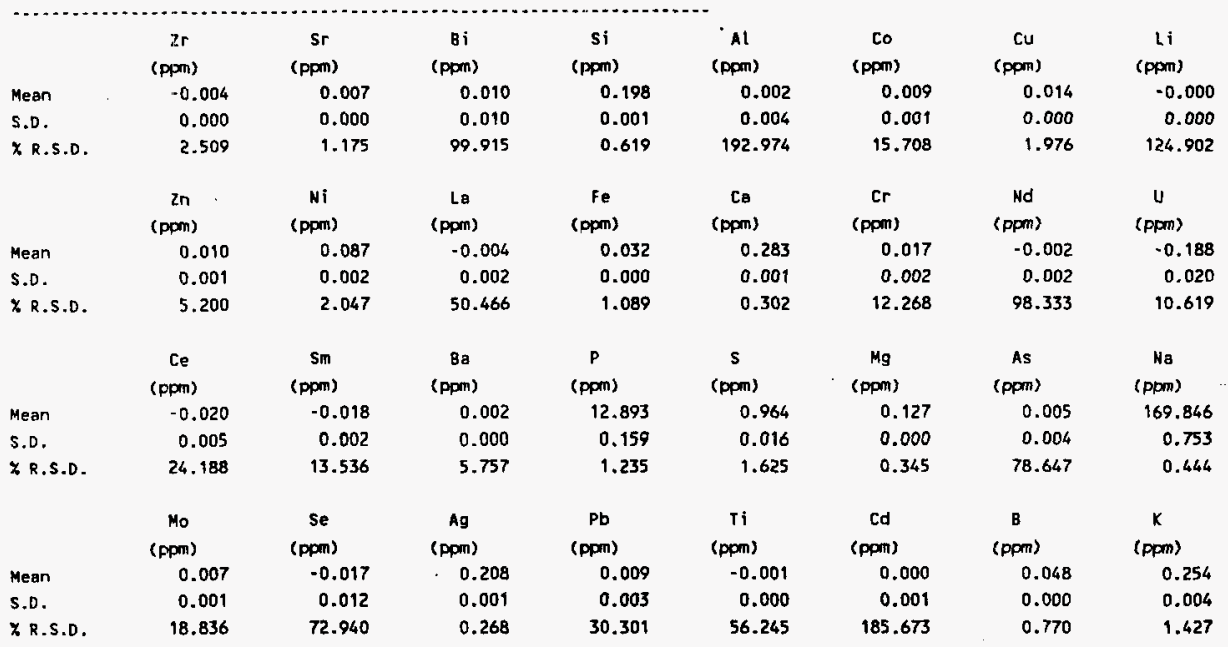

\begin{tabular}{lrrrrr} 
& \multicolumn{1}{c}{ Mn } & \multicolumn{1}{c}{ Sb } & \multicolumn{1}{c}{ V } & \multicolumn{1}{c}{ Be } & \multicolumn{1}{c}{ IL } \\
& (ppm) & \multicolumn{1}{c}{ (ppm) } & \multicolumn{1}{c}{ (ppm) } & \multicolumn{1}{c}{ (ppm) } & \multicolumn{1}{c}{ (ppm) } \\
Mean & 0.025 & 0.006 & 0.001 & -0.000 & -0.011 \\
S.D. & 0.000 & 0.022 & 0.000 & 0.000 & 0.003 \\
\% R.S.D. & 0.566 & 354.365 & 24.171 & 31.462 & 30.312
\end{tabular}


Identity 1: 595R000115_s Identity 2: Direct

Task name : OPT IMA

Sanple weight : $\quad 1.0000$ Solution Volume : $\quad 1.00$

On-Peak Integrations : 3 off-Peak Integrations : 1

$2 r \quad$ Sr $\quad$ Bi

Mean

(ppm)

4.579

(PPm)

S.D.

0.021

\subsection{8}

(ppm)

4.715

0.026

0.548

0.407

2n.

(ppm)

Mean

S.D.

\% R.S.0.

4.789

0.015

0.310

ce

pom)

Mean

S.D.

\% R.S.D.

4.797

0.020

0.425

Mo

4.827

Mean

S.D.

\% R.S.D.

0.021

0.432

(pom)

Mean

4.912

S.D.

0.018

0.364
Ni

(ppm)

4.986

0.025

0.505

Sm

(ppm)

4.828

0.026

0.540

Se

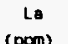

(ppm)

5.002

0.033

0.664

Ba
(ppm)
4.784
0.021
0.439

Ag

1.148

0.003

0.274

1. 121

$\mathrm{Sb}$

(ppm)

4.562

0.030

0.653

(pom)

4.881

0.016

0.321 (ppm)

(ppm) (ppm)

6.459
0.018
0.280

0.280

Fe

(ppm)

4.938

0.045

0.915

P $s$

17.714

0.065

0.366

$\mathrm{Pb}$

4.850

0.038

0.792

Al
(ppm)
4.931
0.023
0.458

Ca

(pom)

S

(ppm)

Ti

(pom)

$\begin{array}{cc}\text { Be } & \text { Tl } \\ \text { (ppm) } & \text { (ppm) }\end{array}$

5.117

0.021

0.419
5.105

0.022

0.433

5.571

0.025

0.452

4.731

0.016

0.347

4.750

0.017

Co
(ppm)
4.873
0.006
0.133

Cr

(ppm)

4.896

0.016

0.329

Mg

(ppm)

4.869

0.012

0.241

Cd

4.799

0.016

0.342

0.362 


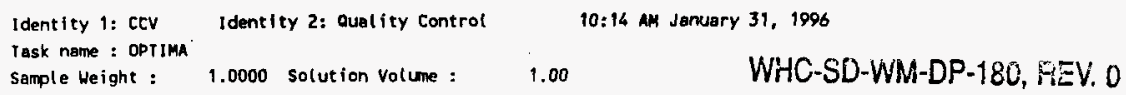

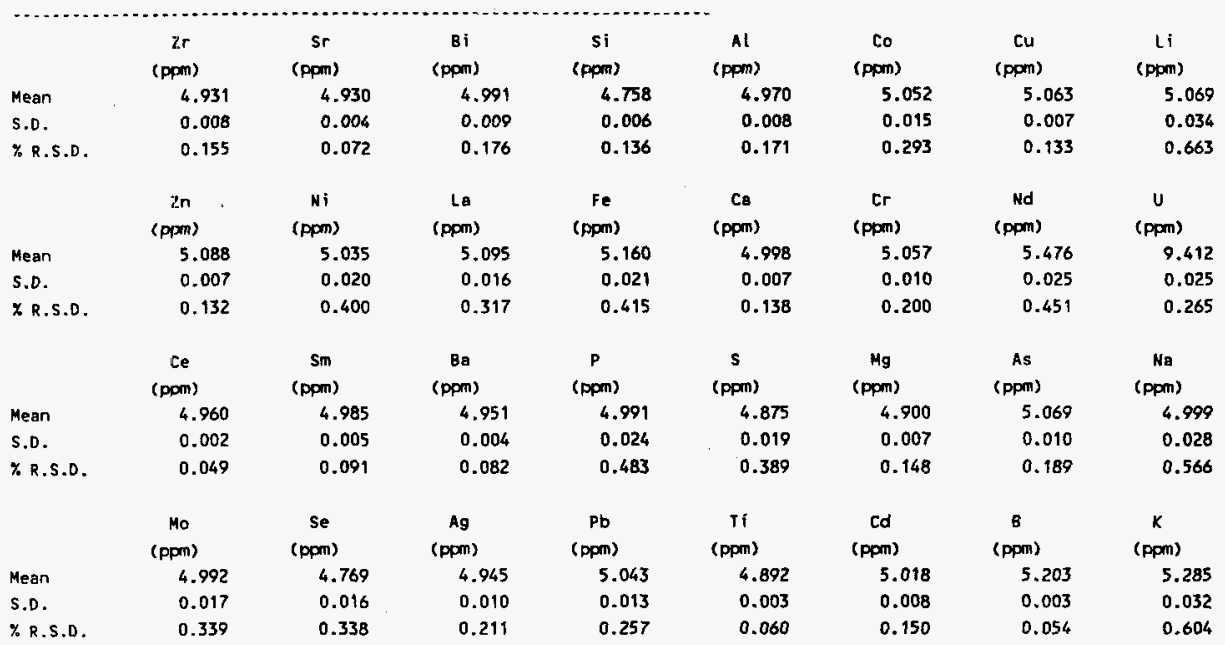

\begin{tabular}{lrrrrr} 
& \multicolumn{1}{c}{$\begin{array}{c}\text { Mn } \\
\text { (ppm) }\end{array}$} & $\begin{array}{c}\text { Sb } \\
\text { (ppm) }\end{array}$ & \multicolumn{1}{c}{$\begin{array}{c}\text { (ppm) } \\
\text { (ppm }\end{array}$} & \multicolumn{1}{c}{$\begin{array}{c}\text { Be } \\
\text { (ppm) }\end{array}$} & \multicolumn{1}{c}{ (ppm) } \\
Mean & 5.039 & 4.677 & 5.094 & 5.153 & 4.916 \\
S.D. & 0.008 & 0.042 & 0.009 & 0.003 & 0.030 \\
\% R.S.D. & 0.164 & 0.903 & 0.185 & 0.058 & 0.607
\end{tabular}


Identity 1: CCB Task name : OPTIMA

sample weight : on-Peak Integrations :

Identity 2: Ouality Control

10:17 AM Januery 31, 1996

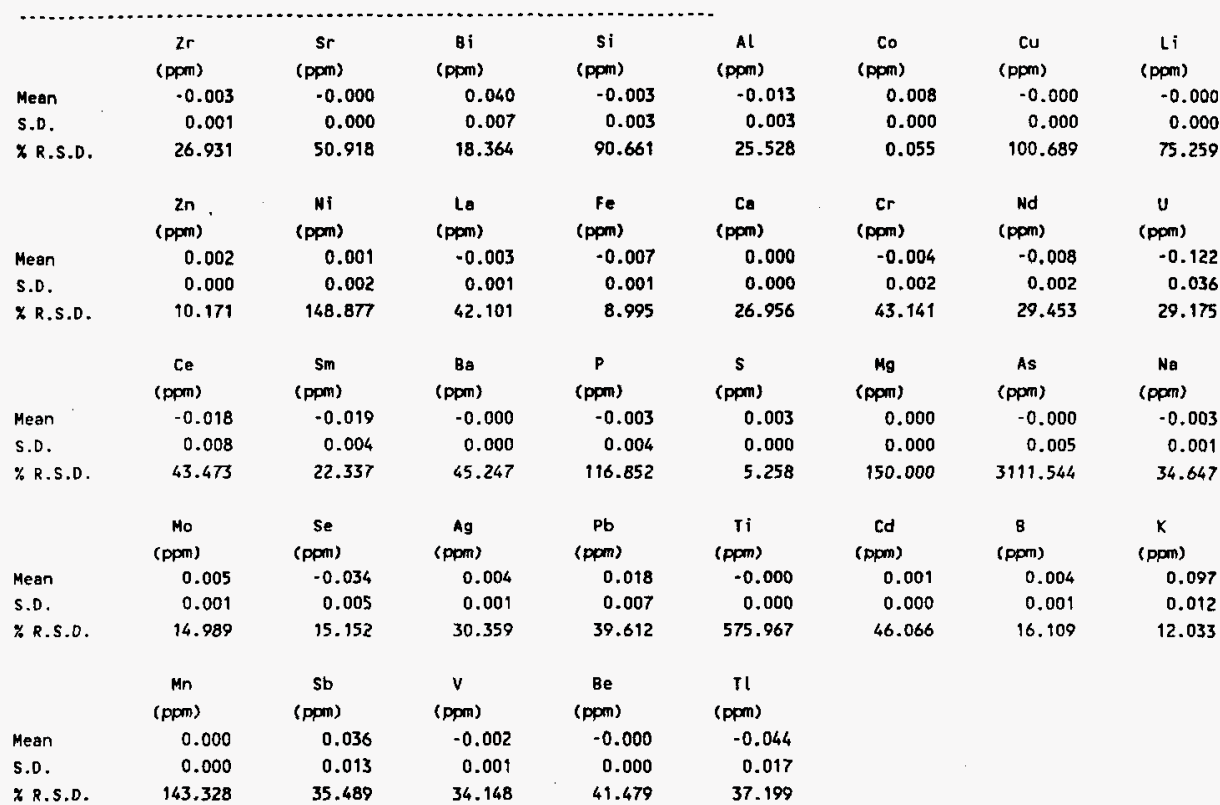


Identity 1: S95R000116_L Identity 2: 2-8 ml

10:22 AM Jenuary 31, 1996

Iosk name : OPTIMA

Sample Weight : $\mathbf{1 . 0 0 0 0}$ Solution volume :

5.00

WHC-SD-WM-DP-180, REV. 0

On-Peak Integrations : 3 off-Peak Integrations :

\begin{tabular}{|c|c|c|c|c|c|}
\hline & $2 r$ & $\mathrm{Sr}$ & $B i$ & si & Al \\
\hline & (ppm) & (ppm) & (ppm) & (ppm) & (ppm) \\
\hline Mean & -0.021 & 0.008 & 0.085 & 0.159 & 0.015 \\
\hline 5.0. & 0.002 & 0.000 & 0.036 & 0.014 & 0.010 \\
\hline \multirow[t]{2}{*}{ X R.S.D. } & 10.708 & 5.658 & 42.291 & 8.505 & 63.574 \\
\hline & $\begin{array}{c}2 n \\
(p p m)\end{array}$ & $\begin{array}{c}\mathrm{Ni} \\
(\mathrm{pPm})\end{array}$ & $\begin{array}{c}\text { La } \\
\text { (ppm) }\end{array}$ & $\begin{array}{c}\mathrm{Fe} \\
(\mathrm{ppm})\end{array}$ & $\begin{array}{c}\mathrm{Ca} \\
\text { (ppm) }\end{array}$ \\
\hline Mean & 0.008 & 0.091 & 0.006 & 0.039 & 0.226 \\
\hline s.o. & 0.002 & 0.005 & 0.010 & 0.005 & 0.001 \\
\hline \multirow[t]{2}{*}{ * R.S.D. } & 22.045 & 5.137 & 166.225 & 11.848 & 0.399 \\
\hline & $\begin{array}{c}C e \\
\text { (ppm) }\end{array}$ & $\begin{array}{c}\text { Sm } \\
\text { (ppm) }\end{array}$ & $\begin{array}{c}\mathrm{Ba} \\
\text { (ppm) }\end{array}$ & $\begin{array}{c}P \\
\text { (ppm) }\end{array}$ & $\begin{array}{c}S \\
\text { (ppm) }\end{array}$ \\
\hline Mean & 0.021 & -0.090 & 0.001 & 12.343 & 0.930 \\
\hline S.D. & 0.034 & 0.042 & 0.001 & 0.149 & 0.010 \\
\hline \multirow[t]{2}{*}{ * R.S.D. } & 162.521 & 46.315 & 48.038 & 1.208 & 1.128 \\
\hline & $\begin{array}{c}\text { Mo } \\
\text { (ppm) }\end{array}$ & $\begin{array}{c}\text { Se } \\
\text { (ppm) }\end{array}$ & $\begin{array}{c}\text { Ag } \\
\text { (ppm) }\end{array}$ & $\begin{array}{c}\mathrm{Pb} \\
\text { (ppm) }\end{array}$ & $\begin{array}{c}\text { If } \\
\text { (ppm) }\end{array}$ \\
\hline Mean & 0.022 & -0.021 & 0.214 & 0.042 & -0.002 \\
\hline S.D. & 0.003 & 0.018 & 0.004 & 0.048 & 0.001 \\
\hline \multirow[t]{2}{*}{ \% R.S.D. } & 14.398 & 86.936 & 1.747 & 114.526 & 33.552 \\
\hline & $\begin{array}{c}M n \\
(p p m)\end{array}$ & $\begin{array}{c}\text { sb } \\
\text { (ppnn) }\end{array}$ & $\begin{array}{c}v \\
\text { (ppm) }\end{array}$ & $\begin{array}{c}\text { Be } \\
\text { (ppm) }\end{array}$ & $\begin{array}{c}\mathrm{Tl} \\
\text { (ppm) }\end{array}$ \\
\hline Mean & 0.024 & -0.078 & 0.004 & -0.001 & -0.111 \\
\hline 5.0 & 0.001 & 0.116 & 0.003 & 0.000 & 0.078 \\
\hline \% R.S.D. & 5.266 & 149.380 & 80.060 & 2.528 & 70.980 \\
\hline
\end{tabular}


Identity 1: S95R000116 Identity 2: Direct

10:25 AM January 31, 1996

Task name : OPTIMA

Sample Weight : $\quad 1.0000$ Solution Volume : $\quad 1.00$

on-Peak integrations : 3 off-Peak Integrations : 1

WHC-SD-WM-DP-180, REV. 0

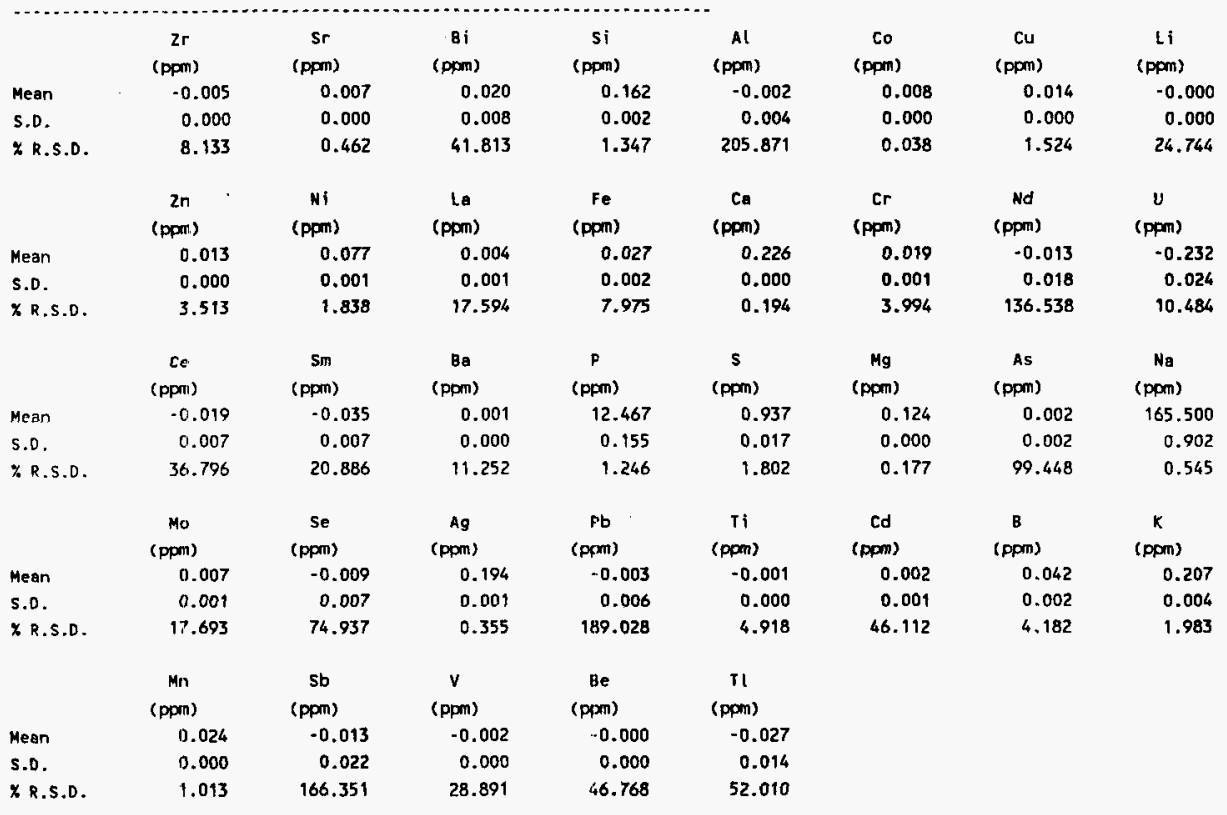


Identity 1: S95R000116_D Identity 2: Direet 10:28 AM Jamuary 31, 1996

Jask name : Oprima

Sample Neight :

1.0000 Solution volume : $\quad 1.00$

WHC-SD-WM-DP-180, FEV. O

on-Peak Integrations : 3 off-Peak Integrations : 1

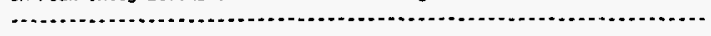

\begin{tabular}{|c|c|c|c|c|c|c|c|c|}
\hline & $\begin{array}{c}2 r \\
(\mathrm{ppm})\end{array}$ & $\begin{array}{c}S r \\
\text { (ppm) }\end{array}$ & $\begin{array}{c}\mathrm{Bi} \\
\text { (ppm) }\end{array}$ & $\begin{array}{c}\text { si } \\
\text { (ppm) }\end{array}$ & $\begin{array}{c}A l \\
\text { (ppm) }\end{array}$ & $\begin{array}{c}\text { co } \\
\text { (pFm) }\end{array}$ & $\begin{array}{c}\mathrm{Cu} \\
\text { (ppm) }\end{array}$ & $\begin{array}{c}\mathrm{Li} \\
\text { (ppm) }\end{array}$ \\
\hline Mean & -0.004 & 0.007 & 0.029 & 0.173 & 0.008 & 0.008 & 0.017 & 0.000 \\
\hline S.D. & 0.001 & 0.000 & 0.006 & 0.003 & 0.005 & 0.002 & 0.000 & 0.000 \\
\hline * R.S.D. & 26.303 & 1.563 & 20.340 & 1.554 & 62.063 & 29.855 & 1.399 & 131.701 \\
\hline
\end{tabular}

\begin{tabular}{|c|c|c|c|c|c|c|c|c|}
\hline & $\underset{(p p m)}{2 n}$ & $\begin{array}{c}N i \\
\text { (ppm) }\end{array}$ & $\begin{array}{c}\text { to } \\
\text { (Ppm) }\end{array}$ & $\begin{array}{c}\mathrm{Fe} \\
\text { (ppm) }\end{array}$ & $\begin{array}{c}\mathrm{Ca} \\
(\mathrm{ppm})\end{array}$ & $\begin{array}{c}\mathrm{Cr} \\
(\mathrm{Ppm})\end{array}$ & $\begin{array}{c}\text { Nd } \\
\text { (ppm) }\end{array}$ & $\begin{array}{c}U \\
(p p m)\end{array}$ \\
\hline Mean & 0.018 & 0.085 & .0 .000 & 0.036 & 0.259 & 0.018 & 0.004 & -0.192 \\
\hline S.D. & 0.000 & 0.001 & 0.001 & 0.003 & 0.000 & 0.001 & 0.009 & 0.038 \\
\hline \% R.S.D. & 1.710 & 1.758 & 1345.974 & 7.727 & 0.174 & 3.086 & 229.256 & 19.994 \\
\hline
\end{tabular}

\begin{tabular}{|c|c|c|c|c|c|}
\hline & $\begin{array}{c}\text { Ce } \\
\text { (ppm) }\end{array}$ & $\begin{array}{c}S m \\
\text { (ppm) }\end{array}$ & $\begin{array}{c}\mathrm{Ba} \\
\text { (ppm) }\end{array}$ & $\begin{array}{c}p \\
\text { (ppm) }\end{array}$ & $\underset{\text { (ppm) }}{\text { S }}$ \\
\hline Mean & 0.007 & -0.022 & 0.002 & 12.891 & 1.012 \\
\hline S.D. & 0.010 & 0.007 & 0.000 & 0.190 & 0.010 \\
\hline \multirow[t]{2}{*}{ *R.S.D. } & 138.127 & 32.211 & 11.111 & 1.670 & 0.957 \\
\hline & $\begin{array}{c}\text { Mo } \\
\text { (ppm) }\end{array}$ & $\begin{array}{c}\text { Se } \\
\text { (ppm) }\end{array}$ & $\begin{array}{c}\mathrm{Ag} \\
(\mathrm{ppm})\end{array}$ & $\begin{array}{c}\mathrm{Pb} \\
(\mathrm{ppm})\end{array}$ & $\begin{array}{c}T i \\
(\mathrm{ppm})\end{array}$ \\
\hline Mean & 0.009 & -0.038 & 0.199 & 0.023 & -0.001 \\
\hline S.D. & 0.001 & 0.001 & 0.001 & 0.008 & 0.001 \\
\hline \multirow[t]{2}{*}{ X R.S.D. } & 9.500 & 2.033 & 0.603 & 36.390 & 125.602 \\
\hline & $\begin{array}{c}\text { Mn } \\
\text { (ppm) }\end{array}$ & $\begin{array}{c}\text { sb } \\
(p p m)\end{array}$ & $\begin{array}{c}V \\
(\mathrm{ppm})\end{array}$ & $\begin{array}{c}\text { Be } \\
\text { (ppm) }\end{array}$ & $\begin{array}{c}\mathrm{Tl} \\
\text { (ppm) }\end{array}$ \\
\hline Mean & 0.025 & -0.030 & 0.001 & -0.000 & 0.033 \\
\hline S.D. & 0.000 & 0.027 & 0.000 & 0.000 & 0.023 \\
\hline \% R.S.D. & 1.001 & 91.793 & 48.862 & 252.205 & 69.337 \\
\hline
\end{tabular}


Identity 1: JCSA

Tagk name : OPTIMA

$\begin{array}{lll}\text { Sample Weight : } \quad 1.0000 & \text { solution Volume : } & 1.00 \\ \text { On-Peak Integrations : } 3 \text { off-Peak Integrations : } & 1\end{array}$
10:33 AM January 31, 1996

WHC-SD-WM-DP-180, FEV. 0

\begin{tabular}{|c|c|c|c|c|c|c|c|c|}
\hline & $\begin{array}{c}\mathrm{Zr} \\
\text { (ppm) }\end{array}$ & $\begin{array}{c}\mathrm{sr} \\
(p p m)\end{array}$ & $\begin{array}{c}B i \\
\text { (pom) }\end{array}$ & $\begin{array}{c}\text { si } \\
\text { (ppm) }\end{array}$ & $\stackrel{\text { Al }}{\text { (ppm) }}$ & $\begin{array}{c}C o \\
\text { (ppm) }\end{array}$ & $\begin{array}{c}\mathrm{Cu} \\
\text { (ppm) }\end{array}$ & $\underset{(\mathrm{ppm})}{1 i}$ \\
\hline Mean & 0.007 & 0.002 & 0.005 & 0.011 & 204.791 & 0.003 & 0.001 & -0.001 \\
\hline S.D. & 0.001 & 0.000 & 0.005 & 0.001 & 0.046 & 0.003 & 0.004 & 0.000 \\
\hline \multirow[t]{2}{*}{ × R.S.0. } & 13.179 & 5.391 & 95.453 & 11.583 & 0.023 & 94.322 & 95.529 & 9.436 \\
\hline & $\underset{(p p m)}{2 n}$ & $\begin{array}{c}\mathrm{Ni} \\
\text { (ppm) }\end{array}$ & $\begin{array}{c}\text { La } \\
\text { (ppm) }\end{array}$ & $\begin{array}{c}\text { Fe } \\
\text { (ppm) }\end{array}$ & $\begin{array}{c}\mathrm{Ca} \\
(\mathrm{ppm})\end{array}$ & $\begin{array}{c}\mathrm{Cr} \\
\text { (ppm) }\end{array}$ & $\begin{array}{c}\text { Nd } \\
\text { (ppm) }\end{array}$ & $\begin{array}{c}\mathrm{U} \\
\text { (ppm) }\end{array}$ \\
\hline Mean & -0.008 & 0.011 & 0.003 & 102.391 & 105.160 & -0.002 & 0.025 & .0 .042 \\
\hline S.D. & 0.000 & 0.002 & 0.002 & 0.053 & 0.055 & 0.001 & 0.009 & 0.050 \\
\hline \multirow[t]{3}{*}{ X R.S.O. } & 4.152 & 18.217 & 68.027 & 0.052 & 0.052 & 28.538 & 36.343 & 118.262 \\
\hline & Ce & Sm & $8 a$ & $P$ & s & Mg & As & $\mathrm{Ne}$ \\
\hline & (ppm) & (ppm) & (ppm) & (PPM) & (ppm) & (ppm) & (ppm) & (PPM) \\
\hline Mean & -0.045 & 0.025 & 0.003 & 0.044 & 0.000 & 102.135 & 0.008 & 190.953 \\
\hline S.D. & 0.010 & 0.007 & 0.000 & 0.001 & 0.009 & 0.301 & 0.005 & 0.780 \\
\hline \multirow[t]{3}{*}{ \% R.S.D. } & 22,082 & 28.611 & 6.807 & 2.563 & 5314.288 & 0.294 & 66.047 & 0.408 \\
\hline & Mo & Se & Ag & $\mathrm{Pb}$ & $T i$ & Cd & B & $K$ \\
\hline & (ppm) & (ppm) & (ppm) & (ppm) & (PPN) & (PpDI) & (ppm) & (ppm) \\
\hline Mean & 0.001 & -0.050 & -0.004 & -0.005 & 0.001 & 0.000 & 0.016 & 0.120 \\
\hline S.D. & 0.001 & 0.016 & 0.001 & 0.008 & 0.000 & 0.000 & 0.001 & 0.008 \\
\hline \multirow[t]{3}{*}{ * R.S.D. } & 64.516 & 32.417 & 24.526 & 166.354 & 64.287 & 590.567 & 3.071 & 6.932 \\
\hline & $M n$ & Sb & $v$ & Be & $T l$ & & & \\
\hline & (ppm) & (Ppm) & (Ppm) & (ppm) & (ppm) & & & \\
\hline Mean & 0.001 & 0.039 & -0.003 & 0.002 & -0.068 & & & \\
\hline S.D. & 0.000 & 0.021 & 0.001 & 0.000 & 0.025 & & & \\
\hline \% R.S.D. & 11.818 & 52.977 & 19.180 & 5.129 & 36.958 & & & \\
\hline
\end{tabular}


Identity 1: ICSAE Identity 2: Quelity Control

10:36 AM Januery 31, 1996

rask name : optima

Sample Weight : 1.0000 solution volume : 1.00

On-Peak Integrations: 3 off-Peak Integrations : 1

WHC-SD-WM-DP-180, PEV 0

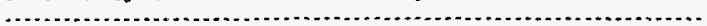

\begin{tabular}{|c|c|c|c|c|c|c|c|c|}
\hline & $\begin{array}{c}2 r \\
(p \mathrm{pm})\end{array}$ & $\begin{array}{c}s r \\
(p o m)\end{array}$ & $\begin{array}{c}\text { Bi } \\
\text { (ppm) }\end{array}$ & $\begin{array}{c}s i \\
(\mathrm{ppm})\end{array}$ & $\begin{array}{c}\text { A! } \\
(\mathrm{ppm})\end{array}$ & $\begin{array}{c}\text { Co } \\
\text { (ppm) }\end{array}$ & $\underset{\text { (pprit) }}{\mathrm{Cu}}$ & $\begin{array}{c}\mathrm{Li} \\
\text { (ppm) }\end{array}$ \\
\hline Mean & 0.001 . & 0.002 & -0.041 & 0.012 & 205.262 & 0.498 & 0.513 & 0.945 \\
\hline s.o. & 0.002 & 0.000 & 0.009 & 0.008 & 0.998 & 0.002 & 0.003 & 0.006 \\
\hline \% R.S.D. & 320.396 & 5.589 & 20.970 & 65.274 & 0.486 & 0.492 & 0.559 & 0.644 \\
\hline & $\begin{array}{c}\text { Zn } \\
\text { (pom) }\end{array}$ & $\begin{array}{c}N i \\
(\mathrm{ppm})\end{array}$ & $\begin{array}{c}\text { Lo } \\
\text { (ppm) }\end{array}$ & $\begin{array}{c}\mathrm{Fe} \\
\text { (ppm) }\end{array}$ & $\begin{array}{c}\mathrm{Ca} \\
(\mathrm{ppm})\end{array}$ & $\begin{array}{c}\mathrm{Cr} \\
(\mathrm{ppm})\end{array}$ & $\begin{array}{c}\text { Nd } \\
\text { (ppm) }\end{array}$ & $\underset{(p p n)}{U}$ \\
\hline Mean & 0.999 & 0.994 & -0.004 & 101.865 & 105.379 & 0.504 & 0.030 & -0.095 \\
\hline s.o. & 0.002 & 0.002 & 0.003 & 0.303 & 0.374 & 0.001 & 0.008 & 0.064 \\
\hline XR.S.D. & 0.222 & 0.178 & 90.716 & 0.298 & 0.355 & 0.229 & 27.321 & 67.843 \\
\hline
\end{tabular}

\begin{tabular}{|c|c|c|c|c|c|c|c|c|}
\hline & $\begin{array}{c}\mathrm{Ce} \\
\text { (ppm) }\end{array}$ & $\stackrel{\mathrm{Sm}}{\text { (ppm) }}$ & $\begin{array}{c}{ }^{B} \\
\text { (ppm) }\end{array}$ & $\begin{array}{c}p \\
(p p m)\end{array}$ & $\begin{array}{c}\mathbf{s} \\
(\mathrm{ppm})\end{array}$ & $\underset{(p p m)}{\mathrm{Mg}}$ & $\begin{array}{c}\text { As } \\
\text { (ppom) }\end{array}$ & $\begin{array}{c}\text { No } \\
\text { (ppm) }\end{array}$ \\
\hline Mean & -0.067 & 0.001 & 0.518 & 0.033 & -0.034 & 99.387 & 0.011 & 192.552 \\
\hline s.o. & 0.015 & 0.013 & 0.003 & 0.001 & 0.014 & 0.205 & 0.005 & 1.054 \\
\hline$x$ R.5.0. & 21.884 & 1333.488 & 0.544 & 4.168 & 41.955 & 0.207 & 41.492 & 0.547 \\
\hline
\end{tabular}

\begin{tabular}{|c|c|c|c|c|c|}
\hline & $\begin{array}{c}\text { Mo } \\
\text { (Fpm) }\end{array}$ & $\begin{array}{c}\text { Se } \\
\text { (ppm) }\end{array}$ & $\begin{array}{c}\mathrm{Ag} \\
(\mathrm{PPm})\end{array}$ & $\begin{array}{c}\mathrm{Pb} \\
(\mathrm{ppm})\end{array}$ & $\begin{array}{c}r i \\
(\mathrm{ppm})\end{array}$ \\
\hline Mean & 0.004 & -0.009 & 1.021 & 1.006 & -0.000 \\
\hline S.D. & 0.002 & 0.013 & 0.001 & 0.010 & 0.001 \\
\hline X R.S.D. & 43.551 & 139.245 & 0.074 & 0.998 & 319,459 \\
\hline & $\begin{array}{c}M_{n} \\
(\mathrm{ppm})\end{array}$ & $\begin{array}{c}\text { sb } \\
(p p m)\end{array}$ & $\begin{array}{c}v \\
(p p m)\end{array}$ & $\begin{array}{c}\text { Be } \\
\text { (ppm) }\end{array}$ & $\begin{array}{c}\text { TI } \\
\text { (ppm) }\end{array}$ \\
\hline Mean & 0.508 & 0.015 & 0.503 & 0.512 & -0.051 \\
\hline S.D. & 0.002 & 0.002 & 0.001 & 0.001 & 0.033 \\
\hline \% R.S.D. & 0.297 & 15.412 & 0.177 & 0.188 & 65.590 \\
\hline
\end{tabular}


Identity 1: CCV Identity 2: Oulity Control

10:50 AN January 31, 1996

Task name : OPTIMA

Sample Height : 1.0000 Solution volume : $\quad 1.00$

on-Peak Integrations : 3 off-Peak Integrations : 1

WHC-SD-WM-DP-180, REV. 0

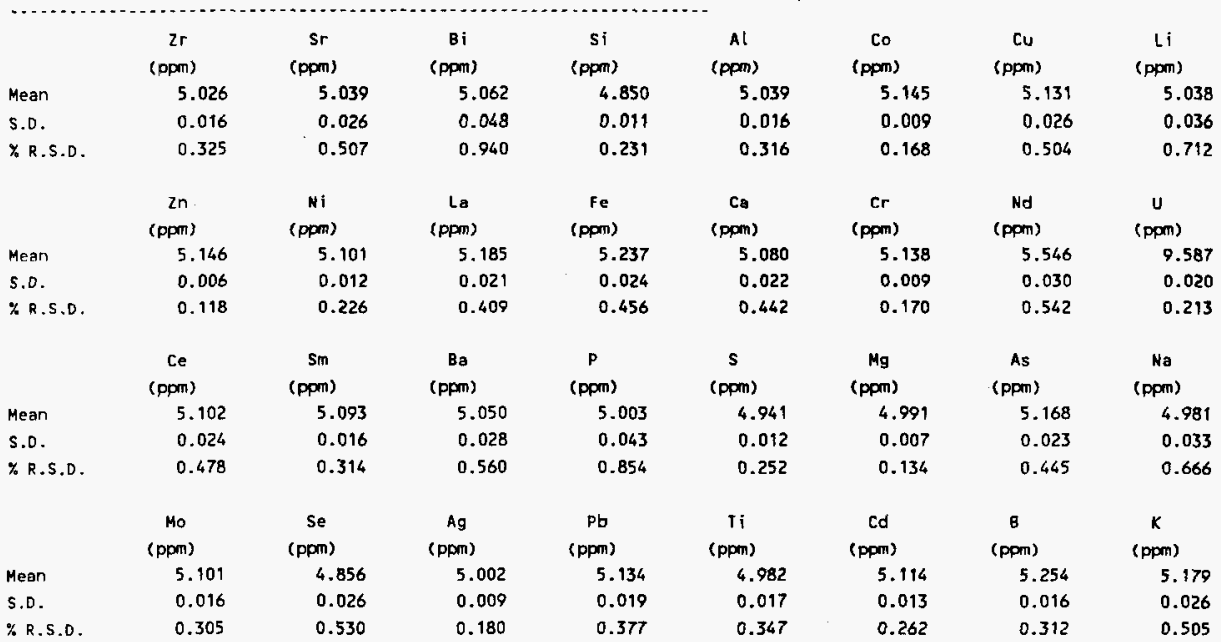

\begin{tabular}{|c|c|c|c|c|c|}
\hline & $\begin{array}{c}\text { Mn } \\
(p p m)\end{array}$ & $\begin{array}{c}\text { sb } \\
(\mathrm{ppm})\end{array}$ & $\begin{array}{c}v \\
\text { (ppm) }\end{array}$ & $\begin{array}{c}\mathrm{Be} \\
\text { (ppom) }\end{array}$ & $\begin{array}{c}T l \\
(\mathrm{pPm})\end{array}$ \\
\hline Mean & 5.115 & 4.874 & 5.174 & 5.239 & 4.928 \\
\hline S.D. & 0.014 & 0.019 & 0.013 & 0.016 & 0.035 \\
\hline F.S.D. & 0.276 & 0.390 & 0.249 & 0.297 & 0.719 \\
\hline
\end{tabular}



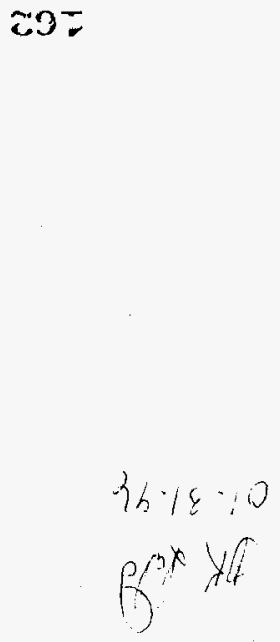

517.91

$900^{\circ} 0$

$920^{\circ} 0-$

(wdd)

$x$

LLサー2E

$700^{\circ} 0$

$110^{\circ} 0$ -

(udd)

eN

$\begin{array}{cc}128 . \angle E & 108^{\circ} 95 \\ 650^{\circ} 0 & 600^{\circ} 0 \\ 551^{\circ} 0 . & 720.0- \\ \text { (udd) } & \text { (udd) } \\ 0 & \text { PN }\end{array}$

956.92

$000 \%$

$100^{\circ} 0-$

(udd)

!?

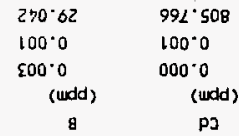

\section{$210^{-09}$}

$200^{\circ} 0$

$500^{\circ} 0$

(udd)

sv

$\angle 85^{\circ} 12$

000.0

$200^{\circ} 0-$

(undd)

nj

607.975

$000^{\circ} 0$

(wodd)

5w

J)

$207 \times 18$

$600 \%$

$700^{\circ} 0$

(urdd)

os

$\begin{array}{ll}E 2 L \angle L & \angle 12^{\circ} L \\ 100 \% 0 & 000 \% \\ 700 \% 0 . & 000 \% \\ \text { (udd) } & \text { (udd) }\end{array}$

ELS* 6

$100^{\circ} 0$

100.0 .

(udd)

$! 1$

as 52

$100^{\circ} 0$

$200^{\circ} 0$ -

(wodd)

$s$

eJ

\section{$622^{*} 72$}

$500^{\circ} 0$

$220^{\circ} 0$.

(udd)

iv

$956^{\circ} 601$
$000 \%$
$000^{\circ} 0$
(udd)
28

$\begin{array}{lc}\angle 00^{\circ} \angle 181 & 955^{\circ} 95 \\ \angle 00^{\circ} 0 & 100^{\circ} 0 \\ 000^{\circ} 0^{-} & 200^{\circ} 0 . \\ \text { (udd) } & \text { (udd) } \\ 9 d & 64\end{array}$

625.65
100.0
$500.0-$
(udd)
$\Lambda$
955.95
100.0
200.0.
(udd)
64

\section{$592^{\circ} 54$}

$500^{\circ} 0$

$500^{\circ} 0$

(udd)

c)

$\S 60^{\circ} 6052$
$500^{\circ} 0$
$000^{\circ} 0$.
(undd)

at

$\varepsilon / 5.69$
800.0
700.0

$700^{\circ} 0$.
(undd)

$970^{\circ} 12$
$000 \%$
$100 \%$
(udd)

917.62

$100^{\circ} 0$

$\$ 00^{\circ} 0$.

(widd)

$\begin{array}{lc}192.922 & 605.57 \\ 950.0 & 000.0 \\ 710^{\circ} 0 . & 000.0- \\ \text { (udd) } & \text { (wdd) } \\ \text { 95 } & \text { WW }\end{array}$

$.0 .2 .8 \%$

0.5

ueaw

un

$\begin{array}{lc}\text { So2. } 111 & 209^{\circ} 97 \\ 500^{\circ} 0 & 100^{\circ} 0 \\ 500^{\circ} 0 & 200^{\circ} 0 \\ \text { (udd) } & \text { (widd) } \\ \text { as } & \text { OW }\end{array}$

$805^{\circ} 282$
$810^{\circ} 0$
$700^{\circ} 0$
(uod)

us

$255^{\circ} 02$
$100^{\circ} 0$
$100^{\circ} 0$
(wedd

in

$850^{\circ} 62 \quad 520^{\circ} 82$

$000^{\circ} 0 \quad 100^{\circ} \mathrm{O}$

$000^{\circ} 0$ -
$7 \varepsilon 2 \div 2$

$510^{\circ} \mathrm{O}$

$550^{\circ} 0-$

(wiodd)

จง

$685^{\circ}<1$
$000 \%$
$100 \%$
(wodd)

uz

$500^{\circ} 0-$

(udd)

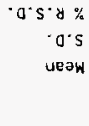

$.0 .2 .4 \%$

- a.s

veaw

IS IS

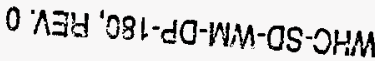

1: : suo!fentajul yead.j10 $\varepsilon$ : suo!les6ajul yead-uo 00\% : senton vo!2njos 0000\% 
Analyst: $\quad \mathrm{SLH}$ Instrument: TIC01

Biook $t+1-1 ;=$

Method: LA-622-102 Rev/Mod C

Worklist Comment: TIC AP-108 25-2

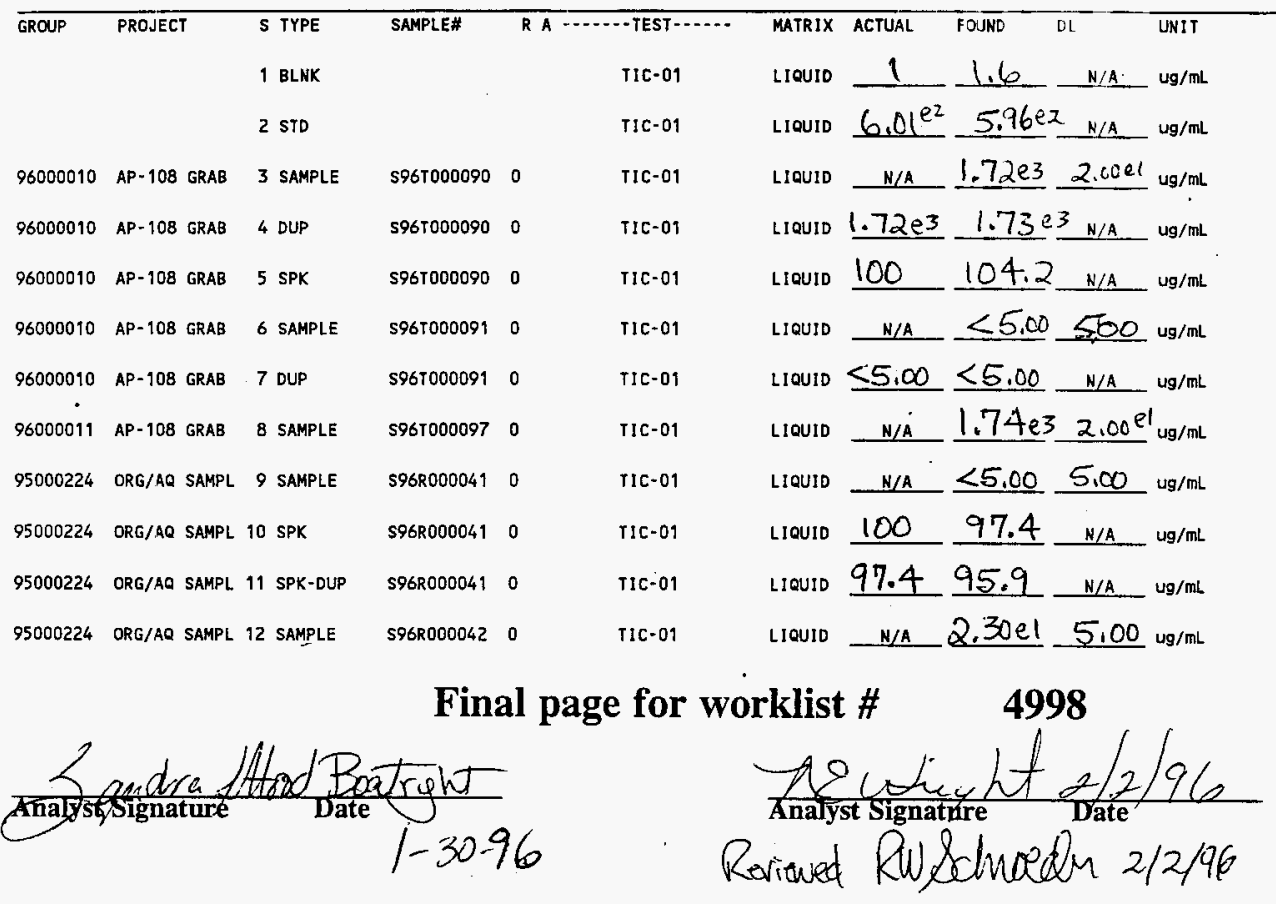

Data Entry Comments:

Units shown for $Q C$ (SPK \& STD) may not reflect the actual units. $D L=$ Detection Limit, $S=$ Worklist Slot Number, $R=$ Replicate Number, $A=$ Aliquot Code. 


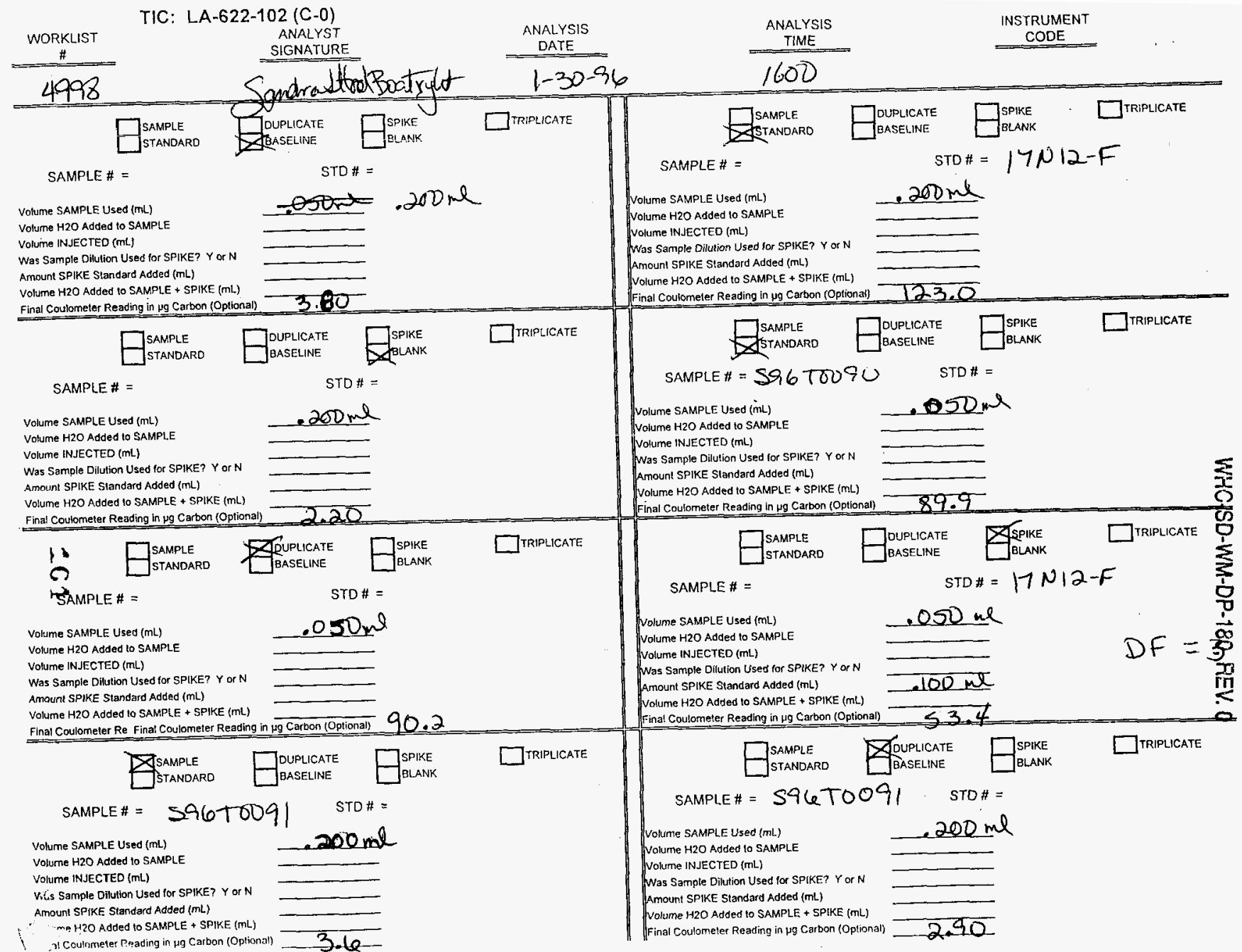


WHC-SD-WM-DP-180, REV. 0

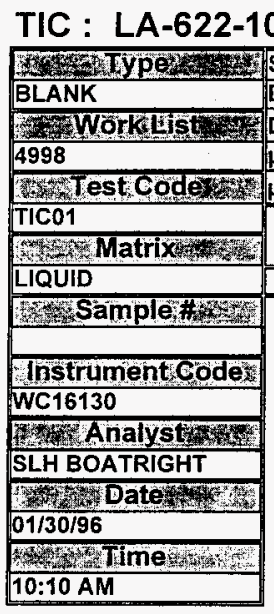

g of Carbon/L

$\mathrm{g}$ of Carbon/L =

pg of Carbon/mL

$\boldsymbol{\theta}$

$\mathrm{g}$ of Carbon/L $1000000 \mu \mathrm{g} / \mathrm{g} / 1000 \mathrm{~m}$

Detection Level $(\mu \mathrm{g} / \mathrm{mL})=1 \mu \mathrm{g} C * \mathrm{DF} \cdot \mathrm{DDF}$

SS

NOTE: Reported Result is Below Detection Level.
(C1-C2) * DF * DDF

SS * 1000
BLANK

(SS)

(DF)
(DDF)

(C1)

(C2) 
WHC-SD-WM-DP-180, REV. 0

\begin{tabular}{|c|c|c|c|}
\hline \multicolumn{3}{|c|}{ LIQUIDS } & STANDARD \\
\hline 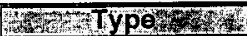 & Sample Volume in $\mathrm{mL}$ & (SS) & 0.200 \\
\hline STANDARD & Dilution Factor & (DF) & 1.000 \\
\hline Work Workist & Digest Dilution Factor & (DDF) & 1.000 \\
\hline 4998 & ug of Carbon in Sample & (C1) & 123 \\
\hline ThTest Coded & pg of Carbon in Blank & (C2) & 3.8 \\
\hline TIC01 & & & \\
\hline W Matrix & & & \\
\hline LIQUID & g of Carbon $/ \mathrm{L}$ & $=$ & $5.96 \mathrm{E}-01$ \\
\hline W Sample & & & \\
\hline 17 N12F & g of Carbon/L. & $\left(C_{1}-C_{2}\right) * D^{*}$ * & DDF \\
\hline Instrument Code & & $S S * 1000$ & \\
\hline WC16130 & & & \\
\hline 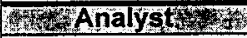 & $\mu g$ of Carbon/mL & g of Carbon/L & $1000000 \mu \mathrm{g} / \mathrm{g} / 1000 \mathrm{~m}$ \\
\hline SLH BOATRIGHT & & & \\
\hline 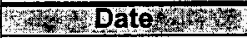 & & & \\
\hline $01 / 30 / 96$ & Detection Level $(\mu \mathrm{g} / \mathrm{mL})=$ & $1 \mu g C * D F * D$ & \\
\hline 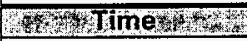 & & ss & \\
\hline 10:10 AM & & & \\
\hline
\end{tabular}

\begin{tabular}{|c|c|c|}
\hline \multirow[t]{2}{*}{ 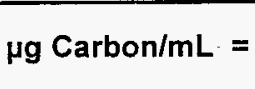 } & \multirow[t]{2}{*}{$5.96 \mathrm{E}+02$} & $\begin{array}{l}\text { DETECTION LEVEL } \\
\text { in } \mu \mathrm{g} / \mathrm{mL}\end{array}$ \\
\hline & & $5.00 \mathrm{E}+00$ \\
\hline
\end{tabular}

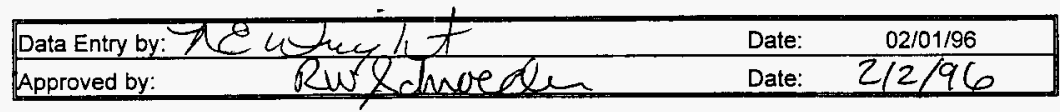

Form 622102_C Rev. $1.1 \quad \ldots 67 \quad$ Page 1 of 1 


\section{WHC-SD-WM-DP-180, REV. 0}

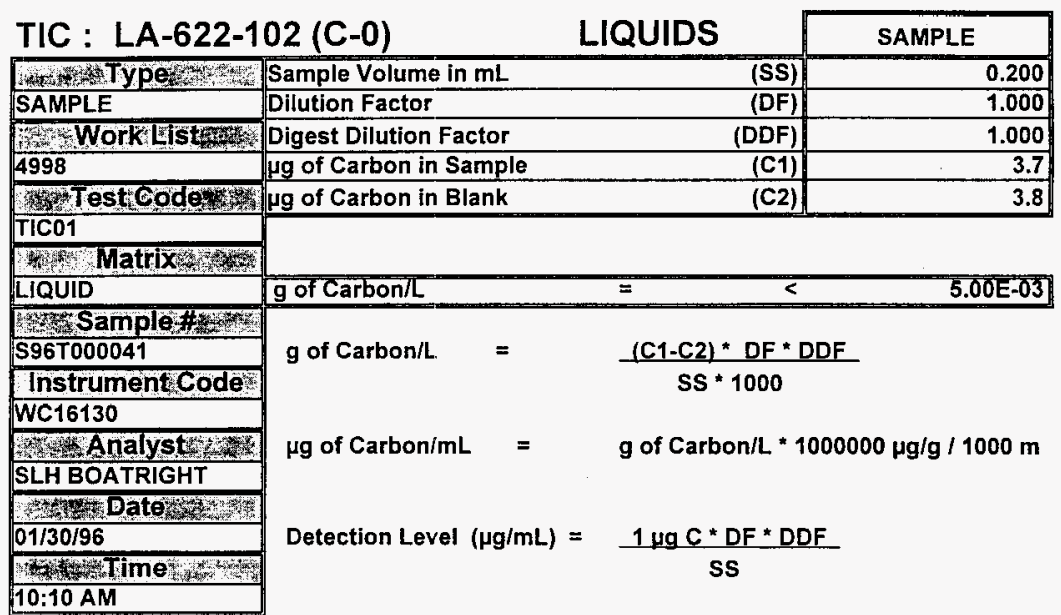

NOTE: Reported Result is Below Detection Level.

\begin{tabular}{c|c|}
$\mu g$ Carbon $/ \mathrm{mL}=\quad<5.00 \mathrm{E}+00$ & $\begin{array}{c}\text { DETECTIONLEVEL } \\
\text { in } \mu \mathrm{g} / \mathrm{mL}\end{array}$ \\
\cline { 2 - 2 } & $5.00 \mathrm{E}+00$ \\
\hline
\end{tabular}

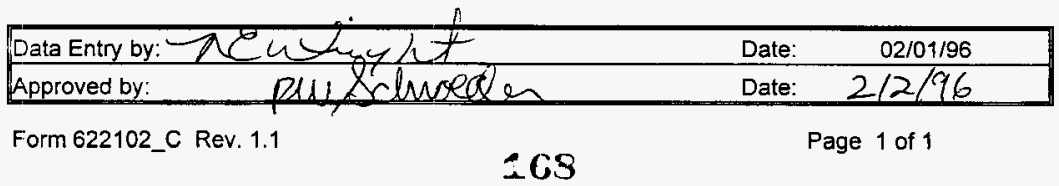




\section{WHO-SD-WM-DP-180, REV. 0}

\section{TIC : LA-622-102 (C-0) SPIKED SAMPLE}

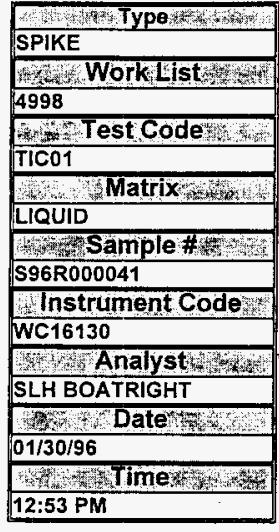

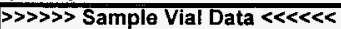
Sample Volume in $\mathbf{m L}$

ug of Carbon in Sample
ug of Carbon in Blank

\begin{tabular}{l|l} 
& 0.2 \\
\hline &
\end{tabular}

\section{PERCENT SPIKE RECOVERY = ug Carbon Recovered from Spike * 100 ug Carbon in Spike}

WHERE : $\mu \mathrm{g}$ Carbon Recovered from Spike =

[ ( $\mu \mathrm{gC}$ in sample + spike - $\mu \mathrm{gC}$ in blank) * (Spike Correction Factor) ]

- [ ( $\mu \mathrm{gC}$ sample - $\mu \mathrm{g} C$ blank) * (Sample Size Correction Factor) ]

Spike Correction Factor =

Sample Size Correction Factor $=$

\section{Iotal volume in spiked sample vial (mL)} Volume injected $(\mathrm{mL})$

Sample size in ( $\mathrm{ml}$ ) in spiked vial Sample size ( $\mathrm{mL}$ ) in sample

WHERE : $\mu g$ Carbon in Spike =

[Spike Value $(\mu \mathrm{g} / \mathrm{mL})$ * Spike Volume $(\mathrm{mL})]$

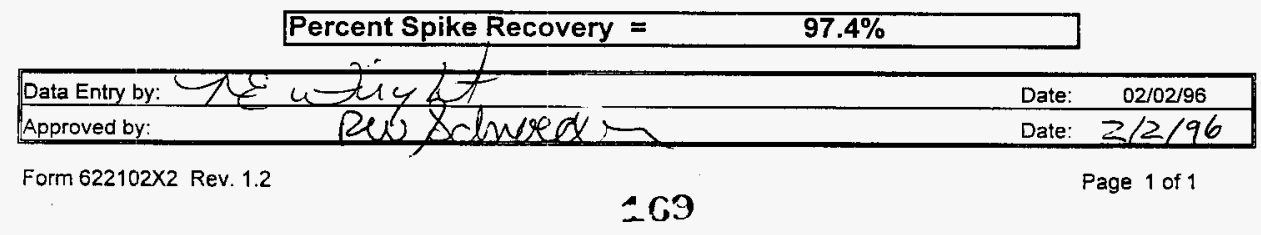




\section{WHC-SD-WM-DP-180, REV. 0}

TIC : LA-622-102 (C-0) SPIKED SAMPLE

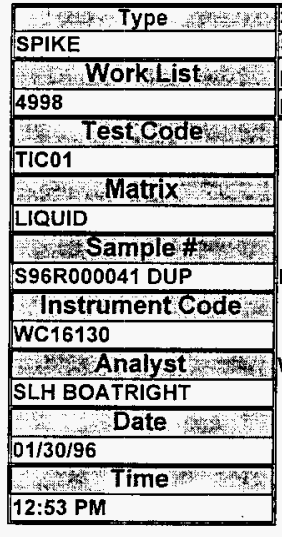

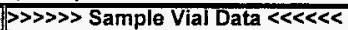
Sample Volume in $\mathrm{mL}$

0.2

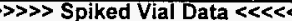

SPIKE

$\mu \mathrm{g}$ of Carbon in Sample
0.200 Sample Volume in $\mathrm{mL}$ 3.7 Spike Volume in $\mathrm{mL}$ ug of Carbon in Blank 3.8 Volume Injected in $\mathrm{mL}$ Spike Value ( $\mathrm{g} / \mathrm{mL}$ ) ug C in Sample + Spike ug $\mathbf{C}$ in Blank 0.200

\section{.} .

\section{PERCENT SPIKE RECOVERY = $\mu g$ Carbon Recovered from Spike *100}

ug Carbon in Spike

WHERE : $\mu g$ Carbon Recovered from Spike =

[ ( $\mu \mathrm{gC}$ in sample + spike - $\mu \mathrm{gC}$ in blank) (Spike Correction Factor) ]

- [ ( $\mu \mathrm{gC}$ sample - $\mu \mathrm{gC}$ blank) " (Sample Size Correction Factor) ]

Spike Correction Factor =

Iotal volume in spiked sample vial $(\mathrm{mL})$ Volume injected $(\mathrm{mL})$

Sample Size Correction Factor $=$

Sample size in (mL) in spiked vial Sample size $(\mathrm{mL})$ in sample

WHERE : $\mu g$ Carbon in Spike =

[Spike Value $(\mu \mathrm{g} / \mathrm{mL})$ ) Spike Volume $(\mathrm{mL})]$

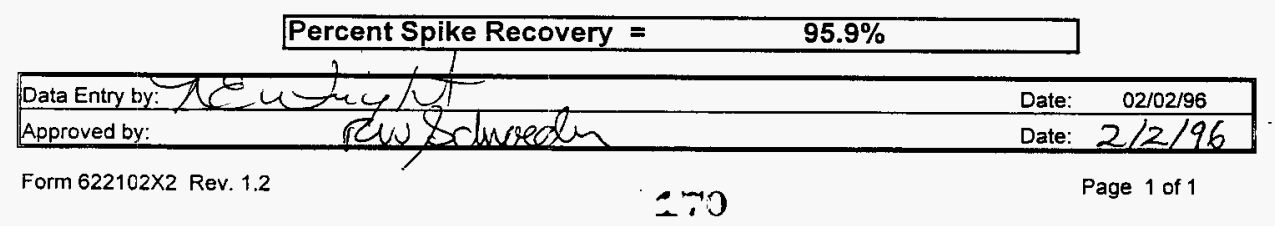


WHC-SD-WM-DP-180, REV. 0

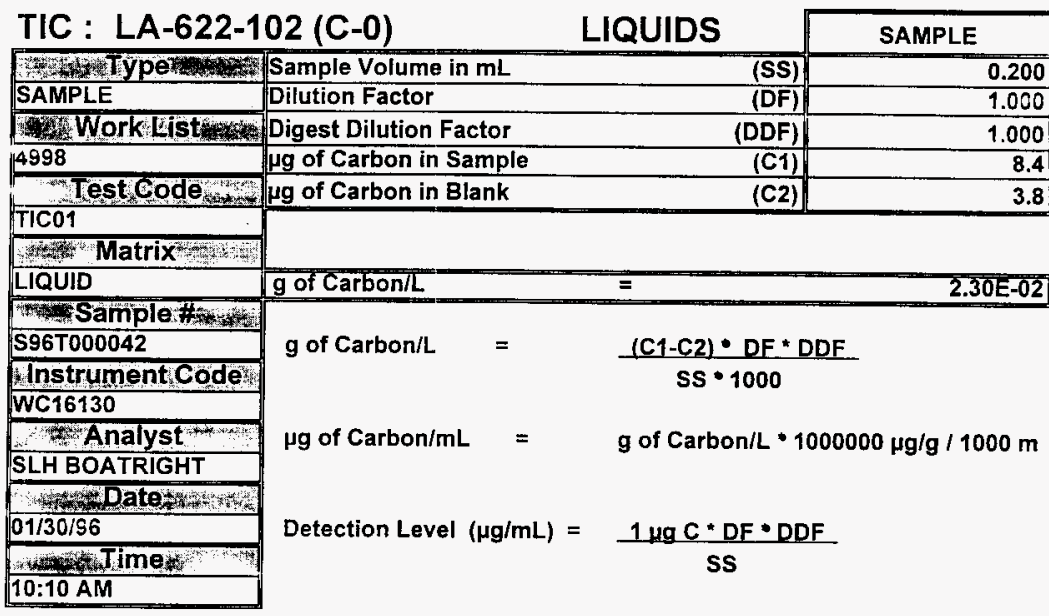

\section{$\mu \mathrm{g}$ Carbon $/ \mathrm{mL}=$}

2.30E+01

DETECTION LEVEL in $\mu \mathrm{g} / \mathrm{mL}$ $5.00 \mathrm{E}+00$

Data Entry by: $\pi$ erstuyt Russchotelen Date: $02 / 01 / 96$

Form 622102_C Rev. 1.1

Date: $2 / 2 / 96$

Form622102_C Rev. 1.1 
WHC-SD-WM-DP-180, REV. 0

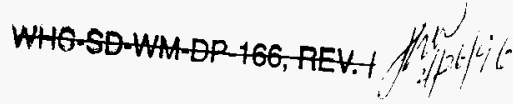

\begin{tabular}{|c|c|c|c|}
\hline TIC : & & LIQUIDS & SAMPLE \\
\hline Type & Sample Volume in $\mathrm{mL}$ & (SS) & 0.200 \\
\hline SAMPLE & Dilution Factor & (DF) & 1.000 \\
\hline WorkLISA & Digest Dilution Factor & (DDF) & 1.000 \\
\hline 4998 & $\mu \mathrm{g}$ of Carbon in Sample & (C1) & 3.7 \\
\hline restcode & ug of Carbon in Blank & (C2) & 3.8 \\
\hline
\end{tabular}

\section{TIC01}

Thatrixy

LIQUID g of Carbon/L

$=<$ 5.00E-03 Samplo * I S96T000041 Thswument code WC16130

$\mathrm{g}$ of Carbon/L =

$\mu \mathrm{g}$ of Carbon $/ \mathrm{mL}=$

Detection Level $(\mu \mathrm{g} / \mathrm{mL})=$ $1 \mu g C^{*} D F$ * DDF SS

NOTE: Reported Result is Below Detection Level.
$<5.00 E+00$

DETECTION LEVEL in $\mu \mathrm{g} / \mathrm{mL}$ $5.00 \mathrm{E}+00$

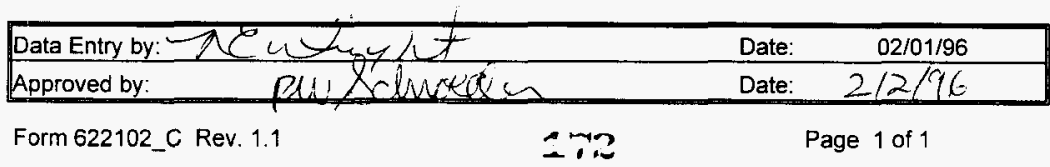


WHC-SD-WM-DP-180, REV. 0

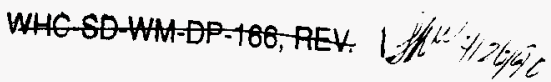

\section{TIC : LA-622-102 (C-0) SPIKED SAMPLE}

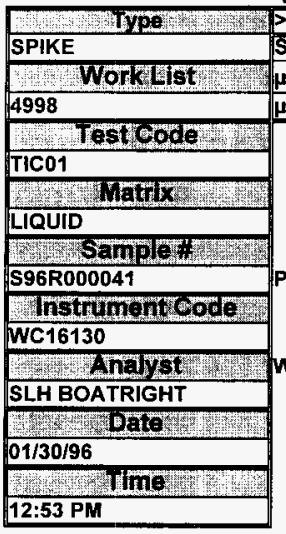

Sample Val Data $\ll \ll<<~$

Sample Volume in $\mathrm{mL}$

$\mu \mathrm{g}$ of Carbon in Sample

ig of Carbon in Blank

1

0.200 Sample Volume in $\mathrm{mL}$

3.7 Spike Volume in $\mathrm{mL}$

3.8 Volume Injected in $\mathrm{mL}$

Spike Value $(\mu \mathrm{g} / \mathrm{mL})$

$\mu g$ C in Sample + Spike

$\mu g \mathrm{C}$ in Blank

SPIKE

PERCENT SPIKE RECOVERY = $\mu g$ Carbon Recovered from Spike * 100

ug Carbon in Spike

WHERE : $\mu g$ Carbon Recovered from Spike =

[ ( $\mu \mathrm{gC}$ in sample + spike - $\mu \mathrm{gC}$ in blank) * (Spike Correction Factor) ]

- [ ( $\mu \mathrm{gC}$ sample - $\mu \mathrm{gC}$ blank) * (Sample Size Correction Factor)]

Spike Correction Factor =

Sample Size Correction Factor =
Total volume in spiked sample vial $(\mathrm{mL})$ Volume injected $(\mathrm{mL})$

Sample size in $(\mathrm{mL})$ in spiked vial Sample size $(\mathrm{mL})$ in sample

WHERE : $\mu g$ Carbon in Spike $=$

[Spike Value $(\mu \mathrm{g} / \mathrm{mL}) *$ Spike Volume $(\mathrm{mL})$ ]

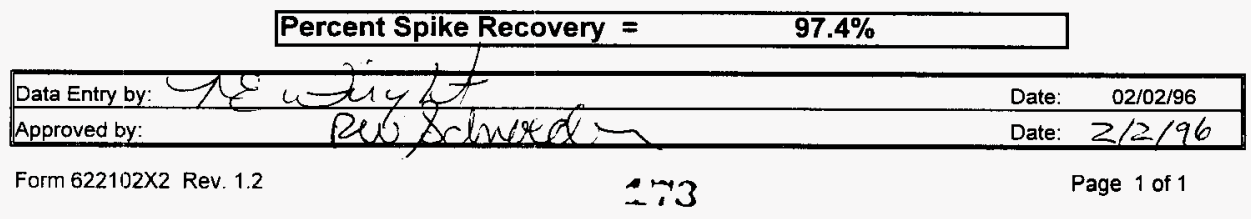


WHC-SD-WM-DP-180, REV. 0

WHG-SQ-WM-DP-166, REV 1 H/\%

TIC : LA-622-102 (C-0) SPIKED SAMPLE

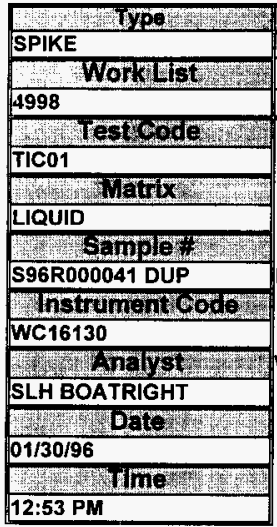

Sample Volume in $\mathbf{m L}$

Data $<\ll<<<$

ug of Carbon in Sample

\begin{tabular}{|l|l|}
\hline ple & \\
\hline &
\end{tabular}

$\mu \mathrm{g}$ of Carbon in Blank

0.20

0.200 Sample Volume in $\mathrm{mL}$

3.7 Spike Volume in $\mathrm{mL}$

3.8 Volume Injected in $\mathrm{mL}$

Spike Value $(\mu \mathrm{g} / \mathrm{mL})$

$\mu \mathrm{g}$ C in Sample + Spike

$\mu g \mathrm{C}$ in Blank

SPIKE

PERCENT SPIKE RECOVERY = $\mu g$ Carbon Recovered from Spike $\star 100$

pg Carbon in Spike

WHERE : $\mu g$ Carbon Recovered from Spike =

[ ( $\mu \mathrm{gC}$ in sample + spike - $\mu \mathrm{gC}$ in blank) * (Spike Correction Factor) ]

-[ ( $\mu g C$ sample - $\mu g C$ blank) * (Sample Size Correction Factor) ]

Spike Correction Factor =

Total volume in spiked sample vial (mL) Volume injected $(\mathrm{mL})$

Sample Size Correction Factor $=\quad$ Sample size in $(\mathrm{mL})$ in spiked vial Sample size $(\mathrm{mL})$ in sample

WHERE : $\mu g$ Carbon in Spike $=$

[Spike Value $(\mu \mathrm{g} / \mathrm{mL})$ * Spike Volume $(\mathrm{mL})]$

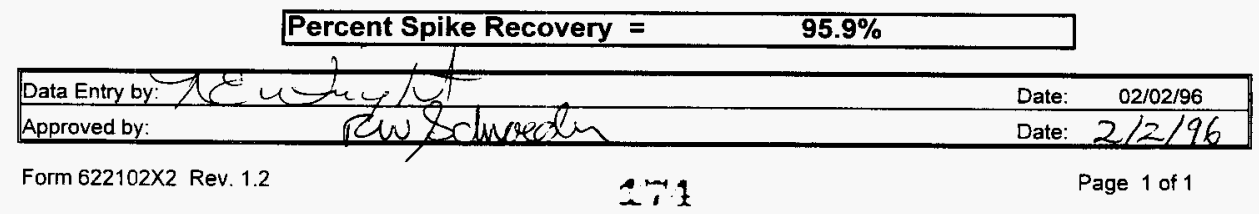


PLACE ANALYTICAL CARD IN BOX BELOW OR ATTACH TRAVELER

$$
\text { WHC-SD-WM-DP-180, REV. } 0
$$

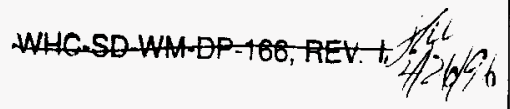

\begin{tabular}{|c|c|c|c|}
\hline \multicolumn{3}{|c|}{ LIQUIDS } & SAMPLE \\
\hline 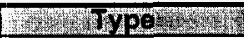 & Sample Volume in $\mathrm{mL}$ & (SS) & 0.200 \\
\hline SAMPLE & Dilution Factor & (DF) & 1.000 \\
\hline 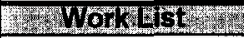 & Digest Dilution Factor & (DDF) & 1.000 \\
\hline 4998 & ug of Carbon in Sample & (C1) & 8.4 \\
\hline 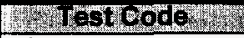 & $\mu g$ of Carbon in Blank & (C2) & 3.8 \\
\hline \multirow{2}{*}{\multicolumn{4}{|c|}{ TIC01 }} \\
\hline & & & \\
\hline LIQUID & \multicolumn{2}{|l|}{ gof Carbon $/ L$} & $2.30 \mathrm{E}-02$ \\
\hline \multirow{2}{*}{$\begin{array}{l}\text { Sampin } \\
\text { S96T000042 }\end{array}$} & \multirow{4}{*}{$\mathrm{g}$ of Carbon/L. } & \multirow{2}{*}{\multicolumn{2}{|c|}{$(C 1-C 2) * D F * D D F$}} \\
\hline & & & \\
\hline Thrument oode & & SS 1000 & \\
\hline WC16130 & & & \\
\hline 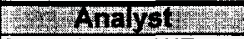 & \multirow[t]{3}{*}{$\mu g$ of Carbon/mL } & \multirow{2}{*}{\multicolumn{2}{|c|}{$\mathrm{g}$ of Carbon/L * $1000000 \mu \mathrm{g} / \mathrm{g} / 1000 \mathrm{~m}$}} \\
\hline SLH BOATRIGHT & & & \\
\hline 6rom & & \multirow{2}{*}{\multicolumn{2}{|c|}{$1 \mathrm{\mu g} C * \mathrm{DF} * \mathrm{DDF}$}} \\
\hline $01 / 30 / 96$ & \multirow[t]{3}{*}{ Detection Level $(\mu \mathrm{g} / \mathrm{mL})=$} & & \\
\hline W & & \multirow[t]{2}{*}{ SS } & \\
\hline 10:10 AM & & & \\
\hline
\end{tabular}

\begin{tabular}{|l|c|}
\hline$\mu g$ Carbon $/ \mathrm{mL}=\quad 2.30 \mathrm{E}+01$ & $\begin{array}{c}\text { DETECTIONLEVEL } \\
\text { in } \mu \mathrm{g} / \mathrm{mL}\end{array}$ \\
\cline { 2 - 2 } & $5.00 \mathrm{E}+00$ \\
\hline
\end{tabular}

\begin{tabular}{lll|}
\hline Data Entry by: Reuzuyt & Date: & $02 / 01 / 96$ \\
\hline Approved by: & Date: & $2 / 2 / 96$ \\
Form 622102_C Rev. 1.1 & & Page 1 of 1
\end{tabular}


Sample: BLK

Sample Size $=200 \mathrm{uL}$ Dil Factor $=1$ Blank ID \# = BLK Blank Value $=\mathrm{N} / \mathrm{A}$
Date: $01 / 30 / 96$

Date: $01 / 30 / 96$

$=$ Readir

$\frac{1}{2}$

3

4

5

6

7

8

9

1.0

11

12

1.3

14
0.51

1.01

1.51

2.01

2. 51

3.01

3.51

4.01

4.50

5.00

5.50

6.00

6.51

7.00
WHC-SD-WM-DP-180, REV. 0

Time: $10: 10: 56$ $\begin{array}{ll}\text { Analyst : } & \text { SL HOOD } \\ \text { Min Readings }= & 14 \\ \text { Max Readings }= & 14 \\ \div \text { Difference }= & 10\end{array}$

Time $====$ Coulometer $=== \pm \div$ Difference $==$

0.20

0.60

0.90

1.30

1.50

1. 90

2.10

2.40

2.60

2.80

3.00

3.30

3.50

3.80
0.00

66.67

33.33

30.77

13.33

21.05

9.52

12.50

7.69

7.14

6.67

9.09

5.71

7.89 


\section{TIC- TOTAL INORGANIC CARBON ANALYSIS REPORT TICTOC REV 2.0 \\ WHC-SD-WM-DP-180, REV. 0}

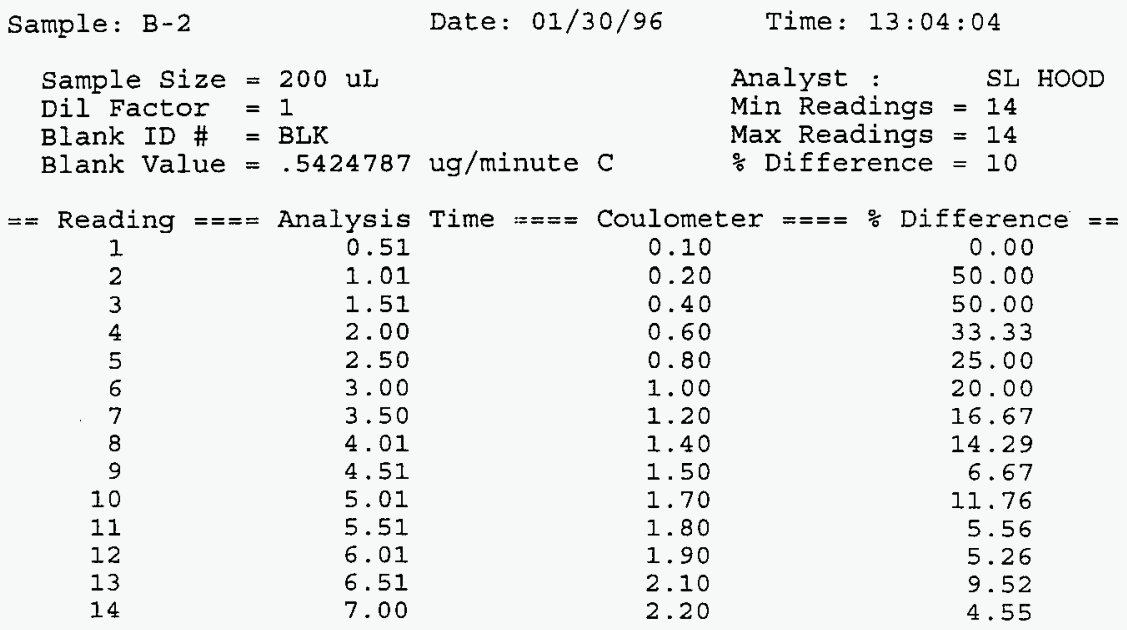

BLANK VALUE $=3.8$ micrograms carbon

BLANK FACTOR $=3.8 / 7.004883=$

+5.4E-01 ug/min Carbon

SAMPLE RESULTS:
$(2.2-3.799967)(1) /(200)$
$<5.00$
$<4.17$
E-3 $\mathrm{g} / \mathrm{L}$ Carbon
E-4 Molar Carbon

Sample Run By:

$\overline{S L ~ H O O D ~} 00000$




\section{TIC- TOTAL INORGANIC CARBON ANALYSIS REPORT \\ TICTOC REV 2.0 \\ WHC-SD-WM-DP-180, REV. 0}

Sample: STD

$\begin{array}{rl}\text { Sample Size }= & 200 \mathrm{uL} \\ \text { Dil Factor }= & 1 \\ \text { Blank ID }=\text { BLK } & \\ \text { Blank Value }= & .5424787 \text { ug/minute } \\ \text { Reading }===\text { Analysis Time === } & 0.51 \\ 1 & 1.01 \\ 2 & 1.51 \\ 3 & 2.01 \\ 4 & 2.51 \\ 5 & 3.01 \\ 6 & 3.51 \\ 7 & 4.01 \\ 8 & 4.51 \\ 9 & 5.01 \\ 10 & 5.51 \\ 11 & 6.01 \\ 12 & 6.51 \\ 13 & 7.00 \\ 14 & \end{array}$

Date: $01 / 30 / 96$

Time: $10: 35: 53$

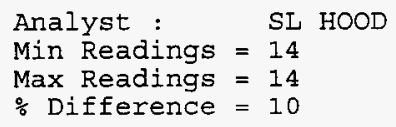

$\begin{array}{cc}\text { Coulometer }===\% \text { Difference }== \\ 0.50 & 0.00 \\ 30.00 & 98.33 \\ 70.40 & 57.39 \\ 97.00 & 27.42 \\ 110.40 & 12.14 \\ 116.70 & 5.40 \\ 119.40 & 2.26 \\ 120.70 & 1.08 \\ 121.30 & 0.49 \\ 121.90 & 0.49 \\ 122.20 & 0.25 \\ 122.50 & 0.24 \\ 122.80 & 0.24 \\ 123.00 & 0.16\end{array}$

BLANK VALUE $=3.8$ micrograms carbon

BLANK FACTOR $=3.8 / 7.004883=$

$+5.4 \mathrm{E}-01 \mathrm{ug} / \mathrm{min}$ Carbon

SAMPLE RESULTS:

$(123-3.799967)(1) /(200)=$

+5.960E-01 g/L Carbon

$(123-3.799967)(1) /(200)(12)=$

$+4.967 E-02$ Molar Carbon

Sample Run By:

\begin{tabular}{ll}
\hline SI HOOD & 00000
\end{tabular} 


\section{TIC- TOTAL INORGANIC CARBON ANALYSIS REPORT \\ TICTOC REV 2.0 \\ WHC-SD-WM-DP-180, REV. 0}

Sample: S96T0041

Sample size $=200 \mathrm{uI}$

Dil Factor $=1$

Blank ID \# = BLK

Blank Value $=.5424787 \mathrm{ug} /$ minute $\mathrm{C}$
Time: 14:02:01

Analyst : SL HOOD

Min Readings $=14$

Max Readings $=14$

$\div$ Difference $=10$

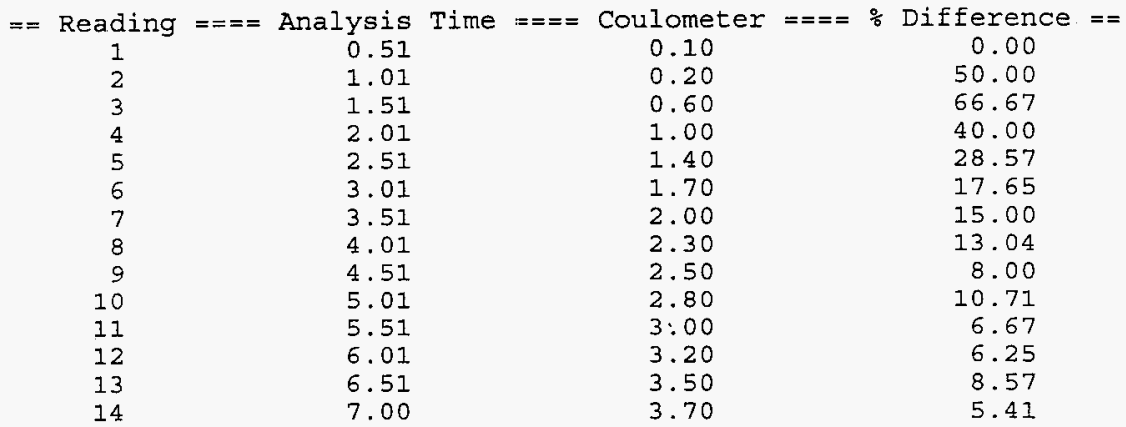

BLANK VALUE $=3.8$ micrograms carbon

BLANK FACTOR $=3.8 / 7.004883=$

+5.4E-01 ug/min Carbon

SAMPLE RESULTS:

$(3.7-3.8)(1) /(200)=$

$<5.00 \mathrm{E}-3 \mathrm{~g} / \mathrm{L}$ Carbon

$<4.17$ E-4 Molar Carbon

Sample Run By:

SL HOOD 00000


TICTOC REV 2.0

WHC-SD-WM-DP-180, REV. 0

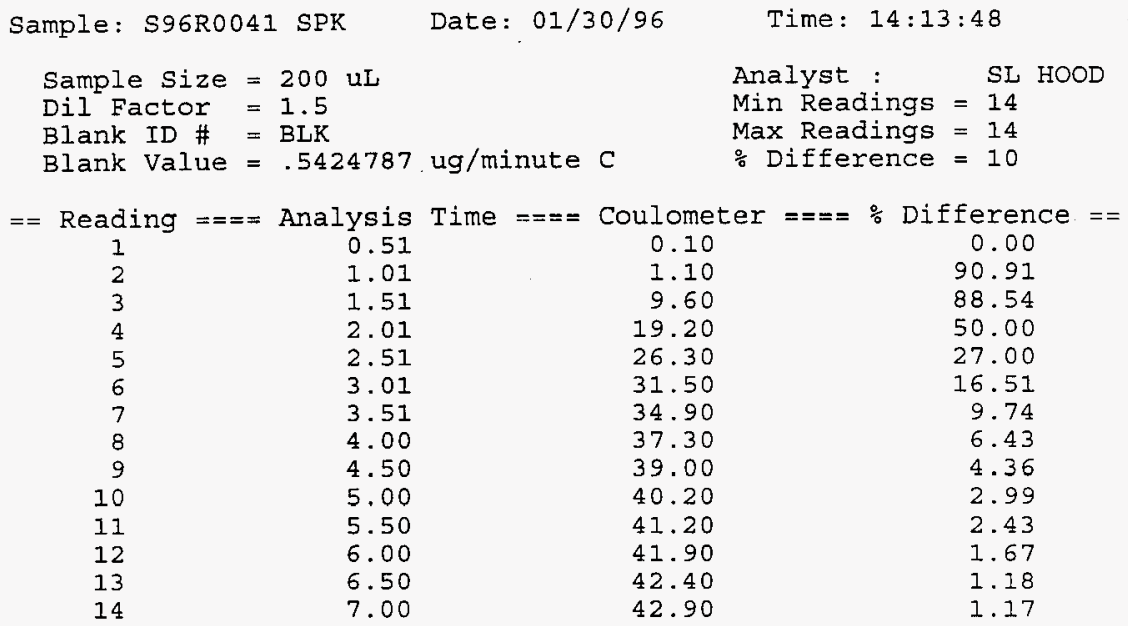

BLANK VALUE $=3.8$ micrograms carbon BLANK FACTOR $=3.8 / 7.004883=+5.4 \mathrm{E}-01 \quad \mathrm{ug} / \mathrm{min}$ Carbon SAMPLE RESULTS:

$(42.9-3.799503)(1.5) /(200)=$

$(42.9-3.799503)(1.5) /(200)(12)=$
$+2.93 E-01$

$+2.44 \mathrm{E}-02$

g/I Carbon

Molar Carbon

Sample Run By: 


\section{TIC- TOTAL INORGANIC CARBON ANALYSIS REPORT \\ TICTOC REV 2.0 \\ WHC-SD-WM-DP-180, REV. 0}

Sample: S96R0041 SPK DUP Date: 01/30/96

Time: $14: 25: 56$

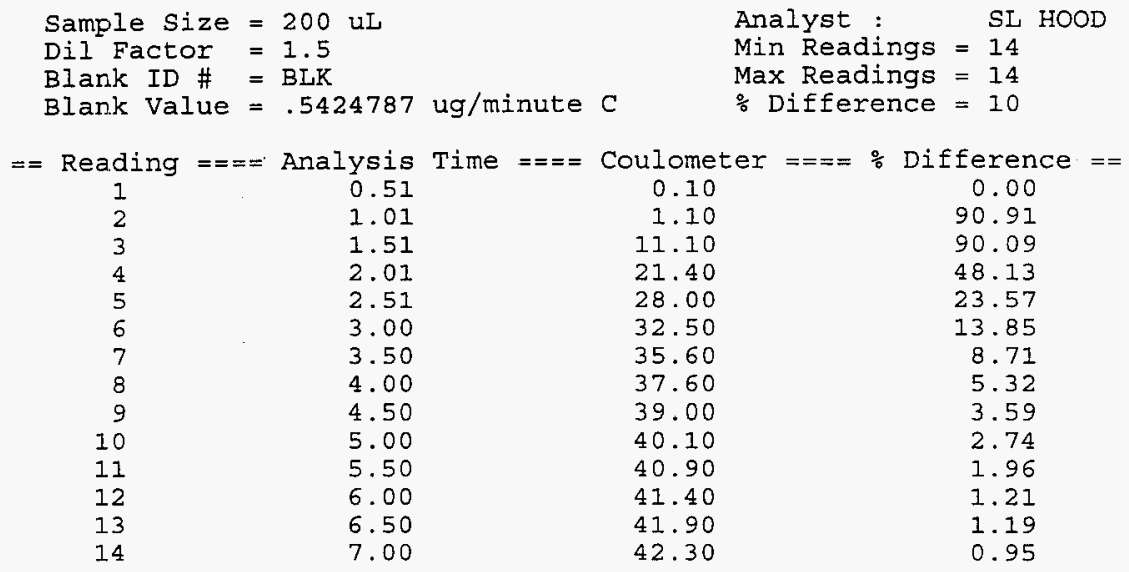

BLANK VALUE $=3.8$ micrograms carbon BLANK FACTOR $=3.8 / 7.004883=+5.4 \mathrm{E}-01 \quad \mathrm{ug} / \mathrm{min}$ Carbon

SAMPLE RESULTS:

$(42.3-3.799536)(1.5) /(200),(12)=$
$(42.3-3.799536)(1.5) /(200)(12)=$

$+2.89 E-01$

g/L Carbon

$+2.41 \mathrm{E}-02$ Molar Carbon

Sample Run By:

\begin{tabular}{ll}
\hline SL HOOD & 00000
\end{tabular} 
Sample: S96R0042

Sample Size $=200 \mathrm{uL}$

Dil Factor $=1$

Blark ID \# = BLK

Blank Value $=.5424787 \mathrm{ug} / \mathrm{minute} \mathrm{C}$
WHC-SD-WM-DP-180, REV 0

Date: 01/30/96 Time: 14:52:56

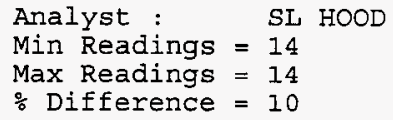

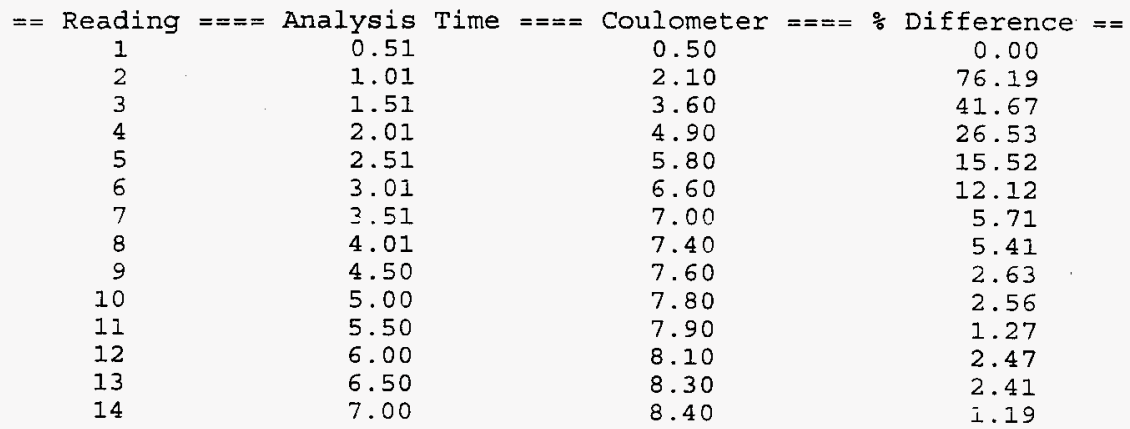

BLANK VALUE $=3.8$ micrograms carbon

BLFAN IRILR $=3.8 / 7.004883=$

$+5.4 \mathrm{E}-01$ ug/min Carbon

SAMPLE RESULTS:
$(8.4-3.799437)(1) /(200)$
$(8.4-3.799437)(I) /(200)(12)=$
$+2.3 E-02$
'I Carbon
$+1.9 \mathrm{E}-03$ Molar Carbon

Sample Run By:

SL HOOD 00000


TIC- TOTAL INORGANIC CARBON ANALYSIS REPORT

\section{WHC-SD-WM-DP-180, REV. 0 \\ TICTOC REV 2.0

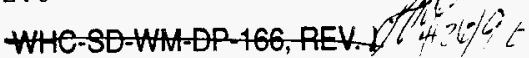

Sample: S96T0041

Date: $01 / 30 / 96$

Time: $14: 02: 01$

Sample Size $=200 \mathrm{uL}$ Dil Factor $=1$

Blank ID \# = BLK

Blank Value $=.5424787 \mathrm{ug} / \mathrm{minute} \mathrm{C}$

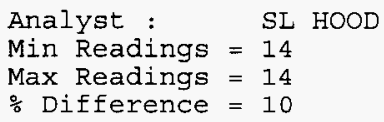

$==$ Reading $====$ Analysis Time $=:==$ Coulometer $===0 \%$ Difference $==$

$\begin{array}{rrrr}1 & 0.51 & 0.10 & 0.00 \\ 2 & 1.01 & 0.20 & 50.00 \\ 3 & 1.51 & 0.60 & 66.67 \\ 4 & 2.01 & 1.00 & 40.00 \\ 5 & 2.51 & 1.40 & 28.57 \\ 5 & 3.01 & 1.70 & 17.65 \\ 7 & 3.51 & 2.00 & 15.00 \\ 8 & 4.01 & 2.30 & 13.04 \\ 9 & 4.51 & 2.50 & 8.00 \\ 10 & 5.01 & 2.80 & 10.71 \\ 1.1 & 5.51 & 3.00 & 6.67 \\ 12 & 6.01 & 3.20 & 6.25 \\ 1.3 & 6.51 & 3.50 & 8.57 \\ 14 & 7.00 & 3.70 & 5.41\end{array}$

BLANK VALUE $=3.8$ micrograms carbon

BLANK FACTOR $=3.8 / 7.004883=$

+5.4E-01 ug/min Carbon

SAMPLE RESULTS:

$(3.7-3.8)(1) /(200)=$

$<5.00$

E-3 g/L Carbon

$<4.17$ E-4 Molar Carbon

Sample Run By:

\begin{tabular}{ll}
\hline SL HOOD & 00000
\end{tabular} 
WHC-SD-WM-DP-180, REV. 0

Sample: S96R0041 SPK

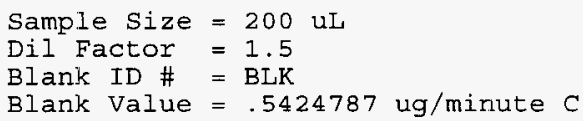

Date: $01 / 30 / 96$

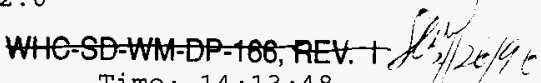

Time: $14: 13: 48$

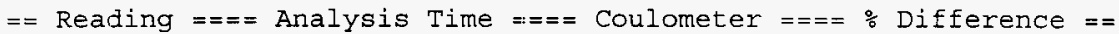

1

2

3

4

5

5

7

B

9

10

11

12

13

14
0.51

1.01

1. 51

2.01

2. 51

3.01

3. 51

4.00

4.50

5.00

5.50

6.00

6.50

7.00
0.10

1. 10

9.60

19.20

26.30

31.50

34.90

37.30

39.00

40.20

41.20

41.90

42.40

42.90
0.00

90.91

88.54

50.00

27.00

16.51

9.74

6.43

4.36

2. 99

2.43

1.67

1. 18

1. 17

BLANK VALUE $=3.8$ micrograms carbon

BLANK FACTOR $=3.8 / 7.004883=$

$+5.4 \mathrm{E}-01 \mathrm{ug} / \mathrm{min}$ Carbon

SAMPLE RESULTS:

$(42.9-3.799503)(1.5) /(200)=$

$(42.9-3.799503)(1.5) /(200)(12)=$

$+2.93 E-01$

g/L Carbon

$+2.44 \mathrm{E}-02$ Molar Carbon

Sample Run By:

\begin{tabular}{ll}
\hline HOOD & 00000
\end{tabular}


WHC-SD-WM-DP-180, REV. 0

Sample: S96R0041 SPK DUP Date: 01/30/96

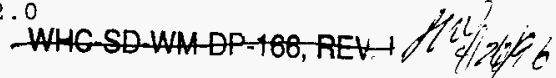

Time: $14: 25: 56$

$$
\begin{array}{ll}
\text { Analyst : } & \text { SL HOOD } \\
\text { Min Readings }= & 14 \\
\text { Max Readings }= & 14 \\
\% \text { Difference }= & 10
\end{array}
$$

$\begin{array}{crcc}\text { Reading }===\text { Analysis } & \text { Time }=== & \text { Coulometer }=== & \text { Difference }== \\ 1 & 0.51 & 0.10 & 0.00 \\ 2 & 1.01 & 1.10 & 90.91 \\ 3 & 1.51 & 11.10 & 90.09 \\ 4 & 2.01 & 21.40 & 48.13 \\ 5 & 2.51 & 28.00 & 23.57 \\ 6 & 3.00 & 32.50 & 13.85 \\ 7 & 3.50 & 35.60 & 8.71 \\ 3 & 4.00 & 37.60 & 5.32 \\ 9 & 4.50 & 39.00 & 3.59 \\ 10 & 5.00 & 40.10 & 2.74 \\ 11 & 5.50 & 40.90 & 1.96 \\ 12 & 6.00 & 41.40 & 1.21 \\ 13 & 6.50 & 41.90 & 1.19 \\ 14 & 7.00 & 42.30 & 0.95\end{array}$

BLANK VALUE $=3.8$ micrograms carbon BLANK FACTOR $=3.8 / 7.004883=$

SAMPLE RESULTS :

$(42.3-3.799536)(1.5) /(200)=$

$(42.3-3.799536)(1.5) /(200)(12)=$

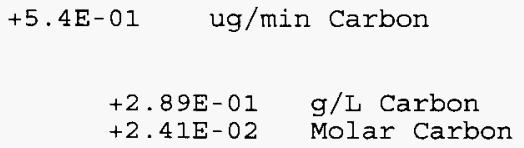

Sample Run By:

\begin{tabular}{ll}
\hline SL HOOD & 00000
\end{tabular} 


\section{TIC- TOTAL INORGANIC CARBON ANALYSIS REPORT \\ TICTOC REV 2.0 \\ WHC-SD-WM-DP-180, REV. 0

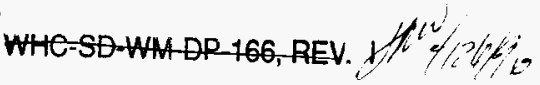

Sample: S96R0042

Sample size $=200 \mathrm{uL}$

Dil Factor $=1$

Blank ID \# = BLK

Blank Value $=.5424787 \mathrm{ug} /$ minute $\mathrm{C}$
Date: $01 / 30 / 96$

Time: $14: 52: 56$

$$
\begin{array}{ll}
\text { Analyst : } & \text { SL HOOD } \\
\text { Min Readings }= & 14 \\
\text { Max Readings }= & 14 \\
\% \text { Difference }= & 10
\end{array}
$$

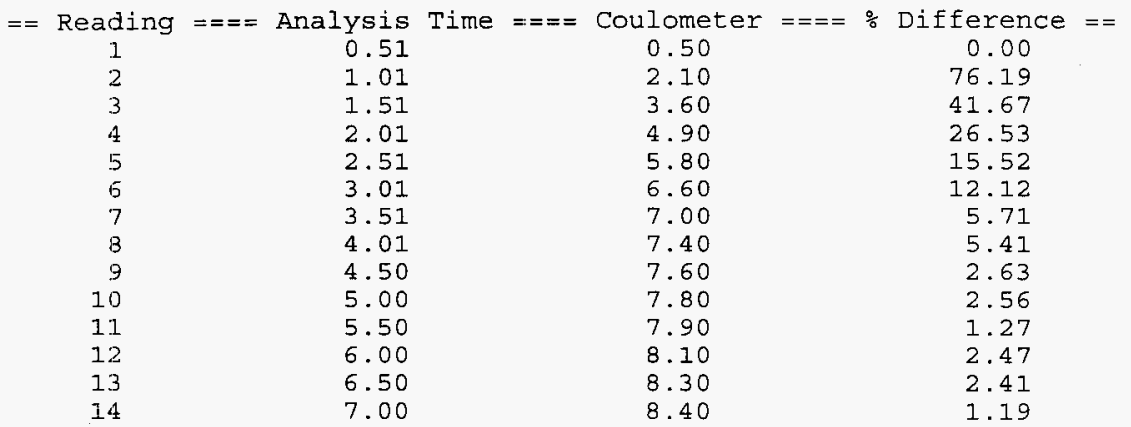

BLANK VALUE $=3.8$ micrograms carbon

BLANK FACTOR $=3.8 / 7.004883=$ +5.4E-01 ug/min Carbon

SAMPLE RESULTS:

$\begin{array}{llll}(8.4-3.799437)(1) /(200) & = & +2.3 E-02 & \mathrm{~g} / \mathrm{L} \text { Carbon } \\ (8.4-3.799437)(1) /(200)(12)= & +1.9 E-03 & \text { Molar Carbon }\end{array}$

Sample Run By:

SI HOOD 00000 


\section{Analyst:

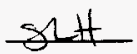 \\ Instrument: TOCO1}

Method: LA-344-105 Rev/Mod $C-O$

Worklist Comment: TOC combustionfap-108 25-2

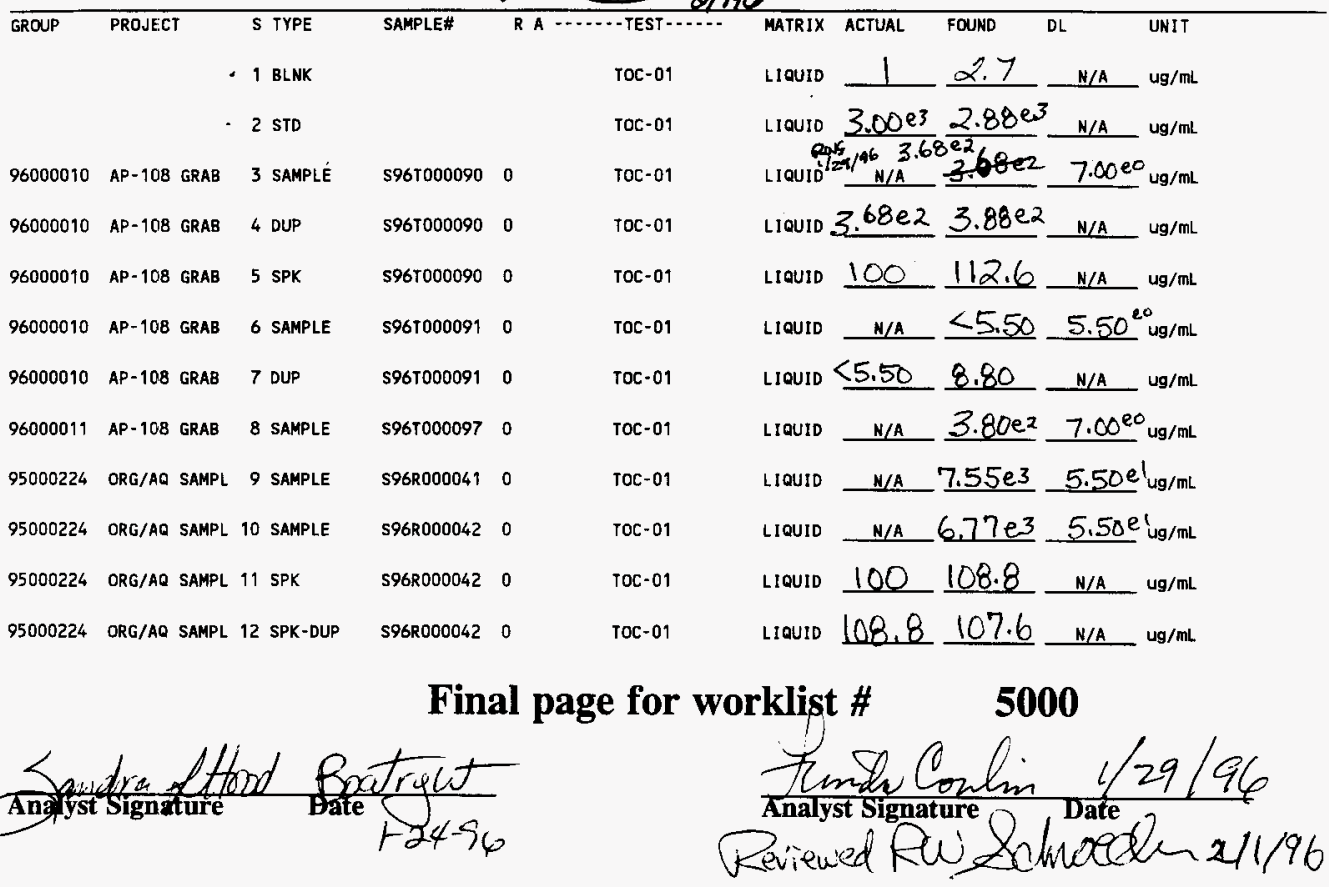

Book \#TOC $16 N / 2-D$

TOK spk INIO-C 


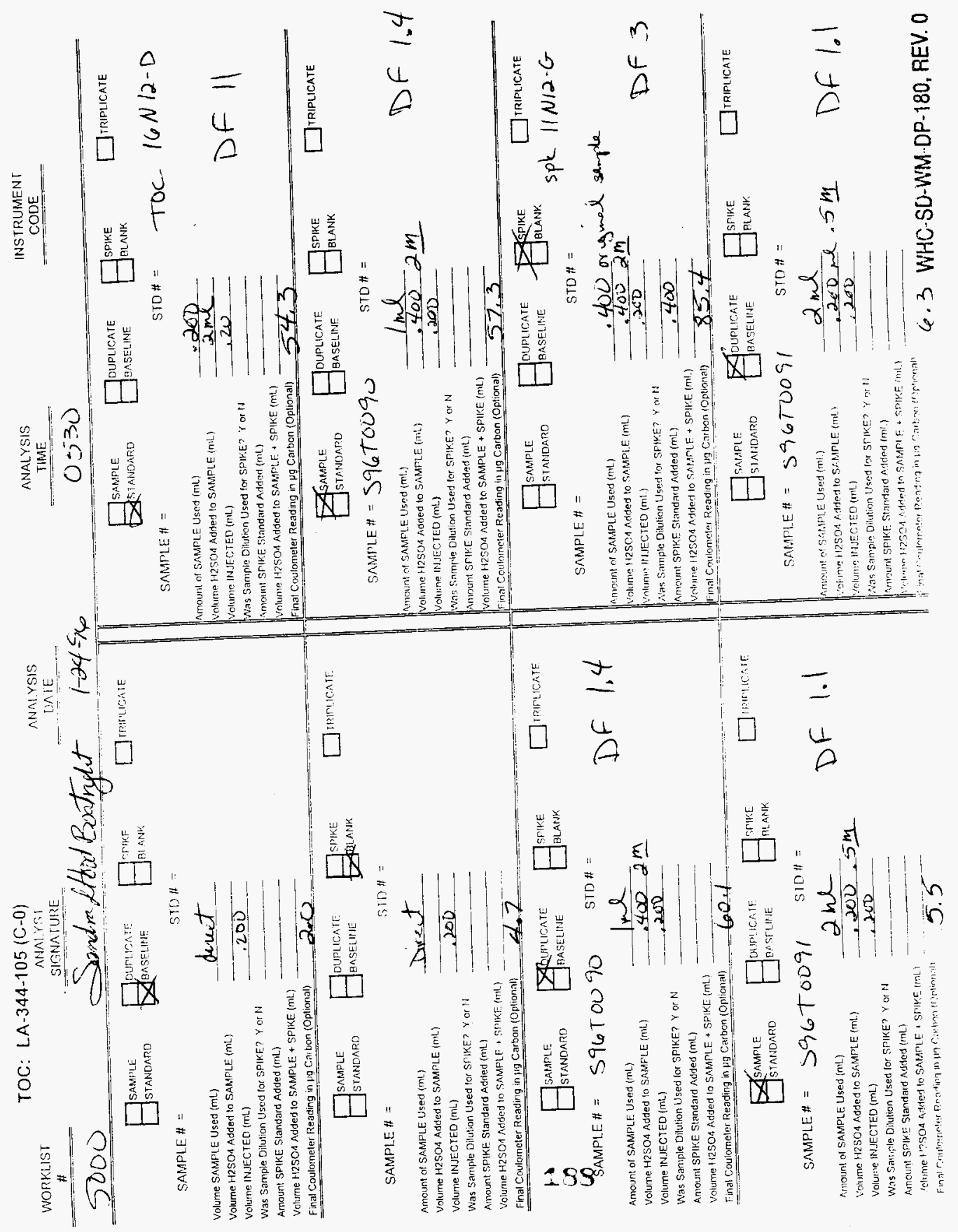




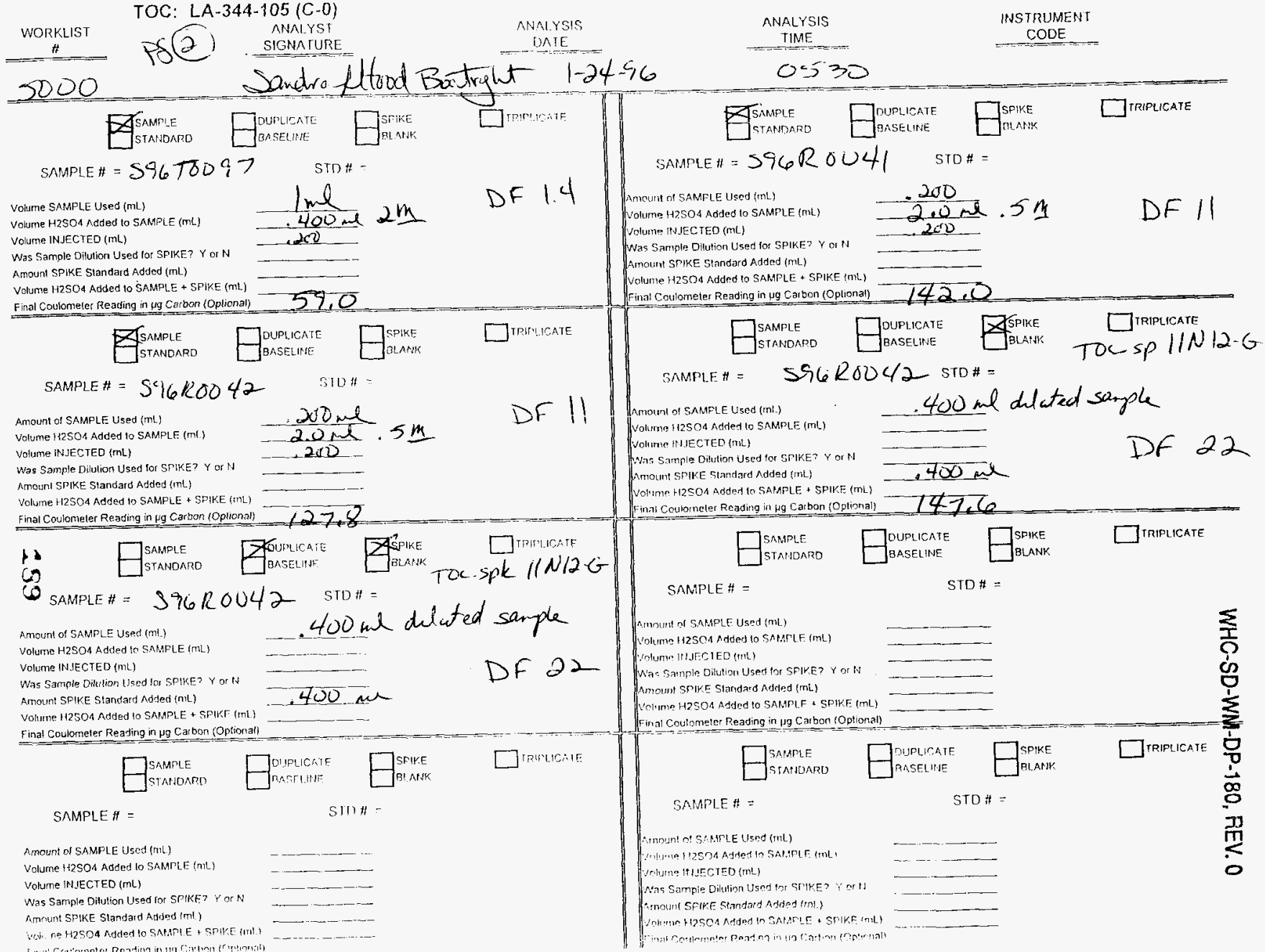




\section{WHC-SD-WM-DP-180, REV. 0}

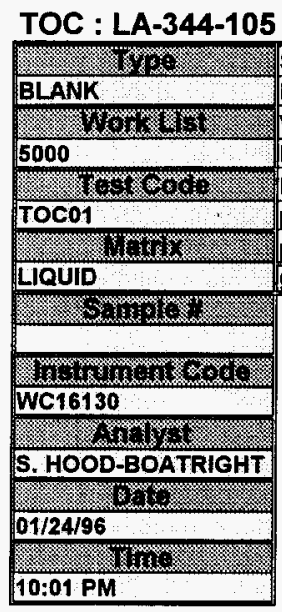

LIQUIDS Sample Volume in $\mathrm{mL}$ H2SO4 Volume in $\mathrm{mL}$ Volume Injected in $\mathrm{mL}$ Dilution Factor

Digest Dilution Factor ug of Carbon in Sample yg of Carbon in Blank g of Carbon/L $=$ $\frac{(C 1-C 2) * D F * D D F}{V I * 1000}$ g of Carbon/L = $\mu \mathrm{g}$ of Carbon $/ \mathrm{mL} \quad=\quad \mathrm{g}$ of Carbon/L $1000000 \mu \mathrm{g} / \mathrm{g} / 1000 \mathrm{~mL} / \mathrm{L}$ Detection Level $(\mu \mathrm{g} / \mathrm{mL})$ $\frac{1 \mu \mathrm{g} C * \mathrm{DF} * \mathrm{DDF}}{\mathrm{VI}}$ (C1) (C2) (Ss) (VR) (VI) (DF) (DDF)

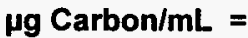 1.35E+01}

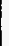


WHC-SiD-WM-DP-180, REV. 0

\begin{tabular}{|c|c|c|c|}
\hline TOC & LIC & & STANDARD \\
\hline $8 \%$ & Sample Volume in $\mathrm{mL}$ & (Ss) & 0.200 \\
\hline STANDARD & H2SO4 Volume in $\mathrm{mL}$ & (VR) & 2000 \\
\hline 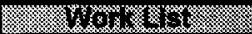 & Volume Injected in $\mathrm{mL}$ & (VI) & 0.200 \\
\hline 5000 & Dilution Factor & (DF) & 11 \\
\hline 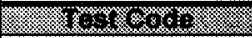 & Digest Dilution Factor & (DDF) & 1 \\
\hline $\mathrm{TOCO1}$ & pg of Carbon in Sample & (C1) & 54.3 \\
\hline 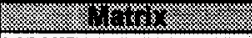 & ug of Carbon in Blank & (C2) & 2 \\
\hline LIQUID & g of Carbon $/ \mathrm{L}$ & $=$ & $2.88 \mathrm{E}+00$ \\
\hline 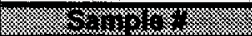 & & & \\
\hline 16N12D & g of Carbon/L & $\left(C_{1}-C_{2}\right)^{*} \mathrm{DF}^{*} \mathrm{DDF}$ & \\
\hline 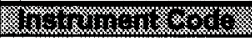 & & $\mathrm{VI} \cdot \mathbf{1 0 0 0}$ & \\
\hline WC16130 & & & \\
\hline . & $\mu g$ of Carbon/mL & $\mathrm{g}$ of Carbon/L * 100000 & $0 \mu g / g / 1000 \mathrm{~mL} / \mathrm{L}$ \\
\hline S. HOOD-BOATRIGHT & & & \\
\hline 48 & & & \\
\hline $01 / 24 / 96$ & Detection Level ( $\mu \mathrm{g} / \mathrm{mL}$ ) & $1 \mu \mathrm{g} C \cdot \mathrm{DF} \cdot \mathrm{DDF}$ & \\
\hline 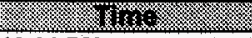 & & VI & \\
\hline 10:01 PM & & & \\
\hline
\end{tabular}

\section{jg Carbon $/ \mathrm{mL}=\quad 2.88 \mathrm{E}+03$}

DETECTION LEVEL in $\mu \mathrm{g} / \mathrm{mL}$ $5.50 \mathrm{E}+01$

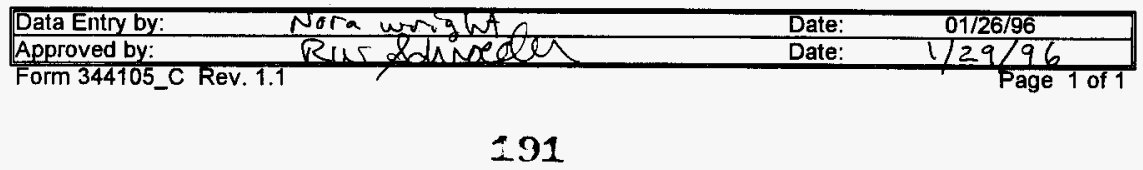


WHC-SD-WM-DP-180, REV. 0

TOC : LA-344-105 (C-0)

\section{LIQUIDS}

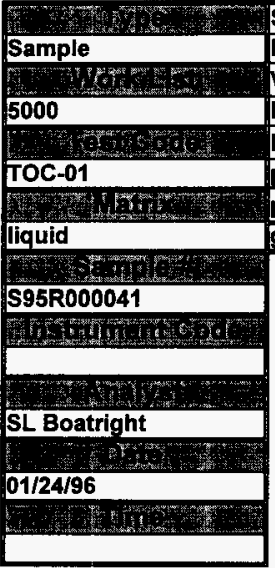

Sample Volume in $\mathrm{mL}$ H2SO4 Volume in $\mathrm{mL}$

Volume Injected in $\mathrm{mL}$ Dilution Factor

Digest Dilution Factor

ug of Carbon in Sample

\begin{tabular}{|r|r|}
\cline { 2 - 2 } \multicolumn{1}{c|}{} & \multicolumn{1}{|c|}{ Sample } \\
\hline (SS) & 0.200 \\
\hline (VR) & 2.000 \\
\hline (Vl) & 0.200 \\
\hline (DF) & 11 \\
\hline (DDF) & 1 \\
\hline (C1) & 142 \\
\hline (C2) & 4.7 \\
\hline
\end{tabular}

$\mu g$ of Carbon in Blank g of Carbon/L

$=$

$g$ of Carbon $/ L=\frac{\left(C_{1}-C_{2}\right) * \text { DF } * \text { DDF }}{V I * 1000}$

$\mu \mathrm{g}$ of Carbon $/ \mathrm{mL}=g$ of Carbon/L* $1000000 \mu \mathrm{g} / \mathrm{g} / 1000 \mathrm{~mL} / \mathrm{L}$

Detection Level $(\mu \mathrm{g} / \mathrm{mL})=1 \mu \mathrm{g} C$ * DF * DDF

VI

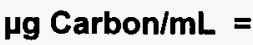

$7.55 \mathrm{E}+03$

DETECTION LEVEL in $\mu \mathrm{g} / \mathrm{mL}$ $5.50 \mathrm{E}+01$

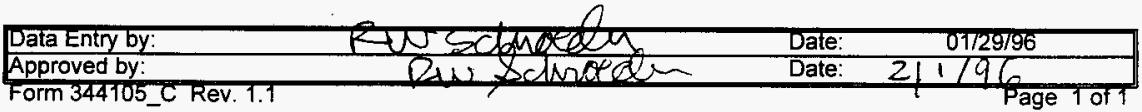


WHC-SD-WM-DP-180, REV. 0

TOC : LA-344-105 (C-0)

LIQUIDS

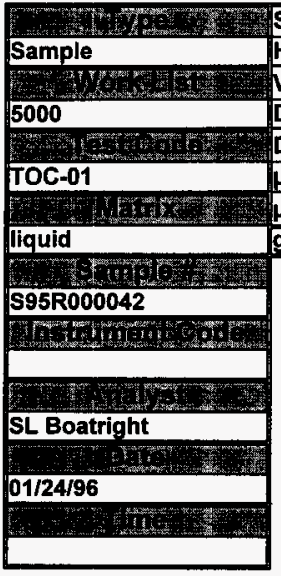

Volume in $\mathrm{mL}$ 2SO4 Volume in $\mathrm{mL}$

Volume Injected in $\mathrm{mL}$

Dilution Factor

Digest Dilution Factor ug of Carbon in Sample

(DF)

(VR)

0.200

$\mu g$ of Carbon in Blank $\mathrm{g}$ of Carbon/L

(C1)

(C2)

\section{Sample}

SS)

2.000

(V)

0.200

$\mathrm{g}$ of Carbon $/ \mathrm{L}=\frac{\left(\mathrm{C} 1-\mathrm{C}_{2}\right) * \mathrm{DF} * \mathrm{DDF}}{\mathrm{VI} * 1000}$

$\mu g$ of Carbon $/ \mathrm{mL}=g$ of Carbon $/ \mathrm{L} * 1000000 \mu \mathrm{g} / \mathrm{g} / 1000 \mathrm{~mL} / \mathrm{L}$

Detection Level $(\mu \mathrm{g} / \mathrm{mL})=\frac{1 \mu \mathrm{g} C \cdot \mathrm{DF} \cdot \mathrm{DDF}}{\mathrm{VI}}$

$\mu g$ Carbon $/ \mathrm{mL}=\quad 6.77 E+03$

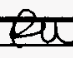

स्u

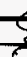

5 3

\section{ज्ञकी} Approved by: Form 344105_C Rev. 1.1
Date: Date: $07 / 29 / 96$ DETECTION LEVEL in $\mathbf{\mu g} / \mathrm{mL}$ 5.50E+01

127.8

4.7




\section{WHC-SD-WM-DP-180, REV. 0}

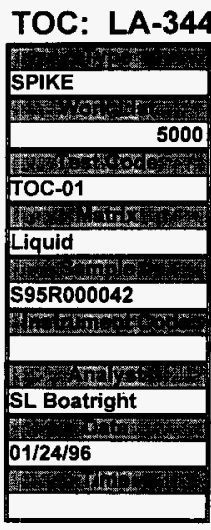

PERCENT SPIKE RE = $\mu$ g Carbon Recovered from Spike * 100 $\mu \mathrm{g}$ Carbon in Spike

WHERE : $\mu g$ Carbon Recovered from Spike $=$

[ ( $\mu g C$ in sample + spike - $\mu g C$ in blank) * (Spike Correction Factor) ]

- [ ( $\mu_{0} \mathrm{C}$ eample - $\mu_{0} \mathrm{C}$ blank) * (Sampla Correctlon Factor) * (Sample Size Correction Factor) * (PDF) ]

Spike Correction Factor $=$

Total volume in spiked sample vial $(\mathrm{mL})$

volume injected $(\mathrm{mL})$

Sample Correction Factor $=$

Total volume in sample vial $(\mathrm{mL})$

Volume injected $(\mathrm{mL})$

Sample Size Correction Factor $=$

Sample size in $(\mathrm{mL})$ in spiked vial

Sample size $(\mathrm{mL})$ in sample

Sample Pre-Spike Dilution Factor $=$ 1

Dilution of Sample Before Added to Spike Vial

WHERE : $\mu g$ Carbon in Spike $=$ Spike Value $(\mu \mathrm{g} / \mathrm{mL}) *$ Spike Volume $(\mathrm{mL})$

\section{Percent Spike Recovery $108.8 \%$}

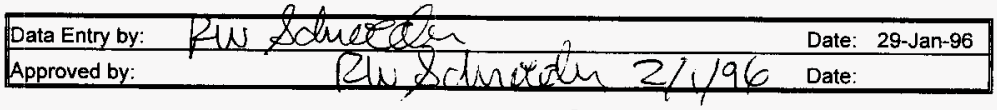




\section{WHC-SO-WWG-DP-180, REV. 0}

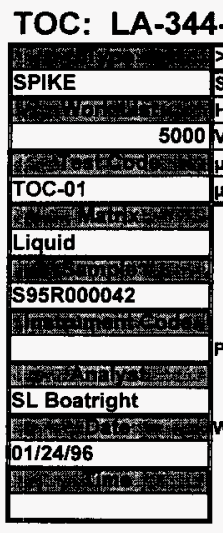

SPIKED SAMPLE

SPIKE

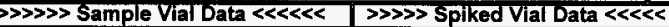

\begin{tabular}{|l|l|l|}
\hline Sample Volume in $\mathrm{mL}$ & 0.200 & $\mathbf{0 . 4 0 0}$ \\
\hline
\end{tabular}

2304 Volumg in $\mathrm{mL}$

2.000 Spike Volume in $\mathrm{mL}$

0.200 H2SO4 Volume in $\mathrm{mL}$

127.8 Volume Injected in $\mathrm{mL}$

jg of Carbon in Sample

4.7 Sample Pre-Spike Dil. Factor (PDF)

Spike Value $(\mu \mathrm{g} / \mathrm{ml})$

$\mu \mathrm{g} C$ in Sample + Spike

$\mu \mathrm{g} C$ in Blank

PERCENT SPIKE RE = ug Carbon Recovered from Spike * 100 ug Carbon in Spike

WHERE : $\mu g$ Carbon Recovered from Spike =

[ ( $\mu \mathrm{gC}$ in sample + spike - $\mu \mathrm{gC}$ in blank) * (Spike Correction Factor) ]

- [ (wgC sampla - mgC biank) * (Sample Correction Factor) * (Smmple Size Correction Factor) * (PDF)]

Spike Correction Factor $=$

Total volume in spiked sample vial $(\mathrm{mL})$

Volume injected (mL)

Sample Correction Factor $=$

Total volume in sample vial $(\mathrm{mL})$

Volume injected $(\mathrm{mL})$

Sample Size Correction Factor $=$

Sample size in ( $\mathrm{mL}$ ) in spiked vial

Sample size $(\mathrm{mL})$ in sample

Sample Pre-Spike Dilution Factor $=$ 1

Dilution of Sample Before Added to Spike Vial

WHERE : $\mu g$ Carbon in Spike = Spike Value $(\mu \mathrm{g} / \mathrm{mL})$ * Spike Volume $(\mathrm{mL})$

\section{Percent Spike Recovery $107.6 \%$}

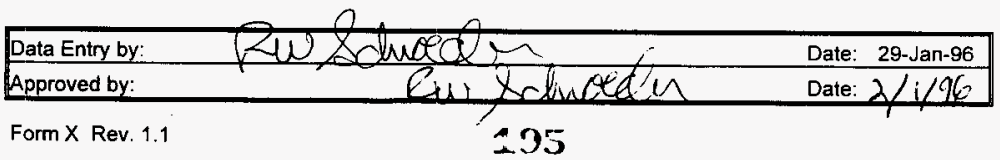


WHC-SD-WM-DP-180, REV. 0

\section{TOC- TOTAL ORGANIC CARBON ANALYSIS REPORT \\ TICTOC REV 2.0 \\ $\ll$ BLANK ANALYSIS $\gg>$}

Sample: BLK

$$
\begin{aligned}
& \text { Sample Size }=200 \mathrm{uL} \\
& \text { Dil Factor }=1 \\
& \text { Blank ID\# }=\mathrm{BLK} \\
& \text { Blank Value }=\mathrm{N} / \mathrm{A}
\end{aligned}
$$

Date: $01 / 23 / 96$

Time: $22: 01: 07$

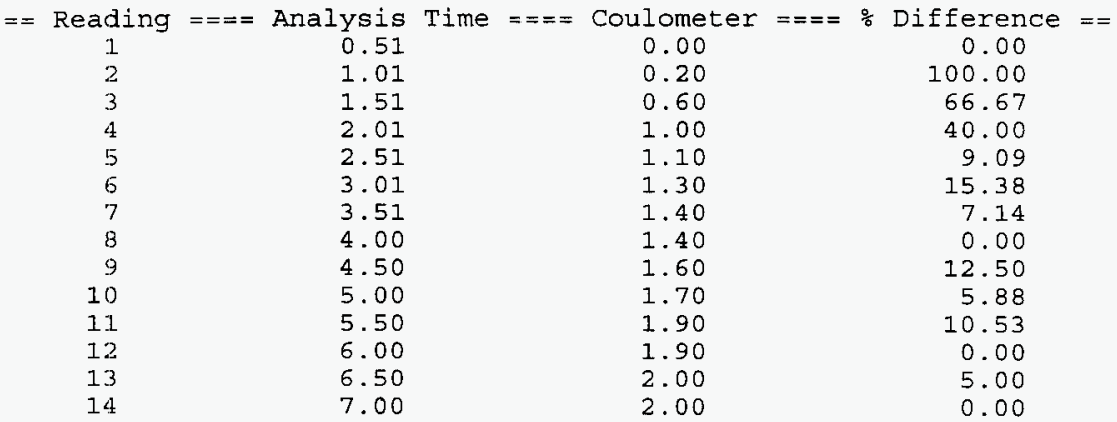


WHC-SD-WM-DP-180, REV. 0

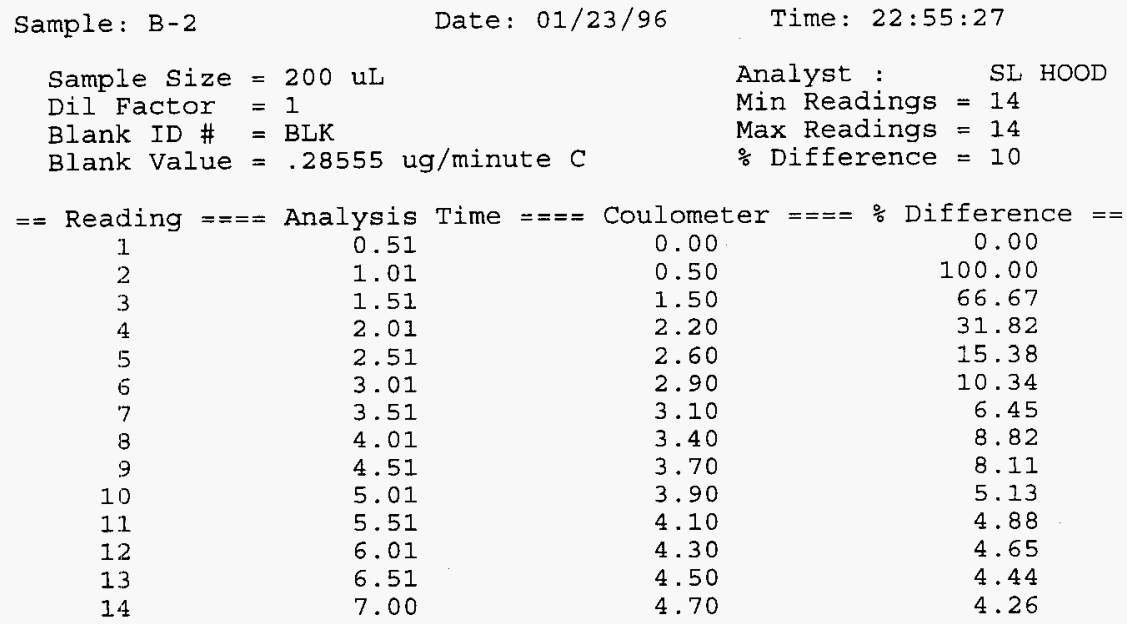

BLANK VALUE $=2$ micrograms carbon

BLANK FACTOR $=2 / 7.004028=$

$+2.9 \mathrm{E}-01 \quad u g / \mathrm{min}$ Carbon

SAMPLE RESULTS :
$(4.7-2.000244)(1) /(200)$
$+1.3 \mathrm{E}-02$
g/L Carbon
$(4.7-2.000244)(1) /(200)(12)=$
$+1.1 \mathrm{E}-03$
Molar Carbon

Sample Run By:

SL HOOD 00000 
TOC- TOTAL ORGANIC CARBON ANALYSIS REPORT

\section{TICTOC REV W'AC-SD-WM-DP-180, REV. 0}

Sample: STD

Sample Size $=200 \mathrm{uL}$

Dil Factor $=11$

Blank ID \# = BLK

Blank Value $=.28555 \mathrm{ug} /$ minute $\mathrm{C}$
Time: $22: 45: 23$

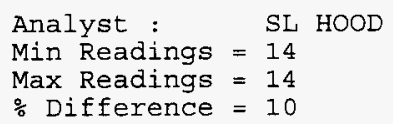

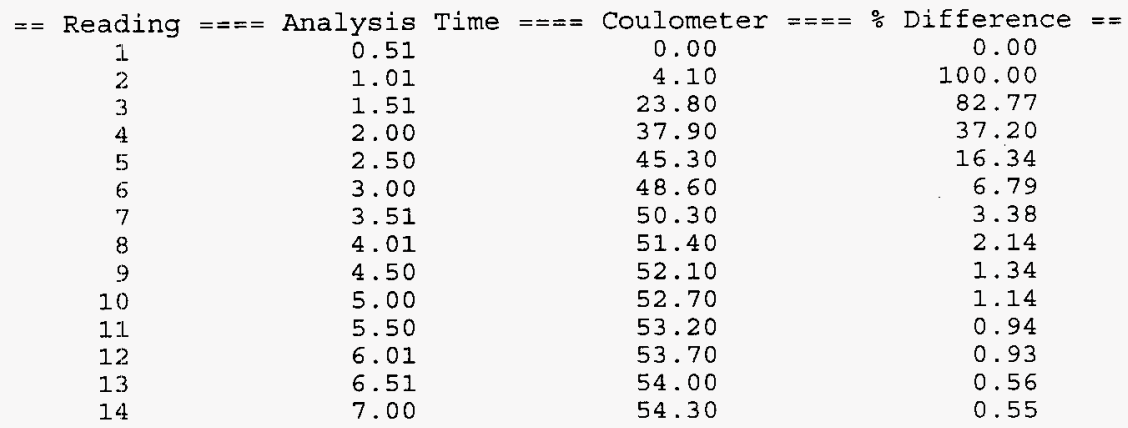

BLANK VALUE $=2$ micrograms carbon

BLANK FACTOR $=2 / 7.004028=+2.9 \mathrm{E}-01 \quad \mathrm{ug} / \mathrm{min}$ Carbon

SAMPLE RESULTS:

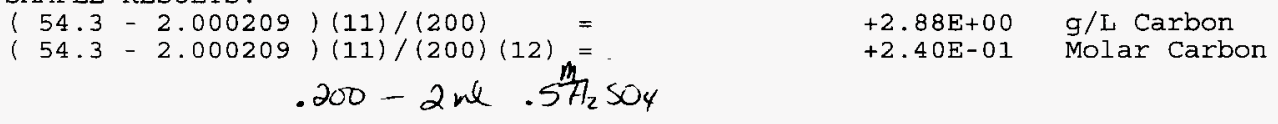

Sample Run By:

$\overline{S L ~ H O O D ~} 00000$ 
WHC-SD-WM-DP-180, REV. 0

Sample: S96R000041

Sample Size $=200 \mathrm{uL}$

Dil Factor $=11$

Blank: ID \# = BLK

Blank: Value $=.28555 \mathrm{ug} / \mathrm{minute} \mathrm{C}$
Time: $03: 33: 48$

$\begin{array}{crcc}\text { Reading }===\text { Analysis } & \text { Time }=== & \text { Coulometer }==+\% & \text { Difference }== \\ 1 & 0.51 & 0.60 & 0.00 \\ 2 . & 1.01 & 44.60 & 98.65 \\ 3 & 1.51 & 86.60 & 48.50 \\ 4 & 2.00 & 101.60 & 14.76 \\ 5 & 2.50 & 112.20 & 9.45 \\ 6 & 3.01 & 119.80 & 6.34 \\ 7 & 3.51 & 125.30 & 4.39 \\ 8 & 4.01 & 129.40 & 3.17 \\ 9 & 4.50 & 132.50 & 2.34 \\ 10 & 5.00 & 135.20 & 2.00 \\ 11 & 5.50 & 137.40 & 1.60 \\ 12 & 6.00 & 138.90 & 1.08 \\ 13 & 6.50 & 140.70 & 1.28 \\ 14 & 7.00 & 142.00 & 0.92\end{array}$

BLANK VALUE $=2$ micrograms carbon

BLANK FACTOR $=2 / 7.004028=$

+2.9E-01 ug/min Carbon

SAMPLE RESULTS:

$(142-1.999991)(11) /(200)=$

$+7.700 \mathrm{E}+00 \mathrm{~g} / \mathrm{L}$ Carbon

$(142-1.999991)(11) /(200)(12)=$

$+6.417 \mathrm{E}-01$ Molar Carbon

$.200 \mathrm{ml}+2.0 \mathrm{ml} .5 \mathrm{~m} \mathrm{H}_{2} \mathrm{SO}$

Sample Run By:

\begin{tabular}{ll}
\hline SL HOOD & 00000
\end{tabular}




\section{TICTOC REV WHCO-SD-WM-DP-180, PEV. 0}

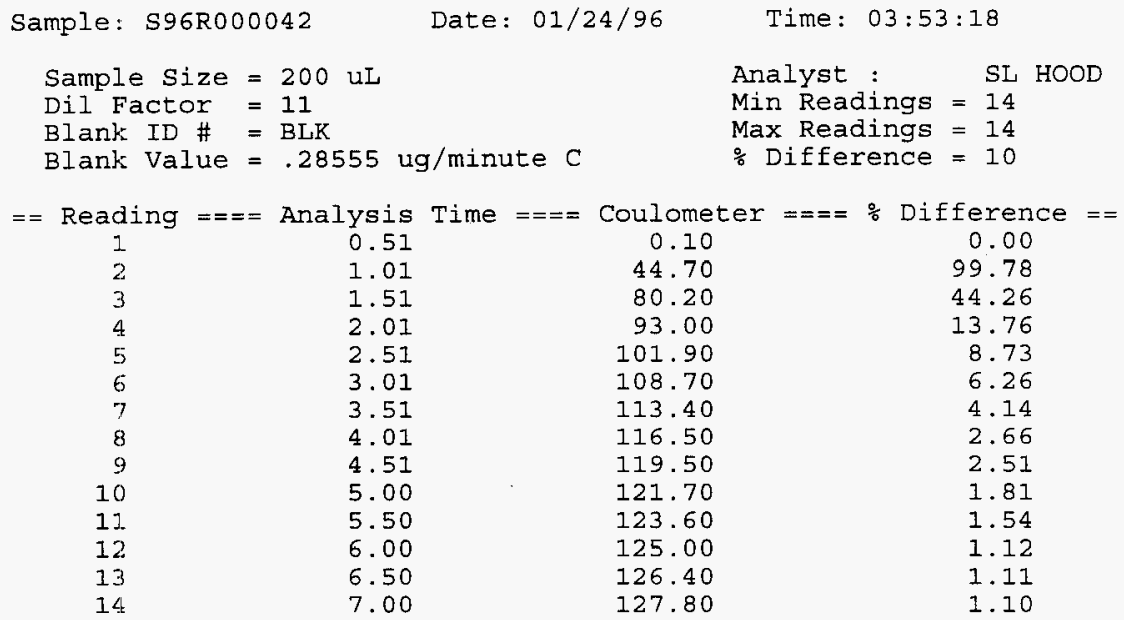

BLANK VALUE $=2$ micrograms carbon

BLANK FACTOR $=2 / 7.004028=+2.9 \mathrm{E}-01 \quad \mathrm{ug} / \mathrm{min}$ Carbon

SAMPLE RESULTS:
$(127.8-2.000231)(11) /(200)=\quad+6.919 \mathrm{E}+00 \mathrm{~g} / \mathrm{L}$ Carbon
$(127.8-2.000231)(11) /(200)(12)=\quad+5.766 \mathrm{E}-01$ Molar Carbon
$.200 \mathrm{ml}+2.0 \mathrm{ml} .5 \mathrm{~m} \mathrm{H} \mathrm{HSO}_{4}$

Sample Run By:

$\overline{\text { SL HOOD }} 00000$ 
TOC- TOTAL ORGANIC CARBON ANALYSIS REPORT

TICTOC REV 2.0

WHC-SD-WM-DP-180, REV. 0

Sample: S96R0042 SPK Date: 01/24/96

Time: 04:03:11

Sample Size $=200 \mathrm{uL}$

Analyst : SL HOOD

Dil Factor $=22$

Blank ID \# = BLK

Blank Value $=.28555 \mathrm{ug} /$ minute $\mathrm{C}$

Min Readings $=14$

Max Readings $=14$

$\div$ Difference $=10$

$\begin{array}{crcc}\text { Reading }===\text { Analysis } & \text { Time }===\text { Coulometer }===0 & \text { Difference }== \\ 1 . & 0.51 & 0.80 & 0.00 \\ 2 & 1.01 & 46.20 & 98.27 \\ 3 & 1.51 & 92.50 & 50.05 \\ 4 & 2.00 & 107.90 & 14.27 \\ 5 & 2.50 & 118.50 & 8.95 \\ 6 & 3.00 & 126.20 & 6.10 \\ 7 & 3.50 & 131.30 & 3.88 \\ 8 & 4.00 & 135.40 & 3.03 \\ 9 & 4.50 & 138.40 & 2.17 \\ 10 & 5.00 & 140.90 & 1.77 \\ 11 & 5.50 & 143.20 & 1.61 \\ 12 & 6.00 & 144.70 & 1.04 \\ 13 & 6.50 & 146.20 & 1.03 \\ 14 & 7.00 & 147.60 & 0.95\end{array}$

BLANK VALUE $=2$ micrograms carbon

BLANK FACTOR $=2 / 7.004028=$

$+2.9 \mathrm{E}-01 \quad u g / \mathrm{min}$ Carbon

SAMPLE RESULTS:

$(147.6-1.999704)(22) /(200) /(12)=$

$+1.602 \mathrm{E}+01 \mathrm{~g} / \mathrm{L}$ Carbon

$+1.335 \mathrm{E}+00$ Molar Carbon

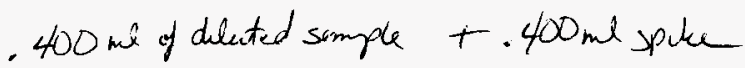

Sample Run By:

$\overline{S L ~ H O O D} 00000$ 
WHC-SD-WM-DP-180, REV. 0

Sample: S96R0042 SPK Dup Date: 01/24/96

Time: $04: 11: 37$

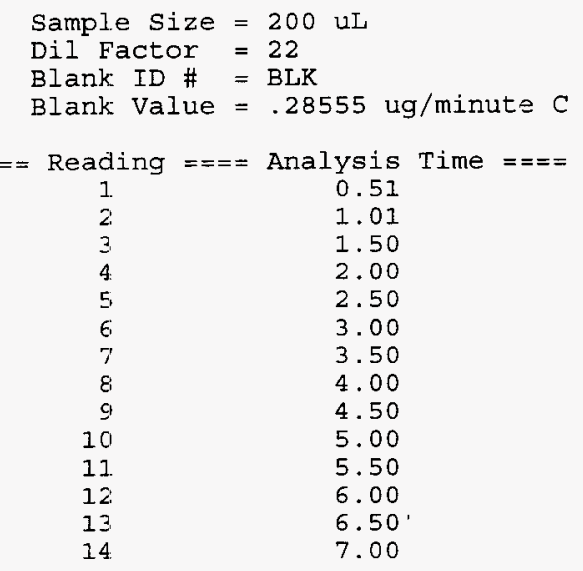
Analyst : SL HOOD
Min Readings $=14$
Max Readings $=14$
$\div$ Difference $=10$

Coulometer $====\%$ Difference $==$

0.70

44.30

90.60

105.70

116.80

125.20

130.90

134.80

137.80

140.10

142.30

144.10

145.50

146.70
0.00

98.42

51.10

14.29

9.50

6.71

4.35

2.89

2.18

1.64

1.55

1.25

0.96

0.82

BLANK VALUE $=2$ micrograms carbon

BLANK FACTOR $=2 / 7.004028=$

$+2.9 E-01 \quad u g / m i n$ Carbon

SAMPLE RESULTS:

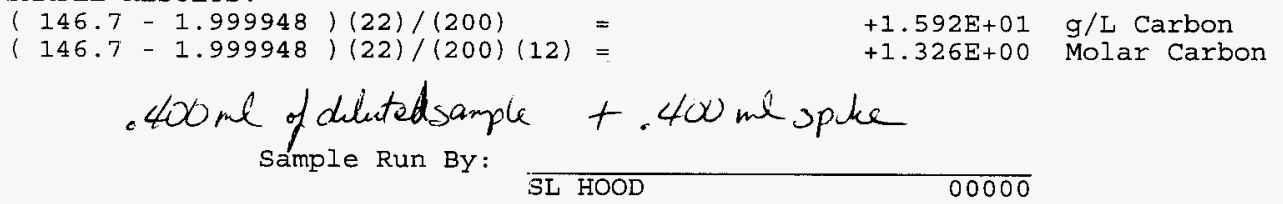


WHC-SD-WM-DP-180, REV. 0

RADIOCHEMICAL ANALYSES

203 
WHC-SD-WM-DP-180, REV. 0

THIS PAGE WAS INTENTIONALLY LEFT BLANK

201 


\section{LABCORE Data Entry Template for Worklist\# 5064}

Analyst: $\quad$ L $1 L$ Instrument: $\mathrm{AB} 00 \quad 14 \quad$ Book\# 23056

Method: LA-508-101 Rev/Mod D. Z

Worklist Comment: DETER SS USING LUDLUM (USE .IML APPROPIATE SPIKE) RTS!

\begin{tabular}{|c|c|c|c|c|c|c|}
\hline 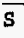 & Type & Sample\# & R A & Test & Matrlx & Project \\
\hline 1 & STD & & & $@ A B-01$ & LIQUID & \\
\hline 2 & BLNK-PREP & & & $@ A B-01$ & LIQUID & \\
\hline 3 & BLNK/BKG & & & $@ A B-01$ & LIQUID & \\
\hline 4 & SAMPLE & S95R000115 & $0 \mathrm{~B}$ & $@ A B-01$ & LIQUID & 95000224 ORG/AQ SAMPL \\
\hline & & alytes Reque & ested & I: ALPHAO1 & , ALPHAOIE, & BETA-01， BETA-01E \\
\hline 5 & SPK & S95R000115 & $\mathrm{OB}$ & $@ A B-01$ & LIQUID & \\
\hline 6 & SPK-DUP & S95R000115 & $\mathrm{OB}$ & $@ A B-01$ & LIQUID & \\
\hline 7 & SAMPLE & S95R000116 & $O B$ & $\triangle A B-01$ & LIQUID & 95000224 ORG/AQ SAMPL \\
\hline & & alytes Reque & ested & : ALPHAOI & - ALPHAO1E, & BETA-01， BETA-01E \\
\hline 8 & SPK & S95R000116 & $\mathrm{OB}$ & $@ A B-01$ & LIQUID & \\
\hline 9 & SPK-DUP & S95R000116 & $\mathrm{O} B$ & $@ A B-01$ & LIQUID & \\
\hline
\end{tabular}

\section{Final page for worklist \# 5064}

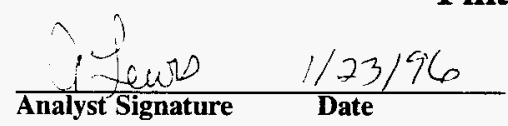

Data Entry Comments:

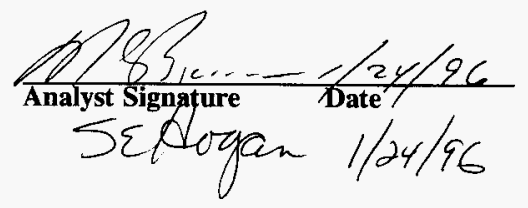




\section{LABCORE Completed Worklist Report for Worklist\# 5064}

Analyst: akl
Instrument: AB14

Book\#

Method:

Rev/Mod

Worklist Comment: DETER SS USING LUDLUM (USE .1ML APPROPIATE SPIKE) RTS!

\begin{tabular}{|c|c|c|c|c|c|c|c|c|}
\hline Seq Type & \multicolumn{3}{|c|}{ Sample\# R A } & Test & Matrix & Actual & Found & DL or Yield \\
\hline 1 STD & & 0 & DAB-01 & ALPHAO1 & LIQUID & $1.02 E-05$ & $9.65 E-6$ & $94.610 \times$ Recovery \\
\hline $1 \mathrm{srd}$ & & 0 & DAB- 01 & ALPHA01E & LIOUID & 1 & $5.20 E+00$ & $5.200 \% \mathrm{ct}$. Error \\
\hline 1 STD & & 0 & aAB -01 & BETA-01 & LIQUID & $46 E-04$ & $1.46 E-4$ & $100.000 \times$ Recovery \\
\hline 1 STD & & 0 & $A A B-01$ & BETA-01E & LIQUID & 1 & $51 E-01$ & $0.950 \% \mathrm{ct}$. Error \\
\hline 2 BLNK-PREP & & 0 & aAB- 01 & ALPHA01 & LIOUID & 1 & $<7.72 E-3$ & $\mathrm{uCi} / \mathrm{mL}$ \\
\hline 2 BLNK -PREP & & 0 & ลAB-01 & ALPI & LIOUID & 00 & $5.00 E+02$ & $500.000 \% \mathrm{Ct}$. Error \\
\hline 2 BLAK - PREP & & 0 & 2AB & BETA-0 1 & LIQUID & 1 & $<4.12 E-2$ & $\mathrm{uCi} / \mathrm{mL}$ \\
\hline 2 BLNK - PREP & & 0 & aA & BETA-01E & LIQUID & 1.00 & $2.33 \mathrm{E}+02$ & $33.000 \%$ ct. Error \\
\hline 3 BLNK/BKG & & 0 & AAB & ALPHA01 & LIOUID & $1.00 E+00$ & $1.00 E+00$ & $1.000 \mathrm{uCi} / \mathrm{mL}$ \\
\hline 3 BLNK/BKG & & 0 & & BETA-01 & LIQUID & $1.00 E+00$ & $1.24 E+00$ & $1.240 \mathrm{uCi} / \mathrm{mL}$ \\
\hline 4 SAMPLE & S95R000115 & O B & ลAB-01 & ALPF & LIQU1D & $N / A$ & $7.72 E-03 \quad 1$ & e-002 uCi/mL \\
\hline 4 SAMPLE & S95R000115 & $0 B$ & QAB-01 & ALPHA01E & LJQUID & $N / A$ & $5.00 E+02$ & $0.000 \%$ Ct. Error \\
\hline 4 SAMPLE & $\$ 95 R 000$ & 0 B & aA & BETA-01 & LIOUID & $N / A$ & $2.37 \mathrm{E}+022.8$ & $0 e-002$ uCi/mL \\
\hline 4 SAMPLE & S95R000115 & $0 \mathrm{~B}$ & $2 A B-01$ & BETA-01E & LIQUID & N/A & $2.35 E-01$ & $0.000 \% \mathrm{ct}$. Error \\
\hline 5 SPK & S95R000115 & $0 B$ & МAB -01 & ALPHA01 & LIOUJID & $3.92 \mathrm{E}-02$ & $3.83 E-02$ & $97.700 \%$ Recovery \\
\hline 5 SPK & S95R000 & O B & $\partial A B$ & BETA-01 & LIQU1D & $1.69 \mathrm{E}-01$ & $1.78 \mathrm{E}-01$ & $105.330 \%$ Recovery \\
\hline 6 SPK-DUP & $595 R 000115$ & $0 \mathrm{~B}$ & aAB & ALPHA01 & LIOUID & $3.83 E-02$ & $3.73 E-02$ & $2.650 \mathrm{RPD}$ \\
\hline 6 SPK-DUP & S95R0001 15 & $\mathrm{OB}$ & QAB-01 & BETA-01 & LIQUID & $1.78 \mathrm{E}-01$ & $1.70 \mathrm{E}-01$ & $4.600 \mathrm{RPD}$ \\
\hline 7 SAMPLE & S95R000116 & $0 B$ & DAB-01 & ALPHA0 1 & LIOUID & $N / A<$ & $1.00 E-021.2$ & $60 \mathrm{e}-002 \mathrm{uCi} / \mathrm{mL}$ \\
\hline 7 SAMPLE & S95R000116 & O B & aAB -01 & ALPHA01E & LIOUIO & $N / A$ & $2.59 E+02$ & $0.000 \% \mathrm{ct}$. Error \\
\hline 7 SAMPLE & S95R000116 & $0 \mathrm{~B}$ & ลАВ-01 & BETA-01 & LIQUID & $N / A$ & $2.34 \mathrm{E}+02 \quad 2.8$ & $0 \mathrm{e}-002$ uci $/ \mathrm{mL}$ \\
\hline 7 SAMPLE & SO5R000116 & $0 B$ & aAB- 01 & BETA-01E & LIOUIO & N/A & $2.38 \mathrm{E}-01$ & $0.000 \% \mathrm{Ct}$ - Error \\
\hline B SPK & \$95R000116 & $O B$ & aAB-01 & ALPHAO1 & LIOUID & $3.92 \mathrm{E}-02$ & $3.82 E-02$ & $97.450 \times$ Recovery \\
\hline 8 SPK & S95R000116 & $O B$ & QAB-01 & BEIA-01 & LIOUIO & $1.69 E-01$ & $1.73 E-01$ & $102.370 \%$ Recovery \\
\hline 9 SPK-DUP & \$95R000116 & $O B$ & DAB- 01 & ALPHA01 & LIOUID & $3.82 \mathrm{E}-02$ & $3.89 E-02$ & 1.820 RPD \\
\hline 9 SPK-DUP & S95R000116 & $0 \mathrm{~B}$ & ลAB-01 & BETA-01 & LIQUID & $1.73 E-01$ & $1.77 \mathrm{E}-01$ & $2.290 \mathrm{RPD}$ \\
\hline
\end{tabular}

\section{Final page for worklist\# 5064}

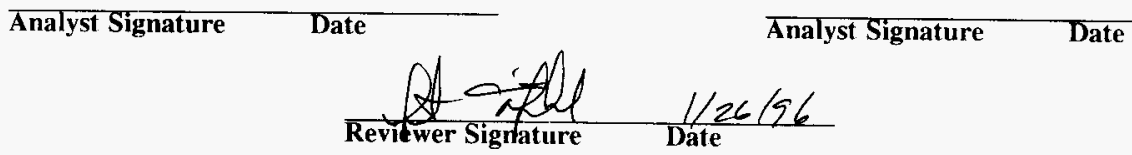

Units shown for $Q C(B L K / B K G)$ may not reflect the actual units. 
WORKBOOK PAGE: STD1

WHC-SD-WM-DP-180, REV. 0

\begin{tabular}{|c|c|c|c|c|}
\hline \multirow{3}{*}{\multicolumn{2}{|c|}{ TB : LA-508-101(D-2) STANDARD }} & \multirow{3}{*}{$\begin{array}{r}\text { STANDARD } \\
14\end{array}$} & \multirow{3}{*}{\begin{tabular}{r|} 
REPLICATE \\
14
\end{tabular}} & \\
\hline & & & & \\
\hline & & & & \\
\hline STD & DISH SIZE $\quad(1,2$, or 5$)$ & 2 & 2 & \\
\hline 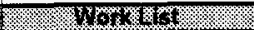 & GROSS COUNTS & 43410 & 44003 & \\
\hline 5064 & COUNT TIME in MINUTES & 30 . & 30 & \\
\hline 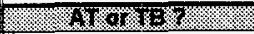 & BACKGROUND in cpm & 10 & 10 & \\
\hline T8 & SAMPLE SIZE in mL & 10.000 & 10.000 & \\
\hline 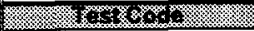 & DILUTION FACTOR & 1 & 1 & \\
\hline (1)AB-01 & STANDARD BOOK NUMBER & 23856 & $23 B 56$ & \\
\hline 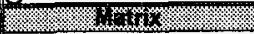 & EFFICIENCY FACTOR & 0.4455 & 0.4455 & \\
\hline LIQUID & Lc, Rmax, or Rs, (SAMPLE RATE) as APPROPRIATE & 1437.000 & 1456.767 & \\
\hline STH & Standard Value in $\mu \mathrm{Ci} / \mathrm{mL}$ & 1.46E-04 & & \\
\hline 96000562 & Concentration in $\mathrm{HCi} / \mathrm{L}$ & 1.45E-01 & & \\
\hline 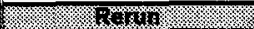 & Replicate Concentration in $\mu \mathrm{Ci} / \mathrm{L}$ & $1.47 E-01$ & & \\
\hline 0 & AVERAGE CONCENTRATION in $\mu \mathrm{CI} / \mathrm{L}$ & $1.4630 \mathrm{E}-01$ & & \\
\hline and & & & & \\
\hline N/A & Rs (Sample Count Rate) & & & \\
\hline W & $=R s * 1000 \mathrm{~mL} / \mathrm{L} * \mathrm{DF} /(\mathrm{EFF} *$ & is $* 2220000 \mathrm{dpr}$ & $n / \mu C i)$ & \\
\hline WL.5064 & $=$ TDTAL BETA $\mu \mathrm{Ci} / \mathrm{L} / 1000 \mathrm{~m}$ & & & \\
\hline 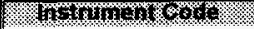 & Relative Counting Error $=[\mid($ The Square Root of $\mathrm{TC}+\mathrm{BKG}$ * & $\mathrm{CT}) /(\mathrm{TC}-\mathrm{BKG}$ & * * $(T) \mid]^{*} 1.96 *$ & \\
\hline WB27807 & Detection Levels and Less Than Values are determined from Pro & cedure LA-508-00 & & \\
\hline 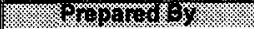 & & & & \\
\hline MCB & & & & \\
\hline (1) & & & & \\
\hline SLF & TOTAL BETA CONTRATION in $\mu \mathrm{Ci} / \mathrm{mL}$ & & $1.46 E-04$ & DETECTION \\
\hline W.6.1\%18 & & & & LEVEL \\
\hline AKL & & & & (2) \\
\hline 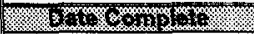 & & & & 2.82E-07 \\
\hline $01 / 24 / 96$ & RELATIVE COUNTING ERROR & & $1.0 \%$ & $\mu \mathrm{Ci} / \mathrm{mL}$ \\
\hline
\end{tabular}

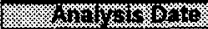

$01 / 23 / 26$

. W

09:00 AM

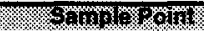

ORG/AQ SAMPLE

\begin{tabular}{|lllll|}
\hline Analyst: & MCB & & Date: 24-Jan-96 \\
\hline Signature of Chernist: & SLF & Date: $/ 26 / 96$ \\
\hline STANDARD.WB1 Rev. 1.0
\end{tabular}




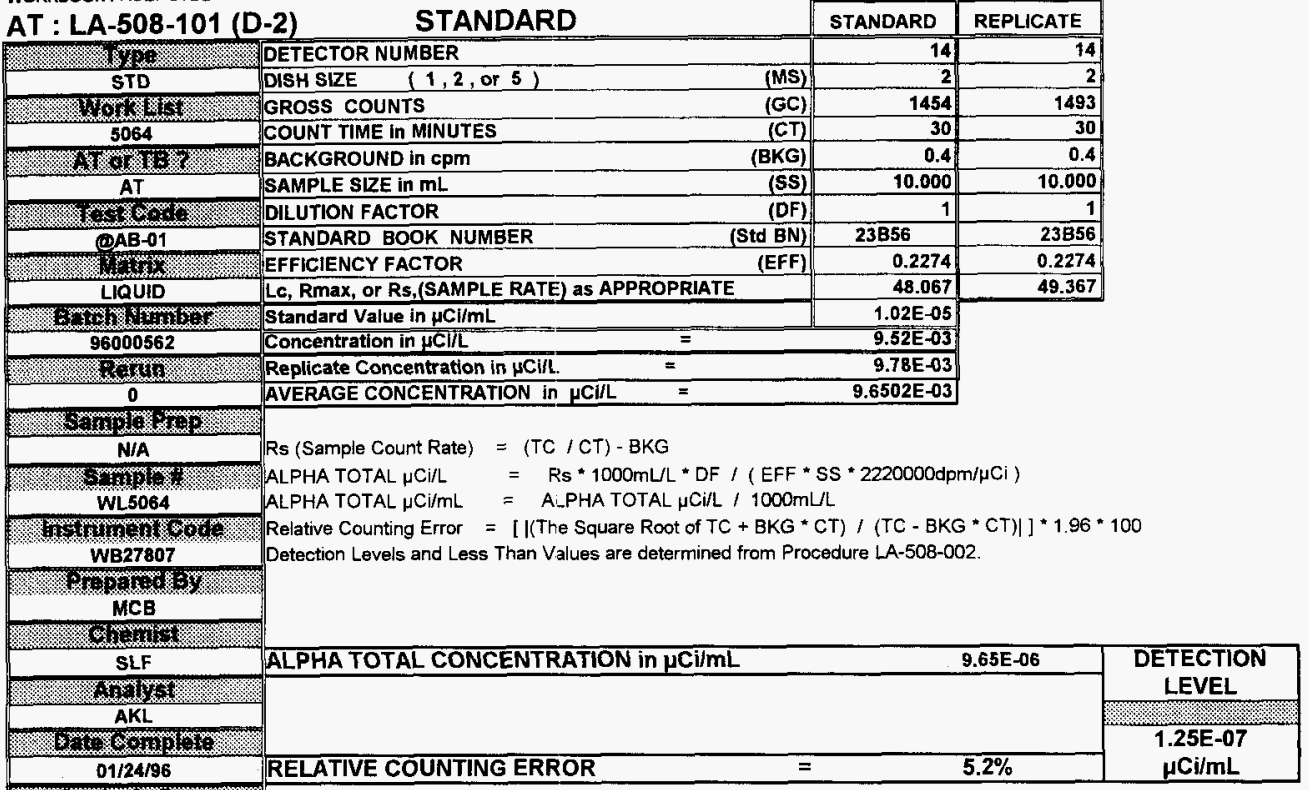

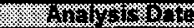

$01 / 23 / 96$

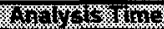

09:00 AM

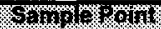

ORG/AQ SAMPLE

\begin{tabular}{|llll|}
\hline Analyst: & MCB & Date: 24-Jan-96 \\
\hline Signature of Chemist: & SLF & Date: 1/26/96 \\
\hline
\end{tabular}


WORKBOOK PAGE: BLANK3

WHC-SL-Wiv-DP-180, REV. 0

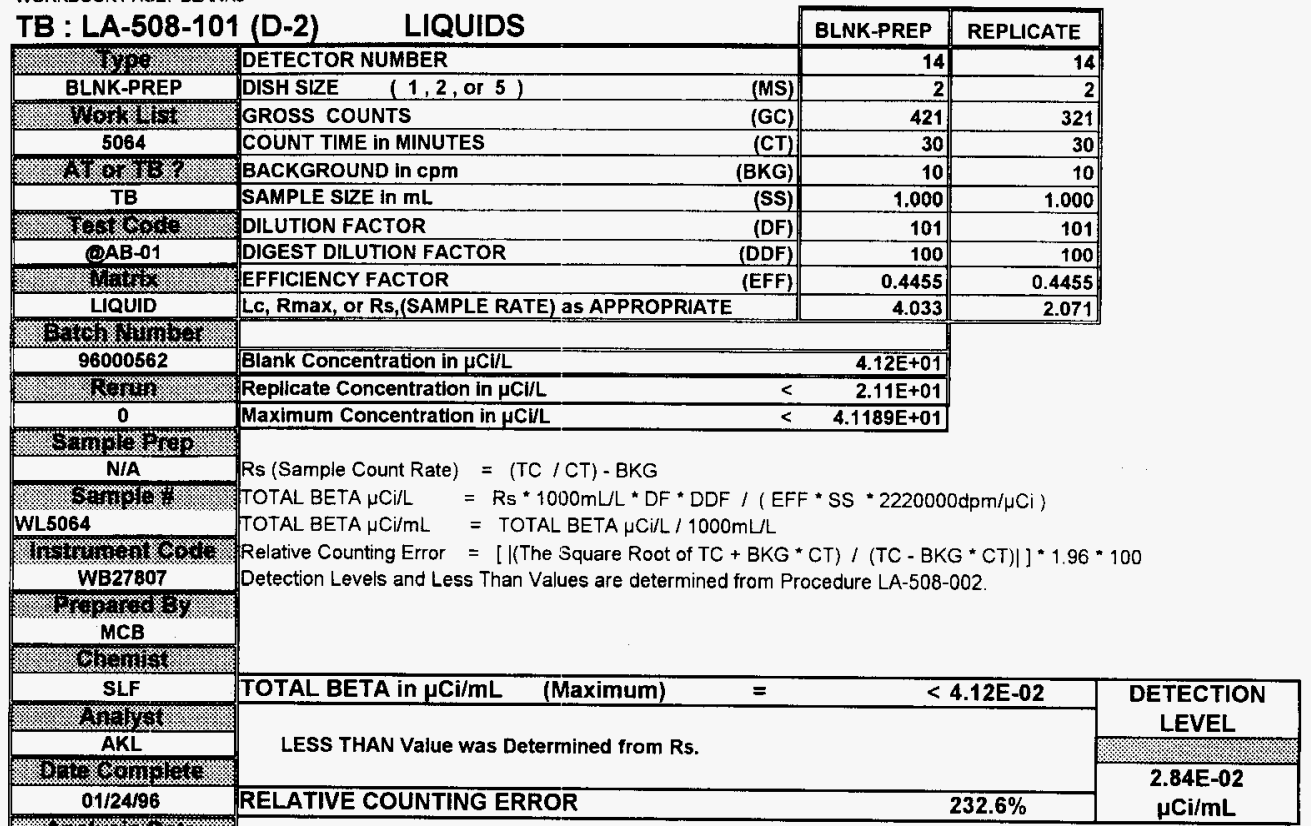

Wa $01 / 23 / 96$

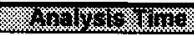
09:00 AM

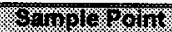
ORG/AQ SAMPLE

\begin{tabular}{|c|c|c|}
\hline Analyst: & AKL & Date: 24-Jan-96 \\
\hline $\begin{array}{l}\text { Signature of Chemist: } \\
\text { BLANK.WB1 Rev } 1.0\end{array}$ & SLF & Date: $1 / 26 / 96$ \\
\hline
\end{tabular}

\section{3}


WORKBOOK PAGE: BLANK4

WHC-SD-WM-DP-180, REV. 0

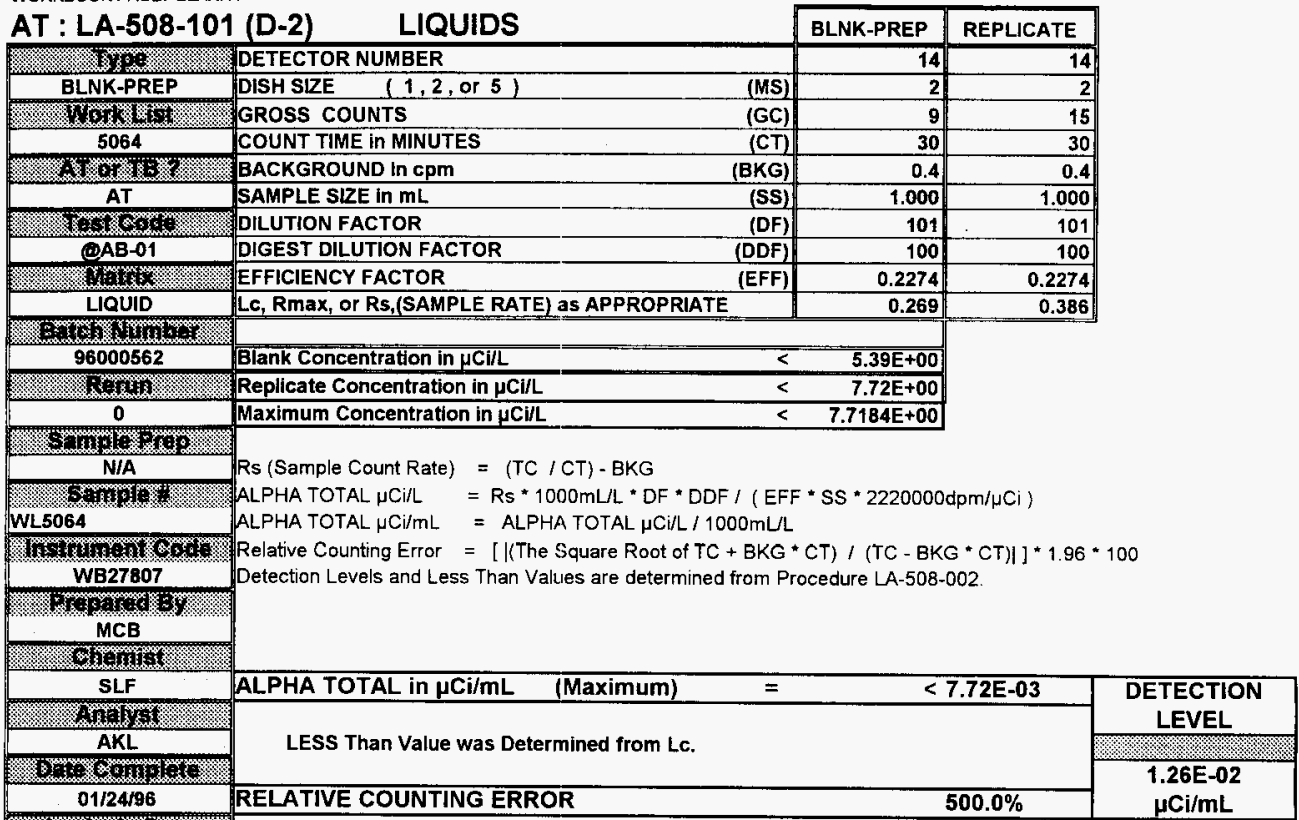

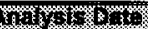

$01 / 23 / 96$

2.125\%

09:00 AM

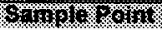

ORG/AQ SAMPLE

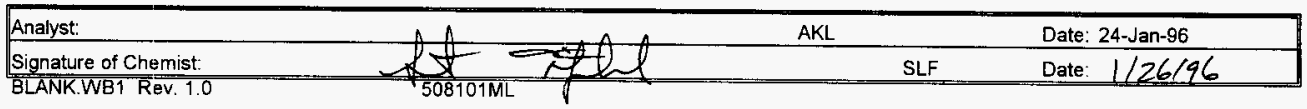

\section{0}


WORKBOOK PAGE: SAM7

WHC-SD-WM-DP-180, REV. 0

\begin{tabular}{|c|c|c|c|c|}
\hline TB : LA-508 & LIQUIDS & SAMPLE & REPLICATE & \\
\hline Xathe & DETECTOR NUMBER & 14 & 14 & \\
\hline SAMPLE & $(1,2$, or 5$)$ & 2 & 2 & \\
\hline 25 & GROSS COUNTS & 696942 & 695469 & \\
\hline 5064 & COUNT TIME In MINUTES & 30 & 30 & \\
\hline Wxink & BACKGROUND in cpm & 10 & 10 & \\
\hline TB & SAMPLE SIZE in mL & 1.000 & 1.000 & \\
\hline 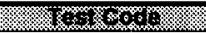 & DILUTION FACTOR & 101 & 101 & \\
\hline (9AB-01 & DIGEST DILUTION FACTOR & 100 & 100 & \\
\hline roston & EFFICIENCY FACTOR & 0.4455 & 0.4455 & \\
\hline LIQUID & \multirow{2}{*}{ LC, Rmax, or Rs, (SAMPLE RATE) as APPROPRIATE } & 23221.400 & 23172.300 & \\
\hline \multirow{2}{*}{$\frac{10.48}{96000562}$} & & & & \\
\hline & \multicolumn{2}{|c|}{ Blank Concentration in $\mu \mathrm{Cl} / \mathrm{L}$} & & \\
\hline isting & \multirow{2}{*}{\multicolumn{2}{|c|}{$\begin{array}{|lr|}\text { Replicate Concentration in } \mu \mathrm{Ci} / \mathrm{L} & 2.37 \mathrm{E}+05 \\
\text { Average Concentration in } \mu \mathrm{Ci} / \mathrm{L} & 2.3689 \mathrm{E}+05 \\
\end{array}$}} & & \\
\hline 0 & & & & \\
\hline \multirow{2}{*}{ 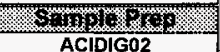 } & \multirow{7}{*}{\multicolumn{4}{|c|}{ 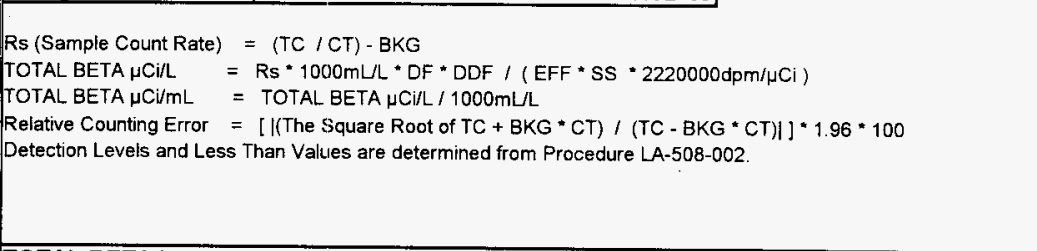 }} \\
\hline & & & & \\
\hline Sasponentis & & & & \\
\hline S95R000115 & & & & \\
\hline 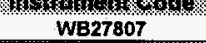 & & & & \\
\hline $\begin{array}{c}\text { P\%ORHOHOH } \\
\text { MCB }\end{array}$ & & & & \\
\hline 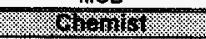 & & & & \\
\hline SLF & TOTAL BETA in $\mu \mathrm{Ci} / \mathrm{mL}$ & & $2.37 \mathrm{E}+02$ & DETECTION \\
\hline Ans & & & & LEVEL \\
\hline AKL & & & & 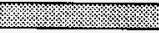 \\
\hline $01 / 24 / 96$ & RELATIVE COUNTING ERROR & & $0.2 \%$ & $\begin{array}{l}2.84 \mathrm{E}-02 \\
\mu \mathrm{Ci} / \mathrm{mL}\end{array}$ \\
\hline
\end{tabular}

Arows. $01 / 23 / 96$

\section{AU⿴囗十)} 09:00 AM

STm:

ORGIAQ SAMPLE

\begin{tabular}{|c|c|c|}
\hline Analyst: & $A K L$ & Date: 24-Jan-96 \\
\hline Signature of Chemist: & SLF & Date: $1 / 26 / 96$ \\
\hline
\end{tabular}


WORKBOOK PAGE: SAMB

\section{WHC-SD-WM-DP-180, REV. 0}

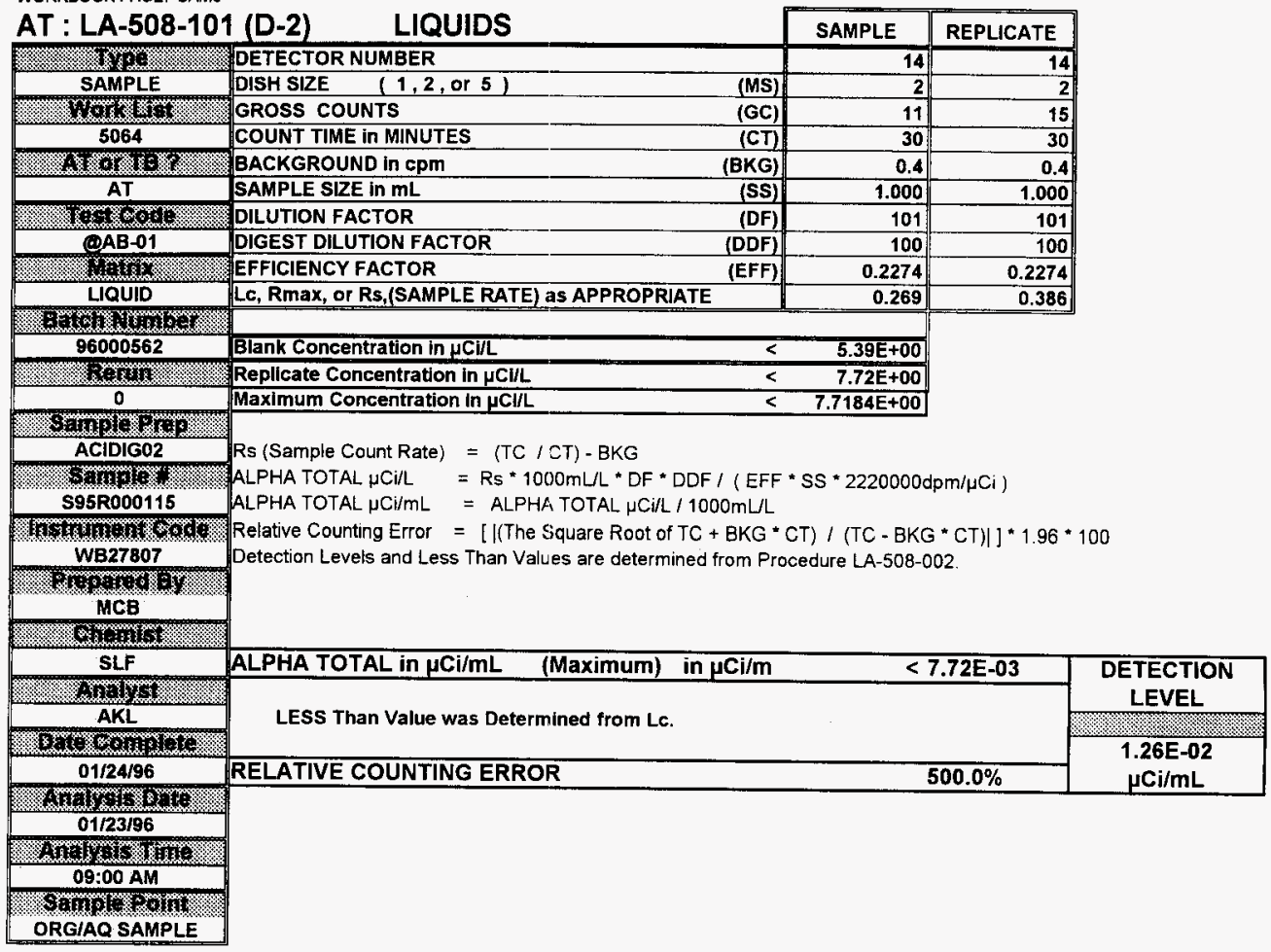

\begin{tabular}{|c|c|c|}
\hline Analyst: & AKL & Date: $24-J a n-96$ \\
\hline Signature of Chemist: $\quad$ L & SLF & Date: $1 / 26 / 96$ \\
\hline
\end{tabular}


TB : LA-508-101

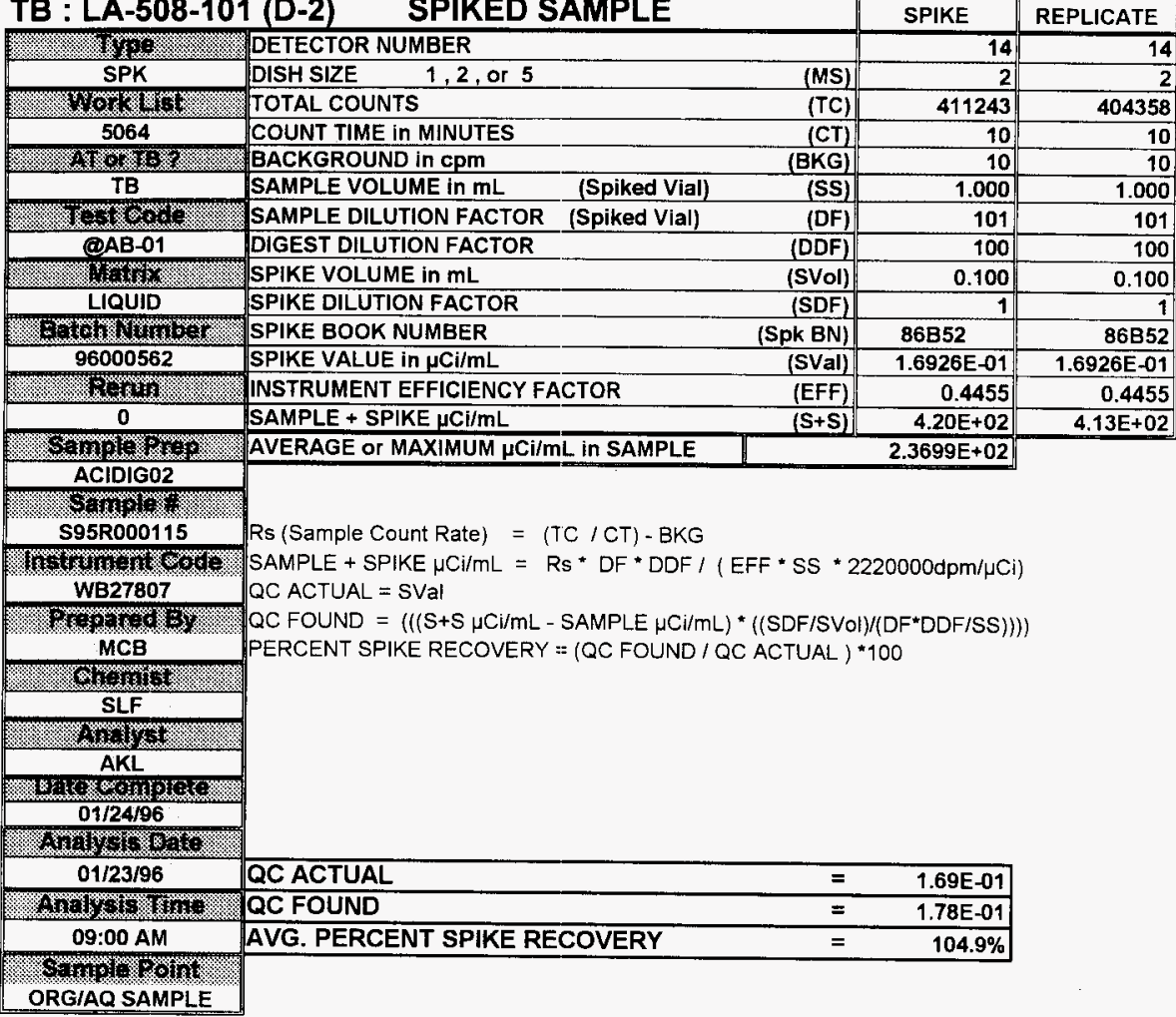

\begin{tabular}{|l|lll|}
\hline Analyst: & MCB & & Date: $24-J a n-96$ \\
\hline Signature of Chemist: & SLF & Date: $1 / 26 / 96$ \\
\hline SPIKE.WB1 Rev. 1.0 & S0810 & & ML
\end{tabular}


WORKBOOK PAGE: SPIKE10

\begin{tabular}{|c|c|c|c|}
\hline \multirow{2}{*}{\multicolumn{2}{|c|}{ WORKBOOK PAGE: SPIKE10 }} & \multicolumn{2}{|c|}{ (1) } \\
\hline & & SPIKE & REPLICATE \\
\hline 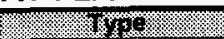 & DETECTOR NUMBER & 14 & 14 \\
\hline SPK & DISH SIZE $\quad 1,2$, or 5 & 2 & 2 \\
\hline 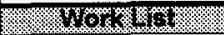 & TOTAL COUNTS & 58422 & 57677 \\
\hline 5064 & COUNT TIME in MINUTES & 30 & 30 \\
\hline 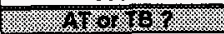 & BACKGROUND in cpm & 0.4 & 0.4 \\
\hline AT & SAMPLE VOLUME in $\mathrm{mL}$ & 1.000 & 1.000 \\
\hline 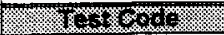 & SAMPLE DILUTION FACTOR (Spiked Vial) & 101 & 101 \\
\hline (9AB-01 & DIGEST DILUTION FACTOR & 100 & 100 \\
\hline HFisis & SPIKE VOLUME in $\mathrm{mL}$ & 0.100 & 0.100 \\
\hline LIQUID & SPIKE DILUTION FACTOR & 1. & 1 \\
\hline 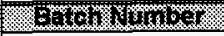 & SPIKE BOOK NUMBER & 119843 & $119 \mathrm{~B} 43$ \\
\hline 96000562 & SPIKE VALUE in $\mu \mathrm{Ci} / \mathrm{mL}$ & $3.9209 \mathrm{E}-02$ & $3.9209 E-02$ \\
\hline 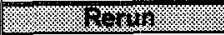 & INSTRUMENT EFFICIENCY FACTOR & 0.2274 & 0.2274 \\
\hline 0 & SAMPLE + SPIKE $\mu \mathrm{Ci} / \mathrm{mL}$ & $3.90 \mathrm{E}+01$ & $3.85 \mathrm{E}+01$ \\
\hline 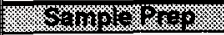 & AVERAGE or MAXIMUM $\mu C \mathrm{i} / \mathrm{mL}$ in SAMPLE & $7.7184 \mathrm{E}-03$ & \\
\hline ACIDIGO2 & & & \\
\hline 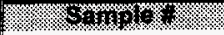 & & & \\
\hline S95R000115 & Rs (Sample Count Rate) $=(\mathrm{TC} / \mathrm{CT})-\mathrm{BKG}$ & & \\
\hline 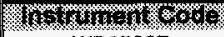 & SAMPLE + SPIKE $\mu \mathrm{Ci} / \mathrm{mL}=\mathrm{Fs} * \mathrm{DF} * \mathrm{DDF} /\left(\mathrm{EFF}{ }^{*} \mathrm{SS} * 2\right.$ & $0000 \mathrm{dpm} / \mu \mathrm{C}$ & \\
\hline WB27807 & QC ACTUAL = SVal & & \\
\hline 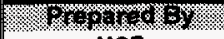 & QC FOUND $=(((\mathrm{S}+\mathrm{S} \mu \mathrm{Ci} / \mathrm{mL}-\mathrm{SAMPLE} \mu \mathrm{Ci} / \mathrm{mL}) *((\mathrm{SDF} / \mathrm{S} \vee O$ & DF*DDF/SS)) & \\
\hline MCB & PERCENT SPIKE RECOVERY = (QC FOUND / QC ACTUAL ) & & \\
\hline
\end{tabular}

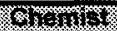
SLF \$1) 31 \% AKL

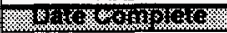
$01 / 24 / 96$

\%. $1 \% 3 \%$

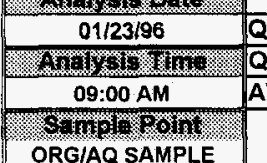

NOTE: Original Sample result was a LESS THAN value. Zero (0) was subtracted from the spiked value for $\mathrm{QC}$ found calculation.

\begin{tabular}{|llr|}
\hline QC ACTUAL & $=$ & $3.92 \mathrm{E}-02$ \\
\hline QC FOUND & $=$ & $3.83 \mathrm{E}-02$ \\
\hline AVG. PERCENT SPIKE RECOVERY & $=$ & $97.7 \%$ \\
\hline
\end{tabular}

ORGIAQ SAMPLE

\begin{tabular}{|c|c|c|}
\hline Analyst: & MCB & Date: 24-Jan-96 \\
\hline Signature of Chemist: & $S L F$ & Date: $1 / 26 / 96$ \\
\hline
\end{tabular}

\section{1}




\section{TB : LA-508-101 (D-2) SPIKED SAMPLE}

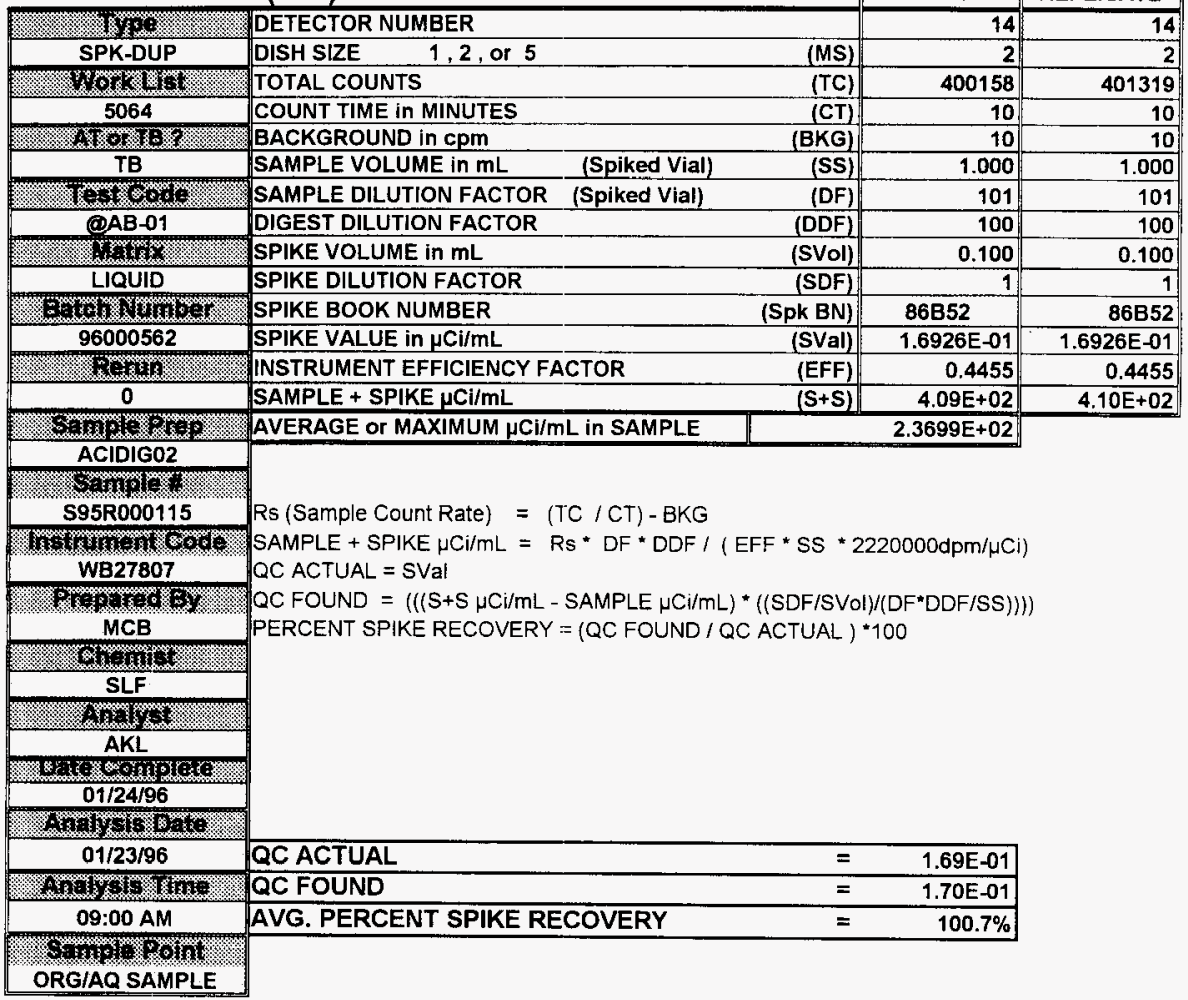

\begin{tabular}{|c|c|c|}
\hline Analyst: & & Date: 24-Jan-96 \\
\hline Signature of Chemist: & SLF & Date: $1 / 26 / 96$ \\
\hline
\end{tabular}




\begin{tabular}{|c|c|c|c|}
\hline & & & \\
\hline AT : LA-508-1 & SPIKED SAMPLE & SPIKE & REPLICATE \\
\hline 6 & DETECTOR NUMBER & 14 & 14 \\
\hline SPK-DUP & 1,2 , or 5 & 2 & 2 \\
\hline $40 x<$ & TOTAL COUNTS & 56197 & 56912 \\
\hline 5064 & COUNT TIME in MINUTES & 30 & 30 \\
\hline Whos & BACKGROUND in cpm & 0.4 & 0.4 \\
\hline AT & SAMPLE VOLUME in $\mathrm{mL}$ & 1.000 & 1.000 \\
\hline $6 r e x-6$ & SAMPLE DILUTION FACTOR (Spiked Vial) & 101 & 101 \\
\hline (9AB-01 & DIGEST DILUTION FACTOR & 100 & 100 \\
\hline 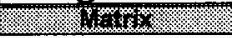 & SPIKE VOLUME in $\mathrm{mL}$ & 0.100 & 0.100 \\
\hline LIQUID & SPIKE DILUTION FACTOR & 1 & 1 \\
\hline 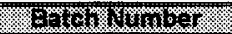 & SPIKE BOOK NUMBER & 119843 & 119B43 \\
\hline 96000562 & SPIKE VALUE in $\mu \mathrm{Ci} / \mathrm{mL}$ & $3.9209 \mathrm{E}-02$ & $3.9209 E-02$ \\
\hline (n) & INSTRUMENT EFFICIENCY FACTOR & 0.2274 & 0.2274 \\
\hline 0 & SAMPLE + SPIKE $\mu \mathrm{Ci} / \mathrm{mL}$ & $3.75 E+01$ & $3.79 \mathrm{E}+01$ \\
\hline 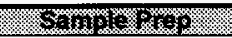 & AVERAGE or MAXIMUM $\mu \mathrm{Ci} / \mathrm{mL}$ in SAMPLE & $7.7184 \mathrm{E}-03$ & \\
\hline ACIDIG02 & & & \\
\hline 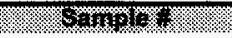 & & & \\
\hline S95R000115 & Rs (Sample Count Rate) $=(\mathrm{TC} / \mathrm{CT})-\mathrm{BKG}$ & & \\
\hline 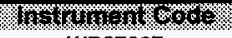 & SAMPLE + SPIKE $\mu \mathrm{Ci} / \mathrm{mL}=\mathrm{RS}^{*} \mathrm{DF} * \mathrm{DDF} /(\mathrm{EFF} * \mathrm{SS}$ & $0000 \mathrm{dpm} / \mu \mathrm{Ci})$ & \\
\hline WB27807 & QC ACTUAL = SVal & & \\
\hline 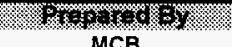 & QC FOUND $=(((S+S \mu \mathrm{Ci} / \mathrm{mL}-S A M P L E \mu \mathrm{Ci} / \mathrm{mL}) *((S D F / S V$ & $F^{*}$ DDF/SS)I) & \\
\hline$M C R$ & 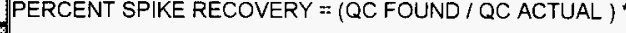 & & \\
\hline
\end{tabular}

\section{2.\% \\ SLF}

Shat 1

AKL

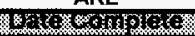
$01 / 24 / 96$

1.11\% 01/23/96

\& 09:00 AM

TrIDI $\%$

ORGIAQ SAMPLE

\begin{tabular}{|c|c|c|}
\hline Analyst: & $\mathrm{MCB}$ & Date: $24-J a n-96$ \\
\hline Signature of Chemist: & SLF & Date: $1 / 26 / 96$ \\
\hline
\end{tabular}

\section{5}


WORKBOOK PAGE: SAM1

WrC-SD-WiV-DP-180, REV. 0

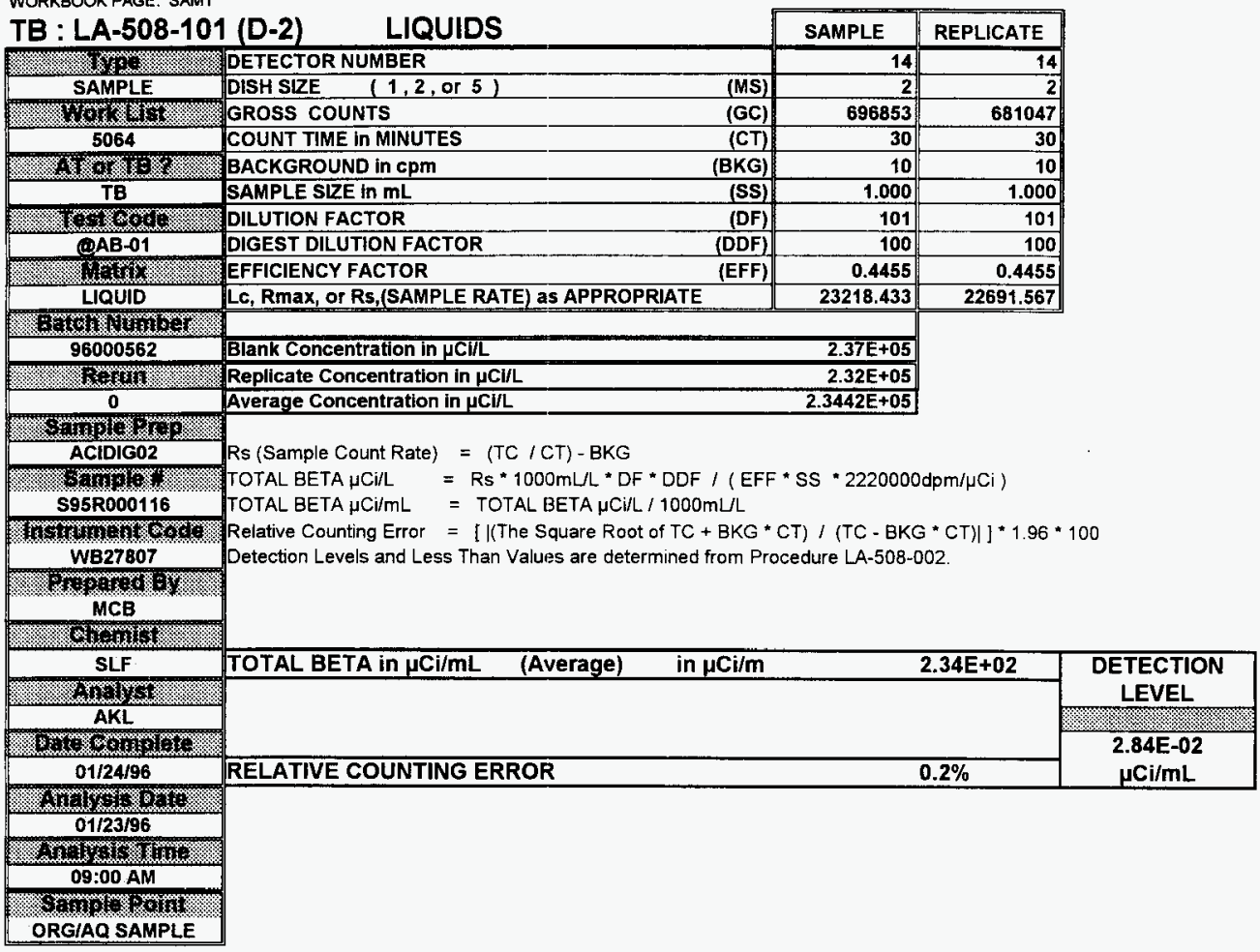

\begin{tabular}{|c|c|c|}
\hline Analyst: & $\mathrm{AKL}$ & Date: $24-J a n-96$ \\
\hline Signature of Chemist: & SLF & Date: $\quad 1 / 26 / 91$ \\
\hline
\end{tabular}


AT : LA-508-101 (D-2) LIQUIDS

\begin{tabular}{|c|c|c|c|}
\hline 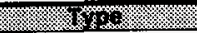 & DETECTOR NUMBER & 14 & \\
\hline SAMPLE & DISH SIZE $\quad(1,2$, or 5$)$ & 2 & \\
\hline 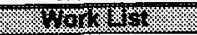 & GROSS COUNTS & 18 & \\
\hline 5064 & COUNT TIME in MINUTES & 30 & \\
\hline 2003 & BACKGROUND in cpm & 0.4 & \\
\hline AT & SAMPLE SZE in $\mathrm{mL}$ & 1.000 & \\
\hline $83 \times 10$ & DILUTION FACTOR & 101 & \\
\hline (1)AB-01 & DIGEST DILUTION FACTOR & 100 & \\
\hline Whis & EFFICIENCY FACTOR & 0.2274 & \\
\hline LIQUID & Lc, Rmax, or Rs,(SAMPLE RATE) as APPROPRIATE & 0.501 & \\
\hline 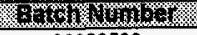 & & & \\
\hline 96000562 & Blank Concentration in $\mu \mathrm{Ci} / \mathrm{L}$ & $1.00 \mathrm{E}+01$ & \\
\hline 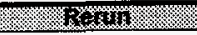 & Replicate Concentration in $\mu \mathrm{CI} / L$ & $8.49 E+00$ & \\
\hline 0 & Maximum Concentration in $\mu \mathrm{Ci} / \mathrm{L}$ & $1.0028 E+01$ & \\
\hline 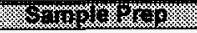 & \multirow{9}{*}{\multicolumn{3}{|c|}{$\begin{array}{l}\text { Rs (Sample Count Rate) }=(\mathrm{TC} / \mathrm{CT})-\mathrm{BKG} \\
\mathrm{ALPHA} \text { TOTAL } \mu \mathrm{Ci} / \mathrm{L}=\mathrm{Rs} * 1000 \mathrm{mLL} * \mathrm{DF} * \mathrm{DDF} /(\mathrm{EFF} * \mathrm{SS} * 2220000 \mathrm{dpm} / \mu \mathrm{Ci}) \\
\text { ALPHA TOTAL } \mu \mathrm{Ci} / \mathrm{mL}=\mathrm{ALPHATOTAL} \mu \mathrm{Ci} / \mathrm{L} / 1000 \mathrm{~mL} / \mathrm{L} \\
\text { Relative Counting Error }=[1(\text { The Square Root of TC }+\mathrm{BKG} * \mathrm{CT}) /(\mathrm{TC}-\mathrm{BKG} * \mathrm{CT}) /]^{*} 1.96 * 100 \\
\text { Detection Levels and Less Than Values are determined from Procedure LA-508-002. }\end{array}$}} \\
\hline ACIDIG02 & & & \\
\hline 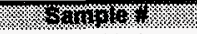 & & & \\
\hline S95R000116 & & & \\
\hline 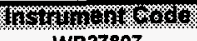 & & & \\
\hline WB27807 & & & \\
\hline $32 \mathrm{PHO} \%$ & & & \\
\hline MCB & & & \\
\hline 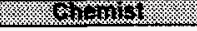 & & & \\
\hline SLF & \multicolumn{2}{|l|}{ ALPHA TOTAL in $\mu \mathrm{Ci} / \mathrm{mL}$ (Maximum) in $\mu \mathrm{Ci} / \mathrm{m}$} & \multirow{2}{*}{$\begin{array}{c}\text { DETECTION } \\
\text { LEVEL }\end{array}$} \\
\hline 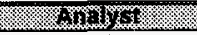 & \multirow{3}{*}{\multicolumn{2}{|c|}{ LESS THAN Value was Determined from Rmax. }} & \\
\hline AKL & & & \\
\hline 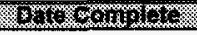 & & & 1.26E-02 \\
\hline $01 / 24 / 96$ & \multicolumn{2}{|l|}{ RELATIVE COUNTING ERROR } & $\mu \mathrm{Ci} / \mathrm{mL}$ \\
\hline
\end{tabular}

\% $01 / 23 / 96$

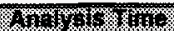
09:00 AM

(5) $30 \%$

ORGIAQ SAMPLE

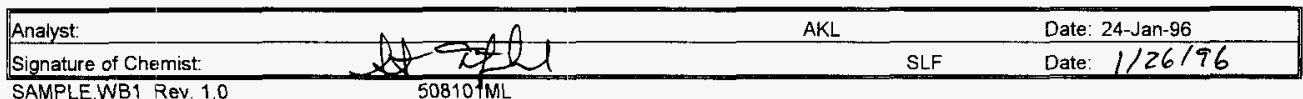




\begin{tabular}{|c|c|c|c|}
\hline \multirow{2}{*}{\multicolumn{2}{|c|}{ TB : LA-508-101 (D-2) SPIKED SAMPLE }} & \multirow[b]{2}{*}{ SPIKE } & \multirow{3}{*}{ REPLICATE } \\
\hline & & & \\
\hline ans & DETECTOR NUMBER & 87 & \\
\hline SPK & DISH SIZE & 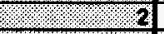 & 2 \\
\hline Hothot & TOTAL COUNTS & 308110 & 404282 \\
\hline 5064 & COUNT TIME in MINUTES & 10 & 10 \\
\hline Whon & BACKGROUND in cPm & 10 & 10 \\
\hline TB & SAMPLE VOLUME In $\mathrm{mL}$ & $\$ 1000$ & 1.000 \\
\hline 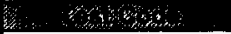 & SAMPLE DILUTION FACTOR (Spiked Vial) & 101 & 101 \\
\hline OAB-01 & DIGEST DILUTION FACTOR & 100 & 100 \\
\hline Hos & SPIKE VOLUME in $\mathrm{mL}$ & $0 / 100$ & 0.100 \\
\hline LIQUID & SPIKE DILUTION FACTOR & 1 & \\
\hline 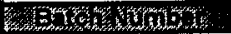 & SPIKE BOOK NUMBER & 86852 & $86 \mathrm{B52}$ \\
\hline 96000562 & SPIKE VALUE in $\mu \mathrm{CI} / \mathrm{mL}$ & $1.6926 \mathrm{E}-01$ & $1.6926 \mathrm{E}-01$ \\
\hline nothos & INSTRUMENT EFFICIENCY FACTOR & 0.4455 & 0.4455 \\
\hline 0 & SAMPLE + SPIKE $\mu \mathrm{CI} / \mathrm{mL}$ & $4.06 \mathrm{E}+02$ & $4.13 E+02$ \\
\hline 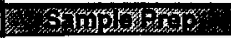 & AVERAGE or MAXIMUM $\mu \mathrm{Ci} / \mathrm{mL}$ in SAMPLE & $2.3442 E+02$ & \\
\hline ACIDIG02 & & & \\
\hline sin & & & \\
\hline S9SR000116 & Rs (Sample Count Rate) $=(\mathrm{TC} / \mathrm{CT})-\mathrm{BKG}$ & & \\
\hline 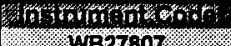 & SAMPLE + SPIKE $\mu \mathrm{CI} / \mathrm{mL}=\mathrm{RS} * \mathrm{DF} * \mathrm{DDF} /(\mathrm{EFF} * \mathrm{SS} * 2$ & $220000 \mathrm{dpm} / \mu \mathrm{Ci})$ & \\
\hline WW27807 & QC ACTUAL = SVaI & & \\
\hline PMCH & QC FOUND $=(((\mathrm{S}+\mathrm{S} \mu \mathrm{Ci} / \mathrm{mL}-\mathrm{SAMPLE} \mu \mathrm{Ci} / \mathrm{mL}) *((S D F / S V o$ & $(y /(D F \cdot D D F / S S)))$ & \\
\hline MeBs. & PERCENT SPIKE RECOVERY = (QC FOUND / QC ACTUAL) & & \\
\hline OPMT: & & & \\
\hline SLF & & & \\
\hline MKKL & & & \\
\hline 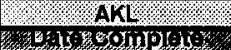 & & & \\
\hline 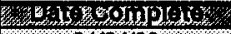 & & & \\
\hline $01 / 24 / 96$ & & & \\
\hline 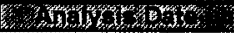 & & & \\
\hline $01 / 23196$ & QC ACTUAL & $1.69 E-01$ & \\
\hline 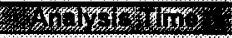 & QC FOUND & $1.73 E-01$ & \\
\hline $0.0900 \mathrm{AM}$ & AVG. PERCENT SPIKE RECOVERY & $102.5 \%$ & \\
\hline 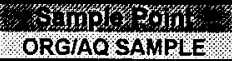 & & & \\
\hline
\end{tabular}

\begin{tabular}{|l|lll|}
\hline Analyst: & MCB & & Date: 24-Jan-96 \\
\hline Signature of Chemist: & SLF & Date: $1 / 26 / 96$ \\
\hline SPIKE.WB1 Rev. 1.0 & & S & \\
\hline
\end{tabular}


WORKBOOK PAGE: SPIKE16

WHC-SD-WM-DP-180, REV. 0

AT : LA-508-101 (D-2) SPIKED SAMPLE

\begin{tabular}{|c|c|c|}
\hline 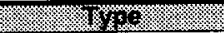 & DETECTOR NUMBER & 14 \\
\hline SPK & 1,2, or 5 & 2 \\
\hline 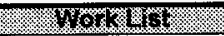 & TOTAL COUNTS & 56752 \\
\hline 5064 & COUNT TIME in MINUTES & 30 \\
\hline \% & BACKGROUND in cpm & 0.4 \\
\hline AT & SAMPLE VOLUME in $\mathrm{mL}$ & 1.000 \\
\hline $8=0.61$ & SAMPLE DILUTION FACTOR (Spiked Vial) & 101 \\
\hline (9AB-01 & DIGEST DILUTION FACTOR & 100 \\
\hline 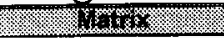 & SPIKE VOLUME in $\mathrm{mL}$ & 0.100 \\
\hline LIQUID & SPIKE DILUTION FACTOR & 1 \\
\hline 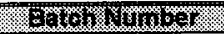 & SPIKE BOOK NUMBER & 119B43 \\
\hline 96000562 & SPIKE VALUE in $\mu \mathrm{Ci} / \mathrm{mL}$ & $3.9209 \mathrm{E}-02$ \\
\hline 80 & INSTRUMENT EFFICIENCY FACTOR & 0.2274 \\
\hline 0 & SAMPLE + SPIKE $\mu \mathrm{Ci} / \mathrm{mL}$ & $3.78 \mathrm{E}+01$ \\
\hline 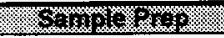 & AVERAGE or MAXIMUM $\mu \mathrm{Ci} / \mathrm{mL}$ in SAMPLE & $1.0028 \mathrm{E}-02$ \\
\hline ACIDIG02 & \multirow{8}{*}{\multicolumn{2}{|c|}{ 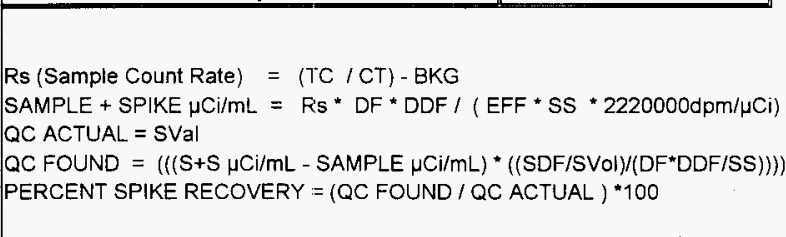 }} \\
\hline 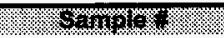 & & \\
\hline S95R000116 & & \\
\hline 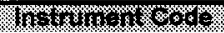 & & \\
\hline WB27807 & & \\
\hline 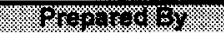 & & \\
\hline MCB & & \\
\hline 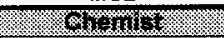 & & \\
\hline SLF & \multirow{6}{*}{ NOTE: } & \multirow{6}{*}{ Zero $(0)$ was s } \\
\hline 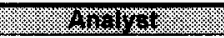 & & \\
\hline$A K L$ & & \\
\hline 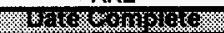 & & \\
\hline $01 / 24 / 96$ & & \\
\hline 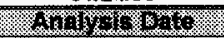 & & \\
\hline $01 / 23 / 96$ & QC ACTUAL & $3.92 \mathrm{E}-02$ \\
\hline 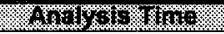 & QC FOUND & $3.82 \mathrm{E}-02$ \\
\hline 09:00 AM & AVG. PERCENT SPIKE RECOVERY & $97.4 \%$ \\
\hline
\end{tabular}

S.14 $10 \%$

ORGIAQ SAMPLE

\begin{tabular}{|lllll}
\hline Analyst: & MCB & Date: 24-Jan-96 \\
\hline Signature of Chemist: & Date: //26/96 \\
\hline SPIKE.WB1 Rev. 1.0
\end{tabular}

\section{$2+3$}




\begin{tabular}{|c|c|c|c|}
\hline 08-1 & SPIKED SAMPLE & SPIKE & REPLICATE \\
\hline tho & DETECTOR NUMBER & (18) & 141 \\
\hline SPK-DUP & DISH SIZE & 2 & 2 \\
\hline Horats? & TOTAL COUNTS & 407395 & 402855 \\
\hline 5064 & COUNT TIME IN MINUTES & 10 & 10 \\
\hline Wh & BACKGROUND in cpm & 10 & 10 \\
\hline TB & SAMPLE VOLUME in $\mathrm{mL}$ & 18000 & 1.000 \\
\hline 31000 & SAMPLE DILUTION FACTOR (Spiked Vial) & 101 & 101. \\
\hline (1)AB-01 & DIGEST DILUTION FACTOR & 100 & 100 \\
\hline $1+1,1$ & SPIKE VOLUME in $\mathrm{mL}$ & 0,100 & 0.100 \\
\hline LIQUID & SPIKE DILUTION FACTOR & 18 & \\
\hline 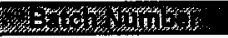 & SPIKE BOOK NUMBER & $86 B 52$ & $86 \mathrm{B52}$ \\
\hline 96000562 & SPIKE VALUE in $\mu \mathrm{CI} / \mathrm{mL}$ & $1.6926 \mathrm{E}-01$ & $1.6926 \mathrm{E}-01$ \\
\hline-301 & INSTRUMENT EFFICIENCY FACTOR & 0.4455 & 0.4455 \\
\hline 0 & SAMPLE + SPIKE $\mu \mathrm{CI} / \mathrm{mL}$ & $4.16 E+02$ & $4.11 E+02$ \\
\hline 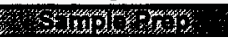 & AVERAGE or MAXIMUM $\mu \mathrm{Cl} / \mathrm{mL}$ in SAMPLE & $2.3442 E+02$ & \\
\hline ACIDIGO2 & & & \\
\hline S95R000116 & Rs (Sample Count Rate) $=(T C / C T)-B K G$ & & \\
\hline How & $\begin{array}{l}\text { SAMPLE + SPIKE } \mu \mathrm{Ci} / \mathrm{mL}=\mathrm{Rs} * \mathrm{DF} * \mathrm{DDF} /(\mathrm{EFF} * \mathrm{SS} * \\
\text { QC ACTUAL }=\text { SVal }\end{array}$ & $2220000 \mathrm{dpm} / \mu \mathrm{Ci})$ & \\
\hline 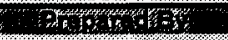 & QC FOUND $=(((S+S \mu \mathrm{Ci} / \mathrm{mL}-S A M P L E \mu C \mathrm{C} / \mathrm{mL}) *((S D F / S V 0$ & ())/(DF“DDF/SS))) & \\
\hline MOB & PERCENT SPIKE RECOVERY = (QC FOUND / QC ACTUAL $)$ & $\bullet 100$ & \\
\hline 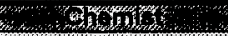 & & & \\
\hline SLF & & & \\
\hline torsts & & & \\
\hline AKL & & & \\
\hline 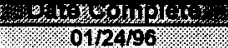 & & & \\
\hline 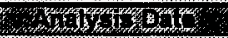 & & & \\
\hline $01 / 23 / 96$ & QC ACTUAL & 1.69E-01 & \\
\hline (Y) & QC FOUND & 1.77E-01 & \\
\hline $09.00 \mathrm{AM}$ & AVG. PERCENT SPIKE RECOVERY & $104.8 \%$ & \\
\hline 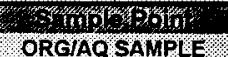 & & & \\
\hline
\end{tabular}

\begin{tabular}{|l|lll|}
\hline Analyst: & MCB & & Date: $24-J a n-96$ \\
\hline Signature of Chemist: & St & SLF & Date: $/ / 26 / 96$ \\
\hline SPIKE.WB1 Rev. 1.0 & $508101 \mathrm{ML}$ & & \\
\hline
\end{tabular}


WORKBOOK PAGE: SP_DUP18
AT : LA-508-101 (D-2) WHA-SD-WM-DP-18Q REV. 0

\begin{tabular}{|c|c|c|c|}
\hline AT : LA-508-1 & SPIKEDSAMF & SPIKE & REPLICATE \\
\hline (m) & DETECTOR NUMBER & 14 & $\overline{14}$ \\
\hline SPK-DUP & 1,2, or 5 & 2 & 2 \\
\hline 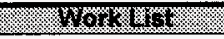 & TOTAL COUNTS & 59197 & 58541 \\
\hline 5064 & COUNT TIME in MINUTES & 30 & 30 \\
\hline 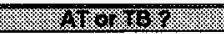 & BACKGROUND in cpm & 0.4 & 0.4 \\
\hline AT & SAMPLE VOLUME in $\mathrm{mL}$ & 1.000 & 1.000 \\
\hline 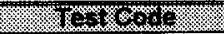 & SAMPLE DILUTION FACTOR (Spiked Vial) & 101 & 101 \\
\hline (QAB-01 & DIGEST DILUTION FACTOR & 100 & 100 \\
\hline When & SPIKE VOLUME in $\mathrm{mL}$ & 0.100 & 0.100 \\
\hline LIQUID & SPIKE DILUTION FACTOR & 1. & 1 \\
\hline 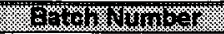 & SPIKE BOOK NUMBER & $119 \mathrm{~B} 43$ & 119B43 \\
\hline 96000562 & SPIKE VALUE in $\mu \mathrm{Ci} / \mathrm{mL}$ & $3.9209 \mathrm{E}-02$ & $3.9209 E-02$ \\
\hline 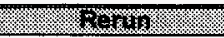 & INSTRUMENT EFFICIENCY FACTOR & 0.2274 & 0.2274 \\
\hline 0 & SAMPLE + SPIKE $\mu \mathrm{Ci} / \mathrm{mL}$ & $3.95 \mathrm{E}+01$ & $3.90 \mathrm{E}+01$ \\
\hline 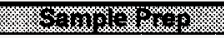 & AVERAGE or MAXIMUM $\mu \mathrm{Ci} / \mathrm{mL}$ in SAMPLE & $1.0028 \mathrm{E}-02$ & \\
\hline ACIDIG02 & \multirow{8}{*}{\multicolumn{3}{|c|}{ 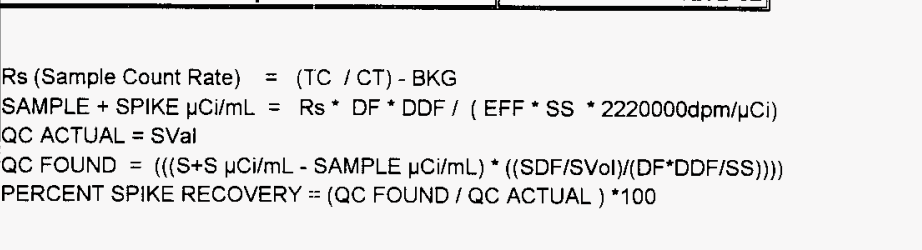 }} \\
\hline 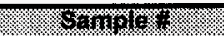 & & & \\
\hline S95R000116 & & & \\
\hline 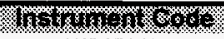 & & & \\
\hline WB27807 & & & \\
\hline of $8+20=0$ & & & \\
\hline MCB & & & \\
\hline 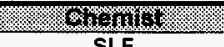 & & & \\
\hline
\end{tabular}

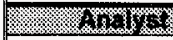

AKL

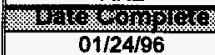

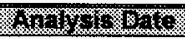

$01 / 23 / 96$

Wh:

09:00 AM

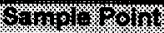

ORGIAQ SAMPLE

\begin{tabular}{|l|lll|}
\hline Analyst: & MCB & Date: 24-Jan-96 \\
\hline Signature of Chemist: & SLF & Date: //26/96 \\
\hline SPIKE.WB1 Rev. 1.0 &
\end{tabular}

Original Sample result was a LESS THAN value. Zero (0) was subtracted from the spiked value for $Q C$ found calculation.

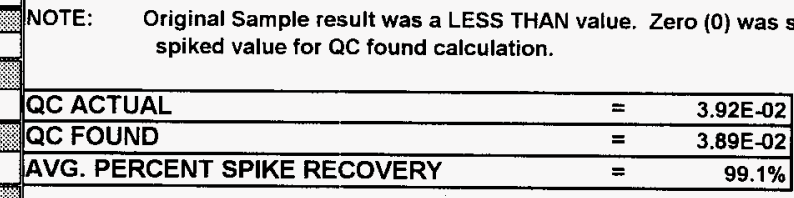




\section{LABCORE Completed Worklist Report for Worklist\# 4973}

Analyst: crj

Instrument: GEA02

Book\# 144652

Method: $L A-548-121$ Rev/Mod $D-1$

Worklist Comment: RUSH! B-Plant GEA, $S S=0.1-10-1$ dilution both samples. -PPB

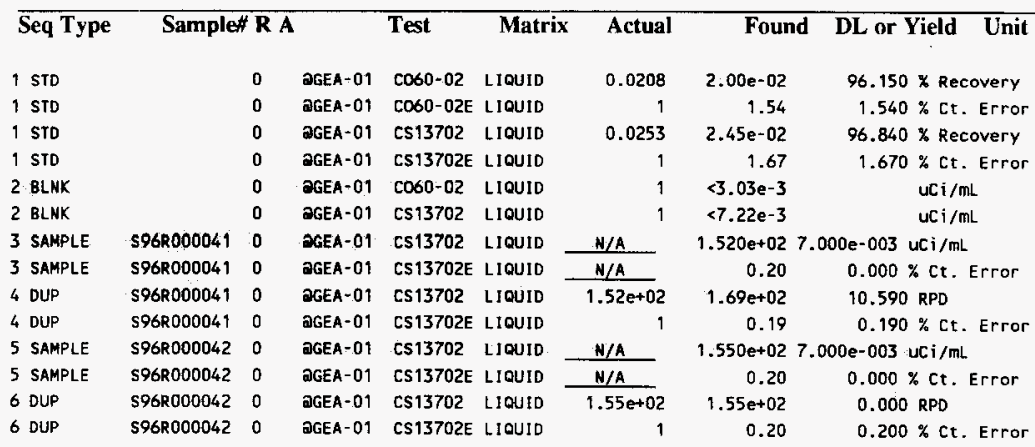

Final page for worklist\# 4973

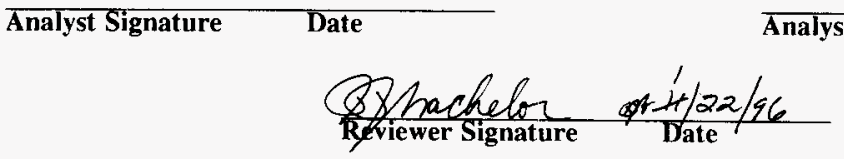

Units shown for QC $(B L K / B K G)$ may not reflect the actual units. 


\section{LABCORE Data Entry Template for Worklist\# 4973}

Analyst: CRg Instrument: GEA00 \$2 Book\#144 BS2

Method: LA-548-121 Rev/Mod D-1

Worklist Comment: RUSH! B-Plant GEA, SS $=0.1-10-1$ dilution both samples. -PPB

\begin{tabular}{|c|c|c|c|c|c|c|c|}
\hline $\mathbf{s}$ & Type & Sample\# & R A & Test & Matrix & Group\# & Project \\
\hline 1 & STD & & & GGEA-01 & LIQUID & & \\
\hline 2 & BLNK & & & CGEA-01 & LIQUID & & \\
\hline \multirow[t]{2}{*}{3} & SAMPLE & S96R000041 & 0 & CGEA-01 & LIQUID & 95000224 & ORG /AQ SAMPL \\
\hline & & Analytes Reque & ested: & $\operatorname{cs} 13702$ &, $\operatorname{cs} 13702 E$ & & \\
\hline 4 & DUP & S96R000041 & 0 & QGEA-01 & LIQUID & & \\
\hline \multirow[t]{2}{*}{5} & SAMPLE & S96R000042 & 0 & CGEA-01 & LIQUID & 95000224 & ORG /AQ SAMPL \\
\hline & & Analytes Reque & estec & $\operatorname{cs} 13702$ &, $\operatorname{cs} 13702 E$ & & \\
\hline 6 & DUP & S96R000042 & 0 & eGEA-01 & LIQUID & & \\
\hline
\end{tabular}

\section{Final page for worklist \# 4973}
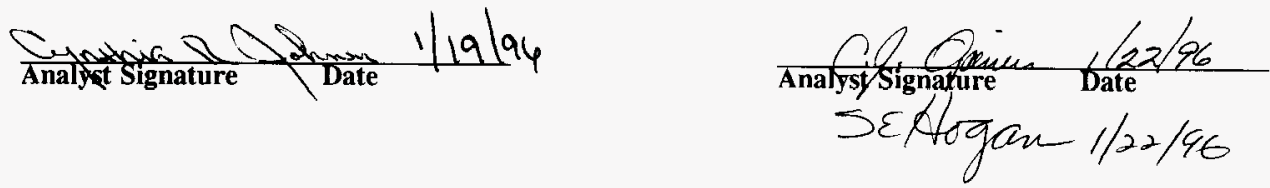

Data Entry Comments:

$S=$ Worklist Slot Number, $R=$ Replicate Number, $A==$ Aliquot Code. 
$>>>>>>>>$ SAMPLE INFORMATION $<<<<<<<<<<~$

Worklist \#:

Sample ID:

Sample Size:

Dilution Factor:

$\gg \gg>>>>>$ COUNT

Detector ID:

File Number:

Geometry:

Count Time:

Real Time:

Dead Time:
4973

WL4 973-STD

$1.00000 \mathrm{E}-03 \mathrm{~L}$

1. $00000 \mathrm{E}+00$

INFORMATION $\ll<く<く<く<~$

GEA2

dka $300:$ [ spec . GEA2 ]2g2589 . cnf

42

0 00:50:00.00 sec

0 00:50:07.18 sec

$0.2 \%$
WHC-SD-WM-DP-180, REV. 0

Removed by:

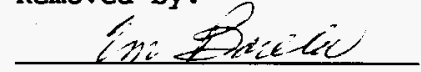

Verified by:

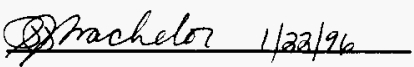
$\gg \gg \gg \gg \gg \gg>$ ANALYSI
Sample Count Time:
Decayed to:
Standard Deviations:
Analysis Library:
Analyst:
Background Subtract:
$19-J A N-199613: 26: 54.86$
2
ENVGEA
EMB
DKA 300 : [ SPEC.GEA2 ] 2GBACK
19-JAN-1996 $13: 26: 54.86$

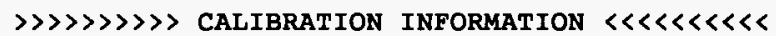

Date of last energy calibration: 21-MAR-1994 09:31:55.15

Date of last efficiency calibration: 21-MAR-1994 09:43:42.61

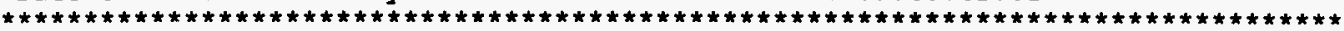

Post-NID Peak Search Report

\begin{tabular}{|c|c|c|c|c|c|c|c|c|c|}
\hline Energy & Area & FWHM & Channel & Left & Pw & \&Er & Fit & Nuclides & $\begin{array}{c}\text { Activity } \\
\text { uCi/L }\end{array}$ \\
\hline $\begin{array}{r}661.35 * \\
1172.80 \\
1332.05\end{array}$ & $\begin{array}{r}17674 \\
10089 \\
9245\end{array}$ & $\begin{array}{l}1.52 \\
1.85 \\
2.01\end{array}$ & $\begin{array}{l}1322.72 \\
2345.66 \\
2664.26\end{array}$ & $\begin{array}{l}1314 \\
2336 \\
2654\end{array}$ & $\begin{array}{l}16 \\
18 \\
21\end{array}$ & $\begin{array}{l}1.7 \\
2.2 \\
2.1\end{array}$ & & $\begin{array}{l}\text { CS-137 } \\
C O-60 \\
C O-60\end{array}$ & $\begin{array}{l}24.5 \\
19.8 \\
20.1\end{array}$ \\
\hline
\end{tabular}


Total number of lines in spectrum Number of unidentified lines

Acquisition date : 19-JAN-1996 13:26:54

Number of lines tentatively identified by NID $3 \quad 100.008$

Nuclide Type :
Nuclide
Hlife
Wtd Mean
CO-60
$5.27 Y$
Decay
Uncorrected
CS-137

$30.00 \mathrm{Y} \quad 1.000$
uCi/L
Wtd Mean
Decay Corr $\mathrm{uCi} / \mathrm{L}$
$1.997 \mathrm{E}+01$
$2.453 \mathrm{E}+01$
1. $997 \mathrm{E}+01$
$2.453 E+01$
Decay Corr 2-Sigma
$0.031 \mathrm{E}+01$
1.54
$0.041 \mathrm{E}+01$
1.67
2-Sigma Error \&Error Flags
Total Activity : $4.450 \mathrm{E}+01 \quad 4.450 \mathrm{E}+01$
Grand Total Activity : $4.450 \mathrm{E}+01 \quad 4.450 \mathrm{E}+01$
Flags: "K" $\begin{aligned} \text { : Keyline not found } \\ E "=\text { Manually edited }\end{aligned}$
"M" = Manually accepted
"A" = Nuclide specific abn. limit 
Mirimum Detectable Activity Report Sample ID : WL4973-STD

\section{Nuclide}

$B E-7$
$N A-22$
$N A-24$
$K-40$
$C R-51$
$M N-54$
$C O-56$
$C O-57$
$C O-58$
$F E-59$
$S E-75$
$S R-85$
$Y-88$
$N B-94$

ZRNB-95

RU-103

RURH-106

AG-108m

CD-109

AG-110M

SN-113

TE-123m

$\mathrm{SB}-124$

$\mathrm{SB}-125$

$\mathrm{TE}-125 \mathrm{~m}$

I -131

CS-134

$\mathrm{BA}-140$

LA -140

CEPR-144

EU-152

EU-154

EU-155

HG -203

TL-208

BI-2 12

PB-2 12

BI - 214

PB-2 14

RA-224

RA-226

AC-2 28

TH-228

TH-229

PA-233

UTH-233

PA-234M

TH-234

$\mathrm{U}-235$

NP -237

NP-239

\section{Bckgnd \\ sum}

900.

66.

15.

116.

923.

539.

535.

1058 .

502 .

526.

1057.

652 .

12 .

553.

445.

753.

518.

443.

924.

1169.

889.

1068 .

516 .

918.

947.

905.

502 .

558.

14.

1119.

26.

66.

971.

1047.

1013.

445.

1256 .

520 .

865.

1251 .

1180 .

623.

945 .

926.

1002 .

1174 .

506 .

889.

1188 .

972 .

958 .
Energy
(kev)

477.59

1274.53

1368.55

1460.75

320.08

834.83

846.76

122.06

810.78

1099.25

264.66

514.01

1836.06

871.09

724.18

497.08

621.93

722.94

88.03

657.76

391.69

159.00

602.73

427.89

109.27

364.48

604.70

537.31

1596.21

133.51

1408.01

1274.51

105.31

279.20

277.36

727.18

238.63

609.31

351.92

240.99

186.10

911.21

84.37

88.47

312.17

245.34

1001.03

63.29

185.71

86.48

106.12
Page : 3

Acquisition date : 19-JAN-1996 13:26:54
$\underset{(\mathrm{MDI} / \mathrm{L})}{\text { WHC-SD-WM-DP-180, REV. } 0}$

$1.2167 \mathrm{E}+00$
$7.9204 \mathrm{E}-02$
$4.0955 \mathrm{E}-02$
$1.1005 \mathrm{E}+00$
$9.1917 \mathrm{E}-01$
$1.5554 \mathrm{E}-01$
$1.5691 \mathrm{E}-01$
$7.2719 \mathrm{E}-02$
$1.4727 \mathrm{E}-01$

$3.4885 \mathrm{E}-01$

$1.4850 \mathrm{E}-01$

$1.1895 \mathrm{E}-01$

$4.4896 \mathrm{E}-02$

1. $6340 \mathrm{E}-01$

2.8661E-01

1. $3110 \mathrm{E}-01$

$2.3971 \mathrm{E}+00$

$1.3741 \mathrm{E}-01$

2. $3340 \mathrm{E}+00$

$1.9775 \mathrm{E}-01$

$1.6411 \mathrm{E}-01$

7. $3114 \mathrm{E}-02$

$1.1836 \mathrm{E}-01$

3. $9128 \mathrm{E}-01$

$2.2813 \mathrm{E}+01$

1. 2400E-01

1. $1725 \mathrm{E}-01$

$4.4996 \mathrm{E}-01$

$4.6829 \mathrm{E}-02$

1. $1177 \mathrm{E}+00$

2.5828E-01

2.3004E-01

3. $1026 \mathrm{E}-01$

$1.0996 \mathrm{E}-01$

1. $3899 \mathrm{E}+00$

$1.8893 \mathrm{E}+00$

$2.0224 \mathrm{E}-01$

2.6148E-01

4. 7831E-01

$2.2395 \mathrm{E}+00$

$2.0041 \mathrm{E}+00$

$6.7704 \mathrm{E}-01$

$7.2470 \mathrm{E}+00$

$3.3864 \mathrm{E}-01$

$2.4568 \mathrm{E}-01$

8. 1287E+01

3. $0042 \mathrm{E}-01$

4. $0942 \mathrm{E}+00$

1. 2220E-01

7. 1844 E-01

2. $9239 E-01$ 
Minimum Detectable Activity Report (continued)

Sample ID : WL4973-STD

Acquisition date : 19-JAN-1996 13:26:54

Nuclide

$$
\text { PU-239 }
$$

AM-241

$A M-243$
Bckgnd

sum

1119.

882 .

896 .
Energy

(keV)

129.30

59.54

74.67
MDA WHC-SD-WVA-DP-180, FEV. 0 (uCi/L)

9.7651E+02

$6.4920 \mathrm{E}-01$

$1.9177 \mathrm{E}-01$ 


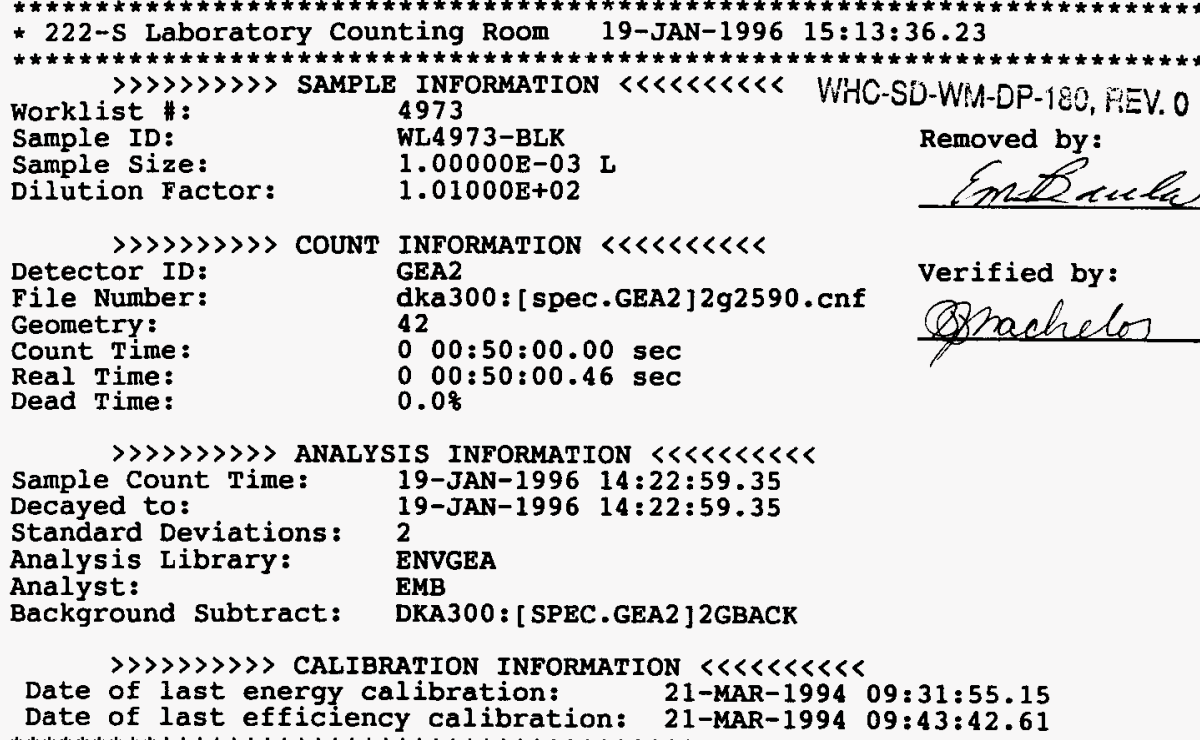

Worklist \#:

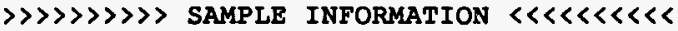

Sample ID:

Sample Size:

Dilution Factor:

$\gg \gg \gg \gg \gg \gg \gg>$ COUNT

Detector ID:

File Number:

Geometry:

Count Time:

Real Time:

Dead Time:

4973

WL4973-BLK

$1.00000 \mathrm{E}-03 \mathrm{~L}$

$1.01000 \mathrm{E}+02$

WHC-SD-WM-DP-180, FEV. 0

Removed by:

Verified by:

GEA2

dka300: [ spec.GEA2]2g2590.cnf

42

$000: 50: 00.00 \mathrm{sec}$

0 00:50:00.46 sec

0.08

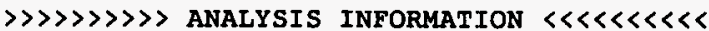

Sample Count Time: 19-JAN-1996 14:22:59.35

Decayed to:

Standard Deviations:

Analysis Library:

Analyst:

19-JAN-1996 14:22:59.35

Background Subtract: DKA300: [SPEC.GEA2]2GBACK

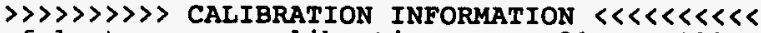

\section{Date of last energy calibration: 21-MAR-1994 09:31:55.15}

Date of last efficiency calibration: 21-MAR-1994 09:43:42.61

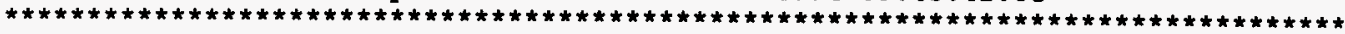

Post-NID Peak Search Report

It Energy Area FWHM Channel Left Pw \&Err Fit Nuclides Activity uCi/L

$\begin{array}{llllll}0 & 609.65 * \quad 20 & 2.02 & 1219.34 & 1214 & 13101.7\end{array}$ 
Total number of lines in spectrum Number of unidentified lines Number of lines tentatively identified by NID $\star \star \star \star$ There are no nuclides meeting summary criteria $\star * \star *$

1 WHC-SD-WM-DP-180, PEV. 0

Flags: "K" = Keyline not found

"M" = Manually accepted

"E" = Manually edited

"A" = Nuclide specific abn. limit 
Minimum Detectable Activity Report Sample ID : WL4973-BLR

Nuclide

\section{Bckgnd \\ sum}

$\mathrm{BE}-7$

NA -22

NA-24

K-40

CR-51

MN-54

CO- 56

CO-57

CO-58

FE- 59

CO-60

SE -75

SR-85

$\mathrm{Y}-88$

NB-94

ZRNB-95

RU-103

RURH- 106

AG-108m

CD-109

AG- $110 \mathrm{M}$

SN-113

TE-123m

SB-124

SB-125

TE-125m

I -131

CS-134

CS -137

BA -140

LA- 140

CEPR-144

EU-152

EU-154

EU-155

HG-203

TL-208

BI-2 12

PB-212

BI-214

PB-214

RA-224

RA-226

AC- 228

TH-228

TH-229

PA-233

UTH -233

$\mathrm{PA}-234 \mathrm{M}$

TH -234

$\mathrm{U}-235$

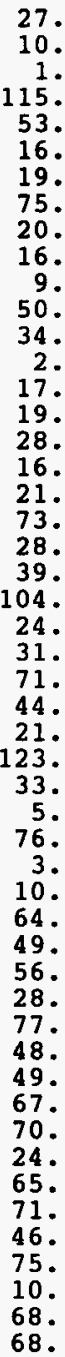

Energy (kev)

477.59

1274.53

1368.55

1460.75

320.08

834.83

846.76

122.06

810.78

1099.25

1332.50

264.66

514.01

1836.06

871.09

724.18

497.08

621.93

722.94

88.03

657.76

391.69

159.00

602.73

427.89

109.27

364.48

604.70

661.66

537.31

1596.21

133.51

1408.01

1274.51

105.31

279.20

277.36

727.18

238.63

609.31

351.92

240.99

186.10

911.21

84.37

88.47

312.17

245.34

1001.03

63.29

185.71
Acquisition date : 19-JAN-1996 14:22:59

MDA WHC-SU-WM-DP-180, FEV. 0 ( $\mathrm{UCi} / \mathrm{L})$

$2.1243 \mathrm{E}+01$

$3.1652 \mathrm{E}+00$

$1.0640 \mathrm{E}+00$

1. $1051 \mathrm{E}+02$

2. $2315 \mathrm{E}+01$

$2.6973 \mathrm{E}+00$

2. $9869 \mathrm{E}+00$

$1.9618 \mathrm{E}+00$

2. $9522 \mathrm{E}+00$

$6.2238 \mathrm{E}+00$

$3.0270 \mathrm{E}+00$

3. $2654 \mathrm{E}+00$

$2.7240 \mathrm{E}+00$

$1.8816 \mathrm{E}+00$

$2.9315 \mathrm{E}+00$

$5.9446 \mathrm{E}+00$

$2.5379 E+00$

4. $2657 \mathrm{E}+01$

3. $0037 \mathrm{E}+00$

$6.6233 \mathrm{E}+01$

3. $1179 \mathrm{E}+00$

$3.4862 \mathrm{E}+00$

$2.3032 \mathrm{E}+00$

2. $5770 \mathrm{E}+00$

7. $2578 \mathrm{E}+00$

$6.3241 \mathrm{E}+02$

$2.7562 \mathrm{E}+00$

$2.4217 \mathrm{E}+00$

$7.2207 \mathrm{E}+00$

$1.1101 \mathrm{E}+01$

$2.8848 E+00$

2. $9374 \mathrm{E}+01$

8. $9539 \mathrm{E}+00$

9. $1780 \mathrm{E}+00$

8. $0567 \mathrm{E}+00$

2. $3909 E+00$

3. $2908 \mathrm{E}+01$

$4.8284 \mathrm{E}+01$

$5.0418 \mathrm{E}+00$

8. $0237 \mathrm{E}+00$

1. 1455E+01

5. $2382 \mathrm{E}+01$

4. $9428 \mathrm{E}+01$

1. $3542 \mathrm{E}+01$

1. $9224 \mathrm{E}+02$

9. $4932 \mathrm{E}+00$

$5.3167 E+00$

2. $0692 \mathrm{E}+03$

4. $2226 \mathrm{E}+00$

1. $1446 \mathrm{E}+02$

2. $9499 \mathrm{E}+00$ 
Minimum Detectable Activity Report (continued)

Sample ID : WL4973-BLK

Nuclide

NP -237

$N P-239$

$\mathrm{PU}-239$

AM-241

$A M-243$
Bckgnd

Sum

77.

58.

81 .

49.

70 .
Acquisition date : 19-JAN-1996 14:22:59

Energy

(kev)

MDA VHAC-SD-WH-DP-18U, FEV.O (UCi/L)

86.48

106.12

129.30

59.54

74.67
$2.0378 \mathrm{E}+01$

$7.2918 \mathrm{E}+00$

$2.6462 \mathrm{E}+04$

$1.5449 \mathrm{E}+01$

$5.3995 E+00$ 
Post-NID Peak Search Report

It Energy Area FWHM Channel Left Pw oferr Fit Nuclides Activity $\mathrm{uCi} / \mathrm{L}$

$\begin{array}{rrrrrrrrrr}0 & 661.34 * & 1081794 & 1.53 & 1322.70 & 1314 & 18 & 0.2 & \text { CS }-137 & 1.516 \mathrm{E}+05 \\ 0 & 1322.07 & 298 & 2.89 & 2644.29 & 2637 & 15 & 23.3 & \end{array}$

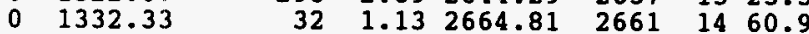


Total number of lines in spectrum Number of unidentified lines

Number of lines tentatively identified by NID

3 WHC-SD-WM-DP-180, REV. 0

$266.67 \%$

Nuclide Type :

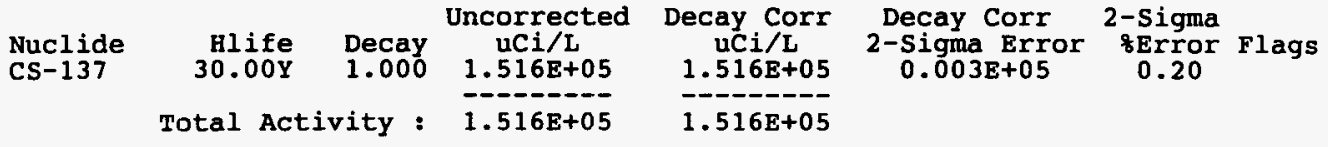

Grand Total Activity : $1.516 \mathrm{E}+05 \quad 1.516 \mathrm{E}+05$

Flags: "K" = Keyline not found

"M" = Manually accepted

"E" = Manually edited

"A" = Nuclide specific abn. limit 
Minimum Detectable Activity Report Sample ID : S96R41-SAM

\section{Nuclide}

$$
\begin{aligned}
& \mathrm{BE}-7 \\
& \mathrm{NA}-22 \\
& \mathrm{NA}-24 \\
& \mathrm{~K}-40 \\
& \mathrm{C} R-51 \\
& \mathrm{MN}-54 \\
& \mathrm{CO}-56 \\
& \mathrm{CO}-57 \\
& \mathrm{CO}-58 \\
& \mathrm{FE}-59 \\
& \mathrm{CO}-60 \\
& \mathrm{SE}-75 \\
& \mathrm{SR}-85 \\
& \mathrm{Y}-88
\end{aligned}
$$

NB-94

ZRNB-95

RU- 103

RURH-106

AG-108m

CD-109

AG-110M

SN-113

$\mathrm{TE}-123 \mathrm{~m}$

SB-124

SB- 125

TE-125m

I-131

CS -134

$\mathrm{BA}-140$

LA-140

CEPR-144

EU-152

EU-154

EU-155

HG-203

TL-208

BI-2 12

PB-2 12

BI -214

PB-214

RA-224

$R A-226$

AC -228

TH-228

TH-229

PA-233

UTH -233

PA-234M

TH-234

U-235

NP -237
Bckgnd
Sum

34054
154
12
123
28515
726
731
30763
874
258
44

31869 .

17902 .

4.

672 .

1269 .

21926 .

7658 .

1263 .

27100 .

50041 .

31214 .

31606 .

7960 .

35941 .

28940 .

29261.

7966.

13297.

31496 .

10.

154 .

28054 .

30348 .

30368 .

1271 .

35585 .

7994 .

28975.

35191 .

40789 .

525 .

27015.

27017 .

28942 .

34022 .

379 .

25089.

40354 .

27347 .
Energy

(keV)

477.59

1274.53

1368.55

1460.75

320.08

834.83

846.76

122.06

810.78

1099.25

1332.50

264.66

514.01

1836.06

871.09

724.18

497.08

621.93

722.94

88.03

657.76

391.69

159.00

602.73

427.89

109.27

364.48

604.70

537.31

1596.21

133.51

1408.01

1274.51

105.31

279.20

277.36

727.18

238.63

609.31

351.92

240.99

186.10

911.21

84.37

88.47

312.17

245.34

1001.03

63.29

185.71

86.48
Page : 3

Acquisition date : 19-JAN-1996 15:17:03
MDA WHO-SU-Wh-DF-180, $1:=6.0$
(uCi/L)

$7.5603 \mathrm{E}+02$

1.2240E+01

$3.6845 \mathrm{E}+00$

$1.1444 \mathrm{E}+02$

$5.1613 \mathrm{E}+02$

$1.8225 \mathrm{E}+01$

$1.8526 \mathrm{E}+01$

$3.9611 \mathrm{E}+01$

$1.9620 \mathrm{E}+01$

$2.4659 \mathrm{E}+01$

$6.8139 \mathrm{E}+00$

$8.2366 \mathrm{E}+01$

$6.2960 \mathrm{E}+01$

$2.5482 E+00$

$1.8192 \mathrm{E}+01$

$4.8885 \mathrm{E}+01$

7. $1452 \mathrm{E}+01$

$9.3108 \mathrm{E}+02$

$2.3427 \mathrm{E}+01$

$1.2766 \mathrm{E}+03$

$1.3068 \mathrm{E}+02$

$9.8199 \mathrm{E}+01$

$4.0174 \mathrm{E}+01$

$4.6937 \mathrm{E}+01$

$2.4728 \mathrm{E}+02$

$1.2735 \mathrm{E}+04$

7. $1225 \mathrm{E}+01$

$4.7168 \mathrm{E}+01$

$2.2178 \mathrm{E}+02$

$3.8134 \mathrm{E}+00$

$5.9902 \mathrm{E}+02$

1. $5802 \mathrm{E}+01$

$3.5542 \mathrm{E}+01$

1. $6840 \mathrm{OE}+02$

$5.9802 \mathrm{E}+01$

$7.6868 \mathrm{E}+02$

$3.2257 \mathrm{E}+02$

$1.0872 \mathrm{E}+02$

$1.0357 \mathrm{E}+02$

$2.8638 \mathrm{E}+02$

$1.2001 \mathrm{E}+03$

$1.1899 \mathrm{E}+03$

$6.2779 \mathrm{E}+01$

$3.9136 \mathrm{E}+03$

$1.8476 \mathrm{E}+02$

$1.3334 \mathrm{E}+02$

$4.4193 \mathrm{E}+04$

$2.6274 \mathrm{E}+01$

$2.1971 \mathrm{E}+03$

7. $1940 \mathrm{E}+01$

$3.8481 \mathrm{E}+02$ 
M $\perp$ nimum Detectable Activity Report (continued)

Nuclide

$\mathrm{NP}-239$

PU-239

$A M-241$

$A M-243$
Bckgnd

sum

Energy

(kev)

28301 .

31498 .

25324 .

25972 .

106.12

129.30

59.54

74.67
MDA WHC-SD-WM-DP-16u, BEV. O (uCi/L)

1. $6056 \mathrm{E}+02$

$5.2335 \mathrm{E}+05$

$3.5141 \mathrm{E}+02$

$1.0429 \mathrm{E}+02$ 


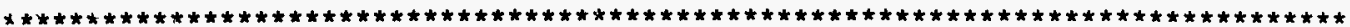
-222-S Laboratory Counting Room 19-JAN-1996 17:14:32.01

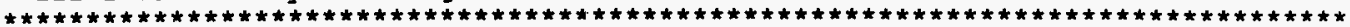

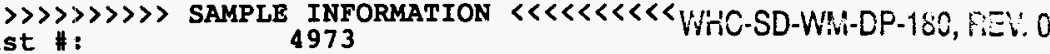

Worklist \# :

Sample ID:

Sample Size:

Dilution Factor:

$\gg \gg \gg \gg \gg \gg \gg$ COUNT Detector ID:

File Number:

Geometry:

Count Time:

Real Time:

Dead Time:
S96R000041-DUP

$1.00000 \mathrm{E}-03 \mathrm{~L}$

1. $01000 \mathrm{E}+02$

INFORMATION $<<<<<<<<<<~$

GEA2

dka $300:[$ spec. . GEA2 ] 2g2592. cnf

42

$000: 50: 00.00 \mathrm{sec}$

$0 \quad 00: 52: 48.70 \mathrm{sec}$

$5.3 \%$

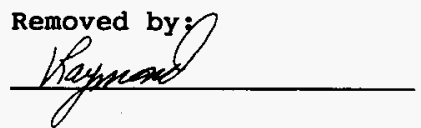

Verified by:

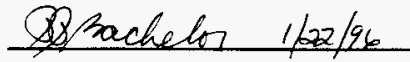

$\gg>>>>>>>$ ANALYSIS INFORMATION $<<<<<<<<<<~$

Sample Count Time: 19-JAN-1996 16:21:04.52

Decayed to: 19-JAN-1996 16:21:04.52

Standard Deviations: 2

Analysis Library: ENVGEA

Analyst: $\quad$ EMB

Background Subtract: DKA300: [SPEC.GEA2]2GBACK

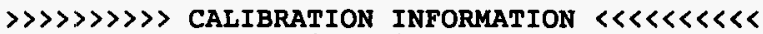

Date of last energy calibration: 21-MAR-1994 09:31:55.15

Date of last efficiency calibration: 21-MAR-1994 09:43:42.61

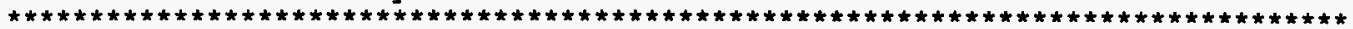

Post-NID Peak Search Report

It Energy Area FWHM Channel Left Pw ofrr Fit Nuclides Activity $\mathrm{uCi} / \mathrm{L}$

$\begin{array}{lrrrrrrr}0 & 661.34 * & 1207092 & 1.53 & 1322.70 & 1314 & 18 & 0.2 \\ 0 & 1322.14 & 338 & 1.44 & 2644.43 & 2638 & 14 & 22.0 \\ 0 & 1331.71 & 44 & 1.04 & 2663.58 & 2656 & 18 & 54.1 \\ 0 & 1764.66 * & 13 & 1.02 & 3529.95 & 3524 & 15 & 76.5\end{array}$


Total number of lines in spectrum Number of unidentified lines

Number of lines tentatively identified by NID
4 WHC-SD-WM-DP-100, FEV. 0

1

$75.00 \%$

Nuclide Type :

Nuclide Cs -137
Wtd Mean Wtd Mean Uncorrected

Hlife 30.0OY

Decay $\mathrm{uCi} / \mathrm{L}$ $1.692 \mathrm{E}+05$ $-------1$ Total Activity : $1.692 \mathrm{E}+05$
Grand Total Activity : $1.692 \mathrm{E}+05$

Flags: "K" = Keyline not found

"E" = Manually edited
$1.692 \mathrm{E}+05$

"M" = Manually accepted

"A" = Nuclide specific abn. limit 
Minimum Detectable Activity Report Sample ID : S96R000041-DUP

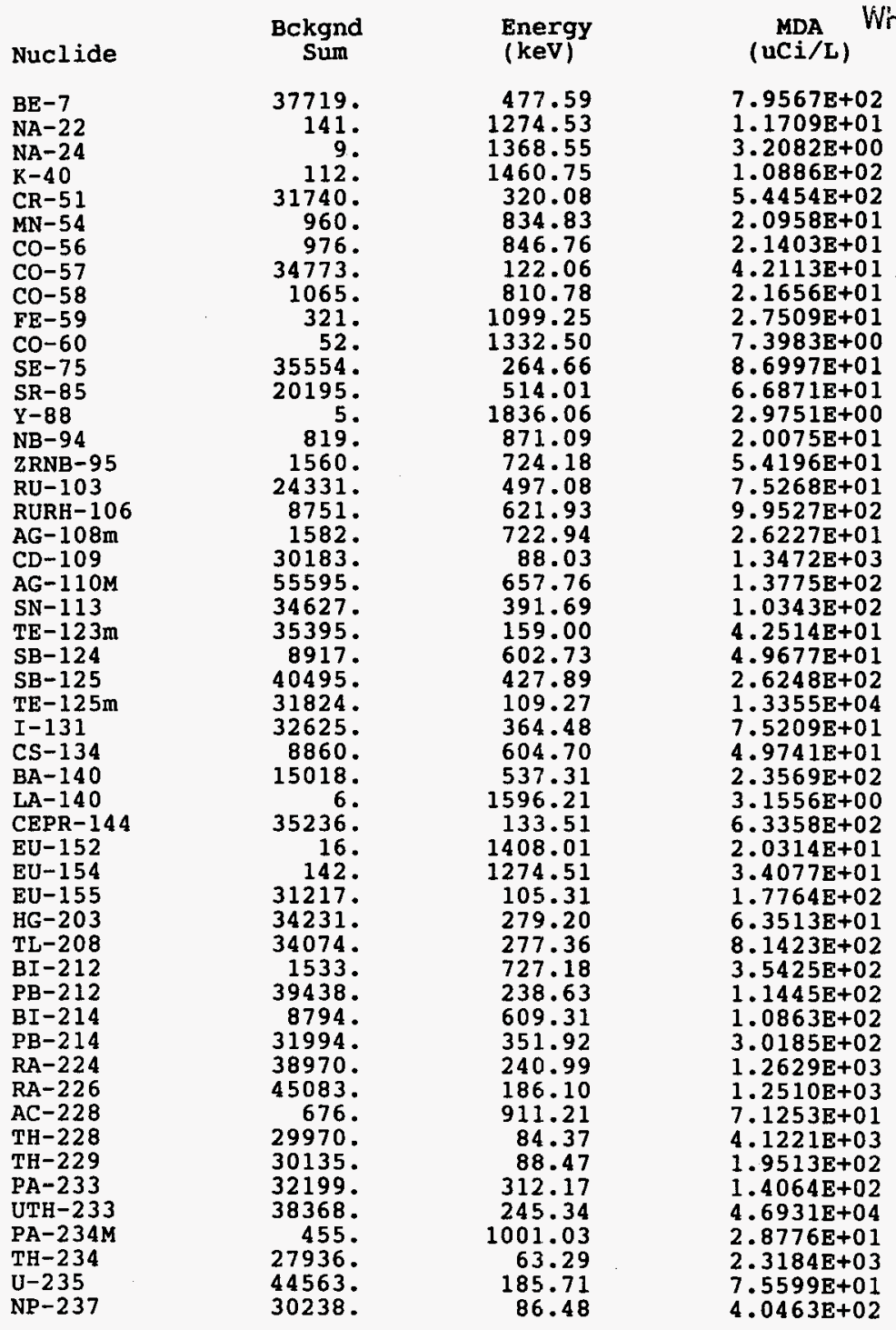

$1.3775 \mathrm{E}+02$
Acquisition date : $19-\mathrm{JAN}-1996 \quad 16: 21: 04$ WHC-SD-WM-DP-16C, HEV. 0 2

$7.9567 \mathrm{E}+02$

$3.2082 \mathrm{E}+00$

$2.0958 \mathrm{E}+01$

$2.1403 \mathrm{E}+01$

$4.2113 E+01$

$2.1656 \mathrm{E}+01$

8.6997E+01

$6.6871 \mathrm{E}+01$

$2.9751 \mathrm{E}+00$

$2.0075 \mathrm{E}+01$

$9.9527 \mathrm{E}+02$

$2.6227 \mathrm{E}+01$

$1.3472 \mathrm{E}+03$

$1.0343 \mathrm{E}+02$

$20678+01$

$2.6248 \mathrm{E}+02$

$1.3355 \mathrm{E}+04$

$7.5209 \mathrm{E}+01$

$4.9741 \mathrm{E}+01$

$6.3358 \mathrm{E}+02$

$2.0314 E+01$

$3.4077 \mathrm{E}+01$

$1.7764 \mathrm{E}+02$

8. $1423 E+02$

$3.5425 \mathrm{E}+02$

$1.1445 \mathrm{E}+02$

$1.0863 E+02$

$3.0185 \mathrm{E}+02$

$1.2629 \mathrm{E}+03$

$4.1221 \mathrm{E}+03$

$1.9513 \mathrm{E}+02$

$1.4064 \mathrm{E}+02$

4.6931E+04

$2.8776 \mathrm{E}+01$

$.5599 \mathrm{E}+01$

$.0463 \mathrm{E}+02$ 
Ninimum Detectable Activity Report (continued) Sample ID: S96R000041-DUP

Acquisition date : 19-Jan-1996 : 4

Bckgnd

Nuclide

Sum

Energy

MDA WHC-SD-WH-DP-130, BEV. 0

NP -239

PU-239

AM- 241

$A M-243$

31220 .

34984 .

28530 .

29123 . (kev)

$(\mathrm{UC} \mathbf{I} / \mathrm{L})$

106.12

129.30

59.54

74.67
1. $6864 \mathrm{E}+02$

$5.5156 \mathrm{E}+05$

$3.7299 \mathrm{E}+02$

1. $1044 \mathrm{E}+02$ 
Worklist \#:

$\gg>>>>>>>$

Sample ID:

Sample Size:

Dilution Factor:

$\gg \gg \gg \gg \gg \gg>$ COUNT

Detector ID:

File Number:

Geometry:

Count Time:

Real Time:

Dead Time:

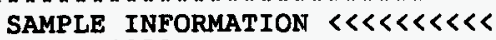

4973

S96R42-SAM

$1.00000 \mathrm{E}-03 \mathrm{~L}$

$1.01000 \mathrm{E}+02$
WHC-SD-WM-DP-180, REV.O

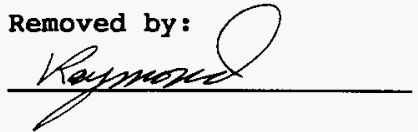

Verified by:
GEA2

dka300: [ spec.GEA2 ]2g2593.cnf

42

$000: 50: 00.00 \mathrm{sec}$

0 00:52:33.85 sec

4.98

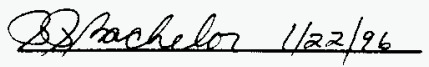

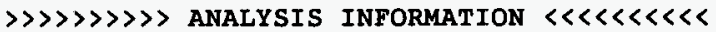

Sample Count Time: 19-JAN-1996 18:55:22.20

Decayed to:

Standard Deviations: 2

Analysis Library: ENVGEA

Analyst: VR

Background subtract: DKA300: [SPEC.GEA2]2GBACK

$\gg>>>>>>>$ CALIBRATION INFORMATION $<<<<<<<<<~$

Date of last energy calibration: 21-MAR-1994 09:31:55.15

Date of last efficiency calibration: 21-MAR-1994 09:43:42.61

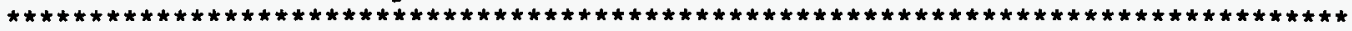

Post-NID Peak Search Report

It Energy Area FWHM Channel Left Pw \&Err Fit Nuclides Activity $\mathrm{uCi} / \mathrm{L}$

$\begin{array}{lrllllllll}0 & 661.34 * & 1105312 & 1.53 & 1322.71 & 1314 & 18 & 0.2 & C S-137 & 1.549 \mathrm{E}+05\end{array}$ 
Total number of lines in spectrum Number of unidentified lines

number of lines tentatively identified by NID
2 WHC-SD-WM-DP-180, REV. 0

150.008 Nuclide Type :

Nuclide CS -137
Wtd Mean Uncorrected

Hlife $30.00 Y$

Decay 1.000 uCi/L

$1.549 \mathrm{E}+05$ $-0 .---1-1$ Total Activity : $1.549 \mathrm{E}+05$
Wtd Mean

Decay Corr Decay Corr 2-Sigma uCi/L

$1.549 \mathrm{E}+05$

$-------2$

$1.549 \mathrm{E}+05$
Grand Total Activity : $1.549 \mathrm{E}+05$

Flags: " $K$ " = Keyline not found

"E" = Manually edited
$1.549 \mathrm{E}+05$

"M" = Manually accepted

"A" = Nuclide specific abn. limit 
Minimum Detectable Activity Report Sample ID : S96R42-SAM

Nuclide
BE-7
NA -22
NA -24
$\mathrm{K}-40$
CR -51
$\mathrm{MN}-54$
$\mathrm{CO}-56$
$\mathrm{CO}-57$
$\mathrm{CO}-58$
FE- 59
$\mathrm{CO}-60$
$\mathrm{SE}-75$
$\mathrm{SR}-85$
$\mathrm{Y}-8 \mathrm{8}$
NB-94
ZRNB-95
RU-103
RURH-106
AG- $108 \mathrm{~m}$
CD-109
AG- $110 \mathrm{M}$
$\mathrm{SN}-113$
TE-123m
$\mathrm{SB}-124$
$\mathrm{SB}-125$
TE $-125 \mathrm{~m}$
I-131
CS -134
$\mathrm{BA}-140$
LA- 140
CEPR- 144
EU-152
EU-154
EU-155
HG-203
TL-208
BI -212
PB-212
BI -214
PB-214
RA-224
RA-226
$\mathrm{AC}-228$
$\mathrm{TH}-228$
TH-229
$\mathrm{PA}-233$
UTH-233
$\mathrm{PA}-234 \mathrm{M}$
$\mathrm{TH}-234$
$\mathrm{U}-235$
NP -237

Bckgnd
Sum

35135.

123.

11 .

99.

29089.

814.

758 .

31382 .

851 .

281.

43.

32593.

18476.

2 .

660.

1290.

22164 .

8081.

1322 .

27739.

50396.

31601 .

32228 .

8078.

36940 .

29512 .

29909.

8031.

13467.

6.

32069 .

14.

123.

28686.

31271 .

31359.

1290 .

36200 .

8066.

29500 .

35865 .

41165.

600.

27733.

27849 .

29289.

35467.

368.

26091.

40761 .

27813.
Energy

(keV)

477.59

1274.53

1368.55

1460.75

320.08

834.83

846.76

122.06

810.78

1099.25

1332.50

264.66

514.01

1836.06

871.09

724.18

497.08

621.93

722.94

88.03

657.76

391.69

159.00

602.73

427.89

109.27

364.48

604.70

537.31

1596.21

133.51

1408.01

1274.51

105.31

279.20

277.36

727.18

238.63

609.31

351.92

240.99

186.10

911.21

84.37

88.47

312.17

245.34

1001.03

63.29

185.71

86.48
Page : 3

Acquisition date : 19-JAN-1996 18:55:22

MDA WHC-SD-WM-DP-180, REV. 0

$7.6793 \mathrm{E}+02$

$1.0938 \mathrm{E}+01$

$3.5273 E+00$

$1.0239 \mathrm{E}+02$

$5.2130 \mathrm{E}+02$

$1.9298 \mathrm{E}+01$

$1.8862 \mathrm{E}+01$

4. $0007 \mathrm{E}+01$

$1.9357 \mathrm{E}+01$

$2.5747 E+01$

$6.6659 \mathrm{E}+00$

$8.3296 \mathrm{E}+01$

$6.3961 \mathrm{E}+01$

$1.8816 \mathrm{E}+00$

$1.8023 E+01$

4. $9278 \mathrm{E}+01$

$7.1838 \mathrm{E}+01$

$9.5644 \mathrm{E}+02$

$2.3970 \mathrm{E}+01$

$1.2915 \mathrm{E}+03$

$1.3115 E+02$

$9.8806 \mathrm{E}+01$

$4.0568 \mathrm{E}+01$

$4.7283 \mathrm{E}+01$

2. $5070 \mathrm{E}+02$

$1.2860 \mathrm{E}+04$

$7.2009 \mathrm{E}+01$

$4.7359 \mathrm{E}+01$

$2.2319 \mathrm{E}+02$

$3.1555 \mathrm{E}+00$

$6.0444 \mathrm{E}+02$

1. $8869 \mathrm{E}+01$

$3.1783 \mathrm{E}+01$

1. $7029 \mathrm{E}+02$

$6.0705 \mathrm{E}+01$

$7.8112 \mathrm{E}+02$

$3.2491 \mathrm{E}+02$

$1.0965 \mathrm{E}+02$

$1.0404 \mathrm{E}+02$

$2.8913 \mathrm{E}+02$

1. $2115 \mathrm{E}+03$

$1.1954 \mathrm{E}+03$

$6.7100 E+01$

$3.9652 \mathrm{E}+03$

$1.8759 \mathrm{E}+02$

$1.3414 \mathrm{E}+02$

4.5121E+04

$2.5873 E+01$

$2.2405 E+03$

$7.2302 \mathrm{E}+01$

$3.8807 \mathrm{E}+02$ 
Minimum Detectable Activity Report (continued)

Sample ID : S96R42-SAM

Page : 4

\begin{tabular}{lccc} 
Nuclide & $\begin{array}{c}\text { Bckgnd } \\
\text { Sum }\end{array}$ & $\begin{array}{c}\text { Energy } \\
(\mathrm{keV})\end{array}$ & \multicolumn{1}{c}{$\begin{array}{c}\text { MDA } \\
\text { (uCi/L) }\end{array}$} \\
NP-239 & 28765. & 106.12 & $1.6187 \mathrm{E}+02$ \\
PU-239 & 32357. & 129.30 & $5.3044 \mathrm{E}+05$ \\
AM-241 & 25899. & 59.54 & $3.5538 \mathrm{E}+02$ \\
AM-243 & 27011. & 74.67 & $1.0636 \mathrm{E}+02$
\end{tabular}




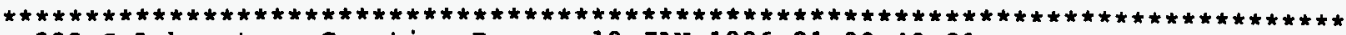
* 222-S Laboratory Counting Room

Worklist \#:

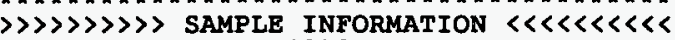

Sample ID:

Sample Size:

Dilution Factor:

$>>>>>>>>$ COUNT INFORMATION $<<<<<<<<<<$

Detector ID:

File Number:

Geometry:

Count Time:

Real Time:

Dead Time:
4973

S96R42-DUP

$1.00000 \mathrm{E}-03 \mathrm{~L}$

$1.01000 \mathrm{E}+02$

GEA2

dka300: [ spec.GEA2 ]2g2594.cnf

42

$000: 50: 00.00$ sec

$000: 52: 34.39 \mathrm{sec}$

4. $9 \%$
WHC-SD-WH-DP-180, PEV. 0

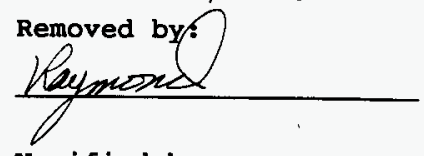

Verified by:

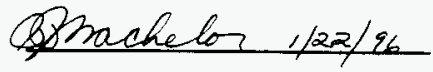

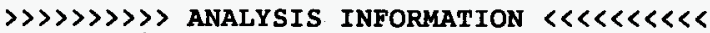

Sample Count Time:

Decayed to:

Standard Deviations:

Analysis Library:

Analyst:

Background subtract:
19-JAN-1996 20:07:37.75

19-JAN-1996 20:07:37.75

2

ENVGEA

VR

DKA300 : [ SPEC. GEA2 ] 2GBACK

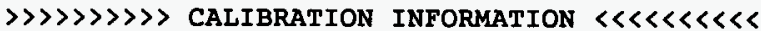
Date of last energy calibration:
21-MAR-1994 09:31:55.15

Date of last efficiency calibration: 21-MAR-1994 09:43:42.61

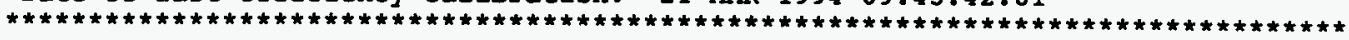

Post-NID Peak Search Report

I

It Energy

Area FWHM Channel Left Pw \&Err

Fit Nuclides

Activity uCi/L

$0661.34 * 1103161$

1321.79

1.531322 .70

277

2.882643 .73

1315

2636

17

.2

1.582664 .52

2660

$17 \quad 28.7$

CS-137

$1.546 \mathrm{E}+05$

o 1332.18

34

1150.5

255 
Summary of Nuclide Activity

Sample ID : S96R42-DUP

Total number of lines in spectrum

Number of unidentified lines

Number of lines tentatively identified by NID
Page : 2

Acquisition date : 19-JAN-1996 20:07:37

3 WHC-SD-WM-DP-180, PEV. 0

66.678
Nuclide Type :

$\begin{array}{lccc}\text { Nuclide } & \text { Hlife } & \text { Decay } & \begin{array}{c}\text { Uncorrected } \\ \text { uCi } / L\end{array} \\ \text { CS-137 } & 30.00 Y & 1.000 & 1.546 \mathrm{E}+05 \\ & \text { Total Activity }: & 1.546 \mathrm{E}+05\end{array}$

Grand Total Activity : $1.546 \mathrm{E}+05$

Flags: "K" = Keyline not found

"E" = Manually edited

\section{Wtd Mean \\ Decay Corr Decay Corr 2-Sigma uCi/L \\ $1.546 \mathrm{E}+05$ \\ 2-Sigma Error \&Error Flags \\ $0.003 E+05 \quad 0.20$}

$1.546 \mathrm{E}+0.5$

$1.546 \mathrm{E}+05$

"M" = Manually accepted

"A" = Nuclide specific abn. limit 
Minimum Detectable Activity Report Sample ID : S96R42-DUP

Nuclide

BE-7

NA-22

NA -24

$\mathrm{K}-40$

CR-51

MN-54

CO-56

CO-57

CO-58

FE -59

CO-60

SE -75

SR -85

$\mathrm{Y}-88$

NB-94

ZRNB-95

RU- 103

RURH-106

AG- $108 \mathrm{~m}$

CD-109

AG-110M

$\mathrm{SN}-113$

$\mathrm{TE}-123 \mathrm{~m}$

SB-124

SB-125

$\mathrm{TE}-125 \mathrm{~m}$

I-131

CS-134

BA- 140

LA- 140

CEPR-144

EU-152

EU-154

EU-155

HG-203

TL-208

BI- 212

PB-2 12

BI-214

PB-214

RA-224

RA-226

AC- 228

TH-228

TH-229

PA-233

UTH-233

$\mathrm{PA}-234 \mathrm{M}$

TH-234

U-235

NP-237

\section{Bckgnd \\ sum}

34821 .

108 .

18.

97.

29121.

788 .

760 .

32195 .

854.

252 .

45 .

32548 .

18203 .

$$
3 .
$$

705.

1293 .

22359 .

7854 .

1305 .

28051 .

50509 .

31955 .

32601 .

8268 .

36671 .

29776.

30077 .

8228 .

13474 .

32738 .

15.

107.

29222 .

30959 .

31240 .

1247 .

36550 .

8025.

29202 .

35963.

41919 .

512 .

28253 .

28083 .

29874 .

35413 .

366 .

26199.

41491 .

28065 .
Energy (keV)

477.59

1274.53

1368.55

1460.75

320.08

834.83

846.76

122.06

810.78

1099.25

1332.50

264.66

514.01

1836.06

871.09

724.18

497.08

621.93

722.94

88.03

657.76

391.69

159.00

602.73

427.89

109.27

364.48

604.70

537.31

1596.21

133.51

1408.01

1274.51

105.31

279.20

277.36

727.18

238.63

609.31

351.92

240.99

186.10

911.21

84.37

88.47

312.17

245.34

1001.03

63.29

185.71

86.48
Page : 3

Acquisition date : 19-JAN-1996 20:07:37

$\underset{(u C i / L)}{\text { MDA }}$ WHC-SD-WM-DP-180, REV. 0

$7.6449 \mathrm{E}+02$

$1.0234 \mathrm{E}+01$

4. $4651 \mathrm{E}+00$

$1.0160 \mathrm{E}+02$

$5.2159 \mathrm{E}+02$

$1.8987 \mathrm{E}+01$

$1.8886 \mathrm{E}+01$

4. $0522 \mathrm{E}+01$

$1.9394 \mathrm{E}+01$

$2.4366 \mathrm{E}+01$

$6.8175 \mathrm{E}+00$

8. $3239 \mathrm{E}+01$

6. $3486 \mathrm{E}+01$

2. $3045 \mathrm{E}+00$

1. $8623 \mathrm{E}+01$

4. $9348 \mathrm{E}+01$

$7.2153 \mathrm{E}+01$

$9.4291 \mathrm{E}+02$

$2.3819 \mathrm{E}+01$

$1.2987 \mathrm{E}+03$

1. $3129 \mathrm{E}+02$

$9 \cdot 9358 \mathrm{E}+01$

$4.0801 \mathrm{E}+01$

4.7837 E+01

$2.4978 \mathrm{E}+02$

$1.2918 \mathrm{E}+04$

7.2211E+01

$4.7935 \mathrm{E}+01$

$2.2325 \mathrm{E}+02$

$3.3816 \mathrm{E}+00$

$6.1071 \mathrm{E}+02$

$1.9508 \mathrm{E}+01$

2. $9689 \mathrm{E}+01$

$1.7187 \mathrm{E}+02$

6. 0400E+01

$7.7964 \mathrm{E}+02$

$3.1952 \mathrm{E}+02$

$1.1018 \mathrm{E}+02$

$1.0377 \mathrm{E}+02$

$2.8769 \mathrm{E}+02$

1. $2132 \mathrm{E}+03$

$1.2063 \mathrm{E}+03$

$6.1997 \mathrm{E}+01$

$4.0023 \mathrm{E}+03$

$1.8837 \mathrm{E}+02$

$1.3547 \mathrm{E}+02$

4. $5087 \mathrm{E}+04$

2. $5806 \mathrm{E}+01$

$2.2451 \mathrm{E}+03$

$7.2947 \mathrm{E}+01$

$3.8982 \mathrm{E}+02$ 
Minimum Detectable Activity Report (continued)

Sample ID: S96R42-DUP

Nuclide

NP -239

$\mathrm{PU}-239$

$\mathrm{AM}-241$

$\mathrm{AM}-243$
Bckgnd

Sum

29319.

32982 .

26153.

27141 .

Acquisition date $19-$ Page : 4

Energy

( keV)

106.12

129.30

59.54

74.67
MDA ( uCi/L)

WHC-SD-WM-DP-180, FEV. 0

1. $6342 \mathrm{E}+02$

5. $3554 \mathrm{E}+05$

$3.5712 \mathrm{E}+02$

$1.0661 \mathrm{E}+02$ 


\section{LABCORE Data Entry Template for Worklist\# 5089}

Analyst: $\quad$ S.C.L Instrument: $\mathrm{AB} 00$ /2 Book\# 9856

Method: LA-220-101 Rev/Mod $P-1$

Worklist Comment: SR,FOR(TK 25-2)(DET SS USING LUDLUM) MAY EXCEED 5RAD/HR RTS!

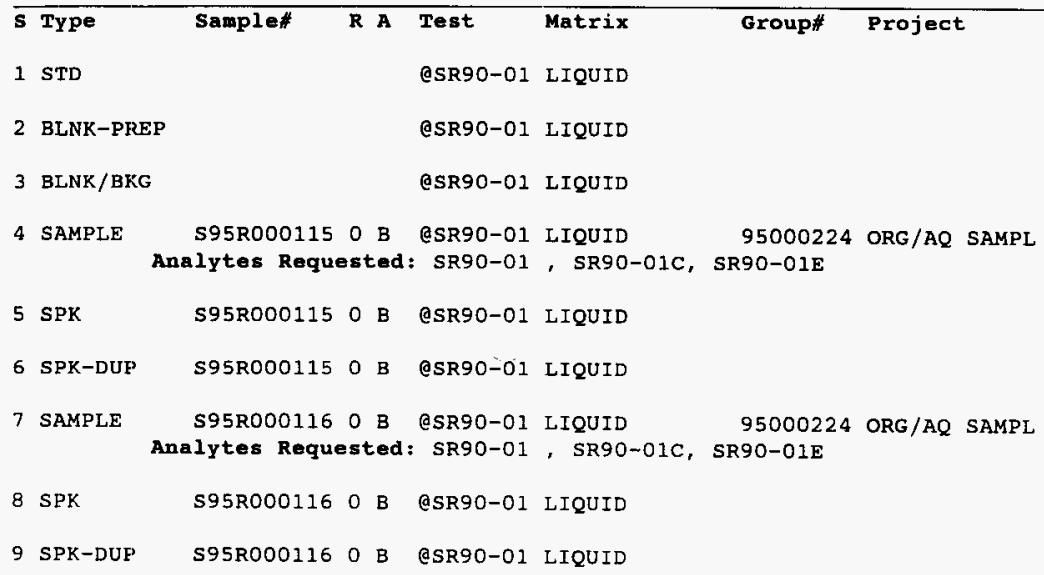

Final page for worklist \# 5089

$\frac{\operatorname{Sus} C \mathcal{L}}{\text { Analyst Signature }} \frac{1-23-96}{\text { Date }}$

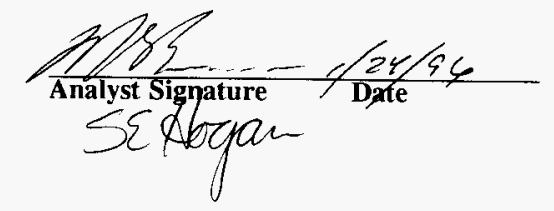

Data Entry Comments:

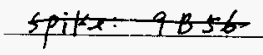

$\overline{S=\text { Worklist Slot Number }}, R=$ Replicate Number, $A=\overline{\text { Aliquon Code. }}$ 


\section{LABCORE Completed Worklist Report for Worklist\# 5089}

Analyst: $\mathrm{scl}$

Instrument: $\mathrm{AB} 12$

Book\#

Method:

$\operatorname{Rev} / \operatorname{Mod}$

Worklist Comment: SR,FOR(TK 25-2)(DET SS USING LUDLUM) MAY EXCEED 5RAD/HR RTS!

\begin{tabular}{|c|c|c|c|c|c|c|c|c|c|c|}
\hline Seq Type & Sample & & $\mathbf{A}$ & & Test & Matrix & Actual & Foun & id $\overline{D L}$ or Yield Unit & \\
\hline 1 STD & & 0 & & OSR90-01 & SR90-01 & LIQUID & $1.248-03$ & $1.15 \mathrm{E}-3$ & 92.740 \& Recovery & \\
\hline 1 STD & & 0 & & ASR90-01 & SR90-01C & LIQUID & 100 & $9.50 \mathrm{E}+01$ & 95.000 \& Recovery & \\
\hline $1 \mathrm{STD}$ & & 0 & & OSR90-01 & SR90-01E & LIQUID & 1.00 & $1.89 E+00$ & 1.890 \& Ct. Brror & \\
\hline 2 BLNR-PREP & & 0 & & OSR90-01 & SR90-01 & LIQUID & 1 & $<1,20 \mathrm{E}-2$ & $\mathrm{uCi} / \mathrm{mL}$ & \\
\hline 2 BLNK-gREP & & 0 & & $\cos 90-01$ & SR90-01C & LIQOID & 100 & $9.45 \mathrm{E}+01$ & $94.500 \%$ Recovery & \\
\hline 2 ELNK-PREF & & 0 & & $\operatorname{OSR90-01}$ & SR90-01E & LIQUID & 1.00 & $2.05 \mathrm{E}+02$ & $205.000 \% \mathrm{Ct}$. Brror & \\
\hline $3 \mathrm{BLNR} / \mathrm{BRG}$ & & 0 & & SRR90-01 & SR90-01 & LIQ⿴囗十D & 1 & $1.23 \mathrm{E}+00$ & $1.230 \mathrm{MCi} / \mathrm{mL}$ & \\
\hline 4 SAMPLE & 5952000115 & 0 & B & $\operatorname{OSR} 90-01$ & SR90-01 & LIQUID & $\mathbf{H} / \mathbf{A}$ & $2.67 \mathrm{E}+01$ & $1.3400-002 \mathrm{uCi} / \mathrm{mL}$ & \\
\hline 4 savets & $\$ 952000115$ & 0 & $\mathbf{B}$ & OSRP0-01 & $\sin 90-01 c$ & LIQUTD & $\mathbf{n} / \mathbf{A}$ & $9.57 \mathrm{E}+01$ & 1.000 -004 \& Recovery & \\
\hline 4 SAMPLE & $\$ 95 R 000115$ & 0 & $\mathbf{B}$ & esR90-01 & SR90-01E & LIQOID & $\mathbf{n} / \mathbf{2}$ & $8.005-01$ & 0.000 \& Ct. Error & \\
\hline 5 SPR & 89512000115 & 0 & B & $\operatorname{OSR90-01}$ & $\operatorname{sR90-01}$ & LIOUID & $1.24 \mathrm{E}-03$ & $1.47 \mathrm{E}-03$ & 118.550 \& Recovery & \\
\hline 6 SPR-DUP & 59512000115 & 0 & B & OSR90-01 & SR90-0I & I.IQUID & $1,47 \mathrm{E}-03$ & $1.20 \mathrm{E}-03$ & 20.220 RAP $7+$ Recompry & $\operatorname{Som} 3 / 2$ \\
\hline 7 SAMPLE & 59512000116 & 0 & $\mathbf{B}$ & esR90-01 & SR90-01 & LIQOTD & $\mathbf{N} / \mathbf{A}$ & $2.90 \mathrm{E}+02$ & $1.3400-002 \mathrm{uCi} / \mathrm{mL}$ & \\
\hline 7 SAMPLE & 59512000116 & 0 & B & $\operatorname{OSR90-01}$ & SR90-01C & I.IQUID & $\mathbf{N} / \mathbf{A}$ & $9.50 \mathrm{E}+01$ & $1.0000-004$ \& Recovery & \\
\hline 7 SAMPLS & 89512000116 & 0 & $\mathbf{B}$ & OSR90-01 & $\operatorname{seg} 90-02 \pi$ & LIQOID & $x / 2$ & $8.42 \mathrm{E}-01$ & 0.000 \& ct. Erxor & \\
\hline$B S P R$ & 59512000116 & 0 & $\mathbf{B}$ & OSR90-01 & SR90-01 & IIQUID & $1.24 E-03$ & $1.09 \mathrm{E}-03$ & 87.900 \& Recovery & \\
\hline 9 SPR-DUP & $595 R 000126$ & 0 & $\mathbf{B}$ & PSR90-01 & SR90-01 & LIQUID & $1.09 \mathrm{~F}-03$ & $1.25 \mathrm{E}-03$ & $13.680 \mathrm{DDD} \quad 7 . R_{\mathrm{N}}$ & Morm 7 \\
\hline
\end{tabular}

Final page for worklist\# 5089

Analyst Signature Date Dnalyst Signature

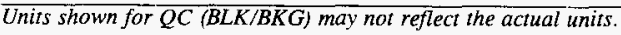


WORKBOOK PAGE: STD1

WHC-SD-WM-DP-180, REV. 0

Sr-89/90 : LA-220-101 (D-1), 102 (E-3), 104 (D-1) LIQUIDS

\begin{tabular}{|c|c|c|c|c|}
\hline 勧 & DETECTOR NUMBER & 12 & CARRIER ADDED in $\mathrm{mL}$ & 1.000 \\
\hline STD & TOTAL COUNTS & 10844 & GROSS WEIGHT & 7.7566 \\
\hline W\% & COUNT TIME in MINUTES & 10 & TARE WEIGHT & 7.6616 \\
\hline 5089 & BACKGROUND in cpm & 4.0 & NET WEIGHT & 0.0950 \\
\hline 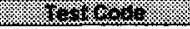 & SAMPLE VOLUME in $\mathrm{mL}$ & 1.000 & DELTA TIME (HOURS) & 5.50 \\
\hline CSRR90-01 & DILUTION FACTOR & 1 & & \\
\hline 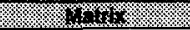 & DIGEST DILUTION FACTOR & 1 & & \\
\hline LIQUID & SAMPLE COUNT RATE & 1080.40 & SR-90 EFFICIENCY FACTO & 0.4180 \\
\hline $\left.4 x_{2}\right)$ & CRITICAL LEVEL & 1.20 & Y-90 EFFICIENCY FACTOR & 0.4660 \\
\hline 96000581 & TIME OF SEPARATION & 08:50 & $R \max$ & N/A \\
\hline 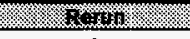 & DATE OF SEPARATION & $01 / 23 / 96$ & DETECTION LIMIT & 2.50 \\
\hline 0 & TIME OF COUNT & $14: 20$ & $\mathrm{Sr}-89 / 90 \mathrm{CONC}$. in $\mu \mathrm{Ci} / \mathrm{L}$ & $1.1515 \mathrm{E}+00$ \\
\hline 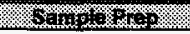 & DATE OF COUNT & $01 / 23 / 96$ & & \\
\hline N/A & STANDARD BOOK \# & 9B56 & & \\
\hline 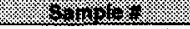 & STANDARD VALUE in $\mu \mathrm{Ci} / \mathrm{mL}$ & $1.2360 \mathrm{E}-03$ & & \\
\hline WL 5089 & \multirow{3}{*}{\multicolumn{4}{|c|}{ Sample Count Rate $(\mathrm{Rs})=($ Total Counts $(\mathrm{TC}) /$ Count Time $(\mathrm{CT}))-$ Background in $\mathrm{cpm}(\mathrm{BKG})$}} \\
\hline 化 & & & & \\
\hline WB27811 & & & & \\
\hline 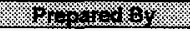 & \multicolumn{4}{|c|}{ Sr-89/90 CONC in $\mu \mathrm{Ci} / \mathrm{mL} \quad$ REPLACE RS WITH RMAX IF RS $<=L C A N D$ RS $>=0$ OR REPLACE RS WITH LC IF RS $<0$} \\
\hline MCB & \multicolumn{4}{|c|}{$\mathrm{RS}^{*} \mathrm{DF}^{*} \mathrm{DDF}{ }^{*} 1000 /\left(\left(\mathrm{C} 1+\mathrm{C} 2^{*}\left(1-\mathrm{e} \text { to the power of }\left((- \text { natural log } 2) / 64.2^{*} \mathrm{DT}\right)\right)\right)^{*} \mathrm{SS}^{*} \mathrm{REC} \mathrm{C}^{*} 2220000\right)$} \\
\hline - & \multicolumn{4}{|c|}{ NOTE: $64.2=$ Half Life for Y-90 and Rec. $=$ Fractional Carrier Recovery $((W 2-W 1) /(C V A * 0.1000))$} \\
\hline SLF & \multicolumn{4}{|c|}{ Relative Counting Error $=$ The Square Root of $\left((T C+B K G * C T) /(T C-B K G * C T)^{*} 1.96\right)$} \\
\hline 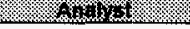 & \multicolumn{4}{|c|}{ Percent Carrier Recovery $=($ Net Weight $/$ Expected weight $) * 100$} \\
\hline SCL & \multicolumn{4}{|l|}{ NOTE: Expected weight $=\mathrm{CVA} * 0.1$} \\
\hline 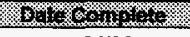 & \multicolumn{4}{|c|}{ Detection Levels and Less Than Values are determined from Procedure LA-508-002. } \\
\hline $01 / 24 / 96$ & \multirow{2}{*}{\multicolumn{3}{|c|}{ Delta Time (hours) $=((\mathrm{DOC}-\mathrm{SD}) * 2.4)+(\mathrm{TOC}-\mathrm{ST}) / 100$}} & \multirow{4}{*}{$\begin{array}{l}\text { DETECTION } \\
\text { LEVEL }\end{array}$} \\
\hline (1) & & & & \\
\hline $01 / 23 / 96$ & \multicolumn{3}{|l|}{ SP-89/90 CONCENTRATION } & \\
\hline OAt & & & & \\
\hline 08:50 AM & \multicolumn{3}{|l|}{ RELATIVE COUNTING ERROR } & \multirow{3}{*}{$\begin{array}{c}2.67 E-06 \\
\mu \mathrm{Ci} / L\end{array}$} \\
\hline 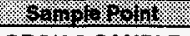 & & & & \\
\hline ORG/AQ SAMPLE & \multicolumn{3}{|l|}{ PERCENT CARRIER RECOVERY } & \\
\hline
\end{tabular}

\begin{tabular}{|c|c|c|c|}
\hline Analyst: & SCL & Date: & 24-Jan-96 \\
\hline Signature of Chemist: & SLF & Date: & $29 / 96$ \\
\hline
\end{tabular}

251 
WORKBOOK PAGE: BLANK2

WHC-SD-WM-DP-180, REV. 0

LA-220-101/ D-1 Sr-89/90 : LA-220-101 (D-1), 102 (E-3), 104 (D-1)

BLNK-PREP

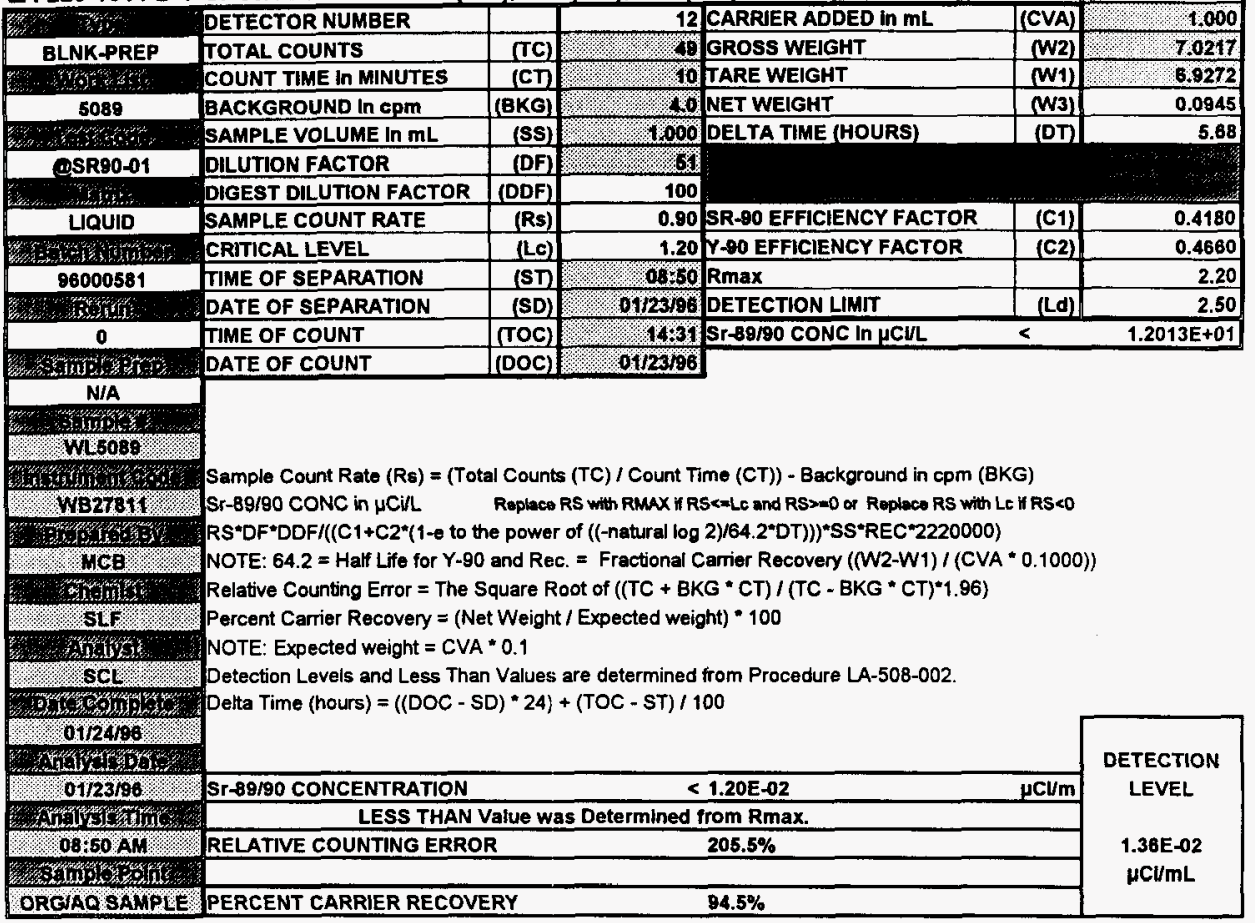

\begin{tabular}{|l|l|l|}
\hline Analyst: & SCL & Date: \\
\hline Signature of Chemist: & SLF & Date: \\
\hline BLANK.WB1 REV 1.2 & 22010 & \\
\hline
\end{tabular}

Sing 
WORKBOOK PAGE: SAM4

WHC-SD-WM-DP-180, REV. 0

\begin{tabular}{|c|c|c|c|c|c|c|}
\hline A-220-101 / D-1 & \multicolumn{5}{|c|}{ Sr-89/90 : LA-220-101 (D-1), 102 (E-3), 104 (D-1) } & \multirow{2}{*}{\begin{tabular}{r|} 
SAMPLE \\
1.000
\end{tabular}} \\
\hline 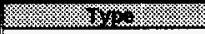 & DETECTOR NUMBER & & & CARRIER ADDED in $\mathrm{mL}$ & (CVA) & \\
\hline SAMPLE & TOTAL COUNTS & (TC) & 49675 & GROSS WEIGHT & (W2) & 7.2015 \\
\hline Wotreter & COUNT TIME In MINUTES & (CT) & 10 & TARE WEIGHT & (W1) & 7.1058 \\
\hline 5089 & BACKGROUND in cPm & (BKG) & 4.0 & NET WEIGHT & (W3) & 0.0957 \\
\hline W & SAMPLE VOLUME in $\mathrm{mL}$ & (SS) & 1.000 & DELTA TIME (HOURS) & (DT) & 5.92 \\
\hline QSRPO-01 & DILUTION FACTOR & (DF) & 51 & & & \\
\hline 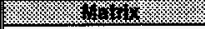 & DIGEST DILUTION FACTOR & (DDF) & 100 & & & \\
\hline LIQUID & SAMPLE COUNT RATE & (Rs) & 4963.50 & SR-90 EFFICIENCY FACTOR & (C1) & 0.4180 \\
\hline H. & CRITICAL LEVEL & (LC) & 1.20 & Y-90 EFFICIENCY FACTOR & (C2) & 0.4660 \\
\hline 96000581 & TIME OF SEPARATION & (ST) & $08: 50$ & Rmax & & N/A \\
\hline 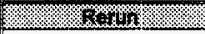 & DATE OF SEPARATION & (SD) & $01 / 23 / 96$ & DETECTION LIMIT & (Ld) & 2.50 \\
\hline 0 & TIME OF COUNT & (TOC) & $14: 45$ & $\mathrm{Sr}-89 / 90 \mathrm{CONC}$ in $\mu \mathrm{Cl} / \mathrm{L}$ & & $2.6665 E+04$ \\
\hline 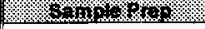 & DATE OF COUNT & (DOC) & 01/23/96 & & & \\
\hline ACIDIG02 & \\
\hline S3us & & & & & & \\
\hline S95R000115 & & & & & & \\
\hline 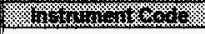 & \multicolumn{6}{|c|}{ Sample Count Rate $(\mathrm{Rs})=($ Total Counts $(\mathrm{TC}) /$ Count Time $(\mathrm{CT}))-$ Background in cpm (BKG) } \\
\hline WB27811 & \multicolumn{6}{|c|}{ Sr $-89 / 90$ CONC in $\mu C V / L \quad$ Replace RS with $R M A X$ if $R S<=L C$ and RS $>=0$ or Replace RS with $L c$ if $R S<0$} \\
\hline 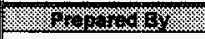 & \multicolumn{6}{|c|}{ RS*DF*DDF $\left./\left(C 1+C 2^{*}\left(1-e \text { to the power of }\left((-n a t u r a l \log 2) / 64.2^{*} D T\right)\right)\right)^{*} S S^{*} R^{*}{ }^{*} 2220000\right)$} \\
\hline MCB & \multicolumn{6}{|c|}{ NOTE: $64.2=$ Half Life for $Y-90$ and Rec. $=$ Fractional Carrier Recovery $((W 2-W 1) /(C V A * 0.1000))$} \\
\hline (8) & \multicolumn{6}{|c|}{ Relative Counting Error $=$ The Square Root of $\left(\left(\mathrm{TC}+\mathrm{BKG}{ }^{*} \mathrm{CT}\right) /\left(\mathrm{TC}-\mathrm{BKG}{ }^{*} \mathrm{CT}\right)^{\star} 1.96\right)$} \\
\hline SLF & \multicolumn{6}{|c|}{ Percent Carrier Recovery $=($ Net Weight $/$ Expected weight $) * 100$} \\
\hline 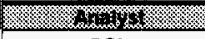 & \multicolumn{6}{|c|}{ NOTE: Expected weight $=C V A * 0.1$} \\
\hline $\mathbf{S C L}$ & \multirow{2}{*}{\multicolumn{6}{|c|}{$\begin{array}{l}\text { Detection Levels and Less Than Values are determined from Procedure LA-508-002. } \\
\text { Delta Time (hours) }=((D O C-S D) * 24)+(T O C-S T) / 100\end{array}$}} \\
\hline 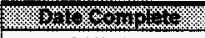 & & & & & & \\
\hline $01 / 24 / 96$ & & & & & & \multirow{4}{*}{$\begin{array}{l}\text { DETECTION } \\
\text { LEVEL }\end{array}$} \\
\hline 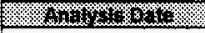 & & & & & & \\
\hline $01 / 23 / 96$ & \multicolumn{3}{|l|}{ Sr-89/90 CONCENTRATION } & $2.67 \mathrm{E}+01$ & $\mu \mathrm{Cl} / \mathrm{mL}$ & \\
\hline 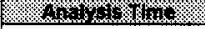 & & \\
\hline 08:50 AM & \multicolumn{3}{|l|}{ RELATIVE COUNTING ERROR } & \multicolumn{2}{|l|}{$0.9 \%$} & \multirow{3}{*}{$\begin{array}{l}1.34 E-02 \\
\mu \mathrm{Ci} / \mathrm{mL}\end{array}$} \\
\hline - & & & & & & \\
\hline ORGIAQ SAMPLE & \multicolumn{3}{|l|}{ PERCENT CARRIER RECOVERY } & \multicolumn{2}{|l|}{$95.7 \%$} & \\
\hline
\end{tabular}

\begin{tabular}{|llll|}
\hline Analyst: & SCL & Date: & 24-Jan-96 \\
\hline Signature of Chemist: & SLF & Date: & //29/96 \\
\hline SAMPLE.WB1 REV 1.2 & 22010NML & & \\
\hline
\end{tabular}


WORKBOOK PAGE: SPIKE5

WHC-SD-WM-DP-180, REV. 0

Sr-89/90 : LA-220-101 (D-1), 102 (E-3), 103 (E-2), 104 (D-1)

SPIKE

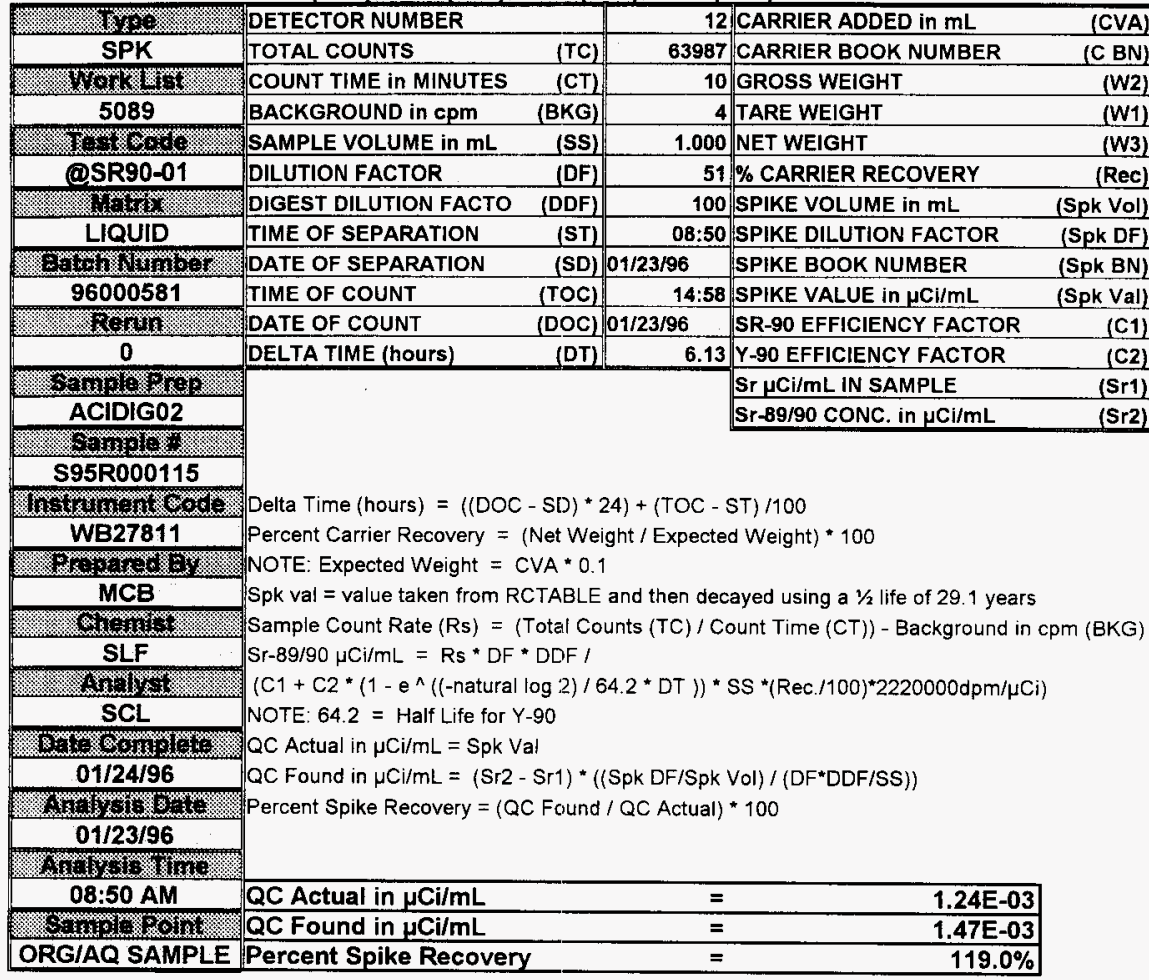

\begin{tabular}{|c|c|c|c|}
\hline Analyst: & SCL & Date: & 24-Jan-96 \\
\hline Signature of Chemist: & SLF & Date: & \\
\hline
\end{tabular}




\begin{tabular}{|c|c|c|c|c|}
\hline 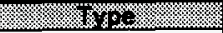 & DETECTOR NUMBER & 12 & CARRIER ADDED in $\mathrm{mL}$ & (CVA) \\
\hline SPK-DUP & TOTAL COUNTS & 61518 & CARRIER BOOK NUMBER & (C BN) \\
\hline 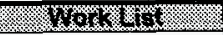 & COUNT TIME in MINUTES & 10 & GROSS WEIGHT & (W2) \\
\hline 5089 & BACKGROUND in cpm & 4 & TARE WEIGHT & (W1) \\
\hline 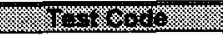 & SAMPLE VOLUME in $\mathrm{mL}$ & 1.000 & NET WEIGHT & (W3) \\
\hline QSR90-01 & DILUTION FACTOR & 51 & $\%$ CARRIER RECOVERY & (Rec) \\
\hline 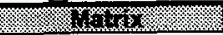 & DIGEST DILUTION FACTO & 100 & SPIKE VOLUME in $\mathrm{mL}$ & (Spk Vol) \\
\hline LIQUID & TIME OF SEPARATION & $08: 50$ & SPIKE DILUTION FACTOR & (Spk DF) \\
\hline$(\mathrm{m}$ & DATE OF SEPARATION & $01 / 23 / 96$ & SPIKE BOOK NUMBER & (Spk BN) \\
\hline 96000581 & TIME OF COUNT & $15: 19$ & SPIKE VALUE in $\mu \mathrm{Ci} / \mathrm{mL}$ & (Spk Val) \\
\hline$\times 28 \times 19$ & DATE OF COUNT & $01 / 23 / 96$ & SR-90 EFFICIENCY FACTOR & (C1) \\
\hline 0 & DELTA TIME (hours) & 6.48 & Y-90 EFFICIENCY FACTOR & (C2) \\
\hline 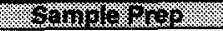 & & Sr $\mu \mathrm{Ci} / \mathrm{mL}$ IN SAMPLE & (Sr1) \\
\hline ACIDIG02 & & & $\mathrm{Sr}-89 / 90 \mathrm{CONC}$. in $\mu \mathrm{Ci} / \mathrm{mL}$ & (Sr2) \\
\hline 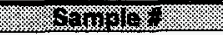 & & & & \\
\hline S95R000115 & & & & \\
\hline 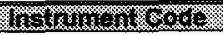 & \multicolumn{4}{|c|}{ Delta Time (hours) $=(($ DOC $-S D) \star 24)+($ TOC - ST $) / 100$} \\
\hline WB27811 & \multicolumn{4}{|c|}{ Percent Carrier Recovery $=($ Net Weight $/$ Expected Weight $) * 100$} \\
\hline $86 x+x=0$ & \multicolumn{4}{|c|}{ NOTE: Expected Weight $=C V A * 0.1$} \\
\hline MCB & \multicolumn{4}{|c|}{ Spk val = value taken from RCTABLE and then decayed using a $1 / 2$ life of 29.1 years } \\
\hline 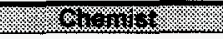 & \multirow{2}{*}{\multicolumn{4}{|c|}{ 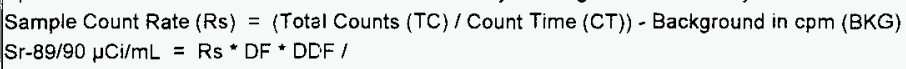 }} \\
\hline SLF & & & & \\
\hline (13) & \multirow{2}{*}{\multicolumn{4}{|c|}{$\begin{array}{l}\left.\left(C 1+C 2 *\left(1-e^{\wedge}((- \text { natural } \log 2) / 64.2 * D T)\right) * \text { SS *(Rec. } / 100\right)^{*} 2220000 \mathrm{dpm} / \mu C i\right) \\
\text { NOTE: } 64.2=\text { Half Life for } Y-90\end{array}$}} \\
\hline SCL & & & & \\
\hline 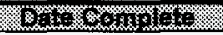 & \multicolumn{4}{|l|}{$\mathrm{QC}$ Actual in $\mu \mathrm{Ci} / \mathrm{mL}=\mathrm{Spk} \mathrm{Val}$} \\
\hline $01 / 24 / 96$ & \multirow{2}{*}{\multicolumn{4}{|c|}{ QC Found in $\mu \mathrm{Ci} / \mathrm{mL}=(\mathrm{Sr} 2-\mathrm{Sr} 1) *((\mathrm{Spk} \mathrm{DF} / \mathrm{Spk} \mathrm{Vol}) /(\mathrm{DF} * \mathrm{DDF} / \mathrm{SS}))$}} \\
\hline 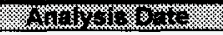 & \multirow{3}{*}{\multicolumn{4}{|c|}{ Percent Spike Recovery $=(Q C$ Fcund $/$ QC Actual $) * 100$}} \\
\hline $01 / 23 / 96$ & & & & \\
\hline 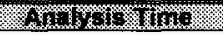 & & & & \\
\hline $08: 50 \mathrm{AM}$ & \multicolumn{3}{|l|}{ QC Actual in $\mu \mathrm{Ci} / \mathrm{mL}$} & \\
\hline 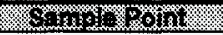 & \multicolumn{3}{|l|}{ QC Found in $\mu \mathrm{Ci} / \mathrm{mL}$} & \\
\hline ORGIAQ SAMPLE & \multicolumn{3}{|l|}{ Percent Spike Recovery } & \\
\hline
\end{tabular}

\begin{tabular}{|c|c|c|c|}
\hline Analyst: & SCL & Date: & 24-Jan-96 \\
\hline Signature of Chemist: & SLF & Date: & \\
\hline
\end{tabular}


WORKBOOK PAGE: SAM7

\section{WHC-SD̈-WM-DP-180, REV. 0}

LA-220-101 / D-1 Sr-89/90 : LA-220-101 (D-1), 102 (E-3), 104 (D-1)

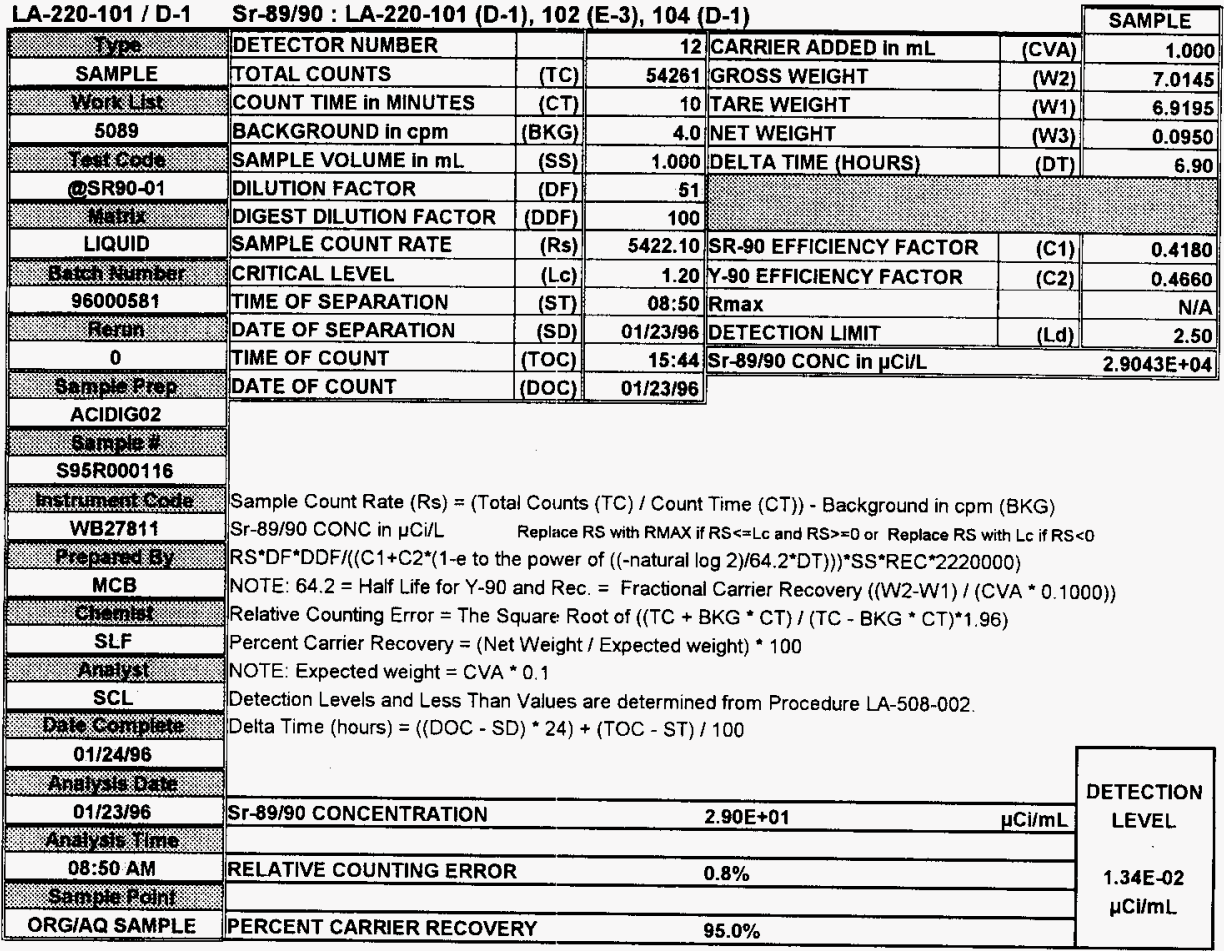

\begin{tabular}{|c|c|c|c|}
\hline Analyst: & SCL & Date: & 24-Jan-96 \\
\hline Signature of Chemist: & SLF & Date: & 196 \\
\hline
\end{tabular}


WORKBOOK PAGE: SPIKE8

WHC-SD-WM-DP-180, REV. 0

Sr-89/90 : LA-220-101 (D-1), 102 (E-3), 103 (E-2), 104 (D-1)

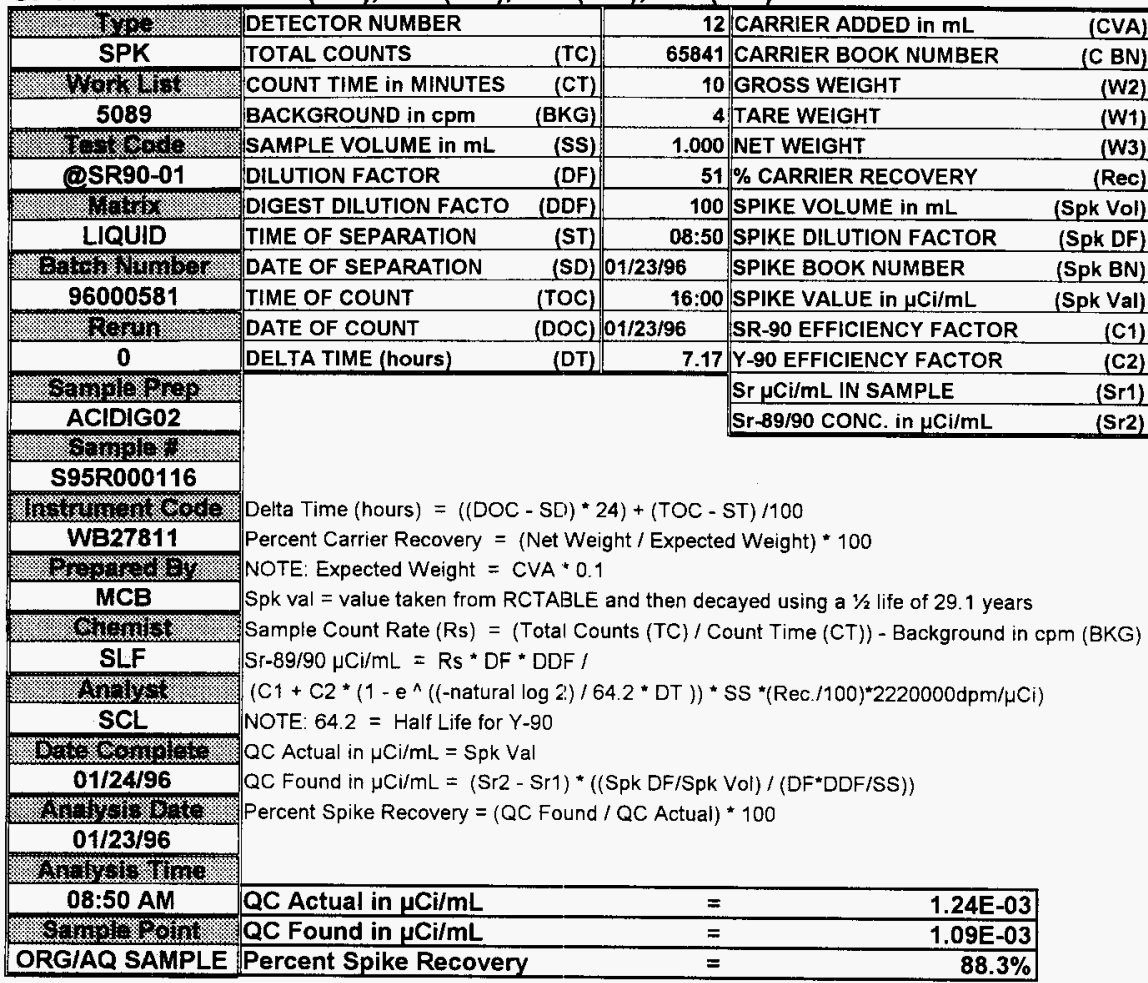

\begin{tabular}{|c|c|c|c|}
\hline Analyst: & $\mathrm{SCL}$ & Date: & 24-Jan-96 \\
\hline Signature of Chemist: & SLF & Date: & $99 / 96$ \\
\hline
\end{tabular}

SPIKE WB1 REV 1.2

$22010 \mathrm{NML}$ 
WHC-SD-WM-DP-180, REV. 0

WORKBOOK PAGE: SP_DUPG

Sr-89/90: LA-220-101 (D-1), 102 (E-3), 103 (E-2), 104 (D-1)

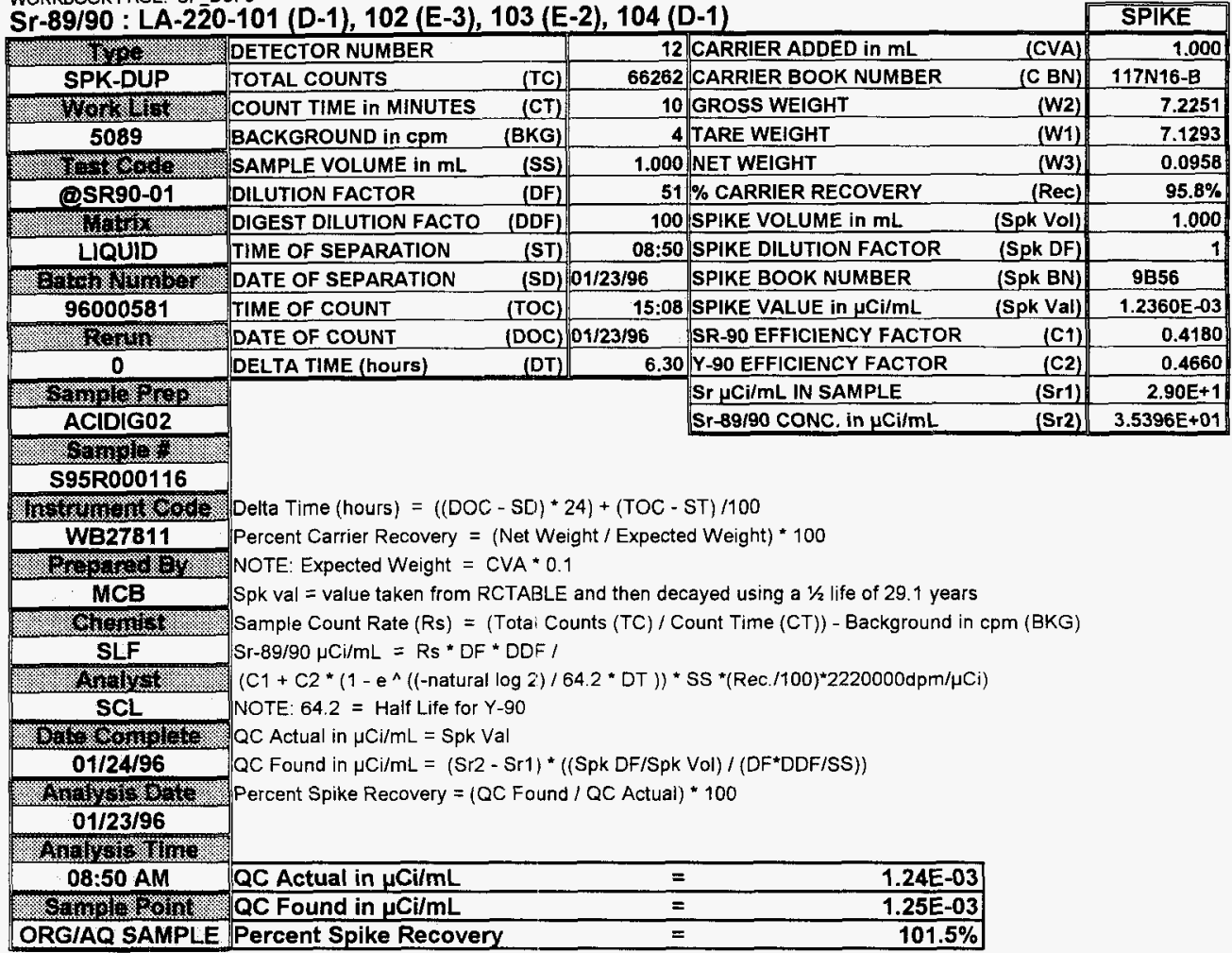

\begin{tabular}{|c|c|c|c|}
\hline Analyst: & SCL & Date: & 24-Jan-96 \\
\hline Signature of Chemist: & SLF & Date: & $1 / 29 / 56$ \\
\hline
\end{tabular}

253 


\section{LABCORE Completed Worklist Report for Worklist\# 5065}

Analyst: akl

Instrument: AM01

Book\# 104843

Method: $L A-953-103$ Rev/Mod $A .4$

\section{Worklist Comment: DETERMINE SS USING LUDLUM RTS!}

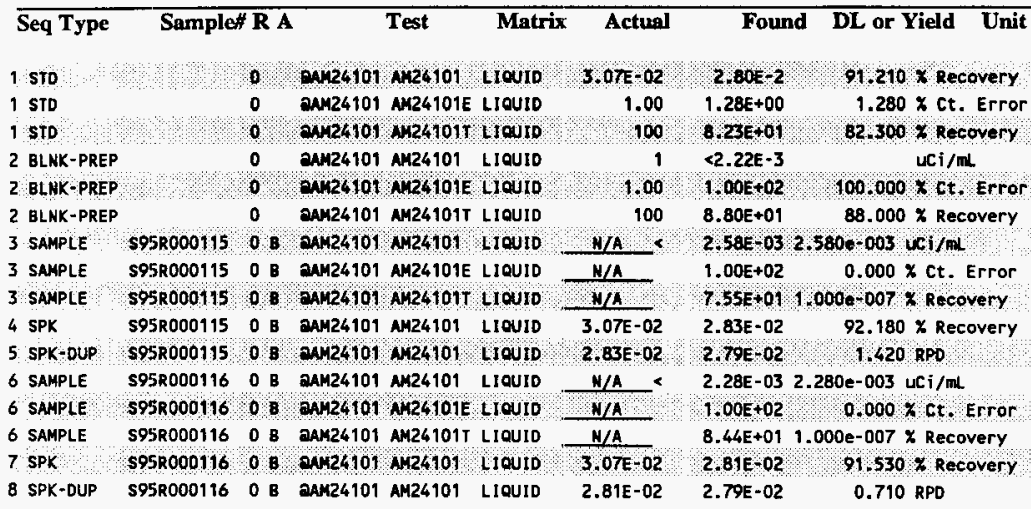

\section{Final page for worklist\# 5065}

Analyst Signature Date

Analyst Signature

Date

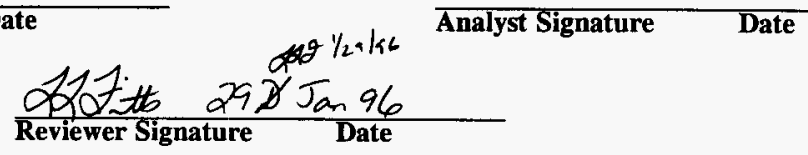

Units shown for $Q C(B L K / B K G)$ may not reflect the actual units. 
$(x-1)$

\section{LABCORE Data Entry Template for Worklist\# 5065}

Analyst: HKL Instrument: AMOI

Book\# 10.4543

Method: LA-953-103 Rev/Mod $A-4$

Worklist Comment: DETERMINE SS USING LUDLUM RTS!

\begin{tabular}{|c|c|c|c|c|c|c|c|c|c|}
\hline $\mathbf{s}$ & Type & Sample\# & $\mathbf{R}$ & $\mathbf{A}$ & Test & Matrix & Group\# & Project & \\
\hline 1 & STD & & & & @AM24101 & LIQUID & & & \\
\hline 2 & BLNK-PREP & & & & $@ A M 24101$ & LIQUID & & & \\
\hline \multirow[t]{2}{*}{3} & SAMPLE & S95R000115 & 0 & B & $@ A M 24101$ & LIQUID & 95000224 & ORG/AQ & SAMPL \\
\hline & & nalytes Reque & est & ted: & : AM24101 & , AM24101E, & AM24101T & & \\
\hline 4 & SPK & S95R000115 & 0 & B & @AM24101 & LIQUID & & & \\
\hline 5 & SPK-DUP & S95R000115 & 0 & $\mathrm{~B}$ & @AM24101 & LIQUID & & & \\
\hline \multirow[t]{2}{*}{6} & SAMPLE & S95R000116 & 0 & B & @AM24101 & IIQUID & 95000224 & $\mathrm{ORG} / \mathrm{AQ}$ & SAMPL \\
\hline & & nalytes Reque & est & ted: & : $\mathrm{AM} 24101$ & , AM24101E, & AM24101T & & \\
\hline 7 & $S P K$ & S95R000116 & 0 & $\mathrm{~B}$ & $@ A M 24101$ & IIQUID & & & \\
\hline 8 & SPK-DUP & S95RO00116 & 0 & $\mathrm{~B}$ & @AM24101 & LIQUID & & & \\
\hline
\end{tabular}

\section{Final page for worklist \# 5065}

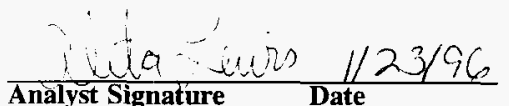

Analyst Signature Date

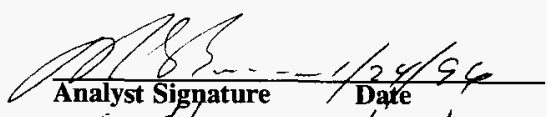

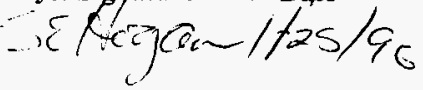

Data Entry Comments:

$S=$ Worklist Slot Number, $R=$ Replicate Number, $A=$ Aliquot Code. 
WORKBOOKPAGE: STD1

WHC-SD-WA-OP-180, AEV.O

Am 241 and Cm 243/244: LA-953-103 (A-4)

\begin{tabular}{|c|c|c|c|}
\hline xising & Date Counted & JAN-23-96 & Am 241 AEA Frac. \\
\hline STD & Sample Volume in $\mathrm{mL}$ & 1.000 & Am 243 AEA Frac. \\
\hline Wow & Sample D.F. & 101 & Cm 243/244 AEA Frac. \\
\hline 5065 & Tracer volume in $\mathrm{mL}$ & 0.100 & Total AT Counts \\
\hline (K) & Digest D.F. & 1000 & AT Count Time (min) \\
\hline OAM24101 & Tracer Book No. & $118 B 43$ & Background in cpm \\
\hline Yrans & Am-243 Tracer Value & 7550.4 & Am $241 \mathrm{cpm}$ \\
\hline LIQUID & Detector Number & 1. & Am $243 \mathrm{cpm}$ \\
\hline 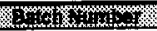 & Detector Efficiency & 0.5000 & $\mathrm{Cm} \mathrm{243/244 \textrm {cpm }}$ \\
\hline 96000563 & Standard Book No & $104 \mathrm{~B} 43$ & AEA Count Time \\
\hline 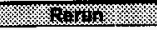 & Standard Value in $\mu \mathrm{Ci} / \mathrm{mL}$ & 0.03067 & Am $241 \mu \mathrm{CilL}=$ \\
\hline 0 & \multirow{6}{*}{\multicolumn{3}{|c|}{ 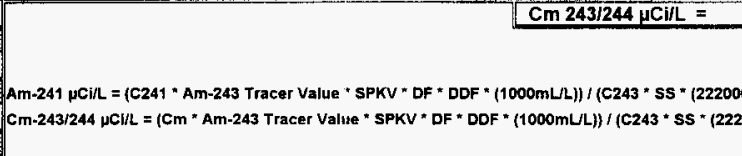 }} \\
\hline $\mathrm{g} \sin 20$ & & & \\
\hline N/A & & & \\
\hline Int & & & \\
\hline WL5065 & & & \\
\hline hat & & & \\
\hline AL10539 & \multirow{4}{*}{\multicolumn{3}{|c|}{$\begin{array}{l}\text { Relative Counting Error }=\text { Square Root of [(1/(Am-243 cpm * min) })+(1 / \text { (Am-24t or Cm-243/244 cp } \\
\text { Am } 243 \text { Tracer Recovery }=(\text { Total AT Counts } / \text { TC }- \text { Bkg) * (1/DetEm) * C243 * } 100 / \text { Am-243 Tracer V }\end{array}$}} \\
\hline 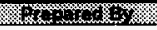 & & & \\
\hline MCB & & & \\
\hline 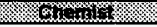 & & & \\
\hline LLF & \multirow{2}{*}{$\begin{array}{c}\text { Am } 241 \mu C / / m L \\
\text { Relative Counting Error }=\end{array}$} & $2.80 \mathrm{E}-02$ & \multirow{3}{*}{$\begin{array}{c}\text { DETECTION } \\
\text { LEVELS } \\
\text { in } \mu \mathrm{Ci} / \mathrm{mL}\end{array}$} \\
\hline 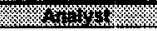 & & $.3 \%$ & \\
\hline AKL & \multirow{2}{*}{\multicolumn{2}{|c|}{ NOTE: Cm-243/244 Result is a LESS THAN Value. }} & \\
\hline 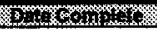 & & & Am 241 \\
\hline $01 / 24 / 96$ & \multirow{2}{*}{$\begin{array}{l}\text { Cm 243/244 } \mu \mathrm{Ci} / \mathrm{mL} \\
\text { Relative Counting Error }\end{array}$} & \multirow{2}{*}{$\begin{array}{c}4.29 E-03 \\
100.0 \%\end{array}$} & 4.29E-03 \\
\hline 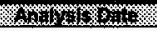 & & & $\mathrm{Cm} \mathrm{243/244}$ \\
\hline $01 / 23 / 96$ & Am 243 Tracer Recovery = & $2.3 \%$ & 4.29E-03 \\
\hline
\end{tabular}

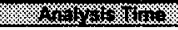

03:30 PM

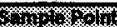

ORGIAQ SAMPLE

\begin{tabular}{|c|c|c|c|}
\hline Analyst: & $A K L$ & Date: & $01 / 24 / 96$ \\
\hline Signature of Chemist: 6257 : & LLF & Date: & 96 \\
\hline
\end{tabular}

STANDARD.WB1 REV 1.2 S53103ML 
WHC-SD-WMM-DP-180, FIEV 0

WORKBOOK PAGE: BLANK2

Am 241 and $C m$ 243/244: LA-953-103 (A-4)

LIQUID / SOLID

BLNK.PREP

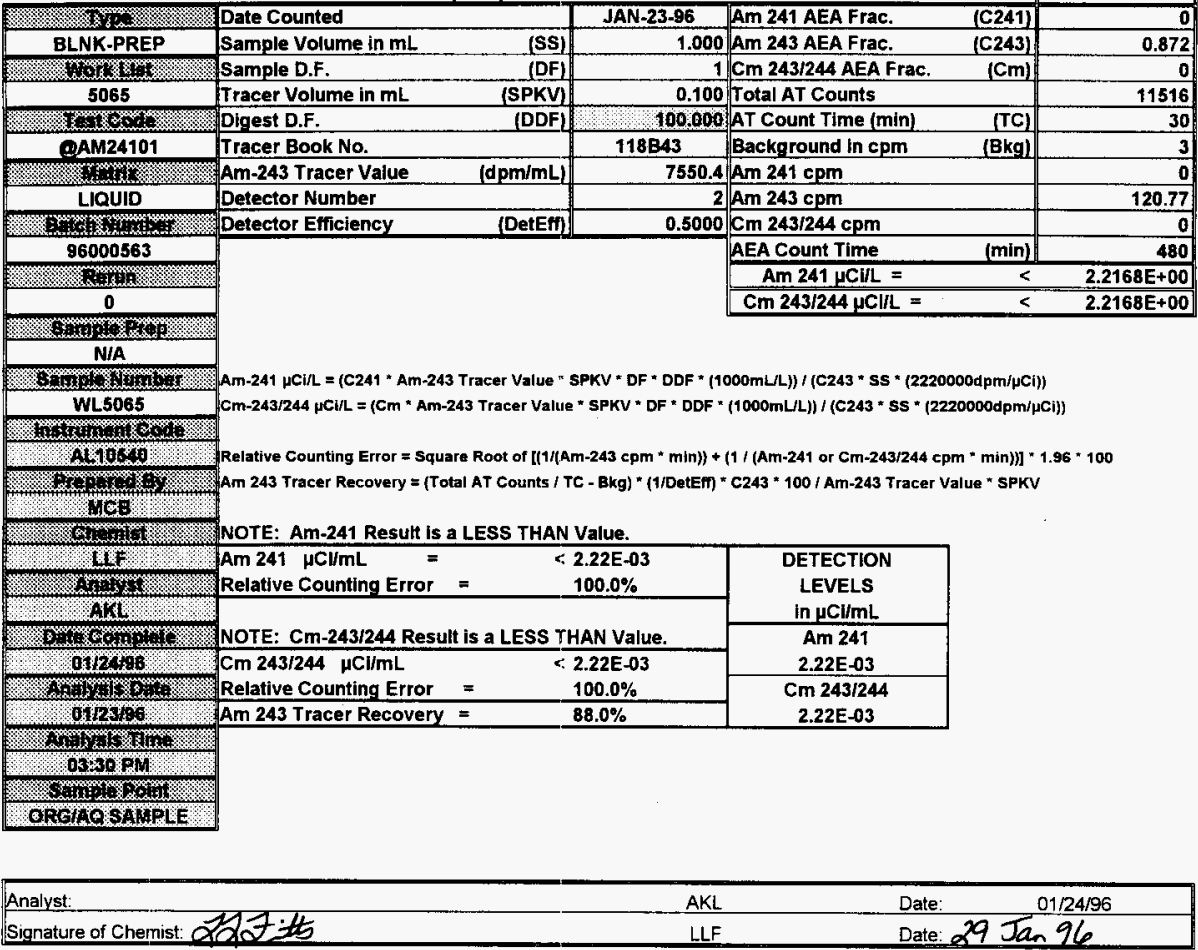

BLANK.WB1 REV 1.2 
WhiC-SD-WM-DP-180, REY. 0

WORKBOOK PAGE: SAM3

Am 241 and $C m$ 243/244: LA-953-103 (A-4)

LIQUID / SOLID

. Date Counted

SAMPLE

Sample Volume in $\mathrm{mL}$

mogng

Sample D.F.

5065

Tracer Volume in $\mathrm{mL}$

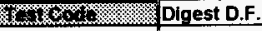

OAM24101

Tracer Book No.

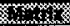

Am-243 Tracer Value

LIOUID

Detector Number

2. Whector Efficiency

96000563

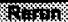

$\frac{0}{0}$

Detector Efficiency (DetEft)

JAN-23-96 Am 241 AEA Frac.

(SS) 1.000 Am 243 AEA Frac.

(DF)

(SPKV)

1 Cm 243/244 AEA Frac.

0.100 Total AT Counts

100.090 AT Count Time (min)

(DDF

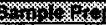

ACIDIG02

(x)

S95R000115

Am-241 $\mu \mathrm{Ci} / L=(C 241$ * Am-243 Tracer Value * SPKV * DF * DDF * (1000mLL)) /(C243 * SS * (2220000dpm/ $/ \mathrm{Cl}))$

spopropos

$\mathrm{Cm}-243 / 244 \mu \mathrm{Ci} / \mathrm{L}=(\mathrm{Cm}$ * Am-243 $\mathrm{T}$ racer Value * SPKV * DF " DDF * $(1000 \mathrm{~mL} / \mathrm{L})) /(\mathrm{C2} 43$ * SS * $(2220000 \mathrm{dpm} / \mu \mathrm{Ci}))$

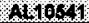

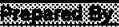 \\ WEE}

Relative Counting Error $=$ Square Root of $[(1 /(\mathrm{Am}-243 \mathrm{cpm}$ * min $)) *(1 /(\mathrm{Am}-241$ or Cm-243/244 cpm * min) $)]$ * $1.96 * 100$

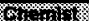

Am 243 Tracer Recovery $=$ (Total AT Counts I TC - Bkg) * (1/DetEm) * C243* 100/Am-243 Tracer Value * SPKV

NOTE: Am-241 Result is a LESS THAN Value.

\begin{tabular}{|c|}
\hline OAL \\
\hline$x_{n+1}$ \\
\hline
\end{tabular}

Am $241 \mu \mathrm{CI} / \mathrm{mL}$

$=$

< 2.58E-03

Relative Counting Error =

$100.0 \%$

Atrk

Frack

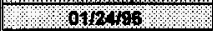

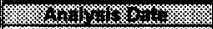

NOTE: Cm-243/244 Result is a LESS THAN Value.

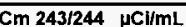

Relative Counting Error =

0 or 3 pos

Am 243 Tracer Recovery =

< 2.58E-03

$100.0 \%$

$\mathbf{7 5 . 5 \%}$

Background in cpm

-

$0 \times 3000$

x.

OROHOSAMPLE

\begin{tabular}{|c|c|c|c|}
\hline Analyst: & AKL & Date: & $01 / 24 / 96$ \\
\hline Signature of Chemist: 8627.75 & LLF & Date: & $\operatorname{In} 96$ \\
\hline
\end{tabular}

SAMPLE.WB1 REV 1.2

$953103 \mathrm{ML}$

263 
WHC-SU-WM-DP-180, REV. 0

WORKBOOK PAGE: SPIKE4

Am-241 : LA-953-103(A-4) Spiked Sample

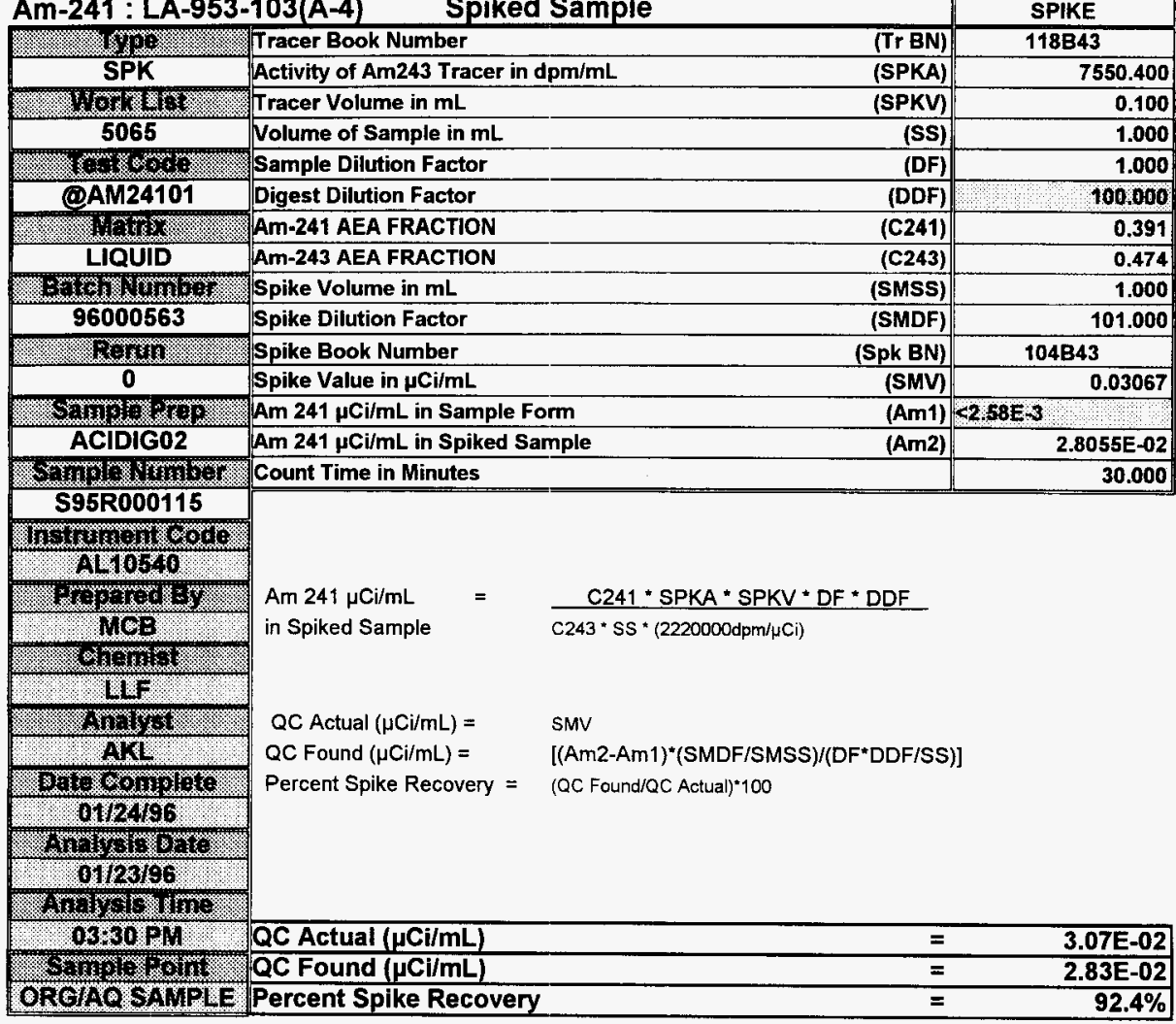

NOTE: The sample dpm was LESS THAN the detection limit (Ld), therefore zero (0) was used for Sample $\mu \mathrm{Ci} / \mathrm{mL}$ in the $Q C$ Found calculation.

\begin{tabular}{|c|c|c|}
\hline Data Entry by: & AKL & $01 / 24 / 96$ \\
\hline Approved by: $26,7 \pm 5$ & LLF & Date: $29 \operatorname{Jan} 96$ \\
\hline
\end{tabular}

SPIKE.WB1 REV 1.2 
WORKBOOK PAGE: SP_DUP5

WHC-SD-WM-DP-180, REV. 0

Am-241 : LA-953-103(A-4) Spiked Sample

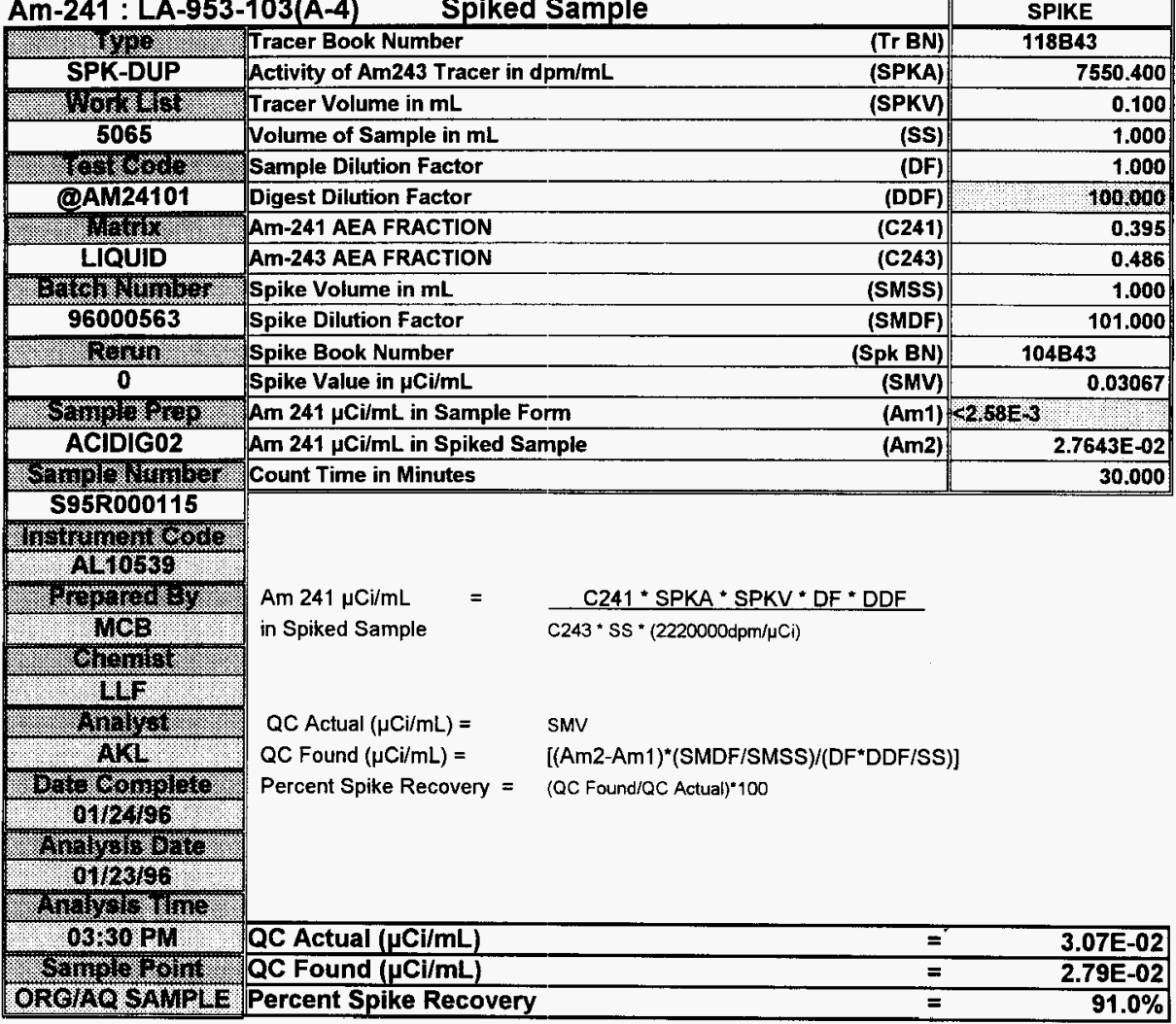

NOTE: The sample dpm was LESS THAN the detection limit (Ld), therefore zero (0) was used for Sample $\mu \mathrm{Ci} / \mathrm{mL}$ in the QC Found calculation.

\begin{tabular}{|c|c|c|}
\hline Data Entry by: & AKL & $01 / 24 / 96$ \\
\hline Approved by: 0607 its & LLF & Date: $29 \operatorname{Tan} 96$ \\
\hline
\end{tabular}

\section{5}


WORKBOOKPAGE: SAM6

LIQUID / SOLID

Am 241 and Cm 243/244: LA-953-103 (A-4)

JAN-23-96 Am 241 AEA Frac.

\begin{tabular}{|c|c|}
\hline & SAMPLE \\
\hline (C241) & 0 \\
\hline (C243) & 0.884 \\
\hline Frac. & 0 \\
\hline & 10997 \\
\hline (TC) & 30 \\
\hline (Bkg) & 6 \\
\hline & 0 \\
\hline & 118,45 \\
\hline & 0 \\
\hline (min) & 480 \\
\hline$<$ & $2.2784 E+00$ \\
\hline inL $=$ & $2.2784 E+00$ \\
\hline
\end{tabular}

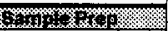

ACIDIG02

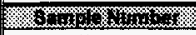

S95R000116

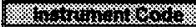

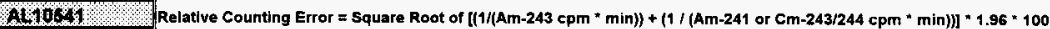

Am 243 Tracer Recovery = (Total AT Counts / TC - Bkg) * (1/DetEn) * C243 * 100/ Am-243 Tracer Value * SPKV ifto:

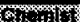

\begin{tabular}{|c|c|c|c|}
\hline $8 \%$ & \multicolumn{3}{|c|}{ NOTE: Am-241 Result is a LESS THAN Value. } \\
\hline LE: & Am $241 \mu \mathrm{Cl} / \mathrm{mL}$ & $<2.28 \mathrm{E}-03$ & \multirow{3}{*}{$\begin{array}{c}\text { DETECTION } \\
\text { LEVELS } \\
\text { in } \mu \text { C } / / m L\end{array}$} \\
\hline 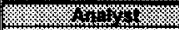 & Relative Counting Error & $100.0 \%$ & \\
\hline Hol & \multirow{2}{*}{\multicolumn{2}{|c|}{ NOTE: Cm-243/244 Result is a LESS THAN Value. }} & \\
\hline 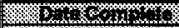 & & & Am 241 \\
\hline 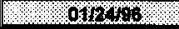 & \multirow{2}{*}{$\begin{array}{l}\text { Cm 243/244 } \mu \mathrm{Cl} / \mathrm{mL} \\
\text { Relative Counting Error }\end{array}$} & \multirow{2}{*}{$\begin{array}{l}2.28 E-03 \\
100.0 \%\end{array}$} & $2.28 E-03$ \\
\hline SWH & & & \multirow{2}{*}{$\begin{array}{c}\mathrm{Cm} \mathrm{243/244} \\
2.28 E-03\end{array}$} \\
\hline ofisiog & Am 243 Tracer Recovery & $84.4 \%$ & \\
\hline
\end{tabular}

NOTE: Am-241 Result is a LESS THAN Value.

s.s.

005020

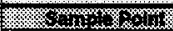

OHBHCOHWFL

\begin{tabular}{|c|c|c|c|}
\hline Analyst: & $\mathrm{AKL}$ & Date: & $01 / 24 / 96$ \\
\hline Signature of Chernist: & LLF & & \\
\hline
\end{tabular}


WORKBOOK PAGE: SPIKE7

Am-241 : LA-953-103(A-4) Spiked Sample

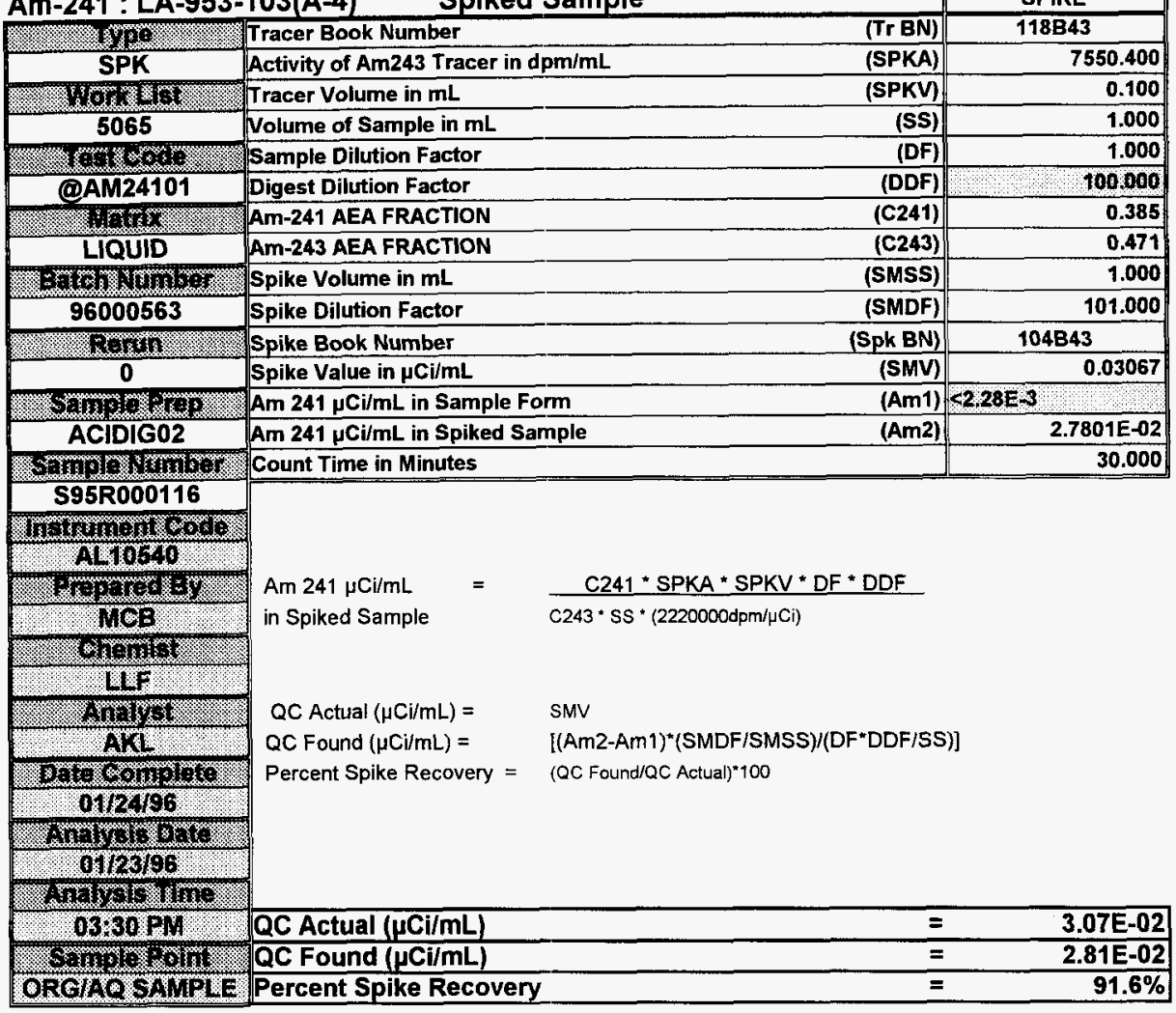

NOTE: The sample dpm was LESS THAN the detection limit (Ld), therefore zero (0) was used for Sample $\mu \mathrm{Ci} / \mathrm{mL}$ in the QC Found calculation.

\begin{tabular}{|c|c|c|}
\hline Data Entry by: & AKL & $01 / 24 / 96$ \\
\hline Approved by: $0807=4$ & LLF & Date: $29 \operatorname{Ja}_{a_{n}} 96$ \\
\hline
\end{tabular}

SPIKE.WB1 REV 1.2 953103ML 
WORKBOOK PAGE: SP DUP8

Am-241: LA-953-103(A-4) Spiked Sample

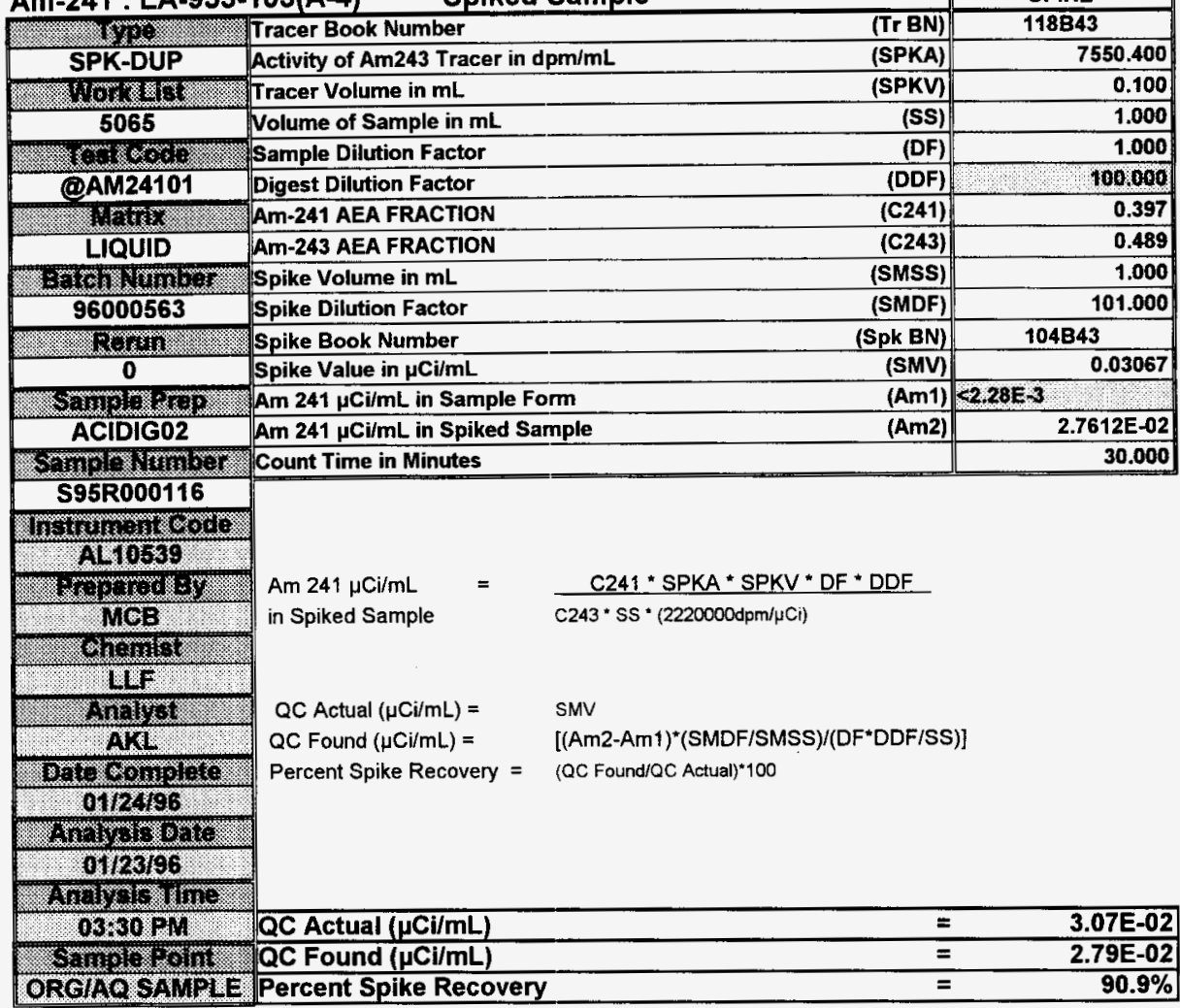

NOTE: The sample dpm was LESS THAN the detection limit (Ld), therefore zero (0) was used for Sample $\mu \mathrm{Ci} / \mathrm{mL}$ in the QC Found calculation.

\begin{tabular}{|c|c|c|}
\hline Data Entry by: & $\overline{A K L}$ & $01 / 24 / 96$ \\
\hline Approved by: QZAOZtte & LLF & Date: $29 \sqrt{a_{n}} 96$ \\
\hline
\end{tabular}

SPIKE.WB1 REV 1.2 
Westinghouse Hanford Co.

$$
\text { i. } 2+46
$$

G E N E R A L

A L P H A E N E R G Y A N A L Y S I S Rev. 2.01

DATA REDUCTION REPORT

WHC-SD-WM-DP-180, REV. 0

SAMPLE

WL5065-STD

File ID: 19a1908.CNF

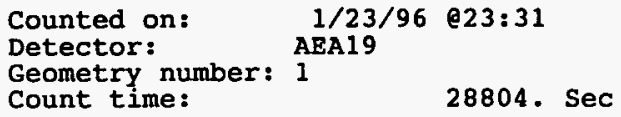

PEAK ANALYSIS

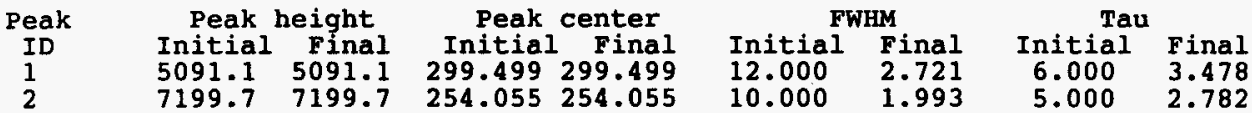

\section{PEAK RESULTS \\ Peak Error Limit: 308}

Peak
ID Isotope
$1 \quad$ Pu238
$2 \quad$ Am241
$2 \quad \operatorname{Am} 243$

Totals:

\begin{abstract}
AEA
Frac

0.396

0.486

$-----$

0.882$$
<--v a l i d \text { ped }
$$

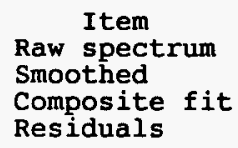

Peak Centroid

Count serr

Exp. Obs. Diff. FWHM Rate $c / m$ Q95

5.4875 .4790 .0080 .01

5.4795 .4790 .000

88.551 .0

$\mathrm{d} / \mathrm{m}$

1273.2

975.2

$5.270 \quad 5.270 \quad 0.0000 .01$

$108.62 \quad 0.9$

1135.8

Activity uCi/ea

$0.573 \mathrm{E}-03$

$0.439 \mathrm{E}-03$
$0.512 \mathrm{E}-03$$$
\text { peaks only--> }
$$$$
197.17
$$

DETECTOR CALIBRATION
Energy (MEV) $=4.101+(0.0046) *$ Channel
Energy range $(\mathrm{MeV}): 4.101$ TO 6.457 Efficiency $=0.0966 \mathrm{CPM} / \mathrm{DPM}$

TOTAL COUNT DATA:

$\begin{array}{cc}\text { Total } & \text { \& Recovery } \\ 107295.0 & 100.000 \\ 107294.9 & 100.000 \\ 94653.7 & 88.218 \\ 12641.3 & 11.782\end{array}$

Analyzed by: 
1 Legend: $\quad$ Raw $=\ldots$ Modeled Peaks $=1,2, \ldots$, etc $\quad$ Display Max.: 36686.8

WHC-SD-WM-DP-180, REV. 0

-

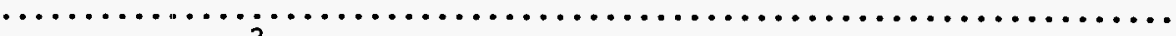

$\ldots \ldots \ldots \ldots \ldots . \ldots \ldots$

$\cdots$

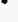

$\ldots \ldots \ldots \ldots \ldots 1$

$\cdots 1 \ldots \ldots \ldots$

1 
Räw Daca Dump for AEA Spectrum: 19 al908.CNF

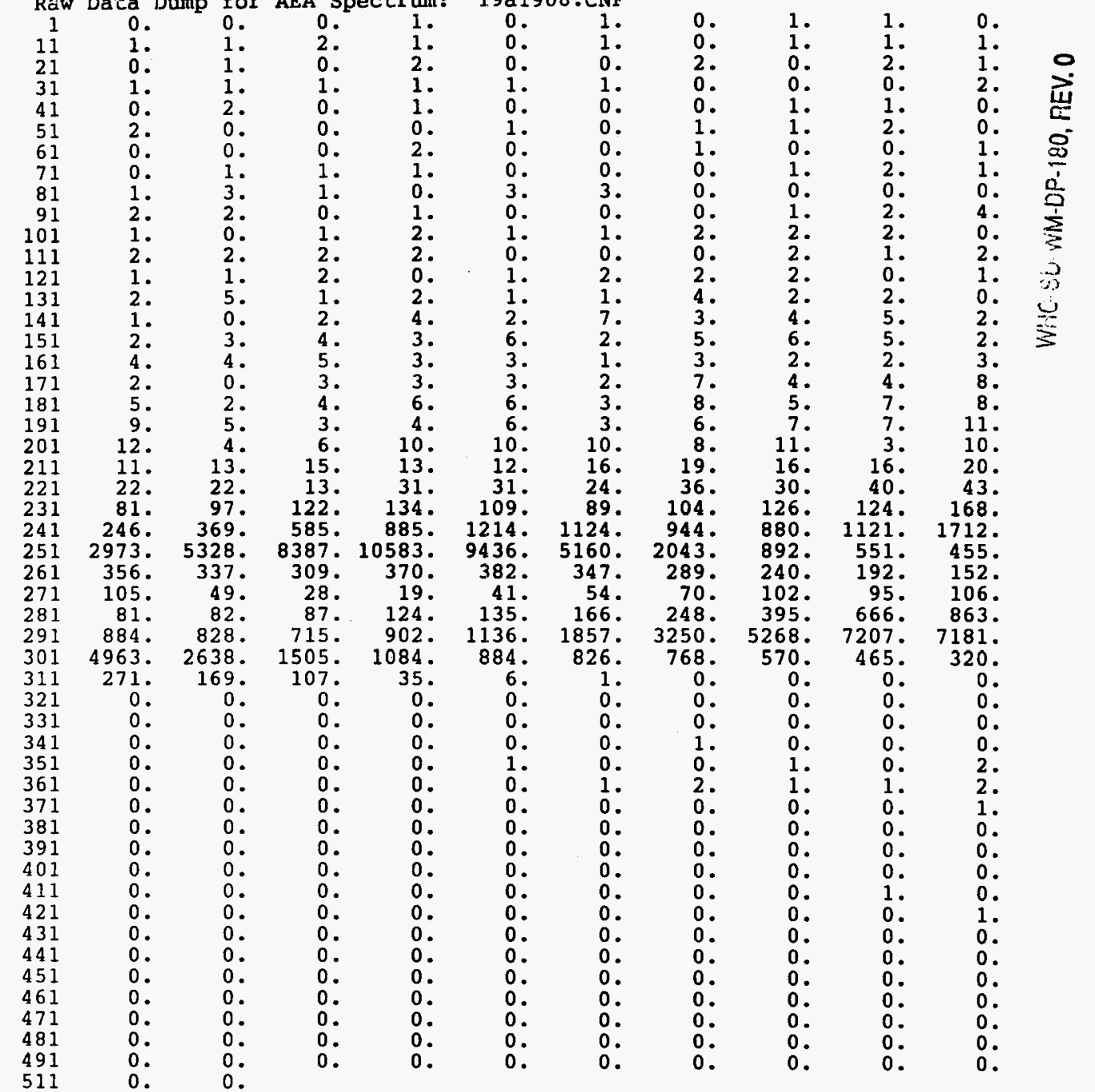




$$
\begin{aligned}
& \text { Q. H. niticia } \\
& 1.2 \text {-46 }
\end{aligned}
$$

Westinghouse Hanford Co.

G E N E R A L

A I P H A E N E R G Y A N A L Y S I S

Rev. 2.01

DATA REDUCTION REPORT

WHC-SD-WM-DP-180, FEV. O

\author{
SAMPLE \\ WL5065-BLK \\ File ID: 20a2011.CNF
}

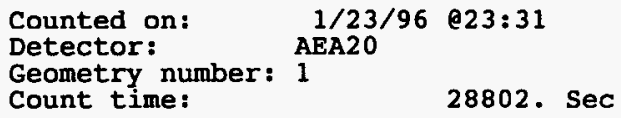

PEAK ANALYSIS

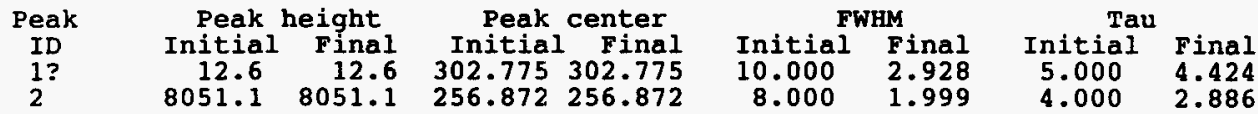

\title{
PEAK RESULTS \\ Peak Error Limit: $30 \%$
}

Peak
ID Isotope
1 Am243

Totals:

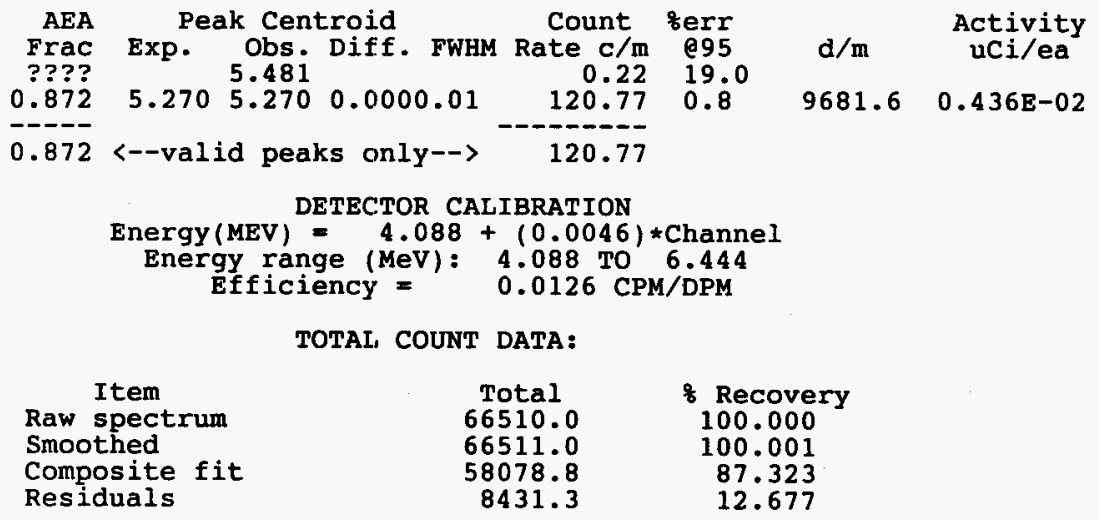

Analyzed by:

$\overline{\text { EMB }}$ 
Spectrum 20a2011.CNF

1 Legend: $\quad$ Raw $=\ldots$ Modeled Peaks $=1,2, \ldots$ etc $\quad$ Display Max.: 32128.6

WHC-SD-WM-DP-180, REV. 0

$2 \ldots \ldots$ 
Raw Daca Dump for AEA Spectrum: 20a2011.CNF

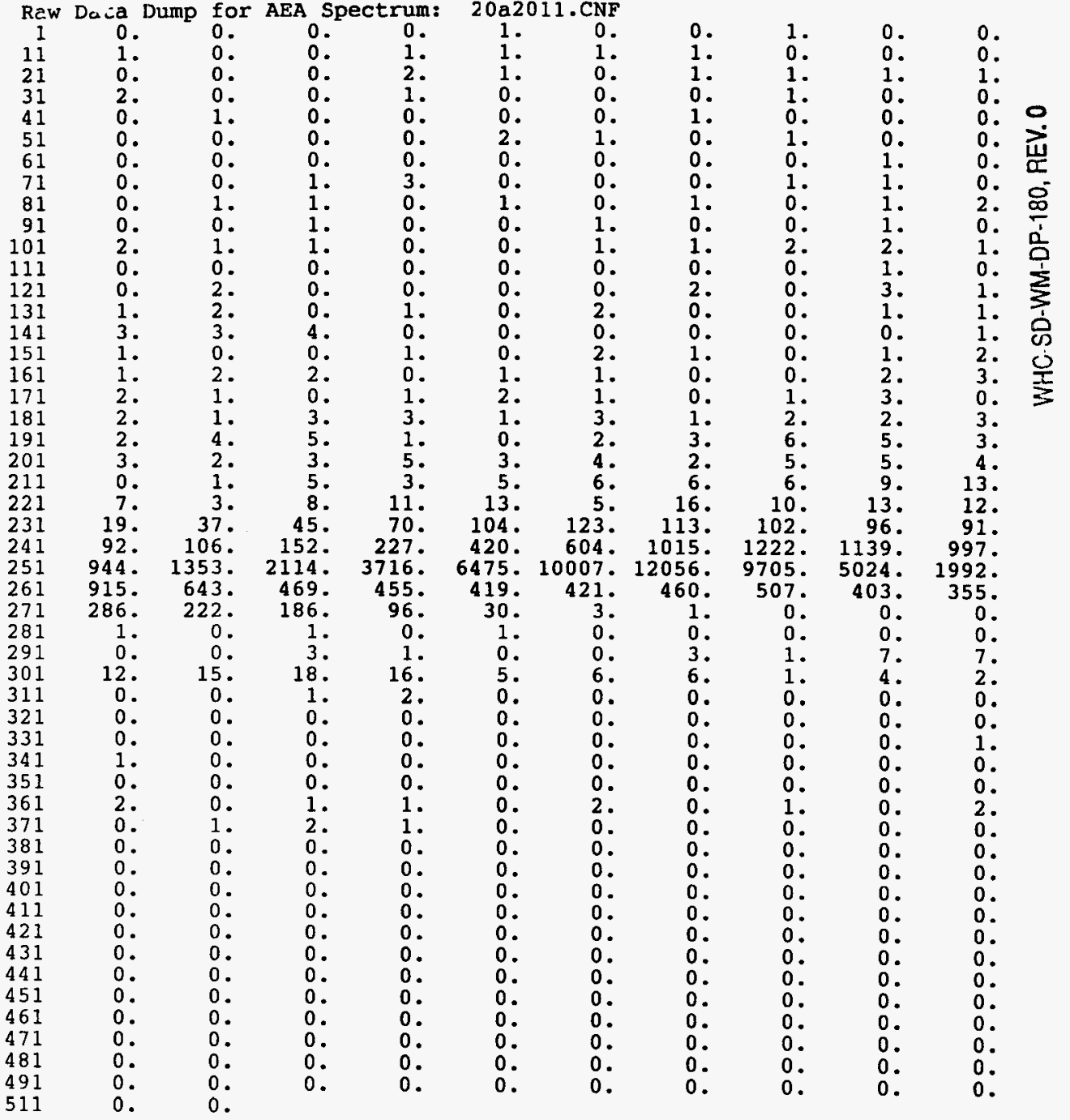


Westinghouse Hanford Co.

D.H. mities $1-2+-96$

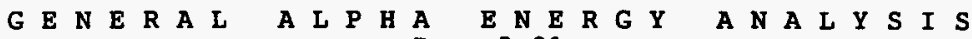
Rev. 2.01

DATA REDUCTION REPORT

WHC-SD-WM-DP-180, FEV. U

SAMPLE

S95R115-SAM

File ID: $21 \mathrm{a} 2115 . \mathrm{CNF}$

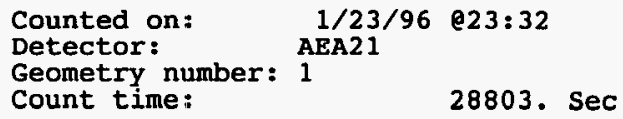

PEAK ANALYSIS

\begin{tabular}{|c|c|c|c|c|c|c|}
\hline $\begin{array}{l}\text { Peak } \\
\text { ID } \\
1 ? \\
2\end{array}$ & $\begin{array}{c}\text { Peak } \\
\text { Initial } \\
21.7 \\
6551.7\end{array}$ & $\begin{array}{r}\text { Fight } \\
\text { Final } \\
21.7 \\
6551.7\end{array}$ & 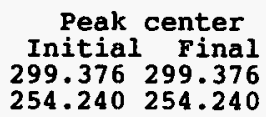 & $\begin{array}{l}\text { Initial } \\
10.000 \\
10.000\end{array}$ & $\begin{array}{l}\text { Final } \\
2.649 \\
2.023\end{array}$ & $\begin{array}{l}\text { Tau } \\
\text { Initial } \\
5.000 \\
5.000\end{array}$ \\
\hline
\end{tabular}

PEAK RESULTS
Peak Error Limit: 308

Peak

ID Isotope

AEA

Peak Centrojd

Count serr

1

Frac

???? Exp Obs. Diff.

FWHM Rate

$\mathrm{c} / \mathrm{m} \quad 895$

0.873

$$
5.270 \quad 5.477
$$

$0.39 \quad 14.4$

$\mathrm{d} / \mathrm{m}$

Activity

$2 \operatorname{Am} 243$

0.873

5.2705 .2690 .0010 .01

$99.51 \quad 0.9$

921.3

uCi/ea

Totals :

0.873

<--valid peaks only--> 99.51
DETECTOR CALIBRATION
Energy (MEV) $=4.100+(0.0046) *$ Channel
Energy range (MeV): 4.100 TO 6.455
Efficiency $=0.1091 \mathrm{CPM} / \mathrm{DPM}$

TOTAL COUNT DATA:

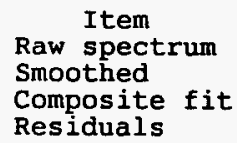
Total
54699.0
54698.8
47956.5
6742.5
\& Recovery
100.000
100.000
87.673
12.327

Analyzed by: 
1 Legend: $\quad$ Raw $=\ldots$ Modeled Peaks $=1,2, \ldots$ etc $\quad$ Display Max.: 33061.0

WriC-SD-WM-DP-180, REV. O

$\ldots+2 \ldots$

 
Raw Da乞a Dump for AEA Spectrum: 21a2115.CNF

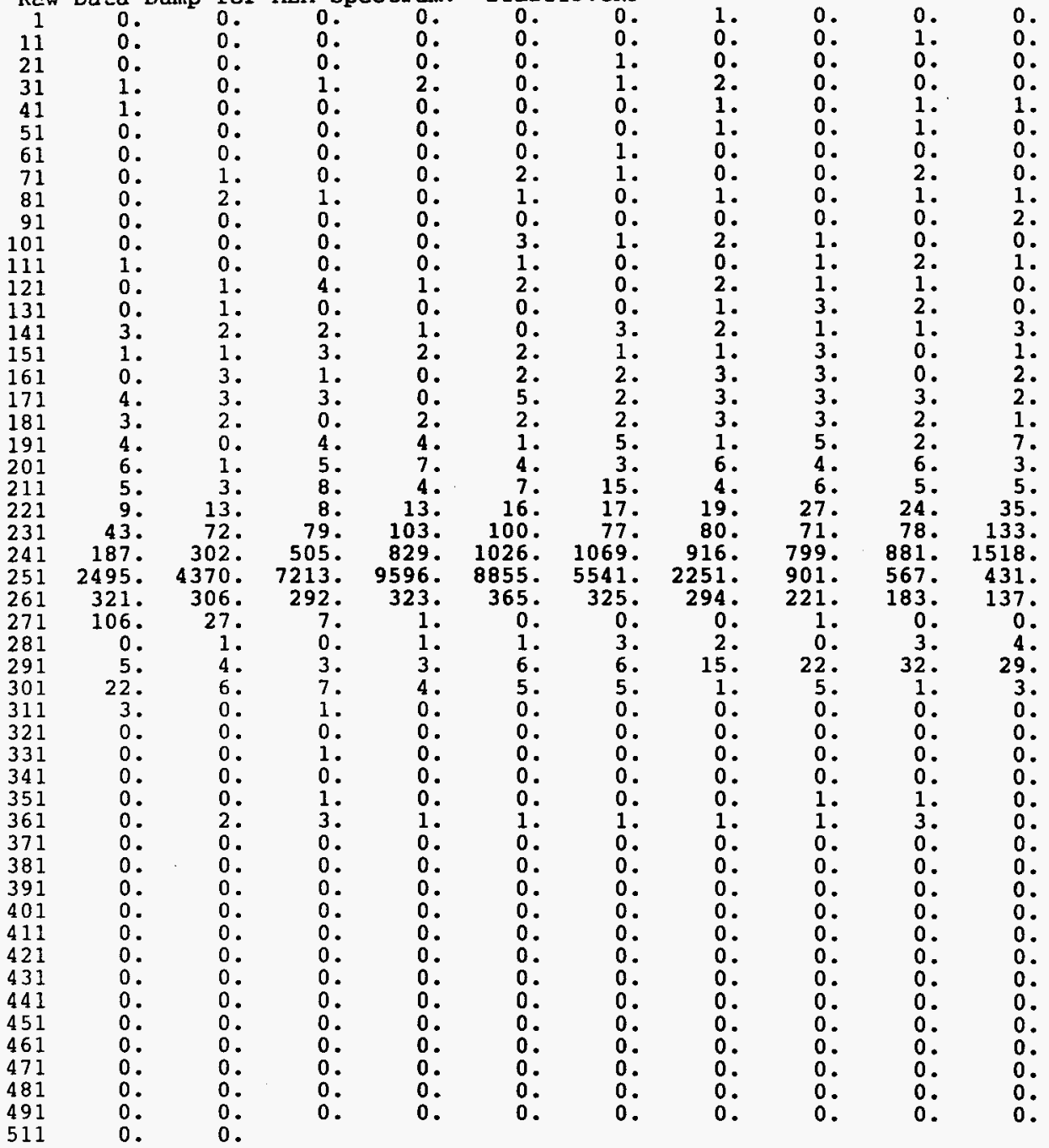


Westinghouse Hanford Co.

$$
\text { S Hmilera }
$$

A L P н A ENERG Y A N A I Y S I S

G E N E R A L

A I P н A
Rev. 2.01

WHC-SD-WM-DP-180, REV. DATA REDUCTION REPORT

SAMPLE S95R115-SPK

File ID: $23 a 2354$. CNF

Counted on: $\begin{aligned} & 1 / 23 / 96 \text { e23:35 } \\ & \text { Detector: } \\ & \text { Geometry number: } 1\end{aligned} \begin{array}{ll}\text { AEA23 } & \\ \text { Count time: } & \text { 28800. Sec }\end{array}$

PEAK ANALYSIS

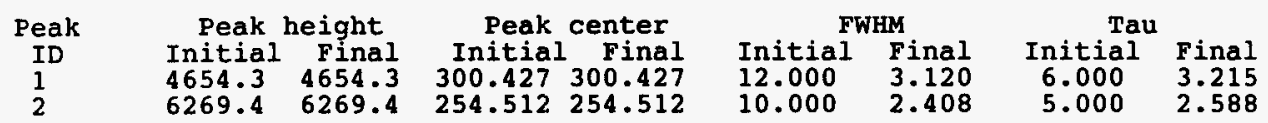

\section{PEAK RESULTS \\ Peak Error Limit: $30 \%$}

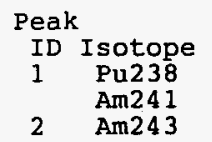

Peak

ID Isotope

$1 \quad \mathrm{Pu} 238$ Am241

$2 \operatorname{Am} 243$

Totals:

\begin{tabular}{|c|c|c|c|c|c|}
\hline $\begin{array}{r}\text { AEA } \\
\text { Frac } \\
0.391\end{array}$ & $\begin{array}{l}\text { Peak Centroid } \\
\text { Exp. Obs. Diff. FWHM } \\
5.4875 .493-.0060 .01 \\
5.4795 .493-.014\end{array}$ & $\begin{array}{r}\text { Count } \\
\text { Rate } \mathrm{c} / \mathrm{m} \\
89.45\end{array}$ & $\begin{array}{r}\text { ferr } \\
\text { e95 } \\
0.9\end{array}$ & $\begin{array}{c}d / m \\
7019.1 \\
5376.3\end{array}$ & $\begin{array}{l}\text { Activity } \\
\text { uCi/ea } \\
0.316 \mathrm{E}-02 \\
0.242 \mathrm{E}-02\end{array}$ \\
\hline 0.474 & $282-.0120 .01$ & 108.28 & 0.9 & 6179.4 & $0.278 E-02$ \\
\hline .865 & <--valid peaks & 197.73 & & & \\
\hline
\end{tabular}

DETECTOR CALIBRATION
Energy $(M E V)=4.111+(0.0046) *$ Channel
Energy range (MeV): 4.111 TO 6.467 Efficiency $=0.0177 \mathrm{CPM} / \mathrm{DPM}$

TOTAL, COUNT DATA:

$\begin{array}{lcc}\text { Item } & \text { Total } & \text { Recovery } \\ \text { Raw spectrum } & 109703.0 & 100.000 \\ \text { Smoothed } & 109704.5 & 100.001 \\ \text { Composite fit } & 94911.9 & 86.517 \\ \text { Residuals } & 14791.1 & 13.483\end{array}$

Analyzed by:

$\overline{E M B}$ 
Spectrum 23a2354.CNF

1 Legend: $\quad$ Raw $=\ldots$ Modeled Peaks $=1,2, \ldots$, etc $\quad$ Display Max.: 32969.4

WHC-SD-WM-DP-180, REV 0 
Raw Data IIump for AEA Spectrum: $23 a 2354$.CNF

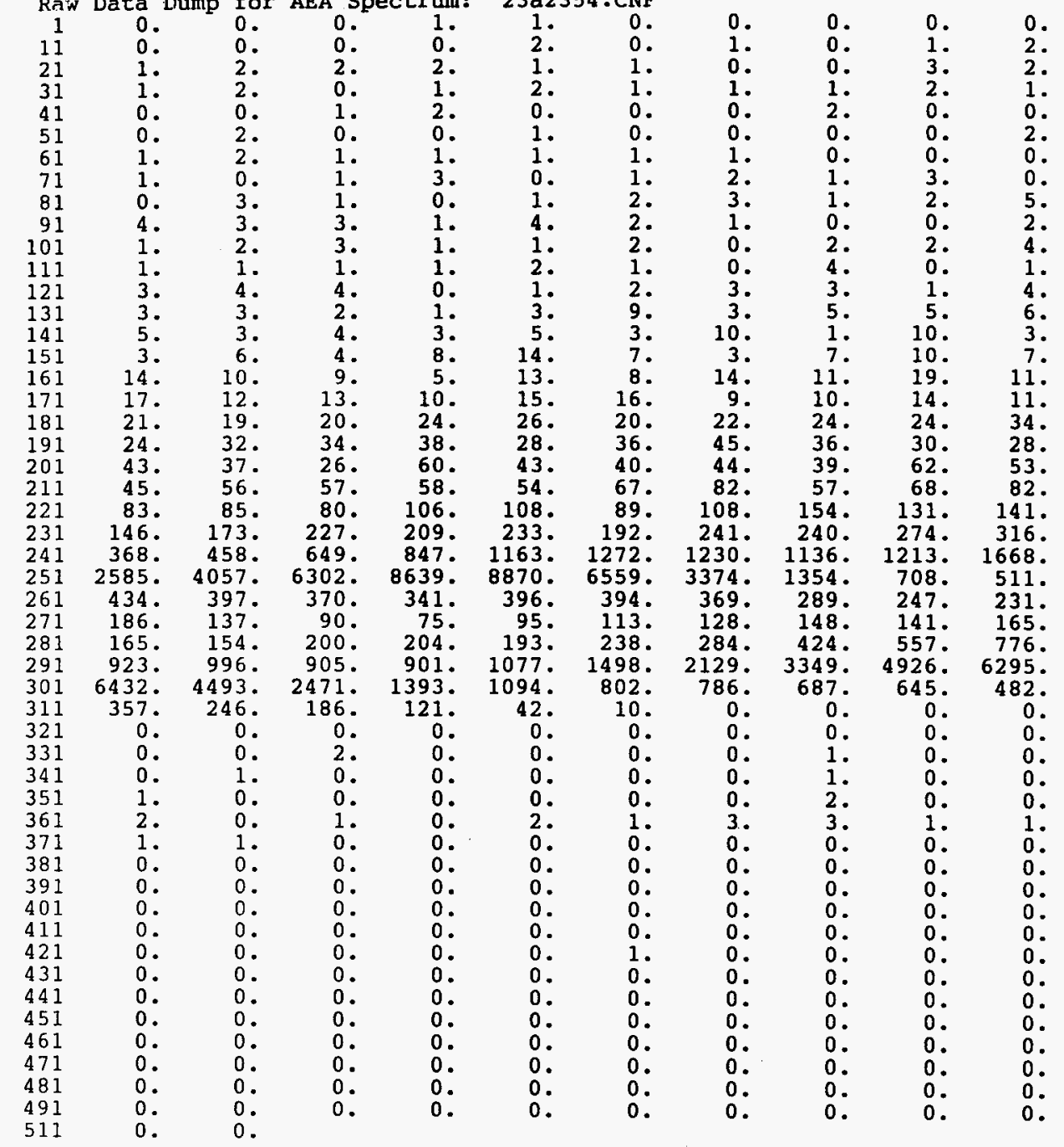




\title{
Westinghouse Hanford $\mathrm{Co}$.
}

G E N E R A L A L P H A EN E R G Y A N A L Y S I S Rev. 2.01

DATA REDUCTION REPORT

WHC-SD-WM-DP-180, FiE: :

\author{
SAMPLE \\ S95R115-SPK DUP \\ File ID: $22 \mathrm{a2258.CNF}$
}

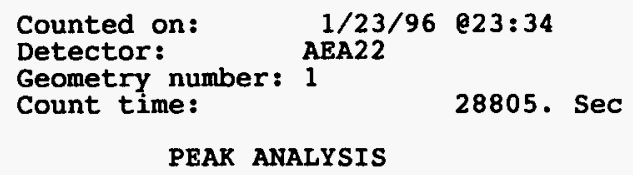

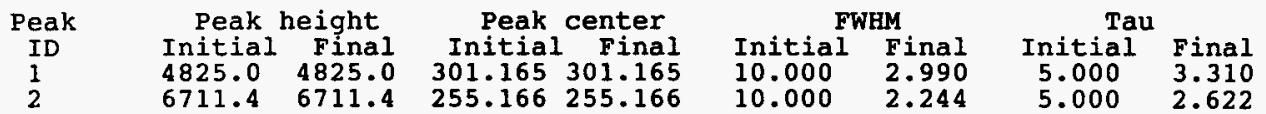

PEAK RESULTS
Peak Error Limit: $30 \%$

$\begin{array}{lc}\text { Peak } & \\ \text { ID } & \text { Isotope } \\ 1 & \text { Pu238 } \\ & \text { Am241 } \\ 2 & \text { Am243 }\end{array}$

Totals :

\begin{tabular}{|c|c|c|c|c|c|}
\hline $\begin{array}{r}\text { AEA } \\
\text { Frac } \\
0.395 \\
0.486\end{array}$ & $\begin{array}{l}\text { Peak Centroid } \\
\text { Exp. } \\
5.487 \\
5.48\end{array}$ & $\begin{array}{r}\text { Count } \\
\text { Rate } \mathrm{c} / \mathrm{m} \\
89.72 \\
110.44\end{array}$ & $\begin{array}{r}\text { serr } \\
\text { eg5 } \\
0.9 \\
0.9\end{array}$ & $\begin{array}{l}\mathrm{d} / \mathrm{m} \\
6663.9 \\
5104.3 \\
5965.4\end{array}$ & $\begin{array}{c}\text { Activity } \\
\text { uCi/ea } \\
0.300 \mathrm{E}-02 \\
0.230 \mathrm{E}-02 \\
0.269 \mathrm{E}-02\end{array}$ \\
\hline .881 & $\langle--v a l i d$ peaks only--> & 200.16 & & & \\
\hline
\end{tabular}

DETECTOR CALIBRATION
Energy $($ MEV $)=4.102+(0.0046) *$ Channel
Energy range (MeV): 4.102 To 6.458
Efficiency $=0.0187 \mathrm{CPM} / \mathrm{DPM}$

TOTAL COUNT DATA:

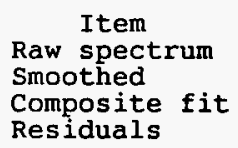

\& Recovery
100.000
100.000
88.052
11.948

Analyzed by: 
1 Legend: $\quad$ Raw $=\ldots$ Modeled Peaks $=1,2, \ldots$ etc $\quad$ Display Max.: 31592.0

WHC-SD-WM-DP-180, REV O 
Raw Date Dump for AEA Spectrum: 22a2258.CNF

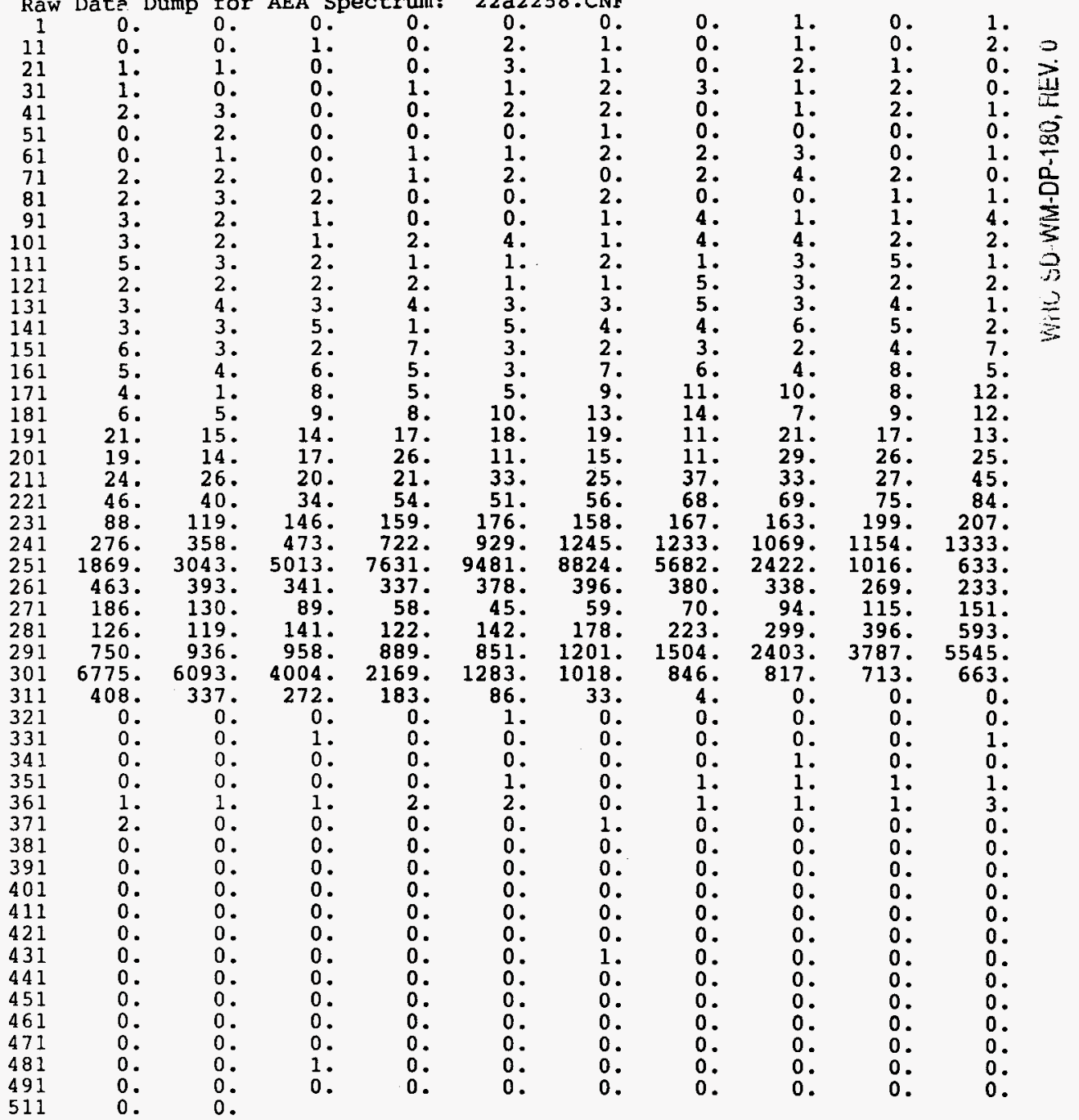


Co tion inticia

Westinghouse Hanford Co. $\quad 1-24-96$

A L P H A E N E R G Y A NAII Y S I S Rev. 2.01 DATA REDUCTION REPORT

WHC-SD-WM-DP-180, FEV

SAMPLE S95R116-SAM

File ID: $24 a 2459 . \mathrm{CNF}$

Counted on: $1 / 23 / 96$ e23:35
$\begin{array}{ll}\text { Detector: } & \\ \text { Geometry number: } 1 & \\ \text { Count time: } & 28804 . \mathrm{Sec}\end{array}$

PEAK ANALYSIS

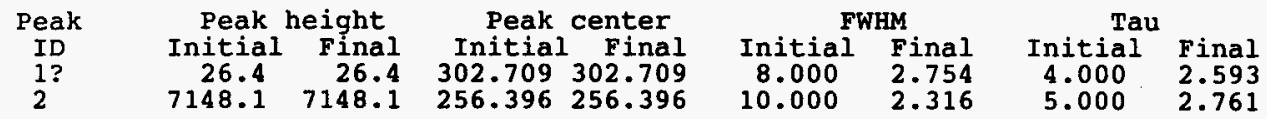

\section{PEAK RESULTS \\ Peak Error Limit: $30 \%$}

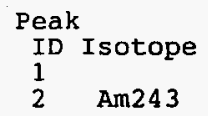

Totals:

\begin{tabular}{|c|c|c|c|c|c|c|c|}
\hline AEA & & ak Cen & troid & Count & ferr & & Activity \\
\hline $\begin{array}{r}\text { Frac } \\
? ? ? ? \\
0.884\end{array}$ & $\begin{array}{l}\text { Exp. } \\
5.270\end{array}$ & $\begin{array}{l}\text { Obs. } \\
5.483 \\
5.270\end{array}$ & $\begin{array}{l}\text { Diff. FWHM } \\
0.0000 .01\end{array}$ & $\begin{array}{r}\text { Rate } c / m \\
0.50 \\
118.45\end{array}$ & $\begin{array}{l}995 \\
12.7 \\
0.8\end{array}$ & $\begin{array}{c}d / m \\
13443.0\end{array}$ & $\begin{array}{c}\text { uCi/ea } \\
0.606 \mathrm{E}-02\end{array}$ \\
\hline 88 & $-v i$ & & nly--> & & & & \\
\hline
\end{tabular}

TOTAL COUNT DATA:

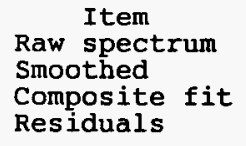

Total
64350.0
64350.2
57100.6
7249.4

Analyzed by:

$$
\begin{aligned}
& \text { Recovery } \\
& 100.000 \\
& 100.000 \\
& 88.734 \\
& 11.266
\end{aligned}
$$


Spectrum 24a2459.CNF

1 Legend: $\quad$ Raw $=\ldots$ Modeled Peaks $=1,2, \ldots$ etc $\quad$ Display Max.: 27075.2

WriC-SD-WM-DP-180, Rian 
Raw Data Dump for AEA Spectrum: 24 a2459.CNF

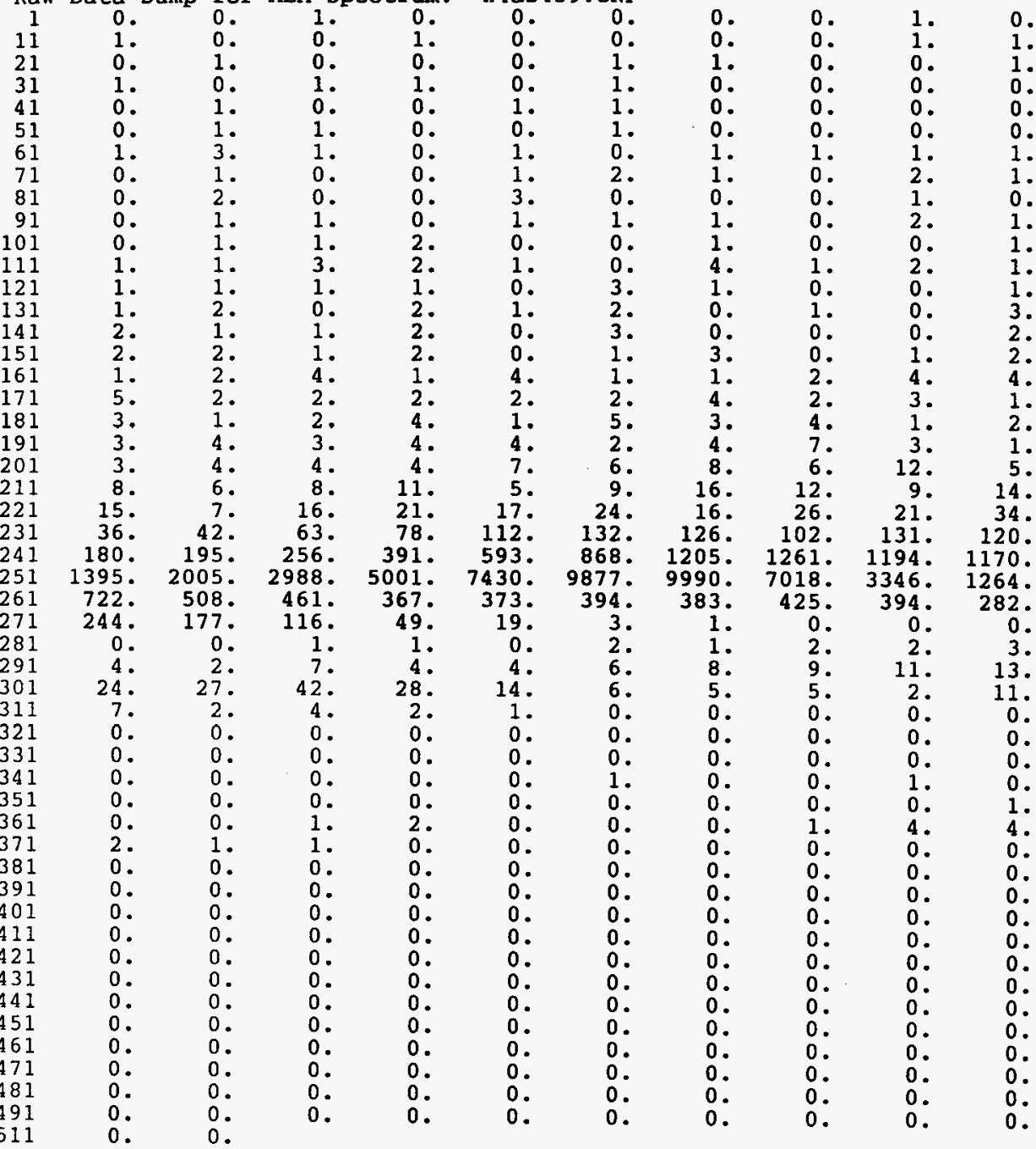


Westinghouse Hanford Co.

$$
\text { CHmitiva }
$$

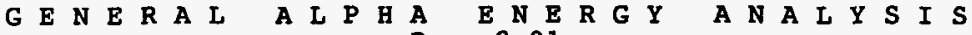
Rev. 2.01 WrC-SD-WM-DP-180, FEV 6

DATA REDUCTION REPORT

SAMPLE S95R116-SPK

File ID: 26 a2663.CNF

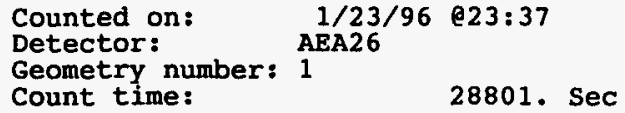

PEAK ANALYSIS

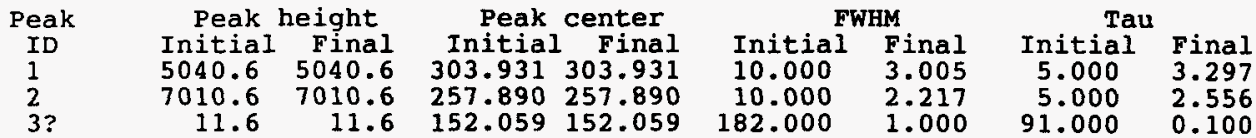

PEAK RESULTS

Peak Error Limit: $30 \%$

$\begin{array}{cc}\text { Peak } & \\ \text { ID } & \text { Isotope } \\ 1 & \text { Pu238 } \\ & \text { Am241 } \\ 2 & \text { Am243 } \\ 3 & \end{array}$

\begin{tabular}{|c|c|c|c|c|c|c|c|}
\hline $\begin{array}{r}\text { AEA } \\
\text { Frac } \\
0.385\end{array}$ & $\begin{array}{l}\text { Per } \\
\text { Exp. } \\
5.487 \\
5.479\end{array}$ & $\begin{array}{l}\text { Cen } \\
\text { Obs. } \\
5.492 \\
5.492\end{array}$ & $\begin{array}{l}\text { troid } \\
\text { Diff. FWHM } \\
-.0050 .01 \\
-.013\end{array}$ & $\begin{array}{r}\text { Count } \\
\text { Rate } \mathrm{c} / \mathrm{m} \\
94.10\end{array}$ & $\begin{array}{r}\text { rerr } \\
\text { e.9.5 } \\
0.9\end{array}$ & $\begin{array}{c}d / m \\
9753.5 \\
7470.8\end{array}$ & $\begin{array}{c}\text { Activity } \\
\text { uCi/ea } \\
0.439 \mathrm{E}-02 \\
0.337 \mathrm{E}-02\end{array}$ \\
\hline $\begin{array}{r}0.471 \\
\text { ???? }\end{array}$ & 5.270 & $\begin{array}{l}5.280 \\
4.793\end{array}$ & -.0100 .01 & $\begin{array}{r}115.26 \\
0.92\end{array}$ & $\begin{array}{l}0.8 \\
9.3\end{array}$ & 868 & -02 \\
\hline 05 & za & $n$ & s only- $\rightarrow$ & 209. & & & \\
\hline
\end{tabular}

Totals:
DETECTOR CALIBRATION

$$
\begin{gathered}
\text { Energy (MEV) }=4.094+(0.0046) * \text { Channel } \\
\text { Energy range }(M e V): \\
\text { Efficiency }=0.094 \mathrm{TO} 6.449 \\
0.0134 \mathrm{CPM} / \mathrm{DPM}
\end{gathered}
$$

TOTAL COUNT DATA:

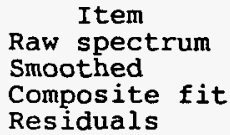

$\begin{array}{cc}\text { Total } & \text { \& Recovery } \\ 117393.0 & 100.000 \\ 117393.4 & 100.000 \\ 100941.0 & 85.986 \\ 16452.0 & 14.014\end{array}$

Analyzed by: 
1 Legend: Raw $=\ldots$ Modeled Peaks $=1,2, \ldots$ etc Display Max.: 34153.4

WHC-SD-WM-DP-180, REV. 0 
Raw Data Dump for AEA Spectrum: 26a2663.CNF

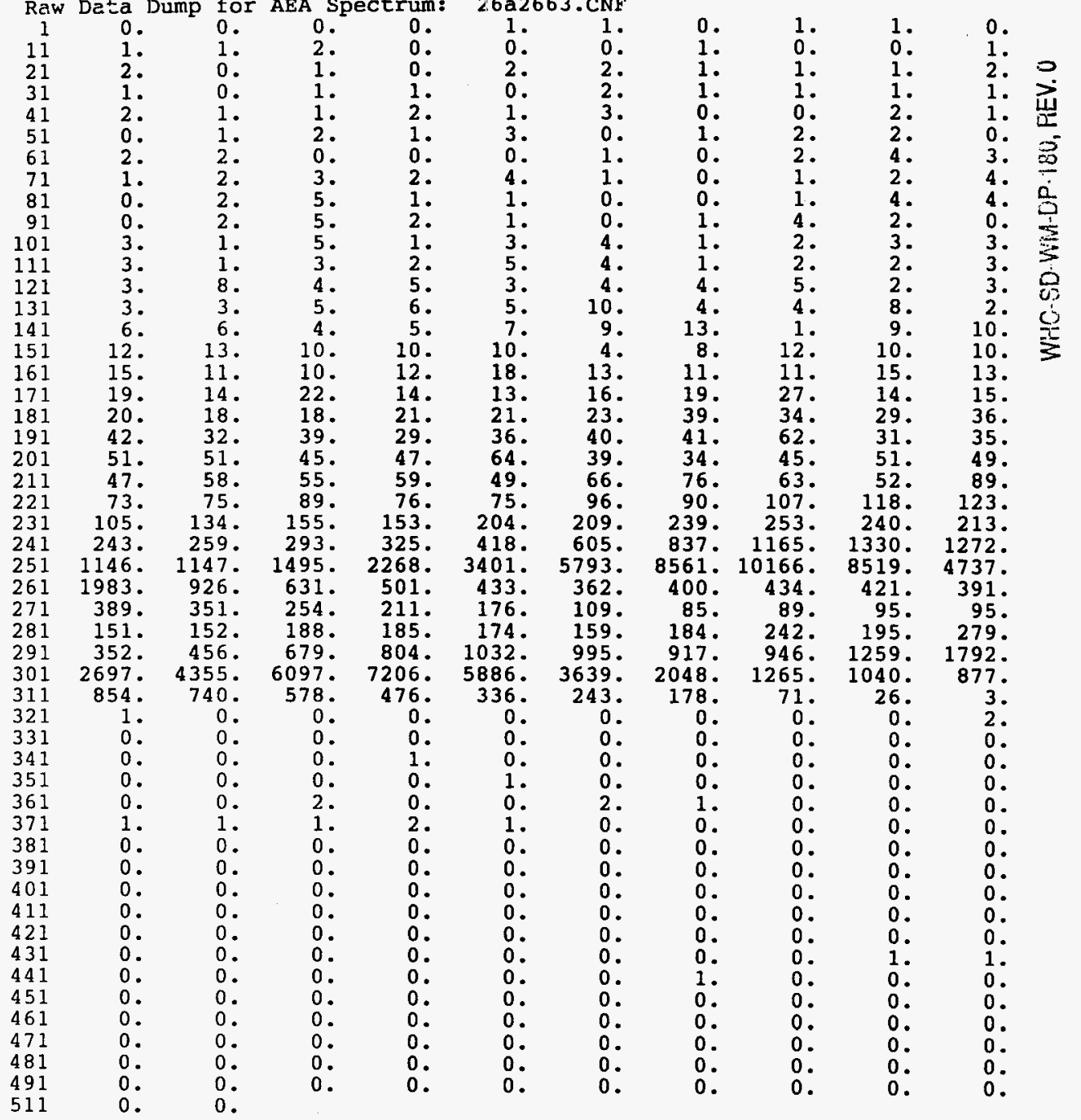




$$
\text { S.pMitrea }
$$

Westinghouse Hanford Co. $\quad 1-24-96$

G E N E R A L A L P H A E N E R G Y A N A L Y S I S Rev. 2.01

DATA REDUCTION REPORT

SAMPLE

WHO-SD-WM-DP-180, FEV . S95RI16-SPK DUP

File ID: 25a2557.CNF

$\begin{array}{ll}\text { Counted on: } & 1 / 23 / 96 \text { e23:36 } \\ \text { Detector: } & \text { AEA25 } \\ \begin{array}{ll}\text { Geometry number: } & \\ \text { Count time: } & 28802 \text {. Sec }\end{array}\end{array}$

PEAK ANALYSIS

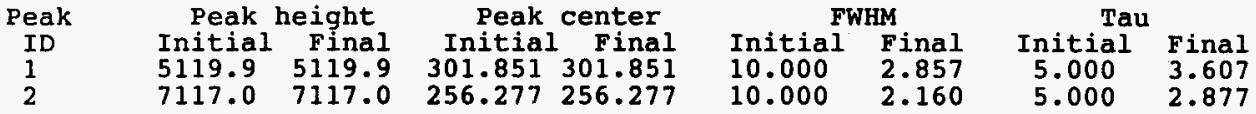

PEAK RESULTS
Peak Error Limit: $30 \%$

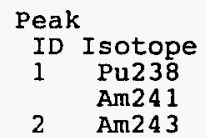

Totals:

\begin{tabular}{|c|c|c|c|c|c|}
\hline $\begin{array}{r}\text { AEA } \\
\text { Frac } \\
0.397 \\
0.489\end{array}$ & 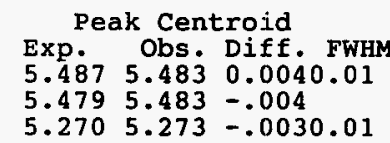 & $\begin{array}{r}\text { Count } \\
\text { Rate c/m } \\
91.07 \\
111.95\end{array}$ & $\begin{array}{r}\text { serr } \\
\text { eg5 } \\
0.9 \\
0.8\end{array}$ & $\begin{array}{r}\mathrm{d} / \mathrm{m} \\
1258.6 \\
964.0 \\
1125.2\end{array}$ & $\begin{array}{r}\text { Activity } \\
\text { uCi/ea } \\
0.567 \mathrm{E}-03 \\
0.434 \mathrm{E}-03 \\
0.507 \mathrm{E}-03\end{array}$ \\
\hline .886 & $\langle--v a l i d$ peaks only--〉 & 203.02 & & & \\
\hline
\end{tabular}

DETECTOR CALIBRATION

Energy $(\mathrm{MEV})=4.094+(0.0046) *$ Channel
Energy range $(\mathrm{MeV}): 4.094 \mathrm{TO} 6.449$
Efficiency $=$

TOTAL COUNT DATA:

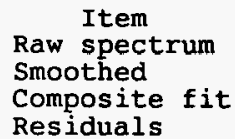

\& Recovery 100.000

99.999

88.600

11.400

Analyzed by: 
1 Legend: Raw $=\ldots$ Modeled Peaks $=1,2, \ldots$, etc Display Max.: 27964.3

WHC-SD-WM-DP-180, REV 0

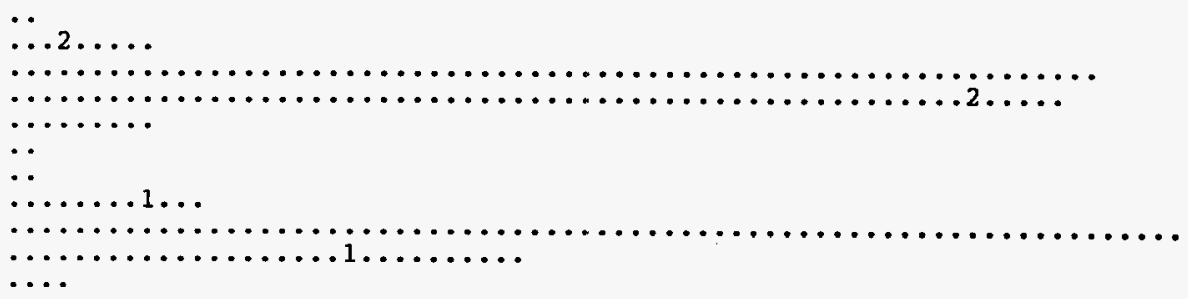


Raw Data Dump for AEA Spectrum: 25a2557.CNF

11

21

31

41

51

61

71

81

91
101

111

121

131

141

151

161

171

181

191

201

211

221

231

241

251

261

271

281

291

301

311

321

331

341

351

361

371

381

391

401

411

421

431

441

451

461

471

481

491

511

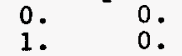

1. $\quad 0$.

1. 2 .

1.1 .

2 . 1 .

0 . 1 .

1.22 .

1.3.

0.2 .

1 . 1 .

1. 0 .

2. 2 .

1. 2.

2.2

10.7

10 .

9.99

15. 27.

35.

142.186.

1166.1706

656.472

208. 189 .

$\begin{array}{rr}95 . & 115 . \\ 528 . & 787 .\end{array}$

6504 . 7377 .

610.418 .

$\begin{array}{rr}0 . & 418 . \\ 0 . & 0 .\end{array}$

0.0.

$0 . \quad 0$.

0.1 .

$0 . \quad 1$.

0.0.

$0 . \quad 0$.

$0 . \quad 0$.

0.0 .

0.0.

0. 0.

0 . 0 .

$0 . \quad 0$.

0.0 .

0 . 0 .

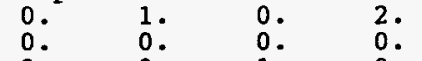

0.1 .0 .1$.

0.1 .

1. 1.

1. 3 .

1 .

1 .

0 .

0.00

2. 1.

2. 3 .

0 .

3.

\section{5.}

\section{5}

2

6.

13.

15.

70 .

234.

2773

392.

83. 912.900.

5832 .

346 .

0 .

0 .

1 .

0.

0 .

0.

0 .

0 .

0 .

0 .

0 .

0 .

0 .

0 .

1.

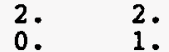

1.1 .

0.1 .

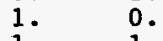

1.1 .

1. 3 .

1.

3.

3.

2.

6.

4.

7.

13.

25.

101.

5102 .

342 .

54.

101 .

900. 799.

3456.1973.

282 . 148 .

$\begin{array}{rr}0 . & 148 . \\ 0 . & 0 .\end{array}$

0 .

0 .

0 .

0 .

0 .

0 .

0 .

0 .

0 .

0 .

0 .

0 .

0 .

0 .

0 .

0 .

2.

4.

5.

4.

3.

10 .

19.

107.
579.

7813 .

373.

79.

0 .

0 .

0 .

2.

0.

0 .

0 .

0 .

0 .

0 .

0 .

0 .

0 .

0 .

0 .

1.
0.

0 .

0.

0.

1.

0 .

0 .

2.

1.

0 .

1.

2

2.

3.

1.

3. 


\section{LABCORE Completed Worklist Report for Worklist\# 5091}

Analyst: akl

Instrument: PU01

Book\# 104843

Method: $\lfloor A-943-127 \quad \operatorname{Rev} / \operatorname{Mod} B-1$

WHC-SD-WM-DP-180, REV. 0

Worklist Comment: Determine sample size using Ludlum. --LLF

\begin{tabular}{|c|c|c|c|c|c|c|c|c|c|}
\hline Seq Type & \multicolumn{3}{|c|}{ Sample\# R A } & & Test & Matrix & Actual & Found & DL or Yield \\
\hline 1 sro & & 0 & & aPt23901 & PU23901 & LIOUID & $.28 \mathrm{E}-01$ & $1.29 E-1$ & $100.780 \times$ Recovery \\
\hline 1 STD & & 0 & & aPU23901 & PU23901E & LIQUID & 1.00 & $2.17 E+00$ & $2.170 \% \mathrm{ct}$. Error \\
\hline 1 STD & & 0 & & apu23901 & PU23901T & LIOUID & 00 & $7.81 E+01$ & $78.100 \times$ Recovery \\
\hline 2 BLHK-PREP & & 0 & & aPU23901 & PU23901 & LIOUID & 1 & $<6.87 E-4$ & $\mathrm{UCi} / \mathrm{mL}$ \\
\hline 2 BLMK-PREP & & 0 & & QPU23901 & PU23901T & LIQUID & 100 & $4.17 E+01$ & $41.700 \%$ Recovery \\
\hline 2 BLNK-PREP & & 0 & & apu23901 & PU23901E & LIQUID & 1.00 & $1.00 \mathrm{E}+02$ & $100.000 \%$ Ct - Error \\
\hline 3 SAMPLE & $\$ 95 R 000115$ & 0 & B & aPU23901 & PU23901 & LIQUID & $N / A<$ & $6.23 \mathrm{E}-046$ & $6.230 \mathrm{e}-004 \mathrm{UCi} / \mathrm{mL}$ \\
\hline 3 SAMPLE & 15 & 0 & B & & & LIOUID & N/A & $4.58 E+011$ & 1.000 e-007\% Recovery \\
\hline 3 SAMPLE & SP5R000115 & 0 & B & apu23901 & PU23901E & LIQUID & N/A & $1.00 E+D 2$ & $0.000 \times c t$. Error \\
\hline $4 \mathrm{SPK}$ & S $95 R 00$ & 0 & B & 01 & PU2 & LIQUID & $=01$ & $1.32 E-01$ & $103.130 \%$ Recovery \\
\hline 5 SPK-DUP & S95R000115 & 0 & B & apu23901 & PU23901 & LJOUID & $1.32 E-01$ & $1.27 E-01$ & $3.860 \mathrm{RPD}$ \\
\hline 6 SAMPLE & s95R000116 & 0 & B & APU23901 & PU23901 & LIOUID & N/A $<$ & $7.54 \mathrm{E}-047$ & $7.540 \mathrm{e}-004 \mathrm{uCi} / \mathrm{mL}$ \\
\hline 6 SAMPLE. & $\$ 95 R 000116$ & 0 & B & aPU23901 & Pu23901T & LIQUID & H/A & $3.92 E+01$ & 1.000 e-007 \% Recovery \\
\hline 6 SAMPLE & S95R000116 & 0 & B & aPU23901 & PU23901E & LIQUID & N/A & $1.00 E+02$ & $0.000 \% \mathrm{Ct}$. Error \\
\hline 7 SPK & $.995 R 000116$ & 0 & & apu23901 & PU23901 & LIQUID & & $1.29 \mathrm{E}-01$ & $100.780 \%$ Recovery \\
\hline 8 SPK-DUP & S95R000116 & 0 & B & apu23901 & PU23901 & LIaUio & $1.29 E-01$ & $1.32 E-01$ & $2.300 \mathrm{RPD}$ \\
\hline
\end{tabular}

Final page for worklist\# 5091

Analyst Signature Date
$\frac{2567 \text { att }}{\text { Reviewer Signature } 30 \operatorname{Ian} 96}$ Date

Units shown for $Q C(B I K / B K G)$ may nor reflect the actual units. 


\section{LABCORE Data Entry Template for Worklist\# 5091}

Analyst:

Method: LA-943-127 Rev/Mod B-I

Book $\# 104643$

Worklist Comment: Determine sample size using Ludlum. --LLF

\begin{tabular}{|c|c|c|c|c|c|c|c|c|c|}
\hline $\bar{s}$ & Type & Sample\# & $\mathbf{R}$ & A & Test & Matrix & Group\# & Project & \\
\hline 1 & STD & & & & ePU2 3901 & LIQUID & & & \\
\hline 2 & BLNK-PREP & & & & @PU23901 & LIQUID & & & \\
\hline 3 & SAMPI,E & S95R000115 & 0 & B & @PU23901 & LIQUID & 95000224 & ORG / AQ & SAMPL \\
\hline & & Analytes Requ & est & ted : & : PU23901 & , PU23901E, & PU23901T & & \\
\hline 4 & SPK & S95R000115 & 0 & B & @PU23901 & LIQUID & & & \\
\hline 5 & SPK-LUP & S95R000115 & 0 & B & @PU23901 & LIQUID & & & \\
\hline 6 & SAMPI.E & $\$ 95 R 000116$ & 0 & B & @PU23901 & LIQUID & 95000224 & ORG / AQ & SAMPL \\
\hline & & Analytes Requ & est & Eed: & : PU23901 & , PU23901E, & PU23901T & & \\
\hline 7 & SPK & S95R000116 & 0 & B & @PU2 3901 & LIQUID & & & \\
\hline 8 & SPK-DUP & S95R000116 & 0 & B & @PU23901 & LIQU ID & & & \\
\hline
\end{tabular}

\section{Final page for worklist \# 5091}
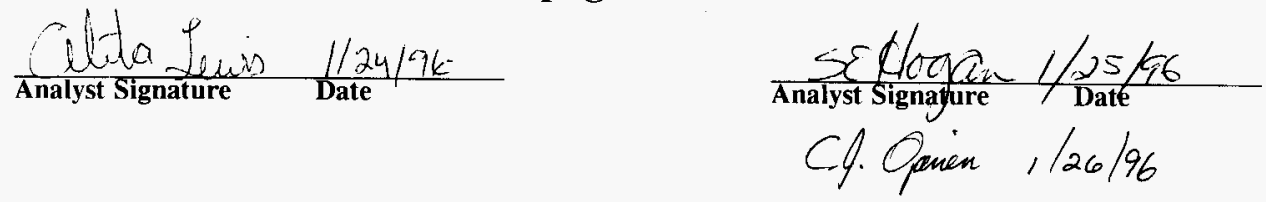

Data Entry Comments:

$\bar{S}=$ Worklist Slot Number, $R=$ Replicate Number, $A=$ Aliquot Code. 


\section{WHC-SD-WM-DP-180, REV. 0}

WORKBOOK PAGE: STD1

Pu 238 and 239/240 : LA-943-127 (B-1)

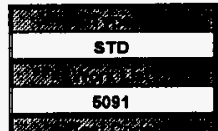

DATE COUNTEO

SAMPLE VOLUME in $\mathrm{mL}$ SS

SAMPLE DILUTION FACTOR DF

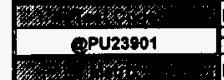

TRACER VOLUME in $\mathrm{mL}$ SPKV

DIGEST DILUTION FACTOR DDF

LUQUID
TRACER BOOK NO DETECTOR NUMBER EFFICIENCY FACTOR

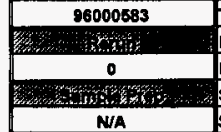

TRACER PREPARATION DATE TRACER PREPARATION VALUE (dpm/mL) PU-236 DECAY CORR'D VALUE (dpm/mL) PU-238 TRACER VALUE (dpm/ml STANDARO BOOK NO STANDARO VALUE in $\mu \mathrm{CV} / \mathrm{mL}$

LIQUID

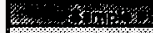 \\ w5.001}

\%,

Decay Time = Date Counted - Tracer Preparation Date

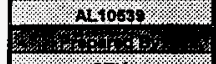
SEH

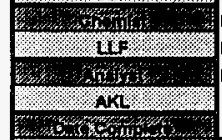

Decay Corr'd Value = Pu-236 Preparation Value "to to the power of $\{(-\operatorname{tn} 2$ * Decay Time/1040.95\}

Pu 236 Tracer Recovery = (Total AT Counts / TC -Bkg)" 1/EFF "C236*100/Pu-236 Decay Cor'd Value * SPKV

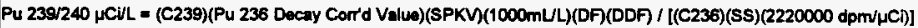

Pu $238 \mathrm{dpm}=$ [(Total AT Counts / TC) - Bkp * 1/EFF * C238] - (Pu-238 Tracer Value *SPKV *Pu 236 Tracer Recovery / 100)

Pu $238 \mu C V L=[(P u 238 \mathrm{dpm})(D F)(D D F)(1000 \mathrm{~mL} / \mathrm{L})] /[(P u-236$ Tracer Recovery $/ 100)(2220000 \mathrm{dpm} / \mu \mathrm{C})(\mathrm{D}$ g/L)(SS)]

Relative Counting Error = Square Root of $[(1 /(P u 236 \mathrm{cpm} *$ min $))+(1 /(P u 238$ or $239 / 240 \mathrm{cpm} *$ min $))] * 1.96 * 100$

\begin{tabular}{|c|c|c|c|}
\hline $1 \% 03 / 25 / 86$ & Pu 239/240 nCi/mL & $1.29 E-01$ & DETECTION \\
\hline 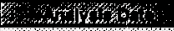 & Relative Counting Error & $\pm \quad 2.2 \%$ & LEVELS \\
\hline $0801 / 2000$ & & & in $\mu \mathrm{Cl} / \mathrm{mL}$ \\
\hline Q How of & & & Pu 239/240 \\
\hline 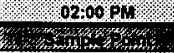 & & & $8.88 E-03$ \\
\hline oRC/AC SAMPLE & Pu 236 Tracer Recovery & $78.1 \%$ & \\
\hline
\end{tabular}

\begin{tabular}{|c|c|c|c|}
\hline Analyst: & AKL & Date: & 25-Jan-96 \\
\hline Signature of Chemist: 267 tts & & Date: & $\operatorname{lan} 96$ \\
\hline
\end{tabular}


WORKBOOK PAGE: BLANK2

Pu 238 and 239/240 : LA-943-127 (B-1)

\begin{tabular}{|c|c|c|c|c|}
\hline & & & & \\
\hline 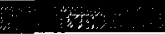 & DATE COUNTED & $3 x_{2} \times 5$ & PU 236 AEA FRAC & 0.978 \\
\hline BLNK-PREP & SAMPLE VOLUME in mL & 4000 & PU 238 AEA FRAC & 0,000 \\
\hline (x, $1, x, t$ & SAMPLE DILUTION FACTOR & $\%$ \%ol & PU 239 AEA FRAC & 0000 \\
\hline 5091 & TRACER VOLUME in $\mathrm{mL}$ & 0.100 & TOTAL AT COUNTS & 1504 \\
\hline nonsen & DIGEST DILUTION FACTOR & - . 6000000 & AT COUNT TIME (MIN) & 30 \\
\hline QPU23901 & TRACER BOOK NO & 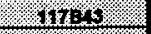 & BACKGROUND in cpm (Bkg) & 6000 \\
\hline Hin & DETECTOR NUMBER & 然 & PU $236 \mathrm{cpm}$ & 11,520 \\
\hline LIQUID & EFFICIENCY FACTOR & 0.5000 & PU $238 \mathrm{cpm}$ & 0.000 \\
\hline 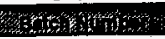 & TRACER PREPARATION DATE & $09 / 12 / 95$ & PU 239 cpm & D.000 \\
\hline 96000583 & TRACER PREPARATION VALUE (dpm/mL) & 2265.00 & AEA COUNT TIME & 480 \\
\hline 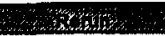 & PU.236 DECAY CORR'D VALUE (dpm/mL) & 2071.65 & Pu 239/240 بCuL = & $6.870 E-01$ \\
\hline & PU.238 TRACER VALUE & 0.00 & & \\
\hline
\end{tabular}

3.

NIA

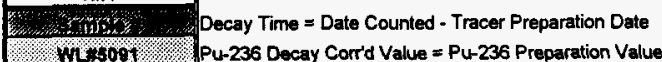

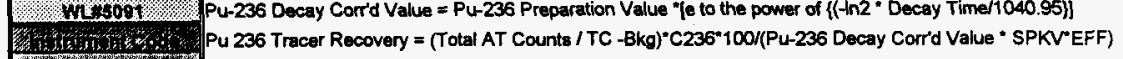

I.

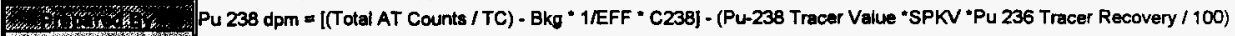

(7)

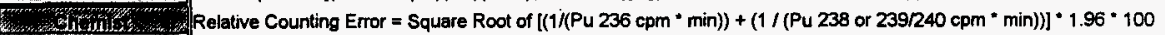

The

Y.

Trat

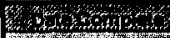

70.

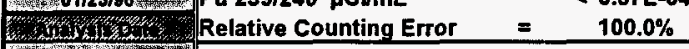

$0+124 / 96$

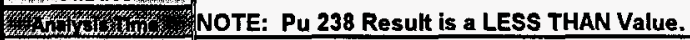

2. 02:00 P N W

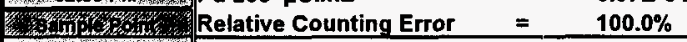

ORGIAO SAMPIL PU 236 Tracer Recovery = $\quad 41.7 \%$

\begin{tabular}{|c|}
\hline DETECTION \\
LEVELS \\
in $\mu$ Ci/mL \\
\hline Pu 239/240 \\
$6.87 E-04$ \\
\hline Pu 238 \\
$6.87 E-04$ \\
\hline
\end{tabular}

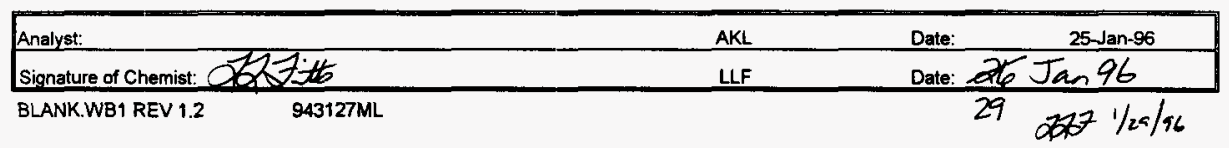

293 


\section{WHC-SD-WM-DP-180, PEV. 0}

WORKBOOK PAGE: SNM3

Pu 238 and 239/240 : LA-943-127 (B-1)

LIQUID / SOLID

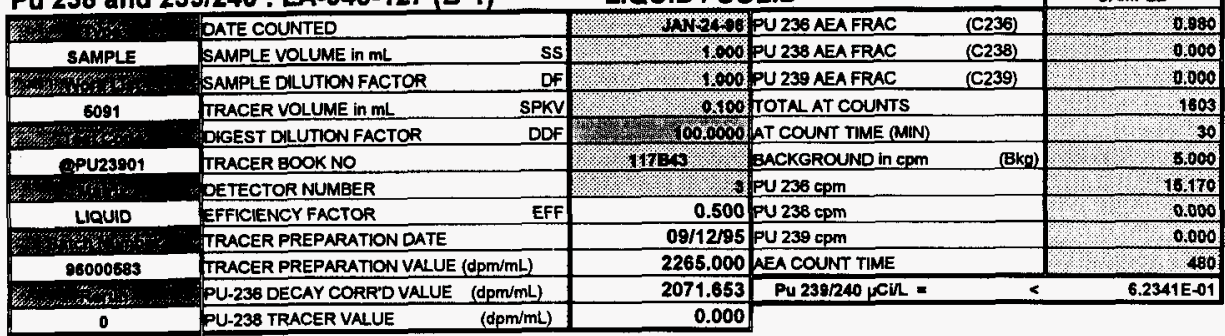

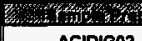 \\ ACIDIO02}

SO5R000115

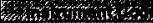

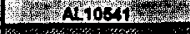

Pu-236 Decay Corrd Value - Pu-236 Preparation Value *io to the power of $\{(-\ln 2$ * Decay Time/1040.95\}]

Pu 236 Tracer Recovery = (Total AT Counts / TC -Bkg) *C236*100/(PU-236 Decay Corrd Value * SPKV * EFF)

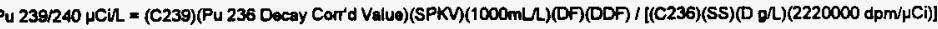

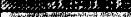

Pu $238 \mathrm{dpm}$ - [(Total AT Counts / TC) - Bkg * 1/EFF * C238] - (Pu-238 Tracer Valus "SPKV *Pu 236 Tracer Recovery / 100)

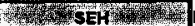

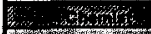

$238 \mu \mathrm{Ch}=[(\mathrm{Pu} 238 \mathrm{dpm})(\mathrm{DF})(\mathrm{DDF})(1000 \mathrm{~mL} /)] /[(\mathrm{Pu}-236$ Trecer Recovery $/ 100)(2220000 \mathrm{dpm} / \mathrm{Ci})(\mathrm{D} \mathrm{g} / \mathrm{L})(\mathrm{SS})]$

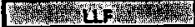

initisicis

S3.

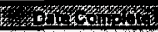

Relativo Counting Error = Square Root of $[(1 /(\mathrm{Pu} 236 \mathrm{cpm}$ * min $))+(1 /(\mathrm{Pu} 238$ or $239 / 240 \mathrm{cpm}$ * min $))] * 1.96$ * 100

7.

(a)

Relative Counting Error

$\begin{array}{r}<6.23 E-04 \\ =\quad 100.0 \% \\ \hline\end{array}$

NOTE: Pu 238 Result is a LESS THAN Value.

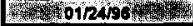

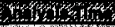

NOTE: Pu 238

$<6.23 \mathrm{E}-04$ $100.0 \%$

A.

Relative Counting Error

ORGIAq SAMPL

$=$\begin{tabular}{c}
$<.23 E-04$ \\
$=\quad 100.0 \%$ \\
\hline
\end{tabular}

\begin{tabular}{|c|}
\hline DETECTION \\
LEVELS \\
In $\mu$ CU/mL \\
\hline Pu $239 / 240$ \\
$6.23 E-04$ \\
\hline PU 238 \\
$6.23 E-04$ \\
\hline
\end{tabular}

\begin{tabular}{|c|c|c|c|}
\hline Analyst: & AKL & Date: & 25-Jan-96 \\
\hline Signature of chemist: 367 Ft, & LLF & Date: & $\sqrt{4} 96$ \\
\hline
\end{tabular}


WORKBOOK PAGE: SPIKE4

\begin{tabular}{|c|c|c|c|}
\hline \multicolumn{3}{|c|}{ VORKBOOK PAGE: SPIKE4 } & \multirow{2}{*}{ SPIKE } \\
\hline Pu 239/240 : L & A-943-127 (B-1) & SPIKED SAMPLE & \\
\hline IIn & \multicolumn{2}{|l|}{ DATE COUNTED } & $01 / 24196$ \\
\hline SPK & \multicolumn{2}{|l|}{ SAMPLE VOLUME In mL } & 1.000 \\
\hline 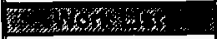 & \multicolumn{2}{|l|}{ SAMPLE DILUTION FACTOR } & 11000 \\
\hline 5091 & \multicolumn{2}{|l|}{ TRACER VOLUME In mL } & 0,100 \\
\hline Whot & \multicolumn{2}{|l|}{ DIGEST DILUTION FACTOR } & 1200.0000 \\
\hline QPU23901 & \multicolumn{2}{|l|}{ TRACER BOOK NUMBER } & $.17 \mathrm{BS}_{43}$ \\
\hline WOWHa & \multicolumn{2}{|c|}{ TRACER PREPARATION DATE } & $09 / 12 / 95$ \\
\hline LIQUID & \multicolumn{2}{|c|}{ PU-236 PREPARATION VALUE $\ln \mu \mathrm{C} V \mathrm{~mL}$} & 2265.000 \\
\hline 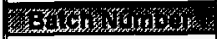 & \multicolumn{2}{|c|}{ PU-236 DECAY CORR'D VALUE In $\mu \mathrm{CU} / \mathrm{mL}$} & 2071.653 \\
\hline 96000583 & \multicolumn{2}{|l|}{ SPIKE VOLUME in $\mathrm{mL}$} & 0.100 \\
\hline 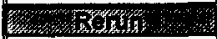 & \multicolumn{2}{|l|}{ SPIKE DILUTION FACTOR } & 101,000 \\
\hline 0 & \multicolumn{2}{|l|}{ SPIKE BOOK NUMBER } & 104843 \\
\hline 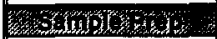 & \multicolumn{2}{|l|}{ SPIKE VALUE in $\mu \mathrm{Cl} / \mathrm{mL}$} & 0.128 \\
\hline ACIDIG02 & \multicolumn{2}{|l|}{ PU 236 AEA FRAC. } & 0.397 \\
\hline 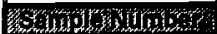 & \multicolumn{2}{|l|}{ Pu 239 AEA FRAC. } & 0.555 \\
\hline S95R000115 & \multicolumn{2}{|c|}{ PU 239/240 FROM SAMPLE FORM in $\mu \mathrm{CU} / \mathrm{mL}$} & $6.23 E-4,1 \%$ \\
\hline 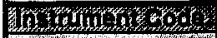 & \multicolumn{2}{|c|}{ PU 239/240 FROM SPIKED SAMPLE in $\mu \mathrm{CV} / \mathrm{mL}$} & $1.3046 \mathrm{E}-02$ \\
\hline AL 10539 \% & \multicolumn{2}{|l|}{ Count Time (Min) } & 30.000 \\
\hline \multicolumn{4}{|l|}{ 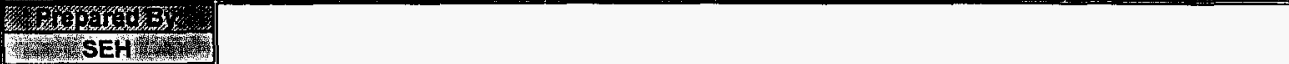 } \\
\hline - & \multicolumn{3}{|c|}{$\mathrm{Pu} 239 / 240 \mu \mathrm{Ci} / \mathrm{mL}=\mathrm{C} 239 * \mathrm{SPKA} * \mathrm{SPKV} * \mathrm{DF} * \mathrm{DDF}$} \\
\hline (4) L L F & \multicolumn{3}{|c|}{$\mathrm{C} 236 \cdot \mathrm{SS} \cdot(2220000 \mathrm{dpm} / \mu \mathrm{Ci})$} \\
\hline (2) & \multicolumn{3}{|l|}{ QC Actual $(\mu \mathrm{Ci} / \mathrm{mL})=$} \\
\hline Hy & \multicolumn{3}{|c|}{ [(PU2 - PUi) * (SMDF/SMSS) / (DF*DDF/SS)] } \\
\hline 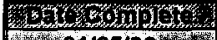 & \multicolumn{3}{|l|}{ Percent Spike Recovery = } \\
\hline $\begin{array}{l}01 / 25 / 96 \\
\text { U. }\end{array}$ & \multicolumn{3}{|c|}{ Decay Time = Date Counted - Tracer Preparation Date } \\
\hline A6 & \multirow{2}{*}{\multicolumn{3}{|c|}{ Pu-236 Decay Corr'd Value (SPKA) $=$ Pu 236 Preparation Value " [e to the power of $\left\{\left(-\ln 2{ }^{*}\right.\right.$ Decay Time) $\left.\left./ 1040.95\right\}\right]$}} \\
\hline 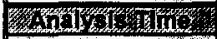 & & & \\
\hline 162:00 PMM & \multicolumn{2}{|l|}{ QC ACTUAL ( $\mu \mathrm{Ci} / \mathrm{mL})$} & 1.28E-01 \\
\hline 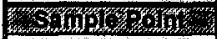 & \multicolumn{2}{|l|}{ QC FOUND ( $\mu \mathrm{Ci} / \mathrm{mL})$} & 1.32E-01 \\
\hline ORGIAQ SAMPLE & \multicolumn{2}{|c|}{ PERCENT SPIKE RECOVERY } & $102.9 \%$ \\
\hline
\end{tabular}

NOTE: The sample dpm was LESS THAN the detection limit (Ld), therefore zero (0) was used for Sample $\mu \mathrm{Ci} / \mathrm{mL}$ in the QC Found calculation.

\begin{tabular}{|c|c|c|}
\hline Analyst: & AKL & Date: $25-J a n-96$ \\
\hline Signature of Chemist: $0327=$ & LLF & Date: $29 \operatorname{Tan} 96$ \\
\hline
\end{tabular}


WORKBOOK PAGE: SP_DUP6

WHC-SD-WM-DP-180, FEV. 0

\begin{tabular}{|c|c|c|c|}
\hline Pu 239/240: I & LA-943-127 (B-1) & SPIKED SAMPLE & SPIKE \\
\hline Was $x_{t}$ & \multicolumn{2}{|l|}{ DATE COUNTED } & $801 / 24 / 96$ \\
\hline SPK-DUP & \multicolumn{2}{|l|}{ SAMPLE VOLUME In $\mathrm{mL}$} & 1,000 \\
\hline 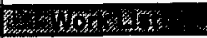 & \multicolumn{2}{|l|}{ SAMPLE DILUTION FACTOR } & $1,1,000$ \\
\hline 5091 & \multicolumn{2}{|l|}{ TRACER VOLUME In $\mathrm{mL}$} & 0.100 \\
\hline 1,1000 & \multicolumn{2}{|l|}{ DIGEST DILUTION FACTOR } & W \\
\hline QPU23901 & \multicolumn{2}{|l|}{ TRACER BOOK NUMBER } & $6.117 \mathrm{~B} 43$ \\
\hline ndins & \multicolumn{2}{|l|}{ TRACER PREPARATION DATE } & $09 / 12 / 95$ \\
\hline LIQUID & \multicolumn{2}{|c|}{ PU-236 PREPARATION VALUE in $\mu \mathrm{CU} / \mathrm{mL}$} & 2265.000 \\
\hline B $(10,1$ und & \multicolumn{2}{|c|}{ Pu-236 DECAY CORR'D VALUE in $\mu \mathrm{C} / \mathrm{mL}$} & 2071.653 \\
\hline 96000583 & \multicolumn{2}{|c|}{ SPIKE VOLUME in $\mathrm{mL}$} & 0,100 \\
\hline Thasume & \multicolumn{2}{|l|}{ SPIKE DILUTION FACTOR } & 101.000 \\
\hline 0 & \multicolumn{2}{|l|}{ SPIKE BOOK NUMBER } & 104843 \\
\hline 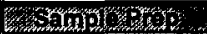 & \multicolumn{2}{|l|}{ SPIKE VALUE in $\mu \mathrm{Cl} / \mathrm{mL}$} & 0.128 \\
\hline ACIDIG02 & \multicolumn{2}{|l|}{ PU 236 AEA FRAC. } & 0.428 \\
\hline 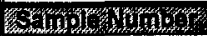 & \multicolumn{2}{|l|}{ PU 239 AEA FRAC. } & 0.575 \\
\hline S95R000115 & \multicolumn{2}{|c|}{ PU 239/240 FROM SAMPLE FORM in $\mu \mathrm{Cl} / \mathrm{mL}$} & 66.23E-4 \\
\hline 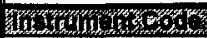 & \multicolumn{2}{|c|}{ Pu 239/240 FROM SPIKED SAMPLE in $\mu \mathrm{CI} / \mathrm{mL}$} & 1.2537E-02 \\
\hline AL 10540 & \multicolumn{2}{|l|}{ Count TIme (MIIn) } & 30.000 \\
\hline \multicolumn{4}{|c|}{ 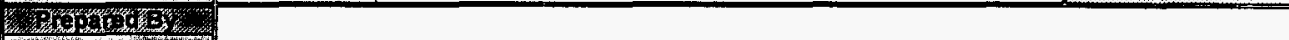 } \\
\hline 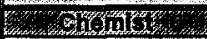 & \multicolumn{3}{|c|}{$\mathrm{Pu} 239 / 240 \mu \mathrm{Ci} / \mathrm{mL}=\mathrm{C} 239 \cdot \mathrm{SPKA} \cdot \mathrm{SPKV} \cdot \mathrm{DF} \cdot \mathrm{DDF}$} \\
\hline J & \multicolumn{3}{|c|}{$\mathrm{C} 236 * \mathrm{SS} *(2220000 \mathrm{dpm} / \mu \mathrm{Ci})$} \\
\hline 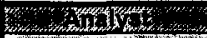 & QC Actual $(\mu \mathrm{Ci} / \mathrm{mL})=$ & \multicolumn{2}{|l|}{ SMV } \\
\hline Her & \multirow{3}{*}{$\begin{array}{l}\text { OC Found }(\mu \mathrm{C} / \mathrm{mL})= \\
\text { Percent Spike Recovery }=\end{array}$} & \multicolumn{2}{|l|}{$[(\mathrm{Pu} 2-\mathrm{Pu} 1) *(\mathrm{SMDF} / \mathrm{SMSS}) /(\mathrm{DF} * \mathrm{DDF} / \mathrm{SS})]$} \\
\hline 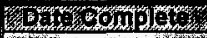 & & (QC Found / QC Actual)* 100 & \\
\hline $01 / 25 / 96$ & & & \\
\hline 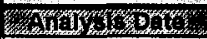 & Decay Time $=$ Date Counted - & Tracer Preparation Date & \\
\hline $01 / 24 / 96$, & Pu-236 Decay Corr'd Value (s & $P K A)=$ Pu 236 Preparation Value ${ }^{*}\left[e\right.$ to the power of $\left\{\left(-\ln 2{ }^{*}\right.\right.$ Dec & cay Time) / 1040.95 \}] \\
\hline 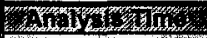 & & & \\
\hline 02:00 PMV & QC ACTUAL $(\mu \mathrm{Ci} / \mathrm{mL}$ & $=$ & 1.28E-01 \\
\hline 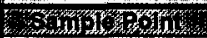 & QC FOUND $(\mu \mathrm{Ci} / \mathrm{mL})$ & $=$ & 1.27E-01 \\
\hline ORGIAQSAMPL & PERCENT SPIKE RE & COVERY & $98.9 \%$ \\
\hline
\end{tabular}

NOTE: The sample dpm was LESS THAN the detection limit (Ld), therefore zero (0) was used for Sample $\mu \mathrm{Ci} / \mathrm{mL}$ in the QC Found calculation.

\begin{tabular}{|c|c|c|}
\hline Analyst: & AKL & Date: $25-J a n-96$ \\
\hline Signature of Chemist: 2767 t5 & LLF & Date: $29 \operatorname{Ian} 96$ \\
\hline
\end{tabular}

293 


\section{WHC-SD-WM-DP-180, FEV O}

WORKBOOK PAGE: SAM

Pu 238 and 239/240 : LA-943-127 (B-1)

LIQUID / SOLID

\begin{tabular}{|c|c|c|c|c|}
\hline 38 an & B. & $\mathbf{J D}$ & ] & SAMPLE \\
\hline $2, \ldots$ & DATE COUNTED & mox & PU 238 AEA FRAC & 0.946 \\
\hline SAMPLE & SAMPLE VOLUME in $\mathrm{mL}$ & 1000 & PU 238 AEA FRAC & 0,000 \\
\hline 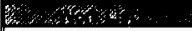 & SAMPLE DILUTION FACTOR & $8 \times 0$ & PU 239 AEA FRAC & 0,000 \\
\hline 6021 & TRACER VOLUME in ML & 0100 & TOTAL AT COUNTS & 1030 \\
\hline rats & DHGEST DILUTION FACTOR & 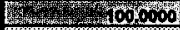 & ATT COUNT TIME (MIN) & 30 \\
\hline PPU23901 & TRACER BOOK NO & 1170 & BACKGROUND in CPm & $1 \%$ \\
\hline 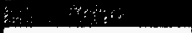 & PETECTOR NUMBER & & Pu $236 \mathrm{cpm}$ & 101630 \\
\hline LIQUID & EFFCIENCY FACTOR & 0.500 & Pu $238 \mathrm{cpm}$ & 0,000 \\
\hline 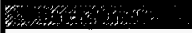 & TRACER PREPARATION DATE & $09 / 12 / 95$ & PU $239 \mathrm{cpm}$ & 0.000 \\
\hline 96000583 & TRACER PREPARATION VALUE (dpm/mL) & 2265.000 & AEA COUNT TIME & 480 \\
\hline 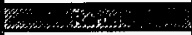 & PU-236 DECAY CORR'D VALUE (dpm/mL) & 2074.653 & Pu $239 / 240$ pir $=$ & 7.5416E-01 \\
\hline 0 & PU-238 TRACER VALUE & 0.000 & & \\
\hline 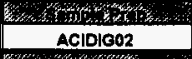 & & & & \\
\hline 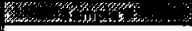 & ecay Time = Dato Counted - Trecer Preparation & Date & & \\
\hline S96R000116 & U-236 Decay Corrd Valus = Pu-236 Preparation & Value "Io to the power o & of $\{(\ln 2 *$ Decay Time 1040.95$\})$ & \\
\hline 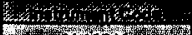 & Pu 236 Tracer Rocovery = (Total AT Counts / TC & $-B k g) * C 236 \cdot 100 /(P u-2$ & 36 Decay Corrd Value "SPKV" EFF) & \\
\hline 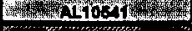 & 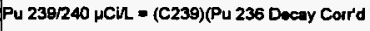 & Value)(SPKV)(1000mL & L)(DF)(DDF) / I(C236)(SS)(D g/) $(22200$ & $000 \mathrm{dpm} / \mu \mathrm{Ci}]]$ \\
\hline B. & Pu $238 \mathrm{dpm}=[$ [Total AT Counts / TC $) \cdot$ Bkg * 1/E & $\mathrm{FF} \cdot \mathrm{C} 238]-(\mathrm{Pu}-238 \mathrm{Tr}$ & racer Value "SPKV "Pu 236 Tracer Reco & very/100) \\
\hline 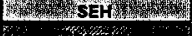 & Pu $238 \mathrm{\mu Cl}=$ = [Pu $238 \mathrm{dpm})(\mathrm{DF})(\mathrm{DDF})(100 \mathrm{~cm}$ & LI)] / /(Pu-236 Tracer R & (ecovery $/ 100)(2220000 \mathrm{dpm} / \mu \mathrm{Cl})(\mathrm{D} g / \mathrm{l})$ & (ss)] \\
\hline W. & Relative Counting Enror = Square Root of [(1//Pu 2 & $236 \mathrm{cpm} * \mathrm{~min}))+(1 /(P$ & u 238 or $239 / 240 \mathrm{cpm}^{*}$ min))] $]^{*} 1.86^{*} 1$ & \\
\hline 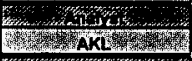 & & & & \\
\hline 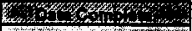 & $\checkmark$ RESULTS V & & & \\
\hline 3. $01 / 26198$ & Pu 239/240 $\mu \mathrm{CV} / \mathrm{mL}$ & $7.54 \mathrm{E}-04$ & DETECTION & \\
\hline 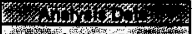 & Relative Counting Error & $100.0 \%$ & LEVELS & \\
\hline 6 $01 / 24 \%$ s & & & in $\mu \mathrm{C} V / \mathrm{mL}$ & \\
\hline 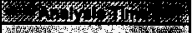 & NOTE: Pu 238 Result Is a LESS THAN & Value. & $P u 238 / 240$ & \\
\hline $5402.00 \mathrm{PH}$ & Pu 238 NCImL & $7.54 E-04$ & $7.54 E-04$ & \\
\hline 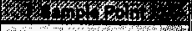 & Relative Counting Error & $100.0 \%$ & Pu 238 & \\
\hline OOAGIAQ SAMPLE & Pu 236 Tracer Recovery & $39.2 \%$ & 7.54E-04 & \\
\hline
\end{tabular}

\begin{tabular}{|c|c|c|}
\hline Analyst: & AKL & 25-Jan-96 \\
\hline Signature of Cheinist: 0827 ats & LLF & Date: $29 \operatorname{Tan} 96$ \\
\hline
\end{tabular}


WORKBOOK PAGE: SPIKE7

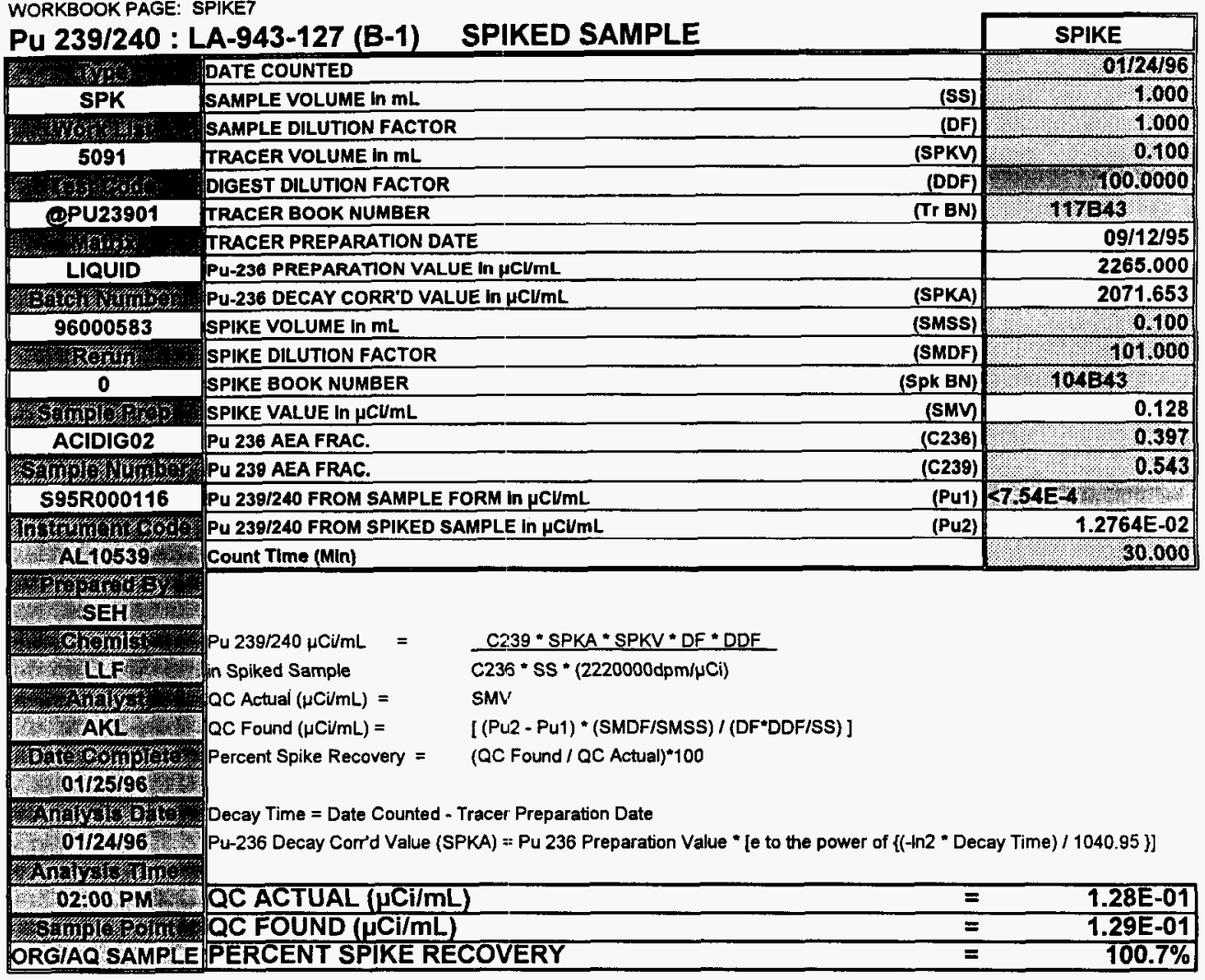

NOTE: The sample dpm was LESS THAN the detection limit (Ld), therefore zero (0) was used for Sample $\mu \mathrm{Ci} / \mathrm{mL}$ in the QC Found calculation.

\begin{tabular}{|c|c|c|}
\hline Analyst: & AKL & Date: 25-Jan-96 \\
\hline Signature of chemist: 367 its & LLLF & Date: $299 \operatorname{Ta} 96$ \\
\hline
\end{tabular}


WHC-SU-WIV-DP-180, FEV. 0

WORKBOOK PAGE: SP_DUP8

\begin{tabular}{|c|c|c|c|}
\hline Pu 239/240 : & A-943-127 (B-1) & SPIKED SAMPLE & SPIKE \\
\hline nition & DATE COUNTED & & 0712496 \\
\hline SPK-DUP & SAMPLE VOLUME in $\mathrm{mL}$ & (SS) & 1.000 \\
\hline $24 x+20$ & SAMPLE DILUTION FACTOR & (DF) & 1,000 \\
\hline 5091 & TRACER VOLUME in $\mathrm{mL}$ & (SPKY) & 0100 \\
\hline ondes & DIGEST DILUTION FACTOR & (DDF) & 1000000 \\
\hline QPU23901 & TRACER BOOK NUMBER & (Tr BN) & $1 \mathrm{TBR}_{3}$ \\
\hline $3 x$ & TRACER PREPARATION DA & & $09 / 12 / 95$ \\
\hline LIQUID & PU-236 PREPARATION VALU & $\mathrm{JE} \ln \mu \mathrm{CU} / \mathrm{mL}$ & 2265.000 \\
\hline 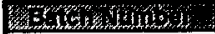 & PU-236 DECAY CORR'D VAL & UE in $\mu \mathrm{C} / \mathrm{mL}$ & 2071.653 \\
\hline 96000583 & SPIKE VOLUME in $\mathrm{mL}$ & (SMSS) & 0100 \\
\hline 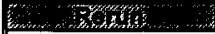 & SPIKE DILUTION FACTOR & (SMDF) & 18101000 \\
\hline 0 & SPIKE BOOK NUMBER & (Spk BN) & 104843 \\
\hline 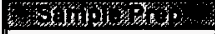 & SPIKE VALUE in $\mu \mathrm{CV} / \mathrm{mL}$ & (SMV) & 0.128 \\
\hline ACIDIG02 & PU 236 AEA FRAC. & (C236) & 0.396 \\
\hline 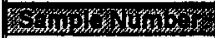 & Pu 239 AEA FRAC. & (C239) & 0.553 \\
\hline S95R000116 & PU 239/240 FROM SAMPLE F & ORM In $\mu \mathrm{C} / \mathrm{mL}$ & T754E-4 \\
\hline 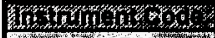 & PU 239/240 FROM SPIKED S & AMPLE In $\mu C V / \mathrm{mL}$ & $1.3031 E-02$ \\
\hline A 10540 \% & Count Time (Min) & & 30.000 \\
\hline 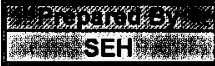 & & & \\
\hline 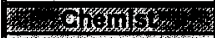 & $\mathrm{Pu} 239 / 240 \mu \mathrm{CV} / \mathrm{mL}=$ & $\mathrm{C} 239 * \mathrm{SPKA} * \mathrm{SPKV} * \mathrm{OF} * \mathrm{DDF}$ & \\
\hline H. U. & in Spiked Sample & $\mathrm{C} 236 * \mathrm{SS} *(2220000 \mathrm{dpm} / \mu \mathrm{Ci})$ & \\
\hline 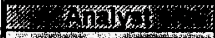 & OC Actual $(\mu \mathrm{Ci} / \mathrm{mL})=$ & SMV & \\
\hline 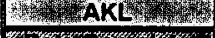 & $Q C$ Found $(\mu \mathrm{C} / \mathrm{mL})=$ & {$\left[(\text { Puz - Pu1 })^{*}(\right.$ SMDF/SMSS $) /($ DF*DDF/SS $\left.)\right]$} & \\
\hline 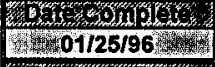 & Percent Spike Recovery = & (QC Found / QC Actual) $* 100$ & \\
\hline 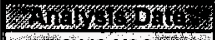 & Decay Time $=$ Date Counted - & Tracer Preparation Date & \\
\hline 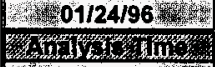 & Pu-236 Decay Corr'd Value (SF & $P K A)=P u 236$ Preparation Value ${ }^{*}[e$ to the power of $\{(-\ln 2 *$ Dec & Say Time)/ 1040.95 \}] \\
\hline 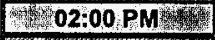 & QC ACTUAL ( $\mu \mathrm{Ci} / \mathrm{mL}$ & $=$ & 1.28E-01 \\
\hline 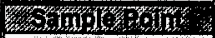 & QC FOUND ( $\mathrm{\mu Ci} / \mathrm{mL})$ & $=$ & 1.32E-01 \\
\hline ORG/AQ SAMPLE & PERCENT SPIKE RE & COVERY & $102.8 \%$ \\
\hline
\end{tabular}

NOTE: The sample dpm was LESS THAN the detection limit (Ld), therefore zero (0) was used for Sample $\mu \mathrm{Ci} / \mathrm{mL}$ in the QC Found calculation.

\begin{tabular}{|c|c|c|}
\hline Analyst: & $A K L$ & Date: $25-J a n-96$ \\
\hline Signature of Chemist: 987 its & LLF & Date: $29 \operatorname{Tan} 96$ \\
\hline
\end{tabular}

SPIKE.WB1 REV $1.2 \quad$ 943127ML. 
Westinghouse Hanford Co.

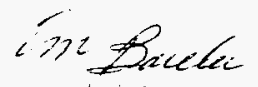

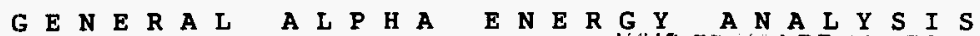
$1 / 341 \% 6$ Rev. 2.01 WHC-SD-WM-DP-180, FEV. 0

DATA REDUCTION REPORT

SAMPLE

WL5091-STD

File ID: 13 a1396.CNF

Counted on: $\quad 1 / 24 / 96$ e17: 7

Detector: AEA 13

Geometry number: 1

Count time:

28802. Sec

PEAK ANALYSIS

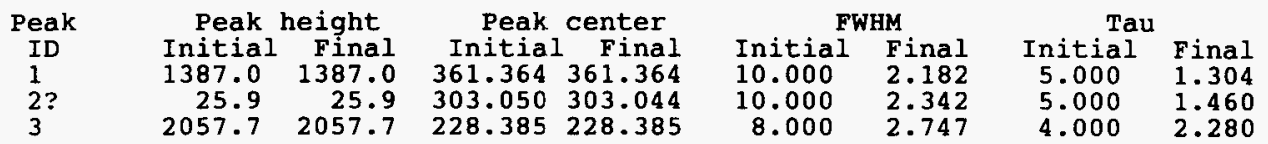

\section{PEAK RESULTS \\ Peak Error Limit: $30 \%$}

\begin{tabular}{|c|c|c|c|c|c|c|c|c|c|}
\hline $\begin{array}{l}\text { Peak } \\
\text { ID } \\
1\end{array}$ & $\begin{array}{l}\text { Isotope } \\
\text { Pu236 } \\
\text { Cm243 }\end{array}$ & $\begin{array}{r}\text { AEA } \\
\text { Frac } \\
0.408\end{array}$ & $\begin{array}{r}\text { Pe } \\
\text { Exp. } \\
5.755 \\
5.779\end{array}$ & $\begin{array}{r}\text { k Cen } \\
\text { Obs } \\
5.768 \\
5.768\end{array}$ & $\begin{array}{l}\text { troid } \\
\text { Diff. FWHM } \\
-.0130 .01 \\
0.011\end{array}$ & $\begin{array}{c}\text { Count } \\
\text { Rate } \mathrm{c} / \mathrm{m} \\
29.54\end{array}$ & $\begin{array}{r}\text { serr } \\
695 \\
1.6\end{array}$ & $\begin{array}{l}d / m \\
310.5 \\
416.8\end{array}$ & $\begin{array}{c}\text { Activity } \\
\text { uCi/ea } \\
0.140 \mathrm{E}-03 \\
0.188 \mathrm{E}-03\end{array}$ \\
\hline $\begin{array}{l}2 \\
3\end{array}$ & $\begin{array}{l}\text { Pu239 } \\
\text { Pu240 }\end{array}$ & $\begin{array}{r}? ? ? ? \\
0.557\end{array}$ & $\begin{array}{l}5.147 \\
5.144\end{array}$ & $\begin{array}{l}5.500 \\
5.157 \\
5.157\end{array}$ & $\begin{array}{l}-.0100 .01 \\
-.013\end{array}$ & $\begin{array}{r}0.55 \\
40.35\end{array}$ & $\begin{array}{l}12.1 \\
1.4\end{array}$ & $\begin{array}{l}415.5 \\
415.5\end{array}$ & $\begin{array}{l}0.187 \mathrm{E}-03 \\
0.187 \mathrm{E}-03\end{array}$ \\
\hline
\end{tabular}

Totals :

$\overline{0.96 \overline{6}}\langle--v a l i d$ peaks only--> $\quad 69.89$

$$
\begin{gathered}
\text { DETECTOR CALIBRATION } \\
\text { Energy (MEV) }=4.106+(0.0046) * \text { Channel } \\
\text { Energy range }(\mathrm{MeV}): 4.106 \text { TO } 6.461 \\
\text { Efficiency }= \\
0.0971 \mathrm{CPM} / \mathrm{DPM}
\end{gathered}
$$
Energy $($ MEV $)=4.106+(0.0046) *$ Channel
Energy range (MeV): 4.106 TO 6.461
Efficiency $=0.0971 \mathrm{CPM} / \mathrm{DPM}$

TOTAL COUNT DATA:

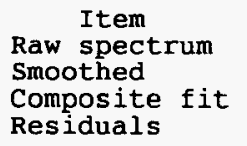

$$
\begin{array}{r}
\text { Total } \\
34741.0 \\
34741.0 \\
33813.6 \\
927.4
\end{array}
$$
\& Recovery
100.000
100.000
97.330
2.670

Analyzed by:

$\overline{\mathrm{SLH}}$ 
1 Legend: $\quad$ Raw $=\ldots$ Modeled Peaks $=1,2, \ldots$ etc $\quad$ Display Max.: 12815.1

WHC-SD-WM-DP-180, REV. 0

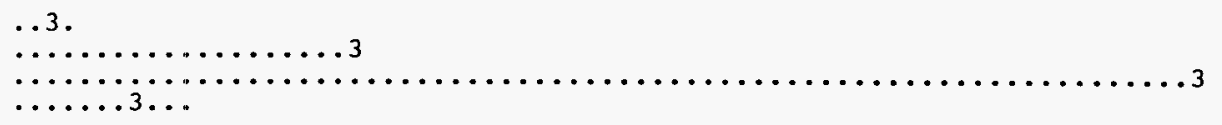

2
2
2

.1

$\ldots \ldots \ldots$

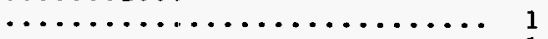

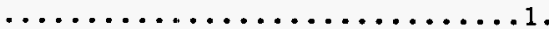

$\cdots$ 
Raw Data Dump for AEA Spectrum: 13 a1396.CNF

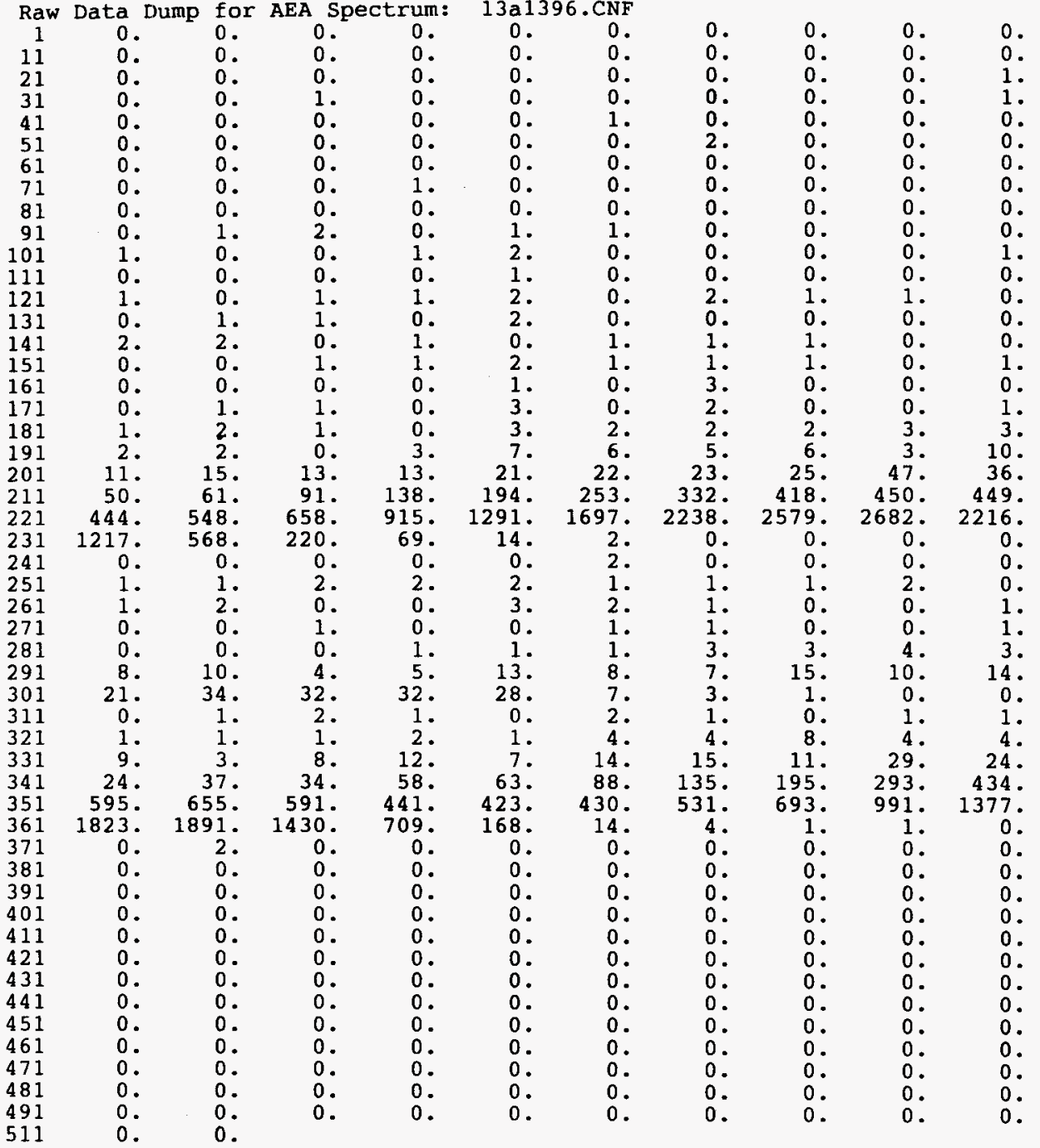


Westinghouse Hanford Co.

$$
\text { In-7wal }
$$

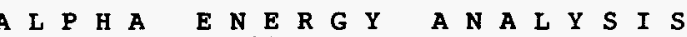

GE N E R A L Rev. 2.01

WHC-SD-WM-DP-180, REV. 0

DATA REDUCTION REPORT

SAMPLE

WL5091-BLK

File ID: 14a1401.CNF

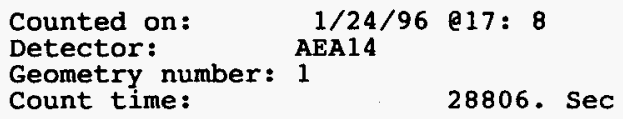

PEAK ANALYSIS

Peak

ID

1
Peak height Initial Final 513.8
Peak center Initial Final

FWHM

Initial Final

$10.000 \quad 2.312$

$$
\begin{array}{cc}
\text { Tau } & \\
\text { Initial } & \text { Final } \\
5.000 & 1.288
\end{array}
$$

\section{PEAK RESULTS \\ Peak Error Limit: 308}

\section{Peak \\ ID Isotope \\ $1 \quad \mathrm{Pu} 236$}

Totals :
AEA

Frac

0.978

$-----$

0.978
Peak Centroid

$$
\text { Exp. }
$$
Obs. Diff $5.7555 .758-.0030 .01$

Count serr$$
\text { <--valid peaks only--> }
$$

$11.52 \quad 2.6$

11.52

DETECTOR CALIBRATION

$$
\begin{aligned}
& \text { Energy (MEV) }=4.091+(0.0046) * \text { Channel } \\
& \text { Energy range (MeV): } 4.091 \text { TO } 6.446 \\
& \text { Efficiency = } \\
& 0.0126 \mathrm{CPM} / \mathrm{DPM}
\end{aligned}
$$

TOTAL COUNT DATA:

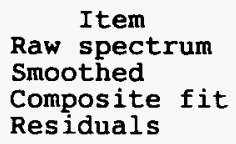

Total

5654.0

5654.0

5531.3

122.7
Activity uCi/ea
Analyzed by: $\mathrm{d} / \mathrm{m}$

933.0 $0.420 \mathrm{E}-03$
Residuals

Recovery
100.000
100.000
97.829
2.171

\section{$\overline{\text { SLH }}$}


1 Legend: Raw $=\ldots$ Modeled Peaks $=1,2, \ldots$ etc $\quad$ Display Max.: 2639.9

WHC-SD-WM-DP-180, FEV. 0

1

1

$\ldots \ldots \ldots \ldots+\ldots \ldots$

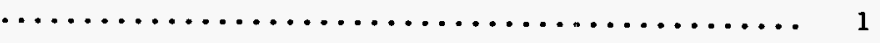

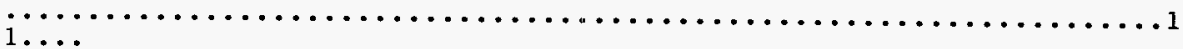


Westinghouse Hanford Co.

G E N E R A L

$\begin{array}{lllllllllllllllllll}A & L & P & H & A & \text { E N } & \text { E } & R & \text { G } & Y & \text { A } & \text { N A } & \text { L } & Y & S & \text { I } & S\end{array}$ ReV. 2.01 WHC-SD-WM-DP-180, FEV. 0

DATA REDUCTION REPORT

SAMPLE

S95RI15

File ID: $15 \mathrm{al} 1582 . \mathrm{CNF}$

$\begin{array}{ll}\text { Counted on: } & 1 / 24 / 96 \text { e17: } 8 \\ \text { Detector: } & \text { AEA15 } \\ \text { Geometry number: } 1 & \\ \text { Count time: } & \end{array}$

PEAK ANALYSIS

Peak

ID

1
Peak height Initial Final 700.4
Peak center Initial Final 362.521362 .521

\author{
Initi
8.00
308
}

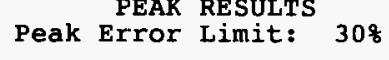

AEA

Frac 0.980

Peak Centroid

Count forr

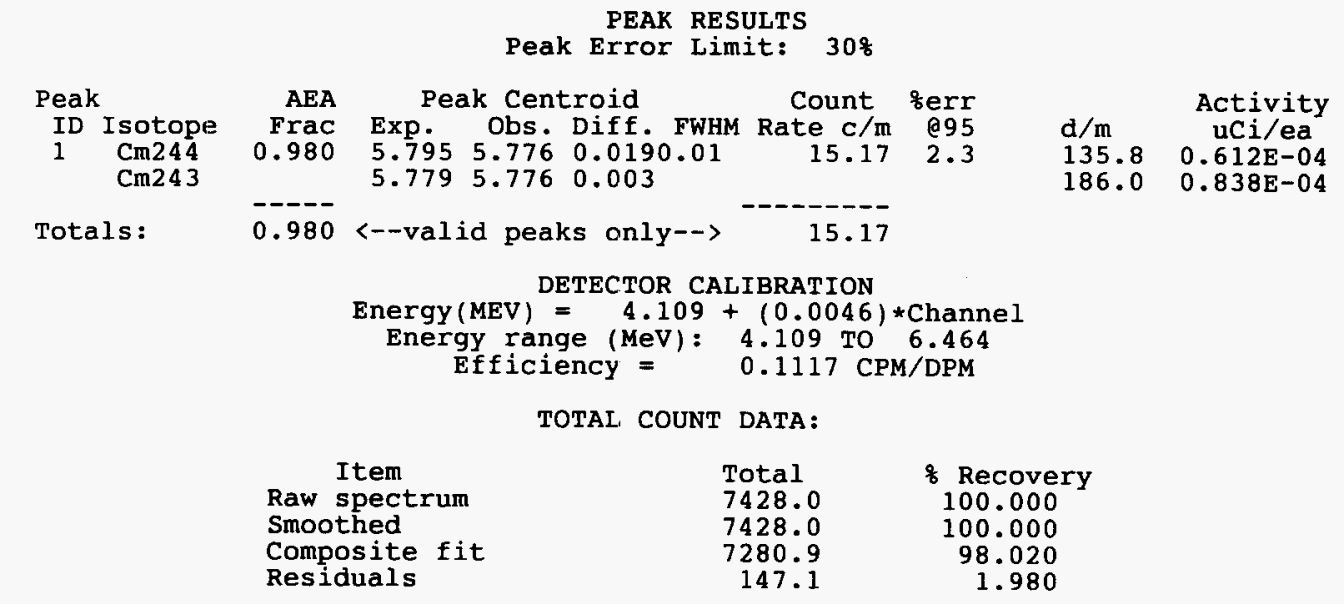

$5.7795 .776 \quad 0.003$

FWHM

Final
2.235

$\begin{array}{cc}\text { Tau } & \\ \text { Initial } & \text { Final } \\ 4.000 & 1.309\end{array}$

$1 / 24 / 26$

$$
\begin{array}{lc}
\text { ID } & \text { Isotope } \\
1 & \text { Cm244 } \\
& \text { Cm243 }
\end{array}
$$

Totals : $\overline{0.980}$ 0.980

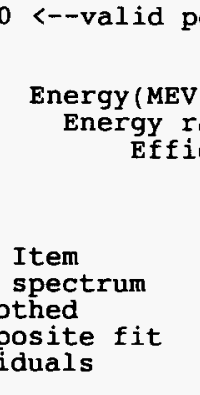

15.17

peaks only-->

DETECTOR CALIBRATION

$=4.109+(0.0046) *$ Channel

ciency $=$

TOTAL COUNT DATA:

$$
\begin{aligned}
& \text { Total } \\
& 7428.0 \\
& 7428.0 \\
& 7280.9 \\
& 147.1
\end{aligned}
$$

Activity

$\begin{array}{lc}\mathrm{d} / \mathrm{m} & \mathrm{uCi} / \mathrm{ea} \\ 135.8 & 0.612 \mathrm{E}-04\end{array}$

$186.0 \quad 0.838 \mathrm{E}-04$

Analyzed by:

Recovery
100.000
100.000
98.020
1.980

$\overline{\text { SLH }}$ 
1 Legend: Raw $=\ldots$ Modeled Peaks $=1,2, \ldots$ etc Display Max.: 3695.1

WHC-SD-WM-DP-180, FiEV. 0

- 1

$\ldots \ldots \ldots+\ldots$

1

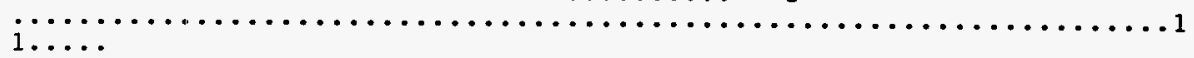

210 


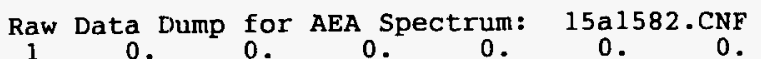

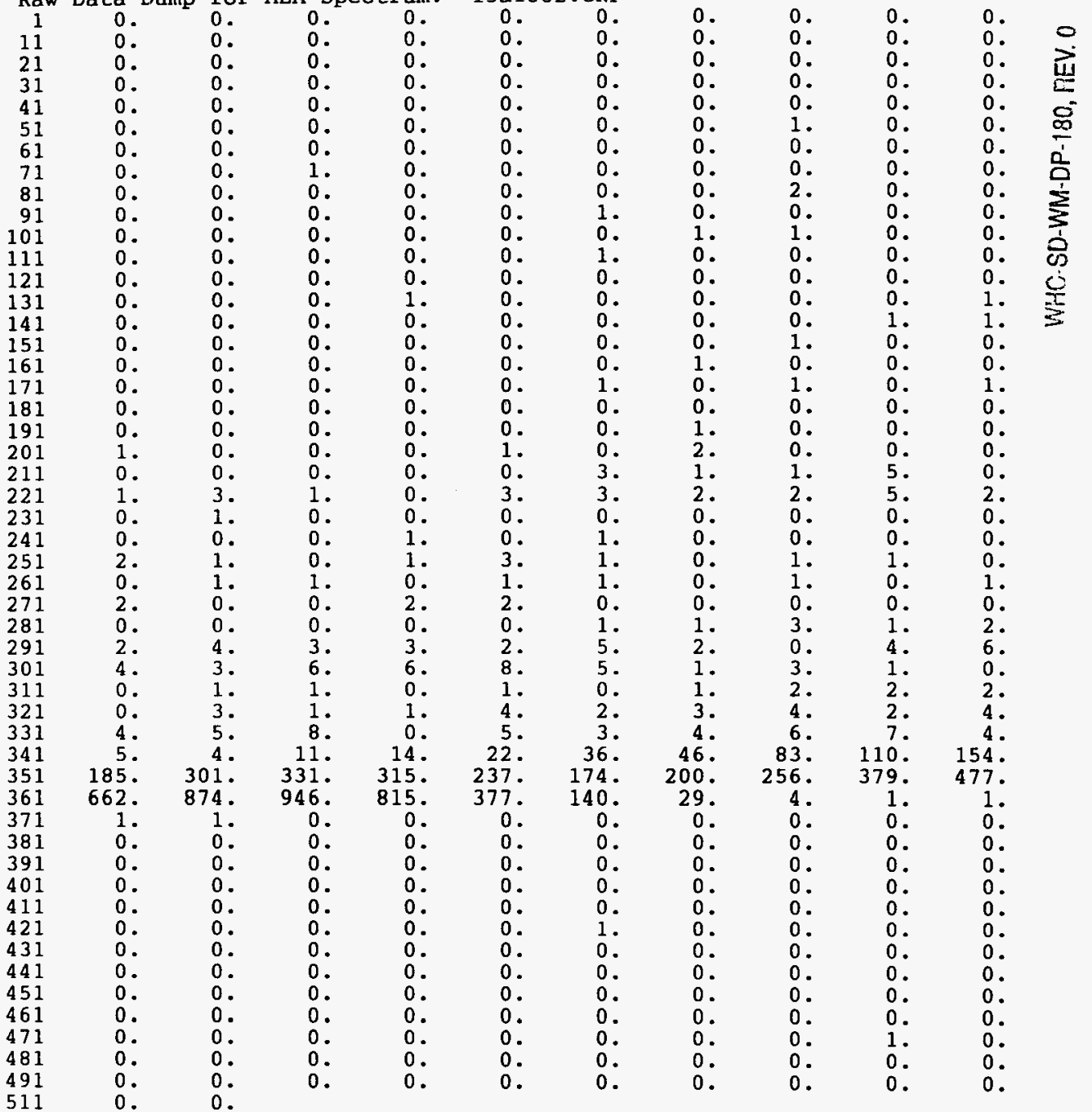


Westinghouse Hanford $\mathrm{Co}$.

ind Dawacia

G E N E R A L $\begin{array}{lllllllllllllllllll}\text { A } & \text { L } & \text { P } & \text { H } & \text { A } & \text { E } & \text { N } & \text { E } & \text { R } & G & Y & \text { A } & \text { N A } & \text { L } & \text { Y } & S & \text { I } & S\end{array}$ Rev. 2.01 DATA REDUCTION REPORT

WHC-SD-WM-DP-180, REV. 0

\author{
SAMPLE \\ S95R115-SPK \\ File ID: 16a1670.CNF
}

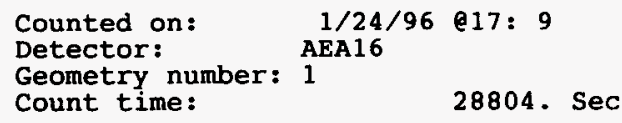

PEAK ANALYSIS

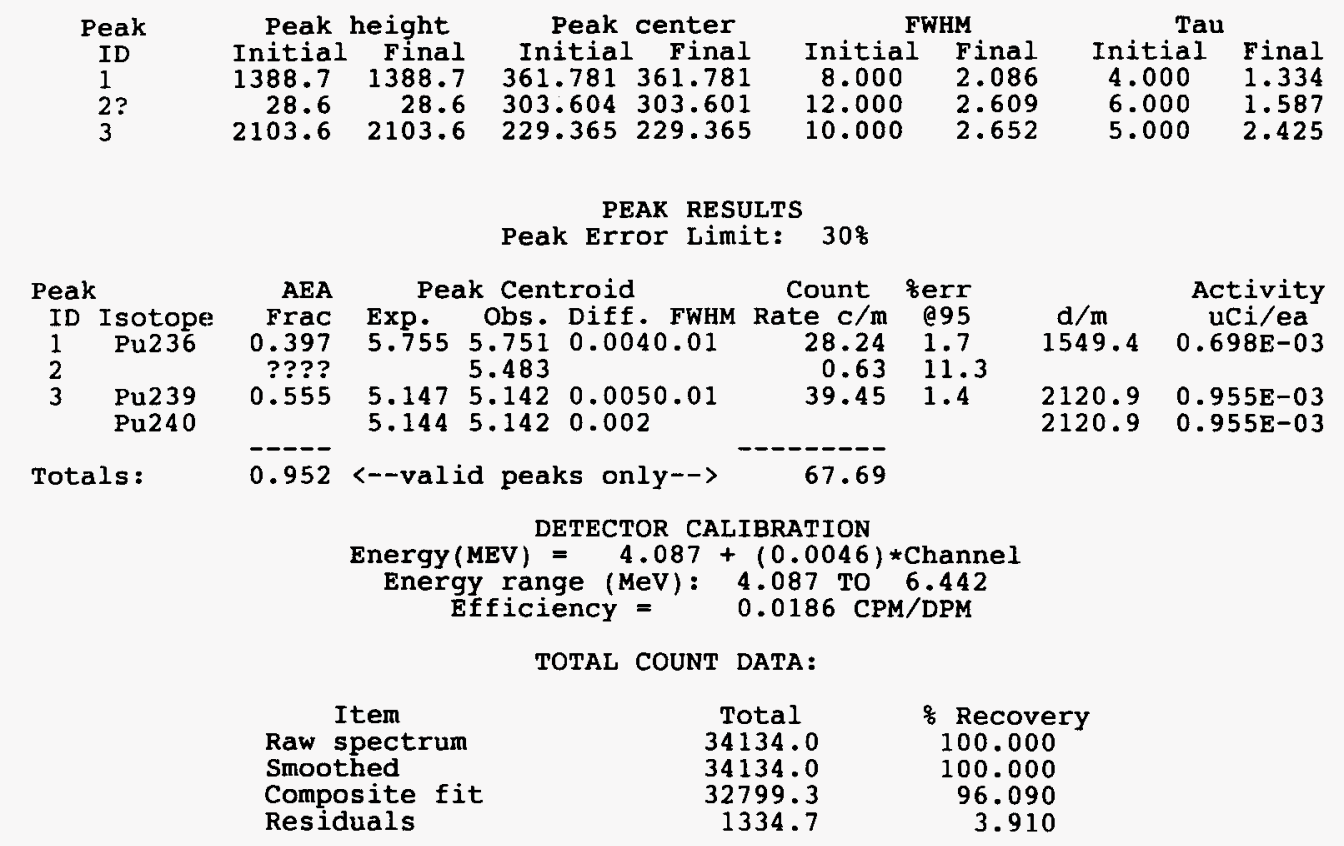

$\begin{array}{cc}\text { Peak } & \\ \text { ID } & \text { Isotope } \\ 1 & \text { Pu236 } \\ 2 & \\ 3 & \text { Pu239 } \\ & \text { Pu240 }\end{array}$

Totals:
PEAK RESULTS

Peak Error Limit: $30 \%$

Analyzed by: 
1 Legend: $\quad$ Raw $=\ldots$. Modeled Peaks $=1,2, \ldots$, etc $\quad$ Display Max.: 12761.4

\section{WHC-SD-WM-DP-180, REV. 0}

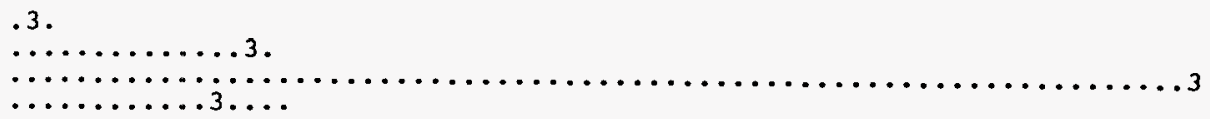

1 $\ldots \ldots 1 \ldots$ $\ldots \ldots \ldots \ldots \ldots \ldots \ldots \ldots \ldots \ldots$ $\ldots \ldots \ldots \ldots \ldots \ldots \ldots \ldots \ldots \ldots \ldots \ldots$ 
Raw Data Dump for AEA Spectrum: 16 a1670.CNF

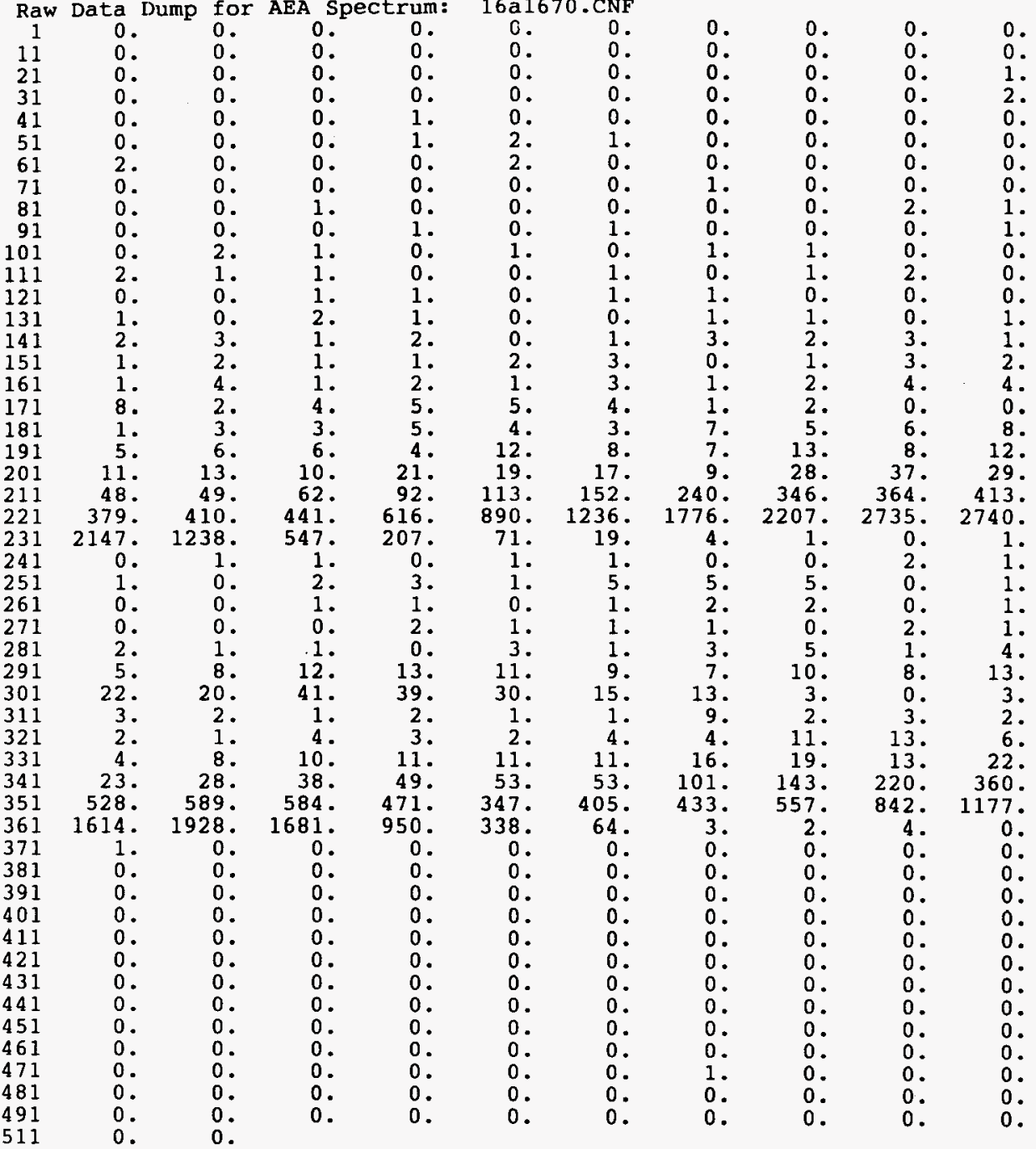


Westinghouse Hanford Co.

infintia

$.11 .24 \% 6$

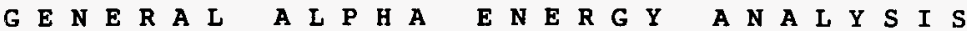
Rev. 2.01 WHC-SD-WM-DP-180, FEV. 0

DATA REDUCTION REPORT

SAMPLE

S95R115-SPK-DUP

File ID: 17 a1753. CNF

Counted on: 1/24/96 e17:10

Detector:

Count time:

28802. Sec

PEAK ANALYSIS

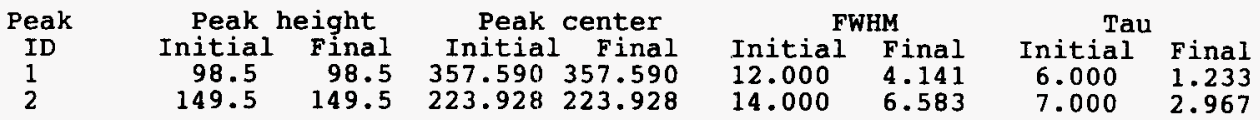

\section{PEAK RESULTS \\ Peak Error Limit: $30 \%$}

Peak

ID I sotope

$1 \quad \mathrm{Pu} 236$

$2 \quad \mathrm{Pu} 239$

Pu240

Totals:

AEA
Frac
0.428
0.575

$----$

1.002

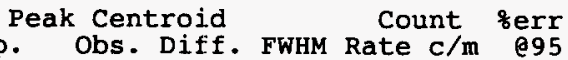

$\begin{array}{llll}5.755 & 5.743 \quad 0.0120 .02\end{array}$

$5.147 \quad 5.128 \quad 0.0190 .03$

$5.1445 .128 \quad 0.016$

3.62

4.86

4.7

4.1

$$
\text { <--valid peaks only--> } 8.48
$$

Activity

$\mathrm{d} / \mathrm{m}$

196.4

258.4

258.4
uCi/ea

$0.885 \mathrm{E}-04$

$0.116 \mathrm{E}-03$

$0.116 \mathrm{E}-03$

DETECTOR CALIBRATION

$$
\begin{aligned}
& \text { Energy (MEV) }=4.098+(0.0046) * \text { Channel } \\
& \text { Energy range }(\mathrm{MeV}): 4.098 \text { TO } 6.453 \\
& \text { Efficiency }=0.0188 \mathrm{CPM} / \mathrm{DPM}
\end{aligned}
$$

TOTAL COUNT DATA:

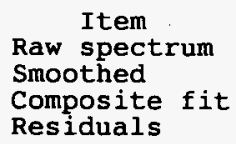

$$
\begin{array}{cc}
\text { Total } & \text { \& Recovery } \\
4059.0 & 100.000 \\
4058.5 & 99.987 \\
4069.0 & 100.246 \\
-10.0 & -0.246
\end{array}
$$

Analyzed by : 


\section{Spectrum 17 a 1753. CNF}

1 Legend: $\quad$ Raw $=\ldots$ Modeled Peaks $=1,2, \ldots$ etc

Display Max.:

947.7

WHC-SD-WM-DP-180, FIEV. 0

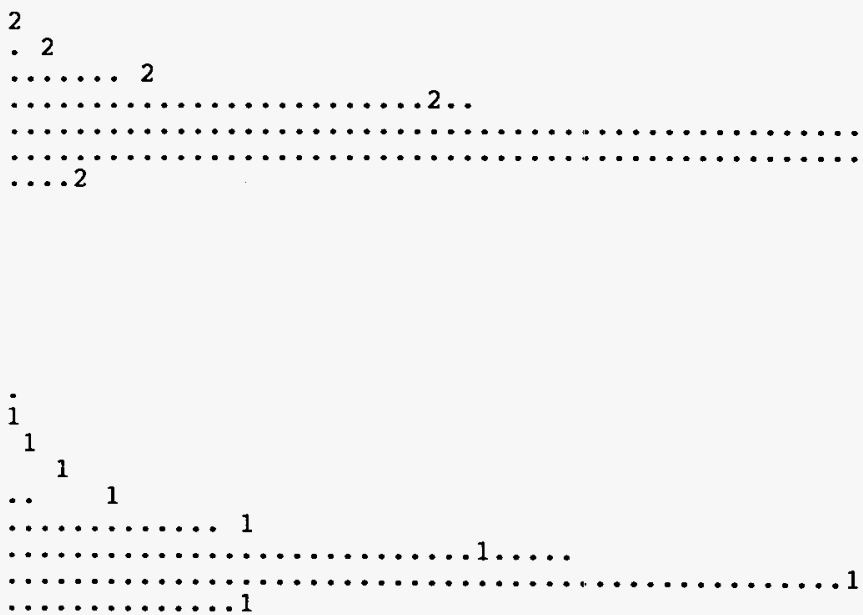


Raw Dat.a Dump for AEA Spectrum: 17 a $1753 . \mathrm{CNF}$

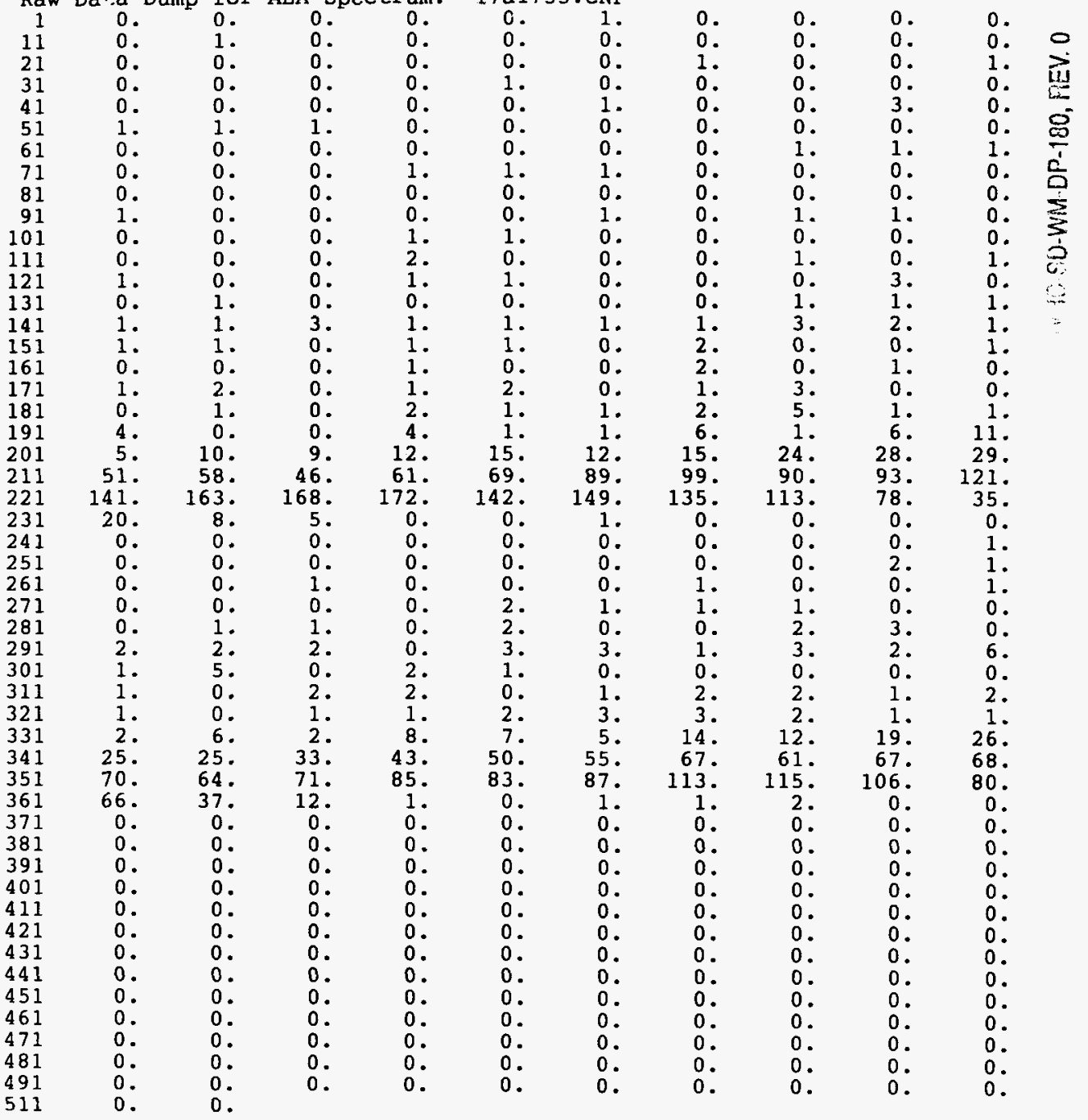


Westinghouse Hanford Co.

A L P H A E N E R G Y A N A L Y S I S Rev. 2.01

DATA REDUCTION REPORT

WHC-SD-WM-DP-180, F.EV.O

\author{
SAMPLE \\ S95R116-SAM \\ File ID: $18 \mathrm{a} 1829 . \mathrm{CNF}$
}

$\begin{array}{ll}\text { Counted on: } & 1 / 24 / 96 \text { e17:11 } \\ \begin{array}{l}\text { Detector: } \\ \text { Geometry number: }\end{array} & \\ \text { Count time: } & \end{array}$

PEAK ANALYSIS

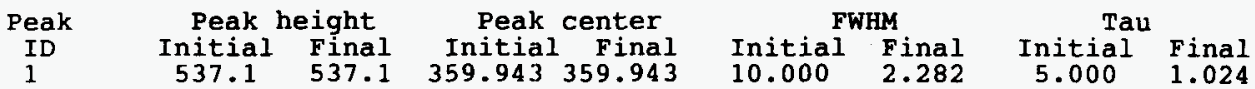

PEAK RESULTS
Peak Error Limit: $30 \%$

Peak

AEA

Peak Centroid

Count serr

ID Isotope

Frac Exp. Obs. Diff. FWHM Rate c/m 995 $\begin{array}{cc}13.63 & 2.4\end{array}$

$\mathrm{d} / \mathrm{m}$

Activity

$1 \quad \mathrm{Pu} 236$

0.946

$5.7555 .757-.0020 .01$

13.63

Totals:

0.946

<--valid peaks only-->

1717.6 uCi/ea
DETECTOR CALIBRATION
Energy (MEV) $=4.101+(0.0046) *$ Channel
Energy range (MeV): 4.101 TO 6.456
Efficiency $=0.0081 \mathrm{CPM} / \mathrm{DPM}$

TOTAL COUNT DATA:

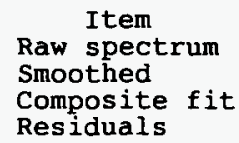

Total

6921.0

6921.4

6545.0

376.0
\& Recovery

100.000

100.005

94.567

5.433

Analyzed by: 
Spectrum 18a1829.CNF

1 Legend: $\quad$ Raw $=\ldots$ Modeled Peaks $=1,2, \ldots$ etc $\quad$ Display Max.: 2764.0

WHC-SD-WM-DP-180, FiEV.

i.

$\ldots 1$

$\ldots \ldots \ldots 1$

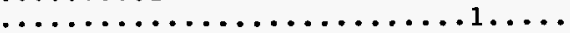

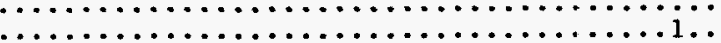


Raw Data Dump for AEA Spectrum: 18 a1829.CNF

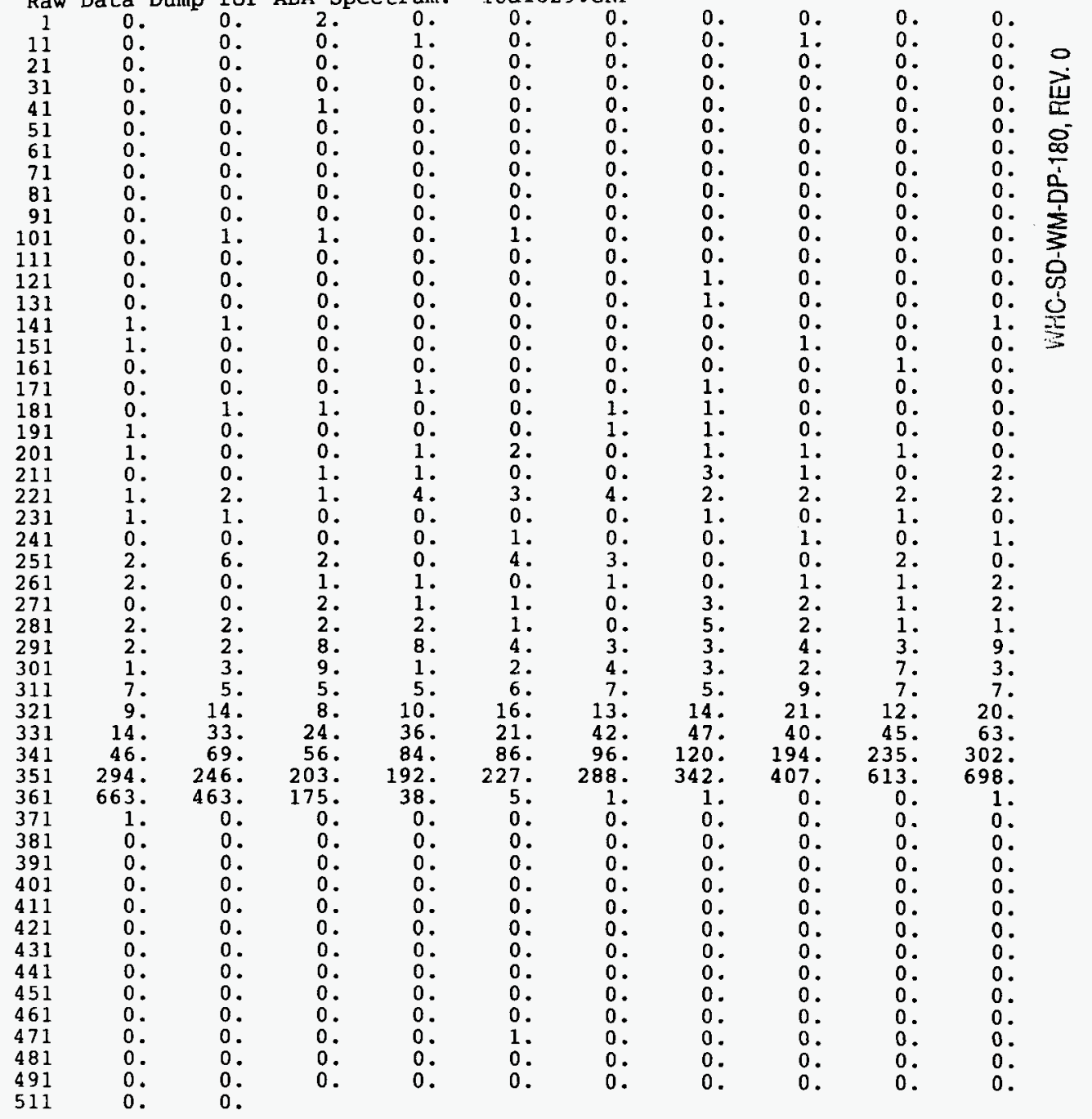


Westinghouse Hanford Co.

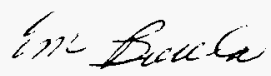
G E N E R A L
A L P H A E N E R G Y
A N A L Y S I S Rev. 2.01
WHC-SD-WM-DP-180, REV. 0 DATA REDUCTION REPORT

\author{
SAMPLE \\ S95R116-SPK \\ File ID: 19a1909.CNF
}

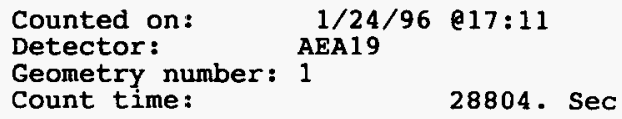

PEAK ANALYSIS

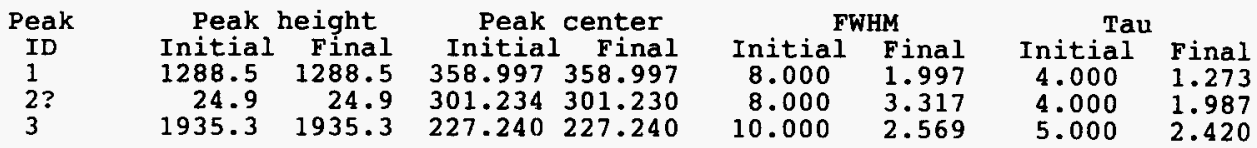

PEAK RESULTS
Peak Error Limit: $30 \%$

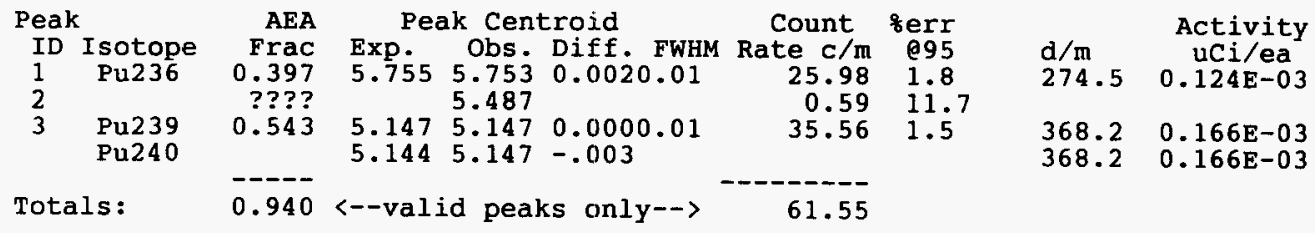

DETECTOR CALIBRATION

Energy $($ MEV $)=4.101+(0.0046) *$ Channel Energy range (MeV): 4.101 TO 6.457 Efficiency $=0.0966 \mathrm{CPM} / \mathrm{DPM}$

TOTAL COUNT DATA:

$\begin{array}{lrr}\quad \text { Item } & \text { Total } & \text { 8 Recovery } \\ \text { Raw spectrum } & 31420.0 & 100.000 \\ \text { Smoothed } & 31420.7 & 100.002 \\ \text { Composite fit } & 29828.9 & 94.936 \\ \text { Residuals } & 1591.1 & 5.064\end{array}$

Analyzed by: 
1 Legend: Raw $=\ldots$ Modeled Peak.s $=1,2, \ldots$, etc $\quad$ Display Max.: 11252.9

WHC-SD-WM-DP-180, REV. 0

..3.

....................

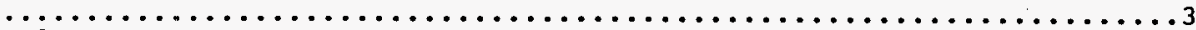

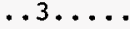

2
2
2

.1

..............

$\ldots \ldots \ldots \ldots \ldots \ldots \ldots$ 
$\begin{array}{ccccc}\text { Raw Data Dump for AEA Spectrum: } & 19 a 1909 . C N F \\ 1 & 0 . & 0 . & 1 . & 1 .\end{array}$

21

31

41

51

61

71

81

91
101

111

121

131

141

151

$-161$

171

181

191

201

211

221

231

241

251

261

271

281

291

301

311

321

331

341

351

361

371

381

391

401

411

421

431

441

451

461

471

481

491

511

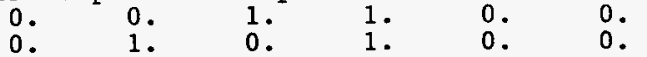

$0 . \quad 0$.

$0 . \quad 0$.

1. 2.

$0 . \quad 0$.

$0 . \quad 0$.

1. 2 .

0.2 .

3. 0 .

$0 . \quad 0$.

2. $\quad 2$.

3.5 .

$4 . \quad 1$.

11. 9 .

11. 13 .

12. 21 .

$59 . \quad 49$.

441.622 .

$\begin{array}{rr}414 . & 150 . \\ 2 . & 0 .\end{array}$

2. 1 .

1.1 .

3. 2 .

10. 11.

29.

3.

36 .

11 .

12

$\begin{array}{r}30 . \\ 461 .\end{array} \quad 47$.

$984 . \quad 359$.

0 . 0

$0 . \quad 0$.

$0 . \quad 0$.

0 . 0 .

$0 . \quad 0$.

$\begin{array}{ll}0 . & 0 . \\ 0 . & 0 .\end{array}$

0 . 0 .

$0 . \quad 0$.

0.0 .

o. $\quad 0$.

$0 . \quad 0$.

0 . 0 . $\begin{array}{llll}0 . & 1 . & 0 . & 0 .\end{array}$

0.00 .01 .

$0 . \quad 0$.

0.1 .

1.1 .

0.0 .

1. 0.

3.1.

$2 . \quad 0$.

3. $\quad 1$.

3. 4.

6.56

9.5 .

7.12 .

5. 16 .

23. 27.

111.172.

61. 10.

1. 2.

1.2 .

0 .

4.2

10.99.

23. 10 .

11 .

5.

10. 17 .

54. 86.

80 .

0 .

0.

0 .

0.

0 .

0 .

0 .

0 .

0 .

0 .

0 .

$\begin{array}{ll}0 . & 0 . \\ 0 . & 0 .\end{array}$
0.0 .

$0 . \quad 0$.

$0 . \quad 0$.

$0 . \quad 1$.

2.2 .

2.2 .

2 .

1.

3 .

2 .

3.

9.

16.

25.

224.

36. 2179 .

4.0 .

1.

1.2 .

3. 0 .

1.2 .

$4 . \quad 3$.

8.

5.

12 .

14.

123 .

486 .

0 .

0 .

0 .

0.

0 .

0 .

0 .

0 .

0 .

0 .

0 .

0 .

0 .

0 .

0 .

0 .

0 .

0 .

0 .

0 .
0 .

0 .

0 .

0 .

0 .

3.

0 .

1 .

1.

2 .

2 .

1.

1.

1.

6.

9.

7.

11.

26.

360 .

2516 .

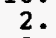

3.

1.

4.

3.

5.

9.

3.

4.

10.

16.

174.

655 .

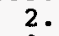

2 .

0 .

0 .

0.

0.

0 .

0 .

0.

0 .

0 .

326.

969.

1.

0 .

0 .

0 .

1.

0 .

0 .

0 .

0 .

0 .

0 .

0 .

1.

1.

1.

$0 . \quad 0$.

0.1 . 1.

0 .

0 .

0 .

1 .

0 .

1.

6.

3 .

2 .

3.

6.

4.

7.

19.

37.

335 .

0.

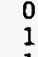

1.

3.

17.

0.

5.

15.

434.

1449 .

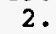

2 .

0 .

0 .

0 .

0.

0 .

0 . 
Westinghouse Hanford Co.

G E N E R A L

$\begin{array}{lllllllllllllllllll}A & L & P & H & A & \text { E } & N & \text { E } & R & G & Y & \text { A } & \text { N A } & \text { L } & Y & S & \text { I } & S\end{array}$

Rev. 2.01

WHC-SD-WM-DP-180, REV. 0

DATA REDUCTION REPORT

SAMPLE

S95R116-SPK-DUP

File ID: 20a2012.CNF

Counted on:

Detector:

$1 / 24 / 96$ e $17: 12$

Geometry number: 1

Count time:

28803. Sec

PEAK ANALYSIS

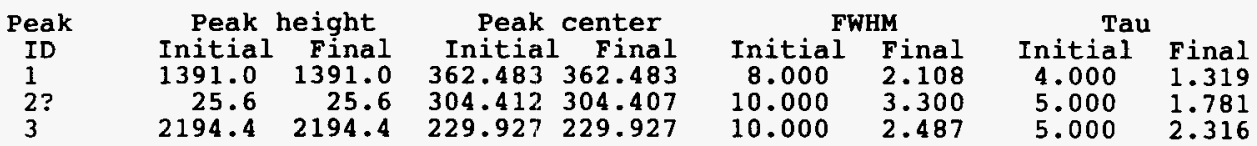

$$
\begin{array}{lc}
\text { Peak } & \\
\text { ID } & \text { Isotope } \\
1 & \text { Pu236 } \\
2 & \\
3 & \text { Pu239 } \\
& \text { Pu240 }
\end{array}
$$

Totals:

\section{PEAK RESULTS \\ Peak Error Limit: $30 \%$}

insuli 104,4 
1 Legent: $\quad$ Raw $=\ldots$ Modeled Peaks $=1,2, \ldots$ etc $\quad$ Display Max.: 12674.7

WHC-SD-WM-DP-180, REV. 0

3.

$\ldots \ldots \ldots+\ldots$

$\cdots \ldots \ldots \ldots \ldots \ldots+\cdots \cdots$

2

2

2

1

.......

$\ldots \ldots \ldots \ldots \ldots \ldots \ldots \ldots 1$

$\ldots \ldots \ldots \ldots \ldots \ldots \ldots \ldots \ldots \ldots \ldots \ldots$

... 


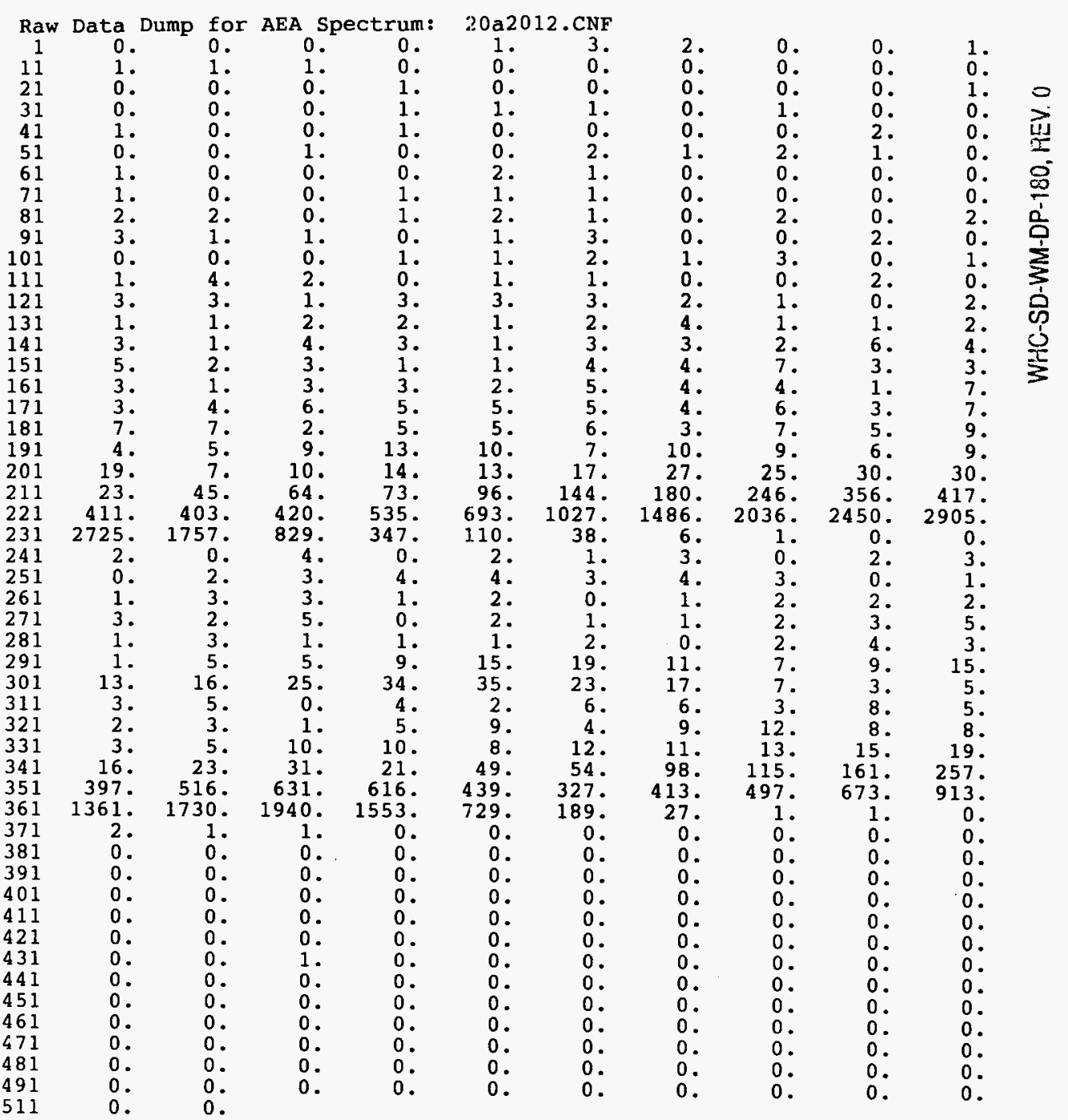




\section{LABCORE Completed Worklist Report for Worklist\# 4751}

Analyst: dgg

Instrument: U01

Book\# 23856

Method: LA-975-009 Rev/Mod A-1.

Worklist Comment: $0.1-10 \mathrm{~mL}$ sample prep / $0.1 \mathrm{~mL}$ spike / jls

\begin{tabular}{|c|c|c|c|c|c|c|c|c|}
\hline Seq Type & \multicolumn{3}{|c|}{ Sample\# R A } & Test & Matrix & Actual & Found & DL or Yield Unit \\
\hline 1 STO & & 0 & au-01 & $\mathrm{u}-02$ & LIOUID & $6.38 E-02$ & $6.31 E-02$ & $98.900 \times$ Recovery \\
\hline 2 BLHK & & 0 & $a-01$ & $U-02$ & LIOUID & 1 & $3.98 E-01$ & $0.400 \mathrm{ug} / \mathrm{mL}$ \\
\hline 3 SAMPLE & S96R000041 & 0 & au-01 & U.02 & LIOUID & N/A & $2.57 \mathrm{E}-014$. & $70 \mathrm{e}-002 \mathrm{ug} / \mathrm{mL}$ \\
\hline 3 SAMPLE & $596 R 000041$ & 0 & au-01 & $\mathrm{U}-02 \mathrm{E}$ & LIQUID & H/A & $1.94 \mathrm{E}+00$ & $0.000 \%$ Inst Error \\
\hline 4 SPK & S96R.000041 & 0 & au-01 & $\mathrm{u}-02$ & LIOUID & $5.69 E+01$ & $6.38 E+01$ & $112.130 \times$ Recovery \\
\hline 5 SPK-DUP & S96R000041 & 0 & au-01 & U-02 & LIOUID & 112.127 & 117.1 & $4.340 \mathrm{RPD}$ \\
\hline 6 SAMPLE & $\$ 96 R 000042$ & 0 & 2u-01 & $\mathrm{u}-02$ & Liauid & NLA & $8.39 \mathrm{E}-024$. & $70 \mathrm{e}-002 \mathrm{ug} / \mathrm{mL}$ \\
\hline 6 SAMPLE & $596 R 000042$ & 0 & au-01 & $U-02 E$ & LIOUID & N/A & $3.98 E+00$ & $0.000 \%$ Inst Error \\
\hline 7 SPK & S98R000042 & 0 & au-01 & $\mathrm{U}-02$ & LIaUnd & $5.69 E+01$ & $7.13 E+01$ & $125.310 \%$ Recovery \\
\hline 8 SPK-DUP & $\$ 968000042$ & 0 & aU-01 & $\mathrm{U}-02$ & LIQUID & 125.308 & 125.1 & 0.170 RPD \\
\hline
\end{tabular}

\section{Final page for worklist\# 4751}

Analyst Signature Date Analyst Signature Date

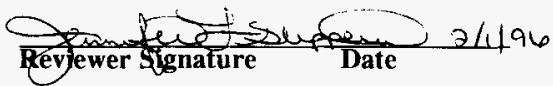


Analyst: $\quad 88$ Instrument: U01

Method: LA-925-009 Rev/Mod A - I
Book\# 22B56

W'HC-SD-WM-DP-180, REV. 0

Worklist Comment: $0.1-10 \mathrm{~mL}$ sample prep / $0.1 \mathrm{~mL}$ spike / jls

\begin{tabular}{|c|c|c|c|c|c|c|c|}
\hline $\mathbf{s}$ & Type & Sample\# & R A & Test & Matrix & Group\# & Project \\
\hline 1 & STD & & & Qu -01 & LIQUID & & \\
\hline 2 & BLNK & & & ed-01 & LIQUID & & \\
\hline \multirow[t]{2}{*}{3} & SAMPLE & S96R000041 & 0 & $\mathrm{eu}-01$ & LIQUID & 95000224 & ORG/AQ SAMPL \\
\hline & & Analytes Reque & ested: & $\mathrm{U}-02$ &,$\quad \mathrm{U}-02 \mathrm{E}$ & & \\
\hline 4 & SPK & S96R000041 & 0 & eu-01 & LIQUID & & \\
\hline 5 & SPK-DUP & S96R000041 & 0 & eu-01 & LIQUID & & \\
\hline \multirow[t]{2}{*}{6} & SAMPLE & S96R000042 & 0 & $\mathrm{au}-01$ & LIQUID & 95000224 & ORG/AQ SAMPL \\
\hline & & Analytes Reque & ested: & $\mathrm{U}-02$ &,$U-02 E$ & & \\
\hline 7 & SPK & S96R000042 & 0 & au-01 & LIQUID & & \\
\hline 8 & SPK-DUP & S96R000042 & 0 & eu-01 & LIQUID & & \\
\hline
\end{tabular}

\section{Final page for worklist \# 4751}
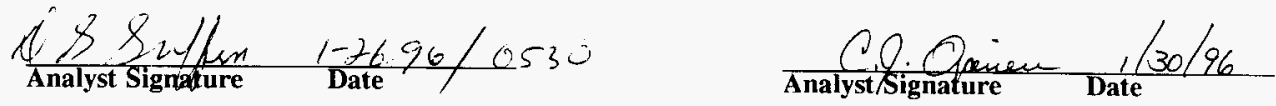

Data Entry Comments:

$S=$ Worklist Slot Number, $R=$ Replicate Number, $A=$ Aliquot Code. 


\section{URANIUM ANALYSIS WTIC-SD-WM-DP-180, FEV. 0}

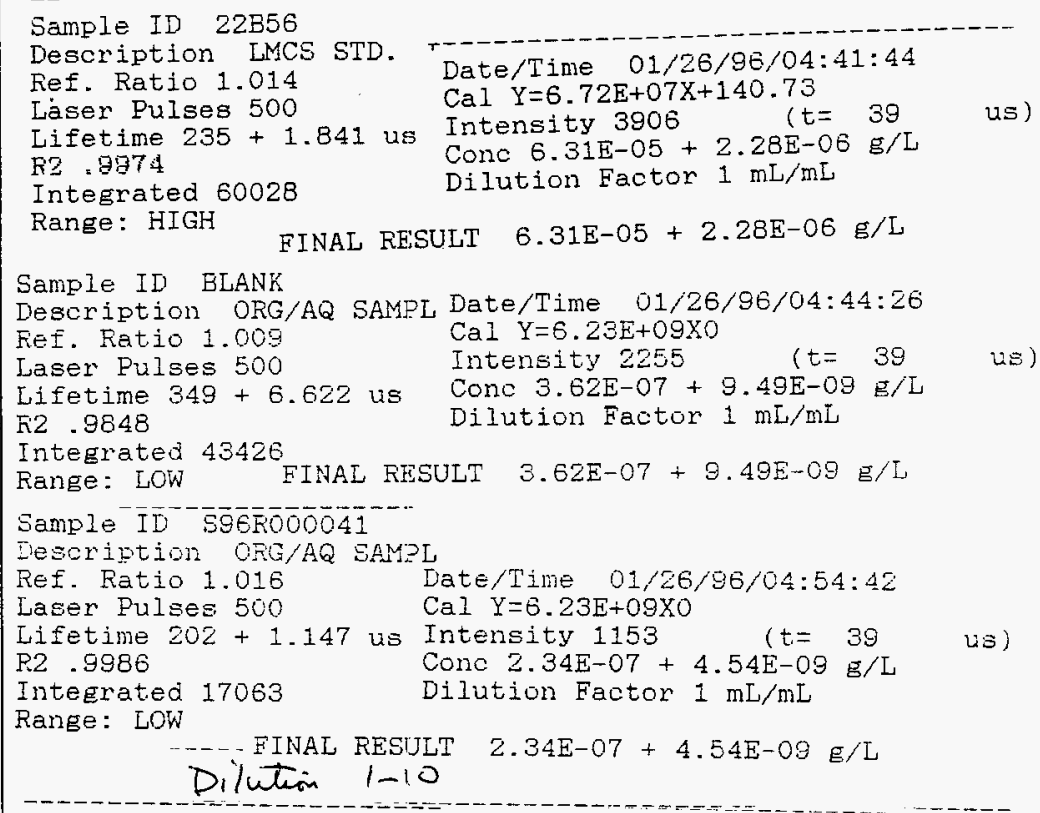

Sample ID S96R0000415FK Date/Time 01/26/96/05:39:11

Description ORG/AQ SAMPL Cal $Y=6.72 E+07 X+140.73$

Fef. Fatio 1.005

$\begin{array}{ll}\text { Laser Pulses } 500 & \text { Conc } 5.82 \mathrm{E}-05+2.01 \mathrm{E}-0 \mathrm{O} \mathrm{E} / \mathrm{L} \\ \text { Lifetime } 218+.831 \text { us } & \text { Dilution Factor }\end{array}$ Intensity $3291 \quad(t=39 \quad$ us:
Cone $5.82 \mathrm{E}-05+2.01 \mathrm{E}-06 \mathrm{E} / \mathrm{L}$ R2 .9994

Integrated 5138 FINAL RESULT $5.82 \mathrm{E}-05+2.01 \mathrm{E}-06 \mathrm{~g} / \mathrm{L}$

Range: HIGH Dilutu 1-10

Sample ID 596RC41SFK-IUP Date/Time 01/26/96/05:45:21

Description OKG/AQ SAMPL Cal $Y=6.72 E+07 X+140.73$

Ref. Ratio 1.005

Laser Pulses 500

Lifetime $206+.563$ us K2 .3997

Intensity $3346 \quad i t=38$

Cone 6.08E-05 + 2.08E-0E E/L

Integrated 50341 FINAL RESULT 6.08E-05 + 2.08E-06 g/L Range: HIGH Piluter_1-10 


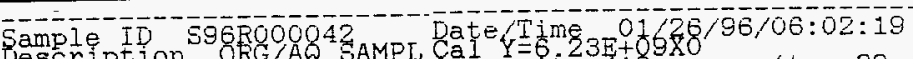

Nescription 8hG AQ SAMPL Cal Y

Laser pulges 500

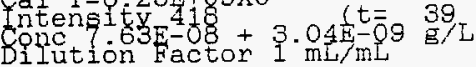

us)

Intégrat

Range:

412 us Dilution Factor $1 \mathrm{~mL} / \mathrm{mL}$

Di/utaid $1=10$

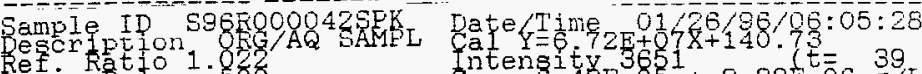

Reser Putses. 500

isetime

Inte-grated 58011 FINAT

Conc $6.49 \mathrm{E}-05^{-}+2.22 \mathrm{E}-0 \mathrm{0} 6 \mathrm{~B} / \mathrm{I}$

Integrated

749 us

Dilution Factor $1 \mathrm{~mL} / \mathrm{mL}$

g/L

$6.49 \mathrm{E}-05+2.22 \mathrm{E}-06 \mathrm{~g} / \mathrm{L}$

$$
\text { Dilution } 1-10
$$

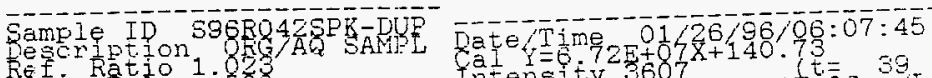

Rét Ratio 1 . 073

Laser pulses 500.667 us

R. 8996

Integrated 60493

Renee: High

FINAL RESULT

fatengity $3607 x+140.2 t=39$

Dilution Factor 1 mL

Riluten $\angle=10$ 
WORKBOOK PAGE: STD1

WHC-SD-WM-DP-180, REV. 0

Uranium by Phosphorescence: LA-925-009 (A-1) LIQUID/SOLID

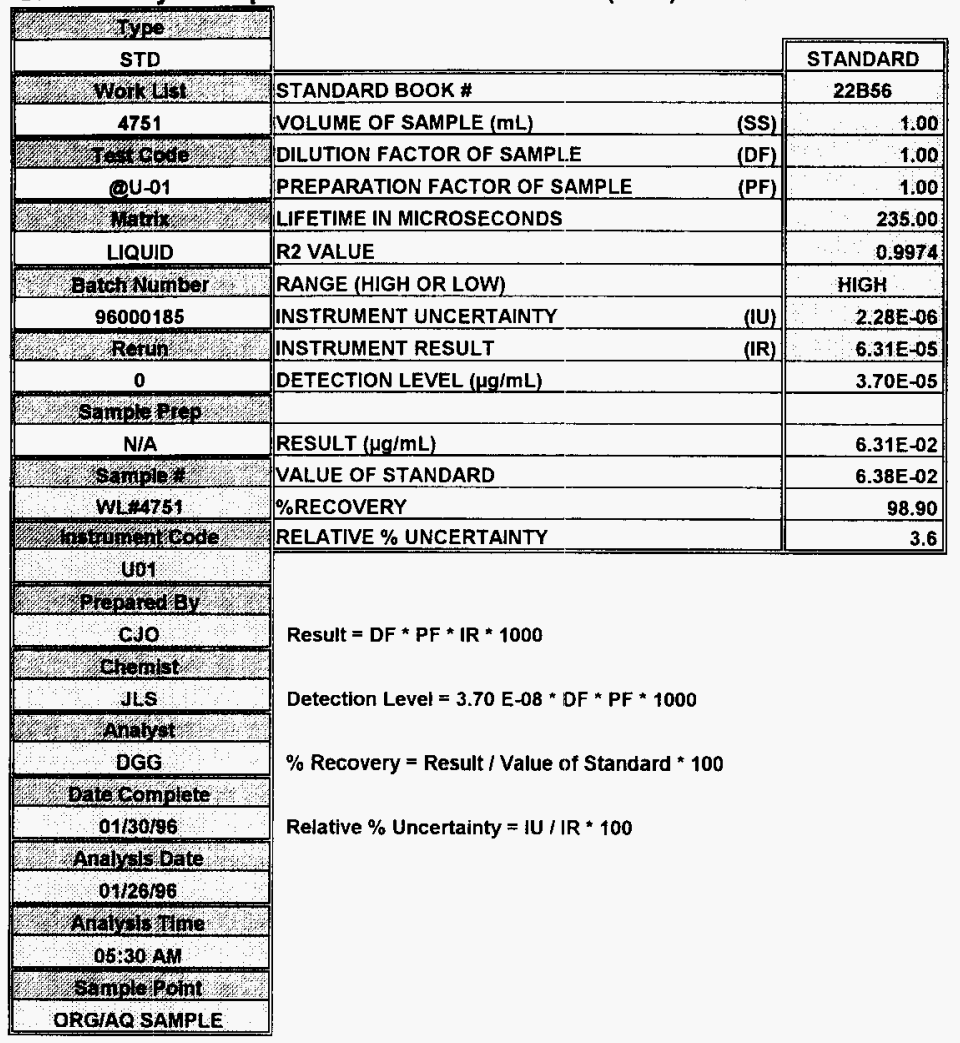

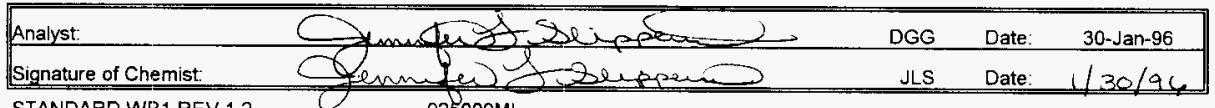

STANDARD.WB1 REV 1.2 925009ML 
WORKBOOK PAGE: BLANK2

WHC-SD-WM-DP-180, REV. 0

Uranium by Phosphorescence: LA-925-009 (A-1) LIQUID/SOLID

\begin{tabular}{|c|c|c|}
\hline 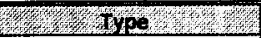 & & \\
\hline BLNK & & BLANK \\
\hline 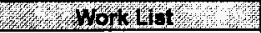 & VOLUME OF SAMPLE (mL) & 1.00 \\
\hline 4751 & DILUTION FACTOR OF SAMPLE & 11.00 \\
\hline 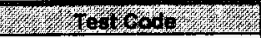 & PREPARATION FACTOR OF SAMPLE & 100.00 \\
\hline @U-01 & DIGEST DILUTION FACTOR & 1.0000 \\
\hline Wrata & LIFETIME IN MICROSECONDS & 349.00 \\
\hline LIQUID & R2 VALUE & 0.9848 \\
\hline Batch Number & RANGE (HIGH OR LOW) & LOW \\
\hline 96000185 & INSTRUMENT UNCERTAINTY & 9.49E-09 \\
\hline Rerun & |NSTRUMENT RESULT & $3.62 \mathrm{E}-07$ \\
\hline 0 & DETECTION LEVEL $(\mu \mathrm{g} / \mathrm{mL})$ & $4.07 E-02$ \\
\hline Shmpleptep & & \\
\hline N/A & & \\
\hline S. Sumpley & RESULT $(\mu \mathrm{g} / \mathrm{mL})$ & $3.98 \mathrm{E}-01$ \\
\hline$W L=4751$ & RELATIVE \% UNCERTAINTY & 2.6 \\
\hline
\end{tabular}

What winent Gode

U01

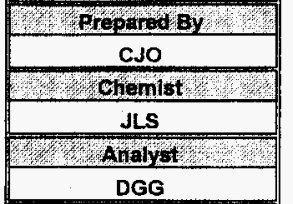

Result $=D F * P F * D D F * I R * 1000$

Detection Level $=3.70$ E-08 * DF * PF * DDF * 1000

Relative \% Uncertainty $=$ IU / IR * 100

Datex complete

01/30/96

Anatysis Date

$01 / 26 / 96$

Enalyoiforime

05:30 AM

Sumplepoint

ORGIAQ SAMPLE

\begin{tabular}{|c|c|c|c|}
\hline Analyst: & DGG & Date: & 30-Jan-96 \\
\hline Signature of Chemist: & JLS & Date: & 130191 \\
\hline
\end{tabular}


WORKBOOK PAGE: SAM3

WHC-SD-WM-DP-180, FEV 0

Uranium by Phosphorescence: LA-925-009 (A-1) LIQUID/SOLID

\begin{tabular}{|c|c|c|}
\hline Why & & \\
\hline SAMPLE & & SAMPLE \\
\hline WoikList & VOLUME OF SAMPLE (mL) & 1.00 \\
\hline 4751 & DILUTION FACTOR OF SAMPLE & 11.00 \\
\hline 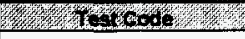 & PREPARATION FACTOR OF SAMPLE & 100.00 \\
\hline$\Leftrightarrow U-01$ & DIGEST DILUTION FACTOR & 1.0000 \\
\hline 6ronth & LIFETIME IN MICROSECONDS & 202.00 \\
\hline LIQUID & R2 VALUE & 0.9986 \\
\hline Batweriontimber & RANGE (HIGH OR LOW) & LOW \\
\hline 96000185 & INSTRUMENT UNCERTAINTY & 4.54E-09 \\
\hline 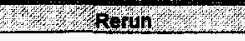 & INSTRUMENT RESULT & 2.34E:07 \\
\hline 0 & DETECTION LEVEL $(\mu \mathrm{g} / \mathrm{mL})$ & 4.07E-02 \\
\hline Stanole prep & & \\
\hline N/A & CONCENTRATION IN SOLUTION (g/L) & 2.57E- 04 \\
\hline WW sampter & RESULT ( $\mu \mathrm{g} / \mathrm{mL})$ & $2.57 \mathrm{E}-01$ \\
\hline S96R000041 & RELATIVE \% UNCERTAINTY & 1.9 \\
\hline
\end{tabular}

instrumenteode

U01

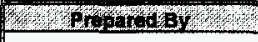

C.JO

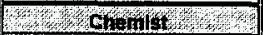

JLS

$\frac{21.42}{\text { DGG }}$

Dati coomplete

$01 / 30 / 96$

Analysulate

$01 / 26 / 96$

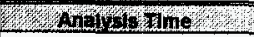

05:30 AM

6. 10

ORGIAQ SAMPLE

Result $=D F{ }^{*} P F{ }^{*} D D F * I R * 1000$

Detection Level $=3.70$ E-08 * DF * PF * DDF * 1000

Relative $\%$ Uncertainty $=I U / I R * 100$

Analyst:

Signature of Chemist:

SAMPLE.WB 1 REV $\uparrow .2$

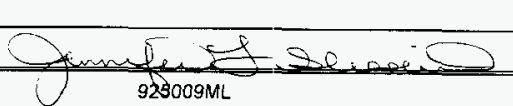

DGG

Date:

30-Jan-96

JLS Date: $1 / 30 / 96$


WORKBOOK PAGE: SPIKE4

WHC-SD-WM-DP-180, REV. O

Uranium by Phosphorescence: LA-925-009 (A-1) LIQUID/SOLID

\begin{tabular}{|c|c|c|}
\hline NTre & & SPIKE \\
\hline SPK & SPIKE BOOK\# & 22855 \\
\hline Wethist: & VOLUME OF SAMPLE + SPIKE (mL) & 1.00 \\
\hline 4751 & DILUTION FACTOR OF SAMPLE + SPIKE & 11,00 \\
\hline mand & PREPARATION FACTOR OF SAMPLE + SPIKE & 100.00 \\
\hline QU-01 & DIGEST DILUTION FACTOR OF SAMPLE & 1.0000 \\
\hline Whitus & LIFETIME IN MICROSECONDS & 218.00 \\
\hline LIQUID & R2 VALUE & $0: 9994$ \\
\hline 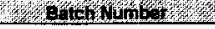 & RANGE (HIGH OR LOW) & HIGH \\
\hline $96000+85$ & INSTRUMENT RESULT & $5.82 E-05$ \\
\hline Pertun & CONCENTRATION IN SOLUTION (g/L) & $6.40 \mathrm{E}-02$ \\
\hline 0 & SPIKE VALUE $(g / L)$ & $5.69 \mathrm{E}-02$ \\
\hline Stholoping & INITIAL VOLUME OF SPIKE (mL) & 0.10 \\
\hline N/A & ORIGINAL SAMPLE VOLUME BEFORE PREP (mL) & 0.10 \\
\hline Sompledurober & CONCENTRATION IN SOLUTSON (g/L) FROM SAMPLE FOR & $2.57 E-04$ \\
\hline
\end{tabular}

S96R000041

Whs trumein oodes

U01

Concentration $=I R^{*} D F * P F$

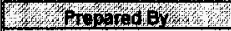

CJO

.

JLS

74t Antyst th

DGG

$\%$ Recovery $=$ QC FOUND $/$ QC ACTUAL

Qoteromplate

01/30/96

Whathat bate

\begin{tabular}{|c|c|c|c|c|}
\hline $01 / 26 / 96$ & QC ACTUAL & $=$ & $5.69 E+01$ & $\mu g / m L$ \\
\hline 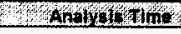 & QC FOUND & $=$ & $6.38 E+01$ & $\mu \mathrm{g} / \mathrm{mL}$ \\
\hline $05: 30$ AM & $\%$ SPIKE RECOVERY & $=$ & $112.1 \%$ & \\
\hline
\end{tabular}

Themplow

ORGIAR SAMPLE

\begin{tabular}{|c|c|c|c|}
\hline Analyst: & DGG & Date: & 30-Jan-96 \\
\hline Signature of Chemist: & JLS & Date: & $30 / 76$ \\
\hline
\end{tabular}


WORKBOOK PAGE: SP_DUPF

WHC-SD-WM-DP-180, REV. 0

Uranium by Phosphorescence: LA-925-009 (A-1) LIQUID/SOLID

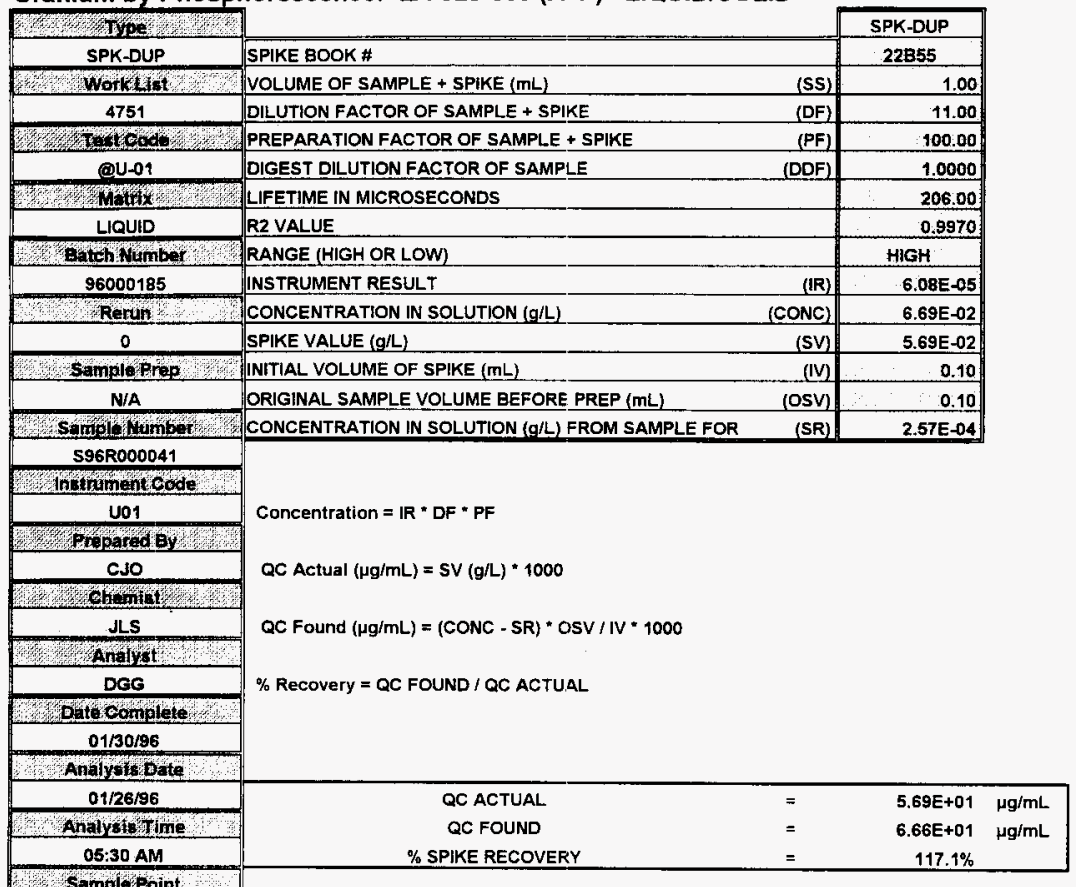

Analyst:

SPIKE.WB1 REV 1.2

$925009 \mathrm{ML}$ 
WORKBOOK PAGE: SAM6

WHC-SD-WW-DP-180, FEV 0

Uranium by Phosphorescence: LA-925-009 (A-1) LIQUID/SOLID

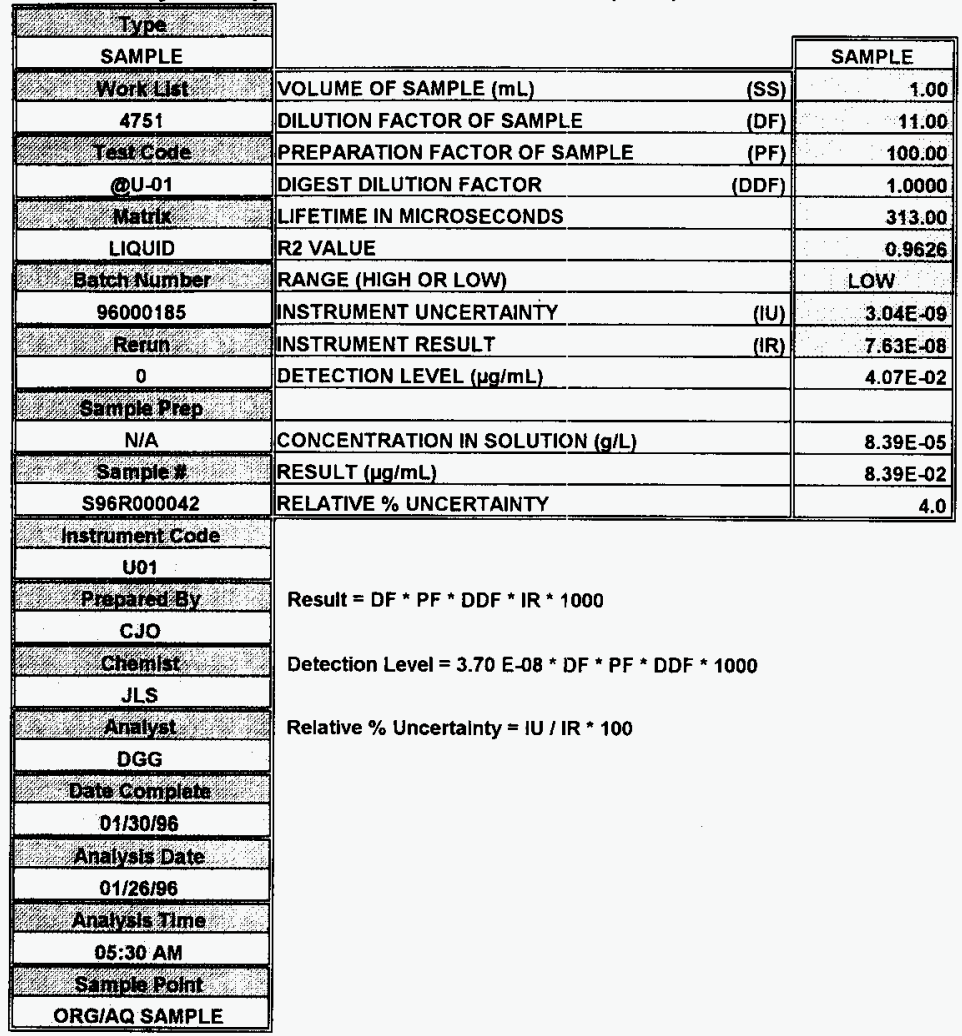

\begin{tabular}{|c|c|c|c|}
\hline Analyst: & $D G G$ & Date: & 30-Jan-96 \\
\hline
\end{tabular}


WORKBOOK PAGE: SPIKE7

WrC-SD-WM-DP-180, 16:-

Uranium by Phosphorescence: LA-925-009 (A-1) LIQUID/SOLID

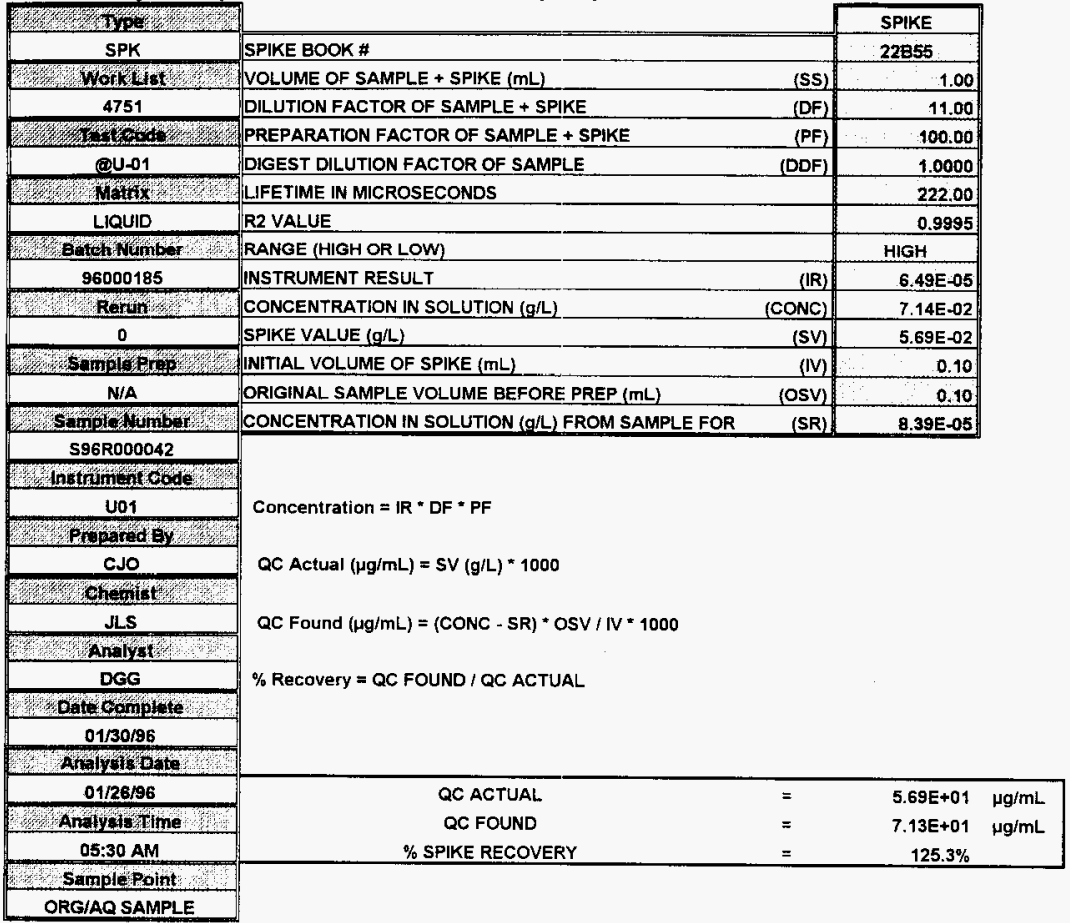

\begin{tabular}{|c|c|c|c|}
\hline Analyst: & DGG & Date: & 30-Jan-96 \\
\hline Signature of Chentist: & JLS & Date: & $1 / 30 / 96$ \\
\hline
\end{tabular}


WORKBOOKPAGE: SP_DUPB

WriC-SD-WM-DP-180, REV. 0

Uranium by Phosphorescence: LA-925-009 (A-1) LIQUID/SOLID

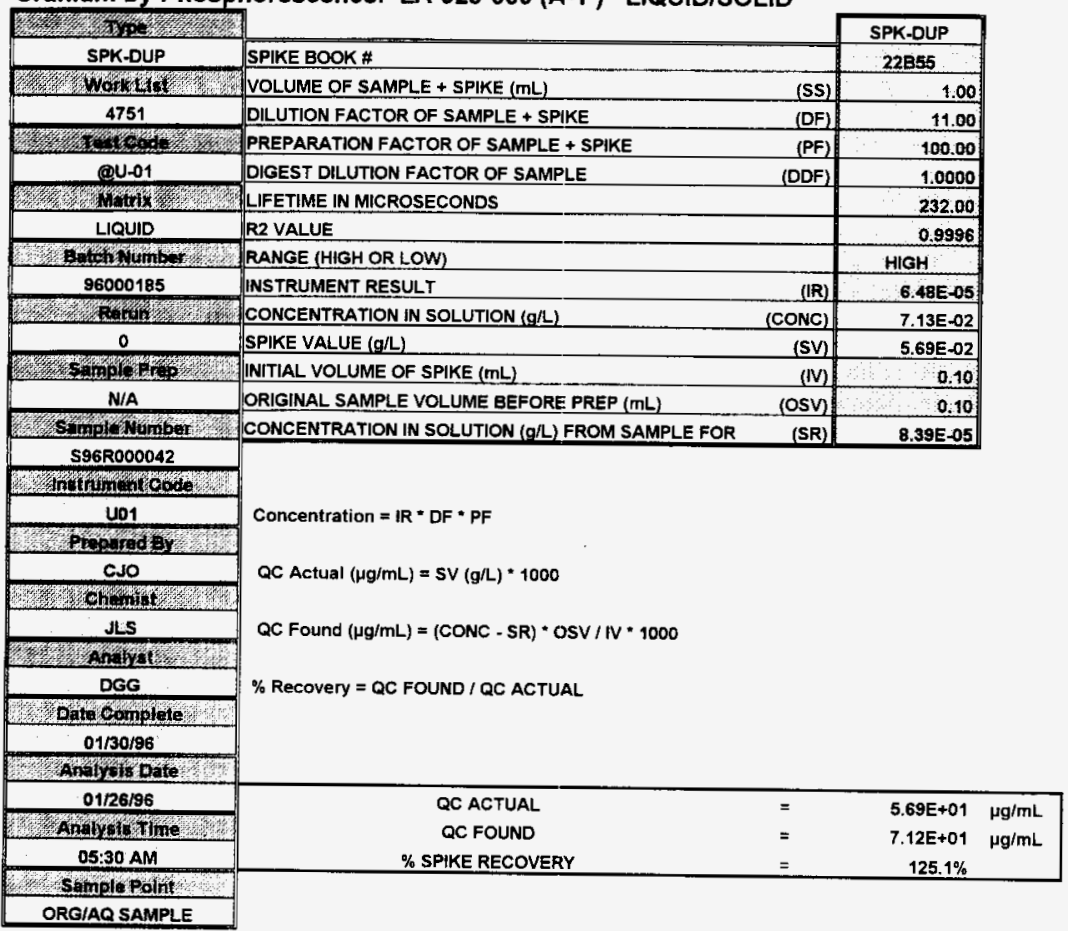

\begin{tabular}{|c|c|c|c|}
\hline Anaiyst: & DGG & Date: & 30-Jan-96 \\
\hline Signature of Chemist: & & & $1 / 30 / 96$ \\
\hline
\end{tabular}




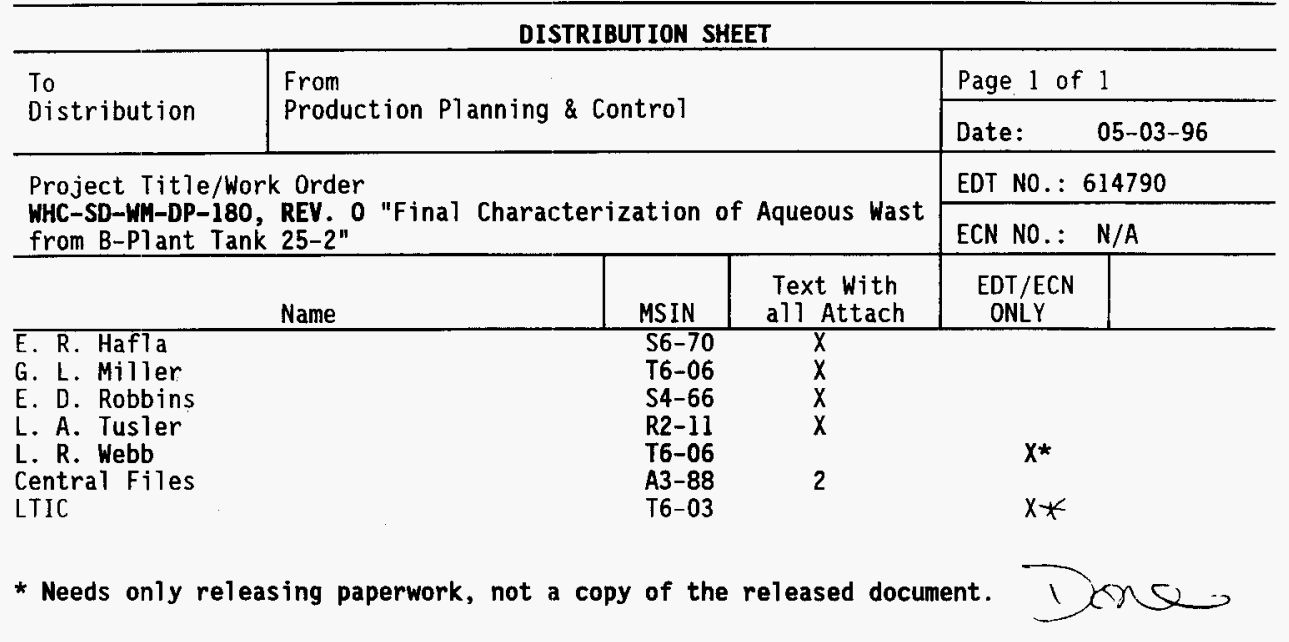

